\title{
सume
}

if - Try Ca - +. हाiा

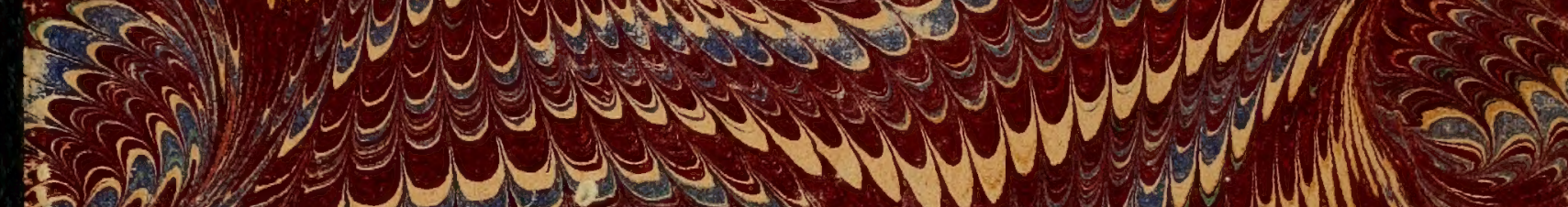
ing tru ny (a) (a) H. 


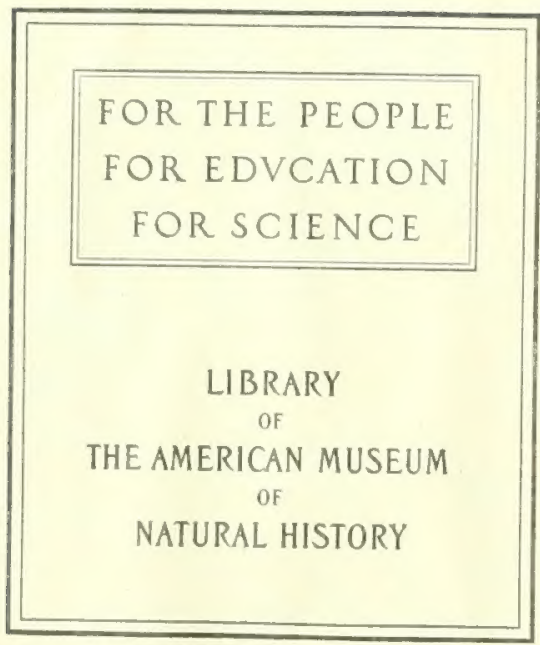



. 


\title{
BEITRÄGE
}

\author{
zणR \\ $59.81,1$

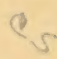

\section{KENNTNIS DER LACERTIDEN-FAMILIE}

(LACERTA, ALGIROIDES, TROPIDOSAURA, ZERZUMIA UND BETTAIA)

VON

$D^{R}$. J. von BEDRIAGA.

(Separat-Abdruck a. d. Abhandlungen der Senckenb. naturf. Gesellschaft Bd. XIV. S. 17.)

FRANKFURT A. M.

In Kom mission bei Moritz Diesterweg.

1886. 
Mit den Fortschritten, welche die Herpetologie in den letzten Decennien gemacht hat, haben sich auch die Entdeckungen dermaßaen angehäuft, daf es wohl an der Zeit sein mag, das uns vorliegende Material zusammenzutragen und monographisch zu bearbeiten. Angeregt durch den Herrn Akademiker Dr. A. Strauch habe ich die Lacerten einer Sichtung unterworfen und meine Forschungen über die kleinen südeuropäischen Eidechsen-Formen, sowie auf alle übrigen Arten ausgedehnt. Ich erlaube mir nun in beifolgenden Blättern das Ergebnis meiner zweijährigen ununterbrochenen Studien einem billig urteilenden Leserkreise vorzulegen.

Der Umfang des Gegenstandes brachte es mit sich, dał ich ihn nicht in dem gewünschten Grade erschöpfen konnte; ich mufs vielmehr vorausschicken, dak meine Untersuchungen sich in ausgedehnterem Maße über die nordafrikanischen und europäischen Species erstreckten. Aus Asien und Südafrika stand mir ein sehr geringes Material zu Gebote, obgleich ich alles mögliche aufgeboten habe, um mir das Fehlende zu verschaffen. Es wird daher auch die Behandlung des Stoffes nicht überall gleichmäßig sein, manche Frage wird man in dieser Schrift nur angeregt, manche jedoch, wie ich hoffe, auch gelöst finden. Von meinem ursprünglichen Vorhaben, sämtliche lejodaktyle Formen zu bearbeiten, habe ich einerseits wegen Mangel an Material, anderseits aber, und zwar hauptsächlich deshalb absehen müssen, weil, wie Herr G. A. Boulenger sich mir gegenüber treffend äufierte, die Unterschiede zwischen der lejodaktylen Gattung Tachydromus und den hier zu beschreibenden Subgenera Lacerta, Algiroides, Tropidosaura, Zerzumia und Bettaia viel frappanter sind, als zwischen diesen zuletzt erwähnten fünf Untergattungen und den pristidaktylen Formen; die von Duméril und Bibron vorgeschlagene Einteilung wäre somit nicht ganz gutzuheifen.

Gegenwärtige Arbeit bitte ich als den ersten Beitrag meiner Studien über die Saurier aufzufassen; unvollständig und mangelhaft wie sie ist, dürfte sie dennoch insofern von Nutzen 
sein, als sie hoffentlich bei der höchst schwierigen Bestimmung der Eidechsen Dienste zu leisten, und einen Überblick über die geographische Verbreitung dieser Tiere zu geben vermag. Bei dieser Gelegenheit möchte ich die Bemerkung einschalten, daß das Sammeln von Notizen über die Fundorte und Synonymik, sowie auch die Entzifferung der Diagnosen und Beschreibungen älteren und neueren Datums, welche in zahireichen periodischen Werken, Reiseberichten und Specialabhandlungen zerstreut sind, nicht weniger als sechs Monate Arbeit in Anspruch genommen hat, und dafs die Beschaffung der bezüglichen Litteratur eine Reise nach Paris, London, Leyden, Frankfurt a. M., Halle, Berlin und Heidelberg erfordert hat. Meine Anwesenheit in diesen Städten habe ich auferdem dazu benutzt, die in den dortigen Museen aufbewahrten Saurier zu durchmustern, um sie mit denjenigen vergleichen zu können, welche ich in den Museen von Wien, St. Petersburg, Leipzig, Zürich, Turin, Mailand, Florenz, Rom, Valencia, Athen, ferner in den Privat-Sammlungen der Herren F. Lataste in Paris und Ed. de Betta zu sehen Gelegenheit hatte. Auch ist es mir vergönnt gewesen, einige Eidechsen, welche die Museen von Genua, Göttingen, Moskau, Charkow und Kiew enthalten, zu untersuchen, sowie auch mehrere seltene und interessante Arten auf meinen Reisen im Süden Europas zu sammeln. Auf diese Weise habe ich das seltene Glück gehabt, mehrere Tausend Stück Lacerten und, was ich besonders hervorheben möchte, die meisten Originalexemplare kennen zu lernen. Unter den neueren und besonders interessanten Eirlechsenformen habe ich leider weder Lacerta princeps Blanf., noch die Originalstücke der strigata Eichw., saxicola Eversm., agilis-orientalis Kessl. und viridis colchica Eichw. untersuchen können. Erstere Art besitzt, wie man mir versichert, ein indisches Museum, während die Originalstucke der zuletzt genannten Abarten entweder nicht mehr vorhanden sind, oder sich im St. Petersburger Universitäts - Museum, das während meiner Anwesenheit in St. Petersburg ferienhalber geschlossen war, befinden. $\mathrm{Zu}$ meinem großen Bedauern haben die Behörden des genannten Instituts es nicht für nötig erachtet, meine Bitte um Zusendung meiner Desiderata zu berücksichtigen; dagegen bin ich umsomehr den Vorständen des Museums der Kaiserl. Akademie in St. Petersburg und der Universitäts-Sammlungen zu Moskau, Kiew und Charkow, sowie allen denen, welche mich bei meiner Arbeit so reichlich unterstützt haben, zu großem Danke verpflichtet; ihrer Zuvorkommenheit habe ich es zu verdanken, daßs ich mich über die fraglichen Punkte hinsichtlich der russischen Formen leidlich orientieren konnte. So habe ich unter anderem durch die gütige Vermittelung Sr. Excellenz des Herrn Dr. A. Strauch die Lacerta Portschinskii, das Eigentum der Herren im St. Petersburger Universitäts-Museum zu sehen bekommen.

Wenn ich den Anforderunger meiner Fachgenossen und Gönner in betreff der scharfen 
Abtrennung der hier zu beschreibenden Formen nicht entsprochen habe, so liegt dies gewís nicht im Mangel an Sorgfalt in der Untersuchung, sondern in der Schwierigkeit des Gegenstandes. Sowohl die größeren Arten, wie z. B. L. pater, ocellata, viridis und agilis, als auch die kleineren Species, - mit Ausnahme der L. vivipara, praticola, ferner der kanarischen und specifisch afrikanischen Formen — sind durch so zahlreiche Zwischen-Varietäten verbunden, dak sie nahezu geschlossene Ketten repräsentieren. So habe ich, wie ich es gern offen gestehe, nicht vermocht die, in so vielen Stücken an die agilis erinnernde, andererseits aber der viridis ähnliche, stark variierende L. paradoxa ganz genau zu kennzeichnen. Das nämliche gilt von Algiroides moreoticus und A. Fitzingeri; letztere Form dürfte möglicherweise in Zukunft nur als insularische Unterart von der ersteren betrachtet werden. Die specifisch afrikanischen Eidechsen, so z. B. L. echinata Cope, L. tesselata Smith, L. taeniolata Smith und L. Cameranoi $\mathrm{m}$. habe ich nur aus Unkenntnis ihres Gerippes unter den echten Eidechsen beibehalten; ihre äußeren Kennzeichen geben mir keine Anhaltspunkte, um sie aus der Gattung Lacerta zu entfernen, obschon ich fest davon überzeugt bin, daßs sie keine echten Lacerten sind; wie ich überhaupt glaube, daß keine Eidechsen den Äquator überschreiten. Indem ich diese Hauptmängel in meiner Schrift hervorhebe, möchte ich die Aufmerksamkeit derjenigen, welche in der glücklichen Lage sind, nach Gutdünken mit Exemplaren dieser Species zu schalten und zu walten, auf das Studium dés Gerippes richten; der Bau des Schädels, die Gestalt des Halswirbels und der Rippen dürften überraschende Resultate ergeben. Mir ist es nur vergönnt gewesen, diese Seltenheiten in den Museen mit gröbter Vorsicht, so zu sagen unter Glas und Riegel zu untersuchen, und war mir daher die Einweihung in den Bau des Gerippes vorenthalten.

Unter den von mir hier erwähnten Echsen befinden sich Lacerta pater, L. Bedriagae Cam. und L. graeca m. als selbständige Arten und »Lacerta Delalandei als Repräsentantin einer neuen Gattung erwähnt, dagegen wird man einige, als gute und echte Eidechsen-Arten beschriebene Saurier vermissen, beispielsweise » L. Schreiberim., $L$. Sturti Blanf., $L$. samharica Blanf., L. carinata Peters, L. spinosa Peters oder solche, welche mit blofen Museums-

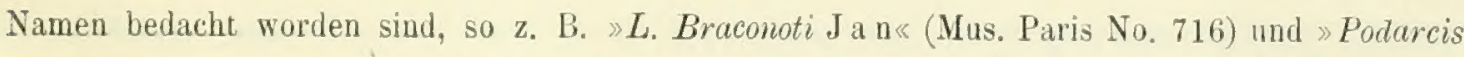
syriaca Fitz. * (k. k. zoolog., Kab. Wien), ferner Algira microdactyla Bttg., Tropidosaura capensis Smith, Trop. Burchellii Smith und Trop. Dumérili Smith.

Was $L$. pater $L$ a t. anbelangt, so finde ich es unmotiviert, dieselbe als Unterart von $L$. ocellata anzuführen; sie ist allerdings vom systematischen Standpunkte aus betrachtet, eine intermediäre, allem Anscheine nach mehr zu ocellata als zu viridis gehörige Form. Phylogenetisch aber 
mußs sie als Mutterform der beiden zuletzt genannten Eidechsen gelten ich sehe überhaupt den Grund nicht ein, weshalb in diesem Falle eine Lacerta, deren Verbreitungsbezirk blof auf Nordafrika beschränkt sein soll, wo, nebenbei sei es bemerkt, weder die ocellata, noch die viridis vorkommt, und welche in betreff ihrer Merkmale die Mitte zwischen den nur in Europa einheimischen Arten, d. h. der Perl- und Smaragdeidechse, einnimmt, zu einer Subspecies degradiert worden ist. Auch kann ich mir nicht erklären, auf welche Weise die viridis aus der ocellata, oder umgekehrt die ocellata aus der viridis durch die Vermittelung der socellata subsp. pater « sich enwickelt haben soll, zumal wenn ich in Betracht ziehe, daf letztere nicht in Europa, sondern nur in Afrika vorkommt. Daßs »ocellata subsp. pater « in Europa ausgestorben, in Nordafrika dagegen im Kampfe ums Dasein mit den Perl- und Smaragdeidechsen sich erhalten haben sollte, ist nicht begreiflich, eher wäre die Annahme gerechtfertigt, daßs die pater die Mutterform und zugleich eine Species darstellt, welche in Afrika ihre ursprünglichen Kennzeichen beibehalten, auf europäischem Boden hingegen dieselben eingebüßt, und neue angenommen hat und auf diese Weise die Keime zur Ausbildung zweier differenter Arten, i. e. der ocellata und viridis erhalten haben dürfte.

Die zwei folgenden Eidechsen, ich meine $L$. Bedriagae Camera no und $L$. graeca, sind nichts anderes als die oxycephala der Autoren, welche Benennung ich für die in Dalmatien einheimische spitzköpfige Art beibehalten will. Der Schlegelsche Name soxycephala ist ein Nomen nudum, d. h. eine Musealbezeichnung für eine spitzköpfige Eidechsenart Dalmatiens, deren Originalstücke ich letzthin in Leyden und Paris zu Gesicht bekommen habe. Duméril und Bibron, denen spitz- oder plattköpfige korsische Eidechsen bei der Abfassung ihrer generellen Herpetologie zu Gebote standen, glaubten nun in diesen Lacerten die oxycephala Schlegel zu erkennen und beschrieben sowohl die korsischen, als auch die dalmatischen Eidechsen als $L$. oxycephala. Daraufhin wurden von F. Steindachner spanische und von mir griechische Eidechsen mit der oxycephala D. B. zusammengeworfen. Erst nachdem ich såmtliche Originalexemplare verglichen hatte, sah ich den Irrtum in Bezug auf die angebliche Zusammengehörigkeit dieser vier geographisch getrennten und verschiedenen Formen ein.

$\left.{ }^{1}\right)$ Dr. L. C a meranos Notiz über die Eidechsen Italiens (Zoolog. Anzeiger 1885, No. 199) ist mir erst zu Gesicht gekommen, als die Abschrift dieser Abhandlung fast vollendet war, so daß sie leider nicht mehr berücksichtigt werden konnte. Da nun zufälligerweise die von $\mathrm{Camerano}$ für die korsische, angebliche oxycephala proponierte Benennung dieselbe Buchstabenzahl aufweist als die meinige, so habe ich meine Benennung sinsularis streichen lassen und diejenige von $\mathrm{C}$ a m e r a n o Bedriagae adoptiert. Sollte trotzdem der Name sinsularis dem Leser zufalligerweise begegnen, so bitte ich denselben durch $\gg$ Bedriagae Ca me r a $0 *$ zu ersetzen. 
Wie schwierig mitunter die Speciesunterscheidung und die Bestimmung mit den uns zu Gebote stehenden Ilülfsmitteln ist, beweist am besten die Thatsache, dalis die alleverewöhnlichsten Vorkommnisse, relche das Berliner Universitäts-Museum enthält, durchaus falsch bestimmt worden sind, obgleich dasselbe unter vieljähriger Leitung eines bewährten Herpetologen gestanden hat. So liabe ich unter anderem gefunden, daßs nicht weniger als vier, die Etiquette $\therefore$ L. oxyccphala tragende Gläser verschiedene Formen der Mauereidechse enthalten.

L. Schreiberi habe ich irrtünlicherweise für eine gute Species gehalten; sie ist aber nu' das Junge einer spanischen, auffallend gekleideten und der viridis var. Gadovii Bouleng. ähnlichen Form der Smaragdeidechse. Die Zeichnung der Jungen dieser beiden spanischportugiesischen Varietäten weicht ziemlich stark von derjenigen ab, welche wir sonst bei den Smaragdeidechsen kennen gelernt haben und sieht eher der Zeichnung von L. pater ähnlich, was wiederum für die Abstammung der viridis von der pater, und für das ursprüngliche Auftreten der Mutterform (d. h. Schreiberi-Gadovii) von der sogenannten typischen Smaragdeidechse auf der pyrenäischen Halbinsel spricht.

Die Delalandei M ilne-Edwards habe ich schon aus dem Grunde aus der Untergattung Lacerta entfernen müssen, weil ihr Rumpf zum größten Teil beschildert, nicht beschuppt erscheint, wie es bei den echten Eirlechsen der Fall zu sein pflegt; ihre Rumpfseiten nämlich sind zur Hälfte mit Schildern bekleidet.

Die sogenaunten $\triangleright L$. samharica, Sturti und carinata sind pristidaktyle Saurier und gehören der Gattung Latastia an ${ }^{1}$ ). Die Peterssche Lacerta spinosa und die Böt t ge rsche Algira microdactyla sind gleichfalls eher pristidalityle als lejodaktyle Formen und müssen deshalb meiner Meinung nach aus der Gattung Lacerta resp. aus der Untergattung Tropidosaura ausgeschlossen werden. Die als $\gg$. Braconoti《 und Podarcis syriaca von Jan und Fitzinger benannten, aber meines Wissens nirgends diagnostizierten Eidechsen sind nachtrïglich ron Peters und G. Doria als $» L$. atlantica und von Gray als $\gg L$. laevis

Was endlich die von mir oben angeführten angeblichen Tropidosaura-Arten betrifft, so mufs erwähnt werden, daf Tropidosaura capensis D. B. und Bianconi (Specim. zoolog. mosambicana, pag. 61) mit Recht in die Synonymik von Ichnotropis macrolepidota versetzt worden ist (Vergl. Peters, Naturwissenschaftl. Reise nach Mossambique, Amphibien S. 45, Berlin 1882). Als ich die Originalstücke der Smith-Duméril-Bibronschen sog. Trop. capensis im British Museum erblickte, fielen mir sofort die der Tropidosaura nicht eigenen

1) Vergl. meine Schrift: Die neue "Lacertiden-Gattung Latastia etc." in: Ann, del Mus. Civ. di St. Nat. di Genora, Vol. $\mathrm{Xx}, 1884$. 
Kiele an der Unterseite der Zehen auf. Herr G, $\Lambda$. Boulenger machte mich bei dieser Beobachtung auf das obige Peterssche Reisewerk aufmerksam, und er fand nun auch, dab die betreffende angebliche Tropidosaura sIchnotropis « heifen muf. Im British Nuseum habe ich ebenfalls znei Gläser vorgefunden mit der Etiquette »Algira Dumérili«; das eine enthält das Smithsche Originalstück rom Cap, das andere aber ein Ichnotropis bivittatus Barboza du Bocage aus West-Afrika. Beide gehören wohl sicher der Gattung Ichnotropis an, stellen aber nicht eine und dieselbe Species vor, vielmehr mübte diejenige von Barboza du Bocage I hnotropis bivittatus, dagegen die von Smith Ichnotropis Dumériti heißen. Tropidusaura Burchelli Smith und Tropidoscura capensis Steind. ') (von Smith, Duméril, Bibron!) müssen einfach in die Synonymik von Tropidosaura montana versetzt werden.

Daỉ es mir überhaupt möglich gewesen ist, meine Forschungen fast über alle lejodaktylen Echsen-Arten auszudehnen, verdanke ich der liebenswürdigen Unterstützung zahlreicher Freunde und Gönner, deren Namen ich hier folgen lasse und denen ich gleichzeitig meinen besten Dank ausspreche: Dr. O. Böttger, Prof. A. Bagdainow, Herr Ed. Boscà, Dr. L. Camerano, Marquis G. Doria, Dr. K. Gestro, Herr Geisenheyner, Herr O. Goldfub, Prof. H. Grenacher, Dr. A. Günther, Dr. F. Hilgendorf, Dr. F. A. Jentink, Herr F. Lataste, Dr. v. Lidth de Jeude, Prof. Erl, von Martens, Dr. C. IIösch, Prof. Paulson, Dr. Y. L. Seoane, Dr. E. Schreiber, Dr. F. Steindachner, Prof. Stepanow, Dr. A. Strauch, Dr. R. Schmidtlein, Prof. L. Vaillant und Dr. R. Collet.

Zu ganz besonderem Danke bin ich Herrn G. A. Boulenger verptichtet, welcher mir während meiner nahezu drei Wochen dauernden Studien im British Museum mit Rat und That in der aufopferndsten Weise zur Seite stand.

Nizza, $1883-85$.

\section{Gattung Lacerta L. (part.)}

Vier unpaare Pileusschilder $\left.{ }^{2}\right)$; vier, nur am Aufsenrande mitunter von kleinen körnerartigen Schuppen gesïumte Supraorbitalschilder. Das untere Lid ist ausnahmstreise durchsichtig. Die gekielten oder glatten, bald gröferen, flachen, spitz oder stumpf endenden, bald

1) Reise d. österreich. Fregatte Norara ete. I. Bd. Reptilien, Wien 1867.

2) Es ist unrichtig, wenn Milne Edwards (Vergl. seine Recherches pour serrir a l'histoire des Lézards in: Aun. des sc. natur. XXII, 1829) angiebt, dás bei Lacerta Dugesi das Scutum occipitale felılt. Bei sämtlichen hier zu beschreibenden Saurierformen ist das Hinterhauptschild rorhanden. 
kleinen und eher körnerähnlichen, :rundlichen oder mit mehr oder weniger scharfen Ecken rersehenen Schuppen an der Rumpfoberseite sind entweder mit ihrer ganzen Grundtäche der Standebene angcheftet, oder von dachziegelartiger Gestalt und Lage. Die Pholidosis ist insofern homogen, als die Dorsalschuppen ailmählich und ohne auffallende Unterbrechung in diejenigen kleineren oder größeren Schuppen, we]che die Überkleidung der Rumpfseiten bilden, überzugehen pflegen. Die Grenzen zwischen den Bauchtafeln und den die Rumpfseiten bekleidenden Schuppen sind mehr oder weniger scharf, aber stets angedeutet. Das Halsband ist mehr oder weniger deutlich ausgeprägt oder wird gänzlich vermist. Die Unterseite der Zehen ist mit glatten Schuppen bedeclit.

Die Gattung Lacerta begreift, meiner Ansicht nach, eine Reihe von Untergattungen, deren Unterscheidung durch naclistehende Übersicht erleichtert werden mag:

A. Die getäfelte Bauchtläche bedentend schmäler als die beschuppte Rückenseite des Körpers. Körperschuppen oder schilderähnliche Schuppen klein, bald mehr, bald weniger flach, bald körnig, glatt oder gekielt, weder aufliegend gekielt, noch deutlich geschindelt. Halsband immer sehr deutlich. Bauchtafeln grols, quer erweitert, spurweise übereinander greifend, die zwei Mittelreihen meist kleiner als die übrigen

\section{Lacerta L. (part.).}

Körperschuppen groß und flach, meist rautenförmig, aufliegend gekielt und volliommen geschindelt. Halsband stets sehr deutlich. Die schwach geschindelten Bauchtafeln sind groß, quer erweitert, die zwei Mittelserien sind kleiner als die übrigen .....

Algiroides Bilr. (= Notopholis).

Körperschuppen grob, flach, rautenförmig, hinten schwach zugespitzt, aufliegend gekielt und vollkommen geschindelt. Halsband vorhanden, obgleich schwach ausgepriigt. Die schwach geschindelten Bauchtafeln sind ziemlich grob, quer erweitert, die zwei Mittelreihen etwas kleiner als die übrigen . . . . . Zerzumia Lataste. Körperschuppen sehr groß, flach, hinten meist scharf zugespitzt, aufliegend gekielt und vollkommen geschindelt. Halsband gänzlich felılend. Bauchtafeln ziemlich klein, rhombisch oder gerundet, sechseckig und geschindelt, zwischen den Mittelıeiben und den angrenzenden Serien ist kein großer Unterschied wahrnehmbar .

\section{Tropidosurera Fitz.}

B. Die getäfelte Bauchfäche bedeutend breiter als die beschuppte Rückenseite. schuppen an Rucken klein, körnerartig, an den Seiten flach, größer werdend und 
schwach geschindelt. Halsband vorhanden. Bauchtafeln grob, quer erweitert und chwath meschimlelt. . . . . . . . . . . . . Bettain m.

Ans diescr Übersicht ist ersichtlich, dat's die zwei extremen, schon in ihrem Gesamtbau und Habitus bedeutende Verschiedenheiten aufweisenden Untergattungen Lacerta und Tropidosaura sich dennoch trefflich aneinander reihen lassen, sobald wir die intermediären Subgenera Algiroides fund Zerzumia berücksichtigen. Algiroides verbindet sich nämlich mit Lacerta und bildet durch Zerzumic den Übergang zu Tropilosaura, die wieder mit einigen pristidaktylen Formen durch die Vermittelung von Böttgers sogenannten Algira microdactyla in Verbindung steht. Bei diesen vier Untergattungen können wir Schritt für Schritt einerseits die stufenweise allmähliche Ausbildung von Ziegelschuppen sowohl am Rücken, als auch am Unterleib, anderseits aber die Rückbildung des Halsbandes verfolgen. Die Linie eines Schemas mutmaßlicher Verwandtschaft dieser Subgenera ließe sich demnach so ziehen:

Halsband fehlend; Oberseite und Unterseite mit
Ziegelschuppen . . . . . . . . . .
Halsband undeutlich; Oberseite mit geschin-
delten, Unterseite mit spurweise ge-
schindelten Schuppen . . . . . .

$$
\begin{gathered}
\text { Seite mit spurweise geschindelten Schildern. } \\
\text { Halsband deutlich; Oberseite mit geschindelten, Unter- } \\
\text { oder spurweise geschindelten Schuppen, Unterleib mit } \\
\text { schwach geschindelten Schildern. }
\end{gathered}
$$

Bettaia Delalandei, die Repräsentantin unserer neuen Untergattung »Bettaia« stellt eine isoliert stehende, abirrende Form dar, welche sich vielleicht an die südafrilianischen sogenannten Lacerten anreihen liefe. Sowohl die erstere, als auch die letzteren müssen erst genauer untersucht werden, bevor sie einen bestimmten Platz im System erhalten.

\section{Untergattung Lacerta.}

Lacerta, Linné, Museum Adolphi Friderici Regis Suecorum etc. Holmiae; Systema naturae. Holmiae (part.). - Lacepède, Hist. nat. quadrup. ovipares. Paris 1787-88 (part.). - Schneider, Amphibiorum physiologiae specimina. Traj. a. Rh. 1799 (part.). - 
Daudin, Hist. nat. génér. et particulière des Reptiles III. Paris 1802 (part.). Latreille, Hist. nat. des Salamandres de France. Paris 1800 (part.). - Brongiart, Essai d'une Classification des Reptiles. Paris 1805 (part.). - Oppel, Die Ordnungen, Familien und Gattungen d. Reptilien. München 1811 (part.), - Merrem, Versuch eines Systems d. Amphibien. Marburg 1820 (part.). - Fitzinger, Neue Klassifikation d. Reptilien etc. Wien 1826 (part.). - Gray, Synopsis reptilium in: Griffiths Animal Kingdom. Loudon 1827 (part.) - Cuvier, Le Règne animal II. Paris 1829 (part.). - Dugès, Mém. sur les espèces indigènes du genre Lacerta in: Ann. sc. nat. 1829 (part.). - Milne Edwards, Recherches zool. pour servir à l'hist. nat. des Lézards in: Ann. sc. nat. Paris 1829 (part.). - Wagler, Natürl. System der Amphibien. München etc. 1830 (part.). - Wiegmann, Herpetologia mexicana. Berlin 1834 (part.). - Tschudi, Monogr. der schweiz. Echsen in: Nouv. Ném. Soc. Helvet. Sc. nat, 1837 (part.). - Bonaparte, Amphibia europaea in: Mém. Accad. Sc. Torino, 1840. - Duméril et Bibron, Erpétologie générale V. Paris 1839 (part.). - Fitzinger, Systema reptilium. Wien 1843. - Gray, Cat. of the specimens of Lizards in the collect. of the Brit. Mus. London 1845. - Schreiber, Herpetologia europaea. Braunschweig 1875. - Camerano, Considerazioni sul Genere Lacerta etc. in: Atti Accad. Sc. Torino, XIII. 1877. - Boulenger, in: Proc. Zool. Soc. of London 1881 (part.).

Seps, Laurenti, Synops. reptil. Wien 1768 (part.).

Zootoca, Wagler, Wiegmann, Fitzinger, Gray, Bonaparte, Tschudi, l. c.

Podarcis, Wagler, Wiegmann, Fitzinger, Bonaparte, Tschudi, Camerano, l.c. Thimon, Bonaparte, Camerano.

Alsodromus, Scelaris, Elaphorus, Phenax, Chrysolamprus, Fitzinger, Systema reptilium.

Nucras, Thetia, Gray, Cat. Rept. Brit. Mus.

Die Unterscheidung der Arten kann in nachfolgender Weise geschehen:
A. Collare denticulatum.
Supralabialia anteriora 4.

I. Discus palpebralis serie squamarum a scutis supraciliaribus seiunctus ${ }^{1}$ ).
a) Sc. massetericum interdum praesens.
Sc. nasofrenalia duo.

Sulcus gularis praesens ${ }^{1}$ ). Sc.abrloninalia per series 6-8 longitudinales disposita : L. viridis La ur.

Sulcus gularis nullus. Sc. abdominalia per series 8 longitudinales disposita :

L. pater Lataste.

Sc. abdominalia per series 10 longitudinales disposita:

L. princeps $\mathrm{Blanf}$.

$\left.{ }^{1}\right)$ Exceptiones haud rarae (L. viridis, L. pater, L. ocellata). 
b) Sc. massetericun praesens. Sc. nasofrenale unicum.

Sulcus gularis praesens. Tempora parvis scutellis vel squamis tecta: L. taurica P all.

Sulcus gularis nullus. Tempora maioribus minoribusque scutis: L. praticola Eversm.

c) Sc. massetericum nullum. Sc. nasofrenalia duo.

Sc. occipitale maximum. Sc. abdominalia in 8-10 series longi-

tudinales disposita. Squamae dorsi carinatae: $\quad$. ocellata Daud.

Sc. occipitale minimum. Sc. abdominalia in $6-8$ series longi-

tudinales disposita. Squamae dorsi laeves. Digiti graciles, longi: (?) L. tessellata. S m i th.

Sc. occipitale minimum. Sc. abdominalia in 8 series longitudi-

nales disposita. Squamae dorsi laeves. Digiti breves,

crassiores quam in $L$. tessellata:

(?) L. Cameranoi de Bedr.

Sc. nasofrenale unicum.

Sc. abdominalia in 6 series longitudinales disposita. Squamae

dorsales parvae, laeves:

(?) L. taeniolata Smith.

Sc. abdominalia in $8-10$ series longitudinales disposita. Squamae

dorsales satis magnae, carinatae:

L. atluntica Peters, Doria.

II. Discus palpebralis a supraciliaribus squamarum serie non separatus.

a) Sc. massetericum praesens rel nullum. Sc. nasofrenalia duo,

Sc. frenale praesens. Digiti breves:

L. agilis Wolf.

Sc. fremale nullum vel 1 Nasofrenale, sc. frenale praesens. Digiti longi: $L$. paradoxa de Be dr.

Sc. nasofrenale unicum.

L. vivipara J a cq.

b) Sc. massetericum nullum.

Sc. nasofrenale unicum.

Squamae in caudae basi maximae, spinosissime aculeatae:

(?) L. echinata $\mathrm{Cope}^{2}$ ).

B. Collare integrum.

I. Discus palpebralis serie squamarum a scutis supraciliaribus seiunctus.
a) Sc. massetericum praesens $\left.{ }^{1}\right)$ !
Sc. nasofrenale unicum.

Sc. abdominalia in 6 series longitudinales disposita.

Squamae in caudae basi sat planae:

L. muralis Laur.

Squamae in caudae basi tuberculatae quasi carinato-mucronatae:

L. depressa $\mathrm{C}$ am.

$\left.{ }^{1}\right)$ Ausnahmsfälle kommen bei $L$. muralis, $L$. depressa und $L$. Bedriagae ror.

") In der deutschen Diagnose mufi es heifen: "Palpebralscheibe ron den Supraciliaria durch keine

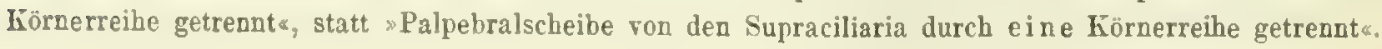


Supralabialia anteriora $5^{1}$ ).

Sc. abdominalia in 12 series longitudinales disposita:

Sc. abdominalia in 6 series longitudinales disposita:
L. Galloti D. B.

L. Bedriagae $\mathrm{C}$ am.

a) Sc, occipitale interparietali minus.

Sc. abdominalia in 6 series longitudinales disposita. Caput pyramidale: L. Dunforli Grïnth.

Sc. abdominalia in 6 series longitudinales disposita. Caput depressum: L. oxycephala D. B.

Sc. abdominalia in 8 series longitudinales disposita. Caputpyramidale: L. Brondti De Fil.
ß) Sc, occipitale scuto interparietali multum maius:
L. laevis Gray.

b) Sc. massetericum nullum.

Cauda duplam corporis longitudinem superans:

Cauda brevis:

Cauda brevis. Palpebra inferior pellucida:
Sc. nasofrenalia duo.

L. graeca de Bedr.

L. Dugesi M. Edw.

L. perspicillata D. B.

II. Discus palpebralis a supraciliaribus squamarum serie non separatus.

a) Sc. massetericum praesens.

Sc. nasofrenale unicum.

L. peloponnesiaca Bibron, Bory.

L. ocellata Daud. Occipitale bedeutend gröfer als das Interparietale, breiter als das Frontale und ebenso breit oder breiter als das Parietale; in einigen Fällen übrigens, so z. B. bei den spanischen Individuen, ist das Occipitale schmäler als das Parietale. Discus palpebralis in der Regel von den Supraciliaren durch eine Reihe Schuppen getrennt. Zwei übereinanderstehende Nasofrenalia. Frenale schmal, das Internasale erreichend. Parietalia am Aubenrande von 2 oder 3 grülieren, schmalen Tafeln umsäumt; Schläfe mit groLien Schildern bekleidet. Iassetericum und Tympanicum fallen durch ihre Grölise in tler Regel nicht auf. Sulcus gularis fehlt. Halsband stets gezähnelt. Bauchschilder in 5 oder 10 Längsreihen angeordnet; Sc. anale von 2 bis 4 Bogenreihen von Schildchen umgeben. Rücken mit kleinen, rundlich eiförmigen oder vierseitig abgerundeten, schwach gekielten Schuppen, Rumpfseiten mit etwas grülïeren Hachen, ungekielten, rundlich pentagonalen und rautenförmigen Schuppen besetzt. - Körper kräftig und gedrungen, Kopf bedeutend breiter als hoch, ziemlich lang. Hinterbeine gewöhnlich die Achseln erreichend. Schwanz erreicht nicht ganz die doppelte Körperlänge (๑)) oder ist nur zweimal so lang als der Rumpf $(\uparrow)$; die oberen Caudalschuppen sind abgerundet und

\footnotetext{
1) Ausnahmsfälle sind selten.
} 
winkelig ausgezogen. - Zähne am Gaumen. - 14 bis 16 Femoraldrüsen. - Totallänge gewöhnlich $544 \mathrm{~mm}\left(\sigma^{7}\right), 459 \mathrm{~mm}(q)$, jedoch sind auch meterlange Individuen beobachtet worden. - Habitat: Südrankreich, Italien (Savona, Ventimiglia), Pyrenäische Halbinsel.

L. pater Lat aste. - Occipitale schmäler und kürzer als das Frontale, bedeutend schmäler als das Parietale und viel breiter und länger als das Interparietale; Frontale verhältnismäßig kurz. Discus palpebralis in der Regel ron den Supraciliaren durch einige Schuppen getrennt. Zwei übereinanderstehende Sasofremalia; Frenale schmal, das Internasale erreichend. Parietalia am Aufenrande von zwei bis drei großen, länglichen Tafeln umsäumt; Schläfe mit grofen Schildern bedeckt, in seltenen Fällen mit einem gröberen Schilde in der Mitte. Tympanicum fehlt, ebenso Sulcus gularis. Halsband gezähnelt. Bauchschilder in 5 Längsreihen angeordnet. Sc. anale durch zwei Bogenreihen von Schildern begrenzt. Rücken mit schmäleren als breiten, hexagonalen oder ziemlich breiten pentagonalen und abgerundet vierseitigen schwach gekielten Schuppen, Rumpfseiten mit abgerundet vierseitigen, spurweise gekielten oder vollkommen

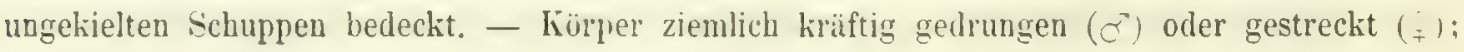
Kopf breiter als hoch, mäßjig lang. Hinterbeine die Achseln nicht erreichend (†) oder über dieselben hinausragend $\left(\sigma^{\top}\right)$. Schwanz fast von doppelter Körperlänge $\left(\sigma^{\circ}\right)$ oder bedeutend kürzer (९), mit oberhalb abgerundeten, winkelig und scharf zugespitzten Schuppen besetzt. Zähne am Gaumen. - 14 Femoraldrüsen jederseits. - Totallänge: 309 bis $315 \mathrm{~mm}$. Habitat: Algerien, Tunis.

L. vividis Laur. Occipitale bedeutend schmäler und kürzer als das Frontale, entweder kleiner oder ebenso grof oder etwas gröfer als das Interparietale. Discus palpebralis in der Regel ron den Supraciliaren durch eine Reihe Schuppen getrennt. Zwei genau übereinanderstehende Nasofrenalia; Frenale das Intermasale erreichend. Parietale am Aufenrande von zwei großen, länglichen Tafeln umsäumt. Schläfe mit grofen Schilderu bedeckt, mitunter mit einem Sc. massetericum in der Mitte; Tympanicum kann fehlen. Sulcus gularis in der Regel deutlich ausgeprägt. Halsband stets gezähnelt. Bauchschilder in 6 bis 8 Längsreihen angeordnet. Sc. anale gewöhnlich durch zwei Bogenreihen von Schildchen umsäumt. Rücken fast immer mit schmalen, länglichen, rundlich-hexagonalen, deutlich längsgekielten Schuppen, Rumpfseiten mit unregelmäßig gestalteten, etwas grötieren, gegen die Bauchgrenze hin flachen und spurweise gekielten Schuppen besetzt. - Körper bald mehr ( $)$, bald weniger schlank ( $)$; Kopf etwas breiter als hoch, mäßig lang. Hinterbeine entweder bis an die Achseln oder etwas darüber hinaus reichend $(\Im)$, oder dieselben liaum erreichend $(\xi)$, lange Hände und Fübe. Schwanz meist ron doppelter Körperlänge mit oberseits scharf zugespitzten Schuppen besetzt. - Gaumen- 
zähne rorhanden. - Drüsenzahl: 16 bis 19 (auch 11 bis 20). - Totallänge: 320 bis $630 \mathrm{~mm}$. - Habitat: Südeuropa, Mitteleuropa, Vorder-Asien.

L. princeps Blanf. - Occipitale gröfer als das Interparietale. Discus palpebralis von den Supraciliaria durch einige Schuppen getrennt. (Vergl. die Abbildung bei Blanford). Zwei übereinander stehende Nasofrenalia. Parjetalia am Aulsenrande von zwei gröberen ]änglichen Randtafeln umsäumt. Schläfe mit grolien Schildern bekleidet. Nassetericum und Tympanicum rorhanden (\%). Sulcus gularis fehlt (?). Halsband gezähnelt. Bauchschilder in 10 Längsreihen angeordnet, Randschildchen vorhanden (\%). Schuppen am Rücken schwach geschindelt, gleich grof3. rautenfürmig, diagonal gekielt, schuppen an den Rumpfseiten ungekielt und etwas kleiner als die des Rückens. - Körper mälijg gedrungen, etwas Alach gedrückt; Kopf konisch. Hinterbeine ibber die Achseln hinausragend. Schwanz die doppelte Kürperlänge übertreffend. Zähne am Gaumen. - 14 Schenkeldrüsen jederseits, - Totallänge: 420 mm. - Habitat: Persien.

L. agilis Wolf. - Occipitale gewöhnlich bedeutend kleiner als das Interparietale, Sc. frontale breit; zwei Nasofrenalia, das obere auf dem unteren und zugleich auf dem Frenale ruhend, oder zwei übereinanderstehende Nasofrenalia, wie es z. B. öfters bei den osteuropäischen und kaukasischen Individuen konstatiert worden ist; in ersteren Falle erreicht das Frenale die Pileusschilder nicht, im letzteren treten das Frenale und das Internasale in Beruhrung. Discus palpebralis von den Supraciliaren durch keine Schuppenreihen getrennt; Ausnahmsfalle sind selten. Parietalia am Außenrande von 2 bis 3 gröferen Tafeln umsäumt. Schläfe mit großen Tafeln bekleidet; Massetericum und Tympanicum fehlen meistens. Die Keblfurche ist mitunter bei den jungen Exemplaren vorhanden. Halsband gezähnelt. Bauchschilder in 6, ausnahmsweise in s Längsreihen angeordnet. Sc. anale meistens durch eine Bogeureihe ron Schildchen begrenzt; bei den russischen und kaukasischen Individuen erreichen die median liegenden Saumschilder zuweilen die halbe Gröbe der Aftertafel. Rückenschuppen in der Vertebralzone bedeuteud schmäler als an den Śeiten des Rückens, länger als breit, polygonal und hexagonal, längsgekielt oder überall ziemlich gleich breit und in diesem Falle breiter als sonst. Rumpfseitenschuppen glatt, spurweise geschindelt und gewöhnlich breiter als die Dorsalschuppen. - Kürper ziemlich kräftig und gedrungen, Kopf hoch, in der Wangengegend schwach backenartig aufgetrieben. Hinterbeine sehr kurz, sie erreichen die Achseln nie. Kurze Hände und FüŁe. Schwanz anderthalbmal so lang als der übrige Körper oder etwas länger; an der Basis rundlich vierseitig, oben eingedrückt. - Gaumenzähne vorhanden. - 11 bis 18 Schenkeldrüsen jederseits. - Totallänge: 167 bis $270 \mathrm{~mm}$. - Verbreitung: Nord- und Mitteleuropa, Transkaukasien Turan, Sibirien. 
L. paradoxa m. - Occipitale bedeutend oder nur etwas kleiner als das Interparietale. Frontale sehr breit und verhältnismäßjig kurz. Ein Nasofrenale und ein das Internasale erreichendes Frenale oder zwei übereinanderstehende Nasofrenalia, Frenale fehlend. Discus palpebralis von den Supraciliaria durch keine Schuppenreihe getrennt. Parietalia am Aulenrande von 2 bis 3 grolien Tafeln umsiumt. Schläfe mit grofen Tafeln bekleidet, Sc. massetericum und Tympanicum mitunter vorhauden. Keblfurche fehlt. Halsband gezähnelt. Bauchschilder in 6 bis 8 Längsreihen angeordnet, im ersteren Falle sind Randschildchen vorhanden. Sc. anale von zwei sehr grołen Schildern umgeben. Die Afterregion erscheint infolgedessen von drei Tafeln bekleidet. Rückenschuppen länglich, schmal, längs gekielt, abgerundet hexagonal. Rumpfseitenschuppen gekielt und glatt, schwach geschindelt, gröber als die Rückenschuppen und etras grüber als die Rumpfseitenschuppen bei $L$. ciridis. - Körper kräftig, gedrungen. Kopf sehr hoch und breit, in der Schläfengegend backenartig aufgetrieben. Hinterbeine länger als bei $L$. agilis, reichen jedoch nie bis zu den Achseln; ziemlich lange Hände und Füße. Schwanz mäkig lang, in eine kurze Spitze ausgezogen, beim Nännchen sehr stark an der Wurzel verdickt. - Gaumenzähne vorhanden. - 13 bis 15 Schenkeldrüsen jederseits. - Totallänge: 220 bis $225 \mathrm{~mm}$. Habitat: europ. Rufiland und Transkaukasien.

L. muralis Laur. - Occipitale in der Regel kleiner, zuweilen aber etwas breiter als das Interparietale. Sc. frontale normal. Ein Nasofrenale. Discus palpebralis von den Supraciliaren durch eine Körnerreihe getrennt. Parietalia am Anbenrande mitunter von etwas grökeren Schildchen umsäumt. Schläfe beschuppt. Massetericum fehlt ausnahmsweise, so z. B, bei persischen, spanisch-portugiesischen (subsp. Steindacheri) und insulanischen Formen. Tympanicun vorhanden. Sulcus gularis vorhanden oder undeutlich ausgeprägt. Halsband ganzrandig, ausnahmsweise bei sicilianischen neapolitrnae spurweise gezähnelt, bei Subsp. Steindacheri aus kleinen Schildchen bestehend. Bauchschilder in 6 Längsreihen, ausnahmsweise bei Individuen vom Faraglioni-Felsen bei Capri in 8 Längsreihen angeordnet. Randschildchen vorhanden. Sc. anale von zwei Bogenreihen Schildchen oder Schuppen umsäumt. Rückenschuppen sind kürnerartig, bald sehr klein oder größer, rundlich oder regulär hexagonal, lünger als hreit, wahezu scharfeckig oder mit abgerundeten Ecken, entweder ziemlich stumpf und schwach oder deutlich gekielt und gewijlbt. Bei Subsp). Steindachneri sind die Rückenschuppen klein, glatt, ziemlich flach, nur nach hinten zu mit einer spurweise emporragenden Spitze versehen; sie sind länglich hexagonal und pentagonal mit abgerundeten Ecken. - Körper gewöhnlich schlank und gestrecht. Kopf pyramidal oder platycephal. Hinterbeine reichen bis $2 u$ den Achseln, bisweilen auch darüber hinaus, nur in einzelnen Fällen erreichen sie dieselben nicht. Langer oder ziemlich kurzer 
Schwanz, mit oberseits ganzrandigen, abgerundeten und winkelig ausgezogenen Schuppen. Am Gaumen mangeln meist die Zähue. - 13 bis 29 Femoraldrüsen jederseits. - Totallänge: 127 bis 250 mm. - Verbreitung: Süd-Europa, Mitteleuropa, Nordafrika, Vorder-Asien.

L. Brandti De Filippi. - Occipitale kleiner als das Interparietale. Sc. frontale lang. Zwei übereinander gestellte Nasofrenalia. Palpebralscheibe von den Supmaciliaren durch eine liürnerreihe getrennt. Parietalia am Außsemrande von drei größeren Tafelu umsäumt. Schläfe uit schuppenähnlichen Schildchen bedecht, Massetericum ziemlich grof, Tymy̨anicum vorhanden, ebenso Suleus gularis. Halsband ganzrandis. Bauchschilder in \& Lïngsteihen angeordnet, Randschildchen vorhanden. Sc, anale von 1 bis 2 Bogenreihen kleiner Schildchen und Schuppen umsäumt. Schuppen am Rücken klein, rund, konvex, kaum gekielt. - Körper schlank, Kopf pyramidal, etwas breiter als hoch. Hinterbeine erreichen nahezu die Achseln. Schwanz mäfigg lang, aber stets länger als der ubbrige Kürper, oberbalb mit gerade abgestutzten oder stumpfwinkelig ausgezogenen Schuppen beleckt. - Gaumenzähne vorhanden. - Jederseits 19 Schenkeldrüsen. - Totallänge: $147 \mathrm{~mm}$. - Habitat: Talysch, Nord-Persien.

L. Danfordi Günth. - Occipitale kleiner als das Interparietale. Sc. frontale lang. Zwei übereinander gestellte Nasofrenalia. Palpebralscheibe von den Supraciliaria durch eine Kürnerreihe getrennt. Parietalia am Aubenrande von einer länglichen, grütieren Tafel und von einigen Schuppen umsäumt. Schläfe mit Schuppen bekleidet, Sc. massetericum hlein, Tryapanicum rorhanden. Sulcus gularis fehlt. Halsband nahezu vollkommen ganzrandig. Bauchschider in 6 Längsreihen, Randschildchen ziemlich grobs. Sc. anale von zwei Bogeureihen gröŁerer und kleinerer Tafeln begrenzt. Schuppen am Rücken vierseitig mit abgerundeten Ecken, vorn glatt, hinten äulierst schwach gekielt, an deu Seiten rhombenfürmig, spurweise gekielt oder glatt. - Körper ziemlich schlank, Kopf prramidal, breiter als hoch. Hinterbeine uber die Achseln hinausragend (志) oder die Achseln nicht, oder kaum erreichend ( mitunter die doppelte hörperlänge übertreffend, beim $\subsetneq$ die doppelte Körperlänge nicht erreichend, oberseits mit fast gerade abgestutzten und gekielten Schuppen bekleidet. - Gaumenzähne fehlen. - 19 Schenkeldrüsen jederseits. - Totallänge: 144 bis $227 \mathrm{~mm}$. - Habitat: Klein-Asien.

L. laevis Gray. - Occipitale auffallend groß, bedeutend breiter und länger als das Interparietale, breiter als das lange Frontale. Zwei übereinander gestellte Nasofrenalia. Palpebralscheibe von den Supraciliaren durch eine Schuppenreilue getrennt. Parietalia an Aufenraude von einer länglichen, grülieren Tafel und von einigen schuppenähnlichen Schildchen unsäumt. Schläfe mit schuppenähnlichen, meist hexagonalen Schildchen bedeckt; sehr grofes Massetericum und Tympanicum. Sulcus gularis mitunter ausgeprägt. Halsband nahezu vollkommen ganzrandig. 
Bauchschilder in 6 Längsreihen angeordnet, Randschildehen vorhanden. Sc. anale grof, von 2 Bugenreihen grölserer und kleinerer Tafeln begrenzt. Rückenschuppen länglich, hexagonal mit abgerundeten Ecken, gekielt. - Körper ziemlich kräftig, breit, etwas plattgedrückt. Kopf pyramidal und ziemlich lang. Hinterbeine kriftig, über die Achseln hinausragend. Langer Schwanz, oberseits mit abgerundeten, gerade abgestutzten und winkelig ausgezogenen Schuppen. - Gaumenzähne vorhanden. - 18 bis 20 Femoraldrüsen jederseits. - Totallänge: 168 bis $234 \mathrm{~mm}$. - Habitat: Syrien.

L. graeca m。- Occipitale gewöhnlich länger und breiter als das Interparietale. Sc. frontale ziemlich lang und breit. Zwei ubereinander gestellte Nasofrenalia. Discus palpebralis von den Supraciliaren durch eine Kïmerreihe getrennt. Parietalia am Außenrande vorn von einer verhältnismälisg kleinen, länglichen, schmalen Tafel umsäumt. Schläfe beschuppt, Massetericum fehlt, Tympanicun vorhanden. Kehlfurche angedeutet. Halsband ganzrandig, aus kleinen Tafeln bestehend. Bauchschilder in 6 Längsreihen, Randschildchen klein oder fehlend. Sc. anale von einer Bogenreihe gröberer Schildchen und ron einer Schuppenreihe umsäumt. Die Oberrumpfschuppen sind ziemlich flach und mit Ausnahme derjenigen am Hinterrïcken, welche eine schwach ausgeprägte Vertiefung aufweisen, glatt; am Rücken pentagonal und hexagonal lïnglich schmal. - Kỏopf ziemlich niedergedrückt, in der Backengegend aufgetrieben. Der Rumpf ist breit und abgeplattet. Hinterbeine die Achseln berührend oder nicht ganz erreichend. Der sehr dünn auslaufende, an der Wurzel erweiterte Schwanz überschreitet die Kürperlänge um mehr als das Doppelte. - Gaumenzähne fehlen. - 22 bis 24 Schenkeldrüsen jederseits. - Totallänge: $239 \mathrm{~mm}$. - Habitat: Süd-Griechenland.

L. oxycephala D. B. - Occipitale kleiner als das Interparietale. Zwei Nasofrenalia. Discus palpebralis von den Supraciliaria durch eine Körnerreihe getrennt. Die äulseren Parietalkanten sind vou 1 bis 3 gröferen, länglichen, schmalen Schildern umgeben. Schläfe beschuppt, Sc. massetericum ziemlich grof, 'Tympanicum länglich schmal. Kehlfurche vorhanden oder fehlend. Ganzrandiges Halsband aus kleinen Schildchen bestehend. Bauchschilder in sechs Lüngsreihen angeordnet. Die Aftertafel ist von zwei Bogenreihen kleiner Schildchen umgeben. Die Rumpfschuppen sind klein, durchweg glatt und ziemlich flach, nur gegen ihren hinteren Rand ist eine schwach ausgeprägte Wölbung sichtbar, am Rücken sind sie länglich hexagonal mit abgerundeten Ecken; die Schuppen an den Seiten sind etwas kleiner als am Rücken. Kopf vorn zugespitzt verschmillert, niedrig, flach; Schläfengegend schwach aufgetrieben. Rumpf kurz, ziemlich breit und abgeplattet, Hinterbeine bis zu den Achseln reichend oder etwas über dieselben hinausragend. Der dün auslaufende Schwanz ist etwa anderthalbmal so lang als der Kürper, oberhalb mit gerade abgestutzten Schuppen bekleidet. - Keine Zühne am Gaumen. — 22 Schenkeldrüsen jederseits. - Totallänge: $160 \mathrm{~mm}$. - Habitat: Dalmatien. 
L. Bedriagae Cam. - Occipitale stets bedeutend kürzer, mitunter etwas breiter als das Interparietale. Frontale lang. Ein Nasofrenale. Discus palpebralis von den Supraciliaren durch eine Körnerreihe getrennt. Parietalia an Aulienrande von :- 4 groblieren Tafeln umsiumt. Schläfe beschuppt, in der Regel mit einem Sc. massetericum in der Mitte; Tympanicum vorhanden. Kehlfurche vorhanden. Halsband ganzrandig, aus kleiuen Tafeln bestehend. Bauchschilder in 6 Längsreihen. Randschildchen vorhanden oder fehlend. Sc. anale grok, von zwei Bogenreihen grotser und kleiner Schildchen mmsäumt. Rückenschuppen glatt, flach, öfters mit einem kleinen Grübchen versehen, entweder fün- oder viereckig oder unregelmäfỉig gestaltet. Körper breit, abgeplattet. Kopf breit, flach, niedrig, in der T'mporalgegend backenartig anfgetrieben. Hinterbeine erreichen dic Achseln. Schwanz an der Wurzel verdickt und oben plattgedrückt; er nimmt etwas mehr als $2 / 3$ der ganzen Lảnge des 'Tieres ein. - Gaumenzähne fehlen. - 17 bis 27 Femoraldrüsen jederseits. - Totallänge $226 \mathrm{~mm}$. - Vorkommen: Korsika.

L. depressa Camerano. - Occipitale kleiner als das Interparietale. Sc. frontale normal. Ein Nasofrenale. Palpebralscheibe von den Supraciliaren durch eine Körnerreihe getrennt. Parietalia am Aulienrande vorn von einem grölieren Schildchen umsäumt. Schläfe beschuppt, Massetericum meist vorhanden, Tympanicum vorhanden. Kehlfurche undeutlich ausgeprägt, Halsband nahezu vollkommen ganzrandig. Bauchschilder in fi Längsreihen, Randschildchen vorhanden. Afterschild von 2 bis 3 Bogenreihen kleiner Schildchen umsïumt. Kleine viler grötiere rundliche, kaum gekielte oder glatte, gewölbte liumpfschuppen. - liumpf und kopf abgeplattet. Hinterbeine reichen beim Männchen bis zu den Achseln, beim Weibchen erreichen sie dieselhen nicht. Schwanz an der Bassis breit, niedergedrückt, die doppelte Körperlänge nicht erreichend, mit oberseits melır oder minder stark ausgeprägten Höckerschuppen. - Gaumenzithne fehlen. - 17 bis 22 Schenkeldrüsen jederseits. - Totallänge: 134 bis $180 \mathrm{~mm}$. - Habitat: Trapezunt.

L. taurica Pall. - Occipitale kleiner als das Interparietale. Langes Sc. frontale. Ein Nasofrenale. Discus palpebralis von den Supraciliaren durch eine Körnerreihe getrennt.

Parjetalia am Aufienrande mitunter von 2 bis 3 länglichen Schildern umsäumt. Schläfe mit schuppenartigen Schildchen bedeckt; Sc. massetericum und Tympanicum vorhanden. Sulus gularis deutlich. Halsband schwach, aber deutlich gezähnelt. Bauchschilier in of Längsreihen angeordnet; grosse Randschildchen. Sc. anale durch zwei Bogenreihen von Schildchen begrenzt. Rückenschuppen entweder abgerundet vier- oder fünfseitig oder hexagonal, längs oder schrïg gekielt; Schuppen an den Rumpfseiten etwas grölier, abgerundet viereckig oder pentagonal. gregen die Bauchgrenze zu ungekielt. - Körper ziemlich schlank. Kopf etwas breiter als hoch, pyramidal. Hinterbeine erreichen nicht ganz die Achseln. Schwanz die doppelte Körperlänge 
nicht erreichend, oberseits mit stumpfwinkelig ausgezogenen Schuppen besetzt. - Gaumenzähne sind vorhanden. - 16 bis 23 Schenkeldrüsen jederseits. - Totallänge: 130-193 mm. — Vorkommen: Krym, Balkan-Halbinsel, Insel Tinos, Corfu (?).

L. peloponnesica, Bibr. Bory. - Occipitale bald breiter und etwas länger, bald schmäler und kürzer als das Interparietale. Frontale in der Regel mäßig groß, ebenso lang oder kürzer als die Frontoparietalia. Palpebralscheibe und Supraciliaria zusammenstossend. Ein Nasofrenale. Parietalia am Aufsenrande mitunter (namentlich bei den Männchen) von 2 bis 3 größeren, länglichen Tafeln umsäumt. Schläfe mit sehr grok̇en Schildern bekleidet. Massetericum meist deutlich ausgeprägt, Tympanicum vorhanden. Sulcus gularis fehlend. Halsband ganzrandig. Bauchtafeln in 6 Längsreihen; Randschildchen vorhanden. Sc. anale durch zrei Bogenreihen von Schildchen und Schuppen begrenzt. Schuppen am Rücken rundlich-hexagonal, ungekielt. Von ziemlich kräftigem und gedrungenem Körperbau. Kopf pyramidal, nur etwas breiter als hoch. Hinterbeine über die Achseln hinausragend. Schwanz mindestens zweimal so lang als der Körper, oberseits mit ganzrandigen und stumpfwinkelig ausgezogenen Schuppen bedeckt. Gaumenzähne vorhanden. - 18 bis 22 Schenkeldrüsen jederseits. - Totallänge 172 bis 239 mm. - Verbreitung: Griechenland und einige griechische Inselu, so z. B. Cephalonia.

L. Dugesi Milne Edwards. - Occipitale etwas breiter, mitunter auch länger als das Interparietale, Sc. frontale ziemlich breit, mäkig lang. Zwei Nasofrenalia. Discus palpebralis von den Supraciliaren durch eine Körmerreihe getrennt. Parietalia am Außenrande ohne größsere Schildchen. Schläfe beschuppt, Massetericum fehlend, Tympanicum vorhanden. Sulcus gularis vorhanden. Halsband fanzrandig. Bauchschilder in 6 Lüngseiben; ziemlich grobe Randschildchen. Sc. anale durch eine Bogrenreihe von Schildchen umsäumt. Rückenschuppen klein, rundlich, gewölbt und ungekielt; Seitenschuppen etwas gröŁer, rundlich oder abgerundet vierseitig. - Körper ziemlich gedrungen, breit. Kopf pyramidal, stark zugespitzt, breiter als hoch. Hinterbeine die Achsel erreichend. Schwanz kurz, mit oberseits abgerundeten und zugespitzten Schuppen besetzt. - Gaumenzähne rorhanden. - 21 bis 23 - auch 15 (nach Duméril) Femoraldrüsen jederseits. - Totallänge 162 mm. -- Habitat: Madeira, Teneriffa (?), St. Mlaria, Graciosa (Azoren.).

L. Gallotti, D. B. - Occipitale etwas breiter und witunter auch länger als das Interparietale. Sc. frontale lang. Ein Nasofrenale. Discus palpebralis von den Supraciliaren durch eine Schuppenreihe getrennt. Parietalia am Aufenrande hinten von einer gröferen länglichen Tafel und von einigen kleinen schuppenähnlichen Schildchen umsäumt. Schläfe mit schuppenartigen, klcinen Schildchen oder Schupnen helieidet; Iassetericum und Trmpanicum rorhanden. 
Sulcus gularis undeutlich. Halsband ganzrandig, bogenförmig. Bauchtafeln in 12 Län๕rsreihen; Randschildchen vorhanden, vorn in zwei Längsreihen gestellt. Sc. anale durch zwei Bogenreihen ron Schildchen begrenzt. Liticliemschuppen lineser als breit, polygonal, hoxagonal, stumpf selicelt, an den Rumpfseiten und an Hinterrücken mehr vierseitig mit leicht abgerundeten Ecken. Körper kräftig, gedrungen. Kopf bei den ausgewachsenen Individuen sehr groli. Hinterbeine bis zu den Achseln reichend. Schwanz ziemlich kurz. - Gaumenzähne vorhanden. - 29-30 Femoraldruisen jederseits. - 'Totallönge bis $330 \mathrm{~mm}$ - - Fundorte: 'Teneriffa, Madeira, Ferro, Gomera.

L. atlantica, P eters, Doria. - Occipitale mitunter etwas grö̈er als das Interparietale. Sc. froutale lang. Ein Nasofrenale. Palpebralscheibe von den Supraciliaren durch eine Schuppenreihe getrennt. Parietalia am Aulienrande hinten von einer gröferen, länglichen Tafel unci von einigen kleinen Schildchen begrenzt. Schläfe mit kleinen Schildchen bekleidet, Massetericum fehlend, Tympanicum vorhanden. Sulcus gularis undeutlich oder fehlend. Halsband gezähnelt. Bauchschilder in 8 bis 10 Längsreihen, Randschildchen in zwei Längsreihen angeordnet. Sc. anale durch 2 Bogenreihen von Schuppen begrenzt. Rückenschuppen ziemlich groli, schwach geschindelt, viereckig, länger als breit, diagonal gekielt oder rhombenförmig, breiter als lang, mit abgerundeten hinteren Ecken; Schuppen an den Rumpfseiten etwas länger und schmäler, entreder spurweise gekielt oder glatt. - Körper ziemlich schlank. Kopf bein ơ pyramidal, stark zugespitzt, beim $q$ etwas Hacher. Hinterbeine beim ơ über die Achseln hinausragend, beim $\bigcirc$ etwas kürzer. Schwanz erreicht nicht die doppelte Körperlänge, oberhalb mit ganzrandigen und winkelig ausgezogenen Schuppen bedeckt. - Gaumenzähne vorhanden. - 17 bis 19 Femoraldrisen jederseits. - Totallänge: 142 bis $145 \mathrm{~mm}$. - Vorkommen: Teneriffa, Madeira, Lancerote.

L. perspicillata, D. B. - Occipitale kürzer, aber breiter als das Interparietale. Sc. frontale breit, mäßigg lang; 2 übereinander stehende Nasofrenalia. Discus palpebralis von den Suplaciliaren durch eine Körnerreihe getrennt. Parietalia am Aulienrande ohue grötsere sichilder. Schläe beschuppt, Massetericum f'ehlend, Tympanicum meist klein. Sulcus gularis vorhanden. Halsband ganzrandig. Bauchschilder in 10 Längsreihen angeordnet, Randschildchen vorhanden. Sc. anale von zwei Bogenreihen kleiner Tafeln umsäumt. Rumpfschuppen ziemlich grof, rundlich, spurweise gekielt. - Rumpf ziemlich breit und kurz. Kopf klein, sehr kurz, in der Schlïfengegend breit. Hinterbeine kurz und zart gebaut, die dchseln nicht erreichend. Schwanz nahezu ebenso lang als der übrige Körper. - Gaumenzähne fehlen. - 18 bis 19 Schenkeldrüsen jederseits. - Cnteres Ausenlid durchsichtig. - Totallänge: $150 \mathrm{~mm}$. - Habitat: Algerien. 
L. vivipara, Jacq. - Occipitale kleiner als das Interparietale. Discus palpebralis und Supraciliaria zusammenstoliend. Ein Nasofrenale. Parietalia an Aulienrande mitunter von zwei grö̈lieren, länglichen Schildchen umsiiumt. Schläfe mit grolien Schildern bekleidet, mitunter mit Sc. massetericum in der Mitte; 'Tympanicum vorhanden. Sulcus gularis fehlt. Halsband stets gezähnelt. Bauchschilder in of Längsreihen angeordnet; bei den osteuropäischen Individuen erreichen die Randschildchen eine bedeutende GröLe. Sc. anale durch zwei Bogenreihen von Schildchen umsämmt. Schuppen des Rückens deutlich längsgekielt, entwedè regelmälisig länglich sechseckig und länger als breit oder ebenso breit oder sogar breiter als lang und unregelmäfßig gestaltet; gegen die Bauchgrenze hin sind die Schuppen gröfer, breiter, flacher, abgerundet vierseitig und spurweise gekielt. - Körper bald mehr, bald weniger schlank, Kopf mäfig gestreckt, breiter als hoch. Vorderbeine selten bis zu den Nasenlöchern reichend, Hinterbeine niemals die Achseln erreichend. Schwanz bis zur Nitte ziemlich gleichdick und gewöhnlich ebenso lang $\left(\sigma^{\top}\right)$ oder nur wenig länger als der Körper $(9)$, mit oberseits stumpfwinkelig und spitz ausgezogenen Schuppen. - »Am Gaumen mangeln meist die Zähne« (Leydig). Zahl der Femoraldrùsen: 9 bis 12 jederseits. - Totallänge: 109 bis $160 \mathrm{~mm}$. - Verbreitung: Nord- und Mitteleuropa, Sibirien.

L. praticola, Eversm. - Occipitale bedeudend lürzer, mitunter breiter als das Interparietale. Ein Nasofrenale. Discus palpebralis von den Supraciliaren durch eine Reihe Schuppen getrennt. Parietalia am Aufsenrande von drei gröferen und kleineren Randtafeln gesäumt. Schläe mit sehr grolisem, die Randtafeln berührendem Sc. massetericum, mit länglich schmalem Tympanicum und wenigen kleineren und größeren Schildchen bedeckt. Sulcus gularis fehlt. Halsband schwach gezähnelt, aus wenigen Tafeln bestehend. Bauchschilder in 6 Längsreihen angeordnet, Randschildchen klein. Sehr großes Afterschild, von einer Bogenreihe kleiner Schildchen umsäumt. Ruckenschuppen länglich, hexagonal deutlich längsgekielt; Schuppen an den Rumpfseiten pentagonal, vierseitig, schwach diagonal gekielt und kleiner als am Rücken. Körper schmächtig, ziemlich liurz; verhältnismäß̊̉ig lang, breiter als hoch. Hinterbeine zart gebaut, etwa bis zu den Achseln reichend. Schwanz nach hinten zu verjüngt umd kurz, oberseits mit zugespitzten Schuppen besetzt. - Zähne am Gaumen mangelnd. - 10 bis 12 Schenkeldrüsen jederseits. - Totallänge: 113 bis $148 \mathrm{~mm}$. - Habitat: Cis- und Transkaukasien.

L. echinata, Cope. - Occipitale kürer, aber breiter oder ebenso breit als das Interparietale. Ein Nasofrenale. Palpebralscheibe von den Supraciliaria durch eine Körnerreibe getrennt. Parietalia am Aufenrande ohne größsere Tafeln. Schläfe beschuppt; Massetericum, Tympanicum und Sulcus gularis fehlen. Halsband gezähnelt. Bauchschilder in 6 Längsreihen; 
gekiclte Randschuppen. Sc, anale von if gröliseren l'afeln umsäumt. Rü̈ckenschuppen vierseitig, mit abgerundetem hinteren und nach aulien gerichteten Eck, diagonal gekielt und lïnger als

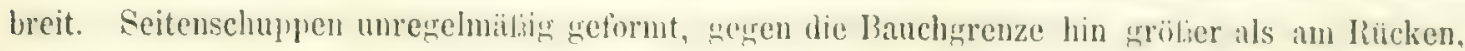
diagonal gekielt. - Körp̣er gestreckt, ziemlich gleich dick, am Rücken gewölbt, mit platter Unterseite; Kopf lang, breiter als hoch. Hinterbeine erreichen nicht die Achseln. Schwanz den Körper fast dreimal abertreffend, oberhalh, am Vordertheile mit dornigr ausgezorenen Schuppen. - Gaumenzäbne fehlen. - 12 bis 13 Schenkeldrüsen jederseits, - Totallänge $370 \mathrm{~mm}$. Habitat: Ober-Guinea.

L. tessellata, Smith. - Occipitale oval, sehr klein nach rückwärts gerückt. Interparietale sehr lang. Frontale ziemlich kurz. Zwei Nasofrenalia. Die äulieren Parietalkanten von 2 bis 8 länglichen Schildchen begrenzt. Schläfe mit kleinen Schildchen bekleilet, Sc. massetericum tehlt, Tympanicum unterscheidbar; 4 vordere Supralabialia. Sulcus gularis fehlend. Halsband äufiserst schwach gezähnelt. Bauchschilder in 6 bis 8 Längsreihen gestellt. Eine Aftertafel. Ruickenschuppen ungekielt, gewölbt, rundlich, hexagonal und pentagonal. -- Körper gestreckt, fast cylindrisch. Hinterbeine bis zu den Achseln reichend. Gaumenzithne vorhanden. - 13 Schenkeldrüsen jederseits. - Totallänge: $132 \mathrm{~mm}$. - Habitat: Süd-Afrika. - subsp. pseudotessellata m. - Zwei Aftertafeln. Hinterbeine die Achseln kaum erreichend, 17 Schenkeldrüsen jederseits. 5 vordere Supralabialia. 'Totallänge: $205 \mathrm{~mm}$. Habitat: 'Tette.

L. Cameranoi m. - Occipitale sehr klein, nach rückwärts gerückt. Imparietale grof, auffallènd lang, beinahe ebenso lang wie das Sc. frontale. Zwei übereinander stehende Nasorenalia. Discus palpebralis von den Supraciliaria durch eine Schuppenreihe getrennt. Parietalia am Aufenrande von einigen größeren Schildern umsäumt. Schläfe beschuppt, Massetericum fehlend, Tympanicum sehr klein. Sulcus gularis fehlt. Halsband äufierst schwach gezähnelt. Bauchschilder in acht Längsreihen angeordnet, Randschildchen vorhanden. Afterspalte von vier kleinen Täfelchen begrenzt. Rückenschuppen kleiner als bei tesscllata. - Körper ziemlich gestreckt; Kopf höher, Hals länger als bei tessellata. Hinterbeine die Achseln berührend, mit bedeutend kürzeren und dickeren Fingern und Zehen als bei tessellata. Schwanz anderthalbmal so lang als der Körper. - Gaumenzähne vorhanden. - 15 Schenkeldrüsen jederseits. - Totallänge $202 \mathrm{~mm}$. - Fundort: Tette.

L. taeniolata Smith. - Occipitale sehr klein und stark nach rückwärts zurückgedrängt. Sc. frontale und interparietale sehr lang. Ein Frenonasale. Discus palpebralis von den Supraciliaren durch Schuppen getrennt. Parietalia am Aufenrande von 3 his 4 Schildchen umsiumt. Schlïfe mit gewolbten Schuppen. Massetericum und Tympanicum fehlen. Sulcus gularis fehlt. 
IJalsband auliserst schwach gezähnelt, Banchschilder in 6 Längsreihen gestellt. Sc. anale mit verhältnismäkig groben Schildchen umgeben. Rückenschuppen glatt, unregelmäßíg gestaltet, fünf- und vierseitig mit abgerundeten Ecken, körnig und eiförmig hexagonal; Schuppen an den Seiten etwas gröfser und schwach geschindelt. - Körper gestreckt; Kopf kurz, ziemlich hoch, in der Temporalgegend stark backenartig aufgetrieben. Hinterbeine die Achseln nicht erreichend. Schwanz von mehr als doppelter Körperlänge mit oberseits stumpfwinkelig ausgezogenen Schuppen. - Gaumenzähne fehlen. - 14 Schenkeldrüsen jederseits. - Totallänge: $184 \mathrm{~mm}$. - Vorkommen: Klein-Namaqua.

Die Linien eines Schemas der Affinität der Lacerten lassen sich in folgender Weise ziehen:

1. Gruppe. - Diese enthält die gröberen Arten ocellata und viridis, ihre Varietäten und endlich die intermediären Formen pater und paradoxa; über die systematische Stellung der princeps ist bis dato nichts Sicheres bekannt.

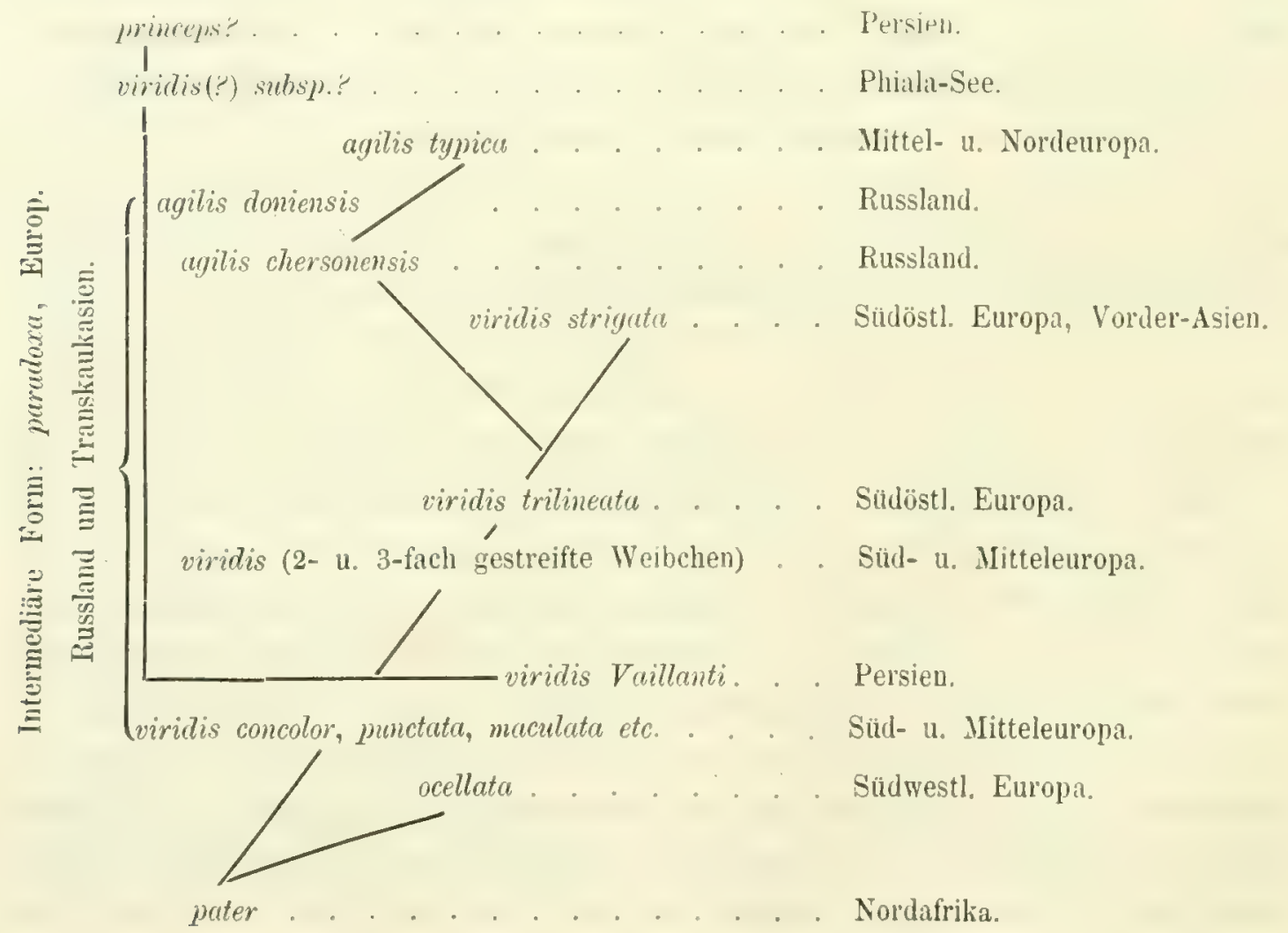


II. Gruppe. - Sie enthält eine Anzahl kleiner, muralisühnlicher, pyramidocephaler, platycephaler und oxycephaler Formen, sowie auch die abirrenden, isoliert dastehenden Arten Galloti, $\because$ atlantica und perspicillata.

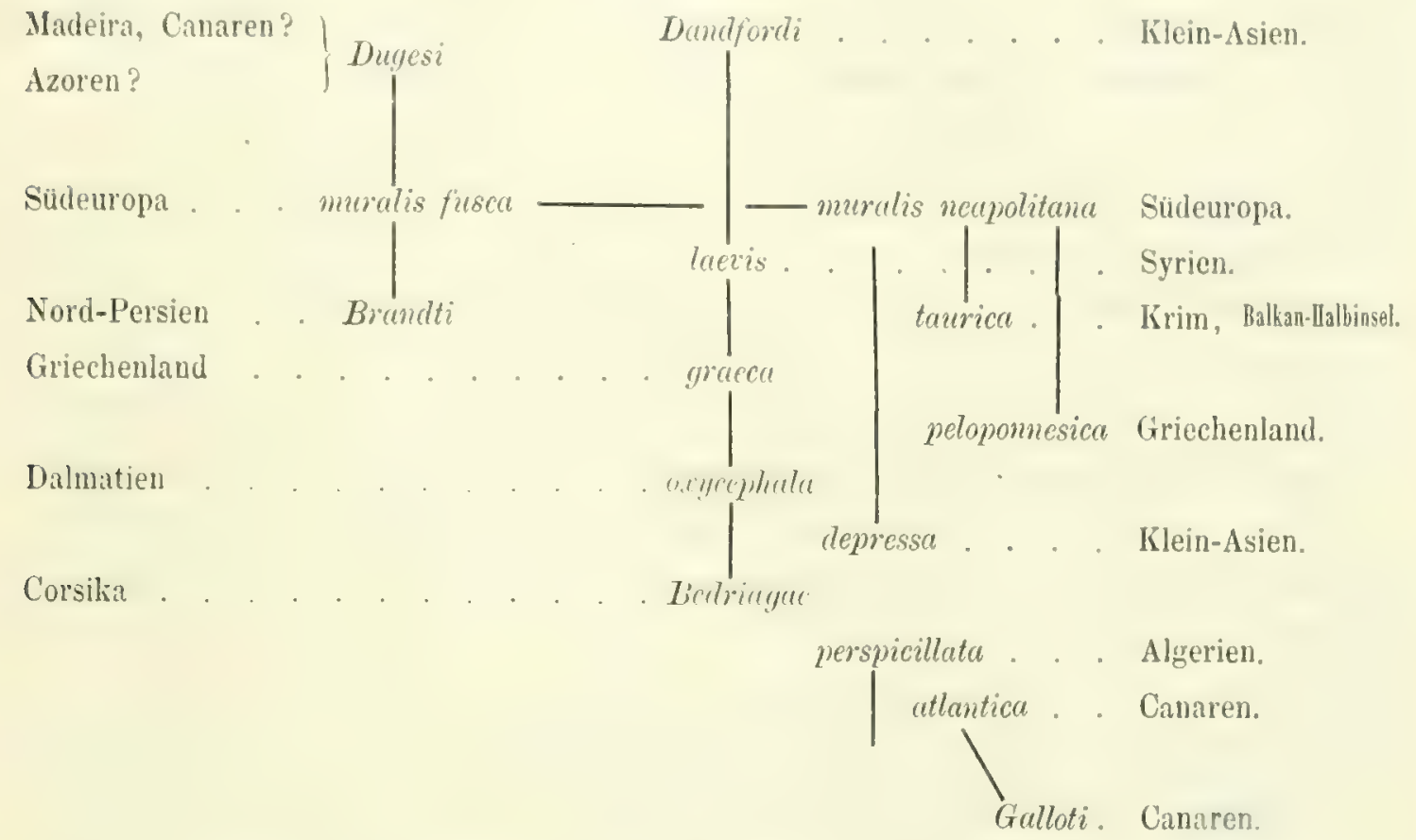

III. Gruppe, L. praticola und vivipara enthaltend; erstere, in den Kaukasusländern einheimische Species kamn als Verbindungsglied zwischen muralis und vivipara betrachtet werden.

Die IV. und V. Gruppe enthalten endlich vollstïndig isoliert dastehende Repräsentanten; es sind dies einerseits die echinata Cope aus Liberia und Kamerun und andererseits die tessellata Smith, taeniolata Smith und Cameranoi m., welche, wie bereits oben angedeutet, wohl eher zwei anderen Gattungen angehören dürften.

\section{Lacerta ocellata Daud. (1802).}

Char. - Scutum occipitale scuto interparietali multum maius, scuto frontali multum latius, scuto parietali acquum vel eo latius. In nonnullis speciminibus hispanicis scutum occipitale scuto frontali patlo latius et scuto parietali paulo angustius. Discus palpebralis in margine externo serie squamarum limbatus; nasofrenalia duo superposita. 'Tempora scutellata, disco masseterico nullo scutisque duobus ad marginem parictalium. Supralabialia anteriora 4. Sulcus gularis nullus. Collare denticulatum. Scuta abdominalia per series octo vel decem disposita. 
Squamae dorsi parvae, granosae, ovatae vel rotundato-subquadrangulares, subcarinatae. Dentes in palato. Caput magnum, pone crassum, multum latius quam altius, satis longum. Corpus valde incrassatum, subcylindricum. Pedes crassi, postici axillas contingentes. Cauda duplan corporis longitudinem non contingens (q) vel bis longior trunco. Pori fémorales utrimque 14-16. - Longitudo $544-600 \mathrm{~mm}$.

Synonymie.

Lacertus major gibraltariensis, Petivier, Gazophylacii naturae et artis decades, tab. XCI, fig. 1. London 1702.

Lacertus viridis, maculatus, major, G. Eduards, Hist. nat. des oiseaux rares, t. IV, pl. CCII. Londres 1751.

Le Líard vert, Bonnaterre, Tableau encycl. méthod. Erpétologie, pag. 46, pl. VI, fig. 3. Paris 1789; var. a. de Provence, Latreille, Hist. nat. des Salamandres, pag. XIII. Paris 1800; Latreille et Sonnini, Hist. nat. Rept., t. I., pag. 235. Paris 1802.

Le grand Lézard vert ocellé, Cuvier, Règne animal 1-re édit., t. II, pag. 28; 2-e édit, t. II, pag. 20. Paris 1817, 1829.

Lacerta ocellata, Daudin, Hist. nat. Rept., t. III, pag. 125, PI. XXXIII. (part.); II e r r em, Versuch eines Systems d. Amphibien S. 65. Marburg 1820; Milne Edwards, Recherches zoologiques etc. in: Ann. des sc. nat. 1829; Risso, Hist. nat. Eur. mérid., t. III, pag. 86. Paris 1826; W agler, Natür]. System d. Amphibien, S. 155. Nünchen, Stuttgart und Tübingen 1830 ; Bo naparte, Iconografia della Fauna italica, II. Roma 1832-40; Wieg mann, Herpetologia mexicana, pars. I, pag. 9. Berlin 1834; Dunéril et Bibron, Erpétologie générale, t. V, pag. 218 (partim); Dugès, Mém. sur les espèces indigènes du genre Lacerta in. Ann. d. sc. nat., t. XVI, pag. 34, Pl. XXV, fig. 2, 7, 8, 9; Desmaret, Faune Française, Rept. Saur. Pl. V; Gray, Cat. Liz. Brit. Mus., pag. 30. London 1845 (part.) und Synopsis rept. in Griffith's Animal Kingdom, pag. 32 (Eyed Lizard); De Betta, Rettili et Anfibi. Fauna d'Italia in: L'Italia sotto l'aspetto fisico, storico etc. Milano 1874; Lataste, Essai d'une Faune herpétol. de la Gironde in: Act. Soc. Linn. Bordeaux, t. XXX; Boettger, Amphibien aus Südportugal ete. in: Zeitschr. f. d. ges. Naturwiss., Bd. LII, S. 502 (var. margaritata Sch inz) und Beitr. z. Kenntu. d. Rept. u. Amphibien Spaniens u. d. Balearen in: Abhandl. d. Senckenberg. naturf. Gesellsch. XII. Bd.; v. Bedriaga, Herpetolog. Studien in: Arch. f. Naturg.; XXXXV. Jahrg., 1: Bd.. S. 316 ; Boulenger in: Proc. Zool. Soc. 1881, pag. 743 ; Schreiber, Herpetologia europaea, 423. Braunschweig 1875. 
Lacerta janaicensis, Daudin, Ilist. nat. Rept., t. III, pag. 119; Ku hl, Beitr. z. Zoologie 1 . vergl. Inatomie, S. 12:. Erankf. a. M. 1820.

Lacerta lepidu, D a udin, l. c. pag. 204. Pl. XXXViI, figg, 1.

Thimon ocellatus, 'T's chudi in: Isis XXIX, S. 551 ; Bonaparte, Amphibia curopaca in:

Mem. Accad. Scienze di 'Torino. Serie II, Tom II, pag. 385 (part.); Camerano, Considerazioni sul Genere Lacerta in: Atti Accad. sc. di Torino, Vol. XIII. 1877.

Chrysolampms occllatus, Fitzinger, Systema reptilium I. pag. 20. Wien 1843 und Amphibien in: Sitzungsber. k. Akad. d. Wissensch. Bd. 42, pag. 401. Wien.

Lacerta margaritata, Schinz, Naturg. und Abbild. d. Rept. S. 98, Taf. XXXVII, fig. 3 (1883) und Europ. Fauna Bd. II, S. 14 (1840).

Lacerta senegatensis, Gray in: Ann. Nat. Hist. II. pag. 279. 1883.

Die grime Eidechse, Bechstein. De Lacepèdes Naturg. d. Amphibien. Bd. II., S. 21 , Taf. II. Fig. 1. Weimar 1800.

Le Lézard gentil, Cuvier, liégne animal 1-re édit. t. II, pag. 28.

Le grand Lézarl vert, Bor y St. Vine. Résum. d'erpét. pag. 104 (nach Duméril und Bibron!).

A proximative II a in Millimetern ausgedrückt:

\begin{tabular}{|c|c|c|c|c|c|c|c|c|c|c|}
\hline \multirow[b]{2}{*}{ Totallänge des Tieres } & & \multirow{2}{*}{\multicolumn{2}{|c|}{. }} & & & \multicolumn{3}{|c|}{$\underbrace{j u v . ~}$} & \multirow{2}{*}{$\begin{array}{l}\text { mas. } \\
514 .\end{array}$} & \multirow{2}{*}{$\begin{array}{l}\text { fem. } \\
459 .\end{array}$} \\
\hline & & & & & - & & 9.4. & 89 . & & \\
\hline Länge des Kopfes & . & & • & . & . & & $11-11^{1 / 2}$ & 12. & 54. & 40. \\
\hline Höbe des Kopfes & . & & • & . & - & & 5. & $61 / 2$. & 32. & 21. \\
\hline Breite des Koples. & . & & & . & . & & $71 / 2$. & $81 / 2$. & 41. & 29. \\
\hline Grülster Umfang des & Kopfe: & & & - & - & & 22. & 25. & 126. & 90. \\
\hline Breite des Pileus. & . & & & . & - & & 6. & 7. & $26^{1 / 2}$. & 19. \\
\hline Umfang des Halses & - & & & . & - & & 21. & 26. & 26. & $18^{1}$ \\
\hline Länge des Rumpfes. & . & & 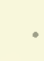 & . & . & & $281 / 2$. & 26. & 140. & 139. \\
\hline Umfang des Rumpfes & . & & & . & & & 22. & 26. & 137. & 119. \\
\hline Länge des Schwanzes & & & & & & & 54. & 55. & 350. & 280. \\
\hline Länge der Vorderext1 & remitiit & & & . & 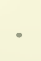 & & 19. & 15. & 58. & $56 \%$ \\
\hline Länge des Torderfulat & es. & & & . & & & 6. & 6. & 25. & 23. \\
\hline Länge der Hinterextr & remitat & & & . & & & $20^{1 / 2}$ & 20. & 85. & S3. \\
\hline Länge des Hinterfulie & es . & & & & & & 10. & 10. & 44. & 42. \\
\hline
\end{tabular}


Allgemeine hörpergestalt.

Unter den in Europa lebenden Echsenarten steht, infolge ihrer Gröbe und Schönheit, die ocellate oben an. Sie erreicht bis ein Meter an Länge ${ }^{1}$ ) und übertrifft alle ihre Geschwister an Stärke. Der, namentlich bei den ausgewachsenen Männchen auffallend grolie, ziemlich deutlich abgesetzte Kopf ist nahezu pyramidal, indem seine Seiten bei oberflächlicher Untersuchung von annähernd gleichem Breitendurchmesser zu sein scheinen. Beim Weibchen ist der Kopf etwas mehr niedergedrückt und steht in Betrefï der Länge und breite hinter demjenigen des Alännchen zuruck. Bei beiden Geschlechtern repräsentiert die Querachse mitten durch die, besonders beim Männchen stark backenartig aufgetriebene Schläfengegend dje gröfte Breiten-Ausdehnung des Kopfes, während sein gröfiter Höhendurchmesser durch die Hinterhauptregion geht. Von den Augen an nach vorn zu erscheint der Kopf nicht nur allmählich schmalschnäuzig werdend, sondern auch im Schnauzenteile, von der Seite gesehen, zusammengedrückt und zugleich vor den Augengruben leicht eingedrückt. Die oberhalb ziemlich thache oder, wie es bei den alten Männchen der Fall ist, in der Mittellinie leicht eingedrückte Kopfdecke senkt sich gegen die abgerundete Schnazenspitze sanft ab. Die Palpebralscheibe, die die Aligenhoble uherdeckt, ist bein Männchen stets winkelig erhoben, während dieselbe bein Weibchen nur äußserst leicht gewölbt erscheint. Ferner zeichnet sich das Männchen durch seinen etwas abgerundet vierseitigen Rumpf, sowie überhaupt durch den auffallend kräftigen und gedrungenen Körper aus, während das Weibchen von schlankerem, minder gedrungenem Körperbau ist und von oben leicht niedergedrückt erscheint. Auferdem muls noch linzugefügt werden, dąs das Weibchen den Rumpfumfang und die Körperlänge des Männchens nicht erreicht. Die Vorderbeine reichen, an den Körper angelegt, in der Regel bis an die Nasenlöcher, die hinteren gewöhnlich bis gegen die Achseln. Der, besonders beim Mäunchen an der Wurzel sehr kräftige, dann aber allnählich dünn ausgezogene Schwanz beträgt bei diesem etwas mehr, beim Weibchen etwas weniger als zwei Drittel der Gesamtlänge.

Äu l̇ere Körperbedeckung.

Die Kopfschilder sind durch starke Vertiefungen von einander getrennt; bei alten männlichen Individuen haben sie ein runzeliges Aussehen und zeigen viele furchenartige Impressionen und Erhabenheiten; bei den jungen sind sie dargegen fast glatt oder absolut glatt. Die hinterste unpare, als Hinterhauptschild bezeichnete Pileustafel zeichnet sich durch ilure bedeutende Gröle aus; sie ist gewöhnlich gut doppelt so breit und beinahe anderthalbual so lang

2) Bullet. de la Soc. des sc. nat. de Neuchatel, t. VII, livraison 2, pag. 226. 
wie das, sich vorn an sie anfügende fünfeckige. rückwärts etwas verschmälerte Interparictale und breiter als das Stirnschild. In Bezug auf seine Configuration ist das Sc. occipitale sehr variabel: bald stellt es, sozusagen ein gleichschenkeliges Dreieck dar, dessen nach vorn gekehrte Spitze abgestutzt oder abgerundet erscheint, bald aber ist es vorn dermafien abgestumpft dass es eine trapezförmige Gestalt annimmt. Sowohl diese beiden genannten median liegenden Tafeln, als auch zum Teil die auf das Interparietale folgenden Frontoparietalen werden jederseits von je einem, nahezu zweimal so langen wie breiten, nach rückwärts ziemlich verschmälerten, vorn aber erweiterten und abgerundeten Parietale begrenzt; sein Innenrand ist stumpfwinkelig gebogen, wobei die Schenkel an der Grenzlinie des Interparietale und des Occipitale aneinander stoßen; sein, hinten von einer kleinen elliptischen oder bohnenförmigen, seitlich von zwei grölseren, länglichen Tafeln begrenzter Aulienrand ist bogenfürmig abgerundet. - Die Beschilderung des Hinterkopfes bei den ganz jungen Exemplaren ist grundverschieden von derjenigen bei den Alten; so ist z. B. das Interparietale verhältnismäßig bedeutend breiter und zwar ebenso breit wie beide Frontoparietalia zusammen genommen, während die Parietalia im.Gegenteil kleiner und mitunter der Breite nach jederseits in zwei schräg von innen nach aufen gestellte Partieen gespalten erscheinen. Statt der bei den älteren ocellata unpaaren, großen Occipitaltafel sind in der Regel fünf, zuweilen aber auch sieben kleine Schildchen konstatierbar; in ersteren Falle sind es hinten zwei breite, ovale nebeneinander und drei davor stehende, gleichfalls in einer Querreihe angeordnete Schildchen; im zweiten Fall stehen vorn zwei hintereinander sich befindende Schildchen und diese werden seitlich und hinten von einer, aus fün Täfelchen gebildeten Bogenreihe umgeben. Da die Veränderungen, welche die zahlreichen Hinterhauptsschildchen bis zu ilurer endgültigen Ausbildung durchzumachen haben, sich stets unter der, zum Abwerfen bestimmten Oberhaut vollzichen, und die jungen 'Tiere nach jedesmaliger Häutung mit Rücksicht auf die Beschilderung der Ocejpitalrenion ein ganz verschiedenes Ausselsen bieten; so lälat sich nicht mit Sicherheit constatieren, auf welche Weise die sieben primären Schildchen bei der Ausbildung der eben beschriebenen Tafeln bei den erwachsenen Perleidechsen participieren. Aus der Untersuchung des mil allerdings kïrglich zu Gebote stehenden Materials an jungen ocellata glaube ich doch schliefsen zu können, dafs die Reduktion der Sieben- resp. Fünfzahl der Hinterhauptsschilder durch Zusanmenwachsen derselben vor sich geht und zwar, indem die zwei hintersten, der Quere nach gestellten Schilder sich zu einem einzigen breiten, etwa ovalen Occipitale vereinigen, um späterhin mit dem, sie vom Interparietale trennenden centralen Täfelchen zusammenzuwachsen. Auf ähnliche Weise findet wohl die Vereinigung der seitlich von letzterem liegenden Schildchen mit den Parietalen statt. 
Was die übrigen Pileusschilder anhelangt, so sind dieselben mit Ausnahme des Interparietale und der Frontoparietalia im Grofen und Ganzen bei jungen und alten Tieren identisch. Das anfangs auffallend breite, vorn stumpfwinkelig endende, hinten und seitlich abgerundete Interparietale wird mit zunchmendem Alter bedeutend schmäler und zwar schmäler als es lang ist; es erhält seitlich und hinten mehı oder weniger gerade verlaufende Kanten und wird fünfeckig. Die, wie gesagt, bei den Jungen mitunter jederseits paarig auftretenden Parietalia verwachsen beiderseits zu einem einzigen Schilde und scheinen sich aukerdem noch auf Kosten des Interparietale in die Breite auszudehnen. Die Frontoparietalia, die ursprünglich breiter als lang sind, erscheinen bei erwachsenen Stücken in Gegenteil länger als breit, indem ihre hintersteu, dem anfangs breiten Interparietale angrenzenden känder zugleich mit der Verengung dieses Schildes bedeutend kürzer werden, und in der Mittellinie des Kopfes unter spitzem Winkel zusammenstoßen. Ihre lateralwärts, also wach aufen hin gelegenen Seiten stoßen hingegen stumpfwinkelig aneinander, während ihre nach vorn gerichteten Ränder meist bogenförmig abgerundet und verengt zu sein pflegen. Das, bei den Jungen stark verlängerte, mit abgerundetem Vorder- und ebenfalls gerundetem oder stumpfwinkeligem Hinterrande und endich mit leicht eingebogenen seitlichen Kanten versehene Frontale ist vorn entschieden breiter als hinten und mitunter in zwei hintereinander liegende Teilc gespalten. Bei älteren Tieren tritt am Stimschilde insofern eine Veränderung ein, als es nach rückwärts zu eine allerdings Lurze Spitze aufweist, welche sich zwischen die Frontoparietalia einkeilt, und auferdem cingebogene Kauten zeigt, nach vorn aber einen bogenförmig geschweiften Rand erhält; dabei dehnt es sich mit zunehmendem Alter, namentlich in seinem hinteren Teile, mehr in die Breite aus und wird somit vorn nur wenig breiter als hinten. Die allmähliche Breitenentwickelung des in Rede stehenden Schildes bleibt selbstverständlich nicht ohne Einfluf auf die benachbarten Tafeln: so erscheinen die über den Augen liegenden Schilder und insbesondere die gröferen mittleren, welche den Discus palpebralis konstituieren, bei den Jungen breiter als bei den Alten; der Aufenrand dieser Schilder ist stets mit kleinen Schuppen, welche in einer Reihe angeorduet sind, besetzt, und folglich von den meistens fünf länglich schmalen Supraciliaren getrennt. An den, in der Jugend eher breiten als langen, im Alter inı Gegenteil längeren als breiten Frontonasalen nimmt man zwei gerade und parallel verlaufende Rinder wahr, von denen der eine nach aufen zu liegen kommt, und das später zu erwähnende Kopfseitenschild, wämlich das Freno-oculare berührt, während der innere Rand an das gleichnamige Schild der entgegengesetzten Kopfseite grenzt. Nach vorn zu sind diese Schilder verengt und zeigen zwei, -unter beinahe rechtem Winkel zusammenstofende Seiten, von denen die uach 
innen grerichtete etwa dreimal so lang ist wie die nach aulien gekehrte. Rückwärts sind greichfalls zwei, aber unter spitzen Winkel zusammenstofiende, zweimal gebuchtete Ränder konstaticrbar. Das breite, nach oben ubergewölbte, fünfeckige, mit leicht ausgerandeten Seiten verschene liüsselschild wird von dem, etwa rhombenförmigen Internasale durch zwei, in der Mittellinie der Schnauzenspitze zusammenstoliende Nasorostralen von abgerundet dreieckiger Gestalt getrennt. Die zuletzt genannten Tafeln umgeben mit ihren ïuferen ausgeschnittenen Kändern die rundlichen, seitlich geruckten und zwar über der Naht des Rostrale und des I. Oberlipen. schildes gelegenen und hinten von zwei zicmlich gleich grofien, fünfeckigen, übereinander gestellten Nasofrenalia bengrenzten Nasenlöcher. Das auf die Nasofrenalen folgende hohe, oben mit dem Frontonasale, unten mit dem II. Supralabiale in Berührung stehende Frenale ist voin abgerundet und hinten ausgerandet; das angrenzende breite, schwach nach oben übergewölbte Freno-oculare legt sich in den bogenförmigen Ausschnitt an Hinterrande der zuletzt genannten Tafel hinein; dabei muli noch bemerkt werden, dafis dieses hinten und unten in eine Spitze ausgezogen erscheint, welche zwischen dem Freno-oculare und dem darunter liegenden Supralabiale eingekeilt ist. Am. Hinterrande des Freno-oculare sind zwei ziemlich tiefe Aussclmitte wahrnehmbar; in diese Ausschnitte legt sich einerseits das Supralabiale I, anderseits aber das ansehnliche, verschieden geformte, bald dreieckigre, bald länglich schmale, vorn winkelig, hinten abgestutat endende und auf dem vierten Oberlippenschilde ruhende Präoculare hinein. Hinten grenzt das Präoculare an das nachenförmige Suboculare, das etwa zwei- bis dreimal so breit ist als die übrigen vorderen Supralabialia. Von den vier vorderen Oberlippensehildern wäre das gleichschenkelige erste viereckig, wenn sein Oberrand nicht bogig geschweift erschiene; die daranf folgenden gleichnamigen Schilder sind mit ihren konvexen Seiten nach vorn und mit ihren konkaven Seiten mach hinten gerichtet und zeigen eine scharf ansgeprägte, den Kieferrändern etwa parallel sich hinziehende und auf das Suboculare übergehende Furche. Supralabialia posteriora sind in der Regel drei vorhanden; sie stellen ziemlich ansehnliche fünfseitige Tafeln dar. Dic grölèen Schläfenschilder sind ebenfalls fünfseitig, die kleineren hingegen sechseckig, länglich schmal und spurweise dachig gekielt. Ein gröberes Cuntralschild, das als IIassetericum gedentet werden könnte, tritt nicht hervor; gegen das Ohrloch hin nehmen die Schilder allmählich an Grölse ab und erscheinen am Ohrrande selbst rundlich körnig; als Tympanicum mag dicjenige Jïnglich ovale Tafel bezeichnet werden, welche sich oben am Vorderrande des Ohrloches befindet. Sowohl die T'emporalia als auch die Supralabialia und die vorn liegenden Schilder werden durch drei bis vier Reihen kleiner Schildchen vom Orbitalrande getrennt. Die undurchsichtigen Augenlider sind mit kleinen, flachen, polygonalen, reihenweise 
angeordneten 'Täfelchen bedeckt. Das ovale, unten in der Regrel schmäler werdende Ohrloch ist seitlich gelegen. Jederseits werden 6 bis 7 Sublabialia unterschieden. Die zwei vorderen Paare und teilweise auch das dritte Unterkieferschilderpaar treten in der Mittellinie des Kopfes in Kontakt; im Ganzen sind 6 Unterkieferschilderpaare vorhanden.

Die „Kehlfurche«, welche sich von einer Ohröffnung bis zur entgegengesetzten querüber hinwegzicht, ist wenig ausgeprägt, obgleich sie sich durch eine Reihe kleiner Schuppen dokumentiert. Diese Schuppenreihe trennt die eigentlichen, vorn langgestreckten polygonalen oder hexagonalen, in der Mitte aber nahezu ebenso langen als breiten abgerundet sechseckigen und an den Seiten wiederum längeren und deutlich sechseckigen Kehlschuppen von den ziemlich regelmäfigig hexagonalen Halstafeln, die stets breiter als lang sind. Die Halsseiten sind mit rundlich körnigen Schuppen besetzt. Das Halsband ist schwach bogig, an freien Rande deutlich gezähnelt und aus 9 bis 11 Tafeln bestehend, von denen die mittlere Tafel merklich vergrö̈ert nud trapezförmig erscheint; außerdem schließen sich diesen gröferen Halsbandtafeln jederseits noch 2 bis 3 kleine Schildchen an. An den Halsseiten und zwar vor den Wurzeln der Vorderbeine setzt sich das Collare nach aufwärts in die sogenannte Schulterfalte fort.

Die Bauchschilder sind in 28 bis 32 Querreihen und 8 bis 10 Längsreilen angeordnet. Das zehnte oder äuferste Paar besteht aus - besonders bei den Weibchen - bedeutend kleineren, das mediane aus etwa halb so breiten Schildern als die daran stoßenden; von den Bauchtafeln gehen 12 bis 18 auf das Brustdreieck. Vor der Afterspalte befindet sich ein grofes, fünfseitiges, mit deutlich ausgeprägten oder abgerundeten Ecken versehenes Anale, das an seiner längsten, der Spalte zugekehrten Kante frei von Schuppen ist; dagegen ist es seitlich und vorn von zwei bis vier Bogenreihen ziemlich grobser, vier und fünfseitiger oder unregelmässig gestalteter Tafeln umgeben. Die Form der Caudalschuppen ist variabel: bei den jungen ocellata sind diese Schuppen oberwärts vorn au ihren freien Rändern leicht abgerundet, seitlich aber in eine Spitze ausgezogen; mit zunebmendem Alter erhalten die oberen, auch die vorderen Schuppen ziemlich spitze Enden, während die zu unterst liegenden vorderen entweder abgestutzt, abgerundet oder aber allmählich nach rückwärts verschmälert erscheinen; gegen das Schwanzende hin werden die Schuppen sowoht oben als unten meist stumpfwinkelig ansgezogen.

Die kleinen rundlichen Rumpfschuppen sind nur in der Rückenmitte, namentlich gegen die Schwanzwurzel hin, obschon schwach, so doch ziemlich deutlich dachig gekielt; in der Nackengegend büfen die körnig aussehenden Schuppen ihre Kiele ein; auf den Rumpfseiten sind gleichfalls ungekielte, aber nach hinten zu leicht aufgetriebene, größere, längere als breite, abgerundete oder vorn abgestutate und nur hinten abgerundete Schuppen vorhanden; sie sind 
weniger dicht gestellt als es auf dem Rücken der Fall ist und sind vielmehr in der Regrel durch zahlreiche winzig kleine eingestrente Körnchen von einander der Quere nach getrennt. Gegen die Bauchgrenze hin zeigen die Schuppen eine mehr vierseitige Gestalt und erscheinen etwas grölšer, dabei kommen die gröliten Schuppen an die Grenze der Bauchtafeln zu liegen und bilden, da sie sehr flach sind, die sogenannten Marginal-Ober- oder Randschildchen, welche somit den Übergang der Schuppen zu den Schildern vermitteln. Drei quere Schuppenreihen entsprechen der Läinge des einzelnen Bauchschildes. Die Zahl der Querreihen schwankt zwischen 150 und 165; diejenige der Längsreihen beträgt 66 bis 74 und endlich die Zahl der Caudalschuppengürtel variiert zwischen 89 und 107.

Die Perleidechse Spaniens weicht in einigen Fällen von der typischen Form ab und ist hinsichtlich ihrer Körperbedeckung ein vollständiges Mittelglied zwischen pater und der südfranzüsischen ocellata; man lïnnte sogar sich geneigt fühlen, sie als europäische Form der pater zu betrachten; ihr Scutum occipitale ist nämlich bedeutend schmäler als bei der zuletzt genannten, da es aber, wie es scheint, stets breiter ist als das Stirnschild, so sind wir infolgedessen verhindert, diese für einige Provinzen der pyrenäischen Halbinsel eigentümliche Form mit der pater zu indentifizieren, oder letztere mit der ocellata zu vereinigen.

Schenkeldrüsen und Zähne.

Die Zahl der Schenkeldrüsen soll zwischen 12 und 20 variieren; die mir zu Gebote stehenden Tiere haben jederseits 14 bis 16 Drüsen.

Der Zwischenkiefer ist mit 9, die Oberkieferhälfte mit 18 bis 19 und der Unterkiefer mit 50 oder 52 Zähnchen bewaffnet; nur die rückwärts sich befindenden Zähne scheinen spurweise zweispitzig zu sein. Am Gaumen zähle ich jederseits 9 bis 11 meistenteils in einer Reihe angeordnete Zühnchen.

Farbenkleid.

Die jungen Perleidechsen messen unmittelbar nach ihrem Auskriechen aus dem Ei 89 bis $94 \mathrm{~mm}$, sie sind oberhalb schieferfarbig, werden aber schon nach zwei bis drei Tagen graubräunlich, später, bei zunehmender Größe, erscheinen sie braun. Die liumpfoberseite ist mit zahlreichen Augen besetzt, die etwa die Größse eines gewöhulichen Stecknadelkopfes erreichen. Diese kleinen Augenflecken, denen, nebenbei bemerkt, die Species ihren Nanen verdankt, sind auf dem Rücken anfangs weils, späterhin aber weiliggelb, auf den Seiten bläulich; schön blau kolorierte Ocelli befinden sich an den Wurzeln der Vordergliedmaßen. Diese bisweilen dunkelbraun eingefaliten Augentlecken sind, wie schreiber in seiner IIerpetologia europaea angiebt, 
gleichmäligg ïber den Rücken verteilt und bilden im Ganzen etwa 11 bis 13 parallele Längsreihen; ein auch nur particlles Zusammenflietien dieser Flecken zu unregelmäligren Querbinden wie es von einigen Forschern beobachtet worden ist, habe ich noch nicht konstatieren können, die Augenflecken waren vielmehr bei den von mir untersuchten jungen ocellata stets von einander entfernt, sie schienen mir beinahe durchweg gleichgrof zu sein und waren nicht von schwarzen Flecken begleitet. Ihre dunkelbraunen Einfassungen sind so fein, dafs die weiben, weiflichgelben und blauen Ocelli verhältnismäfigg grof erscheinen und nicht, wie es behauptet worden, etwa als helle Mittelftcken auf dunklem Felde aufzutreten pflegen. Der Oberkopf ist cinfarbig hellbriun, die Schläfen sind gelbbraun und die übrigen Kopfseiten zum T'eil braun, zum Teil aber, so z. B. auf den Oberkieferschildern, gelb gefleckt; das Iiüsselschild ist gelb. lich braun. Auf dem braun gefärbten Augenlide tritt ein gelber Flecken hervor. Die Oberseite des Schwanzes und der Gliedmafien ist spärlich mit hellgelben Punkten versehen; der Unterleib erscheint grauweiß, die äuferste longitudinale Bauchschilderreihe oftmals grünlich gefärbt. Diese, für die im Herbst - hier bei Nizza im Oktober - aus den Eiern ausgeschlüpften Perleidechsen charakteristische Färbung und Zeichnung ändert sich in dem darauf folgenden Frühjahre sofort nach dem Verlassen der Winterverstecke, und zwar nach stattgefundener Häutung insofern $a b$, als sich der Grundton der Oberseite bedeutend aufhellt und nach und nach anfangs braungelb, späterhin gelbgrü und endlich grün erscheint. Die Zeichnung bleibt im allgemeinen dieselbe, doch werden die Farben lebhafter, gesättigter und die Augenflecken, namentlieh an den Leibesseiten, etwas größer, so dafis sie von jetzt an als Ringflecken, deren Mittelfelder blau, von dunkelbraun oder schwarz umrandet erscheinen. Die Rückenfläche und die Seiten des Kopfes, ferner die Oberseite der Gliedmaken und endlich auch der Schwanz oben und an den Seiten erscheinen genau so koloriert wie die Rumpfoberseite.

Das zweite Frühlingsgewand der Perleidechse - um diese Zeit mißst das 18 Monate alte Tier etwa 17 bis $20 \mathrm{~cm}$ - ist bedeutend farbenreicher und mag wohl Dug ès bei der Beschreibung von seiner »variété tâchetée« vorgelegen haben. Auf dunkelgrünem Grunde der Rückenzone treten nämlich schwarz eingefafite, prächtig blau kolorierte Ocelli auf, von denen diejenigen, welche oberhalb der Achselgegend liegen, sich durch ihre Grölie und Farbenintensität auszeichnen. Die schwarzen Ringe entsenden nach allen Richtungen hin Verästelungen. Die Körperseiten sind gelbgrün und von drei parallelen Reihen blauer, schwarz umrandeter Ocellen durchzogen; ich zähle in der Reihe ungefähr 7 bis 8 solcher hellen Flecken; aufierdem ist noch eine vierte, unterste Reihe vorhanden, welche zum 'leil auf die Bauchgrenze übergeht. Der Kopf ist dunkelgrün, der hintere Teil der Schäleldecke spielt ins Braune. Die vorderen 
Extremitäten sind oben schön grïn, die hinteren braungrün mit gelben Ocellen besetż, welche von brannschwarzen Ringen umschlossen sind. Die Oberseite des Schwanzes ist briunlich, dic Bauchseite weilsgelb mit Ausnahme der, nach auben liegenden Längsreihen von weifien und braun gefleckten Schildern; die übrigen unteren Körperteile sind weid mit einem Stich ins Gelbe. Mit zunehmendem Aiter breiten sich die dunkelbraunen oder schwarzen Umsïumungen der hellen Augenflecken aus, verschmelzen zum Teil untereinander und bilden auf diese Weise schnörkel- oder deltaförmige Figuren. Zugleich mit der Ausdehnung des Schwarz auf Kosten des Grundtones findet eine Abänderung der Rückenzeichnung insofern statt, als in der Mitte der ursprünglich bläulichen, bläulichgrünen oder gelblich- und weiflichgrünen, jetzt aber gelblichen oder hellgrünlichen Augenflecken schwarze oder dunkelbraune Kerne auftreten; diese werden allmählich größer und wandeln sich schliefilich in Augenflecken um, indem sie das, auf der Rückenzone prädominierende gelbweife oder hellgrüne Kolorit der Augenflecken bis auf einen'schmalen Reif verdrängen. Die auf diese Weise ausgebildeten dunklen Ocelli werden somit vom Überrest der ursprünglichen Augenflecken eingerahmt. Schließlich lösen sich die hellgelben oder hellgrünen Ringe zum Teil auf und die schwarzen oder dunkelbraunen oben erwähnten schnörkel- odler deltaförmigen Figuren treten mit den ebenso gefärbten Ocellen in Beriihrung, um mit diesen zusammenzutleben. Die Grundfarbe des Rückens des Tieres ist von jetzt an ein dunkles Braun oder Schwarz, das jedoch von zahireichen unvollstindig geschlossenen

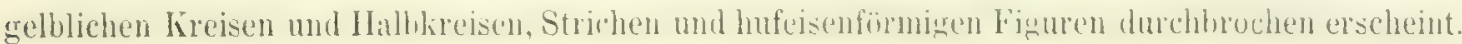
Von den, ursprünglich bei den jungeu Individuen die Rückenzone zierenden blauen, hellgrünen oder gelblichen Augen ist meistens nur noch eine Spur, und das auch in seltenen Fällen nur beim Weibchen, vorhanden. IIingegen auf den Rumpfseiten bleiben die schou bei den Jungen auf dieser Körpergegend rein blau gefärbten Ocelli nicht nur erhalten, sondern erscheinen bei den erwachsenen Stücken hedeutend gröfer - sie haben öfters eineı Durchmesser von 8 mm - und intensiver tingiert; auch fehlt ihnen in den meisten Fällen die schwarze resp. dunkelbraune Umrandung nicht, in anderen Fällen wiederum sind die blauen Seitenflecken nur stellenweise von dunklen Schuppen begrenzt. Überhaupt breitet sich die dunkle Rückenfarbe namentlich beim Männchen nu in unbedeutendem Grade auf die Rumpfseiten aus; die blauen Augen erscheinen vielmehr auf grünlichem, grüngelbem oder hellgelbem Grunde in drei bis fünf, oberhalb und hinter den Ansatzstellen der Vordergliedmalien beginnenden und bis an die Wurzein der Hinterextremitäten sich hinziehenden Lïngsreihen angeordnet zu sein (Vergl. Fig. 9, Taf. XV bei Dugès in den Ann. des sc. nat. t. XVI). Öfters zieren beim Mannchen blane Ocelli die Seiten der Schwanzbasis sowie auch die Halsseiten 
und die Oberseite der Gliedmaßen, namentlich der Hinterbeine; letzteres bei beiden Geschlechtern.

Variationen in Betrefi der Farben und Zeichnung treten insofern ein, als die erwachsenen Perleidechsen mitunter die den Jungen charakteristische Zeichnung aufweisen; so treffen wir beispiclsweise ifters weibliche Individuen, deren Iiumpfoberseite von mehr in die Quere gestellten, dunklen, sich schlängelnden und verästelnden Binden durchzogen ist; dabei erscheinen die augenstreifen- und hufeisenfürmigen Zeichnungen von Gelb, Grüngelb oder Olivengrün und am Vorderrïcken von Graubraun oder Grau begleitet. Bei anderen Exemplaren, sowohl bei männlichen als auch bei weiblichen, sind bei näherer Betrachtung bald hellbraune Flecken auf Schwarz zerstreut, bald enthalten die ringförmigen, gelben oder gelbgrünen Figuren auf dem Rücken gelbe Kerne. Es ist erwähnenswert, dafis nur in seltenen Fällen die Schuppe zweifarbig erscheint; die Oberseite des Körpers sieht bisweilen einer zierlichen Perlenstickerei seh. ähnlich.

Die Kopfdecke und die oberen Partieen der Kopfseiten sind bald einfarbig braun, dunkelbraun graubraun oder braun mit einem Stich ins Grüne, bald auf hellerem Grunde dınkel gezeichnet. Die Zeichnung tritt manchmal dadurch scharf hervor, daf die Schädeldecke - insbesondere bei ganz alten Individuen - zahlreiche furchenartige Vertiefungen und Erhabenheiten, ja man möchte sogar sagen Auswüchse zeigt. Die Kiefer sind hell, mitunter grünlich oder mit braungrünem Anfluge. Die Halsunterseite, das Halsband, der Bauch — mit Ausnahme der äußeren longitudinalen Ventraltafeln, welche bläulich bestäubt und blau gefleckt sind, - ferner die Unterseite der Beine - mit Ausnahme der gröfseren blau- und braunfleckigen Schilder sind gelblich oder weißlich. Die Schwanzunterseite ist graugelb oder lichtbraun; gegen die Sehwanzseiten zu nimmt der braune Ton überhand und kommt namentlich oberwärts gegen das Schwanzende hin sehr zur Geltuvg, während am vorderen Schwanzteile das Braun nur fleckenweise auf gelhlichem oder grünlichem Grunde aufzutreten pttegt; diese braunen Flecken werden öfters von schwarzen oder schwarzbraunen Makeln begleitet. Die Oberseite der Beine ist durch ein dunkelbraunes Netzwerk geziert, dessen Maschen von Blau oder Blaugriin ausgefüllt werden; in anderen Fällen erscheinen schwarze oder schwarzbraune Schuppen eingestreut. Der, bei den jungen Stücken am oberen Lide deutlich, am unteren aber schwach hervortretende Fleck verliert mit zunehmendem Alter an Intensität, scheint aber nie gänzlich zu fehlen.

Mitunter behält die Perleidechse die den jungen Individuen eigentümliche Grundfarbe bei, so habe ich in der. Umgebung von Alicante in Spanien ein altes Männchen erbeutet, dessen Grundton auf der Körperoberseite dunkelgrau ist; vou den geaugten Flecken, welche den Rücken 
bei den Jungen zieren, ist keine Spur zu sehen, auch fehlt die für die ausgewachsenen ocellatu charakteristische dunkle kreisförmige Zeichnung gänzlich. Die liumpfseiten hingegen sind spärlich mit kleinen Argusflecken besetzt.

Während die auserewachsenen Perleidechsen ausführlich beschrieben worden sind, wird dic Beschreibung des Jugendgewandes dieser Species in den herpetologischen Schriften meistens vermilist. Die meisten Autoren scheinen die Jungen der ocellata nicht zu kennen und weisen uns entweder auf die von Dugès (1. c. pag. 371) gegebene Beschreibung hin, oder wiederholen letztere ohne zu ahnen, dalł bug ès nicht etwa die erste Altersstufe, wie er irrtümlich angiebt, soudern eine ziemlich ausgewachsene ocellatı unter Rubrik 1. „Premier îge, variété tîchetée《 beschrieben hat. Vergleicht man die von mir gegebene Beschreibung der bei mir geborenen und aufgewachsenen Tiere mit jener von Dugès, so erweist sich eine beträchtliche Differenz. Dats $L$. ocellatc juv. in der crsten Altersstufe auch grün vorkommt, ist höchst unwahrscheinlich, ich bin vielmehr geneigt zu glauben, daf3 $\mathrm{D}$ a ud in ${ }^{1}$ ), wenn er angiebt, daf sie blaugrün auftritt, eher ein älteres, vielleicht sechs MIonate altes Individuum vor sich gehabt haben dürfte. Es steht nämlich aufer Zweifel, daßs dieser Forscher eine viel jüngere Perleirlechse als Dug ès unter dem Namen s. lepiđa« oder »Lézard gentil du Languedoc « beschrieben hat. Dugès wirft infolgedessen Da udin mit Unrecht vor, diese Eidechse zu dunkelfurbig beschrieben zu haben. Während Daudin die Maßse seiner L. lepida angiebt, wodurch wir deren Altersstufe beurteilen können, schweigt Dug̀̀s darüber.

\section{Vorkommen.}

Lacerta ocellata gehört der südwesteuropäischen Fauna an. In Spanicn und Portugal scheint sie häufig und weit verbreitet zu sein, während sie in Frankreich melır auf die suidlichen Départements beschränkt ist. Von letzterem Lande sind einzelne bis in die ligurischen Distrikte gelangt. Nordwärts dringt sie nicht über Mittel Frankreich hinaus, wo sie auch nur stellenweise so z. B. in den Départements de la Vienne, de l'Isère und du Jura vorkommt und im Ganzen nicht häufig sein soll. Die Südgrenze ihres Verbreitungsbezirkes ist Gibraltar. Es existieren zwar auch Angaben über das Vorkommen dieser Art in Nordafrika, jedoch beruhen diese Angaben auf einer Verwechselung derselben mit der in Algerien und I'unis weit verbreiteten Lacerta pater Lataste.

Als eigentliche Heimat del ocellata muß die pyrenäische Halbinsel gelten, wo sie sowohl in der Ebene, als auch in Gebirge die häufigste lind zugleich auch am weitesten verbreitete

1) Hist. nat. génér. et particulière des Reptiles III, pag. 204. Paris 1802-1804. 
Eidechse ist. Aus den zahlreichen Fundortsangaben zu schliefen, dürfte sie keiner spanischen oder portugiesischen Provinz gänzlich fehlen und in einigen Gegenden sogar in großer Anzahl auftreten. Beifolgende Fundortsangaben dieser Species in Portugal und Spanien entnehme ich hauptsächlich ans den Schriften Boettgers ${ }^{7}$ ), Boscas ${ }^{2}$ ) und Steindachners ${ }^{3}$ ): Portugal ${ }^{4}$ ). - Silves und Monchique sin beiläufig $850 \mathrm{~m}$ Meereshöhe«. (Königreich Algarve); Serra de San Ilamede in Alemtejo; Beira; Bom Jesus do Monte in Entre Douro e Mlinho. Spanien. - Galizieu ${ }^{5}$ ); Oviedo in Asturien; Salamanca und Bejar in Leon; Valladolid und Barajas y Pinar de Navarredonda (Avila); Pamplona in Vascogandas; Aragon; Barcelona ${ }^{6}$ ) und Terragona in Katalonien; Alicante ${ }^{\top}$ ), Valle de l'Abayda, Jativa, Dosaguas, Betera, Foyos und Dehesa de la Albufera in Valencia; Pozo-houdo und Albacete in Murcia; Ciudad-Real, Despoblado de la Caracollera, Toledo, Madrid und Escorial; Don Benito, Magacela, Alomchrón und Badajóz in Estremadura; Sevilla ${ }^{8}$ ), Ruinas de Italica ${ }^{9}$ ); Cadiz, Malaga, Umgebung von Ronda ${ }^{10}$, Gibraltar ${ }^{11}$ ) und Algerziras in Andalusien.

Alsdann bewohnt Lacerta ocellata den Süden Frankreichs und stellenweise auch MittelFrankreich, wie z. B. die Départements de la Charente ${ }^{12}$ ), de la Charente-Inférieur ${ }^{13}$ ), de la Vienne ${ }^{14}$ ), de l'Isère ${ }^{15}$ ) und du Jura ${ }^{16}$ ). Den in nördlicher Richtung angrenzenden Départements fehlt sie ganz bestimmt, weshalb auch ihr angebliches Vorkommen auf der normannischen Insel

$\left.{ }^{1}\right)$ Abhandl. Senckenberg. naturf. Gesellsch. XII. S. 371. - Zeitschrift f. d. ges. Naturwiss. LII, S. 502.

3) Catalogo de los Reptiles et Anfibios observados en España etc. in: Anal. Soc. Esp. Hist. Nat. VI. - Nota herpetologica sobre una excursion etc. Ibidem VIII. pag. 474. - Correcciones y Adiciones al Catalogo de los Reptiles etc. Ibidem X. pag. 89. - Bull. Soc. Zool. de France 1880 pag. 240. Yaris.

$\left.{ }^{3}\right)$ Reptilien in: Reise d. österreich. Fregatte Novara etc. Zoolog. Teil. Wien 1867.

4) Barboza du Bocage in: Revue et Magasin de Zoologie, par G. Méneville, XVI, 2. Série, pag. 332. Paris 1863.

$\left.{ }^{5}\right)$ Seoane, Reptiles y Anfibios de Galicia in: Anal. Soc. Esp. de Hist. Nat. VI. Madrid 1877. Nach Boscà (1. c.) findet sich die ocellata bei Tuy in Galicien.

$\left.{ }^{6}\right)$ Sacc in: Bull. Soc. sc. nat. de Neuchâtel, T. VII. Lirraison 2, pag. 226. Neuchâtel 1866.

$\left.{ }^{7}\right)$ v. Bedriaga in: Arch. f. Naturg. XXXXV. 1 Bd. S. 324.

s) Waltl, Reise nach d. südl. Spanien. Passau 1835. - Lichtenstein, Nomenclator Reptil. et Amphibor. Musei zool. Berol. pag. 15. 1856.

9) M achado, Erpetologia hispalensis in: Revista di Ciencias etc. IV. Sevilla 1859.

$\left.{ }^{10}\right)$ Steind acbuer l. c.

1i) C. et Aug. Duméril, Cat. méthod. de la Collect. des Reptiles. Paris 1851.

12) De Rochebrun n̊e, Catanimax vivant dans le Dép. de la Charente in: Actes Soc. Linn. Bordeaux XII. 1811.

${ }^{13}$ ) Lesson, Cat. d'une faune du dép. de la Charente-Inférieure, ebendaselbst nag. 4. - In der \$ Faun du département de la Charente-Inférieure par Beltrémieux ist sie nicht erwähnt.

14) Mauduyt, Herpétologie de la Vienne. Poitiers 1844.

15) Charvet, Cat. des animaux qui se trouvent dans le dép. de l'Isère. 1816.

16) Ogérien, Hist. uat. du Jura et des départements roisins. Zoologie vivante, t. III. Paris 1863. 
Jersey ${ }^{1)}$ ) höchst aweifelhaft erscheint. IIngegen in den südlichen Départements ist sie überall ziemlich häufig, wenn anch nicht äberall gleich zahlreich anzutreflen ${ }^{2}$ ); so beispiclsweise scheinen im Gironde-Département nur die Laudes d' Arlac unsere Art zu beherbergen "). Im IĆrault aber ist sie bei weitem häufiger ${ }^{4}$ ); C. und $\Lambda$ ug. D uméril (l.c.) und F. M ülle r ${ }^{5}$ ) kennen sie aus der Umgebung von Montpellies. In den Steinbrüchen bei Béziers, ferner bei Lodève, im Bezirk von Saint Pons und unweit vom Meeresstrande findet sie sich ebenfalls ${ }^{6}$ ). Aus der Umgebung von Marseille besitze ich ein Individuum dieser Species und aus 'Toulon ist sie von Duméril aufgefuhrt worden. In den Meeres. Alpen sind mir mehrere von der Perleidechse bewohnte Lokalitäten bekannt geworden: St. Laurent am Var, Pia bei Escarena, Abbadie und Laghetto unweit Nizza, Mont Agèle in der Nähe der Turbie, lioccabruna, Eza und die Berge oberhalb Mentone und Ventimiglia. Als die Gebirge um Nizza noch nicht bewaldet waren, war die ocellata in der nächsten Umgebung der Stadt häufiger; so ist sie an Stellen bei Villafranca wo ich sie früher sicher finden lionnte, jetzt gat nicht mchr, oder nur noch mit grofer Mühe aufautreiben. In Nizza selbst hat sie sich nur noch an den schwer zugänglichen Flecken des unter dem Namen "Chateau bekannten Felsens erhalten.

Von dem gegenwärtig französisch-italienischen Grenzorte Ventimiglia an tritt die ocellata (ler Ligurischen Küste entlang hier und da auf ${ }^{7}$ ); so soll sie beispielsweise nach $\mathrm{F}^{\mathrm{r}}$. Mi üller bei Bordighera erbeutet worden sein ${ }^{8}$ ). Wenn Dehne im Jahre 1856 behauptet hat, daks sie »schon in Ober-Italien ziemlich häufig sei« (Allg. deutsche naturhist. Zeitung II.), so ist wohI darunter vorzugsweise das Département der Seealpen gemeint worden.

Daf $L$. ocellata in Syrien und auf den Canarischen Inseln, ferner auf dem Ätna und endlich gar am Senegal ( $L$. senegalensis Gray) oder auf Jamaica ${ }^{5}$ ) nicht vorkommt, brauche ich

1) Collin de Plancy, Cat. des Reptiles etc. du dép. de l'Aube etc. in: Bull. Soc. Sc. hist. et nat. de Semur 1877.

${ }^{2}$ ) Crespon, Faune méridionale. Nimes et Montpellier. - Risso, Hist. nat. de l'Europe méridionale III. pag. 86. Paris 1826.

3) Lataste, Essai d'une Faune herpétologique de la Gironde in: Act. Soc. Linn. de Bordeaux XXX. 1876.

4) De Serres, Essai pour servir à l'hist. des animaux du Midi de la France 1822.

5) Katalog d. im Mus. u. Universitätskab. Basel aufgestellt. Amphibien etc. in: Verhandlungen d. naturforsch. Gesellsch, in Basel 1878. Basel.

6) Jumeau, Synopsis des Reptiles etc. in: Bull. Soc. d'étude Sc. nat. de Béziers 1879.

7) Sassi, Saggio sopra i pesci, rettili e mammiferi della Liguria. Estratto dal Qualro descretino per VIII. Riunione. Genova 1816 (pag. 37). - De Betta, Rettili ed Anfibi in: Fauna d' Italia IV. Milano 1874 (op. cit.)

$\left.{ }^{3}\right)$ II. Nachtrag z. Katalog il. Basl. Mus. in: Verhandl. naturforsch. Gesellsch. in Basel 1882.

9) Die bezügliche >ocellata aus samaica ist von Georges Eduards in sciner. Histoire naturelle des oiseaux rares. Londres 1751, t. IV auf 'Tafel C C II abgebildet und als sacerta viridis maculatus, major* 
wohl kaum himzuzufügen. Syrische, von Lichtenstein in Nomencl. Reptil. et Amphibior. Mus. 20ol. Berol. pag. 15 citierte socellatu habe ich im Berliner Museum nicht entdecken können, hingegen habe ich Perleidechsen zweifelsohne fälschlich als von den Canarischen Inseln stammend bezeichnet, im crwähnten Muscum sub. No. 996 und No. 1000 aufgestellt vorgefunden. - Die von Sava (Elucubrazioni sulla Flora e Fauna Etnea. Milano 1844) und Min à Palumbo (Prospetto degli studi di Erpetologia in Sicilia. Palermo 1863) für Sicilien angeführte ocellata soll nach Doderlein ${ }^{1}$ ) nichts anders als eine eigentümliche, auf dem Ätna lebende Varietät der $L$. viridis sein, deren Körperseiten von ovalen Flecken geziert werden. Nur als Kuriosum mag hier noch die Behauptung $\mathrm{Fich}$ walds Platz finden, datis die ocellata auch der Fauna Rubijands angehöre. Eichwald sagt nämlich in seiner Fauna caspio-caucasia pag. 82: "Hab. arundineta in ostio Volgae amnis".

\section{Lacerta pater Lataste (1881).}

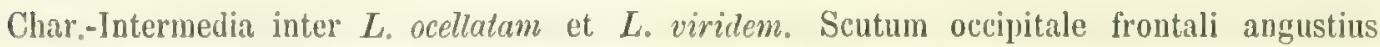
breviusque, parietali multum angustius, interparictali multum latius longiusque. Scutum frontale proportionaliter breve. Discus palpebralis in margine externo serie squamarum limbatus; exceptiones haud rarae. Nasofrenalia duo, superposita. Tempora scutellata, scutis majoribus ad marginem parietalium; scutum massetericum saepius nullum; scutum tympanicum nullum. Supralabialia anteriora 4. Sulcus gularis nullus. Collare denticulatum. Scuta abdominalia per series octo disposita. Squamae dorsales parvae, oblongo sexangulares vel fere quinquangulares vel rotundato- subquadrangulares, subcarinatae. Dentes in maxillis et palato. Pori femorales utrimque 14. Caput magnum, ante pyramidale, rostrum rotundato- obtusum, pone latum a collo distinctum. Cauda corpore fere duplo longior $\left(\sigma^{7}\right)$ vel fere hemiola $(9)$, ad originem incrassata. Pedes postici axillas non contingentes (q) vel superantes $\left(\sigma^{\top}\right)$. - Longitudo $309-315 \mathrm{~mm}$.

Synonymie.

Lacerta ocellata, Daudin, Hist. nat. génér. des Reptiles III, pag. 125. Paris 1802 (partim), Dugès, Mém. sur les espèces indigènes du genre Lacerta in: Ann. sc. nat XVI. 1829 (part.) ; f., g. in Gray, Cat. Liz. Brit. Mus. pag. 30. London 1845; M. Wagner, Reisen in d. Regentschaft Algier etc. III. (Reptilien von Schlegel bearbeitet) Leipzig 1841; bezeichnet, hingegen von Daudin (Histoire naturelle des Reptiles, t. III, pag, 149) in $»$ Lacerta jamaicensis* umgetauft worden!

1) Revista della Fauna sicula dei Vertebrati in: Nuove Effemeride Siciliani, vol. XI. Palermo 1881. 
Du méril et Bibron, Enpétologie générale V, pag. 218 (part.); Gervais, Sur les animaux vertebrés de l' Algérie in: Ann. se. nat. X, pag. 204 (3. série); C. et $\Lambda$. Duméril, Cat. méth. collect. Rept. Paris 1851 (part.); Guichenot, Hist. nat. des Reptiles etc. in: Exploration scientifique de l' Algérie etc. (Zoologie) Paris 1850; 'Tristram, Notes on the Reptiles and Fishes of the Sahara in: Proc. zool. Soc. of London XXVII, pag. 475; Lichtenstein Nomenclator Reptilium ete. pag. 15. Berlin 1856; Strauch, Essai d'une Erpétologie de 1' Algérie in: Mém. Acad. Imp. Sc. de. St. Petersb. VII. Série, t. IV, No. 7; O. Böttger, liüppelstiftung, IV. Reise etc. in: Bericht üb. d. Senckenberg, naturforsch. Gesellsch. in Frankfurt a. M. 1880-81 (var. viridissima Rozet.); Ch. Lallemant, Erpétologie de l' Algérie etc. Paris.

Lézard vert, Shaw, Voyage de M. Shaw dans plusieures provinces de la Barbarie etc. t. I, pag. 323 La Haye 1743.

Lacerta agilis (L.) Poiret, Voyage en Barbarie etc. t. I. pag. 286. Paris 1789.

? Lacerta viridissima ( $\mathrm{W}$ a gle $\mathrm{l}$ ) Rozet, Voyage dans la régence d'Alger, pag. 233 Paris 1833.

Lacerta viridis, P. Gervais in Anm. sc. nat. VI. (2. série), pag. 308 Paris 1837; Du= méril et Bibron, Erp. génér. V, pag. 210. Paris 1839 (part.)

Lacerta ocellata subsp. pater, Lataste, Diagnoses de Reptiles nouveaux d' Algérie iu Le Naturaliste 1880, 15. Novembre. Paris.

Die in Folgendem beschriebene Eidechse war sonderbarerweise von mehreren Autoren übersehen, oder mit anderen Arten verwechselt worden. F. Lataste hat das Verdienst im "Le Naturaliste « (1580), eine genaue Charakteristik derselben gegeben, und sie, wie neucrdings behauptet worden ist, der Vergessenheit entrissen zu haben. Später hat O. Böttger das Farbenkleid dieser Lacerta in eingehender Weise abgehandelt. Durch die Güte der Herren F. Lataste und Dr. Hagenmüller war ich in der Lage, eine Anzahl Exemplare der pater vergleichen zu können, und da ich infolgedessen einige Ergünzungen und Berichtigungen zu den bisherigen Beschreibungen zu gehen vermag, so will ich im Anschluf an die letzteren hier einiges über das Tier und seine Stellung im System mitteilen.

Was zunächst die Benennung der Species anbetrifft, so muß meiner Ansicht nach der Name spater gelten, oder genauer ausgedrückt, dem Namen sviridissima Rozet« vorgezogen werden. Rozet führt allerdings in seinem »Voyage dans la Régence d' Alger 1833 « eine Eidechse unter dem Namen viridissima $W$ agler an, welche möglicherweise mit der pater La taste identisch ist, er bringt aber nichts Näheres darüber und sagt nur: »J'en ai rapporté un 
assez grand nombre d' individus, parmi lesquels $M$. Duverno y a reconnu les espèces suivantes: Lacerta algyra Linn., L. viridissima $\mathrm{Wagler}$, et une troisième espece voisine de celle-ci, mais qui en diffère cependant un peu«. - Wenn wir in Betracht ziehen, daf Rozet seine algierischen Trophäen in "Wasser- und Erdsaurier trennt und dak er sich, wie er selbst zugiebt, bei der Bestimmung seiner Ausbente der Hülfe Duvernoys bedient hat, dabei aber die Differenz zwischen der sviritissima und der dritten unbenannt gebliebenen Species nicht zu begründen im Stande gewesen ist, so müssen wir den Namen »pater wenigstens vorläufig, d. h. so lange es nicht gelingt die Original-Diagnose bei Wagler ausfindig zu machen, acceptieren, Rozet aber keinesfalls als Auktor gelten lassen (Vergl. darüber Böttger, Liste d. v. Dr. Kobelt in Spanien und Algerien gesammelten Kriechtiere in: Bericht üb. d. Senckenberg naturforsch. Gesellsch. 1880-81. ${ }^{1}$ )

In Bezug auf die der pater eingeräumte Stellung im System kann ich mich insofern nicht einverstanden erklären, als sie mir eher in systematischer, als in phylogenetischer Beziehung gerechtfertigt zu sein scheint. Lataste führt nämlich seine pater als Subspecies von ocellata auf und hebt ausdrücklich hervor, dâ3 erstere durch ihre Körpergestalt, ihre Körperbedeckung und Färbung den Übergang zwischen der Perl- und Smaragdeidechse vermittelt. Dafs mein Freund, Herr Lat aste, bei dieser systematischen Anordnung nicht die bloke Ähnlichkeit, sondern auch die Verwandtschaftsbeziehung im Auge gehabt haben dürfte, ist höchst wahrscheinlich ${ }^{2}$ ) und wir gelangen somit zur Schlufifolgerung, daf3 die, der ocellata untergeordnete pater eine Übergangsform vorstellt, deren Vorkommen aber auffallender Weise nur auf Nordafrika beschränkt ist, währenddem die zwei extremen Formen, d. h. die Perleieidechse und die aus der pater entwickelte Smaragdeidechse ausschlieflich der Fauna Europas resp. Asiens angehören, oder wir müssen annehmen, daß3 die pater eine Bastardform vorstellt, welche aus der Kreuzung von den zwei vorhin genannten Arten entsprungen ist. Die geographische Verbreitung aber, welche, nebenbei sei es bemerkt, bei dergleichen Fragen von Belang ist, steht in direktem Widerspruche sowohl mit dieser, als auch mit jener Annahme, denn in beiden Fällen müften wir voraussetzen, daßs diese drei, unter sich verwandten Eidech-

1) Nachträglicher Zusatz. Auch ist die Benennung viridissima anderweitig vergeben; aus F it zingers Versuch einer Geschichte d. Menagerie d. österreich. k. Hofes (Sitzber. d. k. Akad. d. Wiss. Math. naturw. CI. 1855 pag. 626) ersehen wir, daf die viridis Griechenlands von Schreibers in einem, mir leider unbekannt gebliebenen Werke.als Lac. viridissima bezeichnet worden ist.

$\left.{ }^{2}\right)$ Nachträglicher Zusatz. - Herr F. Lataste teilt mir neuerdings folgendes mit: „J'ai la même idée que vous sur les rapports phylogenétiques de pater par rapport à occellata et viridis, et je l'ai exprimé implicitement par. le nom de pater." 
sen einstmals in den Kampf ums Dasein geraten, und daf cinerseits die stärkste, ich meine die ocellata, und die schwächste (viridis) durch die pater vertilgt worden seien, während anderseits, und zwar in Europa, umgekehrt die stärkste und die schwächste form sich erhalten habe. Die Resistenz gegen bestimmte Standortsbedingungen, z. B. die T'emperaturgrade, die Bodenbeschalfenheit II. S. W., kiann in diesem speciellen Fall nicht in Betracht gezogen werden.

Das Auftreten von drei, zum 'Teil in geographischer Hinsicht getrennten, aber offenbar untereinander nahe verwandten Eidechsen, deren Stammform die ocellata sein würde, könnte allerdings dadurch erklärt werden, dał die Perleidechse seiner Zeit nach Afrika ausgewandert ist und unter dem Einflufs von nelien I,ebensbedingungen, versetzt in eine andere Gegend zwischen neuen Konkurrenten, sich in die pater verïndert habe, um dann wieder nach Europa einzuwandern und sich in die viridis umzuwandeln. Jedoch scheint mir dieser Erklärungsversuch etwas kompliziert zu sein und ich glaube eher annehmen zu dürfen, dali die pater, welche die Merkmale von zwei Arten in sich birgt, nur insofern eine Verbindungsform repräsentiert, als sie das Mutterfier sein dürfte, von dem sich erst nachträglich die Tochterfolmen socellata und sviritis« abgezweigt haben und dak sie wohl nicht als eine Zwischenform von unsicherer systematischer Stellung, sonderu eher als selbständige Species aufufassen sei. Wahrscheinlich erstreckte sich der Verbreitungsbezirk der Urform der pater über jene Halbinsel, welche einst, wie es allgemein angenommen wird, im Süden vom Saharameer begrenzt war. Ebenso wahrscheinlich ist es, daf die Isolierung und die veränderten Verhältnisse, welche durch den Durchbruch der Strafe von Gibraltar bewirkt wurden, inre Umwandlung beeinfluft haben.

Körpergestalt und Gröbe.

In der Größse kommt $L$. pater unserer Smaragdeidechse ungefähr gleich, sieht dieser auch in einer gewissen Entfernung ziemlich ähnlich, unterscheidet sich aber von ihr, und namentlich von der im Südwesten Europas einheimischen Form, durch ihren weit krïfigeren Körperbau sowie auch durch die ganz anderen Proportionen des Körpers und erscheint demnach auch hierin als ein Bindeglied zwischen der ocellata und viridis. Ihre Länge beträgt höchstens $470 \mathrm{~mm}$ (Vergl. L. vivintis in Strauch S Érpétologie de l'Algérie, I. c.), meist aber nur $315 \mathrm{~mm}$, wovon beim männlichen Geschlechte nur cin Drittel auf Kopf und Leib zu rechnen ist. Das Weibchen erscheint, des kürzeren Schwanzes halber, weniger schlank als das Männchen; der Kopf ist verhältnismälig dick und stumpfschnauzig; seine Oberfläche ist vorn schwach nach abwärts gewölbt, die Seiten in der Freno-ocularregion ziemlich stark vertieft, in der Schläfengegend dagegen backenartig aufgetrieben. Der gröfte Umfang des Kopfes ist ungefähr demjenigen des Halses gleich. Der Rumpf ist in der Regel beim Weibchen länger und breiter 
als beim Mämchen, so betriagt bei einem $309 \mathrm{~mm}$ langen Weibchen die Rumpflange $103 \mathrm{~mm}$, der Rumpfumfang $90 \mathrm{~mm}$, während ein 314 bis $316 \mathrm{~mm}$ langes Männchen bis 78 Millimeter an Rumpflänge und bis $64 \mathrm{~mm}$ an Rumpfbreite erreicht. Die Gliedmalien sind bei diesem länger als bei jenem; die Vorderbeine des Männchens, nach vorn gestreckt, reichen etwa bis zum Vorderrand des Freno-oculare, diejenigen des Weibchens erreichen nur den Vorderrand der Augen; beim Männchen überragen die Hinterbeine die Achseln, beim Weibehen hingegen erreichen dieselben die Schultem nicht. Der an der Basis kräftige Schwanz ist beim Männchen in cine ziemlich dünne Spitze ausgezogen.

Ich lasse hier einige möglichst genaue Körpermafe von beiden Geschlechtern folgen:

Männchen.

Gesamtlänge des Tieres . . . . . 314-315 mm

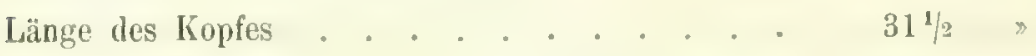

Länge des Halses . . . . . . . . . . 16 》

Länge des Rumpfes. . . . . . . . 78 »

Långe des Schwanzes . . . . . . . . 205

Gröfter Höhendurchmesser des Kopfes . . . . 16

Größter Breitendurchmesser des Kopfes.... 21

Gröbler Umfang des Kopfes. . . . . . 65

Breitendurchmesser des Pileus . . . . . . 15

Umfang des Halses . . . . . . . . . . 64

Grölister Umfang des liumpfes . . . . . . 64

Liinge der vorderen Extremität . . . . . . 41

Länge des Vorderfufies . . ... . . . 18

Länge der hinteren Extremität . . . . . 66

Länge des Hinterfußses . . . . . . . 34
Weibchen.

$309 \mathrm{~mm}$

$33 \%$

23 \%

103 \%

173

18 》

22 »

$70-71$

$17 \%$

69 》

90 》

$46 \gg$

$18 》$

67 》

$31 \%$

Körperbed e ckung.

Was zmächst die Kopfbeschildung anbetrifft, so haben Lataste und Böttger übereinstimmend angegeben, dals das Hauptkennzeichen der pater in der mäßigen Entwickelung des Hinterhauptsschildes besteht; dem kann ich beipflichten. Die Occipitaltafel bei der uns hier interessierenden Art nimmt in Bezug auf ihre Größe die Mitte zwischen derjenigen bei ocellata und hei viridis cin, sie ist nämlich bedeutend kleiner als bei der zuerst genannten, größer aber als bei der zuletzt erwälnten Eidechse. Bei der Perleidechse erscheint der Basalteil, d. h. die hintere, breitere Partie des Occipitale, mindestens ebenso breit wie der größte 
Breitendurchmesser des Parjetale und, wie wil es bereits gesehen haben, bedeutend gröfer als das Interparietale und zugleich breiter als das Stirnschild, währenddem bei der pater das Parietale etwa doppelt so breit, das Interparietale ungefäh zweinal so kilein und das Frontale breiter als das Hinterhauptsschild aufzutreten pflegt; endlich finden wir bei der Smaragdeidechse ein, im Vergleich zum Parietale oder Frontale unansehnliches Sc. occipitale, das bald kleiner, bald gröfser als das Interparietale erscheint; in anderen Fällen wiederum ist es ungefähr ebenso grofs wie das davor liegende Schild. Die Parietalen sind an ihren Augenrändern seitlich und atuch oftmals hinten von grölieren, längliehen Schildern umsäumt. Auf das trianguläre, mitunter vorn stumpf abgerundete oder abgestutzte Occipitale und das vier bis fünfseitige, vorn mit stumpfem Winkel versehene, hinten entweder spitz ausgezogene, oder abgestutzte Interparietale folgen die ziemlich langen, hinten ausgerandeten Frontoparietalia, ferner das verhältnismäßaig kurze und im allgemeinen wie bei ocellata gestaltete Frontale, die gleichfalls kurzen, mit wellig verlaufenden Rändern versehenen Frontonasalen und endlich das etwa rhombische Internasale, das stets breiter als lang ist und welches von dem ziemlich niedrigen, etwas nach oben ïbergewölbten und zugespitzten Rostrale durch die anselınlichen, in der Mittellinie zusammenstofsenden und durch die Nisenlöcher tief eingebuchteten Supranasalen getrennt wird. Die groben, seitlich liegenden Nasenöffnungen sind hinten von zwei übereinanderstehenden Nasofrenalschildern und unten in der Regel von einem schmalen Fortsatze, welchen das Supranasale nach rückwärts entseadet, umgeben; in anderen Fällen wiederum stehen die Nasenlöcher über dem ersten Supralabiale und dem Rostrale. Das schmale, hohe Zügelschild bleibt mitunter gänzlich aus; in diesem Fall legt sich das nach vorn zu etwas verschmälerte, mit einem ausgezackten Hinterrande versehene, ziemlich ansehnliche Freno-oculare direkt an die Nasofrenalia an. Sowobl das relativ grolie, vorn breite Praeoculare als auch das fünfte gröfrte Supralabiale (Suboculare) sind mit einer etwas schief von oben mach unten verlaufenden Längskante und ciner daneben sich hinziehenden tiefen Furche versehen. Auf das oberwärts ausgerandete und erweiterte Suboculare folgen zwei grölsere Supralabialia posteriora. Der obere Orbitalrand erscheint durch vier längliche, schmale Supraciliarschilder geschützt, welche durch eine Reihe oder durch nur zwei bis drei Kornschuppen vom flachen Discus palpebralis getrennt werden. Von den flachen, umregelmäbig polygonal gestalteten, vorn grölseren, hinten kleineren Temporaltafeln ist die central liegende mitunter gröfer als die ihr benachbarten. Sublabialia sind gewöhnlich sechs, Subnaxilaren fünf vorhanden, von letzteren stofen die drei ersten Paare in der Mittellinie zusammen, das dritte und das vierte sind die größten; auf das fünfte Paar folgt noch ein sechstes, aus kleinen Tafeln bestehendes Paar. 
Dic Kehl- und Halsschuppen erscheinen nur in seltenen Fillen durch eine transversale Reihe merlilich kleinerer Schuppen getrenut; eine Kehlfurche ist nicht vorhanden. Die Zahl der Ifalsbandtafeln betrïgt 11 bis 14 (nach Lataste), meist aber nur 11; das Collare ist gezähnelt. Die in Bezug auf ihre Konfiguration der ocellata ähnlichen Bauchschilder sind in acht Längs- und in 30 bis 33 Querreihen angeordnet; die Randschildchen sind mäßig entwickelt. Die Anzahl der Schilder des Brustdreiecks schwankt zwischen 5 und 15. Die grofe, ziemlich lange Analtafel ist mit Ausnahme des freien Hinterrandes meistens von zwei vollkommenen und einer unvollständigen Bogenreihe von Schildern umgeben; bei ocellata sind bekanntlich meistens drei deutlich ausgeprägte, bei viridis aber nur zwei derartige Schilderreihen vorhanden. Die gewöhnlich schwach gekielten Rückenschuppen sind im allgemeinen denjenigen bei der Perleidechse ähnlich, nur scheinen sie verhältnismäbig etwas breiter und zwar nahezu ebenso breit als lang zu sein. Am Rücken erscheinen sie sehr klein, von unregelmäßig pentagonaler oder hexagonaler und rhomboidaler Form, an den Seiten nehmen sie etwas an Größe zu, sind länglich, abbgerundet viereckig, oder höchst unregehmälisig gestaltet und brilien ihre Kiele voll. ständig ein. Um die Leibesmitte sind ungefähr 68 Längsschuppenreihen; die Anzahl der Querreihen schwankt zwischen 167 und 171; etwa zwei bis drei Quergürtel entsprechen der Länge einer Ventraltafel. Die in circa 102 bis 104 Ringeln angeordneten, oberhalb überall gekielten, unterhalb an der Schwanzbasis glatten Caudalschuppen sind in der Regel am ersten Schwanzdrittel abgestutzt; gegen die Schwanzmitte hin erscheinen sie stumpf- oder, wie es namentlich an den Seiten der Fall ist, spitzwinkelig ausgezogen, auf der Schwanzunterseite sind übrigens die Schuppen zum grölten Teil mit einem geraden oder leicht abgerundeten freien Rande versehen.

Schenkeldrüsen-Bezahnung.

Bei mehreren, von mir untersuchten pater traf ich ihrer gewöhnlich jederseits nur 14. Im Oberkiefer zählte ich 18-18, im Zwischenkiefer 9 und im Unterkiefer 20-20 Zähne; dic Intermaxillarzähne sind im Vergleich zu den stark ausgebildeten und mit zwei Spitzen versehenen Maxillarzähnen winzig klein; der Gaumen ist bezahnt,

Färbung und Zeichnung.

In der Färbung herrscht oberseits ein mehr oder minder lebhaftes Grün in verschiedenen Abstufungen von Gelblich- durch Smaragd- bis zu Olivengrün vor, welches auf der Unterseite in Gelb, Grünlich- oder Bläulichgelb übergebt. Blaue oder bläuliche, von einem schwarzen oder dunkelbramen limge eingefalite Perlftecken schmücken reihenweise angeordnet oder 
unregelmälisig zerstreut, mitunter nur die Rumpfseite, mitunter aber auch den Rücken. . In seltenen Fälleu bleiben diese blanen Flecken inselartig auf dem gräneu Untergrunde zerstreut, meistens aber stehen die dieselben einfassenden, dunklen Ringe durch Ausläufe miteinander in Verbindung; aufierdem können zahlreiche unregelmäbịg geformte, bald schnörkel- bald deltaförmige schwarze Flecken und Punkte sich dazwischen mengen und zum Teil eine Marmorzeichnung, zum 'l'eil ein Netzwerk bilden. (Vergl. z. B. Str a u hs L. ocellata in: Erpétologie de l'Algérie 1. c.) Bei den Exenularen, deren Rumpfoberseite üppig gezeichnet erscheint, sind auch die Schläfe, die Beine und der Schwanz, sowohl oberwärts als auch unterwärts reichlich schwarz gefleckt. Auf den Schwanzseiten und an der Bauchgrenze treten auch blaue Flecken auf und am unteren Ende des Unterschenkels, oberhalb des Kniegelenks gesellen sich ihnen blaue (beim Mänchen), oder weibliche (beim Weibchen), schwarz unrandete Augenflecken hinzu. Bei anderen mir vorliegenden Individuen der pater sind die dunklen Flecken oder Punkte nur spurweise angedeutet und treten in sehr geringer Anzahl auf; auch können dieselben, wie es mitunter konstatiert worden ist, gänzlich fehlen, wodurch dann ein Farbenkleid entsteht, das dem Tiere auf den ersten Anblick eine grofe Ähnlichkeit mit $L$, viridis verleiht. Die Kopfoberseite ist meistens olivengrïn, Heckenlos oder spärlich dunkel punktiert, die Zügelgegend olivengrün, die Kiefer blau angehaucht.

Böttger beschreibt in seiner oben erwïhnten Schrift grüne pater, bei denen die Halsseiten mit Ocellenflecken geziert sind, ferner solche, deren grün gefärbte Rücken mit in Längsreihen gestellten, kleinen, meist undeutlichen, schwarzen, mit wenig hellerem Auge versehenen Ocellen geschmückt. erscheint. sBei der letztgenannten Forı», fügt Böttger hinzu, wist anch die Hinterseite der Schenkel mit zwei grolsen schwarzen, weiligeaugten Ocellen geschmückt.»

Die Grundfarbe der Oberseite ist in der Jugend braun, schiefergrau, grünlichbraun oder grün. Vollkommen einfarbige Stücke sind im allgemeinen selten und scheinen namentlich in Verbindung mit grüner Oberseite noch am häufigsten vorzukommen; in den meisten Fällen zeigt die Rumpfoberseite eine grobe Anzahl, zuweilen ziemlich regelmäfig in Längsreihen gestellter, bläulichweilier, dunkelbraun eingefaliter Ocellen; dic Unterscite aller Körperteile ist bläulich. - Die jungen pater sind überhaupt schwer von den Perleidechsen zu unterscheiden.

\section{Vorkommen.}

Als eigentliche Heimat der Lacerta pater haben wir den nordafrikanischen Littoral von der marokkanisch-algerischen Grenze bis Ras-Addar anzusehen. Sie ist gemein auf dem ganzen 
Küüstenstrich Algeriens (M. Wagner), nicht selten im Norden von Tunis (Brit. Mus.) und dringt bis in dic Wüste ein (Tristram). Wo sie häufig ist, begegnet man ihr überall, namentlich im Gebüsch auf sandigem Boden und im Hügelgelände: so, laut 0 . Böttger, bei Telemsen (Tlemcen), nach M. Wagner, A.Strauch, Lalle mant (Erpétologie de l'Algérie etc. Paris) und F. M üller bei Oran, Sidi-bel-Abbes, Algier, Blida, Constantine und Mascara. F. I a taste fand sie bei Sétif Lambèze und Batna. Meine Reptilien-Sammlung enthält Exemplare aus El Guerah, vom Plateau de Sersou, aus Sétif (dedit F. Lataste) und aus der Umgebung von Bôna (dedit Dr. Hagenmüller). Sie fehlt, wie es scheint, in Marokko und in Tripolitanien.

\section{Lacerta viridis Laur. (1768).}

Char. Scutum occipitale frontali multum angustius breviusque, scuto interparietale ant minus aut maius aut aequale. Discus palpebralis in margine externo serie granorum limbatus; nasofrenalia duo superposita. Tempora scutellata, disco masseterico frequentissime nullo scutisque majoribus duobus ad marginem parietalium. Supralabialia anteriora 4. Sulcus gularis rarissime indistinctus. Collare denticulatum. Scuta abdominalia per series octo vel sex disposita. Squamae dorsi carinatae, oblongo - sexangulares fere oblongo - quadratae, angulis rotundatis. Dentes in maxillis et palato. Caput magnum, anticum pyramidali-obtusum, posticum latissimum, pratecipue ad tempora prominens. Corpus cylindricum, minus elongatum, medium incrassatum; collum a capite distinctum. Cauda corpore saepissime duplo longior, tenuissime excurrens. Pedes postici axillas contingentes vel superantes. Pori femorales utrinque $11-20$. - Longitudo $320-630 \mathrm{~mm}$.

Synonymie.

Lacerta major viridis Gesner, historiae animal. lib. II. de quadruped oviparis. Fref. $\left.1617^{1}\right)$.

Lacerta viritis Aldrovandi, de quadruped. digitatis oviparis, pag. 633. Bononiae 1637; Latreille, Hist. nat. Salamandres de France, pag. XIII, XVI. Paris 1800; ? Petiver, Gazophylacii naturac et artis decades, t. 95, Fig. 1; Da udin, Hist. nat. Reptiles, t. III, pag. 144, tab. XXXIV; Wolf in: Sturms Deutschlands Fauna. Nüruberg 1805; Merrem, Versuch eines Systems d. Amphibien pag. 64. Narburg 1820;

Schultzein: Lichtensteins Verzeichnis d. Dubletten d. zool, Mus, d. k. Universität Berlin etc. pag. 92. Berlin 1823 (L. viridis L. et var, coerulea); Dìges in: Ann. sc. nat. t. XVI, pag. 374 (var. concolore, var. piquetée vel tiquetée, var. tachetée, var.

1) Vergl. auch Gesner, Liber de quadrupedibus oviparis. Tiguri 1554. (?). (Lacerta major et viridis, grüner Heydox). 
rayie, var. buriolée) M illet, Faune de Maine - et - Loire. Angers, Paris 1828 (L. viridis et bilineata, pag. 610, 611); Hichwald, Zoologia specialis liossiae et Poloniae III. pag. 189. Vilna 1831; Fitzinger, Fauna d. Herzogtums Österreich, in der Landeskunde von Österreich unter der Ens. 1832; Bonaparte, Iconografia della Fama italica II. Roma 1832-1842. c. tab.; Gachet in: Act. Soc. Linn. Bordeax t. VI, pag. 168 (var. nigra); Glückselig, Synopsis rept. et amph. Bohemiac pag. 14. Prag 1832; Bibron et Bory de St. Vincent in: Expédition scientifique de Morée, t. III. pag. 66. PJ. X. 1 a, b, c, d. 1836; Bonaparte Amphibia europaca in: Aem. R. Accad. Sc. Torino, Ser. II. Tom. II.; Eversmann in: Nouv. mém. soc. imp. Moscou, t. II. pag 340. (1834); Kr y nicki in: Bulletin de Moscon 1837, Nr. 3, pag. 47; W a $l \mathrm{tl}$, Beschreib. d. eisenhalt. Mineralquelle und Badeanstalt Kellberg nächst Passau. 1839; Tschudi, Mlonogr. d. schweiz. Echsen in: Neue Denkschrift d. allg. schweiz. Gesellsch. 1834; Sch inz, Fauna helvetica, ebendaselbst. 1837, S. 138, 'l'af. 37; I) uméril et Bibron, Erpétologie générale, t. V. pag. 210; Sch inz, Europ. Fauna, Bu. II. S. 15. Stuttgart 1S40; Berth old, Ûb. verschiedene neue od. seltene Amphibienarten S. 9. Göttingen 1842 (Act. soc, reg. Goetting. VIII. - L. viridis var. strigata); Eichwald, Fauna caspio-caucasia, pag. 83. 1842 (L. viritis $\mathrm{U}$ aud. var. astrabndensis): Gray, Cat. Liz. Brit. Mus. pag. 31. London 1845; Scliulz, Fauna marchica, pag. 447. Berlin 1845; C. et Aug. Duméril, Cat. meth. de la collect. des reptiles du Mus. d'hist. mat. ì Paris. Paris 1851 (var. concolore, tiquetée de noir, de jame, ì tête bleue, tâchetée, tiquetée ct tâchetée, tâchetée et ì 4 raies, ì 5 raies); De Betta in: Atti Accad. agricolt., arti e commere. di Verona XXXV, pag. 129 (var. concolor, versicolor, maculata B on ap., mento-coendea B on a p., chloronota Rafin., cinereo-nigrescens, bilineate $\mathrm{Da}$ ud., bruno viritiscens bilineata); Prach, Plazové a objzivelnici zeme Ceske, pag. 15. 1861; Fahrer, T'ierwelt von Niederbayern in: Bavaria, Landes- und Volkeskunde von Bayern. 1863; P. Bert iri: Bull. Soc. Sc. hist. et nat. de l'Yonne, Ier trimestre 1864; De Filippi, Note di un viaggio in Persia nel 1862, pag. 354. Milano; Medicus, Die Tierwelt d. Iheinpfalz 1867; Jeitteles in: Verh. zoolog. botan. Gesellsch. Wien. XIII, pag. 278; De Betta, I rettili ed anfibi del Regno della Grecia in: Atti dell' Istituto Ven. sc., lett. ed arti XIII. Ser. 3; T'appe, Die einheimischen Eidechsen, S. 29. Oberhausen 1868; Giebel in: Zeitschr. f. d. gesammte Naturwiss. 1869, S. 159; Fatio, Faune des vertebrés de la Suisse III, pag. 69, pl. 1I, Fig. 1, 2. 
Genève et Bâle 1872; Gredler im: Programm d. k. k. Gymnasiums zu Bozen, S. 6. 1872 ; Ley dig, Die in Deutschland lebend. Arten d. Saurier, S. 191 ; Schreiber, Herpetologia europaca, pag. 443. Braunschweig 1875; Knauer, Die Rept. und Amph. Nieder-Österreichs, S. 6. Wien 1875; Lataste in: Actes Soc. Linn. Bordeaux XXX. pag. 83; Kefler, Zoolog. Reise durch das transkaukasische Gebiet im Jahre 1875 in: Arbeiten d. St. Petersburg. Gesell. d. Naturforsch. St. Petersburg 1878 (Russisch); Brehm, Tierleben (Kriechtiere, S. 164. c. tab.). Leipzig 1878; De Betta, Rettili ed Anfibi in: Fauna d'Italia IV. Milano 1874. (Inscrita nell' opera: »L'Italia sotto l'aspetto fisico, storico etc.); Böttger in: Zeitschr. f. d. ges. Naturwiss. LII, S. 305; Böttger, Die Reptilien und Amphibien von Syrien, Palästina und Cypern in: Jahresber. d. Senckenberg. naturforsch. Gesellsch. 1879-80. Frankfurt a. M.; Franke, Die Rept. und Amph. Deutschlands S. 97. Leipzig 1881; v. Bedriaga in: Bull. Soc. Imp. natur. de Moscou 1881, Nr. 3, pag. 74: Boulenger in: Proc. Zool. Soc. London 1881, pag. 743.

Seps viridis Laurenti, Specimen medicum exhibens synopsin reptilium emendata, pag. 62, CXI. Vindobonae 1768.

Seps terrestris, Laurenti, op. cit. pag. 61, 107, tab. III. Fig. 1.

Seps varius, La urenti, op. cit. pag. 62, tab. III. Fig. 2.

? Seps sericeus, Laurenti, op. cit. pag. 61, tab. II. Fig. 5.

Lacerta tiliguerta, Merrem, Versuch eines Systems d. Amphibien. Marburg 1829 (pag. 64). Grïne Eideclse, Schrank, Fauna boica. Nürnberg 1798; Bechstein, De Lacépede's Naturg. d. Amphibien II, S. 21. Weimar 1800.

Le Lézard vert piqueté, Cuvier, Règne animal. 1. édit. t. II. pag. 29. 1817.

Le Lézard à deux raies, Cuvier, ibidem; Des maret, Faune Française. Reptiles, pl. VI, VIII. Lézard vert, Desmare t 1 . c.

? Lacerta curopaea, B. viridis Pallas, Zoographia rosso-asiatica III. pag. 29. 1831 (1811).

Lacerta smaragdina, Me isner, Mus. d. Naturgesch. Helvetiens I. S. 41, Taf. VI. 1820. Schinz, Naturgesch. und Abbild. d. Reptilien, S. 99. Taf. 37, Fig. 2. 1833.

Lacerta varius, Milne Edwards in: Ann. sc. nat. 1829, pl.V, Fig. 3; pl. VI, Fig. 10; pl. VII, Fig, $2,7$.

Lacerta chloronota, Rafinisque Schmalz, Caratt. alc. nuovi gen. espec. anim. d. Sicilia, pag. 7, 16. 1810 .

Lacerta serpa, Rafinisque Schmalz, ibidem. 
Lacevte sicula, Rafinisque $\mathrm{Sc}$ hualz, ibid.

Lacerta elcyuns, Andrzejowski, Ampli, nostr. in: Nouv. Mém. Soc. Imp. natur. de Moscou II; patg. 6, 328, tab). XXII. Fig. 13

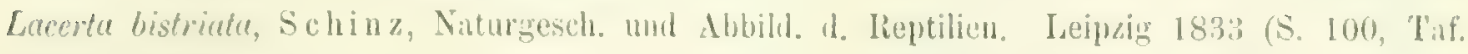
:37. 1.in. 11.

? Lacertu Herremii, Schin\%, Europ. Fauna II. S. 25. Stuttgart 1840.

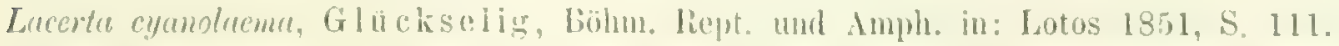

Pordurcis cyunolucmu, Glückselig in: Verbandl, zoolog. botan. Geselisch. Wien XIII. S. 1134 (1863).

Lacerta viridissima (Schreibers) litzinger, Versuch einer Geschichte d. Menagerie d. österreich. k. Hofes, s.. 653 (1855),

Lacerfu strigatu, Eichwald, Zoolog. special, pats posterior (III.) pag. 189, Vilua 1831; Fauna catspio-caucasia, yag. 57, tab. X. fig. 4, 5, 6. Petropoli 1841; Gray, Cat. Liz. Brit. Mus, pag. 32. London 1845; Cope, Notes upon some reptiles of the old world in: Proce of Philadelphia 1867, pag. 337; Berthold, Ueb. verschied, nene od, selt. Amphibienarten I. c. Göttingen 1842; Andersoll, On some Persian, Himalayan and other Reptiles in: Proc. Kool. Soc. London 1572, pag. 371; B Ianford, Zoology in: Eastem Persia 11. pag. 364. London 1876; D ehne in: Allg. deutsche naturhist. Zeit. II. pag. 213.1856.

Lucerta quinquevittufa, Ménétries, Cat. rais. des objets de zool. recueillis dans un voyage an Caucuse ete. pag. 61. St. Petersbourer 1832.

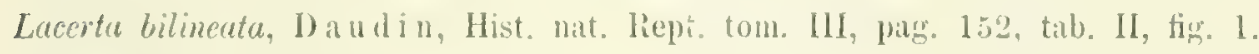

M us e al $\ln$ in $\mathrm{men}$.

Lacerta chloris Fitzinger.

Lacerta Michahelesii F'itz.

Lacerta agilis, $\beta$ bei Linné (Systema naturau 1. pag. 363) wird, meiner Meinung nach mit Unrecht in die Synonymie von Lacerta viridis La ur. versetzt; diese Vim. $\beta$ wird uimlich für die Fauna schwedens von Retzius (Kaum suecica, pag. 289. Leipzig 1800) nambaft gemacht, in Skandinavien aber kommt die Smaragdeilechse bekanntlich nicht vor.

Gröl lo.

Die Smaragleidechse ist die drittgrölite Eidechsenart. Nach S C h re i ber soll sie sogar nahezu die Länge der Lacertu ocellata, nämlich $63 \mathrm{~cm}$. erreichen. 
liörpergestalt.

Der Kopf ist beim Männchen, und namentlich bei der in Dalmatien und Griechenland cinheimischen vividis, krüftig und in der Schläfengegend backenartig nufgetrieben, beim Weibchen um ein kleines kürzer und feinel gebaut; nach vorn zu erscheint er allmählich dreiechig zugespitzt. und weil der Palpebraldiskus gar nicht - wie es öfters bei den Weibchen der Fall ist - orler nur schwach erhoben ist, ziemlich flach. Beim Weibchen zeigt sich diejenige Linie wclche bei der Seitenansicht des Kopfes am äuferen Rande der Parietalschilder und oberhalb der Augen zur Schnautzenspitze sich hinzieht, leicht bogenartig gekrümmt; heim Männchen hingegen tritt die Senkung der Schädeldecke nach vorn him sehr schwach hervor, da die Knochen der Schädeldecke mehr in einer und derselben Ebene liegen. Bei ausgewachsenen männlichen Individuen treten die Kiefer ziemlich stark hervor. In der Jugend erscheint der Kopf verhailtnismäligig kurz, breit und mit gewölbter Oberfläche. Der Rumpf ist walzenförmig, kräftig gebaut und erreicht beim männlichen Geschlecht einen bedeutenden Umfang. Der dünn auslaufende Schwan\% ist in der Regel fast oder doppelt so lang als der übrige Körper, öfters aber übertrifft die Schwanzlänge sogar die doppelte Körper]änge des Tieres. Beim Männchen erscheint, wie es bereits Leydig hervorgehoben hat, die Schwanzwurzel dicker und an der Unterseite gewölbter als beim Weibchen. Bei letzterem scheinen mir die Vorderbeine etwas länger zu sein als bei ersterem; sie erreichen nämlich meistens die Nasenlöcher, während beim Männchen die Vorderextremitäten, an den Körper angelegt, mitunter nur den Hinterrand der Frenalia berïhen. Die Hinterheine reichen bis oder auch etwas über die Achseln hinaus. Beim Männchen sind die Gliedmafsen, insbesondere die Hinterbeine, kräftiger als beim Weibchen, bei letzterem sind sie auferdem mitunter kürzer und reichen nicht ganz bis zu den Achseln. Die Füfe, namentlich die hinteren zeichnen sich durch ihren eleganten Bau und durch ihre Länge aus, besonders im Vergleich zu denjenigen bei der, mit der viridis verwandten Lacerta agilis.

Ä u lisere Körperbedeckung.

Diejenigen Kopfschilder, welche für die Smaragdeidechse charakteristisch sind, d. h. solche, die von denjenigen bei Lacerta agilis und bei anderen mit $L$. viridis verwandten Arten, sei es durch ihre Gestalt, sei es durch ihre Größe oder Anzahl abweichen, werden in folgendem besonders berücksichtigt werden.

Das breite, zuweilen »seicht längsgefurchte und nach aufwärts gewölbte Rüsselschild ist im Vergleich zu dem gleichnamigen Schilde bei $L$. agilis niedrig, infolgedessen erscheinen bei der viridis die in der Mittellinie des Kopfes zusammenstobenden Kanten der Supranasalia ge 
wöhulich etwas linger als dies bei der zuletzt genannten Art der Fall ist. Das Internasale, eine auffillend grobe, volu und seitlich die Supramasalia, die oberen Nasofrenalia und die frenalia berührende 'Tafel, pflegt in der Jugend meistens breiter als lang, im Alter hald breiter als lang, bald aber so lang als breit oder sogar linger als breit zu sein. Bei deu jungen Individuen erscheinen die frontonasalia ebenso lang wie breit, hingegen bei den ausgewachsenen länger als breit; lateralwints fügen sie sich an die nach aufwärts gewölbten und an der Pileusgrenze einen ziemlich stark - besonders bei den orientalischen Stücken - ausgesprochenen leistenartigen Vorsprung zeigenden Freno-ocularen an. Dis bei den Jungen, weil auf líosten der Frontonasalia entwickelte, längere, aber schmälere Stirnschild nimmt bei ausgewachsonen Stücken bedeutend an Breite zu und erscheint seitlich weniger stark bogig ausgerandet, ja sogar mitunter mit sanft geschwungenen oder parallelen Rändern versehen; nach vorn zu ist is gewöhlich bei deu Alten etwis, bei den Jungen stark erweitert, in seltenen Fïllen vorn schmäler als hinten; an seinem Vordermul ist das Frontale entweder abgerundet oder bald in einen äuberst stumpfen, bald in einen spitzen Winkel ausgezogen und zwischen die Frontonasalia eingeschoben; in letaterem Falle sind die Vorderkanten ausgrebuchtet; seine atl die Parietalia sich anlegenden, untel stumpfem Winkel zusammenstokenden Seiten sind entweder grerade oder leicht ausgerandet. Währendem die breit zusammenstolsenden Frontoparietalia in Bezur auf ihre Gröfse und Gestalt verhäItnismäligrg wenig varieren, indem sie bald mehr, bald weniger stark bogig ausgeschnittene orler gerade Hinterränder und mehr oder weniger stark abgerundete Vorderseiten zeigen und nur insofern interessant sind, als bei den Jungeu sie so breit als lang sind, mit zunehmendem Alter aber bedeutend länger werden, zeichnen sich sowohl das Interparietale als auch das Occipitale durch ihre Unbeständigkeit in betreff ihrer Form und Gröbie aus und sind somit in systematischer Berichung vou nicht grolier Bedeutung. Interessant ist es jedoch, dafs dic, in der Beschildung des Hinterkopfes konstatierten Abweichungen, wie ich mich durch Untersuchung zahheicher Excmplare äberzeugt habe, im grofien und ganzen an bestimmte Standorte und auch Altersstufen gebunden sind. Bei den Jungen scheint das meistens trapezische Sc. occipitale nahezu ebenso breit und in manchen fillen ebenso breit aber bedeutend kitrzer als dis davor liegende, in Vergleich zu unserer westeuropäischen ausgewachsenen viridis auffallend breite und kure, fünfseitige, vorn stumpfwinlielig ausgezogene, hinten abgerundete oder fast geriule abgestutzte und verschmälerte Iuterparietale. Genau dasselbe Aussehen bieten in viclen Fällen die vorderasiatischen ausgewachsenen T'iere dar; in anderen Fällen. so z. B. in Syrien erscheint dis Sc. occipitale als äuferst kleines rundliches, vder dreikantiges, vorn abgerundetes, oder endlich als ebenfalls kleines trapexförmiges Täfelchen, wälurenddem das 
Sc. interparictale grofs, vorn hreit und mit stmupfwinkeligen, linten mit gerate abgestutztem oder abgerundetem Rande versehen ist. Aus Rorfu sind mir Exemplate bekannt, bei denen das Occipitale bedentend breiter als das sehr schmale und lange Interparietale erscheint, wiederm bei anderen aus Khodus stammenden Stucken sind Occipitale und Interparietale beide iufserst schunal; das zuletzt erwähnte Schild zeichnet sich aufserdem noch durch einen langen zwischen die Frontoparietalia eingekeilten Vorsprung aus. Währenddem in der Regel das Occipitale in Bezug auf scine Länge dem Interparietale nachsteht und bei den mittel- und südcuropäischen viritis etwas schmäler als die zuletzt genannte 'lafel ist, erscheint es mitunter bei den portugiesischen und griechischen Stücken breiter und ankerdem anch etwas länger als das Interparietale. Die bei den jungen Smaragdeidechsen gewöhnlich relativ kurzen Parietalia erscheinen bei den alten länger und zwar in der liegel länger als das Stimschild; nach vorn zu sind sie stets verschmälert und augerundet, stumpfwinkelig endend oder abgestutzt. Ihre Innenseite zeigt drei, unter stumpfem Winkel zusammenstoliende und sich an die Frontoparictalia, an das Interparietale und an das Occipitale anlegende Kanten; rückwiirts erscheinen sie spurweise, lateralwärts meistens deutlich abgerundet uild von 2 grötieren länglichen Schildern begrenzt, welche, nebenbei bemerkt, zu den Schäfenschildern gehören. Der hei den Männcheu sehr schwach erhobene, bei den Weibchen flache Palpebraldiskus ist lateralwärts gewöhnlich von einer mehr oder weniger laugen Reihe winziger, körnerartiger Schuppen umsäumt und somit von den 4 bis 6 länglich schmalen, gewölbten und ziemlich stark seitlich hervortretenden Supraciliaria getrennt. Diese Schuppenreihe kann aber entweder bis auf eine oder zwei Schuppen reduziert werden oder auch gänzlich ausbleiben, wie es z. B. bei einigen aus 'Turin stammenden und im British Museum konservierten Smaragdeidechsen der Fall ist. Die An- oder Abwesenheit dieser, die Palpebralscheiben von den Scuta supraciliaria trennenden Schuppenreihe kamu somit keineswegs als sicheres Kennzeichen für die Unterscheidung der viritis von der agilis gelten. Von den zwei mittleren gröfseren Supraocularia stölit die vordere, nach rorn zu verengte Tafel an das Frontonasale und grenzt lateralwirts zum Teil an das erste breitere Supraciliare und an das meist dreieckige, den Ram zwischen dem Supraculare, dem Frontoparietale, dem Freno-oculare und dem Supraciliare I ausfüllende erste und kleine Supraoculare. Das rückwiuts liegende grolie Supraoculare ist gewöhnlich etwas breiter und kürzer als das Supraoculare II und erscheint vou den Parietalen durch das kleine, unregelmäbig geformte, bald vier- bald fünfseitige oder abgerundete obere Augenschild IV getrennt. Die Orbitalgrube ist verhältnismälisig schmal, der Augenschlitz nach hinten geräckt; vorn, der Orbitalgrube zunächst befundet sich das grofie Freno-oculare, welches am Hinterrande zwei Einbuchtungen zeigt, in welche oben 
das breite supraciliare und unten das länglich schmale, nach vorn erweiterte und abgerundete Pracoculare hineinpassen. Mit seinem oberen, zuweilen, abov selten, ausgeschittenen liande legt sich dieses Schild an das Frontonasale; mit seinem anderen, etwas verschmälerten Teile grenzt es an das bedentend schmilere Frenale, das seinerseits sich an die zwei kleinen, die ziemlich grofe runde Nasenöfinung von hinten umgebenden und äbereinanderstehenden Nasofrenalen anschlielist; vorn und teilweise auch oben erseheint das über der Rostralnaht des ersten Oberlippenschildes gelegene Nasenloch von dem bereits erwähnten Supranasale begrenzt. Von den Supralabialen, deren gewöhnlich sieben, in selteneren Fällen acht vorhanden sind, befindet sich das fünfte grölite, d. In. längste und höchste, unten verschmälerte, oben erweiterte und leicht ausgerandete Schild unter dem $\Lambda$ uge; dieses Suboculare ist an seinem breitesten T'eile vorn vom Praeoculare, hinten vom Postoculare und oben von einer, anfangs kaun sichtbarea, nach rückwärts aber breiter werlenden Bogenreine von Schuppen, welche die Orbita direkt ungiebt, begrenzt. Währenddem das Nasenloch und das untere Nasofrenale sich oberhalb des ursten Suprabiale befinden, liegt das Frenale dem zweiten, das Freno-oculare dem dritten und das gröbere eine, oder die kleineren zwei P'raeocularen dem Supralabiale III auf. 'Zählt man sämtliche Schlafenschilder - also die 3 bis 4 Postocularia, die 2 bis 3 an die Parietalia anstofienden Tafeln, das Massetericum, Tympanicum und die klemeren Schilder —, so erhält man etwa 23 bis 33 Schildehen, von denen die meisten, namentlich die vorderen grob, unregrelmäligig polygonal, hexagonal und flich sind, die hinteren aber, d. h. diejenigen, welche in der Nähe der Ohröffnuugr sich befinden, etwas kleiner oder viel kleiner und mitunter leicht gewölbt erscheinen. Bei den in Persien einheinischen viridis ist die Schlafenschilderzahl auffallend gering, denn es sind 2 Tafeln, welche die Parietalen begrenzen, 3 bis 4 Postocularia, 1 groties Massetericum, 1 Tympanicum, 6 gröbere und 5 kleinere, also im ganzen nur 18 bis 19 vorhanden, welche Zahl sogar bis auf 16 herabsinken kann. Obschon die Autoren anderer Ansicht sind, so glaube ich dennoch, dab Massetericum und Tympanicum meistens vorhanden sind und nur deshalb wenig auffallen, weil sie von ebenfalls groben Schildern umgeben werden. Sublabialia zähle ich 7 ; in seltenen Fällen habe ich 6 oder 8 konstatieren können. Die namentlich bei den jungen und vorderasiatischen Smaragdeidechsen grolse, bald nalsezu runde, bald ovale Ohröffnung ist vorn mitunter von kleinen, ziemlich stark hervortretenten Schüppchen umsäumt. Die länglich sechskantigen, namentlich vorn zwischen dem dritten oder vierten Submaxillarpaare stehenden schmaleu Kehlschuppen sind in schicfe, mach aufien divergierende. Längsreihen angeordnet und von den breiteren, hinten eckig endenden oder leicht abgerundeten, deutlich geschindelten Halsschuppen durch eine scharf ausgeprägte, und meistens von einer Querfalte 
besleiteten Querfurche getrennt. Diese Querfalte zieht sich gewöhnlich am Hinterrande des Ohres vorbei bis nahezu zu den Parietalen hin; eine zweite kürzere Querfalte nimmt am stark gezähnelten, bogigen, aus 7 bis 11, in seltenen Fïllen aus 6 oder 12 grolien, von autien nach innen schintelformig ubergreifenden 'Tafeln bestehenden Halsbande ihren Ursprung; die mittlere Ilalsbandtafel ist stets etwas grölser' als die ihr benachbarten. Unter den mir zur 'Zeit vorliegenden 35 Smaragdeidechsen besitzen 20 Lixemplare 9 Halsbandschilder; 6 Exemplare 7 ; 5 Exemplare 11; 2 Stücke 10, ferncl je ein Stück 12 und 6 (Berliner Museum Nr.985) Halsbandsschilder.

Das sogenannte l'riangulum pectorale ist ans 3 bis 13 Schildern zusammengesetzt. Die in 26 bis 31 , in seltenen Fällen in 23 oder 32 Quer- und in 6, selten in 8 Längsreihen angeordneten Bauchschilderreihen sind lateralwärts, an den Seiten des Körpers von kleineren Randschildchen begrenzt. Der Unterschied zwischen den echten Ventraltafeln und den Pseudogastrostegal- oder Randschildchen ist ziemlich grobs, scheint aber nicht bei allen Individuen gleich stark ausgeprägt zu sein, infolgedessen möchte ich hierselbst auf denselben näher eingehen, um etwaigen Mißverständnissen vol\%ubeugen. Bei den echten, stets größeren Bauchschilderserien berühren oder überdecken sich die einzelnen Tafeln teilweise; die Randschildchen aber treten entweder untereinander gar nicht in Kontakt, indem sie zwischen sich nehr oder weniger grobe Schuppen oder Schildchen einschliekien, oder sie berühren sich, jedoch ohne mit ihrem nach rückwärts gerichteten 'Teile überzugreifen und einander aufzuliegen. Allem Anscheine nach können die Randschildchen mit zunehmendem Alter größser werden und sich zu echten Bauchtafeln gestalten; in diesen, allerdings seltenen Fällen erscheint das Tier mit 8 longitudinalen Ventralreihen und auferdem jederseits mit einer Randschildchenserie versehen $z$ sein, wie es $z$. B. am spanischen, sub Nr. 2690 im Muséum d'histoire naturelle zu Paris aufgestellten Individuum zu sehen ist. Auch bei manchen osteuropäischen viridis, so \%. B. bei denjenigen von der Ballkanlalbinsel kommt die Zahl 8 vor; dabei sind mir Fälle bekand, wo die äuliersten Bauchtafeln nahezu ebenso breit als die daran stolienden sind. Die Anzahl der Bauchschilderreihen ist folglich nicht von so grolier Bedeutung für die Klassifikation, wie es z. B. Milne Edwards seiner Zeit zu glauben schien. - Die zweite Reihe von der äufiersten echten Longitudinalschilderreihe an gerechnet, besteht gewöhnlich aus doppelt so breiten Schildern als die daran stukisenden 'Tafeln der äuliersten Serie oder aus etwas breiteren Schildern als diejenigen, welche die Mittelserie konstituieren. Sämtliche Serien erreichen etwas hintel der Bauchmitte ihre grölite Breitenentwickelung, um nach vorn zu allmählich, nach hinten zu aber rasch sich zu verschmälern. Die mediane longitudinale Serie zeigt etwas vor der Brustgegend eine Verengung, um in der Brustgegend selbst wiederum etwas breiter zu erscheinen und in die Tafeln des 
Triangulum pectorale aberzugehen; eine bedentende Verengung und der damit verbundene bogige Verlauf der medianen Bauchschilderreihe, wie wir es später bei den Zauneidechsen kennen lernen werden, findet bei $L$. viridis allerdings nicht statt. Die einzelnen 'Tafeln der

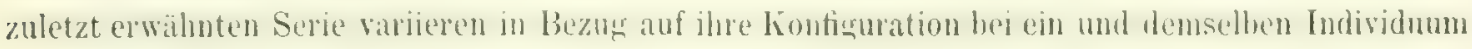
in zienlich betrïichtlichem Grade, bald erscheinen sie nach rückwärts ziemlich stark verschmälert, ja sogar spitz ausgezogen, bald sind sie an ihrem freien Rande abgerundet oder zeigen zwei unter stumpfem Wiokel zusammenstoßende Kanten. Die melr seitlich liegenden Ventraltafeln zeigen meistens drei Fcken und drei Kanten, deren mittlere und grökite mit der äufieren und seitlichen kürzeren unter stumpfem Winkel und mit der nach innen zu gekehrten inneren, ebenfalls kïrzeren kante unter stumpfem, aher abgerundeten Winkel zusammenstolsen; in anderen Fällen wiederum, wie es beispielsweise bei den syrischen viridis öfters der Fall zu sein scheint sehen diese Bauchschilder an ihrem freien Rande abgerundet aus. - Das ziemlich grofie, mit freien abgerundeten Kanten versehene Afterschild ist vorn und seitlich in den meisten Fällen von zwei Bogenreihen kleinerer Tafeln umgeben oder überlagert; die mittleren, dem Anale zunächst liegenden Schildchen sind gewöhnlich größer als die ihnen benachbarten.

Die Beschuppung des Rückens ist je nach dem Standorte vielen Verschiedenheiten unterworfen. Die mir aus Oderberg, Rüdersdorf und Böhmen vorliegenden Stücke zeigen relativ äußerst schmale, länglich hexagonale Schuppen und sehen im Vergleich zu den aus Südfrankreich, Italien oder insbesondere aus Vorderasien stammenden viridis feinbeschuppt aus. Bei den südeuropiïschen und asiatischen Smaragdeidechseu sind in der Regel nur die Schuppen der Mittehregion de's Liuckens schmal. sechseckin oder oval-heximunal und gleich den centraleuropäischen längsgekielt, währenddem die mehr nach den Seiten za liegenden oder selbst die äuß̉eren Schuppen in der medianen Rückenzone breiter, eher rhombenförmig und diagonal gekielt, erscheinen. Die bei den orientalischen viridis bedeutend gröfseren, bei den mittel- und südeuropäischen mäLigg groben abev stets groberen Flankenschuphen als Rüclienschuppen sim vierseitig, leicht abgerundet, nach hinten dreieckig abgurundet, rundhich orler regc Inäßig vierseitig und breitel als lang; sie sind stets stumpf und namentlich bei den vorderasiatischen und russischen Iudividuen stark, zuweilen auffallend stark gekielt; Spuren eines schrägen Kieles sind in der Regel auch noch auf den die Randschildchen umgebenden Schuppen sichtbar. Die kleinen, gekörnten Nackenschuppen sind ebenfalls meistens, wenn auch nur spurweise gekielt, nur diejenigen Schuppen, welche die Pileusschilder begrenzen, scheinen eine Ausnahme davon zu machen. Sowohl die Flanken, als auch die an der Caudalwurzel sich befindenden Schuppen sind spurweise geschindelt. In einer dorsalen Querreihe sind meistens 46 bis 52 Schuppen 
vorhanden, obwohl ihre Zahl bei den europäischen und namentlich bei den portugiesischon viridis bis anf 53 und 57 gesteigert, bej den vorderasiatischen und russischen grobbeschuppten Individuen dagegen bis anf $t 1$ herabsinken liann; die Anzahl der Querreihen der Schuppen wechselt zwischen 100 und 120. In einigen Fiallen kommen drei, in anderen zwei, natstens aber abwechselnd zwei und drei Querreihen von Dorsalschuppen auf die Länge eines Bauchschildes. Die in seltenen Fiallen in 79, gewöhnlich aber in 97 bis 114 Quergürteln angeordneten Schwanzschuppen sind mit Ausnahme der glatten und kurzen, bach hinten zu nur wevig verschmälerten und abgerundeten Schuppen, welche sich in der unmittelbaren Nähe der Afterspilte befinden, mehr oder weniger stark zugespitzt endend, mit in bald stumpferem, bald spitzerem Winkel zusammenstolisenden geradelinigen oder leicht abgerundeten Hinterseiten; sie zeigen mit Ausnahme der vorderen, unteren, meistens leicht abgerundeten Schuppen fünf Écken und sind langlich schmal, oberhalb und unterhalb in der liegel vollkommen, oder nahezu vollkommen gleich-, scitwärts aber ziemlich ungleichseitig und deutlich dachigg gekielt. Die Oberseite der Extremitäten, namentlich der hinteren, ist entweder mit rhombischen und diagonal dachartig gekielten, oder einem liveisausschnitte ähnlich sehenden Schuppen bekleidet.

Schenkeldrüsen und Zähne.

Die Zahl der Schenkeldrüsen wechselt zwischen $1 \pm$ und 22; 12 oder 13 Drüsen jederseits scheinen in seltewen Fällen bei den transkaukasischen und spanisch-portugiesischen viridis vorzukommen. Unter den, von mir in Bezug auf die Drüsenzahl untersuchten 177 Individuen aus den verschiclensten Gerenden zeigen 4 Exemplare jederseits 22 Drüsen, 24 Excmplare 19 Drüsen, 4 Ex. 20, 40 Ex. 18, 72 Ex. 17, 24 Ex, 16, 4 Ex, 15 und drei Exemplare auf der einen Seite 17, is und 18, auf der anderen Seite aber 19, 20 und 17 Drisen. Bei der persischen Form »Vaillanti« habe ich aulierdem 15 bis 17 und bei der spanisch-portugiesischen Abart sGudocis sonderbarerweise nur 11 bis 12 (Muséum d'hist. nat. in Paris. - Espragne, dedit: Graclls) oder 12 bis 13 (Berl. Mus. Nr. 9625) Drusen konstatieren können.

Der Gaumen ist bezahnt. Der Zwischenkiefer ist mit !), (ier Oberkiefer jederseits mit 19 , der Unterkiefer im ganzen mit 23 Zähnen bewaffnet; die Zühne des Ober- und Unterkiefers zeigen eine doppelspitzige krove. Am Grumen zähle ich 12 bis 15 in zwei oder drei Reihen angeordnete einfache Zähne.

Färbung und Zeichnung, Varietaten, II a lise.

Die Färbung und Zeichnung der viridis ist in erster Linie nach dem Alter, dann aber auch nach der. Standorten einigen Abweichungen unterworfen; gewisse Modifikationen richten sich auberdem nach der Verschiedenheit des Geschlechts. Was zunächst die Entwickelung des 
Farbenkleides anbetrifft, so mufs vor allem erwihnt werden, dac die vorherrschend grüne Färbung erst im letaten Stadium ihrer Entwickelung anfutreten pflegt und daf die Farbenabstufungen und verschiedene Zeichnungen, welche die jungen Tiere im Laufe ihrer Lntwickelung durchzu. machen haben, durch die grofic Anzahl von Abänderungen, denen die elterlichen Formen unterliegen, bedeutend beeinflubst und modifiziert werden. Infolgedessen pflegen mitunter die Standortsvarictiten der vividis verschieden gefübte und namentlich verschieden und ganz eigenartig gezeichnete Junge anfzuweisen. Diese Standortsmodifikationen bei den jungen Individuen leisten aber nur in wenigen Fïllen gute Dienste, wem es sich um die Varietätsbestimmung handelt; dadurch nämlich, dafs die Verbreitungskreise der Spielarten der uns hier interessierenden Species in der Regel ineinander greifen und geographisch getrenute "Schöpfungscentren « sich nur sehr vereinzelt finden, entstehen Übergangsformen in Farbe und Zeichung nicht uur bei den älteren, sondern auch bei den jungen Individuen, welche zwischen die Extreme gestellt, keine, older doch nur wenig zuverlässige Abgrenzungen zulassen. Auferdem wirken die Geschlechtsdifferenzen hinsichtlich des Farbengewandes, denen allerdings vielfach ein zu grobes Gewicht beigelegt wird, hemmend bei der Unterscheidung von Varietäten. L. viritis bietet nämlich einige sehr sonderbare Beispiele von Polymorphismus dar, von denen einige als distinkte Arten, andere als Varietäten angesehen werden; und sie alle betreffen an einem Orte, nahezu ohne Ausnahme, das weibliche Geschlecht, während an einem anderen Orte das Übergewicht in der Überlieferung der Kennzeichen beim Männchen dadurch abgeschwächt wird, dals die wohl sicher im Laufe der'Zeit vom Weibchen erworbenen und anfangs nur in weiblicher Linie überlieferten Zeichnungsattribute machträglich auch auf das Männchen übertragen werden. Der Polymorphismus wird in schlagender Weise von den französischen und deutschen weiblichen Smaragdeidechsen dargethan, von welchen eine Reilie den Männchen an Farbe und Zeichnung gleicht, während die anderen eine helle Längsstreifung besitzen, welche sich mitunter nur bei ganz jungen Männchen zeigt, um alsbald \%u versehwinden. Das Weibchen wurde früher als vithneata beschrieben und für eine selbständige Art gehalten, später aher nur zu einer besonderen Varietät erhoben. - Je mehr wir uns nach dem Osten wenden, umso schärfer tritt die Längsstreifung bei dieser Art auf. Nitunter erscheint die Zahl der Streifen bis auf fünf gesteigert; zugleich aber tritt hier beim Männchen cine Neigung zum Polymorphismus auf, indem die Längsstreifung, dieser sekundäre Sexualcharakter des Weibchens, auch auf das männliche Geschlecht überliefert wird! Dafs der Ausdruck »Varietit « für die zuerst erwähnten Fälle weniger als fur den zuletzt angefühten Fall pabt, brauche ich wohl kaum hinzuzufügen. Andrerseits muls aber hemerkt werden, dafs in ähnlichen Fällen, wo Polymorphismus der Ausbildung von Varietiten vorange- 
gangen und letztere sozusagen bedingt hat, es dem Systematiker iuferst schwer fält die Grenze zwischen Polymorphismus und Varietät zu ziehen.

Unter den lokalen Formen der virids, welche vollkommen isoliert vorkommen und charakteristische Modifikationen der Farbe und Zeichnung, ja sogar der Form und Beschildung angenommen haben, steht die iberische, der algerischen $L$. poter Iataste verwandte Form oben an. Diese Form tritt, wie es scheint, in zwei räumlich getrennten Spielarten auf, welche nicht nur in betreff ihres Farbenkleides, sondern auch hinsichtlich ihrer Beschildung Unterschiede anfweisen dürften. Eine dieser Varietäten ist im Norden Spaniens verbreitet, während die andere bishor nur im Süden der pyrenäischen Habinsel gefunden wurde.

Letztere ist neuerdings von G. A. Boulenger als „Var. Gadovii" beschrieben und abgebildet worden (Proc. Zool. Soc. London 1884, p. 418, Pl. XXXVIII); sie ist durch folgende Merkmale ausgezeichnet:

Die Grundfärbung der Oberseite des Körpers ändert von Gelbgrun (B ̈̈t ger) durch lebhaftes Grasgrün (Boulenger) ins Grünichbraune oder Olivengrüne, ja ausnahmsweise bis zu Brau (Berl. Mus. No. 9625) verschiedenartig ab. Diese Färbungen treten jedoch nie allein auf, sondern sind von mehr oder weniger schwarzen oder braunschwarzen, bald riemlich symmetrisch gestellten und in Lüngs- oder Querreihen angeordneten, bald unregelmäräig zerstreuten Flecken unterbrochen, die gewöhnlich beim weiblichen Geschlechte gröfser sind als bei den Männchen und durch breitere Zwischenräume getrennt erscheinen. - In einigen Fällen und namentlich bei dem männlichen Geschlechte ist die Körperoberseite »mit sehr zahlreichen, aber ganz unregelmäßzig gestellten, rundlichen, hie und da ineinander verfliefienden kleinen schwarzen Makeln, die seitlich nach hinten und auf dem Schwanz je einen undeutlichen helleren Seitenstreifen von der Farbe des Grundes freilassen«, bedeckt (Böt tger). Die schwarzen Flecken enthalten mitunter ein lichteres Mittelfeld (Boulenger). - Bei manchen Individuen ist das schwarz gefleckte Rückenfeld von den gleichfalls dunkel gezeichneten Seitenfeldern durch eine Heckenlose Zone abgesondert, was sich, wenn auch um vieles schnäler, noch einmal gregen die Bauchgrenzen wiederholen kann. Auker diesen dunklen Zeichnungen sind auf den Rumpfseiten nicht selten auch mehr weifliche Flecken eingestreut, die meist vollständig schwarz eingefaßt sind, und an häufigsten in der Gestalt von ziemlich grolien Augenflecken auftreten, welche durch regelmäligige Aneinanderreihung jederseits eine, oberhalb der Ohröffnung beginnende und über die Rückenseiten sich hinziehende Ocellenserie bilden. Solche weifgeangte Individuen kommen in beiden Geschlechtern vor. Der Kopf ist olivenfarben oder olivenbraun mit mehr oder weniger zahlreichen schwarzen Flecken und Punkten besetzt; die Lippenschilder zeigen 
stellenweise weibliche oder gelbliche filecken. Die Kehle, die Unterkiefer, ja sogar die Kopfseiten sind in den meisten fillen sowohl zur Begattungszeit als auch post nuptias nnd, was ich hier besonders hervorhehen möchte, bei beiden Geschlechtern mit einem schönen blanen, oder in selteneren Fithlen grünlichen Anfluge versehen. Herı G. $\Lambda$. Boulenger, dem beide Geschlechter der Gadovii vorgelegen haben, giebt in seiner oben citierten Schrift genau das nïmliche an. - Der gelbgrüne Bauch ist meistens mit verloschenen oder rundlichen schwarzen Flecken besetzt, welche sich vorzusweise an den äuferen Bauchtafeln zeigen; diese Bauchflecken können mahezu gänzlich fehlen oder in gröfserer Zahl auftreten und sich auf die Unterkieferschilder, sowie auch nuf die Schwanzunterseite ausbreiten. Die Oberseite und die Seiten des Schwanzes, mitunter auch der lintere 'l'eil des Rumpfes sind braun oder olivenfarben; auf den Schwanzseiten und längs der Schwanzmitte zeigen sich schwarze oder dunkelbraune Flecken, welche durch gegenseitiges Zusammenfliefien ofters bald mehr, bald weniger unterbrochene Längsstreifen hervorbringen.

Die Jungen sind von den Alten ganz und gar verschieden. Die Färbung sämtlicher oberen Körperteile ist olivenbraun; an den Seiten des Rumpfes ziehen sich jederseits zwei Serien von bläulichweiben, schwarzumsäumten Flecken hin, deren obere, am hinteren und nach aufen liegenden Eck des Parietalschildes entspringende und sich an der Schwanzwurzel verlierende Serie aus etwa elf Ocellen besteht, während die untere aus zu kurzen Querstrichelchen vereinigten Augenflecken gebildet erscheint. Die Oberkiefer sind der Quere nach abwechselnd schwarz und weif gestreift. Die gänzlich ungefleckte Unterseite ist grünlichweils. Mit Recht hebt G. A. Bo ulenger hervor, dafs die auf die beschriebene Weise gefärbten und gezeichneten jungen Gadovii eher den Jungen von L. ocellata oder L. pater ähnlich sehen, als denjenigen von $L$. viridis sp. - Nicht nur in Hinsicht auf ihr Farbenkleid, sondern auch in betreff ihrer äuferen Körperformen weicht Var. Gadovii von der zuletzt erwähnten Eidechse $a b$, denn ihre Rückenschuppen sind rauten-eiförmig oder, genaner ausgedrückt, eher oval als rhomboidal und weniger stark gekielt als es bei der typischen Smaragdeidechse der Fall ist. Die Anzahl der Schenkeldrïsen beträgt 11 bis 14. - Schlieflich muf hinzugefügt werden, dals der Rumpf bei der Gadovii, namentlich bei den månnlichen, kürzer zu sein scheint, als bei der viridis der Autoren. Um die gegenseitigen Mafäverhältnisse der einzelnen Körperregionen besser überschauen zu können, lasse ich hier eine Zusammenstellung derselben folgen, indem ich bemerke, daf Exemplar 1 sich im Berliner Museum (No. 9625) und Exemplar 2 in Museum d'histoire naturelle z.u Paris aufbewahrt findet. 


\begin{tabular}{|c|c|c|c|c|c|c|c|c|c|c|c|c|c|c|c|}
\hline 'Totallïnge & . . & . & & & 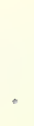 & . & & & & & & $\begin{array}{l}.1 . \\
279\end{array}$ & $\begin{array}{l}r \\
\mathrm{~nm}\end{array}$ & $\begin{array}{l}\text { No. } 2, \\
211\end{array}$ & $\begin{array}{l}\text { } . \\
\mathrm{nm}\end{array}$ \\
\hline lioptlintert & . . & & & & & & & & & & & $\because 2$ & & $1 !$ & \\
\hline liopfbreite & . & . & . & . & & & & & & & & $15 \%$ & " & $12 \%$ & \\
\hline Kopfhöhe & . & . & . & . & & & & & & & & $1.31 / 2$ & $"$ & $10^{1 / 4}$ & $》$ \\
\hline Kopfumfang & . . & . & & . & & & & & & & & $58^{1 / 2}$ & 》 & $40^{1 / 2}$ & \\
\hline Herte les I' & 'ileur- & & & & & & & & & & & $11^{1}$ & & $9^{1}:$ & \\
\hline Halslänge & . & . & . & . & & & & & & & & 11 & 之 & $?$ & 2 \\
\hline Halsumfang & . . & . & & & & . & & & & & & 50 & 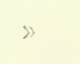 & ? & $\Rightarrow$ \\
\hline Rumpflänge & . & . & . & . & & & & & & & & 67 & \% & 49 & \\
\hline Rumpfumfang & g & . & & & & . & & & & & & 51 & $"$ & ? & \\
\hline Schwanzlänge & e & . . & . & & & 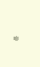 & & & & & & 190 & $"$ & 143 & ” \\
\hline Länge der V & ordere & extre & mität & & & & & & & & & $29^{1 / 2}$ & 》 & $271 / 2$ & $»$ \\
\hline Länge des V & Torderf & fulies & $s$. & & & & & & & & & 12 & * & 12 & $»$ \\
\hline Länge der $\mathrm{H}$ & Hintere & extre & mität & & & . & & & & & & $43^{1 / 2}$ & " & 39 & \\
\hline Länge des H & Iinterf: & uties & . & ${ }^{\circ}$ & & ${ }^{\circ}$ & & & & & & 24 & s & $19^{1 / 2}$ & » \\
\hline
\end{tabular}

Die im British Museum aufbewahrten Originalexemplare stammen laut Boulenger aus der Serra de Monchique in Algarve und zwar aus einer ungefähr 2000 Fuf hohen Gegend. Die im Berliner und Senckenberg'schen Museum in Frankfurt a. M. aufgestellten und als L. viridis oder L. viridis var. punctata bezeichneten Gadovii sind gleichfalls in Monchique in setwa 850 Meter Meereshöhe zwischen Felstrümmern und an den alten Manern erbeutet worden. (V'ergl. Böttger, Amphibien aus Südportugal in: Zeitschr. f. d. ges. Naturwiss. Bd. LII S. 505.) Das Pariser Stück ist einfach als aus Spanien stammend und als Geschenk von Prof. Graells bezeichnet.

Die zweite der pyrenäischen Halbinsel eigenartige Form der viridis ist diejenige, welche ich irrtümlicherweise als selbstündige Art betrachtet und als $>L$. Schreiberi« beschrieben hatte. (Vergl, meine Herpetolog. Studien im: Archiv f. Naturg., XXXXIV. Jahrg., 1 Bd., S. 299, Taf. X, Fig. 3, 4.) Obschon diese Form der vorangehenden sehr ähnlich ist, scheint sie dennoch einige, wenn auch unbedeutende Jerkmale aufzuweisen, durch welche die Unterscheidung dieser beiden Formen ermöglicht wird.

Was zunächst die Färbung und Zeichnung bei den jungen Gadovii und Schreiberi anbetrittit, so weicht letztere von der ersteren nur durch die Farbe der Ocellen ab. Bei den mir vorliegenden 107 bis $120 \mathrm{~mm}$ langen Individuen erscheint der obere Teil des Körpers pracht- 
voll gleichmälizi braun kolotiert; der Rücken glänet in der Sonne wie Gold. Auf den Seiten les Rumpfes ziehen sich vier Reihen von hellgetben I'lecken hin; dieselben sind meistenteils rund, andere wiederum oval und sehen wie Argusflecken aus. Wenn man diese fleckenreihen näher betrachtet, so erscheinen sie sehr regelmälig verteilt; indem nämlich die zweite leihe von der ersten in ciner gewissen Entfernung liegt, befindet sich jeder Augenflectien dieser Reihe ungeführ zwischen je zwei der obersten Flecken; die dritte lieihe entspricht der ersten, dic vierte wielerum der zweiten; bei Somnenbeleuchtung haben sie cinen Stich ins Grünliche; jeder dieser Argustlecken ist bei den ganz jungen Stücken zart, bei ctwas alteren Lxcmplaren aber ziemlich deutlich dunkelbraun umrandet; mit fortschreitendem Alter, bei etwa $122 \mathrm{~mm}$ langen Schreiberi zeigen diese flecken eine entschiedene Tendenz sich in Querreihen zn stellen, um schliefilich zusammenzuttielsen; dabei breitet sich die dunkle Umandung der hellen Flecken auf Kosten dieser dermaben aus, dalás letztere mit fortschreitendem Wachstum zu l'unkten reduziert werden und schlieflich gauz und gar verschwinden. Kopfdecke und Oberseite der Gliedmatien und des Schwanzes sind bedeutend lichter braun, man möchte sagen hellnubbram; namentlich fällt der Schwanz durch seine helle Färbung auf. Die oberen Lippenschilder sind abwechselnd dunkelbraun und grelb gefärbt; vom vierten Augenschilde zieht sich ein héllgelber Streifen am hinteren Raude der Augrenöftnung entlang bis zum 5. Supralabialschilde inkl. hin; diesem parallel läuft ein zweiter, ebenfalls gelber Streifen am vorderen Rande der Ohröffnung und zwischen dieseu beiden Streifen sind zwei bis drei Schläfenschuppen gelb koloriert. Das untere Lid ist schwarzbrann. Die Bauchseite ist grünlich oder b!äulich grün, die Kehle ist bereits bei den $107 \mathrm{~mm}$ langen Individuen blau angehancht. Die Unterseite der Extremitäten sowie auch des Schwanzes ist weiflich oder buttergelb.

Von den in der Jugend vorhandenen Flecken verschwinden die heilen Kernttecken mit fortschreitendem Wachstum wohl immer, wilhrend die dunklen Umrandungen dieser Flecken beim weiblichen Geschlechte sich in grolje, unregelnälsig gestaltete Makeln umwandeln, welche in drei, mehr oder weniger deutliche Längsreihen angeordnet, die Rumpfseiten des T'ieres zieren. Die der Bauchgrenze zunächst liegenden Keihen bestehen aus losen und kleineren rundlichen Makeln, während die obere, oberhalb der Ohröffnung ihren Anfang nehmende und sich auf die Schwanzseiten fortsetzende Reihe aus grofien, breiteren als langen, eher viereckigen als runden und zum l'eil ineinander fliefenden flecken gebildet erscheint. Diesen Seitenttecken gesellen sich noch andere, grofse, unregelmåbig gestaltete, abgerundetc Flecken linzu, welche längs der Rückenmitte etwa in zwei Lüngsreihen gestellt und von den gefleckten Seitenfeldern durch eine schmälere ungetleckte Zone abgesondert sind. Am Vorderrücken und 
an den Vorderbeinen herrscht die reine grüne Grundfarbe vor, welche gegen den hinteren Kumpfteil zu in ein schillerndes Grüngelb oder Gelbgrün übergeht. - Das Männchen ist von dem Weibchen schon durch die Keichnung leicht unterscheidbar: es zeigt statt der groben, auffallonden schwarzen Zeichung ein zierliches und dichtes schwarzes Netzwerk, das aus lingHecken, Punkten und sich schlängelnden und verästelnden und meistens sich nach der Quere dies IRump̧es hinziehenden Iändern gebildet wird und das grüve Grundkolorit verdrängt. Abstufungen von Grïn, wie wir es beim Weibchen kennen gelernt haben, sind am Rücken beim Mannchen nicht vorhanden, nur gegen die Bauchgrenze zu nimmt das Grün des Grunles cinen mitunter stark ausgeprägten Stich ins Gelbe an. Ausgewachsene männliche Schreiberi haben somit, von oben betrachtet, eine grofie Ähnlichkeit mit der typischen viridis; untersucht man aber ihre Bauchseite, so nimmt man alsbald wahr, dak sämtliche unteren Körperteile dunkel punktiert und gefleckt erscheinen; dunkle P'unktierung kommt allerdings auch bei der viridis der Autoren vor, aber bei weitem nicht in dem Habe; auch bleibt sie bei der letzteren meistenteils nur auf die äuferen Bauchschilderreihen und auf die Unterkiefertafeln beschränkt, während bei der Schreiberi, namentlich bei der männlichen, alle unteren Schuppen und Schilder dicht grünschwarz oder schwarz gefleckt erscheinen. Auf jeder Kehlschuppe befindet sich ein dunkler Punkt, die Bauchschilder haben sogar paarweise, auf gelblichem oder gelbgrünen Fond angeordnete rundliche Flecken, während die gelb gerandeten, bläulichen Schwanzschuppen meistenteils mit dunkeln Strichelchen versehen sind. Die Kehle ist bei beiden Geschlechtern und wie es scheint stets blau, sogar dunkelblau gefärbt; selbst die Sub- und Supralabialia können mit Blau überzogen sein. Der Kopf ist oben an den Seiten grün mit brïunlichem Anfluge, olivenbraun oder braun, dunkelbraun oder schwarz gepunktet oder äufserst fein und dicht geadert; bei einigen Männchen gesellen sich auferdem noch gelbe oder grüulich ggelbe, dunkel um. randete runde Punktflecken hinzu. Beim Weibchen flieben die schwarzen, auf bräunlichem Grunde über den Schwauz verteilten Flecken in der Regel incinander und bilden auf diese Weise drei dunkelbraune oder schwarze Längsbinden. Bei den Männchen fehlen dergleichen Binden, die Schwanzoberseite ist meistens auf grünem, braungrünem oder gelblich grünem Fond mit losen dunklen, mehr oder weniger dicht gestellten Punkten, Flecken oder Strichelchen besetzt.

Von den viridis der Autoren unterscheidet sich ferner die Schrciberi im wesentlichen dadurch, dafs das Occipitale breiter und länger als das Interparietale erscheint und dak das Frontale auffallend kurz ist. Die Banchtafeln stehen in acht deutliche Längsieihen angeordnet, deren ïuberste Reihen von grofen Randschildchen begrenzt sind; die Zahl der Querreihen ist 
30-31. Dic Rïckenschuppen sind am Vorderricken hexagonal mit leicht abgerundeten Ecken, nach hinten zu und gegen die Seiten hin zeigen sie eine unregelmälige Gestalt und sind etwa abgerundet vierseitig. Eine eigentliche Kehlfurche fehlt; sie ist durch eine transversale von der einen Ohröftnung bis zur anderen sich hinziehenden Reihe kleiner Schuppen ersetzt. Endlich muls erwähnt werden, dat. die, die Palpebralscheibe von den Supraciliaren trennende Körnerreihe meist unvollständig ist uud auf 1 bis 2 Körnchen reduziert erscheinen kann (in einigen Fällen wird sie gånzlich vermibit) und daf Mibibildungen an den Kopfschildern bei der Schreiberi viel öftel als bei den typischen Smaragdeidechsen vorkommen; nahezu sämtliche von mir untersuchten Tiere hatten ein überzähliges Schildchen bald zwischen den hinteren unpaaren 'Tafeln, bald zwischen den Frontonasalen u. s. w. Auch hinsichtlich des Collare weist die Schreiberi Anomalien auf: das Halsband entbehrt nämlich in vielen Fällen eines grötseren mittleren Schildchens, indem die zwei median liegenden Tafeln etwas auseinanderweichen und einen Zwischenraum deutlich zu erkennen geben.

Die Unbeständigkeit und die individuellen Schwankungen in der Beschildung des Kopfes deuten, wie ich glaube, darauf hin, daf die Merkmale der viridis sp. sich auf der pyrenäischen Halbiusel nicht endgültig ausgebildet oder fixiert haben, dafỉ die Fixation dieser Nerkmale erst nach der Migration dieser Eidechse stattgefunden haben mag und endlich, dafs beide iberische Formen, i. e. die Gadovii und Schreiberi nur Übergangsformen zwischen der Mutterform der viridis und den uns längst bekannten Formen der Smaragdeidechse repräsentieren. Daß̉ diese Übergangsformen ursprünglich ein etwas anderes Aussehen gehabt haben mögen als jetzt, brauche ich wohl kaum zu bemerken, da es genügend bekannt ist, daf, diejenigen Urindividuen der Übergangsformen, denen die Wege zur Auswanderung nicht offen gestanden haben und welche mehr oder weniger unter denselben Lebensbedingungen geblieben sind und dadurch bei der Ausbildung der neuen Art nicht Teil genommen haben, sich im Laufe der Zeiten auch verändern können. - Daßs die $\mathrm{Ul}^{\circ}$-Gadovii resp. Schreiberi mit der pater Lataste noch :̈hnlicher gewesen sind als es jetzt der Fall ist, vermute ich. Vergleicht man auch jetzt noch eine junge Gudorii oder Schreiberi, ja sogar ein ausgewachsenes, weibliches Individium dieser Formen mit den Jungen resp. den ausgewachsenen Weibchen von der algerischen pater, so fällt die frappante Ähnlichkeit zwischen diesen drei Eidechsen sofort auf und wir dürfen, ohne einen Felılgriff zu thun, annehmen, datis die soeben beschriebenen nur unbedentende Abweichungen aufweisenden Formen sozusagen nichts Anderes als die europäischen pater repräsentieren.

Die mir vorliegenden gröferen lixemplare der Var. Schreiberi aus den Sammlungen der Herren V. L, Seoane und $\mathrm{F}$ d. Boscà zeigen folgende Malie: 


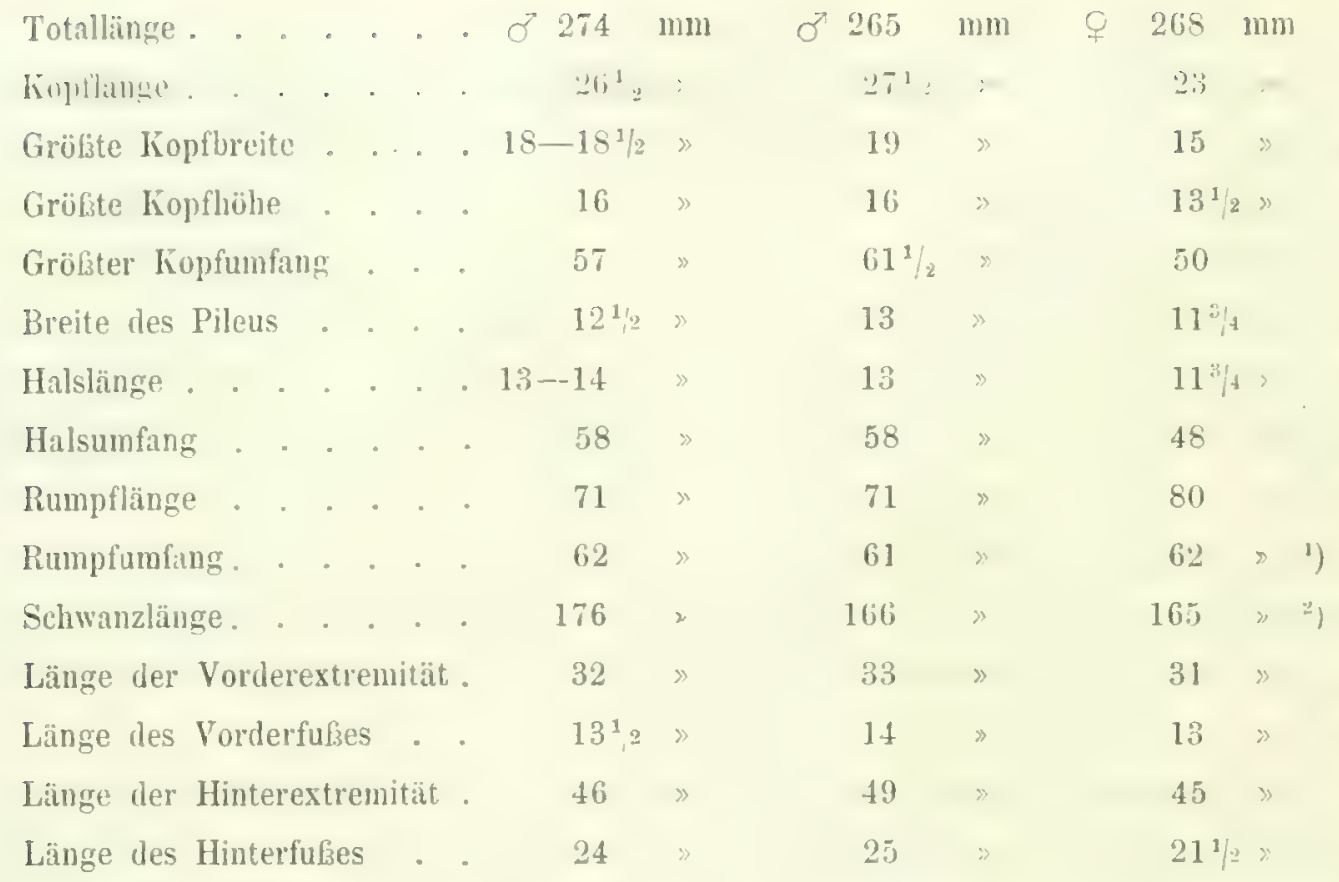

Die Vorderbeine reichen, an den Körper angelegt, bis an den hinteren Rand des Supralabiale II., die hinteren höchstens bis zu den Achseln (bei dem männlichen Geschlechte!) obwohl sie in anderen Fällen, bei den Weibchen nämlich, hinter dieser Länge bedeutend zurückbleiben. Die Anzathl der Femoraldrüsen beträgt gewöhnlich 13 bis 15 ; in seltenen Fällen sind ederseits 16 Drüsen vorhanden.

Die Schreiberi wurde bisher nur in den Wäldern von Arna in Asturien (nach Dr. E. Rasquinet) und in Galizien (nach V. L. Seoane) gefunden. Über das Vorkommen von anderen Formen der viridis auf der pyrenäischen Halbinsel besitzen wir nur spärliche Angaben. Bosca ${ }^{3}$ ) erwähnt das Vorkommen der var. bitheata in Guadarrana (Neu-Kastillien), Zumaya Baskenland) und in Beira (Portugal). Seoane ${ }^{4}$ ) läfst sie iberall in Galizien vorkommen, besonders in der Sierra del Caurel in der Provinz von Lugo. Diese Angaben sind aber durch keine mir persönlich bekannte Belegstiicke erhärtet.

Die zweifach gestreifte viridis ist übrigens keine Varietät, sondern das Weibchen oder das Junge del allgemein bekanuten Snaragdeidechse. D u gìs, als er versucht hat, lie Varie-

') Kumpif leicht zusammengedrückt.

$\left.{ }^{2}\right)$ Schwanzsp tze abgebrochen.

$\left.{ }^{3}\right)$ Bull. Soc. Zool, de France 1880 (1881) pag. 279. Paris.

4) Teptiles y Anfibios in: Anal. le la Soc. Esp. de Hist. nat., Tom. V1. 1877. Madrid. 
tïten der $L$. viridis zu diagnostizieren, kam zu dem nümlichen Schluf und berichtet folgendes darüber: 》J'ai remarqué que cette variété de couleur n'existe guère, chez l'adulte, que dans le sexe féminin « $\left.{ }^{2}\right)$ und darin hat er vollkommen recht, denn weder Leydig ${ }^{2}$ ) noch mir selbst ist je ein ausgewachsenes, zweifach hel!gestreiftes Männchen zu Gesicht gekommen. Unmotiviert scheint es mir leshalb, wenn D ugès, ungeachtet seiner soeben zitierten Bemerkung, die sbilincata« als Varitiat aufrecht zu erhalten versucht.

Unter der auliserhalb der pyrenäischen IIalbinsel vorkommenden Formen der viridis, welche man bis jetzt unterschieden hat, gelten die sogenannten »Var. concolor (Dug̀s) und »Var. punctata (1) a ud.) als die am weitesten verbreiteten und als die bekanntesten. Die zucrst genannte Abart wird ron keiner anderen an Farbenreinheit übertroffen und verdient am meisten den ihr von Schreibers vel Fitzinger ${ }^{3}$ ) verliehenen Namen vviridissimas. Die Oberfärbung dieser, unter dem älteren Varietätsnamen sconcolor allgemein bekannten Form ist einförmig grün, mitunter gelblich- oder dunkelgrün. Säıntliche Unterteile des Körpers sind gelblichweif oder gelb, öfters mit einem schwachen Anfluge von Blau oder Grün, del namentlich in der Kehlgegend zur Geltung kommt; die äußeren Bauchtafeln sind in der Regel mit grünen oder graugrünen Punkten gesprenkelt und gefleckt. Die oberen Kopfschilder sind mitunter braungrau oder braungrün gepunktet und gefleckt, während an den Kopfseitenschildern gelbliche Flecken hervorzutreten pflegen; ein dunkler, nahezu schwarzer Fleck befindet sich an unteren Augenlide. Kleine gelblichweiße, runde Flecken schmücken zuweilen die Rumpfseiten bei den Weibchen, namentlich bei den Insulaner, wogegen die Oberseite, mit Ausuahme der oft bräunlichgrün grfärbten und dunkelbraun gezeichneten Pileusschilder, stets einfarbig ist.

Nach Dugès kummt die concolor in Frankreich selten vor. In Italien scheint sie häufiger zu sein; De Betta führt sie für den Norden Italiens an ${ }^{4}$ ) und ich selbst fing sie zu wiederholten Malen am Langen-See. Bötge $\mathrm{r}^{5}$ ) hat sie jüngst aus Marsala erhalten. In Deutschland kommt die einfarbige viridis in prachtvollen gras- und dunkelgrünen Exemplaren vor, so z. B. bei Kreumach, wo ich sie am sogenannten Kautzenberge ziemlich hüufig angetroffen habe.

Die mit der einfarbigen Spielart am nächsten verwandte Form ist die von Daudin als

2) Jém. sur les espèces du Genre Lacerta in: Ann. Sc. uat., mars 1829. Paris.

2) Die in Deutschland lebenden Arten d. Saurier. S. 185. Tühingen 1872.

3) Yersuch einer Geschichte der Menagerie des österreich. k. Hofes in: Sitzungsber. Akat. Wiss. Math. naturwiss. Cl. 1855.

s) Atti dall Accad. di Agricolt. etc. di Verona, Vol. XXXV.

$\left.{ }^{5}\right)$ Bericht über die Senckenberg. naturforsch. Gesellsch. in Frankfurt a. II. 1830-81. S. 256. 
"Lézard vert, piquetté beschriebene Smaragdeidechse. Unzählige schwarze, dunkelbraune oder olivenbrane Punkte ubbersien bei dieser Form die grüne oder gelblichgrüne Grundfarbe der Körperoberseite; diesen dunklen Punktflecken gesellen sich öfters gelbe, gelblichweiße oder fast rein weißse Punkte hinzu. Die dunkle 'Zcichnung pflegt mitunter die Grundfärbung nahezu gänzlich zu verdrängen, was übrigens nur bei näherer Betrachtung des Tieres auffüllt, denn in der leme bringt das Dunkle, mit Gelb und Grün gemengt, Grün hervol: Betrachtet man die Schuppen näher, so nimmt man alsbald wahr, daks sie mitunter zur Hälfte dunkel, zur Hälfte hell gefärbt sind, oder daf3 das Schwarz oder Olivenbraun sich so weit ausbreitet und die Schuppen dermaßen überzieht, daßs es nur einen schmalen grünlich gefürbten Rand übrig läbit; die dunklen Fleckchen zeigen ührigens verschiedene Sehattierungen, so sind sie gewöhnlich gegren den hellen Rand bedeutend dunkler schwarz oder braunschwarz, sonst aber erscheinen sie etwas heller, meistens olivenfarben. Die oberen und oftmals auch die seitlichen Caudalschuppen erhalten auf grünem oder gelblichgrünem Fond mehr oder minder zahlreiche schwarze oder bräunliche kurze Querstreifen, Längsstriche und schriftartige Zeichnungen; die Extremitäten sind oberhalh auf hellgrünem Grunde dunkel gepunktet oder genetat. Am Kopfe sind die dunkelbraunen und grünlichgelben Fleckchen ziemlich gleichförmig und regelmäfig verteilt und während sie bei einigen Individuen nicht sehr zahlreich und dabei immer ziemlich gleich grof erscheinen, treten sie bei anderen Stücken in viel größserer Anzahl auf und sind viel kleiner und dichter gestellt; mitunter treten diese Flecken als feine, sich verästelnde und zum Teil zusammentliefande, mäandrische Linien auf, wodurch die Kopfdecke ein äußerst zicrliches Aussehen erhält. Die Unterseite ist einfarbig, weißhich oder gelb, zuweilen intensiv gelb.

Diese Spielart wird überall in den von der Smaragdeidechse bewohnten Örtlichkeiten sehr häufig angetroffen und erreicht in einigen östlich gelegenen Ländergebieten, wie z. B. in Dalmatien und Griechenland, sowie auch auf den Cykladen selı grofe Dimensionen. Diese Varietät ist es, welche im Rheinthale und, wenn auch selten, in der Umgebung Berlins vorkommt. Die Varietäten c (»Supra squamis olivaceis nigrisque aequaliter sparsa«) und d (»Supra fuscovirescens, punctis viridibus flavisque variegata bei Schreiber ${ }^{1}$ ) und Varietät 1 bei Fatio ${ }^{2}$ ) dürften ebenfalls hierher gehören.

Ganz besonders verdient die in Sicilien, von einigen als »chloronotos $R$ a $f_{\text {. }}$ unterschiedene braun und schwarz auf gelblichgrün oder auf smaragdgrün gepunktete Eidechse erwähnt zu werden; sie ist schon an den zierlich, symmetrisch verteilten gelben oder grüngelben schrift-

\footnotetext{
1) Herpetologia europaea, S. 441.

$\left.{ }^{2}\right)$ Faune des Vertebrés de la Suisse III, pag. 72.
} 
artigen Zcichungen am Kopfe gut erkembar. Diese Lacerta ist bereits B on a parte durch ihre Schönheit aufgefallen: „Abbiamo«, sagt der Verfassel der Iconografia della Fauna italica »finalmente effigiato nella quarta figura uno de' tanti esemplari che replicatamente ricevemmo vivi da Sicilia per cura dell indefesso Signor Grohman, col capo variopinto, col dorso verde smeraldo scaccato di nero nou meno della coda e degli arti: colle parti laterali e inferiori del capo leggiadramente tinte di un bell' azzuro celeste, da non supporsi mai quello che acquistano i cadaveri di tutti i Ramarri quando principalmente si conservano entro lo spirito di vino: colla pancia finalmente del più ricco color giallo d'oro. Nulla e più magnificamente splendido di questo animale vedute vivo sotto i raggi del sole.« - Dieses prächtige Tier kommt gleichfalls bei Beyrut in Syrien vor (Senchenberg. Mus.), nur scheinen bei den syrischen Stücken die äuferen Bauchschilderreihen stets mit etlichen dunkelgrünen Punkten bedeckt zn sein.

Weniger häufig und, wie es scheint, nur in gewissen Gegenden kommen sowohl männliche als auch weibliche prnctata Daud. mit schön blauer Kehle und blauen Unterkinnladen vor; bei solchen blankehligen Eidechsen können sich auferdem auch die Halsseiten mit Blau überziehen und in seltenen Fïllen zeigt auch noch der Oberkörper einen bläulichen Anflug. Das Verdienst, diese blaukehlige, bei La u renti als Seps viridis oder Var. b (Synops. reptil. pag. 62) erwähnte Lacerta, als eine besondere Spielart abgeschieden zu haben, gebührt, wenn ich nicht irre, dem Prinzen von Canino; B o na parte hat sie nämlich in seiner Jconografia als smentocoerulea«, Glückselig aber als scyanolaemu bezeichnet. Diese Spielart oder Subvarietät wird von einigen Autoren anerkannt, von anderen aber zurückgewiesen und zwar mit dem Hinweis, dąs das Blau der Kehlgegend zum Hochzeitsschmuck gehöre und lediglich ein Hochzeitsattribut des Männchens sei. Letztere liönnen nur insofern zum 'Teil recht haben, als diese möglicherweise (was aber noch nicht nachgewiesen ist) ursprünglich nur wechselnde geschlechtliche Fürbung im Laufe der Zeiten konstant geworden und vom Jännchen auf das Weibchen äbergegangen ist. Der von einigen Fachgenossen erwähnten s'Thatsache«, daf3 in gewissen Lokalitäten nur blaukehlige Männchen und nu zur Brunstzeit beobachtet worden sind, mus ich wiederum die Thatsache gegenüberstellen, dafs an anderen, mir bekannten Orten, so z. B. im Cannobio-Thale am Lago maggiore sowohl blaukehlige Männchen als auch blaukehlige Weibchen während der ganzen schönen Jahreszeit anzutreffen sind. Dåb diese Beobachtung nicht vereinzelt dasteht, brauche ich wohl kaum hinzuzufügen, denn melrere Forscher, welche die Geschlechter einer Eidechse wohl zu unterscheiden wissen, führen die mento-coerulea B on ap arte oder die cyanoluema Glückselig als Varietät an. Auch ganz kürzlich ist sowohl eine münnliche als auch eine weibliche viridis mit blau angelaufener Kehle von einem unserer ersten 
Ilerpetologen in den Proc. Zoolog. Soc. of London 1884, Pl. XXXVIII abgebildet und beschrieben worden.

Der Varietät prnctata Daud. schliefit sich eine braun gefärbte und nur spurweise gelb gesprenkelte, von mir auf der Insel Milo beobachtete viridis an; sie ist von mir seiner Zeit als var. fusca bezeichnet worden ${ }^{1}$ ). Ebenfalls auf den Cyliladen, vorzugsweise auf Tino, ist ferner eine schwarz gepunktete viridis einheimisch, deren Grün der Oberseite sich bis zuı goldgelben Kolorit aufhellen kann. Während die zuerst genannte Form für die Wissenschaft neu sein dürfte, ist letztere, wie ich glaube, von Erhard ${ }^{2}$ ) als Goldechse (Tropidosaura algira Fitz.) benannt und für die Cykladen angeführt worden.

Die schwarzen Punkte auf dem Oberkörper können sich stellenweise dermaßen anhäufen und kommen so dicht aneinander zu stehen, dafs der grüne (var. marmorata F a tio, l. c.) oder grünlichgrane (var. cinereo-migrescens De Betta, l. c.) Grundton mohr oder weniger gemarmelt erscheint. In anderen Fällen wird der Rücken auf grünem oder bräunlichem Grund mit dunkelbraunen, gewöhnlich schwarz umrandeten oder schwarzen, bald runden, bald unregelmälisig viereckigen in Läntss- oder Querreihen gestellten und mitunter von weißen oder gell)lichen Schuppen begleiteten Fleckchen besetzt, welche insbesondere bei den Weibchen scharf hervorzutreten pflegen. Diese Form ist von den meisten Autoren als var. maculata (Dugès, 1. c., Bo naparte, partim, Fatio, Duméril et Bibron) bezeichnet worden. Die mentncocrulea bei Bonaparte (Vergl. seine Tafel, Fig. 4) ist gleichfalls eine maculata, während Fig. 3 auf derselben Tafel eine Zwischenform von der maculata zur bilineata (d. 1. zum of) repräsentiert.

Es sind Fälle, oder genauer nur ein Fall beliannt, der durch ein Belegstück erhärtet ist, wo die Grundfärbung durch die dunkle Zeichnung gänzlich verdrängt worden ist; so enthält die zoologische Sammlung in Bordeaux ein von $\mathrm{G}$ achet als svariété noire du Lézurd vert ${ }^{3}$ ) beschriebenes Individuum, dessen schwarzer, schieferfarbig angeflogener Grundton bei genauer Untersuchung tiefschwarze Flecken zu erkennen giebt und dessen untere Körperteile weiß siud. Daß diese Eidechse auf einen besonderen Varietätsnamen Anspruch haben könnte, bezweifle ich sehr, da wir höchst wahrscheinlich hier mit einem Ausnahmefall zu thun haben: jedenfalls dürfen wir, meiner Meinung nach, vorläufig wohl kaum diese, allem Anscheine nach nur in einem Exemplar vorhandene, schwarze vividis den konstant dunkelfarbigen, an verschiedenen Orten gebundenen muralis oder viripara nigra anreihen, wie es neuerdings Eimer gethan hat.

1) Tergl. meine Arbeit im Bull. de Moscou 1881 (1882), Mr. 3, par. 76.

2) Fauma der Cykladen, S. So. Leipzig 1858.

9) Act. Soc. Linn. de Bordeaux, t. VI. 1883, pag. 168. 
Bei den vorhin erwähnten Varietäten der Smaragdeidechse ist die Existenz zweier Formen im weiblichen Geschlechte nachgewiesen worden; dessenungenchtet hat dieser Dimorphismus des einen Geschlechts keine genügende oder wenigstens keine allgemeine Berücksichtigung seitens der Herpetologen gefunden. Die gewöhnlichste Form des Weibchens ähnelt in betreff ihrer Zeichnung in der Regel ziemlich genau dem Männchen, während die zweite, seltenere Form eine vom Männchen ganz verschiedene und, wie wir später erfahren werden, eher den jungen viridis ähnliche Eidechse ist; es ist nämlich diejenige, welche durch zwei, bald unterbrochene, an den Hinterrändern der Parietalen, oberhalb der Ohröfinung ihren Ursprung nehnende und mitunter sich auf den Schwanzanfang fortsetzende weife, grünlichweibe oder gelbe Längsstreifen ausgezeichnet ist. Die von diesen Streifen umsäunte Rückenregion kann einfarbig grün sein oder bald mehr, bald weniger dunkel punktiert, gefleckt und verschiedenartig gezeichnet erscheinen; die Streifen selbst werden in der liegel ron dunklen Flecken umsäumt, welche zuweilen die Streifen durchbrechen, wodurch an Stelle der langen intakten Streifen zwei Reihen ron streifenähnlichen, hellen Flecken entstehen. In einigen Fällen sind diese hellen Streifen nur spurweise angeordnet, in anderen Fallen aber sind sie auffallend scharf markiert und auch am Kopfe und an den Schwanzseiten nachweisbar. Diesen Streilen gesellen sich zuweilen noch zwei andere hinzu, welche jederseits am unteren Rande des Ohres beginnend, an den Seiten des Rumpfes sich hinziehen und entweder bis zur Wurzel der Hinterextremität oder auch darüber sich erstrecken; diese Rumpfseitenstreifen sind jedoch meistenteils unterbrochen und seln oft nur durch kleine helle Flecken oder dunkel umrandete helle Punkte, welche in gewissen Abständen hintereinander gestellt sind, ersetzt. Während das zweifach gestreifte Weibchen den Namen »bilineata Dugès« oder bistriata Schinz erhalten hat, ist das vierstreifige Weibchen als "punctuto-quadriradiata oder als mmaculato-quadrinadiata $\mathrm{D}$. B.« bezeichnet worden. Daf3 der Ausdruck »Varietät« für solche Fälle von Dimorphismus oder Polymorphismus des einen Geschlechtes nicht lafỉt, habe ich bereits erwähnt. Zweifach oder vierfach @ihellgestreifte ausgewachsene Männchen sind mir nicht bekanmt; unter den jungen Individuen aber finden wir anch gestreifte Männchen vor.

Ganz junge Tiere sind im Westen und Südwesten Europas oberhalb grau oder licht lederbraun, an den Seiten, namentlich voru etwas heller, mit gelblichem oder grünlichem Anfluge; diese Farben sind jedoch erst bei den etwa acht Monate alten Individuen deutlich ausgeprägt. Die jungen viridis schlüpen in der Regel im September aus dem Ei und erst im nächsten Frühling setzt sich die Grundfarbe der Rumpfseiten mehr ins Braune und die ursprüngliche schmutzigweife Farbe der Unterseite in Weib oder Gelblichweils um. Vorzugsweise in 
den südlichen Lïndern tritt schon bei der Geburt eine schwache Andeutung von Längsstreifung anf. Die bräunliche Grundfärbung der Oberseite kam, wenn auch nur in seltenen Fällen, bei den weiblichen Individuen persistieren, bei den Männchen aber setzt sich mit fortschreitendem Alter das Graubraune oder das Braune inmer mehr ins Grüne um und die hellen Längsstreifen verschwinden; zugleich treten die meistens am Rücken vorhandenen, lunklen und oftmals in einander vertliefsenden und schnörlselartige Figuren bildenden Flecken schärfer hervor, oder im Gegenteil sie zerteilen sich in Punktfecken, mit welchen sämtliche Schuppen besetzt erscheinen. Mit zunehmendem Alter endlich können diese Punkte gänzlich verschwinden, wie es beispielsweise bei Var. concolor der Fall zu sein pflegt. Erst bei zwei Jahre alten Stücken, also bei Individuen, welche die Länge yon 20 bis $30 \mathrm{~cm}$ erreicht haben, bildet sich die definitive Färbung und Keichnung aus.

Ich lasse hier die Maße einiger mir zu Gebote stehenden Stücke dieser Spielart folgen, indem ich bemerke, dalo Nr. 1 aus Milo, Nr, 2 und 3 aus Nizza und $\mathrm{Nr}$. 4 aus Athen stammen; $\mathrm{Xr} .5$ ist ein ein Jahr altes, zweifach gestreiftes Individuum aus dem Canobbio-Thal am LangenSee und Nr. 6 ist ein 4 Stunlen altes Exemplar aus Nizza, das in meinem Terrarium geboren ist.

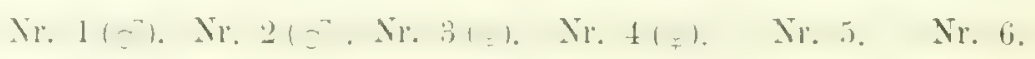

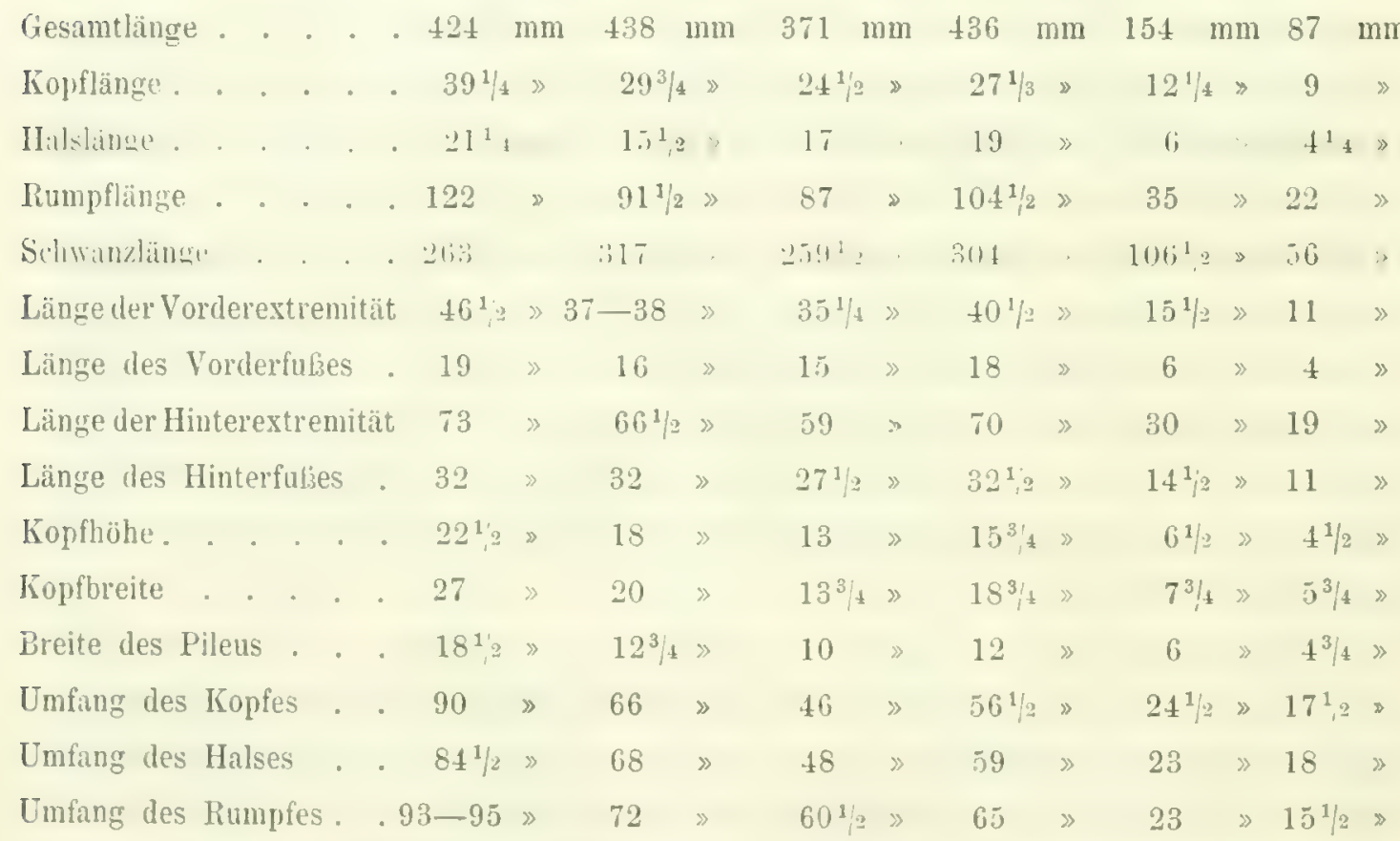

Höchst wahrscheinlich ist es die in Rede stehende Varietät, welche $630 \mathrm{~mm}$ Länge erreichen kann (vergl. Schreiber, Herpetologia europaea, S. 447). 
Wenden wir uns num nach den mehr südöstlich gelegenen Ländern, so finden wir, daßs bereits auf der Balkanhalbinsel die Jugendform der viridis eine wesentlich andere ist. Schon bei den Neugeborenen sind, wenn auch nur unwesentliche Differenzen nachweisbar; einerseits nämlich erscheinen die Tierchen an den liumpfseiten hell, am Rücken aber dunkel auf briunlichgrauem oder grünlichbraunem Grund getleckt. Nach der ersten Häutung, bei den kaum zwei Monat alten Individuen, treten die anfangs spurweise angedeuteten weiflichen oder bräunlichweiben, an den Rumpfseiten in eine oder zwei Längsseihen gestellten Fleckchen schürfor hervor; die Halsgegend und der Vorderrücken sind brïunlich oder olivenbraun gefärbt; an der mittleren Rückenzone heben sich zahlreiche, bald in zwei bis drei Längsteihen gestellte, bald unregelmäbig zerstreute braune Flecken ab, deren Braun etwas dunkler als dasjenige des Grundes ist. Dieses Jugendgewand kann im wesentlichen von weiblichen ausgewachsenen Individuen beibehalten werden, nur insofern tritt cine Veränderung ein, als einerseits die seitlichen hellen Flecken meistenteils ganz rund erscheinen und von einem dunkleu Ring eingeschlossen sind und andererseits das Braun des Grundes einen ausgesprochen grünen Ton crhält. Auch bei den alten männlichen Stücken ist oftmals dieses Jugendgewand nachweisbar, nur ist. bei diesen die dunkle Fleckung schärfer ausgeprägt, die helle dagegen felılt nahezu gäuzlich, oder ganz und gar. Die dunklen, sei es dunkelbraunen oder schwarzen, von weißlichen oder gelblichen Schuppen begleiteten Flecken sind entweder von cinander getrennt, oder teilweise untereinauder zusammenhängend, wodurch eine unregelmäßige Harmorzeichnang entsteht. Diese östliche gemarmelte Form, deren mäunliche Individuen im allgemeinen der Var. maculata gleichen, ist, wie ich glaube, bei Schreiber als Var. 1. ( Supra griseo-virescens, obscurits marmorata, luteribus guttis albidis parris per series duus dispositis. Graecia") bezeichnet. Die scharfe Abrrenzung dieser Form ist schon deshalb millich, weil die Abweichungen in Farbe und Zeichnung nur beim weiblichen Geschlechte in auffallender Weise zu Tage treten. Auf meinen Reisen durch Griechenland habe ich ferner öfters Gelegenheit gehabt zu beobachten, daßi derartig gefärbte und gezeichnete Weibchen nicht nur mit einfarbigen oder dunkel gepunkteten und geflechten Männchen an ein und demselben Orte hausen, sondern dac sie sogar die nämlichen Schlupfwinkel mit den letzteren teilen und sich also auch untereinander begatten.

Die zweite Hauptform der Zeichnung, welche nur bei den in Osten lebenden, sowohl jungen als auch alten Smaragdeidechsen beobachtet worden, ist diejenige, welche von Schreiber als Var. $p$. bezeichnet worden ist. Die Differenz in der Zeichnung besteht nämlich hauptsächlich darin, daß̧ bereits bei den ganz jungen Stücken auß̉er den am hinteren Außsenrande der Parietalia entspringenden und längs der Rückenseiten verlaufenden hellen Längsstreifen 
sowie auch den am unteren Ohrenrande anfangenden und die Rumpfseiten schmückenden Fleckenreihen, eine längs der Mittellinie des liückens sich hinziehende, an der hinteren Occipitalkante beginnende und gewöhnlich an der Schwanzwurzel endende helle, weifliche, grünlich-, blitulich-oder gelblichweilie Linie hinzukommt, welche ich als Vertebrallinie bezeichnen will. Diese Vertebrallinie tritt, so viel ich weif, zum erstenmal bei den in Dalmatien einheimischen Formen auf und wird je mehr wir uns nach Osten wenden, umso häufiger bei dieser Species angetroffen und nicht nur bei den jungen, sondern auch bei den ausgewachsenen weiblichen und, obschon weniger häufig, anch bei den männlichen Stücken. In Syrien und Klein-Asien, wo die mit dem hellen Vertebralstreifen versehenen viridis weit verbreitet zu sein scheinen, kommen übrigens, wie ich nach dem mir vorliegenden Material schliefien kann, die längs der Rückenmitte hell gestreiften Männchen ebenso bäufig vor wie die Weibchen und wir sind daher berechtigt, diese dreifach gestreifte Form als Varietät zu betrachten. Daf die Zeichnung bei dieser Varietät ebenfalls variieren kann und dafis sie bereits bei den ganz jungen Exemplaren je nach dem Standorte Verschiedenheiten unterworfen ist, werde ich sofort Gelegenheit haben zu zeigen.

Bei den vorzugsweise im Südosten Europas lebenden Individuen wird die Färbung und Zeichnung beim Jungen, welche letztere eher aus drei als fünf Längsstreifen besteht, mit geringen Abänderungen auch in Alter ziemlich beibehalten. Bei den mir vorliegenden, etwa sechs Monate alten Stücken ist die Oberseite des Rückens kastanienbraun; der Kopf, die Oberseite der Extremitäten und des Schwanzes lichtbraun. Auf dem Rücken laufen drei bläulichreif̧e Streifen hin, von denen der mittelste hinter dem Hinterhauptschilde beginnt und auf der Caudalwurzel endet; die folgenden seitlichen entspringen über der Ohröffnung am Rande der Parietalia und erstrecken sich bis zum Anfang des Schwanzes oder etwas darüber. Unter diesen Streifen liegen zwei, je aus ungefähr 10 bis 12 kleinen runden, ovalen, weißlichen Flecken oder Strichelchen bestehende Reihen, von denen die unweit der Bauchgrenze sich befindende Reihe bedeutend schwächer ausgeprägt erscheint. Sowohl die Streifen selbst, als auch die Flecken sind in der Regel dunkelbraun umsäumt; mit zunehmendem Alter treten diese Umsäumungen deutlicher auf, sie werden nämlich intensiver und breiten sich stellenweise dermafen aus, dafs sie sich gegenseitig berühren, in anderen Fällen wiederum verschwindet die dunkle Zeichnung nahezu gänzlich, was namentlich bei den dunkelbraun gefärbten Exemplaren stattzufinden pflegt. Die Grundfärbung kann sich in dunkelbraun oder braunschwarz umsetzen oder im Gegenteil bis zum Hellnufbraun oder Grün aufhellen. Die Aufhellung des Grundkolorits betrifft vorzugsweise den Vorderrücken, die Rumpfseiten, den Kopf und die Schwanzoberseite. Die Oberseite 
der Extremitäten bleibt gewöhnlich hellbraun gefïbt; sowohl an den Seiten der Schwanzwurzel als auch am Oberschenkel hinten treten oftmals schön ausgeprägte weif̉e, gelblich-oder grünlichweilse, mit dunklen Ringen umgebene runde I'lecken auf. Die Kopfdecke ist dunkel, die oberen Lippenschilder weiblich gefleckt; das Ohrloch ist nahezu vollständig weib umsäumt, die Schläfe weifs geaugt. Die Farbe der Unterseite ist, wic bei den vorhin erwïhnten Viridis-Formen, an Unterkopfe graublau, blau oder grünlich schillernd, am Bauch mitunter mit metallischem Schimmer, mitunter aber mattweif oder buttergelb und, wie es scheint, stets fleckenlos. Diese mutmalich auch mit der Schreiberschen Var. $q$. identische und, wie ich hierselbst erwähnen möchte, von Schreiber als eine von der strigata vel quinquevittata verschiedene Form angeführte Eidechse hat, wenn ich nicht irre, noch keine Benennung erhalten. Schreiber nimmt allerdings an, dab seine Var. q., ferner Lacerta cxigua Eichw. und $L$. sylvicole Eversm. ein und dasselbe Tier seien, nun aber halte ich in betreff' der zuletzt genannten für nachgewiesen, dafs sie nichts Anderes als das Junge der üstlichen agilis sein kann und glaube ferner, dafo Kessler, der bekanntlich die Lacerten seines Landes aus eigener Anschaung kannte und sie nicht nur an Ort und Stelle studiert hat, sondern möglicherweise auch die Eichwaldschen Originalexemplare einer Untersuchung unterworfen haben dürfte, im Rechte ist, wenn er die Eichwaldsche exigua in die Synonymie der Zauneidechse versetzt, denn nicht nur ähnelt letztere, wenigstens dem Bilde nach zu urteilen (vergl. Taf. X, Fig. 4 in: Fauna caspio-caucasia), durch ihren gedrungenen Körper eher der Zaun- als Smaragdeidechse sondern auch die Angabe Eichwalds, wonach die exiguc im Uralgebirge und an den WolgaUfern einheimisch sein soll, deutet darauf hin, daßs sie die agilis - also wiederum eine östliche Form derselben - repräsentieren dürfte. L. viridis fehlt nämlich im Ural gänzlich und ihr Vorkommen an der Wolga wird, wie es scheint, mit Recht bezweifelt. - Ich glaube daher dic vorhin charakterisierte, dreifach gestreifte und seitlich mit einer oder mit einer doppelten Fleckenreihe versehene virilis als Var. trilineata bezeichnen zu können.

Bringt man bei Var. strigata Eichw. die Zahl der hellen Längsstreifen nicht in Anschlag, so unterscheidet sie sich hinsichtlich ihres Farbenkleides nur wenig von der dreifach restreiften, soeben beschriebenen viridis. Die Farbe des Oberkürpers ist meistens ein Gemisch von Grün und Braun, bald ist die eine Farbe, bald die andere vorherrschend. Bei den männlichen, besonders bei den geschlechtsreifen Individuen nimmt sehr oft der grüne Ton üherhand und kann bis zu einem reinen Grün gesteigert werden, welches in diesem Falle durch schwach und meistens nur am Hinterrïcken angedeutete hellere und in Fünfzahl vorhandene Längslinien unterbrochen erscheint. Diese hellen, sei es hellgrünen, wrinlichgelben oder bläulichen 
Linien fallen oftmals nur dadurch auf, daf sie von grünlichbraunen, braunen oder schwarzbraunen .Iakeln begleitet oder von Spritzflecken begrenzt werden. In anderen Fällen wiederum hebt sich die Längsstreifung deutlich vom dunklen Grundkolorit ab. Aukier denjenigen Flecken, welche die fünf auf der liumpfoberseite hinlaufenden Streifen begleiten oder umsäumen, treten noch andere, zwischen den letzteren liegende und namentlich an der Bauchgrenze unregelmäfig zerstreute, hell und dunkel gefärbte Schuppen auf. Am Schwanzanfung hört die helle Streifung allmählich und meistens vollständig auf; auch erscheint bei den grünen Stücken die Grundfarbe durch Grünlichbraun, Graubraun und Braun verdrängt; die Schwanzoberseite erscheint vorzugsweise brïunlich gefärbt zu sein und in seltenen Fällen und nur an den Seiten hellgestreift. Die drei Rückenstreifen sind genau dieselben, die wir bereits bei der vorhin beschriebenen trilineata kennen gelernt haben, während die zwei übrigen Streifen aus dem Zusammenfliefien der hellen Seitenfteckchen der tritineata entstanden zu sein scheinen. Die Kopfscbilder der strigata sind gewöhnlich heller koloriert als der Rücken, sie sind meistens gänzlich fleckenlos oder nur in der Schläfengegend mit hellen Makeln und Punkten besetzt. Grasgrüne Färbung des Rückens kommt, obschon ziemlich selten, auch bei weiblichen Individuen vor, in diesem Falle aber tritt eine so breite, meist hellbraune Umsåumung der dunklen, am Hinterrücken oftmals sehr zahlreich auftretenden Flecken auf, dab der Grundfond nahezu verdrïngt erscheint. Die fünf hellen Längsrickenstreifen mangeln beim weiblichen Geschlechte keineswegs, im Gegenteil, sie treten sehr scharf auf, erscheinen bläulich oder gelblichweif und gehen mit Ausnahme des Vertebralstreifens, der an hinteren Occipitalrande seinen Ursprung nimmt und an der Caudalbasis endet, auch auf die Seiten des ersten Schwanzdrittels über. Diese hellen Streifen können ziemlich breit auftreten, wie ich es an einem mir vorliegenden, aus der De Filippischen Ausbeute stammenden und dem Museum zu Turin angehörenden Stücke sehe. Bei einem anderen weiblichen Exemplar aus dem Kaukasus, das ich besitze, sind die Streifen nur spurweise angedeutet; Rücken, Kopf und Oberseite der Extremitäten und des Schwanzes erscheinen bei ihm mit zahlreichen dunkelbraunen Flecken besetzt; diese Flecken können bei den oberwärts braun gefürbten Stücken günzlich fehlen oder schnörkelartige Figuren bilden; im ersteren lalle hätten wir die quinquevittata Ménétr., im zweiten. die typische strigata Eichw. vor uns; die Scheidung dieser zwei Eidechsen ist übrigens nicht zuläsig, da die Abweichungen zu gering sind. Die einfarbige, weililiche Unterseite jst bei den oberhalb melı braun wie grün gefürbten Stücken ins Gelbliche geneigt und namentlich hei den Männchen sehr häufig mit einem Bronzeglanz übertlogen; bei den Weibchen gesellt sich ottmals der grünliche und bläuliche T'on dem weiblichen oder gelblichen Lntergrunde hinzu. Auberdem mul; hinzugefügt werden, dat; bei 
beiden Geschlechtern bald weilie, bald grünlich-, bliulich- oder gelblichweilse mit schwarzbraumen Halbringen ungebene oder von Flecken begleitete Ocelli die Oberseite der Gliedmaßen schmücken und dafi diese Zierde insbesondere an der Hinterseite des Oberschenkels schari markiert erscheint. - Die liunf hellen Streifen sind bereits bei ganz jungen, ungeführ $96 \mathrm{~mm}$ langen Individuen vorhanden und heben sich vom kastanienbraunen Fond sehr deutlich ab. Sämtliche oberen Körperteile sind braun und zwar ist am Rücken das Braun in der Regrel dunkler als an den übrigen Körperpartieen; dunkle Flecken fehlen am Rücken, am Kopfe aber sind dunkle Punkte sichtbar; die Unterseite ist in der Regel bläulichweißs. Die dunkle Grundfärbung kann, wie gesagt, das ganze Leben hindurch persistieren oder aber sich aufhellen; so labe ich vor mir ein etwa $170 \mathrm{~mm}$ langes Individuum der strigate, deren Grundton hellnulibraun ist, zwischen den grüugelben Streifen liegen dunkelbraune Flecken verteilt; an den Extremitäten treten die gelblichen, dunkelbraun umrandeten Augen deutlich hervor und die Schwanzoberseite trägt auf bräunlichem Grunde Spuren von einer grünlichgelben Lüngsstreifung. Die Unterseite bei diesem Individuum ist gelblich.

Diese, von der viridis der Autoren durch ihre Zeichnung und Beschuppung abweichende Strigata-Tarietät hat seit längerer Zeit die Aufmerksamkeit mehrerer Forscher auf sich gezogen und hat Veranlassung zu Meinungsverschiedenheiten hinsichtlich ihrer systematischen Stellung gegeben. Eichwald fafte sie als besondere, von der $\mathrm{v}$ audinschen gestreiften, sogenannten Bilineata-Form verschiedene Art auf; Ménétries that das Gleiche, indem er sie als $L$. quinquevittata in seinem Kataloge anführte. Diese Benennungen, insbesondere die Eichwaldsche, haben sich bis heute noch in der herpetologischen Litteratur entweder als Artnamen oder als Varietätsbezeichnungen erhalten; so folgen z. B. Gray, Anderson, Blanford, Cope und Berthold (l. c.) dem Beispiele Eichwalds und Ménétries, indem sie die strigata als selbständige Species betrachten, wäbrend andere Forscher in der strigata vel quinquevitlata blob eine Varietät erblicken (De Filippi, Schreiber, Kessler, Duméril und Bibron) oder dieselbe einfach in die Synonymie der Smaragdeidechse versetzen. Wem es auch schwer fällt, ein bestimmtes Urteil über diejenige Fidechse, welche Eichwald bei der Formulierung der Diagnose seiner $L$. strigata vorgelegen hat, zu fällen, namentlich wenn wir in Betracht ziehen, dafs Eichwald bei einer Durchmusterung der im Museum zu Tübingen aufbewahrten ausgewachsenen männlichen Zauneidechsen mit satt srünem und leicht dunkel gefleckten Rücken dieselben als $L$. strigata bezeichnet haben soll ${ }^{1}$ ), so können wir

1) Vergl. Le ydig, Die in Deutschland lebend. Arten d. Saurier, S. 209. 
dennoch cinerseits vermuten, daf die in der Fauna caspio-caucasia bildich dargestellte strigata eler der viridis und nicht der agilis angehört und andererseits künnen wir mit Bestimmtheit annehmen, dafs die strigata der Nachfolger Eichwalds, ferner die quinquevitfata von Ménétries nichts Anderes als Smaragleidechsen sein können. Hauptsächlich ist es Kessler gewesen, der die kaukisischen und transkaukasischen viridis einer, wie er selbst sagt, grüudlichen Untersuchung unterworfen hat. Unter nicht weniger als 18 Individuen, die Kessler vorgelegen haben, fanden sich meistens strigata vor, welche Form Kessler als eine bemerkenswerte Abart der viridis bezeichnet. Diese Abart soll laut Kessler sich hauptsächlich dadurch von der westlichen rivitis unterscheiden, dal.3 bei ihr der Schwanz selten die doppelte Längre des Körpers zu erreichen pflegt und daf die Zahl der Rückenschuppen und der Femoraldrüsen sich geringer erweist, als es bei der »typischen « Smaragdeidechse der Fall ist. Ferner soll sich die strigata dadurch auszeichnen, daß3 jhre Supraocularia von den Supraciliaria durch eine kurze Körnerreihe, oder nur durch zwei bis drei Schüppchen getrennt erscheinen, endlich, fügt Kessler hinzu, ihnelt diese Form hinsichtlich ihres Farbenkleides eher der agitis und soll so zu sagen eine viridis repräsentieren, welche begonnen hat, sich in die agitis umzuwandeln. Obschon mir Fälle bekannt sind, dafs die Supraciliaren auch bei den norditalienischen wechten viridis s sich direkt den Supraocularen anfügen können, so muß ich dennoch der Kessle rschen Auffassungsweise im grofsen und ganzen beipflichten, denn mehrere von mir untersuchte strigata aus dem Kaukasus und aus Lenkoran zeigen die ron diesem Forscher aufgezählten Kennzeichen und scheinen falitisch einer intermediären Form anzugehören, welche den Übergang von der viridis zu jener russischen agilis vermittelt, welche jüngst unter dem Varictätsnamen »orientalis« beschrieben worden ist und es scheint beinahe, dafs eben diese Ähnlichkeit der strigata mit agilis orientatis Eichwald bewogen hat, gewisse Spielarten der Zauneidechse, welche sich in der Tübinger Sammlung befinden, furr striguta zu erklären. Dies ist allerdings nur eine, wenn auch nicht ganz unbegründete Vermutung. Die Ansicht, daß Eichwald eine viridis, nicht eine Agilis-Form als MLuster bei der Aufstellung seiner Art »strigata vorgelegen haben dürfte, wird von den meisten Forschern geteilt und wird durch Eichwalds Bemerkung in betreff des Vorkommens dieser Eidechse nur noch bekräftigt; in der Fauna caspio-caucasia finden wir nämlich folgendes darüber : „occurrit quoque in Syria, Dalnatia, Jonia und weiter": »In Museo Vindob. haec species e Syria dicitur Lac. viridis var. (Lac. Michahellesii Fitz.) «. Darunter kann wohl kaum die Zauneidechse gemeint sein, weil einerseits das Wiener Museum, soviel ich weif3, keine Zaun-, sondern nur Smaragdeidechsen aus diesen Ländern enthält und andererseits weil die Identifizierung von $L$. ILichahellesii $\mathrm{Fitz}$. mit der strigata zweifelsohne darauf 
hindeutet, daf die strigata der Viridis-Gruppe angehört. Auch finden wir, dab E ichwald die quinquevittato Ménétr., die erwiesenermalien eine viridis repräsentiert, in die Synonymic

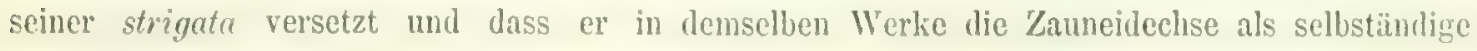
Art unter dem Namen »stimpium Daud.« verzeichnet. Wenn also L ey dig berichtet, dafi Eichwald einige Zauneidechsen der Tübinger. Sammlung für strigata gehalten habe, so glaube ich es dadurch erklären zu kömnen, daf Lichwald während seines Tübinger Anfenthaltes liein Vergleichungsmatcrial zu Gebote gestanden habe. Denjenigen IJerpetologen, welche die russischen und manentlich die südrussischen und kaukasischen viridis und agilis nicht näher kennen, mag es allerdings etwas sonderbar erscheinen, daf cine Smaragdeidechse mit einer Zauneidechse verwechselt werden liöme und dennoch liann dies leicht der Fall scin. Im Westen Europas erscheinen diese beiden Arten grundverschieden und werden sogar vom Laien auf den ersten Blick unterschieden, im südlichen- und asiatischen Rufland aber sind die Abänderungen der Farben, Schuppen und Körpergestalt bei beiden so zahlreich und die gegenseitigen » Nachahmungen « in dem Maßse täuschend, dafs man sich wahrlich nicht zu wundern bracht, dats Eichwald oder Rathke nicht mehr genau wuften, was agilis und was viridis resp. strigutu ist. Kessler hat z. B. vollkommen Recht, wenn er sagt, dafs die Beschreibung, welche Rathke in seiner Arbeit über die Fauna der Krim von der taurischen Sinaragdeidechse geliefert hat, ganz gut auch auf die agitis palit! Ich gestehe offen, daf mir, obschon ich die Unterschiede der im Westen Europas einheimischen viridis und agilis ziemlich genau kenne, sowoll die Bestimmung des mir aus Rufland zugeschickten Naterials als auch die Abfalimng der Diagnosen von diesen zwei Lacerten bei weitem mehr Kopfzerbrechen verursacht hat, als die Beschreibung sämtlicher übrigen in dieser Schrift aufgenommenen Species. Var. strigata darf, meiner Ansicht nach, als Zwischenglied betrachtet werden, welches die Smaragdeidechse und die agilis ovientalis verbindet; namentlich ist die Ähnlichkeit der jungen Individuen von strigata und orientalis so frappant, daf ich bei der Durchmusterung der Pariser Sammlung erst nach näherer Betrachtung, zweier, als » $L$. virictis« von Ménétries bezeichneter und gelieferter jungen Eidechsen dic Gewibheit erlangen konnte, daf, die betreffende Büchse eigentlich zwei Arten und zwar die viridis und agitis enthalte.

Wic es auch sonst bei den intermediären Formen gewöhnlich der Fall zu sein pflegt, zeichnet sich die strigata durch eine grofe Variabilität ihrer äufieren Kennzeichen aus, bald nähert sie sich im allgemeinen so schr der stypischen viridis, daß man erst genaue Untersuchungen vornehmen muss, um erstere von letzterer unterscheiden zu können, bald wiederum weicht sie von der Hauptform dermaßen $a b$, dab man sich beinahe geneigt fühlt sie als selb- 
ständige Species zu betrachteri. Am beständigsten von allen Kennzeichen der strigata scheint die Beschuppung des Rückens zn sein, diese Schupen sind nïmlich grö́ser als bei den übrigen Viridis-Formen und sind meistenteils breiter als lang; längs der Rückenmitte erscheinen sie etwas kleiner und enden winklig, gegen die Seiten hin werden sie dagegen gröber, greifen leicht übereinander und sehen beinahe vierseitig aus. Die relativ bedeutende Breitenentwickelung dieser Schuppen ist bereits Kessler aufgefallen; dieser Gelehrte giebt nämlich an, dal; die Zahl der Schuppen in einer Querreihe an Rücken, und zwar in der Rückenmitte, gewöhnlich 42 bis 46 beträgt, während bei den übrigen Smaragdeidechsen deren 48 bis 52 vorhanden sind. - In Bezug auf die Schenkeldrüsenzahl steht die strigata den ihr verwandten ViridisVarietäten ebenfalls etwas nach, denu sie zeigt jederseits meistens nur 12, 13 und 14 Drüsen welche Zihlen allerdings mitunter bis auf 22 gesteigert erscheinen kimnen. Diejenigen schuppenreihen, welche die Palpebralscheibe von den Supraciliaria trennen, sind bei ihr nur in geringer Zahl vorhanden; zuweilen sind nur 1 bis 2 Schüppchen sichthar. Die Bauchschilder sind in sechs Längsreihen angeordnet.

Über die Verbreitung der strigata giebt Eichwald folgendes an: „Hab. in orientali et australi ora caspia, in insula Oretas, telo velocior ideoque captu difficillima, latebras ut plurimum in soluta arena arundinetorum petens; etiam ad aquas carbnicas Kislawodskienses Caucasi: occurit quoque in Syria, Dalmatia, Joniak. Sie findet sich ferner in Suchum-Kale, in Elisawetpol und Tiflis, im Eriwanschen Gouvernement (Suchoï Fontan, nach Kessler), am Berge Ararat (Mus. in Kiew: Nr. 1980, dedit: Graf M n ischek), bei Lenkoran, im TalyschGebirge, auf der Insel Sara (Kessler), am balchanischen Meerbusen an der Ostküste des Kaspischen Meeres ${ }^{1}$ ), in Astrabad (Kess ier), in Schiraz (Anderson und Blanford) endlich bei Beyrut in Syrien (Böttger) und in Klein-Asien (Skutari, Samml. v. Bedriaga, Nr. 69, dedit: R. Hofman). Nach Berthold (l. c.) kommt die strigata auch bei Konstantinopel vor; ihr Vorkommen aber in Dalmatien und auf der Insel Corfu bedarf, meiner Ansicht nach, noch der Bestätigung, denn es ist leicht möglich, dal’ Eichwald die dreifach gestreifte viridis, eine, vorzugsweise auf der Balkan-Halbinsel und auf den jonischen sowie ägäischen Inseln einheimische Eidechsen-Varietät mit der fünffach gestreiften strigata zusammengeworfen hat.

Um die Gröfenunterschiede der vorzugsweise im Süd-Osten Europas lebenden dreifachgestreiften viridis und der vorderasiatischen strigatu zu zeigen, füge ich hier noch die Mafe

$\left.{ }^{1}\right)$ Eichwald, Reise auf dem Kaspischen Meere und in d. Kankasus I. Stnttgalt u. Tübingen 18:34. S. 278. 
eines mäunlichen Imlividums der trilineatu ans Griechenland an, wolche mit don frühor gerehenen Mafen der vorzugsweise in Westeuropa einheimischen Varietäten verglichen werden mögen.

trilincata. strigata.

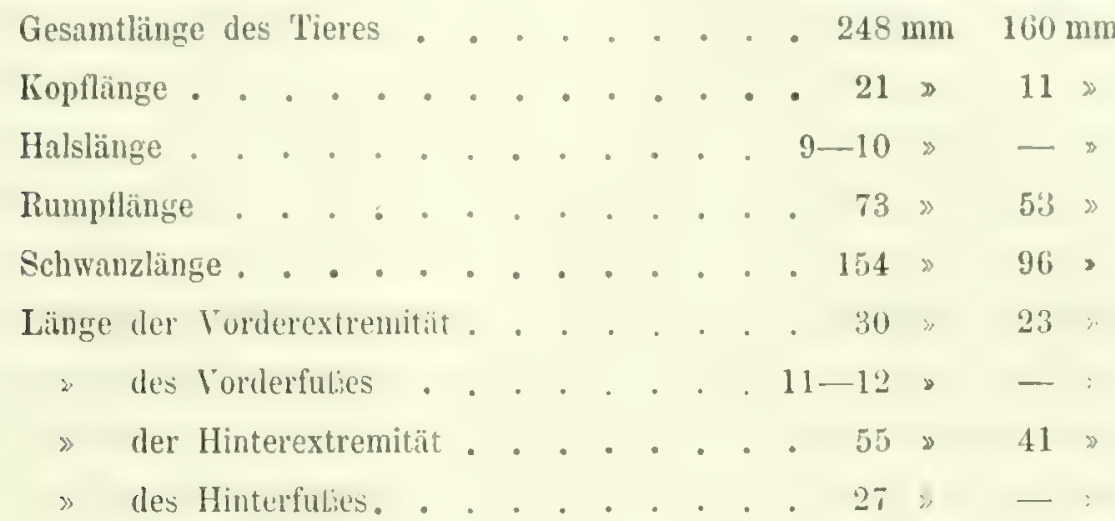

Grölste Kopflöhe . . . . . . . $12 \gg 9-9^{1 / 2} \gg$

\opfbreite.......... 14 . 11 »

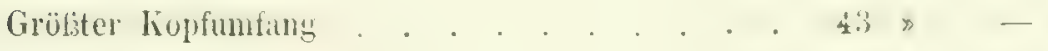

Breite de's I'ileus. . . . . . . . . . $9^{1}{ }_{2}$ × 8

Umfang des Halses . . . . . . . . 45 » - »

» Rumpfes . . . . . . 53 »

Diese Hauptvarietäten der viridis werden nun durch eine grobe Anzahl Zwischenformen verkettet, auf deren Beschreibung ich aber verzichten muf. Kurze Diagnosen dieser, von mir nicht erwähnten Formen hat Schreỉber in seiner Herpetologia europaea auf S. 441-443 gegeben, worauf ich hier verweisen kann. Die mir gänzlich unbekannte, im Gebirgsstock des Montblanc vorkommende mote, vierfachgestreifter L. viritis ${ }^{1}$ ) lasse ich unberticksichtigt und will nur noch einer ziemlich auffallend gefärbten Var. Vaillanti gedenken, deren im C. et Aug. Dumérils Catal. méthod. coll. Rept, in Blanfords Zoology and Geology of Eastern Persia und möglicherweise auch in der Fauna caspio-caucasia ") Erwähnung geschieht. - Bei der mir vorliegenden Var. Faillenti erscheint die Rückenregion ungefleckt, einfarbig olivenbraum; bei einem anderen, im Muséum d'histoire naturelle in Paris aufbewahrten Exemplar sind dunkelbraune Pünktchen am Ruicken sichtbar; die Nackengegend zeigt einen ziemlich stark auswe-

1) Venance Payot, Ernétologie, Malacologie et Paléontologie des environs du Mlont-Blanc in: Ann. des sc. physs. et nat. de Lyon 1864.

$\left.{ }^{2}\right)$ Var. astrabadensis, S. 83. - Im Kataloge von Duméril ist die in Rede stehende Fidechse als svar. concolore bezeichnet. 
prïgten grünen Anflug. Bei beiden Stücken sind die Körperseiten, namentlich die Halsseiten und die Achselgegend mit dunklen Pünktchen besäet. Die Kopfdecke und die Schläfen sind dunkelbraun. Der ungefleckte Bauch ist gelblich, die Kehle grünlichgelb und das olivengrüne Halsband gelblich gerandet. Die Schilder an den Extremitäten erscheinen gleichfalls olivengrün gefürbt und geIb umsäumt; die Schwanzschuppen sind oben uufabraun, unten grünlich, gelb gerandet.

In Bezug auf die äufsere Körperbedeckung unterscheidet sich diese, zu Ehren des Prof. Vaillant als »Vaillanti« benannte Spielart von den ihr verwandten Formen mehrfach. Vor allem fält das auffallend grobe, sechs- bis siebenwinkelige Massetericum auf, das von einer geringen Anzabl größerer und kleinerer Schläfenschilder umringt wird; ferner vermissen wir die für die Smaragdeidechse im allgemeinen so charakteristischen Körnchen, welche den Discus palpebralis von den Supraciliaren zu trennen ptlegen, oder wir finden nur 1 bis 4 solcher Körnchen; die Rückenschuppen sind sehr schwach geschindelt und auch in der Nackengegend gekielt. Es gehen abwechselnd 2,2,2 und 3 Schuppen auf ein Bauchschild; es sind 6 Längsreihen und 25 bis 28 Querserien von Bauchschildern, 9 auffallend lange Halsbandtafeln und 107 Querschuppenreihen von Schwanzschuppen vorhanden. Die Schwanzschuppen scheinen schmäler und in eine stumpfere Spitze ausgezogen zu sein, als bei den übrigen Smaragdeidechsen. - Die Poren sind in der Zahl von 15 bis 17 vorhanden. - Der Körper ist schlanker und gestreckter, der Kopf kürzer und schmäler als dies gewöhnlich bei den viridis der Fall zu sein pflegt. Die Entfernung von Nasenloch und Auge scheint mir bedeutend geringer zu sein als sonst. Der Schwanz ist an seiner Wurzel nicht sehr dick, auch sind die Vorderbeine zart gebaut; der gegen die Spitze hin sehr stark verdünnte Schwanz ist mehr als zweimal so lang wie der Körper. - Die Körpermafe des mir aus Paris zugesandten Individuums (No. 2682) sind folgende:

\begin{tabular}{|c|c|c|c|c|c|c|c|c|c|c|c|c|c|c|c|}
\hline Totall & ainge & . & & . & & & & & & & & & & - 245 & $\mathrm{~mm}$. \\
\hline Kopfl: & inge & . . & 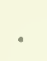 & . & • & • & - & . & , & - & . & & & 19 & $\gg$ \\
\hline Långe & von & der Kopfspitze & bis & 211 & & Sch & war & nzw & urz & el & 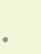 & & & $39-70$ & 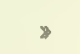 \\
\hline Läinge & des & T'cliwanzes & . & . & . & 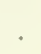 & & . & . & . & & & & 175 & ఎ \\
\hline Länge & der & Vorderextremitä & & . & . & & . & & & . & . & & & 26 & 3 \\
\hline 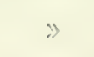 & $\gg$ & Hinterextremität & & . & . & . & - & . & - & . & . & & & 43 & $》$ \\
\hline & des & Vorderfuties . & & . & $\cdot$ & . & • & ${ }^{\circ}$ & . & • & • & & & 11 & \\
\hline$»$ & 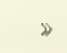 & Hinterfußes & & . & . & 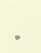 & 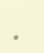 & . & . & . & . & & & $2: 2$ & $\gg$ \\
\hline firülist & $\mathrm{Ko}$ & pthöhe & & . & & & & & & & & & & & נ; \\
\hline
\end{tabular}




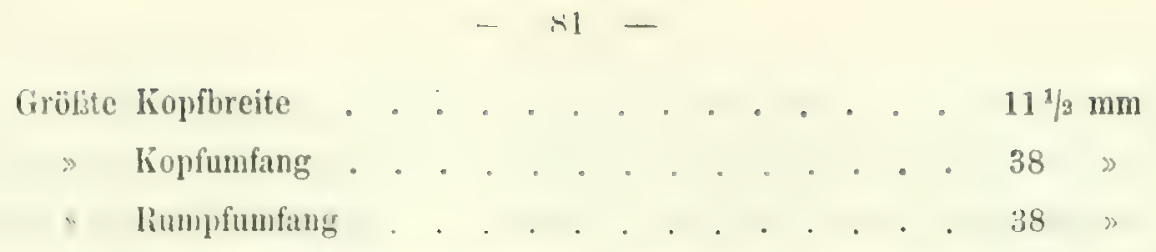

Die hier beschriebenen Exemplare stammen aus der Ausbeute von A ucher-Lloy; sie sind nach dem 'lode dieses Reisenden vom Pariser Museum erworben worden. Sowohl auf der Etikette als auch im Kataloge von C. und A ug. Duméril finde ich Persien als Fundort angegeben.

Die von mir im Vorstehenden erwähnten Zeichnungs- bezw. Farbenvarietäten der Smaragdeidechse sind sonach die folgenden:

1. Var. Gadovii Boulenger 1). - Oberseite grün oder braun mit schwarzen oder braunschwarzen Flecken. Bauch schwarz gefleckt. Beim Weibchen herrscht mitunter Grün am Vorderrücken und Braun an den hinteren Rumpfpartieen vor; beim Männchen findet sich zu beiden Seiten des Rumpfes gewöhnlich eine Reihe weiber Flecken. Ganz junge Stücke sind oberhalb olivenbraun, seitwärts blau geaugt, unterhalb einfarbig grünlichweiß̧. - Vorkommen: Pyrenäische Halbinsel.

2. Var. Schreiberi $\mathrm{m}^{2}{ }^{2}$. - Das Occipitale scheint in der Regel größcr als das Interparietale zu sein; am Bauch sind $\delta$ lange Schilderreihen vorhanden. Bauch bei beiden Geschlechtern (bei ausgewachsenen Stucken) gelblich, dunkel punktiert. Münnchen: Oberseite grün oder gelb mit zahlreichen schwarzen Punkten und Flecken. Kehle blau. Weibchen: Der grüne Vorderrücken und der grünlichgelbe Hinterrücken oder der braune Rücken mit grołen schwarzen Hlecken besetzt oder schwarz genetzt. Junge Tiere: Fleckenlose braune Rückenzone; an den Körperseiten drei bis vier Reihen Augenflecken (gelbe Mitte dunkelbraun umsäumt). - Vorkommen: Raices in Asturien und Galicien in Spanien.

Es ist möglich, daß es später gelingen wird, Übergänge zwischen diesen beiden Formen zu finden und sie unter dem Namen »Gadovii zu vereinigen.

3. Var. concolor D ug ès ${ }^{3}$ ). — Oberseite ganz grün obne Flecken; Unterseite weib,

1) Proc. Zool. Soc. of London 1884, pag. 418. Pl. XxxviII. - ? L. agilis Schreiber, Herpetologia europaca, S. 440. - L. viridis var. punctata D ug è s, Böt tg e r in: Zeitschr. f. d. ges. Naturwiss. Bd. L II. 1879. S. 505. - ? L. stirpium D a ud., II a chado in: Revista di Ciencias etc. IV., pag. 567. Sevilla 1859

$\left.{ }^{2}\right)$ Herpotolog. Studien in: Archiv f. Naturgeschichte 1878. I. Bu. S. 299. Taf. X. Fig. 3 u. 4. Ibiden, 1879. Taf. XVIII. Fig. 2 u. 6. - L. Schreiberi B edr., Boulenger in: Proc. Zool, Soc. of London 1881, pag. 743, - L. Schreiberi Bedx., Boscà in: Anal. de la Soc. Esp. de Hist. Nat. X. 1881. L. Schreiberi bedr., B o scà in: Bull. Soc. Zool. de France 1880, pag. 277.

$\left.{ }^{3}\right)$ Ann. Sc. nat., mars 1829. Article II. - L. viridis var. a. Schreiber, I. c. - L. viridissima Fitzing er in: Sitzber. Akad. d. Wiss., Math. naturw. C1. 1851. I. Bd. X. S. $653-$ L. viridis var. concolor 
gelblich oder intensiv gelb. Beim Weibchen und bei jungen Tieren erscheint die Rückenzone mitunter von zwei weilien oder gelblich-weilien Längslinien umsäumt; auch sind die Jungen oberhalb mehr grünlichbraun wie grün gefärbt. - Vorkommen: Diese Varietät kommt allenthalben, jedoch nicht häufig vor. - Die von einigen Forschern als synonym hierher bezosene $L$. chloronotos $\mathrm{R}$ a fin. dürfte eher zu punctata $\mathrm{Da}$ a d. gehören. Das Werk von Rafinisque Schmalz steht mir allerdings nicht zur Verfügung, jedoch ersehe ich aus den Schriften De Bet $t a$ 's, daßs die Chloronotos auf der Oberfäche mit dunklen Flecken besetzt ist.

4. Var. munctata (Le lézard verd piqueté) D a u din ${ }^{1}$ ). - Oberseite des Körpers grün, blau oder gelbgrün mit schwarzen, braunschwarzen und mitunter auch mit weiß̉en Pünktchen betüpelt; die dunklen Punkte überschreiten in der Regel nicht die Größe einer Schuppe, in den meisten Fällen ist die Schuppe nur dunkel gerandet. Unterseite weißlichgelb oder gelb; die nach auken liegenden Ventraltafeln zeigen einen grünlichblauen Rand oder sind punktiert, wie es $z . B$. vorzugsweise bei den syrischen, durch ihre schöne grelle Färbung des Rückens ausgezeichneten Stücken der Fall zu sein ptlegt. Die Kehle hat öfters und bei beiden Geschlechtern einen blauen Anflug ${ }^{2}$ ). Das Weibchen weicht zuweilen nur dadurch vom Männchen ab, da€ es zwei mehr oder weniger deutlich ausgeprägte weife, gelbliche, grünlich-oder gelblichweilie Streifen aufzuweisen hat, welche die Rückenzone umsäumen (bilineata der Autoren!); in einigen Fällen gesellen sich helle, in Längsreihen gestellte Flecken hinzu, welche die Rumpfseiten zieren (var. à 4 raies D. B.). Junge Exemplare sind mitunter oben auf braun oder grünbraun regelmäbig und spurweise dunkel getfecktem Grunde von zwei weiflichen Längslinien durchzogen. Vorkommen: Diese Varietät ist weit verbreitet, jedoch gehört die zweifach gestreifte Form des Weibchens mehr dem Westen Europas an; namentlich im Süden scheint sie bereits auf der Balkan-Halbinsel durch die dreifach gestreifte Forma ersetzt zu sein.

De Betta, Rettiti ed Anfibi in: Fauna d'Italia, op. cit.; Atti Accad. di Agricoltura etc. Verona, XXXV, pag. 133. - L. viridis var. a. Duméril et Bíb r o n Erp. générale t. V. pag. 214.

1) Hist, nat. Rept. III. pag. 144. - L. smaragdina Schinz, Naturg. u. Abbild. d. Rept. S. 99. Taf. XXXVI. Fig. 2.; M issner in: Mus. d. Naturg. Helvetiens I. No. 6, S. 41. - Var. punctillata F a tio, Faune des Vertebrés de la Suisse III, pag. 72. - $L$. elegans A n d r z e jow ski in: Nouv. Mém. Soc. Imp. Moscou III. pag. 319. - L. viridis var $b, c, d$. S chreiber, l. c. - Var. versicolor D e Betta, 1. c. Var. b. c. D uméril et Bibron, 1. c. - Variété piquetée de jaune et de noir, La tas te in: Act. Soc. Linn. Bordeaux, t. XXX, pag. 88 .

2) Subrar. mento-coerulea Bon a a r te, Iconografia della Fauna italica. Tab. Fig. 4. - L. cyanoluema Gl iu ckselig in: Lotos 1851 S. 111, Podarcis cyanolaema Glückselig in: Verhandl. Zool. bot. Ges. Wien XIII. S. 1134. 1863, - L. viridis var. mentocoerulea De Bet ta l. c. 
5. Var. maculata D u gès. ${ }^{1}$ ) - Oben grün oder graubraun mit größeren schwarzen oder braunschwarzen, mitunter von weililichen oder gelblichen Schuppen begleiteten Flecken. Unterseite gelblichweils oder grüngelb. Die Weibchen sind mitunter mit zwei hellen Liugsstreifen und aufserdem noch manchmal mit zwei, längs der Rumpfseiten verlaufenden hellen Fleckenreihen versehen; in seltenen Füllen verfliefen diese Flecken ineinander, wodurch vier Lïngsstreifen entstehen. Junge Tiere: Wie 4), aber die Flecken am Rücken von der helleren fimundfrhe lebhafter abstechend. - Mit dieser allerurten, innerhalb des Verbreitungsgebietes der smaragdeidechse, vorkommenden gefleckten Varietät scheint die, mir leider unbekanutr Var. cinereo-nigrescens D e Betta ${ }^{2}$ ) nahe verwandt zu sein. - Aufer der zweifach resp. vierfach gestreiften Form des Weibchens kommt sowohl bei Var. 4 als bei Var. 5 ein oberhalb) grunlichbaunes, ungetfechtes mier mit zahlreichen, wenig hervortretenden branen Flecken und schnörkelartigen Figuren versehenes Weibchen vor, das 1 bis 2 Reihen gelblicher, runder Flecken an den Rumpfseiten aufweist. Die jungen Tiere können ganz genau wie diese ausgewachsenen Weibchen gefärbt und gezeichnet erscheinen. Höchst wahrscheinlich sind derart gefärbte und gezeichnete Individuen bei Schre iber sub. Var. k. und 1. erwähnt worden.

6. Var. trilineata. ${ }^{3}$ ) - Oberseite: auf grünlichbraunem oder braunem Grunde drei weibliche, gelblich-, blitulich- ader grtulichweilse, schmale Linngsbinden, von denen sich die eine längs der Vittellinie des Rückens hinzieht; zu beiden Seiten des Rumpfes 1 bis 2 Längsserien gelblichoder grünlichweiß̉er, dunkel umsäumter Augen. Unterseite mit weiłlichem, grünlichem oder graublauem Antluge versehen. Jüngere Stiicke sind den ausgewachseven sehr ähnlich, nur sind die dunkelbraunen Säume und Flecken, welche die hellen Streifen und Augen bei den Alten begleiten, schwach angedeutet oder aber sie fehlen gänzlich. - Vorkommen: Diese wohl öfters mit der strigatu verwechselte Varietät ist von der Balkan-Halbinsel aus über Klein-Asien und Syrien bis zum Libanon-Gebirge verbreitet.

7. Var. strigata. Eichwald $\left.{ }^{4}\right)$. - Oberseite braun od. grünlichbraun mit fünf hellen

i) Var. 4. Tschudi, Monogr. d. schweizer. Eschen. 1837. - Var. maculata B on a parte, 1. c, De Betta, l. c. - Var. marmorata Fatio, l. c. - ? Lac. serpa, sicula Rafinisque Schmalz, l. c.

2) Verhandl. Zoolog. bot. Ver, in Wien 1852. S. 153.

${ }^{8}$ ) L. viridis var. h. (part.) Duméril et Bibron, op. cit. - Var. p. Sc hreiber, l. c.

4) Zoologia specialis 11I. pag. 189; Fauna caspio-cancasia, pag. 87, tab. X, fig. 4, 5, 6. - L. quinquevitata Ménétries. Cat. raisonné etc. pag. 61. - L. viridis var. r, s. Schreiber op. cit. - Var. h. (part.) Duméril et Bibron op. cit. - L. strigata Gray, Cat. Liz. Brit. Mus. pag. 32. - Anderson in: Proc. Zool. Soc. of Lonton 1872, pag. 371. - De Filippi, Note di un viaggio in Persia, pag. 354. - Berthold, Üb. einige neue od. seltene Amphibienarten in: Act. soc. reg. Goetting. VIII. 1842. - Var, strigate Kessler, Zoolog. Reise durch Transkaukasien 1. c. - L. strigata Cope, J. c. 


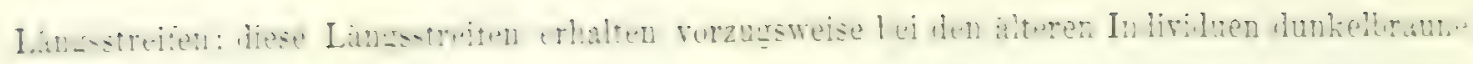
Säume oder werden ron dunklen Flecken begleitet. Unterseite weißlich oder grünlich- und gelblichweiß. - Torkommen: Ziemlich gemein in Kaukasus, in Trankaukasien, in Klein-Asien und in Syrien; soll auch in Schiraz und Astrabad sorrie am balchanischen Meerbusen an der Osthüste des Kaspischen Meeres einheimisch sein. Aus Europa wird diese Varietät von Konstantinopel und aus den Abruzzen ${ }^{1}$ ) rerzeichnet, jedoch steht ihr Vorkommen in Italien ganz rereinzelt da und bedarf noch der Bestätigung.

8. Var. Vaillanti m. ${ }^{2}$ ). - Rückenseite olivenbraun einfarbig oder dunkel gepunktet; Nacken grūn angehaucht. Unterseite ungefleckt, grünlichweiļ. - Vorkommen: Persien (Mus. d'hist. nat. zu Paris, Nr. 2682). - Außer diesen Hauptrarietäten der viridis existieren mehrere andere Zmischenformen, welche in den, ron mir citierten Werken beschrieben worden sind. Auch die Beschreibung dieser Formen mufs ich einerseits regen Mangels an Material und andererseits wegen Mangels an Raum verzichten.

Mit vieler, ja mit der grōbten Wahrscheinlichkeit darf man der Vermutung Raum geben. daß die im British Museum als * L. viridisc aufgestellte, ron Tristram am Phiala-See erbeutete Eidechse entreder eine, mit der vorigen in ihren Grundzügen rerschiedene Form der vividis oder sogar eine selbständige Art repräsentiert. Leider bin ich, wiederum wegen Mangels an Material, nicht in der Lage ein endgültiges Urteil darüber fällen zu können und will, um der roreiligen Einführung: ron neuen Subspecies- oder speciesnamen rorzubeugen, die frustiche Eidechse vom Phiala-See hierselbst kurz beschreiben. Obgleich der Kopf bei der PhialaEidechse kürzer. oben - namentich beim Männchen - oberhalh der Augen stürher gewüb ist mai die schlafeuregion mürlichermeise etmas frononcierter lachenartig anfgetrieben erscheint. als dies bei den echten wrihis der Fall ist, unterscheiden sich leide Lacerten hauptsuchlich durch die Beschildung des Kopfes und Beschuplung les Rumpfes. I as Ireiechige. rorn spurweise abgestutzte Occipitale ist hei der Phiala-Ëidehs. verhaltnismaig winzig kiein. währendem das. vorn auf Kosten der Parictalia stark erweiterte. mit stumpitminheligen Ravde verseheze.

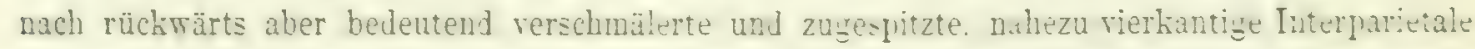

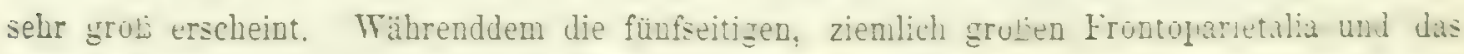

1) Dehne in: Allg. deutsche naturhist. Zeit. II. S. 212. Hamburg 1856.

") L. viridis concolor (part.) C. et Aug. Duméril, Cat. méth. Coll. Rept. Mus. d'hist. nat. Paris.1351. -? L. riridis Daud. rar. astrabadensis Eichmal d, Fauna caspio-caucasia, pag. 83. 
vorn sehr breite, hinten verschmälerte und stumpfwinkelig endende Stirnschild nichts Aufiergewöhnliches bieten, fallen doch die Parietalia dadurch auf, daß sie vorn in bedeutendem Grade verschmälert erscheinen; sie sind an Aufsenrande von 3 Schildern begrenzt. Eine den Palpebraldiscus von den Supraciliaria trenuende: Körnereihe ist vorhanden; T!mplnicum chenfalls, hingegen ist ein durch besondere (irölia hervortretendes Massetericum nicht konstatierbar. Zwei übereinander stebende Nasofrenalia, ein hohes, schmales, zum 'Teil nach oben übergewölbtes Frenalschild, entweder ein lingliches, oder zwei kleine P'acocularia und ein Postoculare. Das Rostrale ist stark auf den Pileus übergewölbt; 4 Supralabialia anteriora, I Suboculare und 2 Supralabialia posteriora, 5 Submaxillaria. Die Schläfe sind mit kleinen sechskantigen Schildchen bedeckt. Kehlfurche vorhanden. Dis gezähnelte Halshand ist aus i grölieren und 2 kleineren Schildern zusammengesetzt. Die Ventralschilder stehen in 29 Längs- und 6 Querreihen; die Randschildchen sind grol.;. Die Aftergegend ist durch ein grölieres Anale bedeckt. das vorn von in zwei Halbkreisen stehenden kleineren Schildchen ungeben ist. Die in 40 Längs- und 96 Querreihen angeordneten gekielten Rumpfschuppen sind am Anfang des Rückens klein und körnig, weiter aber schmal und länglich; nach den Seiten hin entwickeln sie sich dermabien in die Breite, dabs sie breiter als lang erscheinen und zugleich eine regelmäbig vierseitige und viereckige Gestalt annehmen, so dafis die, längs der Mittellinie sich hinziehenden Kỉele die Schuppen in zwei gleiche Hälften teilen. Die Wölbung tritt an den ganz eigentümlich glänzenden, wie emailliert aussehenden Schuppen so stark hervor, dab dic Iinckenhaut beim Anfassen sehr rauh oder grenauer mit dicht stehenden Körnern besetzt urscheint. Schenkeldrüsen sind 18 bis 19 vorhanden.

Die mir vorliegenden zwei Exemplare dieser Eidechse sind oben hellbraun, vom Nacken bis zur Schwanzwurzel von drei grünlichweißen Streifen durchzogen, welche zum Teil von dunkelbraunen, sich vom Grundton abhebenden Zeichnungen begleitet sind. Die auf den Körperseiten verlaufenden, grünlichweifien Streifen oder Binden entsenden nach innen zu kurze, nahezu gegenseitig in Berührung tretende Zweige, welche gewöhnlich an ihren Enden sich zu abgerundeten Flecken ausbreiten und zwischen sich noch andere, vom hellbraunen Fond durch ihre grünlichweilse Farbe abstehenden Ocellenflecken einschliefien. Auf der Bauchgrenze sind auferdem noch andere grünlichweilie Flecken vorhanden, welche teilweise auch auf die äuliersten longitudinalen Bauchschilderreihen übergehen; nach der Bauchmitte hin ist die gelbliche Farbe die herrschende. Die Kehle ist gelblich oder, namentlich gegen die Submaxillaren hin, bläulich; die grünlichgelben Kopfseiten, insbesondere die Schläfen- und Oberlippenschilder sind dunkelbraun yunktiert. Die Extremitäten erscheinen oberhalb auf hellbraun 
spärlich dunkelbraun gepunktet; dunkle Flecken sind auferdem an der Caudalwurzel verteilt; zum Teil gehen auch die seitlichen, am Aufenrande der Parietalschilder ihren Ursprung nehmenden, grünlichweifen Rumpfbinden auf die Schwanzseiten über; die Schwanzunterseite zeigt graublaue gelblich umsäumte Schuppen.

Wenn mich mein Gedaichtnis nicht trügt, so glaube ich diese, hauptsächlich durch die Deschattenheit der Tiudienschuppen und die lionfinuration der hinteren, unyaren Pileusschilder so sehr ausgezeichnete Eidechse auch aus Jerusalem stammend gesehen zu haben.

Vorkommen.

Man war früher der Ansicht, daf L. viridis den Ländern der Mittelmeerküste, also Europa Asien und Afrika, angehöre. Erst als es Strauch, dem wir eigentlich den ersten Versuch zu einer Reptilienfauna Algeriens verdanken, nicht gelungen ist auf seiner großen algerischen Reise in Jahre 1860 auch nur ein Exemplar dieser Art zu Gesicht zu bekommen, warf man die Frage auf, ob die viritis auch wirklich in Algerien vorkomme, wie es bekanntlich Duméril und Bibron, Westphal-Castelnau, Lallemant und so viele andere behauptet haben oder ob es sich um eine Verwechselung mit einer anderen Species handle, wie es Schlegel anzunehmen schien. Die Forschungen F. Latastes, welcher, so zu sagen, den Fukstapfen Strauchs folgend, nahezu ganz Algerien bis in das Herz der Sahara hinein bereiste, ferner diejenigen von Marquis G. Doria in Tunesien, von G. Rohlfs und Dr. A. Stecker im Paschalyk Tripolis und die Sammelreisen von Dr. Kobelt und Premier-Lieutenant Quedenfeld in Marokko haben in Bezug auf das Vorkommen der Smaragdeidechse in Nordafrika ein negatives Resultat ergeben: keiner von ihnen hat diese Species in Nordafrika zu sehen oder zu erbeuten vermocht und wir können ohne Fehlgriff zu thun die viridis getrost aus der Fauna Afrikas streichen und uns daruber nicht weiter bekümmern, daß sie dem Lichtensteinschen Nomendator reptilium et amphibiorum musei zoolorici berolinensis zufolge auf den Kanarischen Inseln vorkommen soll. Währenddem jene mit der viridis durchweg zusammengeworfene Eidechsenform nichts anders sein kann als die beschriebene, intermediäre Species oder „subspecies pater", sind die, angeblich von den Kanarischen Inseln stammenden und im Berliner Museum aufbewahrt gewesenen viridis wohl seit Lichtenstein umetikettiert worden, denn ich habe sie im genannten Iuseum nicht aufzufinden vermocht. - Nicht nur fehlt die viridis in Afrika, sondern sie scheint auch in den östlichen, Afrika zunächst liegenden europäischen Ländern ein ziem!ich seltenes Tỉer zu sein. Sei es, weil die klimatischen Verhältnisse und die Bodenbeschaffenheit ihrem Wesen nicht behagen, sei es, weil sie in jenen Gegenden im Kampf 
ums Dasein mit der stïrkeren Aıt, der Perleidechse, unterlegen, oder sei es, weil der Süiwesten Europas nicht ihre eigentliche Heimat ist und sie hier noch nicht, so zu sagen, festen Boden fassen konnte, wird sie z. B. auf der Pyrenäischen Halbinsel nur stellenweise und in geringer Anzahl angetroffen. In Portugal ist sie nach Barboza du Bocage ${ }^{\text {t) }}$ selten; sie konmt in Beira, am Dom Jesus do Monte (Entre Douro e Minho), am Ufer der Guadiana (Alemtejo) und in Monchique in Algrave vor (E. B oscà ${ }^{2}$ ), 0 . Böttger ${ }^{3}$ ). In Spanien soll sie uach Boscà bei Oviedo, Camprodon in Katalonien, Eskorial, Guadarrama in Neu-Kastilien, Zumaya und Vitoria in Vascoganda, La Serrota und San Idelfonso in Alt-Kastilien, vorkommen. In Galicien ist sie von V. L. Seoane gesammelt worden. Auf den Balearen ist die viridis noch nicht nachgewiesen worden.

Von Spanien erstreckt sich ihr Verbreitungsbezirk auf Frankreich, wo sie namentlich in den südlich, östlich und central gelegenen Departements sehr gemein ist, währenddem sie in den nördlichen und nordöstlichen Gebieten im Gegenteil minder bäufig, oder gar nicht beobachtet worden ist. Nach den zahlreichen Exemplaren iler einfarbigen oder spärlich dunkel getleckten und biliniierten riridis aus Langovian, Biganos, Soulac, Cadillac und Arlac zu urteilen, welche ich in der Sammlung von Herrn Lataste zu sehen Gelegenheit hatte, ist diese Species in der Gironde stark verbreitet ${ }^{4}$ ). Auch im Hérault wird sie laut Jumea $\mathbf{u}^{5}$ ) überall in zahlreichen Farbenvarietäten angetroffen. Stücke aus Montpellier sind im Museum in Paris zu sehen. Im Département du Gard wird sie von Crespon ${ }^{6}$ ) für die Gegend von Aiguesmortes und im Département du Var von C. und A. Duméril ${ }^{7}$ ) für die Halbinsel Giens namhalt gemacht. Aus der Provence, namentlich aus dem Var-Thale, kenne ich sie übrigens aus eigener Erfahrung; sie hält sich hier vorzugsweise am Meeresstrande im Gebüsche auf und wird landcinwärts, in den gebirgigen Teilen des Litorale durch die Perleidechse vertreten; im Hochgebirge aber, wie z. B. in den See-Alpen, tritt die viridis wieder zum Vorschein. In der hiesigen Gegend um Nizza ist sie in letzter Zeit ziemlich selten geworden und scheint nur noch in geringer Anzahl in Gebirge hei Villafranca vorzukommen; dagegen am Cap St. Martin bei

1) Liste des mammifères et reptiles observés en Portugal in: Revue et Magas. de Zool. par GuérinMe nerille XVI. 2 ser. 1863.

\#) Bull. Soc. Zool. de France V. pag. 279. 1880.

3) Zeitschr. f. ges. Naturwiss. Bd. LII. 1879. S. 505.

4) Lataste, Essai d'une Faune herpétologique de la Gironde in: Act. Soc. Linn. Bordeaux, t. XXX.

s) Bull. Soc. d'études sc. nat. de Béziers 1879, pag. 181.

B) Faune méridionale etc. pag. 196. Nimes 1844.

7) Catalogue méthodique de la collection des reptiles. Paris 1851 . 
Mentone und ostwärts gegen die italienische Grenze hin begegnet man ihr häufiger. Nach Ogérien ${ }^{1}$ ) kommt sie auch im französischen Jura-z. B. bei St. Claude-, nach Collin de Plancy)2, Girod-Chantrans ${ }^{3}$ ) und Ollivier $)^{4}$ auch im Département du Doubs vor. Die Angabe $B u c^{9} h \mathrm{z}^{5}$ ) in Betreff ihrer Verbreitung in Lothringen ist insofern bestätigt worden, als Mathie $u^{6}$ ) sie unter die Wirbeltiere der Fauna von Meurthe aufgenommen hat. Ob ihr Wohngebiet im Osten Frankreichs weiter nach Norden sich ausdehnt, ist fraglich; sie wird wenigstens von seiten verschiedener Forscher weder für die, Ardennen noch für Moselle angezeigt und wohl mit Recht, denn in den benachbarten Ländern wie Belgien ${ }^{7}$ ), Luxemburg und auch in Holland ist die Smaragdeidechse bis zur Zeit noch nicht konstatiert worden. Über die Erstreckung ihres Verbreitungsbezirkes nach dem Nordosten Frankreichs äubert sich Lat as te in seinem Verzeichnisse der Kriechtiere aus der Umgebung von Paris folgenderweise: »il est absent au dessus de la ligne qui joindrait la Somme et la Moselle, apparaît pour la première fois aux environs de Paris, où il est rare, et ne se trouve qu'à Fontainebleau « ${ }^{y}$ ). Demnach scheinen die Ungebungen von Paris, namentlich Fontainebleau, Versailles, Limours, Boulogne und der Wald von Verrières - die vorgeschobensten Punkte des Verbreitungsbezirkes der viridis im Westen Frankreichs zu sein. Im Département de l'Aube soll sie nur in den südich gelegenen Distrikten, so z. B. bei Bar-sur-Seine, Riceys und im Walde Marcy beobachtet worden $\operatorname{sein}^{9}$ ). Häufiger scheint sie nach P. Bert, ${ }^{10}$ ) Lataste und Collin de Plancy im Département de l'Yonne vorzukommen. Aus dem Département de la Sarthe ist sie neuerdings durch Amb. Gentil ${ }^{11}$ ) bekannt geworden und aus Morbihan und der Côte du Nord (Le Portrieux) habe ich selbst Exemplare zu untersuchen Gelegenheit gehabt. Im angrenzenden Finistère aber, wie ich aus einer freundlichen Mitteilung vom Grafen de L a u an ne, dem Verfasser

1) Hist. nat. du Jura et des départements voisins, pag. 293. Paris 1863.

2) Catalogue des Reptiles et Batraciens du département de l'Aube etc. Saumur 1878.

$\left.{ }^{3}\right)$ Essai sur la géographie pysique, le climat et l'hist. nat. du Département du Doubs, t. I. Paris 1810.

4) Faune du Doubs etc. in: Mém. Soc. d'Émulation du Doubs. Besançon 1883.

5) Aldrovandus Lotharingiae ou Cat, des animaux qui habitent la Lorraine et les Trois-Evêchés. Paris 1771.

$\left.{ }^{6}\right)$ In: Lepage, Statistique historique et administrative I. Nancy 1843 (Zoologie, pag. 223).

$\left.{ }^{2}\right)$ Ueber das Vorkommen der viridis in Belgien finde ich in der Faune Belge von Selys de Longchamps (I. pag. 173. Liège 1842) folgendes angegeben: son dit qu'il existe dans la forêt de Mormal̆e, mais j'en doute.

$\left.{ }^{8}\right)$ Cat. des Batraciens et Reptiles des eavirons de Paris etc. in: Act. Soc. Linn. Bordeaux, XXX.

9) Nach Collin de Plancy, l. c.

$\left.{ }^{10}\right)$ Cat. méthod, animaux vertebrés qui vivent à l'état sauvage dans le département de l'Yonne in: Bull. Soc. Sc. nat. et hist. de l'Yonne XVIII. 1964.

$\left.{ }^{11}\right)$ Erpétologie de la Sarthe in: Bull. Soc. d'Agricult. Sc. et Arts de la Sarthe 1884. 
eines Verzeichnisses der Süugrer und Vü̈rel von lüustère, ersohe, ist sie noch nicht nachgewiesen worden. Bekannt ist sie von St. Augustin bei Angers, aus der Umgebung von Saumur und aus den Landes de Sceaux und Thorigné im Dép. de Maine et Loire ${ }^{1}$ ). In den Départements de la Vienne ${ }^{2}$ ), de la Charente-Inférieure ${ }^{3}$ ) und de la Charente ${ }^{4}$ ) soll sie ebenfalls nicht fehlen und endlich auch in den Départements Creuze, Drôme, Puy de Dôme und Isère ${ }^{5}$ ) vorkommen.

Die früher mehrfach in Bezug auf die beschränkte Verbreitung der viridis in der Schweiz geäußerten Ansichten haben sich nicht bestätigt. Nicht nur in der wärmeren westlichen und südlichen Schweiz, sondern auch in den nördlich gelegenen Kantonen kornmt die Smaragdeidechse bestimmt vor und steigt sogar sehr hoch hinauf, ja sogar beinahe bis in die subalpine Region. Nach F. M üller soll sie in Wylen bei Basel, an der Rheinhalde und am Grenzacherhorn einheimisch sein ${ }^{6}$ ). Müller bemerkt aufserdem, dafs sie in früheren Zeiten am Isteinerklotz ziemlich häufig angetroffen worden sei; allem Anscheine nach ist sie von hier weiter nördlich in das Rheinthal vorgerückt. Von einem Vorkommen der viridis im benachbarten Jura ist hingegen Müller nichts bekannt. Im Waadt aber ist sie nachgewiesen worden; sie soll hauptsächlich im Genfer und Rhône-Bassin $\left(\mathrm{Fatio}^{7}\right)$ vorkommen. Sion, Salève und die Umgebung der Stadt Genf werden als specielle Fundorte dieser Art angeführt. Der Umgebung des Mont-Blanc soll sie ebenfalls nicht fehlen. Venance Payot giebt in seiner »Erpétologie, Malacologie et Paléontologie des environs du Mnnt-Blanc ${ }^{8}$ ) an, daßs sie auf allen Südabhängen bis zur Höhe von 600 M. und sogar darüber angetroffen werde; es sollen hier, fügt der Verfasser hinzu, typische, gefleckte und sonderbarerweise auch rote gestreifte Smaragdeidechsen einheimisch sein! In Wallis steigt sie laut Tschudi ${ }^{9}$ ) bis 4000 Fub IIeereshöhe hinauf; F. Müller fand sie bei Brieg. Alsdann kennt man sie aus dem Tessin (F atio l. c.) aus

1) Millet, Faune de Maine et Loire. Angers 1828. S. 611 (Supplément paru en 1868).

2) Mauduyt, Herpétologie de la Vienne. Poitiers 1844.

3) Belth rémieux, Faune du département de la Charente-Inférieure in: Acad. de la Rochelle. Section des sc. nat. Annales 1863 (Faune vivante. La Rochelle 1864. S. 37). - Lesson in: Act. Soc. Lin. de Bordeaux XII. 1841, jag. 55.

4) De Rochebrune, Cat. d'une partie des animaux vivant dans le dép. de la Charente, ibidem, t. XII.

5) Cha uvet, Cat. des animaux qui se trouvent dans le dép. de l'Isère 1846 (Statistique du Dép. de l'Isère).

') Vergl. seine für die Zoogeographie wertvollen Arbeiten in den Verhandl. naturforsch. Ges. in Basel $1877,1878,1880$ u. 1882.

$\left.{ }^{7}\right)$ Faune des vertebrés de la Suisse, Vol. III. pag. 74. Genève et Bâle 1872.

$\left.{ }^{8}\right)$ Ann. Sc. physiques et naturelles, d'Agriculi, et d'Industrie de Lyon, VHI, pag. 456.

$\left.{ }^{9}\right)$ Monographie d. schweizer Èchsen in: Nouv. Mém. Soc. Helv. Sc. nat. 1837. 
Graubünden und zwar aus den Thälern von Poschiavo, von Bergel und endlich aus der Züricher Gegend (Mus. in Zürich).

Die Verbreitung dieser Eidechse in Deutschland ist bereits in ausgezcichneter Weise von L e y d i g geschildert worden, da jedoch seit dem Erscheinen seines Werkes über die in Deutschland lebendenden Arten der Saurier nun mehr als ein Jahrzehnt verstrichen, und seitdem an der Zoogeographie rastlos gearbeitet worden ist, so müssen die deutschen Wohnplätze der viridis nochmals aufgezählt und vervollständigt werden. Leydig nimmt wohl sicher mit Recht an, daßs die Einwanderung dieser Art in Deutschland von Frankieich und der Westschweiz her stattgefunden haben wird, denn die Smaragdeidechse sowohl als auch die Mauereidechse sind gewiß̧ südeuropäische Arten par excellence und müssen erst nachträglich ihre ursprüngliche Heimat, die Mittelmeerländer, verlassen, und durch Wanderung längs grołer Flufthäler Vitteleuropa erreicht haben. Obschon die Hauptwege zur Ausbreitung dieser Species in den nördlicheren Zonen genau dieselben gewesen zu sein scheinen, ist die schwächere Art (die muralis) im westlichen Deutschland weiter nach Norden vorgerückt, als die stärker gebaute viridis und hat sich, wie wir es später sehen werden, von den auf jhrem Wanderzug eingeschlagenen Wegen nicht weit zu entfernen vermocht, während $L$. viridis im Gegenteil im Nordosten Deutschlands die Nordgrenze der Verbreitung ihrer Gefährtin bedeutend überschritten, und zugleich sich an einzelnen, oft weit auseinander gelegenen Orten eingebürgert hat, die von ihren gemeinschaftlichen Wanderstraßen sehr entfernt liegen. Diese Thatsache deutet wohl sicher darauf hỉ, dafs die Smaragdeidechse nicht nur das Rhône-, Rhein- und Donauthal benutzt hat, um nach Centraleuropa zu gelangen, sondern dalis sie auch dem Laufe der Elbe und der Oder gefolgt ist, sich hier aber nur an geeigneten Plätzen erhalten hat, während sie an den, für ihre Existenz ungünstigen Zwischenstationen wohl ausgestorben sein dürfte.

Das stufenweise Vorrücken der uns hier interessierenden Species von der Schweiz aus längs des Rheins nach West-Deutschland läßit sich zur Zeit nur am rechten Ufer verfolgen, denn im Gebiete des Oberrheins ist sie meines Wissens aus Elsaf noch nicht nachgewiesen worden, was allerdings einigermafen auffallen muf, da sie einerseits auf dem rechten Rheinufer in Baden an einigen Orten, wie z. B. am Isteiner Klotz [Jä ckel ${ }^{1}$ )] und am Kaiserstuhl, anderseits in den französischen, an Elsal3 grenzenden Departements vorkommt. Erst von - .

1) Korrespondenzbl. d. zool. mineralog. Ver, in Regensburg No. 6, 7. XXV. Jahrg. 1871. S. 81. - Der Bearbeiter der Fauna Badens im Werke „Das Großherzogtum Baden (Karlsruhe 1883) fügt dem längst be• kannten Fundorte Isteiner Klotz sonst keine neuen hinzu. 
Worms an bis etwa zur Mosel- und Lahnmündung findet sie sich an mehreren Punkten auf beiden Ufern des Mittelrheins und ist hier, namentlich in der Wormser Ebene [Glaser $\left.{ }^{1}\right)$ ], bei Bingen und Bingerbrück, in St. Goar und St. Goarshausen (Mus. Senckenberg), bei Caub, $\left.\left[\mathrm{Lex}^{2}\right)\right]$, auf dem Niederwald bei Rüdesheim [F resenius $\left.\left.{ }^{3}\right)\right]$ und auf dem Lorley-Felsen ziemlich häufig beobachtet worden. Vom Mittelrheine aus ist sie längs der Nahe bis Creuznach, wo sie an den sonnenbeglühten Bergwänden allerorts haust, und weiterhin bis Münster an Stein und bis zum Felsen der Ebernburg [Leydigt)] vorgedrungen. Dab sie im Moselgebiete nicht an mehreren Orten und mit mehr Bestimmtheit nachgewiesen worden ist, dürte daran liegren, daf3 man das Tier mit der Zauneidechse verwechselte. Die wenigen Stellen an der Mosel, wo sie bis jetzt entdeckt worden ist, liegen in der Umgebung von Trier. Bei Metz scheint sie bis dato noch gar nie angetroffen worden zu sein, dürfte aber daselbst, wie Noll wohl mit Recht vermutet, nur übersehen worden sein. Überhaupt sind wir in Bezug auf die Verbreitung der viridis in Lothringen nur sehr dürftig unterrichtet. Im sAldrovandus Lotharingiae ou Catalogue des animaux qui habitent la Lorraine et les Trois-Evêchés« von Buchoz 1771 in Paris erschienen, ist sie genannt, während wir sie in del neueren "Zoologie de la Lorraine von Godron (Paris 1863) vermissen. In der benachbarten bayrischen Rheinpfalz soll sie auf dem Haardt ${ }^{5}$ ) häufig, sonst aber, wie wir es aus den übereinstimmenden Angaben von II edicus ${ }^{6}$ ) und Jäckel (I. c.) schlieben können, selteu vorkommen. Das Neckarthal und das Maingebiet ${ }^{7}$ ) meidet sie und scheint überhaupt in Nassau und Hessen nur an den Rheinufern einheimisch zu sein, anderwärts aber gänzlich zu fehlen. In Oberhessen sowie in der darmstädtischen Provinz Starkenburg soll sie durch eine, an den Seiten schön smaragdgrüne agilis vertieten sein. In den zahlreichen mir vorliegenden Arbeiten über die Tierwelt Württembergs finde ich sie nicht erwähnt. Aus Bayern scheint sie nur aus Obernzell unterhalb der Stadt Passau, also dicht an der österreichischen Grenze, bekanut zu sein ( $\mathrm{Jäckel);} \mathrm{vielleicht}$ aber wird es grölserer Aufmerksamkeit gelingen das Tier noch an anderen Orten, so \%. B. in den Schluchten bei Hals, wo Schrank es gesehen zu haben vermutet, nachzuweisen, „Ob

1) Zoolog. Garten XI. S. 157 u. IX, S. 147.

2) Vergl. Leydig, Die in Deutschland lebend. Arten d. Saurier, S. 192.

9) Kirsch baum, Reptilien und Fische d. Herzogt. Nassau 1865. S. 5.

1) Die Anuren d. deutschen Fauna, S. 65. Bonu 1877.

5) Noll, Einige d. Rheinthale von Bingen bis Coblenz eigentüml. Pflanzen u. Tiere etc. in: Jahresber. d. Ver. f. Geographie u. Statistik. Frankfurt a. M. 1878.

$\left.{ }^{6}\right)$ Tiere der Rlueinpfalz. In: Bavaria 1867.

$\left.{ }^{7}\right)$ Leydig, Ủb. d. Verbreit. d. Tiere im Rhöngebirge u. Mainthal mit Ilinblick auf Eifel u. Rheinthal in: Verhandl. d. preufs. Rheinlande u. Westfalen XXXVIII. Jahrg. 4. Folge VIII. Bd. 
L. viridis in Sachsen vorkommt sagt $R$ e i b isch in seiner Abhandlung „Sammlung sächsischer Reptilien $\left.{ }^{1}\right)$, wist noch sehr ungewils, obgleich sie Schulz in seiner Fauna marchica in den Rüdersdorfer Kalkbergen, also nördlich von Sachsen, mit Bestimmtheit aufgeführt hat. Leider werden«, fügt der Verfasser hinzu, »die Männchen von $L$. agilis $L$. oft dafür gehalten。 $O b$ Holle ${ }^{2}$ ), Jäckel (1.c.) und Breh ${ }^{3}$ ), welche sie aus der Umgebung Annabergs, Leipzigs und aus Zeitz im Elsterthal melden, in diesen Irrtum rerfallen sind, bleibt fraglich; jedenfalls aber mőchte ich hier bemerken, daf̉ die Smaragdeidechse mir auf meinen Ausflügen in der Umgebung Leipzigs und im Saalthale, sowie auch überhaupt in den Centralgebieten Deutschlands nie begegnet ist und zugleich die Vermutung aussprechen, dalis sie eler in den an Böhmen grenzenden Gegenden zu finden sein dürfte. Die Angabe, daßs sie im östlichen Deutschland weit nördlich in. das Elbgebiet und zwar bis in die Nähe von Hamburg, wo sie in der Haake gefunden sein soll, hineindringt, ist verdächtig, namentlich seitdem es endlich sicher festgestellt ist, dafs sie der Fauna Meklenburgs faktisch fehlt ${ }^{4}$ ). Nehring bemerkt mit Recht, daf das angebliche Vorkommen der Smaragdeidechse bei Hamburg so aufallend ist, daf man wohl vermuten darf, dieselbe sei dort ausgesetzt«. Der nämliche Forscher fügt hinzu, daßs diese Art von ihm bei Helmstedt und Blankenburg in Braunschweig - also wiederum an isoliert liegenden Örtlichkeiten - konstaticrt worden sei ${ }^{5}$ ). Aus der Mark Brandenburg sind längst einige Fundorte, so z. B. die Rüdersdorfer Kalkberge und Oderberg nordöstlich von Berlin bekannt (Berl. Mus. No. 962, 968 u. 6860). Die Vermutung von Schulz, des Verfassers der Fauna marchica, dafs die Kalkberge bei Rüdersdorf der alleinige Wohnsitz der viridis seien hat sich somit nicht bestätigt. Diese Species soll im Gegenteil früher viel häufiger und an mehreren

1) Sitzungsber. d, naturwissenschaftl. Gesell。 Isis in Dresden 1866, No. 10-12. S. 113. Dresden 1867.

$\left.{ }^{2}\right)$ II. Jahresber. d. Annaberg-Buchholzer Ver. f. Naturkunde 1870. S. 98.

$\left.{ }^{3}\right)$ Kriechtiere in: Brehms Tierleben. 1878. S. 165.

4) In den Heften des Archiv d. Ver. d. Freunde d. Naturgesch. in Meklenburg 1857 S. 180, 1859 S. 152 1864 S. 188 und endlich in dem neueren Bande XXXT. S. 115 ist über das Vorhandensein der viridis in Meklenburg zu wiederholten Malen von Struck und Boll diskutiert worden. In seiner Beschreibung des Meklenburgischen naturhistorischen v. Maltzanschen Museum zu Waren kommt E. Struck zu folgender Einsicht: „Es sei mir hier die Bemerkung erlaubt«, sagt er, sdaf ich das Vorkommen von L. viridis für Meklenburg entschieden bezweifle, obgleich ich früher (1857) entgegengesetzter Ansicht war. In den letzten acht Jahren habe ich reichlich 30 Exemplare (von der agitis nämlich) die alle recht grell grün gefärbt und ron ungewöhnlicher Größe waren, untersucht, jedoch in den meisten Fällen gefunden, was schon Sturm aufgestellt, daß̧ es Männchen waren. Flüchtige Beobachtungen fügt Struck hinzu, stänschen hier leicht.* Meinerseits will ich in Bezug auf die Verbreitung der viridis im Norden Deutschlands hinzufügen, daß sie weder in den Beiträgen zur Naturkunde Lüneburg ( $\mathbf{X}$. Jahresber. d. naturwissenschaftl. Ver. f. d. Fürstent. Lüneb. 1861) noch in dem systematischen Verzeichnis d. Wirbelt. im Herzogt. Oldenburg ron Wiepken und Greve (Oldenburg 1876) aufgeführt sich vorfindet.

5) Zoolog. Garten XXI. S. 303. 
I.okalitäten, ja sogar in der unmittelbaren Umgebung der preufischen Residenzstadt ziemlich gemein gewesen und nur in den letzteren Jahren wieder verschwunden sein; ein Fall dem wir schon mehrfach bei den Kriechtieren begegnet sind. Laut dem Lichtensteinschen Nomenclator besitzt das Berliner Museum Individuen der viridis aus Pommern. Als speciellen Fundort in Pommern soll, wie ich es aus dem neuen Böttgerschen Bericht uber die Leistungen in der Herpetologie ersehe, Barth an der Ostsee genannt worden sein. Zu den wenigen Stellen im Norden Deutschlands, wo. sie bis jetzt sicher nachgewiesen ist, muß ferner die Insel Rügen gezählt werden ${ }^{\mathbf{1}}$ ). Auch in der Provinz Preufen will sie Nowicki²) bei Podgorze und in dem Cherniewicer Walde, an der äufiersten Südspitze der Provinz beobachtet haben. Speciell aus West-Preutien und zwar aus Danzig wird sie von Schreiber ${ }^{3}$ ) und Brehm (1. c.) angeführt. Daß diese Fundorte weder in dem Verzeichnisse der in Ost- und Westpreulsen vorkommenden Wirbeltiere von Rathke, noch in der Fauna prussiaca von Lorek erwähnt werden ist einigermaßen aufallend. In Bezug auf Preubisch-Schlesien ist bis dato, so viel ich weik, nichts Bestimmtes bekannt, obschon es höchst wahrscheinlich ist, daf sie sich bei ihrem Wanderzuge von Mähren aus längs der Oder auch in Schlesien, so z. B. in der Ober-Lausitz,

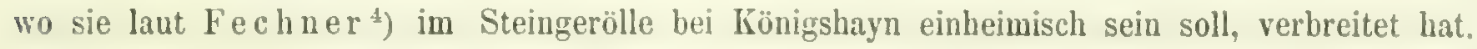
»Ob $L$. viridis in Schlesien wirklich fehlt«, sagt $M$ ilde ${ }^{5}$ ), »oder, wie einige behaupten, bei uns vorkommt, kann ich nicht entscheiden«. Unter denjenigen, 'welche das Vorkommen dieser Eidechsenart in Schlesien behaupten, oder vermuten, gelten wohl Schwenchfeld ${ }^{6}$ ) und Gloger ${ }^{7}$ ), während die übrigen Bearbeiter der schlesischen Fauna, wie z. B. Kaluza ${ }^{8}$ ) und Tobias die viridis nicht verzeichnen. Wenn Heinrich sie unter den Reptilien Mährens und Schlesiens aufführt, so gilt dies wohl sicher nur von Österreichisch-Schlesien. - Daßs L. viridis aus den erwähnten deutschen Lokalitäten nicht weiter nach Norden, so z. B. aach SchleswigHolstein, Dänemark und nordöstlich in die russischen Ostseeprovinzen vorgedrungen ist, scheint mir nachgewiesen zu sein.

Über das angebliche Vorkommen der Smaragdeidechse in Grokbritannien äufert sich

1) Korresnondenzbl. d. Zool. miner. Vereins in Regeusburg XXV. Jahrg. S. 81.

2) Nente Preuk. Provinzialblätter, V. 1848. S. 387.

3) Herpetologia europaea S. 447.

4) R. Tobias, Die Wirbelt. d. Oberlausitz in Abhandl. d. naturforsch. Ges. zu Görlitz XII. S. 92. Görlitz.

5) Verhandl. zool. botan. Gesell. in Wien. 1871. S. 1033.

6) Theritropheum Silesiae. Lignicii MDCIII. pag. 148.

7) Schlesiens Wirbeltier-Fauna. Breslau 1833. S. 66.

$\left.{ }^{9}\right)$ Systematische Beschreib. d. schlesischen Amphibien u. Fische 1815. - Die ron einigen Autoren citierte Auflage 1855 kenne ich leider nicht. 
Cooke in seinem Buche yur reptiles (London 1865j folgenderweise: "That this species has been found in great Britain, in a apparently wild state, is without a doubt, but how it came there is past finding out."Bel1 ${ }^{\text {}}$ ) und Fried e $\mathbb{L}^{2}$ ) hingegen vermuten, dak die Angaben R a ys, Gilbert White und anderer in Bezug auf das Vorkommen dieser Art in Irland, in der Umgebung von Herne Bey, in Devonshire, bei Farnham in Surrey und auf den Clava Mountains auf einer Verwechselung mit $L$, agilis beruhen. Wenn wir die Thatsache in Betracht ziehen, daß das British-Museum bis dato keine britische Smaragdeidechsen mit Ausnahme derjenigen, welche von der normannischen, also geographisch zu Frankreich gehörenden Insel Jersey stammen, besitzt und dals diese Art weder vou Thomas Bell noch von Cooke, Friedel, Flemming, Pennant und Sheppard in ihren faunistischen Arbeiten genannt worden ist, so müssen wir sie aus der Fauma Englands und Irlands ein für allemal streichen und annehmen, dak sie hir und wieder durch Verschleppung nach England gelangt, und da sie dort keine günstigen Bedingungen zu ihrer Erhaltung vorgefunden, wieder verschwunden sein $\left.\operatorname{mag}^{3}\right)$.

Die Apenninische und die Balkan-Halbinsel gelten mit Recht als ihre ursprüngliche Heimat.

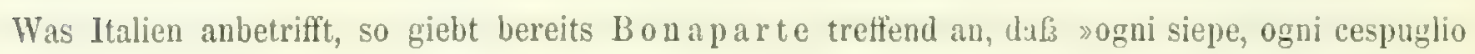
la possiede« und es wäre somit eigentlich einfacher, diejenigen Orte, wo sie bis jetzt wohl sicher nur übersehen worden ist, namhaft zu machen. Sie kommt vorzüglich in den Thälern vor, wird aber auch im hohen Gebirge und in der Ebene, wie z. B. bei Mailand (Samml. von De Betta) ${ }^{4}$ ), bei Viareggio und bei Livorno in Colambrone, wo sie auffallenderweise massenhaft in Gemeinschaft mit Lac. muralis neapolitana dicht am Meeresufer haust, angetroffen. Sonst scheint sie die flachen Meeresufer eher zu meiden als aufzusuchen und sich mehr in den, vom Litorale entfernten Örtlichkeiten aufzuhalten. Aus Genua ( $₫$ L. viridissima Brit. Mus.) und aus Spezia ist sie übrigens auch bekannt (No. 450. Mus. zu Halle). Fur Ligurien ist sie von $\mathrm{Sassi}^{5}$ ) unter dem Namen $\gg$. agilis Daud.« aufgefürt worden. Exemplare der viridis aus

1) A History of British reptiles. London 1839.

2) Zolog. Garten XIX. S. 366.

3) Bei dieser Gelegenheit möchte ich hinzufingen, dą möglicherweise seiner Zeit auch L. ocellata nach England importiert gewesen war. P e n n a n t, der Verfasser der British Zoology erzählt nämlich, daß im Jahre 1741 Eidechsen ron über 2 Fuß Länge in der Umgebung von Woscot (»parish of Swinford, Worcestershire) und in Penburg erschlagen worden seien. H a s $\mathrm{t}$ in $\mathrm{g}$ citiert gleichfalls diesen Fund in seiner Illustration of the Natural History of Worcestershires. London 1834.

4) C. Campeggi, Dei Rettili ed Anfibi presi nei dintorni di Milano. Milano 1883.

5) Saggio sonra i pesci, rettili et mammiferi della Liguria. Estratto dal quadro descritivo per l' VIII Riunione. Genova 1856 pag. 37. 
Turin, welche insofern von Interesse sind, als bei ihnen die Supraocularia und Supraciliaria sich direkt anfügen, besitzt das British Muscum. 1878 fand ich die Form mento-coerulca bei Canobbio am Langen-See, und hier ist sie, worauf ich namentlich diejenigen Fachgenossen, welche daran zweifeln, dals Viridis-Weibchen mit blater liehle vorkommen, anfmerksam machen möchte, nicht selten, denn mehrfach ist sie mir daselbst seit jenem Jahre zu Gesicht gekommen. Aus Tessin ist die

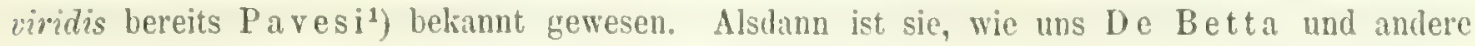
italienische Faunisten ${ }^{2}$ ) mitteilen, in ganz Venezien äuferst häufig und soll aus dem Frioul weiter nördlich in Tirol eindringen. Südlich tritt sic nach Aemilia übel", wo sie namentlich im Modenesischen ${ }^{3}$ ) und bei Bologna gemein ist. Im Fignano, in den Toskanischen Apenninen und in Marken ist sie gleichfalls beobachtet worden. Unter den von Rabenhorst in den Abruzzen gesammelten Reptilien soll sich laut $\mathrm{D}$ e h $\mathrm{n} \mathrm{e}^{4}$ ) eine $L$. strigata $\mathrm{B}$ on a parte vorfinden, worunter aber wohl eine längsgestreifte Smaragdeidechse gemeint worden ist. Aus Neapel (No. 488. Mus, zu Halle) und aus den südlichen Proviazen Kalabrien und Apulien habe ich mehrere Exemplare dieser Art zu untersuchen Gelegenheit gehabt. Auf Sicilien ist sie aus verschiedenen (̈rtlichkeiten bekannt ${ }^{5}$ ) und hommt daselbst in frïchtig gefirbten und gezeichneten Individurn vor $^{6}$ ). Mina $\mathrm{Palumbo}$ hat sie auf Etna beobachtet ${ }^{7}$ ). Böttger erhielt einige Exemplare vom Cap Gallo bei Palermo, von der Insel Maritimo und von Ustica ${ }^{8}$ ). In der Umgebung von Messina ist mir die viridis ziemlich selten und nur in den Gebirgsschluchten begegnet. Sowohl auf Sardinien als auch auf den kleinen Inseln im Tyrrhenischen Meere ist sie durch

1) Atti Soc. ital. sc. nat. Vol. XVI. 1873. pag. 43. Milano.

2) D e B e t t a, Erpetologia d. Provincie Venete e del Tirolo merid. in: Mem. Accad. di Agricolt. Arti e Commercio di Verona, Vol. XXXV. pag. 130. - Canestrini, Intorno alla Fauna del Trentino in: Atti Soc. Vea. - Trent. Sc. nat. 1875, pag. 21 - Scarpa, Cat. Rettili et Anfibi del Trerignano, ibidem, Vol. III. 1876. pag. 192. - Nardo, Prospetti sistematici degli animali delle Prorincie Venete e del Mare Adriatico etc. in: Atti dell' Ist. Veu. 1859-1860. Vol. V. p. 600. Venezia. - B o n a p a rte, Iconografia della Fauna italica II. 1832-41.

$\left.{ }^{3}\right)$ Testi, Contribuzioni alla Fauna erpetologica del Modenese in: Annuario Soc. Naturalisti in Modena XII, pag. 186, - B on izzi, Enumerazione sist. di Rettili ed Anfibi etc. nel Modenese in: L'Eco della Università No. 18-22. Modena 1870. - C a r r u c io, Fauna del' Emilia. Modena 1882.

4) Allg. naturhist. Zeitung II. S. 213. Hamburg 1856.

5) Doderlein, Alcune generalità intorno la Fauna sicula dei Vertebrati in: Annuario Soc. naturalisti Modenesi VI. pag. 200. Modena; Revista della Fauna sicula etc. in: Nuovi Effemeridi Siciliani XI. Palermo 1881.

${ }^{6}$ ) Die im Senckenbergischen und Berliner Museum aufbewabrten männlichen viridis haben in betreft der Färbung und Zeichnung Ähnlichkeit mit denjenigen aus Syrien, die weiblichen aber sind insofern verschieden, als sie auf Sicilien nur zwei longitudinale Rückenstreifen aufweisen, während die syrischen drei resp. fünf Streifen haben.

7) Prospetto degli studii di Erpetologia in Sicilia. Palerma 1863.

B) Bericht üb. die Senckenberg. naturf. Gesellsch. in Frankfurt a. M. 1880-81. S. 134. 
die formenreiche muratis vertreten ${ }^{1}$ ). - Überhaupt ist die viridis, so viel ich erfahren konnte, mit Ansnahme Elbas (Mus. zu Florenz, Ausbeute von Giglioli) auf keiner, westlich von der Apenninischen Halbinsel liegenden Insel angetroffen worden. Eine aus Korsika stammende buntscheckige Form (variété bariolée) der Smaragdeidechse soll in der Sammlung von Westphal-Castelna u aufgestellt sein $^{2}$ ); doch bezweifle ich es sehr, denn während meines längeren Aufenthaltes auf Korsika ist mir die viridis nie zu Gesicht gekommen, ich vermute vielmehr, daf3 in diesem Fall eine Verwechselung init der grünen Mauereidechse stattgefunden haben mag.

Vom Frioul aus zieht sich der Verbreitungsbezirk unserer Eirlechse durch Tirol, Steiermark und Niederösterreich nach Böhmen hin. In Tirol soll sie nach Gredler ${ }^{3}$ ) sowohl dem wärmeren Süden als auch den kälteren Regionen angehören und im Hauptthale der Etsch durch das Vinschgau (Naturns) bis nach Mals, $3300^{6}$ üb. M., - ins Thal von Ulten (vertikal bis Pavigl) und Passeier, im Eggenthale bis Gummer und Welschnofen, 3700 üb. M. steigen. Durch das Eisackthal dringt sie bis in die Gegend von Brixen vor und ist bei Brixen selbst von $\mathrm{L}$ ey $\left.\mathrm{d} \mathrm{i} \mathrm{g}^{4}\right)$ konstatiert; im Nonsberg steigt sie bis Fondo, wo vorzugsweise die D e Bettasche bromne-viridiscens vorkonmt. Ferner wird sie un Merim, Bozen, Eppan und an KalternSee, wo sie stellenweise sehr häufigr ist, laut Leyalig in groben Exemplaren angetroffen; ebenso um Torbole und Arco in Sarkathale, Valsugana und Primier (Gredler). »Nach gut verbürgten Angaben«, sagt Gredler, findet sich die Grünechse auch im unteren Drau- und Iselthale: an der Sonnseite bei Nikolsdorf, Grafendorf, Thurn und stellenweise noch am Gwablerberge bei Ainet«. Nach Mild $\mathrm{e}^{5}$ ) soll sie bei Meran nicht häufig sein und hier auch nicht so hoch hinauf steigen, wie L. muralis. Um Meran soll laut Milde die bilineata und mentocoerulea Bonap. einheimisch sein, was ich besonders hervorheben möchte, weil ich auch von anderen Faunisten für Tirol nur das zweifach gestreifte 'Tier aufgeführt gesehen habe, während im Gegenteil in Dalmatien, meines Wissens nach, nur die drei- oder fünfstreitige viridis be-

1) Das Fehlen der viridis auf Sardinien ist bereits Cett $\mathrm{i}$ aufgefallen. In seiner Naturgeschichte von Sardinien (Leipzig 1799) S. 9 sagt er nämlich: es ist eine auffallende Erscheinung, dał Sardinien die gemeine, eigentlich so genannte Eidechse nicht besitzt. \& Wenn wir dessenungeachtet hin und wieder Smaragdeidechsen als aus Sardinien stammend etikettiert zu sehen belsommen, so ist unter Sardinien das Königreich Sardinien, und in diesem Fall speciell Piemont zu verstehen. Die Angabe Alb. Azuni (Hist. géogr. politique et nat. de la Sarlaigne Vol. II. pag. 67. Paris 1802), daf $L$. viridis auf Sardinien yorkommt, muf auf einer Verwechselung mit $L$. muralis neapolitana beruhen.

$\left.{ }^{2}\right)$ Catalogue de la collection de Reptiles du feu Westphal-Castelnau. Extr. du Compte-rendu des travaux du Congrès scientifique de France tenu à Montpellier, en décembre 1868, pag. 57.

${ }^{3}$ ) Fauna d. Kriechtiere und Lurche Tirols. Programm d. k. k. Gymnusiums zu Bozen, 1872. S. 7.

4) Die in Deutschland lebenden Arten der Saurier, S. 190.

5) 44. Jahresher, d. schlesischen Gesellsch. f. vaterländ. Kultur, 1867. S. 55. 
obachtet worden ist. Diese 'Thatsache, so unbedeutend sie auch zu sein scheint, deutet doch darauf hin, datis die tiroler Smaragdeideclsen aus Italien stammen, wo, wie ich bereits früher erwähnt habe, nm die Bilineata-Weibchen-Form vorkommt, während die dalnatinische viridis ihre gemeinschaftliche Abstammung von der orientalischen, oftmals dreistreifigen Form hat. "Mündlichen Angaben zufolge«, bemerkt Leydig, »kommt $L$. viridis auch im Pusterthal vor.« Für Vorarlberg finde ich sie nicht erwïhnt, hingegen wird sie für Kärntlen angegeben, wo sie laut Gallenstein ${ }^{2}$ ) überall an sonvigen Abhängen oder trockenen Mauern, jedoch sonderbarerweise nur in der Ebene vorkommt. In der P. Kohlmayerschen Schrift »Der Reifkofel und seine üstlichen Abhänge in naturhistorischer Beziehung « ${ }^{2}$ ) geschieht ihrer ebenfalls Erwähnung. Zu Krupp in Unterkrain (bei Prilosje) soll sie laut Freyer ${ }^{8}$ ) wim Gesträuche und dürrem Lande anzutreffen sein; auch in Istrien ist sie zu Hause (Schr e i b e 1; op. cit. S. 447). In Niederösterreich findet sie sich allerorts, stellenweise sehr häufig und kommt in der nächsten Umgebung Wiens, so z. B. auf den steinigen Rainen bei Sievring, Grinzing, am Vogelgesang 4), Kahlenberg, sowie auch an der Türkenschanze ${ }^{5}$ ) nicht selten vor; vormals soll sie nach $\mathrm{F}$ it zinger auch im Wiener Stadtgraben gelebt haben. Ferner ist sie in der Umgebung von Baden, von Vöslau (K nauer), Krems und in den an Ungarn grenzenden Gegenden Niederösterreichs gefunden worden. Nach den übereinstimmenden Zeugnissen von Glückselig ${ }^{6}$ ), Prach $^{7}$ ) und Fritsch ${ }^{5}$ ) kommt sie in Böhmen vor, wo sie hauptsächlich in der Ungebung Prags, im Zavist- und Scharkathal, bei Roztok sowie auch an mehreren anderen Orten recht häufig zu sein scheint. Im Flachund Hügellande von Mähren kommt sie gleichfalls vor ${ }^{9}$ ). Nach Zaw a dzki ${ }^{10}$ ) ist sie in Galizien und in der Bukowina »nicht selten«. Auch nach Oberungarn hat sie ihre Wohngebiete ausgedebnt; sie ist hier in den kalkigen Gebirgen von Toma und zwar im Thal von Komjati und am Burgberg bei Torna beobachtet worden ${ }^{11}$ ). Bei Kaschau und am Tatra soll sie, wie es ausdrücklich hervorgehoben worden ist, fehlen, hingegen sehr häufig in der Umgegend von Ofen

3) Die Reptilien von Kärnthen in: Canavals Jahrber. d. naturhist. Landesmuseum von Kärnthen II. 1853.

$\left.{ }^{2}\right)$ Ebendaselbst, Heft 4. Klagenfurt 1859.

$\left.{ }^{9}\right)$ Fauna der in Krain bekannt. Säugetiere, Vögel, Rentilien u. Fische, S. 41. Laibach 1842.

4) K nauer, Die Reptilien und Amphibien Nieder-Oestereichs. Wien, 1875.

5) Fitzinger, Üb. die Ausarbeitung einer Fauna d. Erzherzogt. Österreich etc. in: Abhandl. Böhmischen Gesellsch. d. Wissenschaften I, neue Folge 1829. S. 324.

$\left.{ }^{6}\right)$ Synopsis reptilium et amphibiorum Bohemiae. Pragae 1832.

$\left.{ }^{7}\right)$ Plazoré a obojzivelnici zeme Ceske in: Zivy 1861. ఛ. Praze.

9) Archiv d. naturwiss. Landesdurchforschung v. Böhmen II. 1871. S. 105.

9) Heinrich, Mährens u. k.k. Schlesiens Fische, Reptilien u. Vögel. S. 38. Brünn 1856.

10) Fauna d. galizisch. bukowinischen Wirbeltiere etc. Stuttgart 1840 (S. 140).

${ }^{11}$ ) Verhandl. zoolog. botan. Gesellsch. in Wien XIII. 1862. S. 278. 
und Budapest vorkommen ${ }^{1}$ ). Erber fand sie bei Orsowa im südlichen Ungarn ${ }^{2}$ ), A. v. Mojsisovics im Keskenderwalde (Vergl. seine letzthin erschienene interessante Schrift „Zur Fauna von Béllye und Darda, II. Graz 1884), Glückselig erhielt die Form »cyanolaema«zugleich mit jener rätselhaften "Lacerta carinata aus Mehadia. An anderen, hier nicht erwähnten Orten längs der Donau dürften sie nur übersehen worden sein. In der »Fauna der Wirbeltiere Siebenbürgens S. 152 (Hermannstadt, 1856) ist sie von Biclz als »nicht selten verzeichnet. Bei Kovil und Tittel im östlichen Teile Slavoniens ist die vividis von Ferrari und Zelebor gesammelt worden ${ }^{3}$ ). In Kroatien, so namentlich bei Agram, und in Dalmatien ist sie eine der gemeinsten Erscheinungen; ob sie auch auf den dalmatinischen Inseln einheimisch ist, vermag ich nicht anzugeben ${ }^{4}$ ). Über die Häufigkeit ihres Vorkommens in Dalmatien giebt eine statistische Tabelle Fiedlers $s^{5}$ ) Aufschluf, wonach im Laufe von sieben Jahren nahezu 1500 Stück allein nach Deutschland versandt worden sind. Da die dalmatinischen Smaragdeidechsen ihrer Gröbe und intensiven Färbung wegen auch im Auslande von Reptilienliebhabern bevorzugt werden, so dürfte der Export noch bedeutender sein, als es Fiedler angiebt.

Obgleich uns nur spärliche Fundortsangaben von der Balkan-Halbinsel vorliegen, können wir, ohne Fehlgriff zu thuu, annehmen, dab sie daselbst nirgends fehlen dürfte. In Bosnien und Herzegowina soll sie, laut v. Möllendo $\mathrm{rff}^{6}$ ) prächtig gefärbt und besonders grof auftreten. Albanesische Individuen dieser Art sind in F. Latastes Sammlung aufbewahrt (No. 1103); junge viridis aus dem Balkan-Gebirge habe ich im Athener Museum zu sehen Gelegenheit gehabt. Berthol ( $^{7}$ ) erhielt Exemplare aus Konstantinopel, darunter die Form mit funf weilien Längsstreifen auf dem Rücken. Die in Griechenland, auf dem Festlande lebenden viridis zeichnen sich durch ihre kolossalen Dimensionen aus und sind den dalmatinischen in dieser Hinsicht ählich. Die vom Parnassus, aus Nauplia und Attika, und zwar aus der Umgebung

1) Zool. Garten XVIII. S. 140.

$\left.{ }^{2}\right)$ Ibidem, XIV. 1863. S. 1133.

3) Nach Steindachner. Verhandl. zool. bot. Ges. in Wien XIII. S. 1122.

4) Nachträglicher Zusatz. - Kolombatovic (Vergl. Pesci delle acque di Spalato e Catalogo degli Anfibi etc. in: Godisnje Izvjesce o c. $k$. velikoj realici u Splitu. U Splitu, 1881) sagt darüber folgendes: - Comune il famoso Poskok di Curzola non sarebbe altro che una varietà di questa; è quindi falso quanto il popolo di Curzola racconta di questa Lacerta, che è assolutamente innocua». Die Smaragdeidechse scheint somit auf der Insel Curzola vorzukommen.

5) Zoolog. Garten XVIII. S. 274.

$\left.{ }^{6}\right)$ Beiträge zur Fauna Bosniens. Görlitz 1873. S. 18.

7) Üb. einige neue od. seltene Amphibienarten in: Act. soc. reg. Goetting., VIII. 1842. 
Whens, Eleusis, vom Laurum-Gehirge und aus der Marathon-Ehene untersuchten Exemplare waren alle cinfarbig oder gestreift; es sollen aber auch ausgewachsene gestreifte Individuen in grolier ' Jahl sowohl in Rumelien als auch in Morea vorkommen. Was die griechischen Inseln aubelangt, so kenne ich die Art aus Syra, wo sie übrigens sehr selten, und nur im nördlichen Teile der Insel anzutreffen ist, aus Tinos, Seriphos, Naxos, Mykonos, Milo, von wo ich eine braungefïbte Spielart mitgebracht habe, ferner aus Andros, Korfü) und Cephalonia; v. Heldreich ${ }^{2}$ ) fand sie auf Zante, Ra lin ${ }^{3}$ ) bei Khalepa auf Kreta.

Die Verbreitung der Smaragdeidechse in Rufland ist bis dato noch sehr wenig bekannt und obendrein muf dasjenige, was wir aus den faunistischen Arbeiten kennen gelernt haben, in vielen Fällen in Zweifel gezogen werden. Die russischen viritis einerseits und die agilis andrerseits variieren nämlich in solcher Weise und produzieren so zahlreiche, schwer determinierbare Zwischenformen, dals die Faunisten sich veranlafist gesehen haben, neue Arten zu kreieren und für dieselben neue Namen, wie elegans Andrzej., chersoncnsis Andrzej., strigata Eichw. u. S. w., zu proponieren. Was eigentlich, sowohl unter diesen Benennungen, als auch unter den als $L$. viridis, agilis, stirpium und ocellata aufgeführten Eidechsen gemeint worden ist, läft sich in einigen Fällen mit Sicherheit nicht sagen, umsomehr, da recentere russische Faunisten in der Regel die Arten ihrer Vorläufer als solche nicht anerkennen wollten und verschieden aufaEten. Infolgedessen sind auch die Angaben in betreff der Fundorte meistens verdächtig.

Die wenigen Stellen im Südwesten Ruflands, wo sie bis jetzt, insbesondere durch K ess le r, nachgewiesen worden, reicheu mindestens bis $51 .{ }^{\circ} \mathrm{n}$. Br. und nicht bis zum $480^{\circ} \mathrm{n}$. Br. wie es Kry nicki, der Verfasser der »Observationes quaedam de reptitibus indigenis $\left.{ }^{4}\right)$, zu glauben scheint. Laut Taszanowski ${ }^{5}$ ) soll sie noch weiter nach Norden vordringen und zwar bis in die Warschauer Gegend, wo ibr Vorkommen allerdings sich nur auf den Wald von Kampinos beschränken soll; dieser Forscher fügt auferdem hinzu, daß sie an diesen nördlichen Punkten ihrer Verbreitung im russischen Reiche nur in geringer Anzahl vorkomme ${ }^{6}$.) Dieses stimmt

1) Bulletin de Moscou 1881 (1882), No. 3, S. 75.

2) La Faune de Grèce. Athènes 1878 , pag. 68.

$\left.{ }^{3}\right)$ Descrip. phys. de l'île de Crète in: Act. Soc. Linn. Bordeaux 1869 pag. 691.

4) Bulletin de Moscou 1837, No. 3, pag. 47.

$\left.{ }^{5}\right)$ Bull. Soc. Zool. de France 1877, pag. 167.

${ }^{6}$ ) Seidlitz läft $L$. viridis Petiver in den Ostseeprovinzen sehr selten vorkommen (Vergl. sein Verzeichuis d. Säuget., Vögel, Rept. u. Amphibien d. Ostseeprovinzen); ich bezweifle es aber, auch finde ich sie nicht in einem neueren Werkchen, sDie Reptilien Kur-, Liv- und Estlands๔, จon O. $\nabla$. L ö w is (Riga 1884) verfakt, erwähnt. 
völlig damit übercin, was wir über das Auftreten der viridis in den nördlichen Zonen, so im Norden Deutschlands, kennen gelernt haben, nämlich, daß̉ diese Art, je höher sie nach Norden vorrückt, um so weniger zahlreich auftritt. In Podolien und in den Gouvernements kiew und Poltava, ferner im südlichen Teile Wolhyniens und des Gouvernements Tschernigow soll das Tier zu Hause sein, wie dies von Kessler in der mir leider unzugänglichen, in russischer

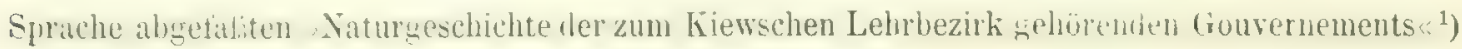
bezeugt wird. Angaben über ihr Vorhandensein am Dnjestr, am Buy und am Dnjeper enthält Andrzejowslis Arbeit "Reptilia imprimis Volhyniae, Podoliae et gubernii Chersonensis ${ }^{2}$ ) wo sie bekanntlich unter dem Namen $\gg L$. eleguns erwähnt wird. Näheres über ihr Vorkommen in der Lmgesend ron Kimenetz-Podolski finden wir bei Belke angegeben. Belke sagt in seiner » Esquisse d'histoire naturelle de Kameniec-Podolski« $\left.{ }^{3}\right)$ : "L. stirpium Daud. et Lac. viridis Daud. se trouvent en abondance. Une belle variété de cette dernière espèce décrite par le prof. Andrzejowski sous le nom $L$. elegans est plus rare et aime à se tenir dans les fentes des rochers couverts de broussailles. Je l'ai trouvé près de Nihine et Karatsch-Koftzé, elle est deux fois plus grande que l'espèce type à Zwanietz«. Exemplare aus Kamenetz-Podolski, aus Odessa und Nikolaeiew enthält das zoologische Museum der $\mathbf{K}$. Akademie zu St. Petersburg (Nr. 5964,5965,3900 und 3179). Die Angaben in betreff des Vorkommens der viridis in den Gouvernements Kiew, Podolien und Poltawa sind durch Belegstücke erhärtet, welche Prof. Paulson vor kurzem die Freundlichkeit hatte, mir aus dem Kiewschen zoologischen Museum zur Ansicht zu übersenden (Nr. 1958,1960,1961 u. 1962). Nach Aussage T a rdents ${ }^{4}$ ) sollen in Bessarabien grüne Eidechsen (»lézards verts«), - welche wohl auf die uns hier interessierende Art zurückzuführen sein dürften -, häufig sein. Im Charkowschen Gouvernement fand sie $\left(z e r n a y^{5}\right) 1848$ und 1849; für das Gouvernement Woronesch wird sie von Sewertzo $w^{6}$ ) angregeben. Derselbe Gewähsmaun spricht von C̈bergängen der Smaragd- zur Zauneidechse.

1) Zoologie. Bd. II. Kiew 1853.

${ }^{2}$ ) Auch unter dem Titel: Amphibia nostratia seu enumeratio Sauviorum, Ophidionum nec nom Sireniorum in excursionitus per Volhyniam, Podoliam guberniumque Chersonense usque ad Euxinum observatorum Nouv. Mém. Soc. Imp. natur. de Moscou II., pag. 321. 1832.

3) Bulletin de Moscou XXXII, 1. 1859, pag. 24.

4) Essai sur l'hist. nat. de la Bessarabie, pag. 12. Lausanne 1841.

5) Beobachtungen gesammelt auf Reisen im Charkowschen u. d. anliegend. Gouvernements in d. Jahrea 1844 u. 1849 in: Bulletin de Moscou 1851, 1. pag. 269. - Bei dieser Gelegenheit möchte ich mir die Bemerkung erlaubea, daß unter den zablreichen Eidechsen, welche mir Prof. Stepanow aus der Umgebung Charkows zuzusenden die Güte hatte, sich keine einzige viridis befand.

$\left.{ }^{6}\right)$ Period. Erscheinungen im Leben d. Säuget., Vôgel u. Kriecht. des Gourernement Woronesch, 1855. S. 88 (Russisch l). 
Die Aunahme Eversmanns, L. viridis, käme nicht östlich von der Wolga vor"), scheint mir gerechtfertigt zu sein; auch glaube ich kaum, daf ihr Wohngebiet sich bis zu den Wolga-Ufern crstrecken dürfte, denn Kessler, dem eine große Anzahl Eidechsen von den Wolga-Ufern zu Verfügung gestanden haben sollen, versichert, dals sich darunter keine einzige $L$. viridis befand, dafs vielmehr sämtliche, ihm unter dem Namen »Smaragdeidechse« zugesandten Stücke sich als agilis erwiesen.

Merkwürdigerweise lauten die Nachrichten über die Krim widersprechend; wo von einer Seite das Vorkommen der ririlis bestimmt behiuptet ${ }^{2}$ ), wird es von anderer seite angezweifclt ${ }^{3}$ ). Obschon sämtliche sich widersprechende Angaben von Pallas, Eichwald, liathke und Kessler darauf hinzudeuten scheinen, daf die Krim eine schwer zu bestimmende, zum Teil der agilis, zum Teil aber der viridis ähnliche Eidechse beherbergt, wäre es, meiner Ansicht nach weiser, das Vorhandensein der Smaragdeidechse in der Krim nicht gänzlich in Abrede zu stellen, da das Berliner Museum und, wenn mich mein Gedächtnis nicht trügt, auch das Pariser Muséum d'hist. nat. angeblich krimer Exemplare dieser Art vom Fürsten Demidow erhalten haben. Demidowsche Schenkungen lassen allerdings, wie ich mich überzeugen konnte, vieles in Bezug auf die Fundorte und in betreff der Determination zu wünschen übrig, jedoch sind wir verpflichtet, die angeblichen Beleastincke zu beruckisichtigen. So enthält beispielsweise das Berliner Museum eine junge agitis und eine junge, der viridis frappant ähnlich sehende Eidechse - beide in ein und derselben Büchse - mit der Etikette $\gg$ L. viridis L., L. exigua et strigata. Krim. Demidoff. Nr. 6186«. Obschon beide Tiere nahezu gleich grofs und sich sehr ähnlich sehen, fällt dennoch die junge Zauneidechse durch ihre Zeichnung auf und zwar hauptsächlich dadurch, daß längs der Rückenmitte drei schmale, etwa grauweilse Streifen fortlaufen und dals ihre liumpfseiten jederseits mit drei Längsteihen äuliserst kleiner helier Ocelli geziert erscheinen, während die andere junge Eidechse, welche ich für eine viridis oder eine der viridis ähnliche Lacerta halte, fünf ununterbrochene, etwas breitere und hellere Streifen zeigt, welche längs der Rückenmitte und der Leibesseiten fortlaufen. Die sub. Nr. 2334 im Muséum in Paris aufbewahrte, angeblich aus Taurieu stammende Eidechse scheint, wie ich es aus meinem Notizhefte ersehe, ein etwas ålteres Exemplar der viridis zu sein; dagegen ist eine

$\left.{ }^{1}\right)$ Nour. Mém. Soc. Imp. natur. de Moscou. 1834, pag. 340.

2) Pallas, Zoographia rosso-asiatica, III. pag. 29. - Rathke, Beitr. z. Fauna d. Krim in: Mém. des Savans étrangers de l'Acad. de St. Petersbourg III. pag. 291. 1837. - E ic hwal d, Fauna caspio-caucasia, pag. 66. 1841 .

3) Kessler, Zoolog. Reise durch Transkaukasien. St. Petersburg 1878 (Russisch); Reiseber. aus d. Krim in: Bull. de Moscou 1878, Nr. 3. S. 209. 
andere taurische, ebenfalls von $\mathrm{Demidow}$ crhaltene Eidechse falsch als $L$. viridis bestimmt worden; ich meine Nr. 2340, die zweifelsohne der Art stauricu angehört. Endlich besitzt das nämliche Pariser Museum eine als viridis determinierte L. agilis aus Taurien (Nr. 2683, ded. Demidow). Im Senckenbergischen Museum habe ich ebenfalls kürzlich einige, als $L$. viridis strigata bestimmte Exemplare aus Feodosia zu sehen Gelegenheit gehabt, glaube aber, dals die betreffenden Stücke einer besonderen Zwischenform - vielleicht der agilis orientalis Kessl. angehören, welche von einigen als $L$. viridis (Rathke, Eichwald), von anderen als $L$. agilis (Kessler) betrachtet worden ist; so finde ich unter den, mir von Prof. Paulson in Kiew anvertrauten Saurier-Arten einige aus der Umgebung von Sympheropol und Jalta stammende, von Kessler als L. stirpiam determinierte Eilechsen (Mus. Kiew: Nr. 1954, 1955), welche ganz genau denjenigen $\gg L$. viridis var. strigata aus Feodosia, welche sich in der Senckenbergischen Sammlung aufbewahrt befinden, ähnlich sehen. Der Umstand, daf ein und dasselbe Tier aus zwei nahe aneinander grelegene: Lokalitäten in den Museen unter verschiedenen Species-Namen figuriert, fällt keineswers denjenigen zur Last, welche die Bestimmung vorgenommen haben, sondern deutet vielmehr darauf hin, dals in der Krim eine schwer determinierbare Übergangsform lebt, welche ich, um weiteren Konfusionen vorzubeugen, wenigstens provisorisch, als Krimer agilis chersonensis Andrzej. aufuführen mir erlaube. - Das Vorkommen der Smaragdeidechse in der Krim wird von Kessler entschieden bezweifelt. Dieser Forscher hatte sich, wie er selbst in seinem Reiseberichte aus der Krim (l. c.) angiebt, bei seiner Exkursion nach Tamak unter anderem die Aufgabe gestellt, die Verbreitung der Eidechsen in der mittleren Steppe der Krim möglichst genau zu erforschen. „Bekanntlich«, sagt Kessler, »führt Rathke in seinem Beitrage zur Fauna der Krim eine L. viridis auf, von der er aussagt, dafs sie allein nur in der Steppe vorkomme und von der er dann eine ziemlich ausfuhrliche Beschreibung liefert. Nun aber besitze ich eine recht ansehnliche Sammlung von Eidechsen aus den verschiedensten Teilen der Krim und doch befindet sich unter denselben keine einzig wahre $L$. viridis $L$. Stark vertreten dagegen ist in meiner Sammlung die L. agilis L., deren Rathle gar nicht erwähnt. Es waren daher schon früher Zweifel in mir aufgestiegen, ob die $L$. viridis $\mathrm{Rathke}$ auch wirklich die echte $L$. viritis $L$. und ob nicht dieselbe vielmehr auf die $L$. agilis $\mathrm{L}$. zu beziehen sei.... « »eine Exkursion nach Tamak hat mich in meiner früheren Annahme noch mehr bestärkt. Es sind auf dieser Exkursion von mir recht viele Ejdechsen sowohl in der Steppe, als auch auf der Landzunge Arabat gesammelt worden, aber keine $L$. viridis fand sich darunter; alle von mir erhaltenen Eidechsen erwiesen sich als L. agilis. Es befinden sich darunter recht grofe Tiere von $245 \mathrm{~mm}$. Die meisten gehören der Färbung 
nach zu jener Varietät der $L$. agilis, welche von mir in meiner jüngst publizierten Übersicht der Reptilien und Amphibien des Faukasus als var, orientalis bezeichnet worden ist und welche der von Eichwald $L$. strigata benannten Varietät der $L$. viridis sehr nahe kommt. Auferdem ist mir durch Herrn Obergärtner Schmidt in Tamak ein Lxemplar zugestellt worden, bei dem die ganze Rückenseite rein grasgrün gefärbt ist, ohne jede Spur von hellen Längsstreifen oder dunklen Wlecken, und welches daher auf den ersten Blick leicht für eine echte $L$. viridis $L$. genommen werden könnte, dennoch aber nichtsdestoweniger der Art $L$. agilis angehört. Es steht somit fest, daß die L. agilis in der Krim eine grofe Verbreitung hat, in groliser Anzahl die Steppen der Krim bewohnt, aber auch in dem gebirgigen Teil der Halbinsel

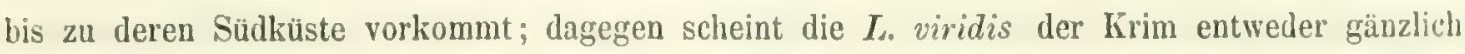
zu fehlen oder doch wenigstens nur eine geringe Verbreitung daselbst zu haben, vielleicht atuf die Umgegend von Perekop beschränkt zu sein, wofür es einige Andeutungen giebt.«

Bevor ich zur Aufzählung der liakiasischen Fundorte der uns hier interessierenden L. viridis übergehe, möchte ich die Aufmerksamkeit des Lesers noch auf die kürzlich in den »Beitr. z. Kenntnis d. Russischen Reiches u. d. angrenzend. Länder Asiense Bd. VI, S. 62. St. Petersburg 1883 erschienene Schrift »Zur Herpetologie der Krim» von Fr. Th. Köppen lenken. Dieser kenntnisreiche Forscher bringt allerdings nichts speciell Neues über die Verbreitung der Smaragdeidechse in Rufland vor, aber die Zusammenstellung der älteren, in verschiedenen Werken zerstreuten Angaben ist geschickt angeordnet und dürfte diese Abhandlung iherhaupt auf die Herpetologie Südrußlands fördernd wirken. Daß wir diesem selben forscher einige für die Zoogeographen höchst interessante Arbeiten über die Verbreitung einiger Säugetiere in Rufland verdankes, brauche ich wohl kaum hinzuzufügen.

Das Vorkommen der viridis in Cis- und 'Transkaukasien ist bereits von Eichwald und Eversmann konstatiert worden. Eversmann (Nouv. Mém. Soc. Imp. natur. de Moscou, t. III, pag. 340. 1834) sagt nämlich folgendes: sim Kaukasus ist sie sehr häufig, und erreicht eine beträchtliche Größe; nicht allein auf den Grasplätzen, sondern häufiger noch findet man sie an trocknen Felsen in den dort wachsenden Sträuchern umherlaufen«. Eichwald (1. c.) fügt in betreff der Verbreitung seiner viridis und strigata ergänzend hinzu: $» L$. viridis Daud.... Hab. in Caucaso, cis et ultra jugum ejus inque astrabadensi littore;«..., $\gg$ L. strigata, m... »Hab. in orientali et australi ora caspia, in insula Oretas, telo velocior ideoque captu difficilima, latebras utplurimum in soluta arena arundinetorum petens; etiam ad aquas carbonicas Kislawodskienses Caucasi: occurrit quoque in Syria (In Mus. Vindob. haec species e Syria dicitur L. viridis. Var. Lac. Michahellesii, Fitz.), Dalmatia, Jonia«. - Iu Cishaukasien hat sie 
Kessler ${ }^{1}$ ) in Piatigorsk beobachtet; nach II énétries ${ }^{2}$ ) ist sie namentlich in der gestreiften Form (" $L$. quinquevittata《) unweit der Sauerbrunnen sehr häutig und am Westufer des haspischen Veeres fand sie Eichwald bei Tarki ${ }^{3}$ ). In Transkakasien hat Kassler (I. c) sie in Zakataly, Nucha, Signach, Elisawetpol, Delischan, fermer in Eriwan und in Suchoï Fontan im Eriwanschen Gouvernement und endlich auf der Insel Sara gefangen oder beobachtet. Unter den Dubletten des zoolog. Mus. d. k. Akad. zu St. Petersburg habe ich ein Fxemplar der viridis aus Suchum-Kale und ein anderes fünffach gestreiftes junges Stück, das voin Grafen Mnischek auf dem Ararat erbeutet worden ist, unter den mir zur Ansicht aus dem Kiewer Museum zugesandten Eidechsen vorgefunden. Daßs die Smuragdeidechse auch bei Lenkoran und im Talisch-Gebirge einheimisch ist, wissen wir aus den Arbeiten De Filippis (Note di un Viaggio in Persia nel 1862. pag. 354. Milano 1865) und Holnenackers (Bull. de Mloscou 1837, No. 7, pag. 145). Ihr Vorkommen an der Ostküste des kaspischen Meeres finde ich nur. bei Eichwalı angegeben; dieser Forscher lälit sie, die strigata nämlich, am balchanischen Meerbusen vorkommen, sonst dürfte sic auf der ganzen Aralo-kaspischen Niederung sicherlich fehlen ${ }^{4}$ ); ich finde sie wenigstens nicht unter (len von Alenizin am Aralsee beobachteten und verzeichneten Reptilien. - Das Verbreitungsgebiet der Smaragdeidechse im russischen Reiche ist uns soweit nur annähernd bekannt und es wäre infolgedessen erfreulich, wenn unser rühmlichst bekannter Herpetolog seine Studien über die Líriechtiere Ruflands fortsetzen und uns mit einem Saurier-Werke, das den »Schlangen des russischen Reiches ebenbürtig sein würde, beschenken wollte.

Über die vorderasiatischen Wohnplätze der Smaragdeidechse liegen mir gleichfalls nur dürftige Angaben vor, jedoch glaube ich mehrere Fundorte denjenigen, welche ich in meinem im Bulletin de Ioscou 1879 erschienenen Verzeichnisse der Amphibien und Reptilien VorderAsiens genannt habe, hinzuzfügen zu können. Man kennt diese Art aus Klein-Asien, wo sie in Skutari (Samml, v. Bedriaga), in Brussa ${ }^{5}$ ), in Trapezunt (Mus. Berlin No. 6191), in Xanthus, von Cilicien, wo sie im Zebil Bulghar Dagh bis 4000 Fuls Meereshöhe

1) Arb. d. St. Petersburg. naturforsch. Gesell. VIII. Supplement-Heft 1878 (Russisch!).

2) Catalogue raisonné des objets de Zoologie etc. Iag. 61. St. Petersb. $18: 32$.

3) Reise auf d. Kaspischen Meere u. in d. Kaukasus. Stuttgart u. Tübingen 1834 (Bd. I. S. 97).

4) In seiner »Reise nach Orenburg und Bucharae giebt Eiversmann an, dafs $L$. agilis durch das ganze asiatische Rufland in allen trockenen Gegenden sehr häufg sei, daf $L$. viridis dagegen nur in dem südlichen Teile und hauptsächlich in Gebirgen vorkommt; es ist mir aber leider uicht gelungen ausfindig zu machen, welche Gegenden eigentlich darunter gemeint sind.

$\left.{ }^{5}\right)$ Steindachner, Verzeichnis d: von H. II n n bei Brussa gesammelt. Reptilien in: Verhandl, zool. botan. Ges. in Vien XIII. 1563. S. 1123. 
himaufsteigen soll (Brit. Mus, dedit I) and ford), ferner von Aleppod) und endlich von Rhodus (Brit. Mus.) ${ }^{2}$ ), von Kreta (bei Khalepa, nach Raulin, l. c.) und von Cypern (Berl. Mus. No. 956). In Syrien und Palästina soll sie nach Bötger ${ }^{3}$ ) bei Beyrut, nach Günther am Sce Nerom, nach L L ortet ${ }^{4}$ ) und $\Lambda$ nderson (Brit. Mus.) bei Rascheya und an Bêt Jem, dem östlichen Abhange des Grob-Hermon, ferner bei 'Tabarieh am Genezareth-See (- Tibériade. Mus. zn Paris. A. 2334, dedit: Let o u ne ux) und endlich bei Jerusalem (Günther) einheimisch sein. Lortet bemerkt, dak diese Art in Syrien eine ziemlich seltene Erscheinung sei. Die zahlreichen, schön gestreiften und gefärbten und jenem Eichwaldschen Bilde von L. strigata so ähnlich sehenden viridis, welche aus einer unbekannten Lokalitit stammen und im Muscum 7u Berlin sub No. 977, 978, 983-986 und 988 bis 990 aufgestellt sich befinden, sind, wie ich fest glaube, in Syrien oder Palästina gesammelt worden. - Über die Fundorte in RussischAsien habe ich bereits berichtet und es bliebe mir nur noch übrig einiges über ihre Verbreitung in Persien hinzuzufügen. Unter der Ausbeute von A ucher-Eloy in Persien befinden sich zwei Exemplare einer, wie ich glaube, für die Wissenschaft neuen Form - ich meine nämlich die ohen beschriebene. Var. Vaillanti - welche im Muséum d'histoire naturelle in Paris zu sehen ist (No. 2682, Pergament-Likette). Laut Eichwald ${ }^{5}$ ) ist sie aulierdem bei Astrabad mil laut Kessler (l. c.) bei Schiraz beobachtet worden. Blanfor ${ }^{6}$ ) hingegen scheint sic nicht gefunden zu haben, denn er citiert nur diejenigen Individuen der »Var. strigatak, welche Major St. John in Schiraz gestmmelt und von Anderson in den Proc. Zool. Soc. of London 1872, pag. 372 erwähnt worden sind.

Nachdem ich im Vorstehenden das Vorkommen der Smaragdeidechse, so weit als möglich, genau besprochen babe, will ich versuchen, einen allgemeinen Überblick über die Grenzen ihres Wohngebietes zu geben. Ihr Verbreitungsbezirk wird im Westen von den atlantischen İüsten der pyrenäischen Halbinsel und Frankreichs, im Osten von einer vielfach geschlängelten Linie begrenzt, die im europäischen Rubiland den $40^{\circ}$ oder den $41^{\circ}$ ö. L. von Paris, in asiatischen aber den $46^{\circ}$ oder den $51^{\circ}$ ö. L. von Paris (Balchan-Busen, Eversmann!), in Persien etwa den $53^{0} 0 \ddot{0}$ L.

1) L. Lortet in: X. Rapport du Mus. Sc. nat. Lyon, p. 15 (nach O. Böttger!).

2) Vergl. auch Erber, Bericht üb. eine Reise nach Rhodus in: Verhandl. zool. lotan. Gesell. in Wien XVIII. 1868.

3) Die Reptilien u. Amphibien v. Syrien, Palästina u. Cypern in: Jahresber. d. Senckenberg, naturforsch. Gesellsch. in Frankfurt a. M. 1879-80.

4) Poissons et Reptiles du Lac de 'Tibériade in: Archives du Mis. d'hist. nat. de I,yon III. pag. 187. 1883.

${ }^{5}$ Fauna Caspio-caucasia, pag. 66.

c) Eastern Persia, Vol. II. pag. 36t. London 1876. 
von Paris (Astrabad, Eichwald!) crreichen dürfte. Das Verbreitungsgebiet erstreckt sich ubbrigens nicht ununterbrochen bis zum $53^{\circ}$ o. L. v. Paris, denn in Arabien, also von den Euphrat-Ufern oder von der persisch-mesopotamischen Grenze an bis zum westjordanischen Bergland und Antilibanon, dürfte das Tier nur an einigen gebirgigen syrischen Punkten vorkommen. - Im Norden Frankreichs wird ihr Wohngebiet von einer Linie begrenzt, welche im Westen ihre nördlichsten Punkte in Morbihan und Fontainebleau, im Osten bei Troyes crreicht; von hier tritt ihre Begrenzungslinie nach Lothringen über (Buchoz!), berührt Trier und Boppard, senkt sich längs des Rhejnstromes südlich, berührt Baselland und wendet sich dann wieder nach Osten, wo sie über die südlichen Gebiete der Schweiz und Südtirols geht; von hiel tritt sie in nördlicher Richtung nach Niederösterreich, Böhmen, Mähren, Galizien und in den südlichen Teil Wolhyniens über. Nördlich von der gezogenen Grenze kommt die viridis an wenigen Stellen inselartig vor, so z. B. hie und da in der Provinz Preufen (nach Nowicki bei Podgorze und in dem Chernewicer Walde, an der äußersten Südspitze dieser Provinz; nach Schreiber und Brehm bei Danzig), in Russisch-Polen(Warschauer Gegend, nach Taszanowski), in Sachsen (Holle, Jäckel, Brehm), im Elbgebiet (sogar in der Haake bei II mburg!) in der Mark Brandenburg (Rüdersdorfer Kalkberge, Oderberg) und in Braunschwein. -- In der Ukraina'geht die Nordgrenze, allem Anschein nach, über' den nördlichsten 'Teil des Gouvernement Kiew, Poltawa und Charkow (Czernay!); dann geht sie wieder eine kurze Strecke nördlich (Gouvernement Woronesch), um sich, hüchst wahrscheinlich lïngs des Flucies Don zu senken. In Ciskaukasien dürfte die von Jekaterinodar durch Piatigorsk, Tarki und der russichpersischen Südkïste des Kaspisees entlang gezogene Linie die Nordgrenze der Smaragdeidechse bilden. - Die curopäisch-asiatischen Küusten des Mittelländischen Meeres bilden die Südgrenzen ihrer Verbreitung. Die südlichsten, von ihr bewohnten Punkte liegen in Persien (Schiraz), in Palästina, auf Cypern, Kreta, in Sicilien und im Süden Spaniens. Die nordafrikanischen Küsten, Sardinien und Korsika meidet sie; in Algerien und in Tunis ist sie durch eine verwandte Species, ich meine die pater Lataste vertreten.

Was die vertikale Verbreitung anbetrifft, so wissen wir, daßs sie ziemlich hoch hinaufsteigt und noch in Höhen von 4000 Fuß vorkommen kann (so im Wallis, T'schudi, Fatio) im Gebirgsstock des Mont-Blanc steigt sie nach Venance Payot selten über 2000 Fub; in 'Tirol soll sie nach Gredler' sowohl dem wärmeren Süden als den kälteren Regionen angehören und im Hauptthale der Etsch durch das Vinschgau bis nach Mals, 3300 Fufí über den Mecresspiegel, und im Eggenthale bis Gummer und Welschnofen, 3700 Fuf üb. M. steigen. 


\section{Lacerta princeps Blanf. (1874).}

"L. magna, fere sesquipedalis, dentibus palatalibus pracdita; scutis postnasalibus utrinque binis; prafrontali unico; verticalis marginibus lateralibus parallelis, anteriore posterioreque in medio prominentibus; squamis temporalibus polygonalibus, antice majoribus; collare libero, denticulato; squamis dorsalibus rhomboideis, carmatis, in series transversas ordinatis; ventralibus in decem series longitudinales, extremas valde angustiores; poris femoralibus utrinque 14; supra griseo-olivacea, subtus albida, maculis 4-5 coeruleis, nigro marginatis, longitudinaliter ordinatis, post axillam utrinque oruata.

Hab. in Persia meridionali.«

Synonymic.

Lacerta princeps W. B I anford, Description of new Reptilia and Amphibia from Persia and Baluchistan in: Ann. and Mag. Nat. Hist. XIV, pag. 31; the 'Loology and Geology' in: Eastern Persia, Vol. II. pag. 364. Pl. XXIV. London 1876. - L. C a merano, Considerazioni sul genere Lacerta Linn. etc. in: Atti. R. Accad. Sc. di Torino, XIII. Tav. I. - J. v. Bedriaga, Verzeichnis d. Amphibien und Reptilien Vorder-Asiens in: Bull. de Moscou, No. 3. 1879. S. 28.

Dil ich die, wie es mir dünkt, der Smaragdeidechse sehr nahe stehende L. princeps leider nicht selbst untersuchen konnte, so habe ich mich lediglich darauf beschrïnken müssen, vine nach Kräften genaue Übersetzung der in englischer Sprache abgefalisten Original-Diagnose zu geben; doch, um mich vor etwaigen Vorwürfen zu schirmen, füge ich gleichzeitig eine Abschrift der ursprünglichen enslischen Beschreibung bei. Die voranstehende lateinische Diagnose habe ich aus dem zweiten Bande von »Eastern Persia entlehnt. Da ich aufserdem, um Miliverstïndnissen rorzubeugen, bei den Schildern des Kopfes die Blanfordschen Benennungen beibehalten habe, so bin ich dem Lescr eine Erklärung in Bezug auf die von diesem Gelehrten gerählten Bezeichnungen schuldig. Eine Erklärung dürfte umsonelır wünschenswert sein, da Blanford in seiner Arbeit nicht durchweg die nämlichen Namen gebraucht hat, wodurch die sich zufällig eingeschlichenen Schreib- oder Druckfehler den Leser leicht irre leiten könnten; so habe ich nach längerem Suchen nicht herausfinden können, welches Schild eigentlich Blanford als Frontale (frontal) bei seiner Lacerta princeps bezeichnet, denn jene Tafel, die wir als Stirnschild zu bezeichnen pflegen, hat ja bei Blanford den Namen Verticale (svertical«) erhalten! - Blanfords »nasals« sind mit unseren Supranasalia identisch; seine »postnasals« entsprechen den Frenonasalen und scin "praefrontal ist unser Internasale; ferner heilst bei 
Blanforil das Frontale vertical《, die Palpebralscheibe ssuperriliary disk«, das Interparietale »anterior central occipital« und das Occipitale pposterier central oceipitale. Lndlich bezeichnet B blanford die Frontonasalen als »postfrontals«, die Supraorbitalen als ssuperciliary shields«, die Frontoparietalia als »anterior occipitals«, die Parietalen als spostoccipitals«, das Frenale und Freno-oculare zusanmen als 》loreals «, die Supralabialen einfach als »labials«, die Sublabialen als slower labials« und die Unterkieferschilder (Submaxillaria) als schin shields". Wie man sieht, ist somit kein Schild übrig geblieben, das als prontal bezeichnet werden könnte.

»Beschreibung${ }^{1}$ ): Der Gaumen ist bezahnt. Die Nasenlöcher sind am unteren nach

1) DDescription: Palatal teeth present. Nostrils in the lower posterior angle of the nasal shield followed by two postnasals. Lower eyelid opaque, scaly. Temples covered with polygonal shields, large in front, small behind. Scales of the neck above and at the sides granular, passing gradually on the shoulders into subimbricate, equal, rhomboidal, diagonally carinate scales of the back. Scales of the sides rather smaller than those of the back, and not keeled. Scales of the sides and back in transverse rows of about 34 each Scales of the throat imbricate behind, about the same size as those of the back; collar well marked, with a denticulated edge, formed by the projecting points of 7 enlarged imbricate plates. Ventral scales in 31 transverse, and, in the middle of the belly, 10 longitudinal rows, the outer longitudinal row much smaller than the others, and the 2 central rows narrower than the rest. Praeanal plate slightly larger than the others; 14 fomoral pores on each thigh. Limbs covered with smooth scales; those on the lower portion of the fore-arm and tarsus very little larger than on the bumerus and thigh. Scales on the under part of the feet smooth, convex; toes with transverse plates below; those beneatl the proximal portions of all the toes, except the first on the fore-feet and the fifth on the hind-feet, divided in the centre (This may of course be an indivilual peculiarity); plates near the claws undivided. Tail with all the scales keeled and in distinct rings. - Habit of the body moderately stout, rather depressed: tail more than twice the length of the body; head conical; limbs moderate; when the fore-leg is lail forward the longest toe reaches to the nostril, the hind-limb extends about four-fifths of the distance to the axil. Length $17 \mathrm{in}$., of which the tail from the anus measures 13.5 ; the head, from the snout to the hinder margin of the occipital shields, 1.15 ; forelimb, to the end of the toes, 1.75 ; longest toe (third or fourth) 0.5 ; hind-limb 2.7 ; longest toe (fourth) 0.95 . - Colour: Olivacens grey above, whitish below; there are a few small black spots on the back and sides of the neck, and a row of 3 or $\$$ blue ocelli (those in frount double), with black margins, behind each shoulder, extending in a line for a short distance down each side. The sides of the head are bluish, a tint especially narked on the labials; throat yellow. - Head shields: Rostral moderate, broader than high; nasals forming a suture behind the rostral, and articulating also with the rostral and upper postnasal. Nostrils in the lower posterior angle of the nasal shield, surrounded by the nasal, rostral, first labial, and 2 small subequal postnasals. I'raefrontal single, broader than long; postfrontals each about equal in size to the froutal, meeting behind it in a broad suture: their length exceeds their breadth, and the posterior margin of each is very convex exteriorly where it fits into the hollow between the vertical and superciliary disk, and concave towarảs the middle to receive the convex anterior edge of the vertical. Vertical with a very slight groove in the middle; sides parallel, anterior and posterior margins convex in the middle. Superciliary shields 4 on each side; the anterior small, the 2 central ones nearly equal; posterior about onethird the size of a central one; only a very few granules along the exterior elge of the central superciliares between them and the supraorbital ridge. 2 anterior occipitals of rather irregular form, convex in front and behind, and with a salient angle exteriorly, each a little smaller than the vertical. 2 postoccipitals (parietals), each about treble the size of an anterior occipital; 2 central occipitals; the anterior the 
rückwats gerichteten Winkel des Nasale gelegen und von zwei l'ostuasalia begrenzt. Das untere Augenlid ist modurchsichtig, beschuppt. Die Schlife sind mit polygonalen und zwar vorn mit grolien, hinten mit kleinen Schildchen bedeckt. Die Halsschuppen sind oberwärts und

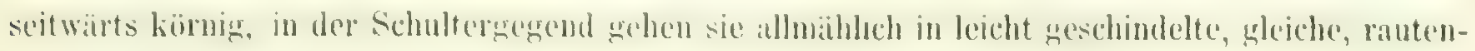
:ihnliche und diagonal gekielte Rückenschuppen über. Die ungekielten Seitenschuppen sind etwas kleiner als diejenigen an Rücken. Die transversale Rücken- und Seitenschuppenreihe besteht aus ungefäh 34 Schuppen. Die hinten geschindelten Kehlschuppen sind cbenso gro 3 wie diejenigen am Rücken; das deutlich ausgeprägte Halsband ist mit gezähneltem Rande versehen, der durch die hervortretenden Partieen von sieben breiten geschindelten Tafeh gebildet wird. Es sind 31 Quer- und in der Bauchmitte 10 Längsreihen vorhanden, von denen die äulieren longitudinalen Reihen viel kleiner und die zwei mittleren Reihen etwas schmäler sind als wie die übrigen. Die I'neanaltafel ist etwas grölier als die abrigen; 14 Femoralporen befinden sich an jedem Schenkel. Die Gliedmation sind mit glatten Schmpen bedeckt; diejenigen, welche an der unteren Partie des Vorderarmes und am Tarsus sich befinden, sind ein klein wenig gröber als diejenigen am Humerus und am Schenkel. Die Schilder an der unteren Seite der liülie sind glatt und gewölbt. Die Zehen sind unterwärts mit transversalen Tafeln besetzt, diejenigen zu unterst liegenden Schilder, welche an den allen Zehen (mit Ausnahme der ersten am Vorderfús und der fünften am Hinterfußs) zunächst sich befindenden Partieen liegen, sind in der Mitte geteilt; dies könnte natürlich nur eine individıelle Eigentümlichkeit sein; die neben den Klauen sich befindenden Tafeln sind nicht geteilt. - Der Schwanz ist mit in distinkten Ringehn angeordneten, gekielten schuplen bekleidet. Der Kürper ist mäilig gredrungen, eher Hach gedrückt. Der Schwanz übertrifft die Körperlänge um mehr als das Doppelte. Der Kopf ist konisch. Die Gliedmafien sind mäfigig entwickelt; das nach vorn ausgestreckte Vordersmaller, with an oval depression in the centre; the posterior nearly triagular, its posterior margin forming a right line with the same margins of the postoccipitals. 2 loreals, the posterior about double the size of the anterior; 8 upper labials, the last small; the sixth enlarged above and forming the lower portion of the orbit. Temples covered with polygonal shiclds all much larger than the neck scales, those in front larger than those behind, and 2 elongate shields above touching the postoccipitals. Ear-opening not toothed; a rather large shield on the upper anterior edge. Lower labials 6 ; five pairs of chin shields, the 3 first. in contact in the middle of the chin, the fonrth the largest. - Of this very fine lizard but a single specimen was obtained. 'This was shot by my collector in brushwood on a pass near Niriz, about 100 miles east of Shiraz, and at an elevation of about 7000 feet above the sea. - The nearest allies of this form appear to be Notopholis Fitzingeri, Wiegmann, and its allies, which have similar scales on the back. All are small and ditfer widely from the present species. They are placed by Gray (Cat. Liz. Brit. Mus. p. 34) in the genus Notopholis. But the type of Notopholis of Wagler, as Dumeril and Bibron pointed out, had previously been separated as Psammodromus by Fitzinger, and the type species $\mathrm{I}^{\text {. }}$. hispanicus ditfers in

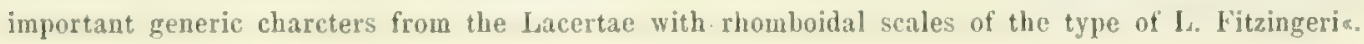


bein crreicht mit seincr längsten Zche das Nasenloch, das Hinterbein übertrifit un cin Fünftel seiner Gesantlïnge die Lntfernung der Achsel von der Ansatzstelle der Hinterextremitit. Die Lïnge betrïgt 17 englische Inches, wovon auf den Schwanz, vom After gemessen, 13.5 kommen. Dic Kopflänge von der Schnauzenspitze bis zum Hinterrand der Occipitalschilder mifst 1.15; llinterextremität: 2.7 ; längste Zehe (IV.): 0.95 ; Vorderextremität (bis zu den Euden der Zehen): 1.75 , längste Zehe (III, oder IV-te): 0.5 .

Farbe: - Oberwärts olivengrau, unterhalb weililich; auf dem Rücken und auf den Seiten des Halses befinden sich wenige, kleine schwarze Flecken; hinter jeder Schulter stehen drei oder vier blate, schwarz eingefitite Ocelli, welche vorn doppelreibig angeordnet erscheinen, wach hinten aber einreihig werden und sich auf eine kurze Strecke auf die Rumpfseiten fortsetzen. Die Kopfseiten sind bläulich, welche Farbe namentlich auf den Labialen zur Geltung kommt; die Kehle ist gelb.

Kopfschilder: - Das mäßig entwickelte Rüsselschild ist breiter als hoch; die Nasalen bilden hinter dem Rostrale cine Sutur, sie fügen sich an das Rostrale und an das obere Postnasale an. Die am unteren, hinteren Winkel des Nasenschildes gelegenen Nasenlöcher sind vom Nasale, Rostrale, Labiale I und von zwei kleinen, nahezu gleichen Postuasalia umgeben. Es gibt nur ein Praefrontale, das breiter als lang ist; von den, rückwärts breit zusammenstobenden Postfrontalia ist ein jedes ungefälır von der Gröfe des Frontale; die Länge des Postfrontale übertriftt die Breite, sein Hinterrand ist nach aufen hin, an jener Stelle, wo es zwischen dem Verticale und dem Supraciliardiscus cingeschoben erscheint, stark konvex; nach innen zu dagegen und zwar da, wo der konvexe Rand des Verticale sich einschiebt, ausgerandet. Das Verticale zeigt in del Mitte eine schwach ausgeprägte Vertiefung; es ist mit parallelen Seiten und einem in der Mitte konvexen Vorder- und Hinterrande versehen. Es befinden sich jederseits vier Supraciliarschilder, das vordere ist klein, die zwei mittleren sind nahezu gleichgroß, das rückwärts liegende ungefihr drei mal so klein wie das mittlere Schild; es befinden sich nur wenige, längs des Aufenrandes der mittleren Supraciliaria angeordnete und zwischen diesen und der Supraorbitalfurche liegende Kürnchen. Die zwei vorderen Oceipitalen sind von ziemlich unregelmälïiger Gestalt, sie sind vorn und hinten konver und nach außen mit volspringendem Winkel versehen; jedes dieser Schilder ist etwas kleiner als das Verticale. Von den zwci Postoccipitalia (Parietalia) erreicht ein jedes etwa die dreifache Größe des vorderen Occipitale; von den zwei centralen Occipitalia ist das vordere das kleinste und zugleich in der Mitte mit einer eiförmigen Vertiefung versehen; das hintere Occipitale ist beinahe triangulär, sein IInterrand bildet zugleich mit dem nämlichen Rande der Postoccipitalia eine gerade Linie. Von den zwei Lorealia 
ist das hintere etwa doppelt so grof wie das vordere; von den acht oberen Labialen ist das letzte klein, das sechste, die untere Partie der Orbita bildende, ist oben breiter. Die Schläfen sind mit polygonalen sehildern bedeckt, welche sämtlich bedeutend grötier sind als diejenigen auf dem Halse; die vorn liegenden Schlifenschilder sind gröfser als die hinteren; zwei verlängerte Schilder berülıren oberwärts die Postoccipitalia. Der Ohrrand ist nicht gezähnelt; eine ziemlich große Tafel am oberen Vorderrande. 5 Par Kinnschilder, von denen die 3 ersten in der Mittellinie zusammenstofen; das vierte ist das gröfte. 6 untere Labialia.

Von dieser schönen Eidechse ist nur ein einziges Exemplar erhalten worden; es wurde im Strauchholze in einem Eng-Paß neben Niriz, etwa 100 Meilen östlich von Schiraz entfernt, in einel ungefähren Höhe von 7000 Fufs üb. I. von meinem Sammler erschossen.

Am nächsten scheint diese Form mit Notopholis Fitzingeri W iegmann, sowic auch mit ihren Geschwistern, welche ähnliche Schuppen auf dem Rücken zeigen, verwandt zu sein. Letztere gehören alle einer kleinen Rasse an und unterscheiden sich beträchtlich von der gegenwärtigen Species; sie sind durch Gray in der Gattung Notopholis cinverleibt worden (Cat. Liz. Brit. Mus. p. 34), allein der Typus von Notopholis Wagler ist, wie es Duméril und Bibron gezeigt haben, bereits vorher durch Fitzinger als Psammodromus abgeschieden worden; auch unterscheidet sich die typische Species $P$. hispanicus durch gewichtige generische Merkmale von den Lacertae mit rhomboidalen Schildern vom 'Typus von $L$. Fitzingeri«.

\section{Lacerta agilis Wolf (1799).}

Char. - Scutum occipitale interparietali plerumque multum minus; scutum frontale latum. Sc. nasofrenalia duo, quorum superius in inferiori et in frenali positum, vel duo scuta nasofrenalia superposita et scutum frenale unicum, internasale attingens. Discus palpebralis a scutis supraciliaribus plerumqque nulla squamarum serje seinnctus. Scutir parietalia in margine externo 2-3 scutis maioribus circumdata; tempora scutis magnis tecta, scutum massetericum et tympanicum plerumpue nulla. Scuta supralabialia anteriora 4. Collare denticulatum, sulcus gularis nullus, scuta abdominalia per series 6 vel 8 disposita. Scuta analia $1-3$. Squamae dorsales longiores quam latiores, plus minusve angustae, sexangulares, carinatae. Squamae trunci laterales latiores squamis dorsalibus, subimbricatae laevesque. Dentes in maxillis et palato: Pori femorales utrinque 11-18. Corpus satis robustum, cylindricum, compactum. Caput altum, satis obtuse terminans, in regione temporali subamplificatum, a trunco vix seiunctum. Cauda $\mathbf{1}^{\mathbf{1}} / 2$ totius corporis vel paulo longior. Digiti antici et postici breves. Pedes postici brevissimi, axillas non attingentes. - Longitudo $167-270 \mathrm{~mm}$. 
Synonymie.

Lacerta commuis Gess n er, Liber de quadrupedibus oviparis, pag. 30. 'Tiguri 1854.

? Lacertus viridis Schwenckfeld, Theriotropheum Silesiae etc. pag. 148. Lignitz 1603.

Lacerta indigena viridis $\mathrm{Seb}$, Thesaurus rerum naturalium locupletissimus II, 'Tab. IV. Iig. 5 , pag. 84 .

Seps caenulescens La urenti, Synopsis reptilium, pag. 62, Tab. I, Figr. 3. Viennae 1868.

Seps argus Laurenti, pag. 61, Tab. I, Fig. 5.

Seps nuber La urenti, pag. 62, l'ab. III, Fig. 3.

Seps stellatus Schrank, Fauna boica I, 1. Abteil. S. 296. 1798, Nürnberg.

Lacerta agilis Wolf in: Sturms Deutschlands Fauna III. Heft 2. 1799. - Grassoi Dissert. inang. medica de Lacerta agili Linn. Helmstedt 1788 (partim). - Linné, Systema naturae I. Holmiae 1766 (p. 363). - Mer rem, Versuch eines Systems d. Amphibien S. 66. Marburg 1820, - Fleming, Philosophy of Zoology II, pag. 273. Edinburgh 1822. - Fitzinger, Neue Klassifikation d. Reptilien etc. S. 1 (var, Erythronotus). Wien 1826. - Schultze in: Lichtensteins, Verzeichnis d. Dubletten d. Zoolog. Mus. Berl. S. 94 (var. a, b, d, e). Berlin 1823. - Kaluza, Syst. Beschreib. d. Schlesischen Amphibien u. Fische, S. 25. 1815. - Wagler, Natürliches System d. Amphibien etc. S. 155. München, Stuttgart u. Tübingen 1830. Wiegmann, Herpetologia mexicana. Berolini 1834. - Eversmann, Lacertae imperi rossici etc. in: Nouv. mém. Soc. Imp. natur. Moscou 1834, pag. 341. - Bujak, Naturgesch, d, höheren Tiere etc. Königsberg, 1837. S. 260。- Schinz, Fauna helvetica in: Neue Denkschrift d. allg. schweiz. Ges. f. d. gesamt. Naturwiss, Bd. I. S. 138. Neuchâtel 1837; Europ. Fauna. Bd. II. S. 17. 1840. - Rathke, Verzeichnis d. Wirbelt, in Ost- u. Westpreußen vorkommend in: Neue Preufs. Provinzialblätter, Bd. II, S. 16. Königsberg. — Glückselig, Böhmens Reptilien u. Amphibien in: Lotos, S. 12. 1832. - Hahn u.v. Reider, Fauna boica, 1832. - Tschudi, Monographie d. schweizer. Echsen in : Nouv. Mém. Soc. Helv. Sc. nat. t. I, pagr. 21. 1839. - B e 11, A History of British Reptiles, pag. 17. London 1839. - Gray, Cat. Liz. Brit. Mus. pag. 32. London 1845. - Bell, op. cit. second. edition, 1849. - Bielz, Fauna d. Wirbelt. Siebenbürgens etc. S. 152. Hermannstadt 1856. - Schlegel, De Dieren van Nederland, pag. 4, Tab. 1, Fig. 1. Haarlem 1862, - Prach, Plazové a obojzivelnici zeme Ceske, S. A. S. 13. 1861, v Prage. - Lichtenstein, Nomenclator rept. et amphibior. Mus, zoolog. Berolinensis, pag. 14 (L. agilis u. var. dilepis). Berlin 1856. - 
Cooke, Our Reptiles etc, pag. 27. London 1865. - Müller, Zoologiae Danicae prodromus, pag. 36, No, 299. Ilavniae. - Linné, Fauna suecica 1761. No, 284 ( $\beta$ viridis); Linné-Retzius, Fauna suecica, pag. 290. Lipsiae, 1880. - Fritsch in: Arehiv d. naturw. Landeselurchforsch. v. Böhmen II. S. 105. - Leydig, Die in Deutschland lebemd. Art. d. Samrer, S. 197. Tübingen 1872. - I ï ckel in: Korrespondenzbl. 1. zool. mineralog. Ver, in Regenshurg XXV (1871), S. 81. - Schreiber, Herpetologia emopaea S. 433. - Kessler, Zoolog. Reise nach Transkakasien im Jahre 1875 in: Arbeiten St. Petersb. Gesellsch. d. Naturforscher VIII. SupplementHeft, S. 150. St. Petersh. 1878 (var. orientalis).

I. arenicola, Daudin, IIist. nat. génér. Lept. Vol. III. p. 230, Tab. XXXVIII, Fig. 2. Paris 1803. - Lesson, Cat. d'une Faune du dép. de la Charente Inférieure in: Act. Soc. Linn. Bordeaux, t. XII, p. 55.

I. stivpium, Daudin, opr. cit. Vol. III. p. 155, Tab. XXXV, Fig. 2 (var. 2-5). - Dugès, in: Ann. Sc. nat. t. XVI, pag. 376. - Crespon, Fame méridionale, pag. 192. Nîmes 1844. - Duméril et Bibro u, Erpétologie générale, V. p. 196. Paris 1839. Jenyns, Manual of british vertebrate animals, p. 291. Cambridge 1835. - De SelysLongchamps, Faune belge I, pag. 169. Liège 1842. - Ménétries, Cat. raisonné dles objets de zoologie recueillis dans un voyage au Caucase ete. pag. 61. St. Petersbour 1832. - Bonaparte, Amphibia europaea in: Mem. Accad. Sc. di Torino, Serie II, Tom. II, p. 385. - Milne Fdwards, Recherches zoologiques pour servir à l'hist. des Lézards in: Ann. Sc. nat. XXII. PI. V, Fig. 4. - Kirschb a um, Die Reptilien u. Fische d. Herzogt. Nassau. S. 9. Wiesbaden 1865. - Fatio, Fianne des vertebrés de la Suisse, vol. III. pag. 75. Genève et Bâle 1872. - De Betta, Rettili el Anfibi in: Fauna d'Italia. Parte IV (op. cit.). Milano 1874. - 'T'appe, Die einheimischen Eidechsen, S. 23. Oberhausen 1863. - Boulenger in: Proc. Zool. Soc. of London, 1881, pag. 743.

L. stellata, Glückselig, Synopsis reptilium et amphiborum Bohemiae, p. 12. 1832.

L. sericer, Glückselig, Böhmens Reptilien und Amphibien in: Lotos 1851, S. 113.

L. viritis, Linné, Funa Suecica. Stockholmiae 1746. - Rathke in: Mém. des Savans étrangers. Acad. St. Petersb. III. pag. 291. - Latreille, Hist. nat. Salamandres de France, p. XV (va: c, e). Paris 1800. -

L. angniformis, Sheppard in: Transact. Linn. Soc, vol. VII, P. 51. 1804. -

L. europaea, Pallas, Zoographia rosso-asiatica III. pag. 29, 31. Petropoli 1831 (part.). 
L. chersonensis, Andrzejowski in: Nouv. Mém. Soc. Imp. des naturalistes de Moscou 1832 , p. 327 , tab. XXII, fig. 11.

L. muralis, (Daud.) Eichwald, Zoolog. special. III. Vilna 1831, (part.).

I. donionsis, v. Bedriaga, Üb. d. Entstehung d. Farben bei d. Eidechsen. Jena 1874.

Die grane Eidechse, Bechstein (non Lacèpede!), De Lacèpedes Naturgesch. d. Amphibien etc. II. S. 3. Tá. I. Fig. 1, 2, 9, . Weimar 1800-82.

? Green Lizard var., Shaw, General Zoology III. pag. 233. London 1802.

L. sylvicola, Eversmann, Lacertae imperii rossici etc. in: Nouv. Mém. Soc. Imp. natur. Moscou 1834, pag. 344, tab. XXXI, fig. 1.

L. pardus, Razoumowski, Hist. nat. du Jorat etc. t. I, pag. 107, pl. II. fig. 4. LauSanne 1789.

Zootoca exigua, Eichwald, Fauna caspio-caucasia, p. 89, tab. X. Fig. 1-3. Petropoli 1840. ? Lacerta ocellata, Eichwald, ibidem.

Obschon es allgemein gilt, daf die Zauneidechse ihrem ganzen Wesen und Benehmen nach in so auffillender Weise von der viridis abweicht, dat eine Verwechselung dieser beiden nicht gut denkbar ist, so sind dennoch Fälle bekannt, welche das Gegenteil zeigen. In meinem Kapitel über $L$. viritis habe ich darauf hingewiesen, dab Pallas und selbst Eichwald, welcher, nebenbei bemerkt, nach allen Arbeiten, die er uns hinterlassen hat, zu urteilen, die russischen Eidechsen besser als Pallas gekannt haben dürfte, beide in Rede stehenden Arten zusammengeworfen haben. Beschränken sich unsere Kenntnisse nur auf die westeuropäischen Lacerten, so mag allerdings eine derartige Verwechselung nicht nur dem Herpetologen von Fach, sondern sogar dem Laien sonderbar erscheinen, denn wer wirl heutzutage z. B. in Deutschland die schöne, flinke Smaragdeidechse und die einficher gekleidete braune oder bram und grün gefärbte Zauneidechse nicht zu unterscheiden im Stande sein? Ziehen wir aber zum Vergleich auch die osteuropäischen und asiatischen Eidechsen und namentlich diejenigen, welche dem kaukasischen und transkaukasischen Gebiete eigen sinı hinzu, so werden wir alsbali zugeben müssen, dafs es oftmals recht schwer fällt, eine scharfe Grenze zwischen der Smaraglund Zauneidechse zu ziehen, insbesondere dann, wenn man auf die Formulierung einer präcisen Diagnose hinzielt. Die Zwischenvarietäten sind nämlich in den genannten zoogeographischen Übergangsregionen so zahlreich und die Kennzeichen bei diesen Varietäten so unbeständig, dafs man leicht irre gefüht wird und entweder die Arten selbst verwechseln oder die Übergangsformen falsch auffassen kann. Die, wie ich es aus eigener Erfahrung weik, äuferst schwierige Aufgabe, die ostemropäischen, in unseren Sammlungen ziemlich selten vertretenen Eidechsen zu 
bewäligen, fiel den russischen Faunisten der vicrziger Jahre zu; sie hinterliefen uns, wie man es wohl kaum anders von einen krstlingsversuche erwaten konnte, etliche offenbar ganz falsche Angaben über die Verbreitung von L. viridis im Uralgebirge und in Sibirien, ferner über das Vorkommen von Abarten der s. muraric und viridis« - nicht agilis, wie wir es wohl erwartet hitten - in Lithumen oiler Volhynien nebst einer ganzen Suite von neuen Artmamen, wic 2. B. L. cxigua, curopaca, strigata, sylvicolu, clegans, chersonensis, quinquevittata u. S. w. bie Kreirung von so zahlreichen nenen Namen für nu zwei Arten, ich mene die agilis und iridis, und fur einge Abarten dieser Species ist auch dadurch erklälich, daf.3 die Jugendzustände der usteuropäischen agilis und viridis einerseits sich seln ähnlich sehen, anderseits von denjenigen, der in Westenropa einheimischen Smaragd- und Zameidechsen meistens so grundrerschieden sind, dals sogitr unsere Zeitgenossen die sogenannten „L. sylvicola Eversm.« und $L$. exigua Eichw. grewöhnlich in die Synonymie der viridis versetzen und also nicht zu wissen scheinen, dats unter den erstgentunten eigentlich der Laurentische Seps argus, d. h. der Jugendzustand der russischen Ziuneidechse geneint ist. Indem die eigentümliche helle Längsstreifung der Oberseite bei den Jungen der agilis und viridis oftmals auch noch bei den Alten sehr deutlich zu 'Tage tritt, entstehen Übergangsformen, welche sich nicht ebenso leicht bestimmen lassen wie die west- und centralemopäischen agilis und viridis, bei denen die Jungen von der Geburt an verschieden gezeichnet erscheinen und mit zunchmendem Alter durch die weitere Ausbildung ihrer, sie unterscheidenden Charaktere noch im höheren Grade voneinander abweichen. Bereits in Jahre 1855 soll Sewertzow auf intermediäre, im Gouvernement Woronesch lebende Formen, welche die Smaragd- und Zauneidechsen verketten, hingewiesen haben. Ganz kürzlich ist Kessler auf diesen Gegenstand zurückgekommen und hat nicht mit Umrecht es für nöthig gefunden, auf die Variabilität dieser beiden Lacerten näher cinzugehen und einige bis dahin noch fraglich gebliebene Abarten zu klassifizieren. Der Kesslersche Beitrag zur Kenutnis dieser Eidechsengruppe ist insofern von besonderem Interesse, als er, so zu sagen, in indirekter Weise eine Aufklärung über jenen Umstand giebt, daf́ Eichwald - der Auctor der $L$. strigata - zuletzt selber nicht mehr genau wubte, ob seine strigata eine selbständige Art vorstelit, oder ob sie mit vividis oder gar mit agilis zu identifizieren sei. Die Ïhnlichkeit, welche sowohl zwischen den jungen als auch ausgewachsenen orientalischen viridis und agilis zu Tage tritt, deutet, wie ich glaube, darauf hin, dak beide Arten nahe verwandt sind, währenddem ihre ungreheure Variabilität im Süd-Osten Europas darauf hinweisen dürfte, dals der Umwandlungsprozels von der einen Form in die andere, und zwar, wie ich vermute, der viridis in die agilis im Süden Rulblands oder in Transkakasien vor sich gegangen ist 
und dals die Ausbildung und Fixation der heutzutage von den Systematikern bei der Speciesunterscheidung, für die Zauneidechse benutyten Merkmale erst nach stattgefundener Emigration der sbeginnenden Art und zwa im westlichen und centralen Europa, der jetzigen Wolnstätte der agilis der Autoren, stattgefunden habe. IJat doch schon Kessler die viridis var, strigutu als eine Form bezeichnet, welche sich in die agitis und speciell in die sogenannte längsgestreifte "Var. orientalis«, die in Rubiland uinheimisch ist, umzuwandeln begonnen hat. Ob dies wirklich der Fall ist, oder ob, wie ich eher zu glauben geneigt bin, die jetzigen gestreiften viriclis und agilis blok im Laufe der Zeiten veränderte Formen der ursprünglichen Übergangsvarietäten sind, kann selbstverständlich nicht entschieden werden, obschon jch meinerseits eher amnehme, dafs ein Umwandlungsprozets der viridis in dic agilis hentzutage, wie es Kessler vermutet, wohl nicht.mehr stattfuden dürfte, daf vielmehr jener Abkömmling der vividis oder jene Mutterform unserer westeuropäischen agilis nicht mehr existiert oder durch nachtrïgliche Ausbildung and relative Fixation neuer Charaktere einerseits die 》Vir. oricntulis oder chersonensis und anderseits die paradoxa erzeugt habc.

Körpergestalt.

Das Hauptgewicht bei der Bestimmung der, nir in grober Anzahl aus mehreren europäischen und asiatischen Lokilitäten vorliegenden Zameidechsen habe ich anf den Bau des Körpers gelegt, auch habe ich alle Details derselben mit Genauigkeit berücksichtigt, da mit hier einige charakteristische Eigentumlichkeiten anfstiefien, welche sehr wohl geeignet zu sein scheinen, um in denjenigen schwierigen Fällen, wo die osteuropaiischen agilis sonst einen merkwürdigen Kollektivtypus repräsentieren, worin sich Elemente finden, welche teils zu den Eigentümlichkeiten der Smaragdeidechse, teils zu denjenigen der westeuropäischen Form der Zauneidechse gehören, gute Dienste zu leisten. Die agilis sind in der Regel bedeutend kileiner als die viridis, nur in einigen kaukasischen (rebieten erreichen sie nahezu die Länge der viridis, indem sie $220 \mathrm{~mm}$ und sogar darüber mossen, wovon $21 \mathrm{~mm}$ aû́ den Kiopf fillen. Der Kopf zeichnet sich durch eine bedeutende Breiten- und Höhenentwickelung aus; unterhatb der Ohröffnung, an jenen Stellen, wo der Unterkiefer sich an die Schädelkilusel anfügt, zeigt er. namentlich bei den Männchen, die gröfste Breitenausdehnung; dazu kommt noch, dafis er nicht die langgestreckte Form besitzt, wie es $z$. B. bei den ausgewachsenen viridis der Fall zu seiu pflegt. Die Schläfengegend ist bei beiden Geschlechtern mehr oder weniger stark backenartigy aufgetrieben; von den Augen nach vorn zu erscheint der Kopf zienlich schnell in die kurze, leicht abgerundete oder nahezu stumpf abgestutzte Schnauze verengt, die stets höher ist als breit; seitlich vor den Augen siud Vertiefungen sichtbar, welche, obschon schwach ausgeprägt, 
dadurch auffillen, dals die kleinen Augen stak hervorzutreten pflegen; dic Palpebralscheiben latgen bei den west- und centraleuropaischen Individnen deutlich hervor, waihrend bei den sudl'ussischen ayilis diese Particen entweder gar nicht oder leicht erhoben sind und fie form eines sanften, thachen Bogens amnehmen; sonst erscheint die Schädeldecke in ihrem Hinterteile ziemlich abgeplattet, gegen die Schnauzenspitze hin sanft abfallend. Die Nasenöffumgen licgen seitlich; die Ohröffungen sind grok, meistenteils oval. Der. IIals ist in der Régel sehr breit, sogar breiter als der liopf eine schwach angedentete Halseinschürung ist meistens an der Ansatzstelle des Halses an den Kopf erkennbar. Der allmählich, insbesondere bei dem Weibchen, nach hinten zu an Umfang zunchmende Rumpf ist verhältnismäifig liurz, kräftig und plump gebaut; hinsichtlich der Rumpflänge scheinen die Männchen in der Regel den Weibchen nachzustehen. Die kräftig gebauten Beine sind kurz, insbesondere erscheinen die läß̉e kurz ${ }^{1}$ ) und ylump gestaltet. Die Vorderbeine, an den Kürper angelegt, berühren gewöhnlich den Vorderrand der dugen, bei den krimer Individuen sind sie allordings etwas lïnger und reichen bis zum Freno-Oculare oder bis zum Frenale; die Hinterbeine erreichen entweder nur die halbe Entfernung zwischen den Wurzeln der Vorder- und Hinterextremitïten oder ragen etwas darüber hinaus; sie scheinen aber nie die Achseln zu erreichen. $L$. agilis weicht somit in dieser Hinsicht von der vorigen Species erheblich ab. Die Candalwurzelgegend ist namentlich an jener Stelle, wo der liumpf in den Schwanz ïbergeht, also zwischen den Gliedmafen, sehr breit; der Schwanz erscheint an seiner Basis rundlich-viereckig, von oben, in der Mitte der Lïnge nach cingedrückt, nach hinten zn wieder fast rund, verdünnt sich allmählich und geht in eine kurze. ziemlich stumpf endende Spitze über. Die Schwanzlänge ist verschieden; bei den westeuropäischen agilis ist der Schwanz durchschnittlich nahezu anderthalbmal so langr als der übrige Kö̈rper; bei den osteuropäischen hingegen nimnt diese Schwanzlänge fast zwei Drittel der ganzen Körperlänge hinweg, olıne jedoch die Länge des Schwanzes und die schlanke Form desselben wie bei der Smaragdeidechse zu erreichen. So besitze ich z. B. etliche Zauneidechsen aus der Heidelberger Gegend, deren Totallänge sich auf 167 mm beläuft und deren Schwanzlinge $88 \mathrm{~mm}$ beträgt, während die gröbten mir aus Transkaukasien vorliegenden Individuen $220 \mathrm{~mm}$ messen, wovon auf den schwanz $137 \mathrm{~mm}$ fallen. K essler berichtet, dafi diese Art im Bezirk von Kíban die Länge von $270 \mathrm{~mm}$ erreicht. Bei den überhaupt schlanker gebauten Weibchen scheint der Schwanz stets etwas länger zu sein, als bei den Mläunchen; auferdem vermissen wir bei dem Weibchen die dem Männchen eigentümliche Verdickung an der Schwanzwuzel; der Schwanz ist bei ersterem deutlich vom Rumpf abgesetzt; seine Hinterbeine sind kirzer

1) Vergl. meine Tafel, Fig. 26. 
und weniger kräftig gebant, der IRumpf ist länger und zeigt cinen breiten Umfang, endlich scheint der Kopf des Weibchens verhältnismäfig länger aber schmäler zu sein als beim Minmehen.

İ ubere körlerbedeckung.

I)ie äulsere Bedeckung bei dieser species ist attrerordentlich veränderlich, indem sowohl die Beschuppung des Rückens sehr variert, als atch die form und Kahl der líopfschilder cinem mammigfaltigen Wechsel unterworfen ist. In der liegel zeichmen sich die sehilder der Kopfoberseite durch ihre excessive Breitenentwickehng aus, sogar das kleine, trapezförmige Hinterhauptsschild ist offer's ebenso breit oder breiter als lang. Das unpaare, diesem Schilde zunächst liegende, längliche fünfeckige Interparietale ist bedeutend grölser und erreicht mindestens dio doppelte Länge des Occipitale; nach vorn zu ist es meistens ziemlich bedeutend erweitert und in stumpfem Winkel zwischen die füfseitigen Frontoparietalen cingefügt; nach hinten erscheint es verschmälert, oder, wie es weit seltenel der Fall zu sein pHegt, ebenso breit wie an seinem Vorderteile. Die Frontoparietalia laben nichts Charakteristisches an sich; sie zeigen funf Hauptkanten, zu denen sich zuweilen noch eive kurze, die hintersten Supraocularia berührende Koate gesellt; verglichen mit den nämlichen Schildern bei $L$. viridis, erscheinen die Frontoparietalia bei agilis verlältnismätỉir kürzer und zugleich etwas breiter. Die l'arietalen sind von gewöhnlicher Bildung; sie sind entweder mit abgerundetem Seitenund IInterrande und mit vier, unter stumpfem Winkel zusammenstobenden inneren Kanten, oder mit stumpfwinkeligem äuberen Seiten- und mehr oder weniger geschweiftem Vorderrande versehen und in der Temporalgegend durch zwei grobe, längliche und ziemlich stark auf den Pileus übergewölbte Schilder unsäumt. Das Stirnschild ist nächst den Parietalen das grölate Kopfschild; namentlich bei den russischen Stïcken ist es sehr stark in die Breite entwickelt und verhältnismälig kurz; sein Vorderrand ist entweder bogenfürmig gekrummt, oder etwas stumpfwinkelig ausgezogen, nach rückwärts erscheint es unmerklich verengt und mit zweimal schwach gebuchtetem, aber äulierst stumpfwinkeligem Rande versehen; seitlich ist es mehr oder weniger deutlich ausgerandet. Die Palpebralscheibe ist schmal, das vordere, also 2. Supraoculare ist durch eine ziemlich lange, dreieckig abgerundete Tafel repräsentiert, während das darauffolgende Schild kürzer, sowie auch etwas breiter und mehr rundlich irregulär-vierseitig ist. Auf diese über den Augen liegenden Schilder wird bei der Speciesunterscheidung großes Gewicht gelegt und angenommen, dab bei der uns hier interessierenden Lacerta die Palpebralscheibe sich unmittelbar an die Supraciliaria anfügt, während bei anderen Eidechsenarten diese schilderserien durch cine Anzahl kleiner Körnerschuppen von jencn Tafeln entweder vollkommen 
oder wenigstens teilweise, wie es z. B. bei ler westeuropäischen vividis der Fall zu sein pflegt, getrennt erscheinen. Daf dies bei der westeuropäischen agitis der Fall ist, steht aufer Zweifel: mahezu simtliche Exemplare aus [netschland. Liankreich und der schweiz, die jeh zu sanmeln (irlegenheit hatte, zeigen diese von meinen Vorgängern hervorgehobene Eigentümlichkeit, hingegen unter den agilis russischer Herkunft, so z. B. aus den Wolga-Gegenden, sind mir wiederum mehrere Stücke bekannt, bei denen der Palpebraldiskus durch eine Reihe kleiner Schuppen von den Supraciliaren getrennt erscheint. Diese Erscheinung deutet, glaube ich, auf die nahe Verwandtschaft der viridis mit der agilis hin und mag die Annahme rechtfertigen, dab die Übergangsform zwischen diesen beilen Arten im entfernten Osten Europas zu suchen ist. Tedenfalls bietet uns die minutiöse Verglrichums der im Westen Europas einheimischen Formen dieser zwei Species gar keinen Anhaltspunkt, daks die event. Umwandlung der einen Eidechse in die andere im Westen stattgefunden habe, denn abgesehen von der Zeichnung bei den gan\% jungen Individuen jener auf der pyrenäischen Halbinsel lebenden, im vorigen Kapitel heschricbenen Gadovii-Scheiberi-Varjetäten der viridis, welche allerdings an die Zeichnung der westoder centraleuropäischen Agilis-Form im allgemeinen erinnert, sehen die westlichen Smaragdund Zauneidechsen grundverschieden aus und werden sogar von Laien auf den ersten Blick unterschieden. - Hinsichtlich der Supraocularia mußs hinzugefügt werden, dalỉ das 4. und zugleich kleinste Täfelchen in der Regel mit dem Freno-oculare zusammenstölist, während bej den hier zum Vergleich gezogenen Smaragdeiderhsen dieses Oberaugenschildchen meistens vou dem grofen Supraoculare II, sowie dem größeren vorderen Supraciliare and dem Frontonasale eingeschlossen erscheint. Die äufsere und gewöhnlich längste seitliche Kante des Frontonasale grenzt an das meistens böhere als breite, unregelmäfig gestaltete, $d . h$. vorn und hinten mit gebuchteten oder geschwungenen Seiten versehene Freno-oculare; die nach innen gelegene hante des Frontonasale stölst ali das gleichnamige Schild der entgegengesetzten Kopfseite. während seine längere hintere Kante sich an das Frontale anfügt und seine kürzere, ebenfalls hintere Kante mit dem Supraoculare I und II in Berührung kommt; diese beiden Kanten stoken meistenteils in spitzem Winkel zusammen. Von den zwei vorderen Seiten des Frontonasale grenzt die längere, inedianwärts gelegene an das Zwischennasenschild, während die kûrzere, mehr lateralwärts liegende Seite in der Regel an das obere Nasofrenale grenzt. Das die Frontonasalia und die großen, vorn und unten das Nasenloch ungebenden Supranasalia voneinater trennende Internasale ist verschieden geformt, bald ist es einem Kreisausschnitt ähnlich, dessen bogenförmig gelirümmte Seite nach hinten und dessen spitz ausgezogene Partie nach vorn gerichtet erseheint, bald ist es von etwa gerundet rhombischer Gestalt; 
das eine Mal ist es breiter als lang, das andere Mal wiederum länger als breit. Das Rostrale ist hoch, sein oberer Teil erscheint als dreieckige, mehr oder weniger deutlich aut die Kopfoberseite übergewölbte Spitze zwischen die Supranasalen eingeschoben. Diesem Iiüsselschilde schlieben sich nach hinten jederseits 7 Suprababialen an, von denen das hinterste allerdings giemlich kiein ist, die vorderen höher als breit, viereckig und mit bogenfürmig abgerundeter Vorder- und schwach ausgerandeter Hinterkante versehen erscheinen. Dem 4., etwa trapeaförmigen, d. h. gegen seine Basis etwas erweiterten, vorderen Supralabiale schlielist sich das ziemlich bedeutend grölsere, nach unten zu verschmillerte und die untere Begrenzung der Augenhöhle bildende Supralabiale V an, das durch ein schmales, selten in zwei kleinere Schildchen geteiltes Praeoculare vom Freno-oculare getrennt wird. Die Zügelschilder, die sonst bekamutlich zuverlässige Merkmale zur Unterscheidung der Eillechsenarten abgeben können, erweisen sich bei L. agilis sowohl in betreff ihrer Zahl als auch ihrer Anordnung und Konfiguration sehr unbeständig. Bei der westeuropäischen Form befindon sich zwischen den Seitenkanten des Rostrale und dem Freno-oculare 3 , etwa ein Dreieck bildende Tafeln, von denen die eine, oberhalb liegende, an das Internasale grenzende und als oberes Nasofrenale bezeichnete 'Tafel zum Teil über dem unteren Nasofrenale, zum T'eil ïber dem Frenale gestellt zu sein pflegt. Das zuletat genannte Schild erscheint somit sehr niedrig und vollkommen durch das mach aufwärts gewälbte obere Nasofrenale vom Pileus getrennt. Bei den in Südrulisland, namentlich an der Südküste der taurischen Halbinsel und im Kaukasus einheimischen Zauneidechsen zeigt die Beschilderung der Zügelgegend einige Abweichungen un! zeichnet sich durch ihre Unbestindigkeit aus; in vielen Fällen erscheint das Frenale seh" hoch und tritt mit den Schildern der Kopfoberseite in Kontakt (also genau wie wir es bei $L$. vividis kennen gelernt haben), während die Nasofrenalen übereinander gestellt sind und somit ihrer ganzen Höhe nach mit dem Frenale zusammenstofien. Mitunter kommt es aber vor, dafis die 3 in liede stehenden Schilder in mehrere Teile zerfallen und auf diese Weise eine Gruppe von 4 bis 6 Täfelchen bilden. Darauf, dafi bei $L$. agilis öfters Unregelmäligkeiten in betreff der 'Täfelung der Zügelgegend vorzukommen ptlegen, hat bereits Schreiber hingewiesen; es bliebe mir nur noch übrig, hinzuzufügen, dabs diese Unregelmäßjigkeiten namentlich bei den russischen Individuen Jermalien häufig auftreten, då sie leicht irre führen können und die Bestimmung in höchsten Grade erschweren; anch möchte ich gleichzeitig in Erinnerung bringen, dabs jene angebliche $L$. viridis bei $\mathrm{R}$ athke, welche, nebenbei bemerkt, zweifelsohne eine der agilis als der viridis näher stehemle, krimer Eidechsenfornı repräsentiert, jederseits mit 4 Zügelschildern versehen sein soll, »von denen dicht hinter dem Nasenloch eines über dem anderen steht." Die Zahl 


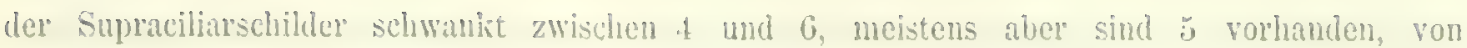
denen das vordure und längste zientich breit ist. Die Temporalgegend ist in inrem oberen 'Teil vou einem kleinen und von "s grölieren unregehmaigig greformten, bald länglichen, fünbis siebenseitigen, bald fast quadratischen, an die Sc. parietalia grenzenden l'afeln bedeckt, während auf den übrigen. 'Teilen sich ziemlich zahlreiche, grolse, ungleichartig gestaltete, meistens unregelmälig polygonale und hexagonale und ziemlich Hache Schilder hefinden, in deren Mitte ein durch seine Grölie hervorstehendes Massetericun bei den westeuropaitischen agilis selten, bei den sührssischen aber ofters ausgeprïgt zu sein pflegt. Lin lïnglich geformtes T'ympanicum scheint nur ausnahmsweise vorhanden zu sein; die Unsïunung der groben Ohrüfnung geschicht durch eine lieihe winziger länglicher Schuppen. Die Zahl 6 der lünglichen und schmalen Sublabialen und die Zahl 5) der Submaxillaren scheint zienlich konstant zu sein; die 3 ersten Submaxillarpare stolien zusammen; das Mentale ist breiter als Jang. Eine eigentliche Kehlfurche ist nicht vorhanden, jedoch werden die länglichen, lateralrärts etwa hexagonalen, medianwärts oval-hexagonalen Kehlschuppen von den dahinter liegrenden viel breiteren Halsschuppen durch eine unvollständige transversale Serie kleiner 'Täfelchen oder Schuppen getrennt. Bei den jungen Individuen tritt der Sulcus gularis öfter's zum Vorschein. Eine Kehlfalte, von einer linearen Verticfung begleitet, kommt bei den ausgewachsenen Stücken meistens nur seitlich, unterhalb der Ohröftinung zum Vorschein. Sümtỉiche Schuppen an der Unterscite des Kopfes sind melı oder weniger geschindelt. Das bald schwächer, bald stärker gezähnelte Halsband besteht aus 8 bis 9 , in selteneren Fällen aus 7 oder 11, von aulien mach innen schindelförmig übergreifenden 'Tafeln, von denen die wittlere breiter als lang erscheint, withend die abrigen etwas länger als breit sind. Die Seitenteile des Halses sind mit rundlichen, etwa köinerartigen, ungekielten Schuppen bekleidet, die Nackenschuppen hingegen sind vou eher länglich hexagonaler Form und erscheinen mit deutlichen Längskielen versehen.

IVas die Beschuppung des Rückens anbetrifft, so kann diese nach den Standorte ungemein wechselu. Die in West- und Mitteleuropa lebende Form ist sofort durch ihre, in 6 bis 12 Längsserien gestellten, sclumalen, bedeutend längeren als breiten, längsgekielten medianen Rückenschuppen von allen übrigen Arten mit Leichtigkeit zu unterscheiden; diese Schuppen heben sich durch ime Gestalt und Grölỉe vou den anstolienden, rundich hexagonalen und bedeutend breiteren und ungleichseitigen Schuppen der Rückenseiten sehr deutlich ab; gegen die Flanken hin nehmen sie an Breite zu, büßsen aber ihre Kiele ein, verHachen sich und erscheinen vierseitig mit abgerundeten Ecken. Eine gleiche scharfe Trennung zwischen Rücken- und Rumpfseitenschuppen habe ich nur in seltenen Fällen bei den südöstlichen russischen, namentlich bei 
den Frimer und kaukasischen ayitis beobachten können. Der Übergang der etwas schmäleren polygonalen oder hexagonalen, entweder ieicht abgerundeten oder ziemlich scharfeckigen Dorsalschuppen in die breiteren, geschindelten, oftmals diagonal gekielten, etwa rundlich hexagonalen orler mehr vierseitigen oberen liumpfschuppen geht ganz allmählich von statten; gegen die Bauchgrenze hin erscheinen diese Schuppen ungekielt, irregulär, vierseitig mit abgerundeten Ecken und relativ gröber als bei $L$. viridis. R a thke hat zweifelsohne eine in dieser Weise eigentümlich beschuppte agilis mit der viridis verwechselt, denn er hebt ausdrücklich hervor; dafs die an der oberen und an der rechten und linken Seite des Körpers seiner angeblichen Smarageidechse aus der Krim liegenden »Schilder sich in Hinsicht der Zahl, der Form und der Lagerung wie bei »L. stirpium Dugès《 verhalten; die scharfe 'Trennung del dorsalen und lateralen Schuppen bei dieser und der leise Übergang zwischen diesen Schuppen bei jener ist him aber nicht aufgefallen. Hingegen scheint Lich tenstein auf die Unterschiede, welche die Beschuppung bei der agilis zeigt, aufmerksan geworden zu sein, da er in seinem Nomenclator reptilium et amphibiorum eine agilis aus der Kirgisensteppe als svar, dilcpis« folgenderweise charakterisiert: „squamis dorsi mediis angustioribus quam in ceteris speciminibus.» Allem Anschein nach hat dieser Autor seine dilcpis lediglich mit südrussischen, soeben beschriebenen Individucn verglichen, wobei ihm der Unterschied in der Beschuppung aufgefallen ist und hat den Vergleich mit den durch schmälere dorsale Schuppen ausgezeichneten agilis ans West- und Central-Europa unterlassen. Var. dilepis ist meiner Ansicht nach nichts anders als die sogenannte typische Form. - In der Mitte des Rumpfes zähle ich in einer Querreihe 40 bis 48 und in einer Iängsreihe 84 bis 101 Schuppen; von diesen in regelmärige Quergürtel angeordneten Schuppen gehen je zwei, zuweilen aber drei Gürtel auf die Länge eines Ventralschildes. Die Anzahl der Querbauchschilderreihen beträgt gewölnnlich 26 bis 30; die in 6 Längsreihen stehenden Bauchschilder werden seitlich von grö̉eren Randschildchen begrenzt, welche oftmals sehr grols erscheinen und ein supplementarisches viertes Bauchschilderpaar bilcten; die medianen und nach auken liegenden Tafeln sind stets etwas oder bedeutend schmäler als die dazwischenliegenden. Das Brustdreieck besteht aus 7 bis 13 Schildern. Bei der westlichen Form erscheint die Afterspalte an ihrem Vorderrande von einer grofen, vorn und lateralwärts meistens nur von einem Halbkreise kleiner Schildchen umsäumten Tafel begrenzt; hingegen bei den russischen agitis sind meistens zwei Reihen solcher Randschildchen an Anale vorhanden; außerdem zeigen mitunter die zwei mittleren Randschildchen eine so auffallende Breitenausdehnung, daf sie beinahe halb so grof, wie das Afterschild erscheinen. Diese Unbeständigkeit in der' Täfelung der Aftergegend bei Individuen ein und derselben Specjes zeigt, dałb der Be- 
Kleidung dieser Region vom systematischen Gesichtspunkte aus nur ein untergeordneter Wert beigemessen werden kaun und darfis die kürzlich proponierte, auf der Anordung und Anzahl der Analtafeln basierte Einteilung der echten Eidechsen nicht ganz einspruchsfrei zu scin scheint. Es ist aber leicht möglich, dalis die bei einigen russischen Zauneidechsen abweichende Belileidung der Aftergegend, des Oberkörpers und der Zügelgegend zu subspecifischen Morkmalen erhoben werden könnte; lediglich wegen Mangels an genügendem Material sehe ich augenblicklich davon ab, die agilis der Autoren in zwei wohlgeschiedene Unterarten zu klissifizieren. - Auf der Oberseite der Extremitäten, namentlich auf den hinteren, sind die Schuppen gekielt und geschindelt. Die 52 bis 90 Schwanzringel bestehen oben aus länglichen, sehr deutlich dachartig gekielten und nach hinten spitzwinkelig endenden, unten, mit Ausnahme der kürzeren, aber breiteren Hachen Schwanzwurzelschuppen, aus länglichen, schmalen, deutlich gekielten und linten in eine transparente und pigmentlose Spitze ausgezogenen Schuppen.

Schenkeldrüsen und Zähne.

Die Zahl der Schenkeldrüsen scheint bei den osteuropäischen und asiatischen agilis in der Regel grölfer zu sein als es bei den westemropäischen der Fall ist, so habe ich hei den mir aus der Kirgisensteppe, aus Franzfeld am Dnjepr und aus Jalta in der Krim (Nr. 1955, 1954. Mus. zu Kiew) vorliegenden, $13-15,14-14,15-15$ und 16-17 Drïsen konstatiert; nach K ess l er kann die Schenkeldrüsenzahl bei den russischen agilis bis auf 18-18 und nach Rathke sogar bis auf 20-20 steigen; hingegen, nach den übereinstimmenden Zeugnissen vicler Autoren sind bei den westeuropäischen Stücken jederseits meistens nur 11 bis 14 Drüsen vorhanden, obwohl ihre Zahl nach Fatio sich mitunter auch auf 18 belaufen kann. 7 bis 9 Zahne im Zwischenkiefer, 15 bis 16 im Oberkiefer, 42 im Unterkiefer. Der Gaumen ist bezahnt. Die ober- und Unterkieferzähnchen sind deutlich zweispitzig.

Färbung und Zeichnung, Varietäten und Máse.

Wemn verschiedenerseits behauptet worden ist, dals die Zauneidechse in betreff ihrer Fårbung und Zeichnung wenig variiert, so ist dies insofern richtig, als die mannigfaltigen Farbenänderungen bei dieser Art sich um eine gewisse, allerdings ziemlich geringe Anzahl von Grundformen gruppieren lassen; die Zwischenformen aber, sowie auch jene Farbenerscheinungen, welche vom Alter und Geschlecht oder von der Jahreszeit abhängig zu sein pflegen, sind keineswegs gering. Jedenfalls dürfte die agilis mindestens ebenso stark varieren wie die Smaragrdeidechse.

1. Var. typice (? var. dilepis Lichtenst.). - Die vorzugsweise in Mittel- und WestEuropa lebende Form del Zauneidechse ist diejenige, welche als Typus gilt und von IVolf als 
L. andis benannt worden ist. Bie Geschlechter und die Alterstnfen dieser stypischen agilis» sind in der Tegrel so verschieden, dafs thas Farbenkleid der Vämohen und Weibchen und damn anch der Jungen Anlalis zur Aufstellung von besonderen Species gegeben hat; so bezeichnete

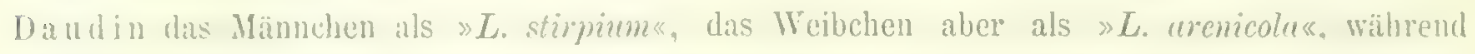
Laurentis w Seprorgus ge wif nichts anders als das Junge dieser agitis und zwar in seinem zartesten After repräsentiert. Nach Leydius soll die reine Argusform, eigentich nur fur den Sommer mul Herbst des dihres, in welchen die 'liere aus dem Ei grelirochen, hestehen. Dunkelbraune, nahezu schwarz umsitumte, oder blok von schwarzbramen Makeln begleitete, rundliche, weisliche Flecken erscheinen nämlich bei den neugeborenen Individuen über den ganzen Oberkijhyer zerstreut und zejgen öfters eine Neigung, sich der Länge nach zu reihen und auf diese Weise 6 bis a Fleckenserien zu bilden, von denen die medianen dorsalen Serien aus weiblich längsgestreiften dunkelbraunen Flecken bestehen, wälmend die Leibesseiten mit echten Augenflecken besetzt erscheinen. Mitunter aber sind nur die Rumpfseiten mit solchen Augenflecken geziert, währeud die Rückenfleckung gänzlich fehlt. Das erste Frühlingsgemand der jungen raitis-typica zeigt etliche Modifikationen: las Gruncikolorit ist etwas dunkler und nimmt eine ausgeprägtere braune Tinte an; vier lichte schmale Binden durchziehen den Oberkörper, wodurch die branne Grundfarbe in ein mittleres, ziemlich brejtes Band. das über den Rücken in der Breite des Hinterhautsschildes herabläuft und jederseits in zwei Seitenbänder gesondert erscheint. Die Kopfschilder sind oben lrellbraun gefärbt, Heckenlos oder spärlich gefleckt, wïhrend die Kopfseiten in der Rearel ziemlich stark dunkel gezeichnet erscheinen. Der Schwanz zeigt an seiner vorderen Partie ziemlich genau dieselbe Streifun wie der Rüclien, indem er oben eine mediane dunkelbraune, hell umsïumte, mach ruckwärts sich verengende Binde aufweist und seitlich nochmals ein braunes, an den hellen saum angrenzendes und nach unten zu von einem weifien Streifen begrenztes schmales Band zeigt. Die Bauchteile sind gelblich oder grüulichweil, Heckenlos oder nur spurweise gesprenkelt. Mit fortschreitendem Wachstum des Tieres treten mehr oder weniger auffallende Abänderungen in betreff der Färbung und Zeicluung ein, welche in bedeutendem Grade vom Geschlechte ahhängig sind; so hellen sich beim Männchen die lichtbraunen, längs der dunklen Rückenzone sich hinziehenden Binden stärker auf als es beim Weibchen der Fall zu sein ptlegt; die dunklen, ursprünglich als blofe Umrandung der weifien Augen dienendeu Makeln werden teilweise durch gegenseitiges Zusammenfließen, teilweise wohl auch durch ihre Ausdehnung größser und heben sich entweder als etwa quadratische, in zwei, voneinander durch die weißlichen kurzen Striche getrennte Reihen ab, oder treten als deltaoder schnörkelförmige, weife Eerne enthaltende Figuren auf, oder endlich erscheinen sie als 
breite, ein weilses Feld umschlieliende Ringe, welche in einer Iangsreihe atuf hellerem Ibaun angeordnet sind. Seitwäts, meistenteils auberhalb, aber dicht an diesen dunkelbramen Flecken befinden sich wielerum lume weifse striche, Punkte orler unregelmälising gestaltete fileckehon, wolche nichts Anderes als die Überbleibsel jener Augen sind, mit denen die junge agitis-tymica versehen zu sein ptlegt. Die iunkle unnterbrochene Längsstreifung der liumpfseiten verschwindet gänzlich oder erscheint nur noch äuberst schwach ausgeprïgt; so tritt sie mitunter bei den erwachsenen Weibehen auf, un den, zwischen den ebenfalls nach und nach gröber gewordenen dunkellnannen Seitenttecken übrig gebliebenen Ramn auszufülen. Die Rumpfseitenflecken ptlegen bein Weibehen schïrer als beim Männchen hervorzutreten; entweder erscheinen sie in zwei bis drei Längsreihen angeordnet und enthalten dazwischen weililiche Makeln oder sic repräsentieren drei, auf hellbriunem Grunde verlanfende weifsceangte Fleckenserien. Andre Weibchen aber behalten zum 'T'eil ilı Jugendgewand auch im erwachsenen Zustande bei; ih" Obcrkörper erscheint nämlich mit cincr grolän Anzahl sehr kleiner weifer Ocellen besäet, welche von äuferst kloinen dunkelbramen Flecken begrenzt werden; dabei zeichnen sich die unteren Kö̈rperteile dadurch aus, dals sie mur änlierst spärlich und undeutlich auf hell bläulichgrauem Grunde dunkelgrün gepunktet erscheinen, whähend sonst der bauch mebr oder weniger stark aber stets zienlich scharf auf gelblichem oder grünlich-gelbem Fond gepunktet oder gefleclit ist. Bei den Hännchen, vorzugsweise während der Brunstperiode, kommt an den Rumpfseiten ein grüner Farbenton hinzu, welcher bei den jungen Individuen gänzlich vermilit wird und bei den ausgewachsenen Weibchen selten und nur an den Bauchgrenzen, sowie auf đen äufiersten ventralen Schildern spurweise zu sehen ist. Dieses Grün tritt in zahlreichen Schattierungen auf; bald gesättigt, balı gelblich, bräunlich oder auch bisweilen bläulich; darüber weg verteilen sich entweder mehr oder weniger scharf dunkelbraun oder schwarz umrandete und in Längsreihen angeordnete weif3e Fleckchen oder blols schwarze, zwischen die grüne Grundfarbe der Rumpfseiten eingestreute, mitunter dicht aneinander gestelite Punkte. Während der Hochzeitsperjorle dehnt sich das Grün auf Kosten des braunen Rückenbandes aus und zwar dermaßen, daf dieses gänzlich oder fast sảnzlich verdrängt werlen kann; im letzteren Fall crhält es einen Stich ins Gelbliche. Auch kann die grüne Farbe sich auf die Gliedmalien, die Hals- und Kopfseiten, sowie auch auf die übrigen unteren Körperteile ausdehnen, wodurch das Tier eine Ähnlichkeit mit der Smaragdeidechse erhält und mit dieser auch thatsächlich verrechselt worden ist. Mitunter aber zeigt sich eine dunkle, entweder schwarze oder schwarzhraune Fleckung auf den Rumpfseiten und auf den Beinen so vorherrschend, dafis sie zur Grundfärbung wird, während das ursprüngliche grüne Grundliolorit in Form von Punlten. Sprenkeln 
orler geschlängelten Linien zu Tage tritt. Das gänzliche Verschwinden des helleren Untergrundes ist ebenfalls konstatiert worden; so berichtet 'Tschudi über eine, angeblich im Kanton Glarus nicht selten vorkommende dunkle Spielart der agilis, die er mit folgenden Worten charakterisiert: »Kopf oben bram, über den Rücken läuft ein tief schwarzes Band, das von zwei weiblichgrauen Streifen eingeschlossen wird. Die Seiten sind schwarz, am Bauche ins Tieforüne übergehend, mit einer Reihe weilser Punkte und Ringe. Der Schwanz ist mit \& Längestreifen von abwechsehnd dunkler oder heller Farbe bedeckt, Kehle und Bauch sind schmutzigweilß ${ }^{1}$ ) Hingegen bei der sogenannten typischen Form der agilis erscheinen sämtliche Unterteile des Körpers auf gelbgrünem oder weíblauem Grunde, namentlich an den nach aufan zu liegenden Ventraltafeln ziemlich dicht dunkelgrün oder schwarz gesprenkelt.

Bei den aus dem Mainthal und zwar aus Wertheim stammenden, von Leydig untersuchten Stücken erscheint der Grundton stellenweise, so in der Gegend der Afterspalte und der Schwanzwurzel, durch die schwarze Besprenkelung ganz verdrängt. Überhaupt zeigt die westeuropäische agilis hinsichtlich der Färbung und Zeichnung eine überaus großse Veränderlichkeit; die Farbe der Rumpfseiten kann nämlich bei den männlichen Individuen vom Braun oder Graubraun einerseits durch Gelblichbram ins Gelbliche oder Smaragdgrüne, andererseits durch Lichtgrau oder Braungrau selbst bis zum Schwarz mannigfaltig abändern; das verwaschen braune, gesättigt braune, bräunlich gelbe, mattschwarzbraune, tiefschwarze oder grüne, seitlich grau, geiblich, grünlich- oder grauweif ${ }^{2}$ ) umsäunte Vertebralband ist selten Heckenfrei, meist mit

1) Darüber, ob wir es hier mit einer selbständigen Rasse oder mit der melanischen Ausartung einzelner Individuen, wie es bekanntlich angenommen worden ist, zu thun haben, kann ich kein Urteil fällen. Nach F. Müller (Verhandl. naturforsch. Ges. Basel 1878, S. 624) soll das Basler Museum eine Var. atra von agilis enthalten, welche aus Stollenhäuser bei Schauenburg stammt. Leider geht M iille r auf die Beschreibung dieser svar. atra nicht näher ein. - Bei dieser Gelegenheit entsinne ich mich, dafs Jä ckel ebenfalls angeblich eine schwarze Abart der Zauneidechse für die hochgelegenen Berggegenden Bayerns verzeichnet (Korrespondenzbl. d. zool. mineralog. Ver. Regensburg, XXV. S. 81). Der Umstand aber, dak dieser Forscher dabei auf $L$. nigra Wolf zu sprechen kommt und angiebt, das die schwarze Zauneidechse von Dr. Hahn auf der Grüneckalpe bei Tegernsee und von Koch bei Reichenbach, » wo sie so schwarz wie gewichstes Leder vorkommt", ferner bei dem Städtchen Roding bei Cham in der Oberpfalz und endlich in den Berchtesgadener Alpen gefunden worden sei, deutet darauf hin, dab $\mathbf{J}$ äckel die schwarze vivipara für eine agilis gehalten haben mag.

$\left.{ }^{2}\right)$ Rösels Naturgeschichte der einheimischen Frösche und Schlegels "Dieren van Nederland enthalten Abbildungen der agilis, deren Rücken ein blau umsäumtes oder von Blau durchzogenes braunes Band aufweist und deren Leibesseiten auferdem schön blau gefleckt sind. Wenu Leydig, dem diese Zuthaten nicht unbemerkt geblieben und merkwürdig erschienen sind, die Vermutung ausspricht, der liolorist der Abbildungen bei Schlegel habe sich lediglich die Röselsche Figur und nicht die Natur zum Vorbilde genommen, so muß ich ihm darin beistimmen, denn reines, gesättigtes Blau habe ich ebenso wenig wie Leydig bei der Zauneidechse auf ihren oberen Teilen des Körpers wahrzunehmen Gelegenheit gehabt; hingegen tritt ein blauer Anflug mitunter, allerdings aber nur spurweise, auf. 
einer oder zwei licihen looseb, oder teilweise der Länge nach zusammentlietiender, bald grober, wenig zathreicher, rundlicher, quadratischer oder hufeisenfürmiger, bald kleiner und in gröferer Anzahl zerstreuter Flecken versehen. Die geaugten Rumpfseitenflecken können gänzlich fehlen oder im Gegenteil so zahlreich auftreten, dafs sie miteinander in Kontakt treten und auf diese Weise scharf gestellte Querbinden hervorbringen können. Endlich können die weifien Fleckchen bald rund, oval oder in Form cines kurzen Striches in der Mitte der dunklen Makel auftreten, oder sich diesen blolis anfügen und zum Teil der Länge nach zusammenstolien.

Weniger mannigfaltig sind die Farben- und Zeichnungskombinationen bei dem weiblichen Geschlechte. Die Grundfube der Kürperseiten ändert von Taubengrau oder Gelblichbraun durch Rötlichgrau oder liötlichbraun bis zu gesättigtem Braun; wälnend die stets durch ihr dunkles Braun vom Untergrunde der Limpfseiten sich abhebenden Flecken bald weibliche, bald hellgrünliche oder bräunlichweifse Kerue oder Striche enthalten, können diese weibsen Fleckchen auf der Rückenzone auch gänzlich fehlen. Bei anderen Individuen wiederum sind die dunklen Iiuckentlecken nur nach außen hin fein hell umsäumt. Treten diese Säume partiell in Berührung, so entstehen längs des dunklen Vertebralbandes helle unterbrochene Längslinien, welche die hellbraunen, dunkelbraun gefleckten und weißs geaugten Rumpfzonen von der schmalen Rückenzone trennen. Grünlichgelbe oder graublaue Nuancen sind mitunter auf der Bauchgrenze wahrnehmbar. Daßs die Bauchseite spärlich auf hellbläulichgrauem oder auf grünlichgelbem Grunde melır oder weniger deutlich gefleckt und gepunktet ist, habe ich bereits erwähnt und es bliebe mir nur noch übrig hinzuzufügen, dal3 diese Fleckchen mitunter in 7-9 Längsreihen angeordnet erscheinen, zuweilen aber gänzlich vermist werden; in diesem Fall sind sowoh die Bauchschilder als auch die übrigen Tafeln auf der Unterseite des Körpers taubengrau, grünlich oder bläulichgrau, hinten hell, sei es gelblichweiß oder grauweiß umsäumt.

Dak die Gegend des Torkommens auf die Färbung dieser Eidechse Einfluł auszuüben rermag und dats bei dieser Species eine Anpassung des Kolorits an die Farbe des Bodens stattfinden kann, ist durch Leydig nachgewiesen worden; so berichtet dieser Gelehrte, dab ihm auf einer Exkursion von dem Steinbruch bei Öhningen nach Stein am Rhein an den warmen sandigen Abhïngen zahlreiche agilis autfielen, deren Grundfärbung (bei beiden Geschlechtern!), „gleichsam in Aupassung an den hellen Boden der Molassenhügel, äufert licht« gewesen ist. (Vergl. Die in Deutschland lebend. Arten d. Saurier, S. 201.) »Bei den Weibchen«, fügt Leydig hinzu, »war die Grundfarbe hellbraun, bei den Männchen grüngelb. Dadurch hoben sich die Augenflecken nit rein weiber Mitte aufs schärfste ab. Selbst auf der Rückenfläche des Kopfes trat die Fleckenbildung deutlich hervor. Und dafs es sich wirklich um eine Anpas- 
sung an die Färbung des Molassensandsteins hamdle, bestitigte sich mir als ich in Jahr darauf, Mitte Septembers, an der Südseite des Gebhardsberges bei Bregenz die Lacerta ayilis von der gleichen lichtgrauen Färbung traf. Ton demselben Gesichtspunkte war mir cine Anzahl mämlicher Tiere merkwürdig, welche ich im April 1869 an den sonnigen Bergen bei Weinheim an der Bergstralise gefungen hatte. Hier steigerte sich das Grün während des Monates Mai zu einem wahrhaft leuchtenden (brün; es zog sich selbst von den Seiten des liopfes in das Braun der Iiopfschilder. Die Mitte der Augentecken, sonst weilikich, war selbstverständlich auch grün. Dazu kam, ditlis die dunklen Flecken grölier waren als gewöhnlich, von buchtiger form und indem sie rou Stelle zu Stelle zusammentlossen in hübscher Verteilung das Grün durchzogen.«

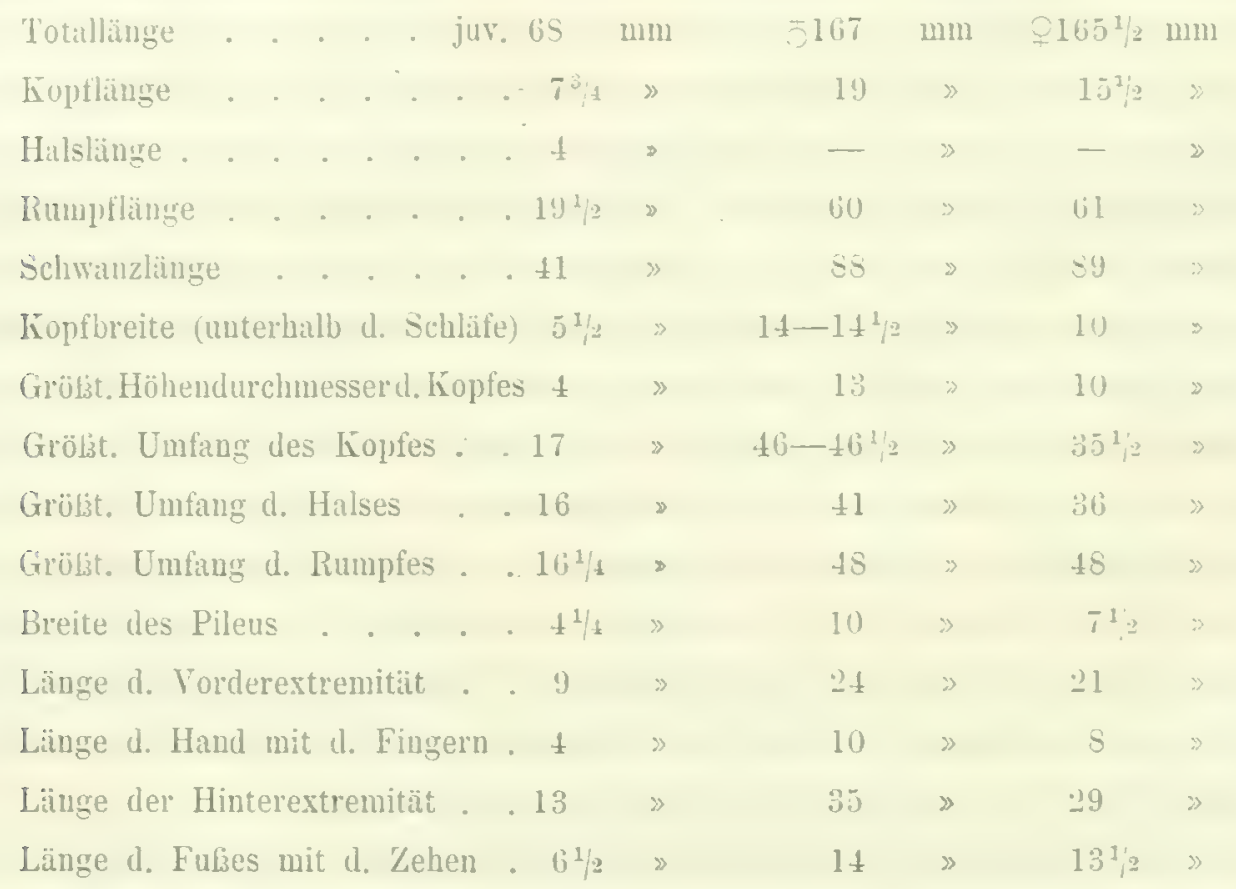

2. Var. mura Laur. - Während die von Leydig beschriebene agilis vom Molassenhiugel zweifelsohne blobs eine Lolalform repräsentiert, muß die rotrückige, von Laurenti als » Seps mier«, von Schrank als seps stellatus und von Fitzinger, Glückselig und ron mir selbst als LL erynthronotus, sericea und ischlensis« bezeichnete Zauneidechse als bestinmt geschiedene Varietät gelten. Über ihren Rücken zieht sich nämlich vom Nacken an ein ziemlich breites, der Breite des Pileus entsprechendes, kupferrotes Band hin, welches auch auf den Schwanz übergeht; in der Regel entbehrt lieser Streifen jeglicher Flecken, mitunter aber treten dunkle Iakeln auf, aber nur spurweise; an den Leibesseiten befinden sich beim Männchen auf grünlichem, grünlichgelbem oder graubraunem, beim Weibchen auf bräunlichem oder grau- 
bramem Fond mehrere in 2 bis 3 Längsteihen angeordncte, weifiliche (q) oder grünlichweilic $\left(\sigma^{7}\right)$, schwarz oder dunkelbraun eingefatite Flecken (Seps stellatus Schrank, Fauna boica I, S. 286,266. - Lac. rubre v. Reider u. Hahn, Fauna boica, Tab.). Nach Schreiber (Herpetolog. emrop., pag. 439) künnen, wie es scheint, diese dugentlecken fehlen und in diesem Fall sind die Rumpfseiten ganz unregelmälisig schwarz gesprenkelt. Die grünlichweilie Bauchseite ist bald meln', bald weniger dicht schwarz punktiert. Auf die Fundorte dieser auffallend schön kolorierten Varietät werde ich weiter unten näher eingehen. - Bei den jungen etwa 78 mm langen Individuen dieser Varietat ist die breite Rückenzone nubbraun, ungefleckt; dic Rumpfseiten pftegen etwas dunkler zu erscheinen und enthalten zwei Längsreihen weifser, dunkelbraun eingefaliter Punkte; eine dritte weilie Punktserie pHegt spurweise an den äuferen Bauchschilderreihen angedentet zu sein; die Kehlgegend erscheint grunlich, der Bauch mit gelblichgrauem Antluge versehen. Genau dieselbe Färbung und Zeichnung wird bisweilen auch beim ausgewachsenen Weibchen angetroffen. Junge mbre sehen im allgemeinen in betreff ihres Farbenkleides meinel viridis var. Sclueiberi juv. etwas ïhnlich, nur ist der Untergrund bei der letzteren in der Regel etwas dunkler, während die seitlichen Flecken grelbe Kerne einschliefen. - Ziemlich gute Abbildungen von Var. mbra enthält Loreks Fauna prussica (L. stellata auf Taf. III). Wenn ich nicht irre, figuriert die stypische Form« in dem nämlichen Werke unter dem Namen $\gg L$. crocen Wolf«, während die rotrückige Abart bei Rathke (Verzeichnis d. in Ost- $n$. Westpreufen vorkommenden Wirbeltiere, l. c.) als »I. stelluta Sch rank k verzeichnet ist; v. Reider und Hahn nennen sie in ihrer Fauna boica »L. mbra».

Alsdann beschreibt Schreiber (op. cit.) eine mir leider gänzlich unbekannte spanische agilis folgenderweise: "Alle mir aus Spanien zu Gesicht gekommenen Individuen waren von unseren deutschen an Größe nicht verschieden, zeichmeten sich aber stets durch einen entschiedenen ins Grünliche oder Gelbliche ziehenden Ton der Grundfarbe sowie häufig durch das sehr tiefe Schwarz der Flecken aus, die teils ziemlich rundich und oft in sehr grofer Menge und merklicher Gröfe über die ganze Oberseite zerstreut und in diesem Falie meist ohne weiße Beimischung waren, teils aber wieder an den Seiten zu sehr scharf ausgeprägten hufeisenförmigen Querbinden zusammenstieß̧en, die an ihrer nach rückwärts geöffneten Konkavität eine weile Makel einschlossen. Die schwarze Punktierung der Unterseite war bei diesen Formen auch im männlichen Geschlechte nur wenig ausgesprochen.« - G. A. Boulenger (Proc. Zool. Soc. of London 1884, p. 421) ist geneigt anzunehmen, daf der Verfasser der eben citierten Herpetologia europaea eine eigentünliche und, wic es scheint, nur auf der prenaischen Halbinsel rorkommende Varietit der viridis, und zwar die $\gg$ Gadovï«, mit der Zauneidechse verwechselt habe; ob dies 
wirklich der Fall ist, vermag ich nicht zu entscheiden, möchte mir aber die Bemerkung erlauben, daf mir die agitis auf meinen Reisen in Spanien nicht begegnet ist; ebensowenig habe ich Individuen spanischer Herkunft in den von mir besuchten Museen entdecken können, auch fanden sich unter den zahlreichen, mir ron meinen Korrespondenten aus Spanien zur Ansicht gesandten Eidechsen keine agilis vor. Daf die Verwechselung der beiden erwähuten Formen möglich ist, beweist eine aus Granada stammende junge vividis Schreiberi, welche ich im $\mathrm{k}$. zoolog. Kabinett in Wien als $" L$. agilis bestimmt vorgefunden habe; namentlich sehen die ganz jungen spanisch-portugiesischen rividis den Jungen der westeuropäischen agilis ähnlich, indem sic hell auf dunklem Grunde geaugt erscheinen. Diese ganz eigentiumliche und interessante Erscheinung läbt aber zu event. Vemutungen über die verwandtschaftlichen Beziehungen zwischen den pyrenäischen Formen der Smaragdeidechse und der westeuropäischen agilis schon deshalb keinen Raum, weil die osteuropäischen Zeichnungsformen dieser beiden Lacerten insofern sich ebenfalls ähnlich sehen, als die jungen und mitunter auch die ausgewachsenen Individuen längsgestreift erscheinen.

3. Tar. chersonensis Andrzejowshi ${ }^{1}$ ). - Die dritte mir vorliegende Varietät der agitis, nämlich diejenige, reelche Andrzejowski als »L. chersonensis« und Kessler als $\gg L$. agitis rar. orientatis« beschrieben haben, zeichnet sich durch ihre Rückenstreifung aus. Über ihre Rückenmitte läuft nämlich in der Breite der Kopfschilder ein braunes oder grünlichbraunes Baud hin, das rom hopf bis zum Schwanz durch einen hellen, bald grünlichen oder grauweißen, bald grünlichblauen Streifen in zwei schmälere Zonen geteilt wird und lateralwärts, also nach außen hin, jederseits von ähnlichen Streifen umsäumt wird, so dafł dadurch ein Paar Rückenzonen entstehen, welche beim Männchen etwas dunkler und von ziemlich großen quadratischen Makeln besetzt erscheinen, beim Weibchen abel in der Regel etwas heller sinc und von kleineren, dunkelbraunen, unregelmäßig gestalteten und unzusammenhängenden Flecken oder Strichen begrenzt werden; gegen den Schwanz hin vereinigen sich diese dorsalen Zonen zu einem einzigen, nach rückwïrts dünn auslaufenden Streifen. An den Rumpfseiten befinden sich jederseits auf hellbraunem oder bräunlichgrumem Fond 3, beim Männchen scharf prononcierte und zum Teil der Länge nach rerbundene, beim Weibchen aber schwach oder nur andeutungsweise ausgeprägte und loose dunkelbranne Lïngsflechenserien, welche meistens von weiflichen oder grünlichweifen Ocellen begleitet werden; die zwei oberen Reihen dieser Flecken nehmen ihren

1) Nour. Mém. Soc. natur. de Moscon III, lag. 319 (Moscou 1832). - Tar. orientalis in: Tiesslers Reise durch Transkaukasien im Jahre 1876, 1. c. - L. stivium in: Eichwalls Fauna caspio-caucasia, pag. 84. - L. agilis rar. dd. in: Lichtensteins Terzeichnis d. Dubletten d. zoolog. Mus. d. L. Unirersitat zu Berlin. S. 95. Berlin 1823. 
Ursprung am linterrande der Ohrüthungen me gehen auch auf die Schwanzbasis über, während die unterste Fleckenserie in der Achselgegend anfïngt und an der Ansatzstelle der Hinterbeine endet. Der hopf und die Beine sind oberseits und lateralwärts auf bräunlichgrünem oder grünlichem Grunde dunkel gezeichnet. Die unteren Schwanz- und Bauchtafeln erscheinen entweder dunkelgrïn oder bläulichgrün, fein gefleckt oder sie sind der Breite nach blaugrün gestreift mit einem hellen Rande versehen. Die Kehle endich zeigt einen blauen Anflug. - Bei den jungen, etwa $10 \mathrm{~cm}$ langen Exemplaren dieser östlichen Abart laufen über den liücken hin 3 grünlichweilse oder ganz hellbraune Längsstreifen, von denen der mittlere vom Hinterraude des Occipitale anfangende und an der Schwanzwurzel endende schmälere Streifen ein der Breite des Pileus entsprechendes braunes, dunkelbraun getlecktes Band in zwei solche spaltet; die übrigen zwei seitlich liegenden Streifen dienen zur Umsäumung dieser Bänder und trennen zugleich diese letzteren von den ebenfalls braunen, aber denuoch in ganzen etwas helleren Rumpfseitenzonen. 3 bis 4 Längsreihen weiblicher, entweder dunkelbraun umrandeter oder nur ron dunkelbraunen Makeln begleiteter Augentlecken zieren die Rumpfseiten. Die Kopfseiten sind einfarbig hellnubbraun oder äuferst zart dunkelbraun gezeichuet. Der Schwanz zeigt oberhalb einen medianen dunkelbraunen Streifen, welcher aus der Vereinigung der beiden oben erwähnten Rückenbinden entstauden ist und von den lateralwärts gelegenen ähnlichen Streifen durch eine lichtbraune Linie gesondert erscheint. Helle Augentlecken sind am Schwanze nur selten zu sehen und nur an del Caudalwurzel seitlich konstatierbar; meistens rber vereinigen sich diese Ocellen und bilden eine weibliche Linie, welche sich vom braunen Seitenstreifen ziemlich scharf abhebt. Sämtliche unteren Körperteile, mit dusnahme der äufersten Iongitudinalen Ventraltafeln, sind ungefleckt und zwar am Kinn und Bauch mit einem bläulichen, in del Analgegend und an der Schwanzunterseite mit einem gelblichen Antluge versehen. - Die als $L$. sylvicola von Ever'smann ${ }^{1}$ ) beschriebene Eidechse repräsentiert zweifelsohne eine noch jüngere agilis chersonensis als diejenige, welche ich soeben beschrieben habe; sie soll kupferbraun sein und keine dunkelbraune Rückentleckung aufweisen. Eine der sylvicolı, wie sie Eversmann abgebildet hat, sehr ähnliche agilis-chersonensis aus Saratow hat mir Prof. P a u s on aus dem Museum zu Kien freundlichst zur Ansicht zugesandt; das betreffende, mit der Museumsetikette L. stirpium var. sylvicolu, ded. Kind ermann, To. $1953 \ll$ versehene, $90 \mathrm{~mm}$ lange Exemplar

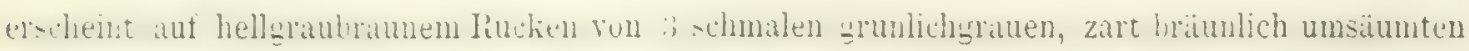
Streifen durchzogen, von denen der mittlere Streifen, wie gewöhnlich vom Hinterrande des Occipitale beginnend, längs der Wirbelsäule sich hinzieht, um an der Schwanzbasis zu enden.

\footnotetext{
3) Lac. imp. ross. in: Xouv. mén. soc. imp. natur. de Moscou III (183ł), pag. 3ł́́, tab. XXXI, fig. 1.
} 
Die Rumpfseiten sind mit 3 Längsreihen weilibher, fein bräunlich umsäumter Augen und Strichen gezeichnet, wovon die 2 obersten scharf ausgeprägt zu sein pflegen; diese Fleckenreihen entspringen hinter dem Ohrrande; die obere geht auch auf die Schwanzseiten ibber, wälırend die unteren sich nur bis zu den hinteren Gliedmaßen hinziehen. Die oberen Kopptafeln sind einfarbig grau; die äulieren Parietalränder erscheinen hell umsätumt; die Schläfen cnthalten etliche weililiche Augenflecken auf grauem Fond. Die Unterseite sämtlicher unteren Körperteile ist weiblich oder grauweils. - Diejenigen Unterschiede, welche Eversmann zwischen seiner L. sylvicolu und der agilis gefunden zu haben behauptet, können meines Erachtens nach keine Berücksichtigung finden, im Gegenteil sie können nur dazu beitragen uns zu überzeugen, dal; wir in der sylicicola sicher eine junge, vielleicht eben dem Ei entschlüpfte orientalische Zauneidechse, und nicht $L$. viridis, wie man es sonst anzunehmen scheint, vor uns haben. Das nämliche gilt in Bezug auf die exigua Eichw., welche Eidechse wohl nichts Anderes als eine junge chersonensis mit abnormer Beschildung der Zügelgegend darstellt; hat doch schon Eichwald selbst seine $L$. exigua mit der Eversmannschen sylvicola identifiziert.

Obschon diese, wie es scheint, nur im Süden Rufilands, in Kaukasus und vielleicht auch in Klein-Asien ${ }^{1}$ ) einheimische Abart oder Unterart der Zauneidechse in betreff des Farbenkleides eine gewisse Ähnlichkeit mit $L$. viridis var. strigata $\mathrm{E} \mathrm{ichw.} \mathrm{besitzt,} \mathrm{so} \mathrm{kann} \mathrm{sie} \mathrm{den-}$ noch nicht mit ihr verwechselt werden; letztere zeigt nämlich 5 deutlich ausgeprägte helle Längsstreifen, während die agitis-chersonensis nur 3 solcher Streifen aufzuweisen hat. Eher noch liefe sich die chersonensis mit der viridis-tritineata vergleichen; namentlich sehen sich die jungen Individuen dieser zwei Formen ähnlich, jedoch heben sich die hellen Streifen bei der viridis-tritineata viel deutlicher ab, indem sie bedentend heller und prononcierter zu sein pflegen. Auffallend und für unser Verständnis noch unerklärlich erscheint uns einerseits die Ähnlichkeit der westeuropäischen geaugten Jugendform der agitis mit den jungen spanisch-portugiesischen Smaragdeidechsen (Var. Scheiberi, Var. Gadorii), andererseits aber wieder die Ähnlichkeit

1) Das British Museum enthält nämlich eine als $>$ L. strigata bezeichnete, in Lilein-Asien von $\mathrm{H}$. Dandford erbeutete, ganz eigentümliche Eidechse ron etwa $136 \mathrm{~mm}$ Länge, welche wir wegen der Zügelschilder, des Sulcus gularis und einiger anderer untergeordneter Kennzeichen zu $L$. viridis und wegen der lingekielten Flankenschuppen, der Körpergestalt (kurze, die Achseln nicht erreichende Hinterbeine und s. w.) und endlich des Farbenkleides halber eher zu agitis rechnen müssen. Obschon ich wegen Mangels an Material und namentlich in Anbetracht dessen, daf $L$. agitis und $L$. viridis durch ihre $Z$ wischenformen anf eine höchst eigentiumliche Art und Weise rerkettet erscheinen, mir nicht erlauben kanu ein Urteil über diese fragliche Eidechse aus Klein-Asien zu fällen, bin ich doch geneigt anzunehmen, daf sie der Gruppe der agilis näher steht als derjenigen der viridis, jedenfalls repräsentiert sie keine strigata $\mathrm{Eichw}$, eher düfte sie einer neuen Species angehören. 
zwischen dem hell gestreiften Jugendgewande bei agilis-chersonensis und der ebenfalls lüngsgestreiften östlichen Form der vimilis, während die centraleuropäischen - italienischen, französischen und deutschen — Stüclie dieser beiden Arten sowohl in ihrer Jugend als auch in ihrem Alter ganz und gar verschieden gezeichnet sind. - Sowohl diejenige Eidechse, welche bei Rathke ${ }^{1}$ ) als $L$. viridis beschrieben worden ist, als auch diejenigen, welche als strigata aus Feodosia im Senckenbergischen Museum und als stirpium aus der Umgebung von Simpheropol im Museum zu Kiew aufbewahrt werden, gehören meiner Ansicht nach hierher, »Die alten und ausgewachsenen Exemplare«, sagt Rathke, ssind an der oberen und an der rechten und linken Seite entweder smaragdgrün, oder grün mit einem Stich ins Gelbe. Die drei schmalen Streifen auf Rumpf und Schwanz spielen etwas ins Bläuliche, oder sind ganz undeutlich. Die schwarzen Flecken auf der oberen Seite sind entweder ganz geschwunden, oder teils selır klein und verwischt, teils liaum bemerkbar. Der weiklichen Flecken an den Seiten giebt es bei vielen Exemplaren nur zrei deutliche Reihen und fast ein jeder solcher Fleck hat dann cinen schwarzen vollständigen oder unvollständigen Saum, so daf die Flecken Augen darstellen. Bei anderen Exemplaren aber sind diese Flecken in gröferer Zahl vorhanden, sehr klein und gehören einzeln genommen nur 3 oder 4 Schuppen an. Die untere Seite des Körpers ist entweder fast citronengelb oder schwach saftgrün.« »Seltener«, fügt Rathke hinzu, »findet man fast erwachsene Exemplare, die am Rücken ebenso grau sind, wie die . . . . jüngeren. Bei der mir aus dem Museum zu Kiew vorliegenden Eidechse (No. 1954) verlaufen 3 hellgrüne Längsstreifen auf dem Rücken; zwischen ihnen liegen kleine, unregelmälig geformte, dunkelbraune Flecken, welche sich ziemlich deutlich vom bräunlichgrünen Fond abheben; auf der rechten und linken Seite des Rumpfes erscheint der bräunliche Untergrund durch zahlreiche kleine, braune und schwarzbraune Flecken unterbrochen; an den Rumpfseiten vermisse ich bei diesem Individuum die von $\mathrm{Rathke}$ erwähnten weißlichen Augenflecken; bei einem anderen Stücke aber, das mir ebenfalls aus dem Museum zu Kiew vorliegt (No. 1955 aus der Umgebung von Jalta), bemerke ich auf den Rumpfseiten zwei parallele Reihen klejner, weiligrauer, unvoliständig dunkel- und hellbraun umsäumter Augenflecken auf grünlich-braunem Grunde; dieses Exemplar unterscheidet sich auferdem noch insofern von dem zuerst beschriebenen Stück, als es blol’ zwei nach imnen zu von Dunkelbraun umsäumte Längsstreifen zeigt, welche zwischen sich die schmale graugrüne, nit gröburen hellbrannen Flecken besetzte Rückenzone cinschlietien. Ler. Batuch ist bei diesen Stucken gelhlich, die auberen Banchschilderserien mit blïulichem An-

ij Beiträge z. Fauna d. Lrym in: Miém. prés. à l'Acad. Imp. des sc. de St. Y'etersb. par divers sarans III, p. 299. 1837. 
fluge versehen oder grünlich-grau gepunktet. Die Submaxillaren zeigen einen Stich ins Blaugrün; die Kehle ist ebenfalls bIïulichgrün oder gelblich. Die Halsseiten erhalten eine grünlichgrane Jarmorzeichnung. Die bräunliche oder hellgrünlich-braune Kopfdecke erscheint nur sehr spärlich braun gepunktet.

Unter den fünf im Senckenbergscheu Museum meiner Meinung nach irrtümlich als viridisstrigata bezeichneten Eidechsen aus Feodosia befinden sich drei junge Individuen und ein ausgewachsenes Stück der agilis-chersonensis, während das fünfte Exemplar das Junge der L. puradox sp. n. zu repräsentieren scheint. Beim ausgewachsenen Weibchen sieht man 3 weiligraue, mälig voneinander entfernte, leicht geschlingelte Lïngsstreifen, welche längs des Rückeus auf braunem Untergrunde verlaufen; die zwischen diesen Streifen sich bandartig hinziehenden Zwischenräume der Grundfarbe erscheinen von grolien dunkelbraunen Makeln unterbrochen. An den Seiten des Rumpfes gesellen sich den dunkelbraunen Flecken noch grauweißse Augen hinzu. Nach rückwärts zu erhält der Bauch einen Stich ins Grünliche; die unteren Schwanzschuppen, insbesondere gegen die Seiten hin, sind punktiert. - Die jungen Krimer chersonensis, welche ich im Senckenbergischen Museum zu sehen Gelegenheit hatte, entsprechen im grofen und ganzen derjenigen Beschreibung, welche $\mathrm{Rathke}$ uns über die junge Krimer »viridis« gegeben hat; sie sind nämlich oberseits auf bellbraunem Grunde dreifach hell längsgestreift, unterseits mit bläulichem oder grünlichem Anfluge versehen; an den Seiten treten, soviel ich mich erinnern kinn, dunkle Flecken mit eingemischten, weißlichen Schuppen hervor.

Die Größenverhältnisse bei der uns hier interessierenden Var. chersonensis sind folgende: Charkow. Krim.

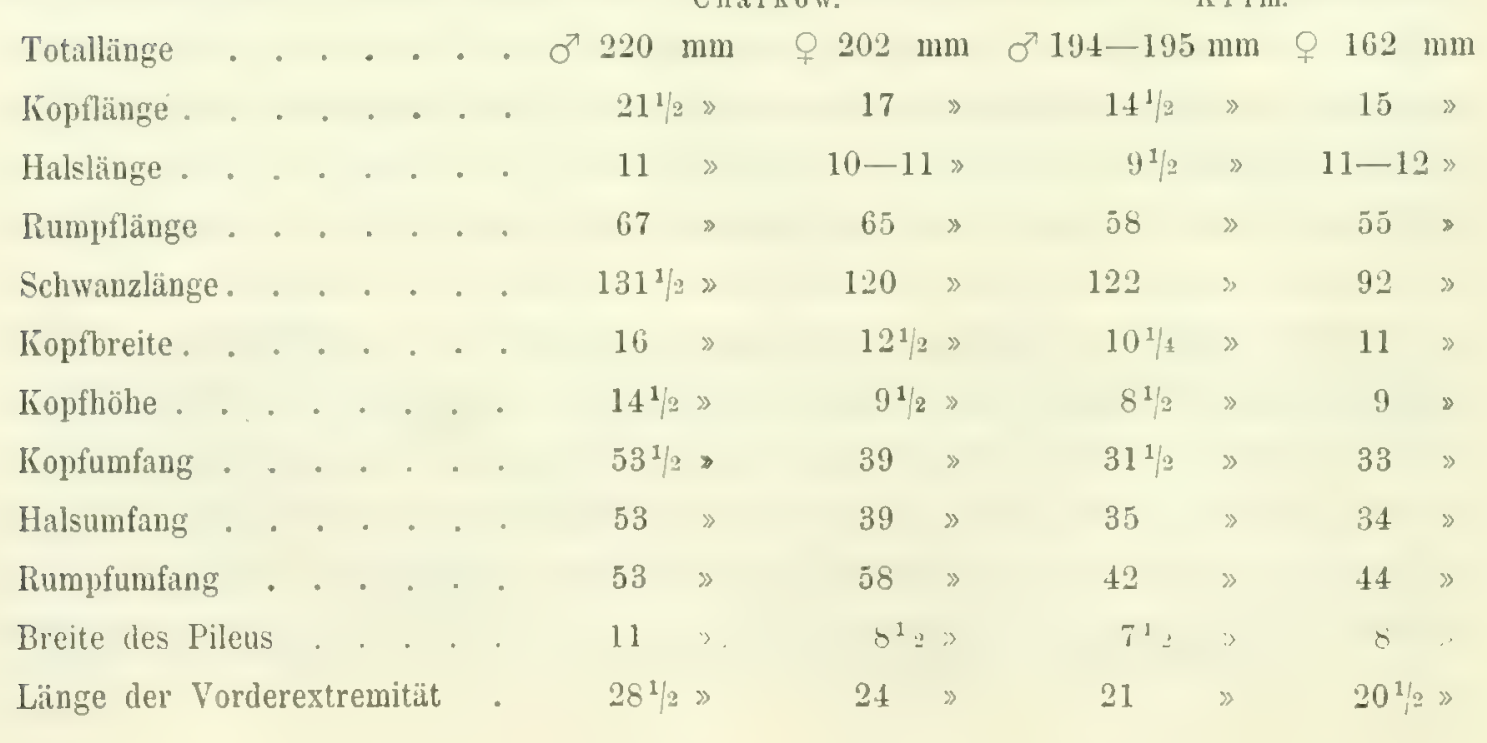




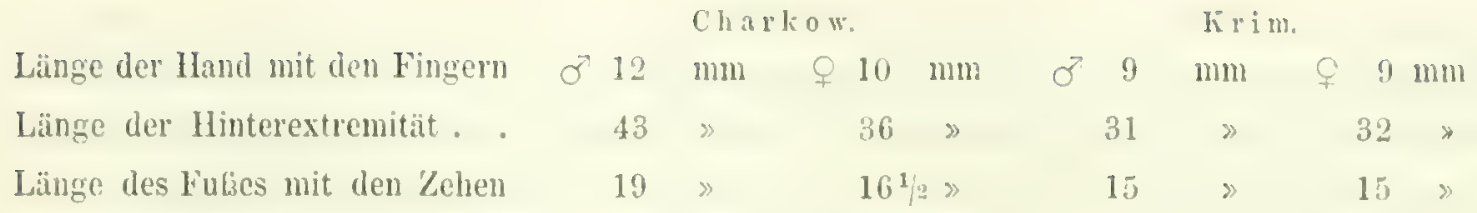

Die mir aus Charkow (Samml.v. Bedriaga, dedit: Prof. Stepanow), aus Elenowki in Transkaukasion (dedit: Dr. Strauch) und aus der Krim (Mus, zu Kiew) vorliegenden chersoncnsis, als auch diejenigen, welche ich im Senckenbergischen Wuseum zu sehen Gelegenheit hatte, zeigen keine scharfe Trennung zwischen den Vertebral- und übrigen Schuppen an den Seiten des Rückens und zeichnen sich auferdem noch durch die Unbeständigkeit in der Beschildung ihrer Zügelgegend aus; in vielen Fällen nümlich sind 2 genau übereinander gestellte Nasofrenalen vorhanden, welche hinten von einem hohen, die I'ileustafeln erreichenden Frenale begrenzt werden. Obschon wil genau dieselbe Yerteilung der Zügelschilder bei der Smaragdeidechse wiederfinden, müssen wir, meiner Ansicht nach, diese abnorm beschuppten und beschildeten Eidechsen wegen ihrer Kärpergestalt und sonstigen Merkmale zu L. agilis rechuen.

4. Var. doniensis m. ${ }^{1}$ ) - Obgleich es 'lhatsache ist, dafis das grüne Kolorit bei den westeuropäischen agilis vorzugsweise während der schönen Jahreszeit nach stattgefundener mehrmaliger Häutung gesättigt, oder überhaupt aufzutreten pflegt, um gegen den Herbst wieder zu verschwinden und folglich gerade diese Farbenausbildung mit IRecht als Beispiel der rythnisch wechselnden geschlechtlichen Färbung, l. h. einer erst im Laufe der Zeiten erworbenen Eigenschaft gelten kann, so existiert dennoch in Rußland, vorzugsweise im Süden und im Südosten des Landes, eine Agrilis-Form, deren Farben keinem ausgeprägten periodischen Wechsel unterworfen zu sein scheinen. Die betreffende Form ist wohl mit derjenigen identisch, welche Leydig aus der Gegend von Sarepta an der unteren Wolga erhalten und in seinem Werke über die deutschen Saurier S. 209 beschrieben hat. Die Grundfurbe an der Oberseite des Kopfes, Halses und Rückens ist hell oder dunkelgrün, bei einigen, besonders bei jüngeren Exemplaren mit einer schwächeren oder stärkeren Beimischung von Grau oder Blau. Längs der Rückenmitte befinden sich zwei voneinander vermittelst einer öfters unterbrochenen lichtgrünen und geschlängelten Vertebrallinie abstehende Lïngsreihen von schwarzen oder dunkelbraunen grolien, quadratischen, dreieckigen oder unregelmäligg gestalteten Flecken, welche nach aufien hin ron Lichtgrïn umsäumt erscheinen. Diesen Fleckenserien parallel stehen auf den Iumpfseiten andere kleinere, schwärzliche oder dunkelbraune, bald mehr, bald weniger zahlreich auftretende und untereinander teilweise verbundene delta- und schnörkeltörmige Figuren, welche 
sich mitunter verästeln und den Untergrund dermatien verdrängen, dab das Grün in Form von dugenflecken zu Tage tritt. Die Bauchgrenzen sind mehr oder weniger stark mit kleinen dunkelbraunen Punkten und lichtgrünen Schuppen versehen. Zuweilen tritt eine Zerteilung der oberen Rumpfflecken ein, die dann als dunkle Punkte zwischen die Hauptfärbung eingestreut erscheinen; auch kann die mediane Fleckenreihe am Rücken sich bedeutend aufhellen, namentlich tritt dies bei dem Mlittelfelde dieser Flecken derart auf, daß das grüne Grundkolorit durchzuschimmern pflegt und somit von einem mehr oder weniger breiten, dunklen Saume eingerahmt erscheint, welcher seinerseits von Hellgrün umgeben ist. Untersucht man derart gekleidete agilis nicht näher, so glaubt man eine frappante Ähnlichkeit mit den dunkel bespritzten viridis zu entdecken. In anderen Fällen aber treten namhafte Unterschiede auf, indem bei dieser agilis die zwei dorsalen Fleckenreilen an Intensität zunehmen und sowohl am Vorderrücken als auch vor der Caudalwurzel zusammenfliefen und nur in der Rückenmitte durch weifliche oder grünlichweife Punkte getrennt zu sein pflegen. Parallel mit dieser Punktserie ziehen sich. an den Leibesseiten meistens zwei, zuweilen aber drei Reihen scharf prononcierter und schwarzbraun oder schwarz umzogener Augenflecken hin. Je deutlicher die Rückenzeichnung ausgeprägt ist, um so üppiger erscheint die Oberseite des Kopfes, des Schwanzes und der Extremitäten dunkel gezeichnet. Auf grünem, blaugrünem, olivengrünem oder hellnulbraunem Grunde des Koopfes sind unregelmäß̊g gestaltete Flecken oder Punkte und geschlängelte Linien verteilt; gegen die Unterkiefer hin kommt die dunkle Zeichnung. nur spärlich zum Vorschein, wobei die grüne Grundfarbe einen Stich ins Blaue zeigt. Die Schläfe und die Oberseite der hinteren Gliedmaß3en zeigen etliche kleine, weisliche Fleckchen; sämtliche Rumpfzeichnungen wiederholen sich gewöhnlich auch auf dem Schwanze, nur mit dem einen Unterschiede, daß die Flecken kleiner erscheinen, der Breite nach zusammenflielien und überhaupt gedrängter auftreten; sind die IIakeln auf dem Rumpfe spärlich vorhanden und von hellerem Kolorit, so zeigen sie sich auch am Schwanz lichter und in geringerer Anzahl, können mitunter auch gänzlich fehlen. Sämtliche von mir, sowohl im Frühjahr als auch im Sommer und im Herbst an den Wolgaund Don-Ufern beobachteten doniensis scheinen gleich grell gefärbt zu sein, und ich glaube deshalb nicht, daf bei dieser Varietät, sowie auch bei der vorhergehenden eine Übergriunung des Oberkörpers während der Hochzeitsperiode aufzutreten pflegt. Hingegen bietet Var. doniensis einen Fall von Dimorphismus dar, indem zwei weibliche und, wie es scheint, räumlich getrennte Formen zu einer männlichen gehüren. Im europäischen Rußland ähnelt nämlich das Weihchen dem Männchen nahezu ganz und gar, obschon das Grundkolorit beim letzteren einen etwas höheren Grad der Sättigung zu erreichen pflegt; hingegen bei den mir aus Transkaukasien 
und aus der Kirgisensteppe vorliegenden weiblichen Exemplaren erscheint der grüne I'on bis auf nur eine dorsale Medianzone durch Braun verdringt zu sein, auch scheinen bei diesen die dunklen Elecken an de! Körperoberseite schïrfer mononciert aufutreten. Bei den oberseits grün gefürbten Individuen beiderlei Gescllechts zeigen simtliche unteren Particen eine Tendenz ins Bläulich- oder Grünlichgelbe, dabei elscheinen die freien Schilderränder heller grefärbt. Jede 'Tafel am Bauche, an den Gliedmalsen und oftmals auch am Halsbande enthält einen oder mehrere schwarze oder dumkelgrüne, mehr oder weniger scharf ausgeprägte Eleckchen oder Punkte; mit ähnlichen Zeichnungen sind ebenfalls die Unterkicferschilder, sowie auch die unteren Schuppen an der Schwanzbasis versehen. Bei den oben mehr braun wie grün kolorierten Weibchen pflegen die unteren Körperteile auf gelblichem Fond spärlich dunkel gefleckt oder gepunktet zu erscheinen.

Anbei die Kürpermafe einer männlichen doniensis: 'Totallänge: 24t mm; Kopflänge: $19 \mathrm{~mm}$; Halslänge: 10-11 mm; Rumpflänge: $67^{1 / 2} \mathrm{~mm}$; Schwanzlïnge $157^{1 / 2} \mathrm{~mm}$; gröliter Höhendurchmesser des Kopfes: $12 \mathrm{~mm}$; grölister Breitendurchmesser des Kopfes: $13^{3 / 1} \mathrm{~mm}$; Breite des Pileus: $9^{1 / 2} \mathrm{~mm}$; gröhter Umfang des Kopfes: $40 \mathrm{~mm}$; Halsumfang: $45 \mathrm{~mm}$; Rumpfumfang: $50^{1}{ }_{2} \mathrm{~mm}$; Länge der Vorderextremität: $26^{1 / 2} \mathrm{~mm}$; Länge der Hand mit den Fingern: $12 \mathrm{~mm}$; Länge d. Hinterextremität: $40^{1 / 2} \mathrm{~mm}$; Länge des Fulỉes mit den Zehen: $19 \mathrm{~mm}$.

Geographische Verbreitung.

L. agilis, die gemeinste unà nächst der vivipara auch am weitesten verbreitete EidechsenSpecies, bewohnt Mittel- und Nord-Europa, Sibirien, die russischen central-asiatischen Besitzungen und einen sehr beträchtlichen Teil von Vorder-Asien.

Was zuerst ihr Vorkommen im russischen Turkestan und in Sibirien anbetrifft, so liegen mir folgeude Angaben vor. Beginnen wir mit Sibirien. Nach Kessler geht die Zauneidechse im Süden Sibiriens bis zu den Quellen des Jenissei, d. h. bis Minusinsk. Dieser letztgenannte Ort ist nun auch der östlichste Punkt, bis zu welchem die uns hier interessierende Eidechsenart mit Sicherheit konstatiert worden ist. Die ersten sibirischen Exemplare der agilis, die nach Europa kamen, waren von Humboldt und Eversmann auf ihren Reisen im Altai-Gebirge erbeutet und dem zoologischen Museum in Berlin eingeschickt worden (No.935). Die Mitglieder der westsibirischen Expedition haben sie ferner aus den noch nördlicher, bei Semipalatinsk, gelegenen Arkad-Bergen gesammelt und von Akademiker Dr. Strauch ist meiner ReptilienSimmlun: nemerdings ein zwischen Semipalatinsk und Ajaguz erhentetes Exemplar nebst anderen aus der Kirgisen-Steppe stammenden Stüclien tauschweise überlassen worden. Einer Mitteilung Finschs zufolge kommt sie auch in der Steppe am Ala-Kul, am Dschasil-Kul im dsunga- 
rischen Ala-Tau und in der Steppe am Kiarakölfusse vor. ${ }^{2}$ ) Alsdann enthält die Sammlung von Herm F. Lataste in Paris Exemplare der agilis, welche bei Lepsa im Ala-Tau gefangen worden sind (No. 359). Schultze ${ }^{2}$ ) spricht von grünen Zauneidechsen ( $L$. arenicola Daud. var.) aus der Gegend des Aralsees; es sind höchst wahıscheinlich diejenigen, welche Eversman n von seiner Reise nach Buchara mitbrachte und die noch jetzt im Berliner Museum zu sehen sind. Dasselbe Museum enthält ferner etliche Stücke aus der »kleinen Tartarei (No. 944, 945), aus Maiterek (9183) und aus der Kirgisensteppe (911, var. dilepis Licht.).

Wie es um die Verbreitung in Kleinasien steht, läßst sich zur Zeit nicht angeben, da, soweit mir bekannt, überhaupt nur eine einzige Notiz über ihr Vorkommen in der »Levante« und, wie ich gleichzeitig hinzufügen möchte, im nördlichen Afriki (!) existiert. ${ }^{3}$ ) Das British Museum enthält allerdings eine in Bezug auf Zeichnung und Körpermałe der agilis etwas ähnliche, als L. strigata bezeichnete, von Herm Dandford aus Klein-Asien zurückgebrachte Lacerta, welche sich jedoch durch ihre homogene Beschuppung des Rückens von der echten Zauneidechse unterscheidet. In Persien fehlt $L$. agilis. Was uun schlieklich das Vorkommen dieser Art in Syrien und Palästina anbelangt, so liegt mir die Angabe L. Lortets ${ }^{4}$ ) vor, aus welcher hervorgeht, dats sie in Saida, Sur (Tyr), St. Jean d'Acre, Safed und Hananue einheimisch sein soll; nichtsdestoweniger haite ich diese Behauptung nicht ganz stichhaltig, da ich kürzlich ein angeblich aus Syrien stammendes Exemplar einer sagilis« beim Naturalienhändler Herru Schlü ter in Halle acquiriert habe, welches allerdings einer Zauneidechse ähnelt, aber grołe Rückenschuppen aufweist und deshalb wohl eher einer anderen Form angehören dürfte. - Da $L$. agilis und $L$. laevis Gray verschiedene Species sind, so múi infolgedessen das von Böttger in seiner Arbeit über die Krriechtierfauna von Syrien, Palästina und Cypern ${ }^{5}$ ) in betreff des Vorkommens der Zauneidechse in Jerusalem sowie auch am Toten Meer Gesagte sich auf die Graysche laevis beziehen. Wenn aber Büttger angiebt, daf der Verbreitungsbezirk der in Rede stehenden Art sich auf Transkaukasien erstreckt, so könneu wir ihm darin nur beistimmen. Über ihr Vorkommen in Trans- und Ciskaukasien berichten mehrere Forscher. Eichwald ${ }^{6}$ ) (der diese Art -- oder richtiger den Jugendzustand dieser

$\left.{ }^{1}\right)$ Reise uach West-Sibirien im Jahre 1876 in: Verhandl, zool, botan. Gesellsch. in Wien XXIX. 1879. S. 115.

$\left.{ }^{2}\right)$ In: Lichteustein, Terzeichnis d. Iubletten d. zoolog. Mus. d. k. Uuiversität zu Berlin, S. 87. Berlin 1823.

3) Merrem, Versuch eines Systems der Amphibien. Marburg $18 \% 0$.

4) Yoissons et Reptiles du Lac de Tibériade in: Arch. Mus. d'hist. nat. Lyon III. p. 187. Lyon 1883.

5) Jahresber. Senckenberg. naturforsch. Ges. 1879-80. Frankfurt a. MI.

$\left.{ }^{6}\right)$ Fauna caspio-caucasia, pag. 89. 
Species - untel" dem Samen "Zootoca exigua = Lacertu sylvicola Ever'sm." beschreibt) erwähnt ihres Vorkommens auf den Grasplätzen im Kaukisus und bezeichnet die Umgegend von Baku als Fundort für diese Eidechse. Méuétries ${ }^{1}$ ) kennt sie ebenfalls aus der Umgebung von Baku und giebt an, dałs sie daselbst nicht selten ist. Dalis sie noch bedeutend südlicher vorkommt, bezeugt $\mathrm{H}$ ohenacker2), nach dessen Angabe die agilis in der "Provinz Talysch« vorhanden ist. Genatuere Nachrichten über das Vorkommen und die Verbreitung der Zauneidechse in den Kaukasusländern liefert $\mathrm{k}$ essler in seinem in russischer Sprache verfalsten Bericht über seine zu zoologischen Zwecken unternommene Reise durch Transkaukasien. ${ }^{3}$ ) Nach diesem findet sie sich sowohl in Cis- als auch in Transkaukasien, so z. B. im Kubanschen Distrikte, bei Piatigorsk, in Poti, in Semenowka, einem Dorfe unweit des Sees Goktscha und in Jelenowka (beide Ortschaften liegen in Höhen von etwas über 6400 Fuß ü. M.). Derselbe Gewährsmann fügt die Bemerkung hinzu, daf seine kaukasischen Exemplare der von Evers. mann und machträglich von ihm selbst unter dem Namen var. orientulis beschriebenen, dreifach längsgestreiften Form angehören. Was nuu das Vorkommen dieser Species im europäischen Rukland betrifft, so bemerkt Eversmann mit Recht, dafs sie sowohl im nördlichen als auch im südlichen und östlichen Rulłand in grasreichen Gegenden häufig ist. Was zuerst iln Vorkommen im Osten Rufalands anbelangt, so soll sie, wie Eichwald (l. c.) und Sabanejew ${ }^{4}$ ) übereinstimmend angeben, im Ural-Gebirge, namentich in der Mittel-Uralkette allenthalben ziemlich gemein sein. Ältere Schriftsteller geben ferner an, daß sie in den Wäldern an der Wolga, prorzüglich zwischen Simbirsk und Sisran in grasreichen Gegenden« häufig vorkommt (Eversmann 1. c.). Im Gouv. Samara, so namentlich längs des Nebenflusses Samara, und im Gouv. Saratow, so z. B. bei Saratow und im Kreise Balaschow, sind die Zaunedechsen, wie ich es aus eigener Erfahrung weib, nicht selten; auch aus dem siidlicher gelegenen Sarepta (Le y dig, l. c.) und aus Astrachan (Brit. Mus., Berl. Mus.) ist diese Art bekannt. In den Gouv. Woronesch und Charkow, ferner in den Gouv. Poltava, Kiew und Podolien sowie auch in Cherson ist sie gleichfalls sehr verbreitet und kommt an vielen Örtlichkeiten vorzugsweise in grüner Varietiit vor. Alsdann bewohnt sie die Krim und scheint sowohl in der Steppe als auch in den gebirgigen Teilen dieser Halbinsel bis zur Südküste sehr verbreitet zu sein. Die auf der Landzunge von Arabat einheimischen agitis sollen meistens jener Abart angehören, welche $R$ athke als $L$. viridis und $\mathrm{Kess}$ e $\mathrm{r}$ als agilis var, orientalis bezeichnet haben. Unter den Krimer

1) Cat. raisonne des objets de Zoologie recueillis dans un voyage au Caucase etc, pag. 61 ( $L$. stirpium).

$\left.{ }^{2}\right)$ Bulletin de Moscou 1837. VII. pag. 145.

3) Arbeiten d. St. Petersb. Ges. d. Naturforsch. Bd. VIII. Supplement-Heft. St. Petersb. 1878.

J) Bulletin de Moscou 1871. II. p. 273. 
Fundorten finde ich folgende genannt: Tamak, das Thal Salgir, die Umgegend von Jaita ${ }^{1}$, die deutsche Kolonie Zürchthal ${ }^{2}$ ), Feodosia ${ }^{3}$ ) und Burunduk. ${ }^{4}$ ) Über ihr Vorkommen in WestRulsland liegen mir mehrere Angaben vor: Doengin ${ }^{5}$ ) behauptet, daf sie bei hischinew in Bessarabien beobachtet worden sei, Belke ${ }^{6}$ ) spricht von Exemplaren aus der Umgebung von Kamenetz-Podolski und Iaczanowski ) giebt an, dab sie in Russisch-Polen verbreitet sei. Unter den mir vou Prof. Paulson zur Ansicht gesandten Eidechsen aus dem Kiewschen Museum fanden sich Stucke der agitis aus Wolhynien (No. 1947) und aus Orel (1950) vor; andere Exemplare viederum liegen mir aus dem Gour. Moskau vor (Mus, in Moskau). In Livland soll sie, wie Fischer ${ }^{8}$ ) und Seidlitz ${ }^{9}$ ) übereinstimmend angeben, häufig vorkommen und mamentlich süberall auf sumpfigen Wiesen« anzutreffen seiu. Auch O. v. Löwis, der letzthin die herpetologische Fauna der Ostseeprovinzen bearbeitet hat, erwähnt, dabi sie in allen drei Provinzen und auch auf der Insel Ösel gleichmäfigig verbreitet und sehr gemein sei ${ }^{10}$ ). In den Gouv. Pskow und St. Petersburg ${ }^{11}$ ) ist die agitis gleichfalls einheimisch, und zwar besitzt das Muséum d'histoire naturelle Exemplare derselben, welche M énétries in der Umgebung von St. Petersburg croeutet haben soll; die betreffenden Stüclie sind als $L$. viritis etikettiert worden (Nr. 2343). Obschon ihrer in Mejakows Schrift über die Tierwelt des Gouv. Wologda nicht Erwähnung geschieht, ist es dennoch möglich, daßs sie noch weiter nach Norùn vordringt, dem einerseits behauptet $\mathrm{Mehl} \mathrm{wald}^{12}$ ), die agitis in Norwegen noch im $63^{\circ} \mathrm{n}$. Br. gefunden zu laben und anderseits liegt mir eine Mitteilung über ihr Vorkommen in Finnland vor ${ }^{13}$ ). Der Melu 1 aldschen Angabe gedenkt allerdings R. Collet in seinen

1) Kessler, Reiseberichte aus d. Krym in: Bulletin de Moscou 1878. No. 3, pag. 209. - Fr. Th. Köppen, Zur Herpetologie d. Krim in: Beitr. z. Kenntnis d. Russischen Reiches u. d. angrenzend. Länder Asiens. II. Folge. Bd. TI. S. 80. St. Petershurg 1853.

2) liathke, Beiträge z. Fauna d. Lírim, 1. c.

s) Nach Köppen, 1. c.

$\left.{ }^{2}\right)$ Senckeubergisches Museum in Frankfturt a. M.

5) Bulletin de Moscou XXx. 2. S. 249.

6) Ibidem, Bu. XXXII. 2. S. 32 .

7) Bullet. Soc. Zool. de France 1877, pag. 167.

") Versuch einer Naturgeschichte v. Livland, S. 228. Lünigsberg 1791.

und Dorpat.

${ }^{9}$ Verzeichnis der Säugetiere, Vögel, Reptilien und Amphibien der Ostseeprovinzen. Dubeln

$\left.{ }^{10}\right)$ Die Reptilien Kur-Lir- und Estlands. Riga 1884.

${ }^{11}$ ) Kessler, Zoologische Reise nach Transkaukasien, 1. c. - v. Fischer in: Zoolog. Garten XIV. 1873. S. 324 .

12) Sitzungsbericht $d$. Isis in Dresden 1870 (1871). S. 159 .

${ }^{13}$ ) Soviel ich mich erinnern kann, ist es A. J. Méla gewesen, welcher die Zauneidechse in Finnland koustatiert hat. Aus den Berichten iiher die Leistungen in der Herpetologie, welche dem Archiv für Natur- 
"Bemaerkinger on Norges Reptilier og Batracher" nit lieiner Silbe; er scheint diese Art in Norwegen überhaupt nicht gefunden zu laben. Für Schweden hingegen wird sie von Nilson ${ }^{1}$ ) für mehrere Örtlichkeiten aufgefüht; so soll sie z. B. bei Ystad und Trelleborg in Skone, bei Fogelsang (Lud), bei Hör und Billinge, bei Heckeberg und bei Börringesjön einheimisch sein und gleichfalls in den Länen Blekinge, Halland (bei Frölinge), Smäland, Ostergöttland, Upland (bei Upsala) und Dalarna (bei Moril) vorkommen. Bereits Linné gedenlit in seiner Fauna suecica des Vorkommens der agilis aus Schweden.

Nach einer Mitteilung des bekannten Herpetologen G. A. Boulenger soll L. agilis in England nur in Dorset und Haupshire mit Gewibheit machgewiesen sein. Jenyns (Manual of British Vertebrate Animals. Cambridge 1835. S. 291. L. agitis Berkenh., L. stirpium Daud.) und Bell (A History of British Reptiles. London 1839. S. 26. V'gl. auch: Coolie, Our Reptiles. London 1865. S. 27 ) erwähnen ihrer aus der Umgebung von Poole und speciell aus dem Dorfe Hamworthy bei Poole - also aus dem Süden Englands. Nach Norden, etwa bis Liverpool odel gar bis nach Schottland, wie man es angegeben hat, scheint sie jedoch nicht rorzudringen. Der Verfasser der "Biographical Notice in Ann. Nat. hist. or Mag. of Zool., Bot. and Geol. vol. I, p. 223 (London 1838) lïbt sich folgenderweise über das angebliche Vorkommen dieser Art in Schottland vernehmen: „We are not aware that the Lo agilis Linn. Be 1l, L. stirpium of Jenyns has yet been discovered in Scottland; since the publication of the Manual by the lastnamed naturalist we have been looking anxiously for it, but in all the inland localities the little Zootoca vivipara only occurs«. - Es sei mir schlielisich hier die Bemerkung erlaubt, daf die Zauneidechse in Irland fehlt und daf die, dem British Museum ron Dr. Johnston übermittelten sagitis vivipara sind und dafs die betreffenden Fundortsangaben wohl nicht durchweg richtig sein dürften.

In ganz Mitteleuropa ist $L$. agilis sehr verbreitet; ihr Vorkommen erscheint aber nicht allerorten gleich luaufig; namentlich in den südlich gelegenen Gebieten, wie z. B. im Süden Frankiteichs, südich der Alpen, jenseits des Brenner (d. h. in südlicher Richtung) ist sie nur stellenweise - und auch das nur selten - angetroffen worden. Speciell in Deutschland ist sie fast überall gemein; dabei tritt sie bald als eine Bewohnerin der Ebene, bald, obschon seltener, auch im Gebirge auf. Bisweilen zieht sie zum Aufenthaltsorte trockenen, sandigen Grund ror, bisweilen aber wird sie auf feuchten Wiesen und gar in Mooren und an Dämmen geschichte beigefügt werden, ersehe ich ferner, dak Sahlberg die agilis am Flusse'Svir, der die Seen Onega und Ladoga verbindet und der nördlicher als St. Petersburg liegt, gesammelt haben soll (Vgl. Meddelanden of Societas pro fauna et Flora fenica I, pag. 65).

3) Skaudinarisk Fauna III. Lund 1860. 
und ofters in Gesellschaft mit der, eher ein amphibisches Leben führenden $L$. vivipara ange. troffen. Im östlichen Deutschland ist sie laut $\mathrm{Kaluza}^{1}$ ) und $\mathrm{Gloger}^{2}$ ) in Schlesien sehr häufig und fast überall, vorzugsweise aber in hügeligen Gegenden bis weit ins Gebirge hinein sehr gemein. Speciell für die Umgegend von Breslau wird sie von Mild $\mathrm{e}^{3}$ ) angegeben. In der Oberlausitz ist sie ebenfalls in verschiedenen Abänderungen häufig, namentlich bei Görlitz an den Obermühlbergen, an den Bergen längs der Rothenburger Straße und an ähnlichen Orten, wo dürftiger Graswuchs vorherrscht ${ }^{4}$ ). Aus Ost- und West-Preulien ist sie durch mehrere Forscher bekannt geworden und scheint bei Königsberg auch init rotem Rückenkleide vorzukommen ${ }^{5}$ ). In der Fauna der Mark Brandenburg gehört sie zu den gemeinsten Erscheinungen ${ }^{6}$ ). Rotrückige Exemplare aus der Umgebung von Berlin, beispielsweise aus dem Park Brieselang (Senckenberg. Mus.) kenne ich aus eigener Erfahrung. Unter den Reptilien Pommerns und Mecklenburgs fehlt sie ebenfalls nicht. Als Fundorte sind Greifswald und die Gegend von Malchin ${ }^{7}$ ) angreführt. In den Beiträgen zur Naturkunde des Fürstentums Lüneburg, deren Autor mir leider unbekannt geblieben, ist sie für die Lüneburger Haide als »sehr häufig* verzeichuet ${ }^{8}$ ). Zweifelsohne dringt sie auch nach Schleswig-Holstein vor. F. Brü ggemann erwähnt sie aus der Gegend von Bremen, ${ }^{9}$ ) Wiepken und Greve aus Oldenburg, wo sie sich nur auf Sandboden aufhalten soll ${ }^{10}$ ). Überhaupt scheint die Zauneidechse, nach den Exemplaren zu urteilen, welche in den deutschen Museen aufgestellt sind, im Norden Deutschlands ziemlich weit verbreitet und von hier aus nach Dänemark ${ }^{11}$ ) und nach den Niederlanden ${ }^{12}$ ) eingewandert zu sein. In Westfalen und in der Rheinprovinz ist sie hauptsächlich im Rheinthale

1) System. Beschreibung d. schlesischen Amphibien u. Fische. S, 26. 1815.

8) Schlesiens Wirbeltier-Fauna. Breslau 1833. S. 65.

3) Verhandl. d. zoolog. botan. Gesellsch. in Wien 1870. S. 1033.

4) Tobias, Die Wirbeltiere der Oberlausitz in: Abhandlung naturforsch. Gesellschaft zu Görlitz. Bd. XII. S. 92 .

$\left.{ }^{5}\right)$ Leydig, 1. c. - In seinem Verzeichnis d. in Ost- und Westpreußen vorkommenden Wirbeltiere (1. c.) führt Rathke die rotrückige agilis unter dem Namen stellata Schrank auf und bemerkt, daß sie in Ostpreufsen "sehr selten vorkommt. Höchst wahrscheinlich ist Lacertus stellatus, Lacertus ferrugineus maculas habens bei Schwenkfeld (Theritropheum Silesiae etc. Lignicii, p. 148) ebenfalls mit unserer rotrückigen agitis identisch.

$\left.{ }^{6}\right)$ Schulz, Fauna marchica. Berlin 1845. S. 448.

$\left.{ }^{7}\right)$ E. Struck, in: Archiv d. Ver. d. Freunde d. Naturgesch. in Mecklenburg 1857. S. 129.

$\left.{ }^{8}\right)$ X. Jahresber. d. naturwissenschaftl. Ver. f. d. Fürstentum Lüneburg 1861. S. 15.

$\left.{ }^{9}\right)$ Abhandl. d. naturwiss. Ver. $2 u$ Bremen 1874, S. 210. (Über einige Amphibien u. Reptilien d. Fauna von Bremen.)

${ }^{10}$ ) Systemat. Verzeichnis d. Wirbeltiere im Herzogt. Oldenburg. S. 73, Oldenburg 1876.

11) 0. F. Müller, Prodromus Zool. Dan. pag. 36. Boie in: Isis 1841.

12) Schlegel, Die Dieren van Niederland (Kruipende Dieren). S. 4. Haarlem 1862. 
und in den Nebenthälern, wie z. B. im Main- und Moselthal weit verbreitet; sie kommt aber auch im östlichen Teile Westfalens vor, so z. B. im Regierungsbezirke Arnsberg, wo sie selbst im Hochlande uirgends selten ist ${ }^{1}$ ). An der Ruhr düfte sie nirgends fehlen. G. A. Boulenger kennt sie aus Düsseldorf, Melsheimer ${ }^{2}$ ) erwähnt sie aus Linz a. Rh. Leydigg fand sie in der Eifel, bei Gerolstein, Bertrich, Altenahr und am Litacher-See. Im Moselgebiete ist sie insbesondere für den Regierungsbezirk Trier namhaft gemacht worden ${ }^{\text {t) }}$. Über ihre Verbreitung in Deutsch-Lothringen und Luxemburg teilt uns De La Font a in $\mathrm{e}^{5}$ ) folgendes mit „Elle est peu commune, quoiqu'elle se rencontre à peu près partout dans les localités qui lui conviennent, depuis Arlon et les bords de l'Eisch et de la Mamer jusqu'i Echternach, sur la Sure et Hettange près de Thionville, ainsi que sur toute la partie du plateau des environs de Luxembourg, situés sur le grès infraliasque«. - Im Nahethal kommt sie hauptsächlich bei Kreuznach vor. In Hessen-Nassau soll sie nach Kirschbaum ${ }^{6}$ ) überhaupt häufig sein und in den mannigfachsten Varietäten vorkommen. Besonders grofie und schön gefäbte Stücke habe jch in Langen-Schwalbach gesammelt. Liöner $\mathrm{r}^{\mathrm{i}}$ ) fand sie bei Frankfurt a. M. und an den Abhängen des Tiunus, wo sie häufig ist, aber nirgends eine Höhe von 1400 bis 1450 Fuf überstejgt. Im Mainthal ist sie von Leydig $\left(l_{*} c_{\circ}\right)$ »besonders zahlreich auf sandigem Boden konstatiert worden; in den Thäleru des Odenwaldes ebenfalls. Giaser ${ }^{8}$ ) fand sie hier bei Heppenheim auf der Bergstrake und spricht die Vermutung aus, dafs sie in der Bergstrabe die Nordgrenze ihrer süddeutschen Verbreitung erreiche. »Die oberschlesische Nuance der agilis«, fügt Glaser hinzu, sist fast olme Ausnahme an den Seiten schön smaragdgrün. Graue, an den Seiten gar nicht oder kaum grünliche, aber uber den Rüchen mit dunkelumzogenen, hellen Flecken gezeichnete 'Tiere sollen, litut demselben Forscher, im Darmstädtel'

1) Suffrian in: Jahrbücher d. Ver. f. Naturliunde in Herzogt. Nassau III. S. 126. Wiesbaden 1846. Für die Verbreitung der L. viridis ist folgende Äuberung des Verfassers interessant: "L. agilis ändert durch Verschiedenheit in Alter und Häutungsperioden mehr der Grundfarbe als der Zeichnung nach ab, und ihre grünen Varietaten sind schon manchmal als $L$. viridis L. gegeben, welche innerhalb unseres Bezirks noch nicht sicher nachgewiesen ist. .

2) Korrespondenzbl. d. naturhist. Ver. d. preub. Rheinl. u. Westfalen 1876. S. 90.

$\left.{ }^{3}\right)$ Über die Verbreit. d. Tiere im Rhöngebirge u. Mainthal mit Hinblick auf Eifel und Rheinthal in: Ferhandl. d. nat. Ver. d. preußs. Rheinl. u. Westfal. XXXVIII. Jahrg. 4. Folge. VII. Bd.

4) Schnur in: Jahresber. d. Gesellsch. f. nützl. Forschungen zu Trier vom Jahre 1857. S. 69. Trier 1858. - Schäfer, Moselfauna etc. Bd. I. Trier 1844.

5) Faune du pays de Luxembourg (Reptiles), pag. 7. Luxembourg 1870.

$\left.{ }^{6}\right)$ Reptilien u. Fische des Herzogt. Nassau. Wiesbaden 1865.

7) Zoolog. Garten XXI (1880), S. 189.

3) Ebendaselbst, Bd. XI (1870), S. 157. 
Bosquet einheimisch sein. Aus der Rheinpfalz ist sie durch Medicus ${ }^{1}$ ) bekannt. Nahezn gamz grüne Exemplare aus Strafburg im Elsals sind im Senckenbergischen Museum aufgestellt. In Grofherzogtum Baden labe ich sie vorzugsweise im Norden bei Mannheim und Karlsruhe beobachtet und ihre Verbreitung in Neckarthale bis Heilbronn verfolgen können; im Schwarzwald ist sie selten und scheint hiel durch die vivipara vertreten zu sein. Nü $\mathfrak{b}_{1}$ in $^{2}$ ) spricht die Ansicht aus, daß3 sie in Barlen »nur in der Ebene und den Vorbergen heimisch ist. In Württemberg ist sie von Plieninger ${ }^{3}$ ), G. v. Martens ${ }^{4}$ ), Leydig ${ }^{5}$ ) und Krauss (Württemberg. Fauna in: Das Königreich Württemberg. 1882) konstatiert worden. In Bezug auf das Vorkommen der agitis in Württemberg teilt Leydig die interessante Beobachtung mit, dals diese Art bei Tübingen, soweit der Keuperboden sich ausdehnt, noch recht zahlreich ist, während sie auf dem Gebiet des Muschelkalkes gånzlich fehlt. Leydig fügt auberdem noch hinzu, da (3 es sich ebenso mit der Alb verhält, daf er neben der dort häufigen vivipara zwar auch agilis beobachtet hat, aber verhältnismäligg doch sehr vereinzelt. - Nach $J a ̈ c k e{ }^{6}$ ) ist sie in ganz Bayern »an sonnigen trockenen Stellen der Anger, Raine, Straßengräben«, u. s. w. gemein und »variiert.mannigfaltig«。 „Eine ganz grüne Varietät, « sagt dieser Forscher, »fand einst Gistl in der Gegend von Freysing; eine zweite mit einem einfarbigen, kupferroten Streifen am Rücken und der Oberseite des Schwanzes, ohne Flecken (Lac. rubra Laur. L. erythronotus Fitz.) in den Waldungen der Oberpfalz. Nach $\mathrm{K} \ddot{\mathrm{r}} \mathrm{rber}$ (Die in der Umgeb. v. Ausburg vorkommend. Reptilien. VIII. Bericht d. naturh. Ver. in Ausburg Nr. 1, S. 37) »äulierst selten bei Ausburg angetroffen«. Jäckel führt außerdem noch eine dritte für Bayern eigentümliche, schwarze Abart auf, welche wohl sicher eine vivipara vorstellen dürfte. Die rotrückige Spielart der Zauneidechse scheint, nach den gleichlautenden Angaben von Jäckel, v. Reider und Hahn ${ }^{7}$ ) und von Leydig zu schlietien, in Bayern nicht selten zu sein. Leydig giebt an, daf er sie

1) Tierwelt d, Rheinfalz. Bavaria, Landes- und Volkeskunde von Bayeru 156:.

2) Tierwelt in: Das Großherzogtum Baden. Karlsruhe 1883.

${ }^{3}$ ) Jahresheften d. Ver. f. vaterländ. Naturkunde in Württemberg III. S. 194. 1847.

4) Üler Württembergs Fauna in: Korrespondenzbl. d. landwirtschaftl. Ver. März 1830. Stuttgart. Die Zauneidechse ist unter dem Namen $L$. stirpium Daud.«, die Mauereidechse aber unter dem Namen vagilis Daud. erwähnt worden.

$\left.{ }^{5}\right)$ Skizze zu einer Fauna Tübingensis (Aus ier "Beschreibung d. Oberamts Tübingen«, herausgegeben v. d. k. statistisch-topographischen Bureau. Stuttgart 1867).

$\left.{ }^{6}\right)$ Korrespondenzbl. d. zoolog. mineralog. Ver. in Regensburg, Nr, 6, 7. XXV. Jahrg. 1871. S. 81. Vgl. auch: Schrank, Fauna boica. I. Band. 2. Abt. S. 285. Nürnberg 1795 und Koch, HerrichSchäfer und Forster, Fauna Ratisbonnensis in: Naturhistor. Topographie v. Regensburg. III. S. 34. Regensburg 1840 .

$\left.{ }^{7}\right)$ Fauna hoica. Nürnberg 1832 . 
bei München, wo sie auch v. Reider und Hahn gesehen haben, dann im bayrischen Hochland und in der Ramsau (Gebirg von Berchtesgaden) gefunden lrat (Vergl. sein bereits citiertes Werk uber die deutschen Saurier, S. 205). Normal gefübte agilis kommen aulierdem bei Bamberg, bei Würburg, seltener bei Rothenburg (L eydig l. c.), an Weinbergslagen bei Kissingen, bei Lohr, Miltenberg, Amorbach (Leydig, Üb. d. Verbreit. d. Tiere im Khöngebirge etc. 1. c.), um München, im Bade Kreuth (Wagler), in Bayrisch-Schwaben ${ }^{1}$ ) und, wie bereits erwihnt, in der Rheimpfalz vor. In der eigentlichen Rhön dürfte sie nach Leydig nicht fehlen. Aus den 'Thüringischen Staaten ist sie mir leider' nur aus einigen Orten, so z. B. aus Eisenach, Weimar, Jena, von wo aus ich ihr nördliches Vordringen an der Saale bis Halle verfolgen konnte, und aus Gera bekannt. Einer brieflichen Jitteilung des Herm O. Goldfufis zufolge kommt sie in verschiedenen Zeichnungsformen am Mannsfelder See bei Halle vor. Bechstein giebt in der von ihm übersetzten und umgearbeiteten Naturgeschichte der Amphibien S. 10 (Weimar 1800) an, daf er die Spielart mit bramnötlichem ungefleckten Rücken und braunen Seiten in Thüringen gesehen habe, daf sie aber daselbst weit seltener als andere sei. Über das Vorkommen der agilis in Sachsen liegen mir die Angaben von Th. Reibisch vor, wonach sie in Sachsen überall heimisch sein würde ${ }^{2}$ ).

Alsdann bewohnt die uns hier interessierende Species Bölmen und scheint hier die häufigste aller Eidechsen zu sein $^{3}$ ); sie tritt in verschiedenen Abänderungen auf und weist mitunter eine rotbraune Rückenbinde auf (stellate Schrank-4). Ebenfalls ausnehmend häufig findet sie sich in Niederösterreich und kommt schon unterhalb Wiens am Linienwalle, dem Augartendamme und an anderen Orten vor ${ }^{5}$ ). Nach $\mathrm{Heinrich}{ }^{6}$ ) ist sie auch in Nähren und Schlesien zu Hause. Jeitteles ${ }^{7}$ ) fand sie bei Kaschau in Oberungarn; im südlichen Ungarn, bei Orsova, kommt sie nach Erber ${ }^{8}$ ) vor; Graf Ferrari hat sie anf der Sandwüste bei Basiasch, A. v. II ojsisovicsim Cikononie-Distrikt Brailafeld und in der Waldbereitung Béllye gefunden. Exemplare aus Transsylvanien besitzt das British Museum. A. Bielz kennt sie aus Sieben-

\footnotetext{
1) Erhardt, Physisch-medizinische 'Topographie von Memmingen.

$\left.{ }^{2}\right)$ Sitzungsbericht der naturwissenschaftlichen Gesellschaft Isis in Dresden. Nr. 10. 12. 1866. S. 113. Dresden 1867.

$\left.{ }^{3}\right)$ Fritsch, Die Amphibien Böhmens in: Archiv. d. naturwiss. Laudesforschung v. Böhmen II. S. 105.

4) Glückselig, Synopsis reptilium et amphibiorum Bohemiae, p. 16. Prag 1838.

5) Knauer, Die Reptilien u. Amphibien Nieder-Österreichs. S. 8. Wien 1875.

6) Mährens u. k. k. Schlesiens Fische, Reptilien u. Vögel. Brünn 1856.

7) Verhandl. zoolog, botan. Gesellsch. in Wien XIII. (1862). S. 278.

8) Ebendas. 1864 (Die Amphibien d. österreichischen Monarchie).

$\left.{ }^{9}\right)$ Zur Fauna v. Béllye u. Darda II. Graz 1884. (Mitteil. d. naturwiss. Ver. f. Steiermark 1883).
} 
bürgen ${ }^{1}$ ) und A. Zawadski crwähnt sie in seiner Fanna der galizisch-bukowinischen Wirbelticre S. 140 (Stuttgart 1840). In Bosnien findet sie sich sowohl in den nördlichen wie auch in den südlichen Gegenden ${ }^{2}$ ). In den österreichischen Kronländern fehlt sie in Dalmatien und Istrien. Das in »Ausflug mach Triest und dem Quarnero (1861) von Grube über die im Boschetto bei 'Triest vorkommende $L$. agilis Gesagte, bezieht sich auf $L$. muralis neapolitana. Das Vorkommen der agilis auf der Insel Veglia im Quarnero ist ganz neuerdings ebenfalls behauptet worden ${ }^{3}$ ), bedarf aber, meiner Ansicht nach, noch der Bestätigung. Die Angabe H. Freyers in Bezug auf ras Vorkommen der Zauneidechse in Irrain ${ }^{4}$ ) ist wohl unrichtig, denn der Herpetologia europaea zufolge würde diese Art in Illyrien gänzlich fehlen. Für Kärnten, wo sie allenthalben an Hecken, sonnigen Abhängen und Gesträuchen in ebenen Gegenden gemein sein soll, wird sie von v. Gallenstein genannt ${ }^{5}$ ); es ist leicht möglich, daf auch diese Angabe zum Teil auf einer Verwechselung mit der grünen muralis beruhen könne. - Bei Ischl im Salzkammergut lommt sie an greeigneten Orten oft in llenge vor. Auf dem Wege nach der Kaltwasser-Anstalt trifft man vorzugsweise die rotrückjge Spielart. In den Salzburger Alpen ist sie ebenfalls beobachtet worden (Leydig); nach E. Schreiber kommt sie beispielsweise sin dem mit lockeren Erdreich bedeckten Gaisberge bei Salzburg selbst in 4000 Fuł Meereshöhe noch ziemlich häufig« vor. Bei Innsbruck und in der Gegend von Kufstein, wo sie ebenfalls hoch hinauf steigen soll, hat sie Leydig lionstatiert. Laut Gredler ${ }^{6}$ ) findet sich die agilis nur auf Nordtirol beschränkt, wo sie als die einzige dem Volke bekannte Eidechse der 'Thalebene das ganze obere und untere Innthal stellenweise, wie um Telfs und Hall, fast zahlreich bewohnt; auch in alle Seitenthäler (Natrei im Wippthale, Mieders in Stubai, Achenthal u. S. w.), sowie auf Hochplateau (Seefeld, 3800 Fufi üb. M.) ziemlich weit aufsteigt. Südlich den Centralalpen scheint diese Art zu fehlen, jedenfalls bedarf ihl Vorkommen in Trentino der Bestätigung, namentich seitdem es nachgewiesen worden ist, dab die von Ambrosi in seiner Statist. d. Trentino, Vol. I, pag. 290 erwähnte agilis, sich auf $L$. muralis bezieht ${ }^{\top}$ ). De Betta, der ausgezeichnete Kenner des Nordostens ltaliens,

1) Fauna d. Wirbelt. Siebenbürgens, S. 152. Hermannstadt 1856.

$\left.{ }^{2}\right)$ r. Möllendorf, Beitr. z. Fauna Bosniens, S. 18. Görlitz 1873.

3) Böttger in: 19, 20 u. 21. Bericht d. Offenb. Ver. f. Naturtunde 1880, S. 86.

4) Fauna d. in Krain bekannt. Säuget., Tögel, Rept. u. Fische. S. 41. Laibach 1842.

5) Die Reptilien r. Kärnten in: Canavals Jahresber. d. naturhist. Landesmus. v. Kärnten II. 1853.

$\left.{ }^{6}\right)$ Fauna der firiechtiere und Lurche Tirols in: XX̃l. Programm des k. k. Gymnasiums zu Bozen. Bozen. 1872

`) De Betta, Erpetologia delle Prorincie Fenete e del Tirolo Ieridionale, pag. 157. Verona 1857. 
kennt sie weder aus dem Trentino, noch aus Venezien, noch aus der Lombardei ${ }^{1}$ ), obschon Ja n in seinen Cenni sul Museo Civico, pag. 40. Milano 1857 eine agilis aus der Lombardei verzeichnet. Die bezügliche Eidechse im Mailïnder. Museum soll jetzt, laut De Betta, mit der Etikette Italia« versehen sein. Daf die Zauneidechse im Walserthal und durch ganz Vorarlberg hanfig ist, wissen wir aus $\mathrm{Br}$ uhins Arbeit über die Wirbeltiere Vorarlberges (Verhandl. zool. botan. Gesellsch. in Wien, 1868).

Sach Tschudi soll das Tier in der nürdlichen, sowie auch in der mittleren und südlichen Schweiz zu finden sein und sich im Süden vorzugsweise auf Wiesen aufhalten. F a tio, der recentere Bearbeiter der schweizerischen Wirbeltier-Fauna, fügt hinzu, dab er die agilis in den meisten Kantonen mehr oder weniger häufig angetroffen habe, jedoch besonders zahlreich im Osten des Landes. Aus den mir vorliegenden Angaben ersehe ich, dak sie in der Umgebung von Chur ${ }^{2}$ ), bei Flims ${ }^{3}$ ) und Appenzell, wo sie übrigens nach Schläpfer ${ }^{4}$ ) nicht häufig sein soll, vorkommt. Im Kanton Glarus entdeckte 'T chudi (l.c.) eine sonderbare agilis mit tiefschwarzem, von zwei weilichen Streifen eingeschlossenem Rückenbande und mit schwarzen, am Banche ins 'Tiefgrine übergehenden und von einer Reihe weifier Punkte und Ringe gezierten Seiten. Am Vierwaldstädter See habe ich die gewöhnliche Form hauptsächlich bei Lüzern und am Züricher See bei Horgen und bei Zürich erbeutet. Für Basel und für die Umgegend Basels, wie beispielsweise für Schauenburg und für die Stollhäuser bei Schauenburg, hat sie F. M üller ${ }^{5}$ ) angegeben. Nach demselben Forscher kommt sie in der zuletzt grenannten

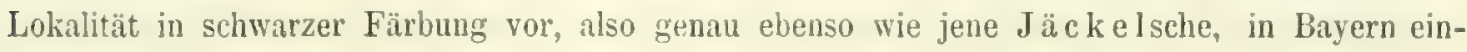
heimische schwarze Form, welche ich eigentlich für eine vivipara zu halten geneigt bin. In Ramsach bei Läufelfingen kommt die agilis ziemlich häufig vor. Sodann findet sie sich in Weilienburg im Simmerthale und in Gryon (Kanton Waadt; nach F. M üller). Im Kanton Tessin dürfte sie selten sein oder gänzlich fehlen; an den Ufern des Lago-Maggiore wenigstens habe ich nur die viridis und die muralis zu Gesicht bekommen. Die Angabe Tschudis, wonach die Zauneidechse »nur Bewohnerin der Ebenen und der collinen Region sein soll, ist

1) Im Museum in Lailand habe ich $L$. agitis nod $L$. viripara in einem Glase als $L$. muralis rar. disjuncta Lomb.e etikettiert rorgefunden. Ein anderes Glas entbält eine $\gg$ L stirpium aus $\gg$ Italien $\approx$.

$\left.{ }^{2}\right)$ Brügger, Naturgeschichtl. Beitrüge z. Kenntnis d. Ümgeb. v. Chur, S. 151. 1867.

3) F. Müller, I. Nachtrag z. Káatalog d. herpetol. Samml. d. Basler Mus. in: Verhandl. d, naturforsch. Gesellsch. in Basel 1880.

4) Versuch einer naturhist. Beschreib. v. Appenzell. Trogau 1829.

j) Verhanil. d. naturf. Ges. in Basel 1878, S. 623. 
insofern nicht bestätigt, als Ven a nce Pa yo ${ }^{1}$ ) meldet, dafis sie im Gebirgsstock des Mt. Blanc bis zu den Ungebungen von Moutiers und Courmayer - also bis zu einer Meereshöhe von 1000 Meter - steigt. Allem Anschein nach ist der Mont-Blanc und Umgebung die Südgrenze ihrer Verbreitumg in der Schweiz.

In den an die Schweiz grenzenden französischen Departements ist $L$. agitis gleichfalls einheimisch, so erwähnt Ogérien ${ }^{2}$ ) ihr Vorkommen im Jura. Girod-Chantrans ${ }^{3}$ ) und F. Olivier ${ }^{4}$ ) verzeichnen sie unter den Reptlien ron Doubs. Exemplare aus Haute-Saroie, und rorzugsweise solche, die ron den Ufern des Genfer See herstammten, habe ich selbst zu untersuchen Gelegenheit gehabt. Über ihr Vorkommen im Département de l'Isère berichtet Chauret5). Collin de Plancy kennt sie aus dem Dép. de la Côte d'Or und aus dem Dép. de la Meurthe et Moselle $\left.{ }^{6}\right)$. In der \#loselfauna von Schäfer ist sie, wie bereits erwähnt, verzeichnet. In den Ardennen ist sie noch nicht gefunden, oder wohl eher übersehen worden ${ }^{\circ}$ ), da sie einerseits im benachbarten Luxemburg, andererseits in Belgien, obgleich ziemlich selten und mit Bestimmtheit nur in den Bergen der. Umgegend von Arlon ${ }^{8}$ ), beobachtet worden ist. Für Lothringen, jedoch ohne nähere Fundortsangaben, finde ich sie als gemein von Godron in seiner "Zoologic de la Lorraine" Paris 1863, p. 22 angezeigt. In Bezug auf das Vorkommen der agilis in den nördlich gelegenen Departements liegen mir keine Nachrichten vor, mit Ausnahme einer gefälligen brieflichen Mitteilung des Grafen de Lauzanne, wonach die Zauneidechse möglicherweise im Finistère einheimisch sein dürfte ${ }^{\mathrm{s}}$ ). Hingregen für die Départements de la Seine, Seine-et-Marne und Seine-et-Oise ist sie zu wiederholten Malen und unter anderen von De Sinety ${ }^{10}$ ), Lataste ${ }^{11}$ ) und Collin de Plancy (l. c.) genant

3) Ann. Sc. phys. et nat., d'Agriculture et d'Industrie de Lyon VIII, pag. 456.

2) Hist. nat. du Jura et des Iépartements roisins III, p. 292. Paris 1863.

a) Essai sur la Géographie phys., le Climat. et l'Hist. nat. du Dép. du Doubs, t. I. Paris 1810.

4) Faune du Doubs etc. Besançon 1883

$\left.{ }^{5}\right)$ Catalogue des animatux qui se trourent dans le Dép. de l'Isère. $18+6$.

6) Catalogue des Reptiles et Batraciens du Dép. de l'Aube etc. in: Bull. Soc. Sc. histor. et nat. de Semur 1877.

$\left.{ }^{7}\right)$ Bull. Soc. Zool. de France 1. pag. 211. Paris 1876.

8) De Selys-Longchamps, Faune belge I, pag. 169. Liège 1842. Der Verfasser fügt folgendes hinzu: on croit aussi l'avoir ru près de Liège sur les borls de l'Ourthe.*

9) Aus dem Verzeichnis der Reptilien ron Paris ron Lataste ersehe ich, daf Baillon die agilis bei Abberille gefuuden hat. Ygl. sein Catalogue des Mammifères, Oiseaux etc. d'Abberille.

10) Totes pour servir à la Faune de Seine-et-Marne in: Rerue et Mag. de Zoologie, t. VI. 185õ. L. agilis soll in den ausgetrochneten Morästen einheimisch sein. Nach Collin de Plancy kommt sie im Walde ron Fontainebleau ror, aber seltener als die rividis und muralis.

11) Catalogue des Batraciens et Reptiles des environs de Paris etc. in: Act. Soc. Linn. de Bordeaux IXX. 
und nicht nur als in unmittelbarer Nähe ron Paris, wie z. B. bei Levallois-Perret, Chaville und Meudon ( $\mathrm{L}$ a $\mathrm{t}$ ste), sondern auch in Paris selbst, so beispielsweise im XIV Arrondissement und im Jardin des Plantes (Collin de Plancy) vorkommend angefuhrt. In der Sammlung des Herrn F. Lat as te habe ich kxemplare aus dem. Walde von Sénart gesehen und Daudin ${ }^{1}$ ) behauptet die rotrückige Spielart (»Seps rouge de L a ureti ) im Boulogner Wäldchen erbeutet zu haben. Dafs $L$. agilis im Dép. de l'Aube, de l'Yome und d'Allier nicht mangelt, daruber liegen uns sichere Angaben von Collin de Plancy (l. c.), P. Bertat) und E. Ollivier ${ }^{3}$ ) vor; schlieflich kommt sie ebenfalls im Dép. P’uy de Dôme vor (Sammlung ron Lataste: Nr. 355), - Aus dem Westen Frankreichs wird sie angegeben aus den Dép. Maineet-Loire ${ }^{4}$ ), Charente-Inférieure (Beltrémieux, L. stimpium I) a ud., L. arenicola D a ud. ${ }^{5}$ ) und Sarthe ${ }^{6}$ ). Im Südwesten scheint sie zu fehlen, wenigstens sind mir bis jetzt weder Angaben noch Belegstücke bekannt ${ }^{7}$ ). Die im Berliner Iuseum sub. Nr. 934 aufgestellten rotrückigen Stücke sind nit der Etikette »Südl. Frankreich« olme nähere Fundortsangabe versehen. In Bezug auf ihre Verbreitung im Suden Frankreichs sind wir wenig unterrichtet. De Serres ${ }^{8}$ ) macht sie für das Dép. de l'Hérault namhaft, wo sie laut G. Jumeau ${ }^{y}$ ) am Flüfschen Valras bei Béziers einheimisch sein soll. Dug ès spricht über ihr Vorkommen in der Provence, jedoch ohne die Fundorte zu nennen ${ }^{10}$ ) und Scarpa will sie aus Nizza erhalten haben ${ }^{11}$, wo sie, wie ich es aus eigener Erfahrung weib, nicht vorkommt. In der Zoologie des Alpes-Maritimes von Verany (Nice 1862) ist sie nicht erwähnt. Hingegen im Hochgebirge in den See-Alpen scheint sie zu Hause zu sem. Sowohl J. Crespon ${ }^{12}$ ) als auch R isso ${ }^{13}$ ) und Lichtenste in ${ }^{14}$ )

1) Histoire naturelle des lieptiles III, p. 163. Paris 1804.

$\left.{ }^{2}\right)$ Cat. des animaux vertébrés qui virent à l'état sauvage dans le Dẻp. de l'Yonne etc. in: Bull. Soc Sc. hist. et nat. de l'Yonne 1864.

3) Essai sur la faune de l'Allier etc. I. in: Bull. Soc. d'Emulation de l'Allier 1880. Moulins-Paris.

5) Millet, Faune de Maine et Loire etc. p. 612. Paris 1828.

5) Faune du Dép. de la Charente-Inférieure in: Acad. de la Rochelle. Sect. Sc. nat. Annales $1862-63$. (Faune rirante. La Rochelle 1864.)

6) A mb. Gentil, Erpétol. de la Sarthe. Bull. Soc. d'Agricult. Sc. et. Arts de Ia Sarthe 1884.

${ }^{7}$ ) Tergl. Lataste, Essai d'une l'aune herpétologique de la Gironde in: Act. Soc. Linn. Bordeaux, t. $\mathbf{X x}$, nag. 348 .

$\left.{ }^{8}\right)$ Essai pour servir à l'hist. des animaux du Midi de la F'rance. Éspèces du Dép. de l'Hérault et particulièrement de celles qui caractérisent la ligne isotherme de 15 à $20^{\circ}$.

$\left.{ }^{9}\right)$ Bull. Soc. d'Etudes Sc. nat. de Béziers 1879, p. 180.

${ }^{10}$ ) Vgl. Latastes Faune herpétologique de la Gironde 1. c.

11) Scarpa, Catalogo della raccolta zoologica del Dott. G. Scarpa in Treviso, pag. 17. Treriso 1882.

12) Faune méridionale. Nìmes et Montpellier 184 .

13) Hist. nat. des principales prouluctions de l'Europe méridionale etc. t. III, p. 86. Paris 1826.

i4) Somenclator reptilium et amphibiorum musei zoologici Berolinensis, p. 14. Berlin 185 f. 
qeben uns keinen befriedigenden Aufschlußs über die südfranzösischen Fundorte der uns hier interessierenden Eidechsen-Art.

Wie es um ihr Vorkommen auf der pyrenäischen Halbinsel steht, lïsst sich zur Zeit nicht genau bestimmen, und selbst E. Boscà, der beste Kenner der Fauna scines Landes, hat nicht ermitteln können, ob sie in Spanien einheimisch ist oder nicht ${ }^{1}$ ). Es geben zwar mehrere Autoren Madrid, Granada und Sevilla unter den spanischen Fundorten an, jedoch bin ich eher geneigt anzunehmen, dafo es sich hier um eine Verwechselung der Arten oder vielleicht der Fundorte handelt, Nach alldem, was wir sonst über die geographische Verbreitung dieser' Species kennen, zu urteilen, ist es höchst zweifelhaft, daß3 sich ihr Wohngebiet ausuahmsweise im Südosten Europas so weit südlich, wie es Perez Ar $\mathrm{Cas}^{2}$ ) und $\mathrm{MaChad0^{3 }}$ ) behaupten, ausdehnt, umsomehr, da ich die angebliche Granada-Agilis, welche im Hofnaturalien-Kabinett zu Wien aufbewahrt wird, für falsch bestimmt halte. Die von Schreiber untersuchten, aus Spanien stammenden Individuen, die sich stets durch einen entschieden ins Grünliche oder Gelbliche spielenden Ton der Grundfarbe, sowie häufig durch das sehr tiefe Schwarz der Flecken, die teils ziemlich rundlich und in sehr großer Menge und merklicher Grölbe über die ganze Oberseite zerstreut sind, teils aber wieder an den Seiten zu scharf ausgeprïigten hufeisenförmigen Querbinden zusammenstoken, welche ihrerseits weibe Makeln einschlieken, auszeichnen, sind wohl eher in den Pyrenäen, in Asturien oder in Galicien gesammelt worden*). Für Asturien finde ich nämlich die agilis von $\mathrm{Pas}$ to $\mathrm{r}^{5}$ ), für Galicien von Seoan $\mathrm{e}^{6}$ ) mamhaft gemacht. Aus beiden Provinzen habe ich allerdings zu wiederholten Malen Eidechsen-Sendungen durch die Herren V. L. Seo ane und E. Rasquinet erhalten, ohne darunter jemals auch nur ein Exemplar der Zauneidechse, das als Beleg für das Vorkommen dieser Art in den genannten Gegenden dienen könnte, vorgefunden $z u$ haben ${ }^{7}$ ).

$\left.{ }^{2}\right)$ Bull. Soc. Zool. de France 1880, pag. 240. Paris.

2) Elementos de Zoologia. Madrid 1863.

s) Erpetologia hispalensis in: Revista di Ciencias, Literatura y Artes IV. Sevilla 1859.

4) Meine Vermutung über das Fehlen der agilis in Spanien wirl mir huffentlich ron denjenigen, welche das Gegenteil angeben, nicht übel vermerkt werden, denn wenn einerseits der Zoogeograph seinem Leser die möglichst genaue Aufzählung der Fundorte einer Species vorzulegen verpflichtet ist, muß er andererseits diejenigen Fundortee, welche ihm verdächtig zu sein scheinen herrorheben. Damit dürfte sowohl der Wissenschaft als auch dem Leser gedient sein.

${ }^{5}$ ) Apuntes sobre la fauna austuriana. Oviedo 1859.

$\left.{ }^{6}\right)$ Reptiles y Anfibios de Galicia in: Anal. Soc. Esp. de Hist nat. VI. Madrid 1877.

7) In einem an mich am 3. Mărz 1885 gerichteten Schreiben teilt mir Herr V. L. Seoane mit, daG L. agilis in Galicien nicht vorkommt; er bittet mich ferner in einem rom 13. März 1885 datierten Brief seine diesbezŭgliche Mitteilung zu reröffentlichen, indem er hinzufügt, dá die angeblich aus Sevilla und Granada 
Für Portugal ist die agilis, so viel ich weib, nicht aufgefuhrt worden'). Auf Mallorki dagegen soll sie laut Barcelo y Combis²) beobachtet worden sein. Forscher, w. z. B. II. Braun, E. Boscà, Lientenant Will und J. V. Bedriaga, welche die Balearen in letaterer Zcit bereist haben, können aber diese Angabe nicht bestätigen.

Auf Sardinien, Korsika und Sicilien fohlt die Art ganz bestimmt. R. Sava ${ }^{3}$ ) behauptet zwar $\gg L$. seprum (agilis) auf Etna gesehen zu haben und Duméril und Bibronª erwähnen sie auch von Sicilien ohne die Fundorte zu nemen, jedoch beruhen sowohl diese Angaben als auch diejenigen von Gervais ${ }^{5}$ ) und Poiret ${ }^{6}$ ), wonth die agilis in Algier vorkommen soll, wie bereits Mina-Palumbo ${ }^{3}$ ) mit Bezug anf Sicilien bemerkt, auf einer Verwechselung der agitis mit einer Varietät von muratis, dem aufer den genamten Forschern ist es noch niemand gelungen die Zameidechse ant Sicilien oder in Algier aufzufinden (Vergl. die letzthin erschienene "Revista della Fauna sicula dei Vertebrati von Doderlein in: Nuove Effemeridi Siciliani 1872). Bezüghich der italienischen Inseln möchte ich noch bemerken, dalá Spallanzani zweifelsolne die Mauereidechse im Auge hatte, als er die agitis für die Liparischen Inseln in seinem Reisewerke 》Viaggi alle due Sicilie« (l'aris 1792) auffuhrte. Der Speciesname agilis Linné vel Wolf hat sich nämlich vorzugsweise nur in Deutschland eingebürgert und ist von den Deutschen beinahe ausnahmslos nur als Bezeichnung fur unsere Zauneidechse verwendet worden, wälrenddem die französischen und italienischen Autoren läugere Zeit hindurch, dem Bejspiele Daudins folgend, die Mauereidechse als agilis und die Zauneidechse als stirpium vel arenicola« bezeichnet, und erst nachträglich sich den Deutschen angeschlossen haben.Dafis es bis jetzt weder De Betta noch sonst einem Forscher gelingen wollte, die Zauneidechse

stammenden Zauneidechsen, welche sich in seiner Sammlung befinden, von einem Naturalienhändler in Mad̉rid erstanden wordcn sind und daß3 er infolgedessen für die Richtigkeit der Fundorte nicht garantieren könne.

1) Vergl. Barboza du Bocages in der lievue et Mag. de Zool. XVI, 2. sér. 1863 und Böttgers in der Zeitschrift f. d. ges. Naturwiss. LII. 1879, S. 497 veröflentlichten Arbeiten über die líriechtiere ron Portugal.

2) Catalogo de los Reptiles y de los Moluscos observados en las Islas Baleares. I'alma de AIallorca 1876. S. 72.

5) Lucubrazioni della Flora e della Fauna Etnea, Milano 1844.

4) Erpétologie générale, t. V. pag. 203.

5) Ann. Sc. nat. VI. p. 308.

$\left.{ }^{6}\right)$ Toyage en Barbarie. 1. Partie. pag. 286. - Strauch (Essai d'une Erpétologie de l'Algérie in: Mém. Acad. Imp. Sc. de St. Petersb. VII. 4. sér. No. 7. 1862) und S c hreiber (Herpetologia europaea S. 428) rermuten, daf die Angaben von Gervais und Poiret, daf die Zauneidechse auch in Nordafrika rorkommt, auf einer Verwechselung mit der Perleidechse beruhen. Schlegel aber rersetzt die agilis Poiret in die Sy. nonymie ron Eremias junctulata.

`) Prospetto degli studi di Erpetologia Sicula. I'alermo 1863. 
in Norditalien oder in Italien überhaupt ausfindig zu machen habe ich schon früher erwähnt und es bliebe mir nur noch übrig hinzuzufügen, daf G. v. Martens, wie mir Prof. Ed. v. I artens freundlichst mitteilt, $L$. agilis $\mathrm{D}$. ( $L$. muratis Merrem) und $L$. arenicola D a u. in sein Verzeichnis der venezianischen Tiere (Vergl, seine Reise nach Venedig. Bd. II. S. 405 u. Bd. I. S. 321. Ulm 1824) aufgenommen, dafs er aber in dem späteren Werk »Italien« (Bd. II S. 316. Stuttgart 1844) den Namen »arenicola« in vvelox Pallas « umgeändert hat. G. v. Martens liam nachtrïglich selbst von dieser offenbar irrigen Bestimmung zurück und bezeichnete das Tier in einem handschriftlichen Zusatz zu obiger Stelle in » Reise nach Venedig« als $>$ Lac. muralis var. campestris De Betta auch Leydig«.

$L$. agilis scheint vorzugsweise eine binnenländische Art zu sein und meidet die Inseln entschieden. Mit Ausnahme von der Insel Veglia im Adriatischen Meere, wo sie vielleicht einheimisch sein mag, Siciliens und Cypern ${ }^{1}$ ), wo sie bestimmt fehlen dürfte, ist sie sonst von keiner anderen Insel erwähnt worden. Wenn O. Böttger in seiner Arbeit über die Reptilien und Amphibien von Syrien, Palästina und Cypern ${ }^{2}$ ) angiebt, daf sie auf der Balkanhalbinsel nicht vorkommt, so glaube ich ihm in Bezug auf Griechenland beistimmen zu müssen, obschon das Berliner Museum im Besitze von einer, angeblich aus Griechenland stammenden agitis ist und ich selbst ein junges Exemplar als aus Nord-Griechenland herkünftig acquiriert habe; namentlich kommt mir der Fundort »Athen« der sub No. 928 im Berliner Museum aufgestellten Stücke sehr verdächtig vor, denn Attika ist hinlänglich von L. Münter, 'T'h. v. Heldreich und mir selbst bereist. worden, olne dafi wir jemals dieser Species begegnet wären ${ }^{3}$ ). In den zoologischen Berichten der Expédition scientifique de Morée ist sie ebenfalls nicht genannt worden. Dalis die Museen oftmals falsche Fundortsangaben aufweisen, habe ich leider öfters Gelegenheit gehabt zu konstatieren. Mit Bezug auf die agitis erinnere ich mich im Züricher Museum zwei Exemplare dieser Art (No. 397) als aus Madeira stammend bezeichnet gesehen zu haben.

Aus der vorstehenden Zusammenstellung aller mir bekannt gewordenen Fundorte der agilis ergiebt sich nun, dab diese Art in Schweden den $63^{\circ} \mathrm{n}$. Br., im europäischen Rubland den $61^{\circ} \mathrm{n}$. Br. und in Sibirien etwa den $54^{\circ} \mathrm{n}$. Br. erreicht und dafis sie in Transkaukasien und in Turkestan weit südlicher vordringt als dies in Europa der Fall ist. Ihr Vorkommen auf

1) Vergl. die Abhandlung Böttgers über die Reptilien und Amphibien von Syrien etc. in: Jahresber. d. Senckenberg. naturforsch. Gesellsch. 1879-80. Frankfurt a. M.

2) Ebendaselbst.

3) De Heldreich, La Faune de Grèce. Athènes 1878. - J. v. Bedriaga, Die Reptilien u. Amphibien Griechenlands in: Bull. de Moscou 1881, No. 2, 3 u. 4. 
der pyrenäischen Ilalbinsel halte ich als noch nicht vollkommen nachgewiesen und ziehe daher vor anzunehmen, dafis die Südgrenze (resp. Westgrenze) ihrer Verbreitung erst im Département de la Charente-Inféricure, also ungefahr unter dem $45^{\circ} \mathrm{n}$. Br. beginnt, um sich von da unter dem $1^{0}$ ö. L。 von Paris bis zum $43^{1} / 2^{0} \mathrm{n}$. Br. (Dép) de l'Hérault nach De Serres und G. Jumea u; Provence nach Dug ès) zu senken; von hier scheint sie der französisch-italienischen Grenze zu folgen und in die Schweiz uberzutreten und zwar, wie es scheint, ohme Italien zu berühren. Da das Vorkommen im Trentino noch nicht bestätigt worden ist, so müssen wir wenigstens vorläufig mit Gredler annehmen, dafs dic Südgrenze ihrer Verbreitung in Nordtirol zu suchen sei. Je mehr wir uns nach Osten wenden um so schwerer ist es, die Südgrenze ihrer Verbreitung zu ziehen, denn einige Forscher lassen sie in Krain und Istrien (Insel Veglia im Quaruero) vorkommen, andere wiederum stellen ihr Vorkommen in den südlich der Apen gelegrenen üsterreichischen Kronlïntern, also in Illyrien, Istrien und Dalmatien, in Abrede. Dasselbe gilt auch für die Balkanhalbinsel, wo sie nach v. Möllendorff sowohl in den nördlichen wie auch in den südlichen Gegenden Bosniens und nach dem im Berliner Museum aufbewahrten Material zu schliefen, bei Athen vorkommen soll, nach Schreiber aber daselbst fehlen dürfte. Im Russischen Reiche erreicht der Verbreitungsbezirk der agitis die Küsten des Schwarzen Meeres, ferner in T'ranskaukasien nahezu den $40^{\circ} \mathrm{n}$. Br. (Goktscha-See), im transkaspischen Gebiete den $40^{\circ} \mathrm{n}$. Br. (BaIchan-Busen) und endlich an der russisch-chinesischen Grenze das Ala-Tau-, das Altai- und das Sajanische Gebirge. In Syrien und Palistina soll sich ihr Verbreitungsbezirk bis Akra erstrecken. Das im Britisch Museum anfbewahrte, als »L. strigata benannte Exemplar soll, nach der Etikette zu schließen, in „Kaisariuk in Klein-Asien erbeutet worden sein, da ich jedoch einen Ort dieses Namens nicht kenne, so vermute ich, daf darunter eigentlich Kaisarich (Caesarea) oder Mazaca im früheren Kappadocien gemeint ist. Sowohl die Ost- als auch die Nordgrenze ihrer Verbreitung scheint an den Quellen des Jenisei bei Minusinsk zu liegen. Von hier tritt, so viel wir wissen, die Nordgrenze in die Umgebung von Semipalatinsk über und wendet sich in westlicher Richtung zum Aral-See hin. Im europäischen Rußsland finden wir sie im mittleren Urial, an [Flusse Swir wieder, also etwa unter dem $61^{0} \mathrm{n}$. Br., ferner in Schweden unter dem $63^{\circ} \mathrm{n}$. Br. und in Süd-England, wie es scheint etwa unter dem $51^{\circ}$ n. Br.

Zum Schlub ein paar Worte aber ihre vertikale Verbreitung: in den schweizer Alpen soll sie nach F a tio (l. co) bis 4000 Fufs Meereshöhe linaufsteigen, im Gebirgsstock des MontBlanc jedoch, laut einer Mitteilung von Venance Payot, soll sie nur selten in Jer Höhce von 1000 Metern angetroffen werden, sondern in der Regel nur bis 800 odler $900 \mathrm{M}$. üb. Meer 
hinaufsteigen. In Nordtirol begegnete ihr Gredler in einer Höhe von 3800 Fuf üb. Meer und nach Schreiber kommt sie in dem Gaisberge bei Salzburg sselbst in 4000 Fuf. Meereshöhen noch ziemlich häufig« vor.

\section{Lacerta paradoxa $\mathrm{m} .^{1}$ )}

Char. - L. paradoxa inter Lo vividem et agilem intermedia, corporis forma et integumento $L$. agili similis, longitudine coloreque $L$. viriti acqualis. Corpus robustum compactunque. Caput magnum, altum, latum, in regione temporali valde amplificatum et a trunco distincte seiunctum. Cauda mediocriter longa, in acumen breve attenuata, maris pars basalis valde incrassati. Pedes postici longiores quam in $L$. agilis, ad nunquam usque ad axillas attingentes. Digiti antici et postici satis longi. - Scutum occipitale interparietali multum vel paulo minus; scutum frontale latissimum et proportionaliter breve. Nasofrenale unicum, scutum internasale attingens, scutum frenale unicum vel duo nasofrenalia superposita, scutum frenale nullum. Scuta supralabialia anteriora 4. Discus palpebralis a supraciliaribus squamarum serie non separatus. Scuta parietalia in margine externo $2-3$ scutis maioribus circumdata. 'Tempora magnis scutis tecta; scutum massetericum et tympanicum interdum adsunt. Sulcus gularis nullus, collare denticulatum. Scuta abdominalia per series 6 vel 8 diposita. Regio analis 3 scutis maioribus tecta. Squamae dorsales oblongo-angustae, Inngitudinaliter carinatae, rotundato-sexangulares. Squamar trunci laterales laeves, subimbricatae. Dentes in maxillis et palato. Pori femorales utrinque 13-14. - Longitudo $252 \mathrm{~mm}$.

Synony mie.

? Lacerta viridis var. colchicu2) Eichwald, Fauna caspio-caucasia, pag. 83. 1841.

Es hat diese intermediäre, höchst wahrscheinlich als »viridis colchica« bei Eichwald bezeichnete Eidechsenform einige Ähnlichkeit mit der Smaragdeidechse und noch mehr mit

1) Vergl. meine Tafel, Fig. 10 u. 23.

$\left.{ }^{2}\right)$ Die Senckenbergsche Sammlung in Frankfurt a. M. besitzt eine, wie ich glaube mit Unrecht als "var. colchica bezeichnete agilis aus Burunduk (Krim). Das betreffende Stück zeigt eine, wenn auch schwach ausgeprägte, der westeuropäischen Zauneidechse eigene Zeichnung und unterscheidet sich von demjenigen Stuick aus Strafburg, das ebenfalls in der Senckenbergschen Sammlung zu sehen ist, nur insofern, daf beim letzteren auf dem Rücken kurze, weifliche Striche verteilt sind, während diese beim ersteren gänzlich vermißst werden. Bei diesen beiden Exemplaren sind die vorzugsweise der westeuropäischen agilis charakteristischen schmalen Dorsalschuppen deutlich von den gröberen, daneben liegenden Schuppen abgesondert. Diese Stücke sind auberdem noch dadurch interessant, daß wir aus der Vergleichung derselben leicht den Schlub ziehen können, daf das Vorlandensein oder das Fchlen des Snlcus gularis sich bei der agilis von geringem Werte hei event. Bestimmung erweist, denn bei dem elsäßser Individum ist die Querfurche dentlich konstatierbar, whärend dieselbe bei dem Krimer Stück fehlt! 


\section{$-155-$}

L. agilis; ich habe infolgedessen lïngere /eit gezögert, dieselbe von der letateren zu trennen. List nenerdings ist es mir gelungen, durch die Güte des IIern Prof. P'aulson und durch Tausch von Ilemn Dr. Strauch sechs Exemplare von dieser rïtselhatten Lacentu zu erhalten und aus der Vergleichung des mir vorliegenten Materials bin ich zu der Linsicht gelangt, dab ihre, sowohl in Bezug auf Körpergestalt als auch hinsichtlich der Beschildung und Fürbung von der Kauneidechse abweichenden Merkmale sich beständig erweisen und deshalb wohl als specifisch gelten können.

\section{Körpergestalt und Grölie.}

Was zunächst ihre Körpergestalt und Gröte anbetrifti, so muf bemerkt werden, dabs sie bedeutend stärker gebaut und in der Regel gröber ist als L. agilis, denn sic erreicht bei einer Linge von $227 \mathrm{~mm}$ einen Umfang von oft nahezu $53 \mathrm{~mm}$. Ihr Kopf und Hals, namentlich bei den männlichen Individuen, ist ebenfalls durch eine sehr bedentende Breiten- und Höhenentwichelung ausgezeichnet, welche sogar, im Verhältnis zu den übrigen Körperdimensionen, diejenige von $L$. viridis zu übertreffen scheint. Der grölste Breitendurchmesser des Kopfes liegt in einer, durch die hinteren larticen des Unterkiefers gelegten Horizontalen. Die Schlafengegend ist mehr oder weniger stark backenartig aufgetrieben; von den Augen nach vorn zu crscheint der Kopf ziemlich schmell in side kurze, zusespitzt gerundete Schnauze verengt; seine Oberfläche ist von der Hinterhauptsgegend an sehr sanft nach vorn geneigt und erscheint nur über den Augen leicht gewölbt; die Seiten fallen vorn fast senkrecht ab, die Zügelgegend ist kaum merkbar oder auch gar nicht vertieft. Die ziemlich grobien Nasenöffuungen liegen seitlich; die Ohröffnung ist sehr grol3. Der liumpf ist kräftig und gedrungen; der an seiner Basis durch eine schwach ausgeprägte Einschnürung vom Rumpf abgesonderte, oben plattgedrickte und etwa vierseitige Schwanzanfang zeigt einen sehr bedeutenden Umfang und zeichnet sich aufserdem noch durch seine auffallende Höhenentwickelung aus. Der Schwanz ist mälı̈ig lang und erscheint in eine kurze Spitze ausgezogen. Die Vorderbeine sind kurz, sie erreichen meist nur den Vorderrand der Augen oder ragen höchstens nur etwas dirüber hinaus, indem sie das Freno-oculare erreichen. Die Hinterbeine sind etwas länger als bei der Zauneidechse, reichen jedoch nie bis zu den Achseln. Beifolgende Details über die Małse von fünf männlichen Individuen, sowie auch die beigefügten Abbildungen werden ungefähr einen Begrifl von ihrel' Körperform geben :

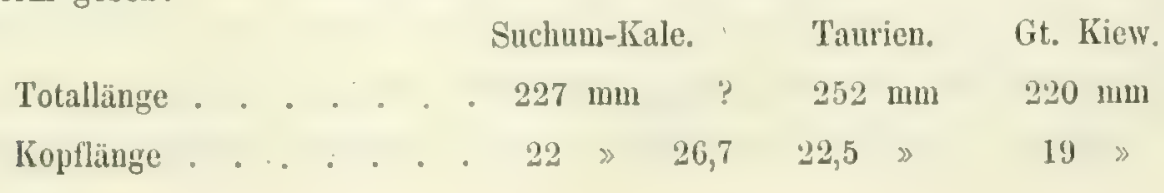




\begin{tabular}{|c|c|c|c|c|c|c|c|c|}
\hline Halslänge . . . . & $\begin{array}{l}\text { Suchu } \\
10 \mathrm{~m}\end{array}$ & 1 & $\begin{array}{l}\text { Kale. } \\
2-13\end{array}$ & $\mathrm{~mm}$ & Taurien. & 1. $G t$ & t. Kier & \\
\hline liunpfliugn . . & lin & & 87,5 & & (1) & 2 & - & s \\
\hline Schwanzlänge . & 137 & " & ? & ") & 160 & ” & 150 & $"$ \\
\hline Grölite Breite in d. Schläfengegrend & 15,3 & 》 & 18,7 & 3 & 14,7 & " & - & 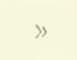 \\
\hline Grölste Breite des Unterkiefers & 15,5 & 》 & 21 & " & 16 & $\gg$ & - & \\
\hline Gröbte Höhe des Kopfes. . & 13,7 & 》 & 17,7 & " & 14 & » & - & " \\
\hline Grölite Breite d. Pileus . . & 18,2 & 》 & 14,7 & $》$ & 12,3 & $\gg$ & - & \\
\hline Gröliter Umfang des Kopfes . & 52,5 & 》 & 65,5 & $»$ & 54 & $»$ & - & \\
\hline Grölister Halsumfang . . . & 47,5 & " & 55 & 》 & 49 & » & - & \\
\hline Umfang des Rumples . & 53 & $》$ & 60 & » & ? & \% & - & \\
\hline Umfang der Schwanzwurzel . & 34 & $»$ & 42 & $»$ & 39,5 & " & - & $»$ \\
\hline Längre der Vorderextremität . & 28,7 & $»$ & 32 & " & 28 & $"$ & - & ” \\
\hline Laänge d. Hand m. d. Fingern & 11,5 & » & 14 & " & 12 & 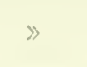 & - & $》$ \\
\hline Länge d. Hinterextremität . & 42 & ” & 45 & 》 & 43 & $》$ & - & 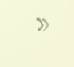 \\
\hline Länge d. Fulses m. d. Zehen . & 20,5 & $»$ & 22 & $»$ & 19 & $\gg$ & - & $»$ \\
\hline
\end{tabular}

\section{Schilder und Schuppen.}

Auch hierin unterscheidet sich L. paradoxa von der agilis und viridis. Die nach hinten etwas verschmälerten und deutlich abgerundeten, seitlich mit 2 ziemlich gerade verlaufenden und an 2 grolse obere Schläfentateln angrenzenden, nach innen und vorn mit geraden und geschweiften Kanten versehenen grofien Parietalen fassen zwischen sich ein dreieckiges, voru abgestutztes längliches Occipitale und ein etwas oder bedeutend gröferes, nach vorn zu erweitertes und mit seinel Spitze zwischen die Frontoparietalia eingeschobenes fünfseitiges Interparietale ein; in den meisten Fïllen ist dieses nach linten zu verschmälerte Schild länger und breiter als das dahinter liegende Occipitale. Es ist erwähnenswert, daß̉ die Parietalia weiter nach rückwärts reichen als das dazwischen liegende Sc. occipitale, ferner, daf3 die am hinteren l'ileusrande liegenden Nackenschupıen auffallend grol zu sein pflegen. Die lïnglichen, zicmlich schmalen Frontoparietalia stolien mit ihrer längsten Kante in der Mittellinie des Kopfes ancinander; ihre kürzesten, abgerundeten vorderen Seiten grenzen an den hinteren, etwas verschmälerten Teil des Stirnschildes, während ihre in der Regel etwas längeren, nach hiuten zu grekehrten Seiten sich den vorderen, leicht ausgerandeten Interparietalrändern anpassen; die zwei seitlichen Rïnder endlich sind meistenteils schwach bogenförmig gekrümmt. Das ziemlich 
grolie, etwa trapezföminc supraculare IV ist nach innen zu vom vorspringenden, abgestutzten Teile des Frontoparietale begrenzt. Die mittleren Supriocularia sind länger als bei der agilis, sie legen sich direkt an die Supraciliaria; das vordere an das kleine, langliche Supraoculare angrenzende Supraciliare ist auffallend breit. Das meist, im Verhailtnis zu seiner Breite, kurze Stirnschild erscheint nach rückwärts zu nur mäßjig verengt und ist mit bogigen Aufen- und in stumpfem Winkel zusammenstofienden, öfters leicht geschwungenen Vorderseiten versehen; nach hinten zu ist es in eine äulierst kurze und wenig aufallende Spitze ausgezogen. Die nach l'ückwärts meist abgestutzten Frontonasalen sind von gewöhnlicher Bildung, sie sind allerdings etwas länger als bei der hier zum Vergleich gezogenen Zauncidechse. Das nach vorn leicht abgerundete, hinten geralle, unter stumpfem Winkel zusimmenstotiende Rander aufweisende, etwa rhombische Internasale ist breit, viel breiter als lang und erscheint durch 2 ansehnliche, seitlich stark ausgerandete Supranasaliat von dem hohen, nach oben übergewölbten Russelschilde getrennt. Das grobe Nasenloch wird vorn vom Supranasale, unten vom Supralabiale I und hinten zum grötsten Teil von einer dreieckigen Nasofrenaltafel begrenzt, während der obere Teil des Supranasale mit der oben erweiterten Partie des Frenale in Berührung kommt, wobei das Supranasale und das Nasofrenale durch einen schwach ausgeprägten, mitunter bis zum Rande der Nasenöffnung reichenden Vorsprung des Frenale voneinander getrennt werden. Das Frenale und das Nasofrenale stellen zusammengenommen eine viereckige Tafel dar, welche höher als breit ist und (leren vordere, untere abgeschnittene Lcke das Nasofrenale renuit:entiert. ${ }^{1}$ ) Der bedeutend nach unten zu verengte Teil des Frenale stützt sich auf das zweite Supralabiale. Unter den 6 mir vorliegenden Stücken dieser Lacerla vermisse ich bei einem Exemplar das Frenale gänzlich, dagegen aber sind 2 genau äbereinander stehende Nasofrenalia dentlich sichtbar. Diese eigentümliche Beschildung der Zügelgegend schien mir anfangs lediglich eine Míbildung zu sein, erst nachdem ich vier aus Suchum-Kale und zwei angeblich aus Taurien und aus dem Gouvernement Kiew stammende Eidechsen zu vergleichen Gelegenheit hatte und bei 5 Individuen genau dasselbe hinsichtlich der Zahl und Anordunng dieser Schilder fand, habe ich mir die Frage aufwerfen müssen, ob wir nicht hierin specifische Merkmale crblicken müliten. - Das grobe nach vorn zu verschmälerte Sc. Frenale ist länger als hoch, seine hintere Kante ist zwei- bis dreimal ausgerandet. Supralabialia sind jederseits 7 bis 8 vorbanden, von denen das fünfte, unter dem Auge sich befindende, das gröfte Schild repräsentiert. Die Schläfe ist oben mit 2 sehr grofien, an die Parietalen grenzenden Tafeln bekleidet. Die übrigen Temporalschilder sind ehenfalls ziemlich grob; sie sind fün- bis achtseitig und 1) Vergl. meine Tafel, Fig. 23. 
schliefien zwischen sich mitunter ein gröfseres Massetericum ein. Ein eigentliches längliches Tympanicum fehtt, jedoch kann das an den vorderen oberen Ohrrand grenzende Schlafenschild als Tympanicum gelten. Sublabialen sind 6 Paare, Unterkieferschilder 5 Pare vorhanden, von denen das dritte Paar zu divergieren anfängt; das vierte Paar ist das grölate. Die sechsseitigen Kehlschuppen sind gegen die Seiten hin etwas länger als breit, sonst erscheinen sic insofern von den Halsschuppen nicht verschieden, als sie ebenso breit, mitunter sogar etwas breiter als lang sind. Die Kehlfurche ist nicht sichthar, doch ist sie bisweilen durch eine transversale Reihe kleiner Schuppen ersetat. Das Halsband besteht aus 10 längeren als breiten, stark gezähnelten Tafeln, von denen die mittelste die größte ist. Das Brustdreieck enthält etwa 6 bis 11 Schilder, der Bauch ist mit 27 bis 30 Querreihen, 6 Längsreihen echter Ventral tafeln und zwei aus kleineren Randschildchen bestehenden Längsreihen bedeckt; die mittleren Schilder sind halb so grols wie die ihnen angrenzenden; sie sind, wie ich gleichzeitig bemerken möchte, kleiner als bei der agilis oder viridis. Das sehr breite, aber nicht sehr lange Afterschild ist vorn und seitlich von 2 Bogenreihen von Schildern umsäunt, von denen die zwei vorderen mittelsten, dem Anale zunächst liegenden halb so breit, aber in der Regel länger als das Sc. anale selbst erscheinen; wir können somit von 3, den Praeanalraum deckenden Schildern sprechen. ${ }^{3}$ ) Bei einigen mir zu Gebote stehenden Stücken sind die mittleren Rumpfseitenschuppen mit Ausnahme derjenigen, welche die Randschildchen begrenzen, gekielt, bei anderen aber, so z. B. bei dem angeblich aus Taurien stammenden Stücke treten die Kiele erst von der achten oder neunten Längsreihe an auf, d. h. vom Bauche an gerechnet. Die anfangs, also an den Bauchgrenzen, verhältnismäßjig großeı, abgerundet vierseitigen, schwach geschindelten Schuppen gehen in die länglichen, bedeutend schmäleren, längsgekiclten, mehr oder weniger abgerundet hexagonalen, oder am Vorderrücken nahezu pentagonalen Rückenschuppen über. Der Rumpf enthält etwa 100 bis 107 Quer- und 41 bis 48 Längsschuppenreihen. Der Nacken ist mit etwits kirzeren erhabenen Schuppen bekleidet; sehr grob erscheinen diejenigen Schuppen, welche die Kopfschilder umsiumen. Die Oberseite der Hinterbeine ist mit abgerundet vierseitigen, meist diagonal gekielten Schuppen bekleidet. Die in 79 bis 82 Quergürtel angeordneten Schwanzschuppen sind oberseits stumpf- bis spitzwinkelig und deutlich gekielt; auf der unteren Seite erscheinen sie vorn glatt und zeigen einen ziemlich abgerundeten hinteren Rand, nach rückwärts aber sind sie stumpfgekielt und in eine meist ziemlich scharfe Spitze ausgezogen.

1) Genau dieselbe Zahl der Praeanaltafeln kommt auch bei den südrussischen $L$. agilis vor. 
Drüsen, Zähne und Figentümlichkciten am Schädel.

An der Unterseite der Schenkel sind 13-14, 14-14 und 15-15 Druisen vorhanden.

Die Zahl der Zähne am Zwischenkieferknochen ist 9, im Oberkiefer sitzen jederseits 16, im Unterkiefer 21 Kähne. Der fiammen ist bezahnt.

Die Nichtzusammengehörigkeit der parudoxa zu vivilis kann sofort durch die Untersuchumer des Schädels nachgewiesen werden. Itetztere zeigt nämlich, wie es bekanntlich Leydig nachgewiesen hat, in der Schläfengegend eine Verkalkung der Haut, oder besser gesagt, vier bis fünf von der Haut überzogene und den Raum zwischen Augen und Ohr zum Teil ausfüllende Knochentafeln, welche schon beim Anfühlen des intakten Kopfes der Smaragdeidechse dadurch auffallen, dafs die Schläfe eine gewisse Resistenz zeigt und dem Druck wenig orler gar nicht nachzugeben pflegrt. Die äufere, knöcherne Wandung der Schädeldecke fehlt hingegen sowohl bei den Zauneidechsen als anch bei der uns hier interessierenden L. paradoxa.

\section{Färbung und Zeichnung.}

Unsere neue Art scheint von der Smaragdeidechse hinsichtlich der Farbe so wenig abzuweichen, dals beim ersten Anblick eine Verwechselung dieser beiden Lacerten selur leicht stattfinden kann. Ihre Fürbung scheint nur in geringem Mafe zu variieren; der Rücken ist entweder rein gras- orler dunkelgrün oder bräunlichgrün, ungefleckt oder mit mehr oder weniger zahlreichen kleinen, bald schwarzen, bald dunkelbraunen Punkten bedeckt. Bei dem am Rücken ungefleckten Stücken erscheinen die Rumpfseiten yleichmälizg grün oder bräunlichgrün koloriert oder bald mit einer, bald mit zwei Längsteihen weißlicher kleiner, mitunter von duukelbraunen orler schwarzen Schuppen hegleiteter Punktflecken besetzt, welche meistenteils nur vorn am Halse und oberhalb der Ansatzstellen der Vordergliedmaßen deutlich zu 'Tage treten; bei denjenigen Exemplaren aber, deren Rücken mit eingemischten dunklen Schuppen oder mit deutlichen, obwohl wenig zahlreichen schwarzen Fleckchen versehen ist, sind die Rumpfseiten ziemlich stark schwarz punktiert, oder mit undeutlich ausgepriagten dunklen Zeichnungen und weiflichen oder grünlichweísen Augenflecken geziert. Mitunter zeigen die Rumpfseiten eine Neigung ins Bläuliche, während der Rücken mit grünem Anfluge versehen ist. Bei der mir aus dem Gouvernement von Kiew vorliegenden paradoxa befinden sich lings des Rückgrates etwa 9 dunkle Punlitflecken verteilt. Die Kopflecke erscheint bei diesem Exemplar bräunlichgrün, dunkelbraun gepunktet, ebenso die Zügelgegend; bei den Individuen aus Suchum-Kale sind die Pileusschilder durchwegr dunkler als der übrige Körper, etwa olivengrün oder bräunlich, entweder fleckenlos oder spärlich mit dunklen Punkten und kurzen Strichen besetzt. Die hellgrünliclı- 
blauen Zü̈gelschilder sind ungefleckt, wogegen die Schlifenregion sowohl bei den kaukasischen, als auch Krimer Stücken spärlich braun und schwarz gezeichnet ist. Unterkopf und Bauch pflegen grünlich oder hell- bis dunkelblau, mehr oder weniger stark dunkel gepunktet oder grefleckt zu sein; gegen die Mitte der Kehle hellt sich dic Färbung bisweilen bis zum Weiligell, auf. Die Submaxillaren, namentlich die vorderen, entbehren oftmals gänzlich der dunklen Zeichnung, erhalten hingegen breite weiligelbe Striche in ihrer Mitte; auch am Bauch tritt manchmal die dunkle Fleckung weniger stark hervor; in diesem Fall sind die Tafeln auf gelblichem Grunde blau gefleckt. Das Blau der Kehlgegend ist in der Regel gesättigter als auf den übrigen Körperteilen. Die Vorder- und Hinterbeine, ferner die Schwanzunterseite und sogar die Schwanz- und Halsseiten überziehen sich öfters mit Blau oder Grünlichblau. Junge Exemplare dieser Art zeigen auf der Oberseite ein helles Grünlichbraun; sie sind meistenteils fleckenlos, nur in seltenen Fällen enthalten die Rumpfseiten etliche helle, undeutlich ausgeprägte runde I'leckchen. So viel ich mich erinnern kann, enthält die Senckenbergische Samnlung ein junges Stück dieser Species aus Feodosia.

Fundorte.

Die mir vorliegenden Stäcke stammen aus Suchum-Kale, aus dem Gouvernement Kiew (Mus. zu Kiew, No. 1957, L. viridis Dand. var, punctiligera) und angeblich aus Taurien. Ferner glaube ich Exemplare aus Trapezunt und aus Konstantinopel gesehen zu haben.

\section{Lacerta muralis Laur. (1768).}

Char. - Scutum occipitale plerumque minus, interlum paulo latius quam scutum interparietale. Scutum nasofrenale unicum. Scuta supralabialia anteriora 4-5. Discus palpebralis in margine externo serie granorun limbatus. Tempora granosa, scuta parietalia in marginibus scutis maioribus limbata (Subsp. Steindachneri: Scuta parietalia in marginibus in parte anteriore scuto paulo maiore limbata). Scutum massetericum plerumque adest, exceptis nonnullis formis insularibus (var. coerulea), persicis (var, persica), hispano-lusitanicis (subsp. Steindachneri). Tympanicum semper adest. Sulcus gularis distinctus vel indistinctus, collare integrum, perraro in speciminibus sicilianis subdenticulatum. Scuta abdominalia in sex series perraro in octo series longitudinales disposita (var. coerulea). Squamae dorsales granosae, aut minimae aut paulo maiores, rotundulae vel regulariter sexangulares, longiores quam altiores, angulis acutis vel rotundatis, sat obtuso-carinatae vel minime carinatae, interdum laeves convexae (subsp. Steindachneri: Squanae dorsales parvae, laeves, satis planae, ad partem posteriorem versus 
subacuminatae). Dentes in palato uulli; exeptiones haud rarae. - Caput pyramiclale vel depressum in anteriore parte acuminato-angustatum. 'Iruncus plerumque gracilis porrectusque, interdum sat robustus et compactus, ut in speciminibus insulas Balearicas inhabitantibus (subsp. bulcarieu, valr. pyt!nusensis, var. Lilfordii, (riglimlii). Pedes postici axillas attingentes, interdum etiam superantes, raro non attingentes. Cauda longa vel satis brevis. (Subsp. Steindachneri: Caput parvum, valde depressum, in regione temporali latissimum, ante acuminato-angustatum. Iruncus planus. Pedes postici axillas attingentes vel paulo superantes. Cauda valde attenuata plerumque $2 / 3$ totius corporis). Pori femorales utrinque $13-29$. - Longitudo $127-250 \mathrm{~mm}$.

Synonymie.

Lacerta Portschinsliii Kessler, Zoolog. Reise durch das transkaukasische Gebiet im Jahre 1875 in: Arbeiten d. St. Petersb. Gesellsch. d. Naturforscher, Bd. VIII, SupplementHeft. St. Petersb. 1878 (Taf. I).

Seps muralis Laurenti, Synops, rept. pag. 61. Wien 1768.

Tiliguertu o Caliscertula Cetti, Storia naturale di Sardegna III, pag. 15. Sassari 1777. Bettoni, Sulla Tiliguerta di Cetti etc. in: Soc. ital. sc. nat. XII. Fasc. 3. Milano 1868. Tiliguerta Lizard, Shaw, Gener. Zool. III. p. 249. 1802. - Lacerta tiliguerte, Sonini, Latreille, Hist. nat. Rept. t. I, p. 229. 1801. - De Filippi Cenno sulla Tiliguerta di Cetti in: Nuovi Annali Sc. nat, di Rologna V. p. 69 (Serie III) Bologna 1852. - Daudin, Hist. nat. Rept. III. p. 167. Paris 1802. - De Betta, Sulla Tiliguerta o Caliscertula Cetti in: Atti R. Istit. Veneto. Serie V, Tom. V. Podarcis tiliguerta, Camerano, Considerazioni sul Gen. Lacerta etc. in: Atti Accad. Sc. di Torino, Vol. XIII. : 1877. - De Filippi, Regno animale, pag. 258. Milano 1852. - Gené, in: Mem. Accad. Sc. di Torino XXXVI, p.302. 1833.

Ameiva tilignerta Mleyer, Synopsis reptilium etc. No. 2, p. 28, 1795.

Lézard gris, Daubenton et Bonaterre, Diction. erpétol. in: Encyclop. méth. III, p. 636.

Paris 1784-92. - Razoumowsky, Hist. nat. du Jorat etc. t. I, pl. I, fig, 2 a. Lauzanne 1789. - D a ubenton in: Mem. Soc. Roy. de Médecine 1780 - 81.

Lacerta caliscertula Bonaterre, Tableau encyclopédique et méthod. des trois règnes etc. Erpétologie. Paris 1789.

Le Lézard rert, A zuni, Hist. géogr. polit. et naturelle de la Sardaigne II., p. 66. Paris 1802. Lacerta Bromynardii Daudin, Hist. nat. des Reptiles III, p. 221. Paris 1803. - Des marest, Faune Française. Reptiles. Pl. IX. Paris 1820-30. - Daudin, Hist. nat. Rept. III, 1). 211. 
Lac. acrolampra Costa, Fauna di Aspromonte e sue adiacenze, P. 72. Tav. II. fig. 2. a, b. Napoli 1828.

L. sericea, Merrem, Versuch eines Systems d. Amphibien. S. 63. Marburg 1820.

L. saxicola, Eversmann, Lacertae imperii rossici etc. in: Nouv. Mém. Soc. Imp. natur. Moscou III, p. 349. Tab. XXX, fig. 1. 1834. - Krynicki, in: Bull, de Moscou 1837. No. 3, pag. 47 .

L. chalybdea, Eichwald, Fauna caspio-caucasia p. 91, tab. XI, fig. 1, 2, 3. Petropoli 1841. L. agilis Risso, Hist. nat. des principales productions de l'Europe etc. III. p. 86. Paris 1826. - Daudin, Hist, nat. Rept., Ill. p. 211, Pl. 38, fig. 1. - Ménétries, Cat. raisonné des Objets de Zoologie recueillis dans un voyage au Caucase etc. p. 60. St. Petersb. 1832. - Eichwald, Fauna caspio-caucasia p. 86. Petropoli 1841. De La Fontaine, Faune du Pays de Luxembourg etc. Reptiles. Luxembourg. 1875. p. 8.

Zootoca quadritineata Gray in: Aun. Nat. Hist. Vol. I. 1838. pag. 279.

Z. muralis (Wag 1.) M a chado, Erpetologia hispalensis etc. in: Revista di Ciencias, Literatura y Artes V. 1859. - Gray, Cat. Liz. Brit. Mus. p. 28. London 1845.

Z. Lilfordi Günther in: Ann. and Mag. Nat. Hist. XIV. p. 159 (1874).

Podarcis defilippii, Cam e rano, Considerazioni sul Gen. Lacerta Linn. in: Atti R. Accad. Sc. di 'Torino, Vol. XIII. 1877.

Podarcis muratis Wagler, Natür. Syst. d. Amphibien, S. 155. Nünchen, Stuttgart u. Tübingen 1830. - De Betta, Rettili ed Anfibi in: Fauna d'Italia IV (L'Italia sotto l'aspetto fisico, storico etc.). Milano 1874 (var. albiventris, flaviventris, rubriventris, nigriventris, lineata, campestris, muatis auctor). - Tschudi, Monogr. schweizer. Echsen in: Nouv. Mém. Soc. Helv. des sc. nat. 1837. - Bonaparte in: Mem. Accad. Sc. di Torino. Serie II. Tom. II. p. 385. - Gené, ebendas. T. I. P. 257. - Bonaparte, Iconografia della Fauna italica, l'ar. fig. a, b, c (var. mbriventris, albiventris, olivaceus albiventris, siculus, maculatu, nigriventris). - II assalongo, Saggio di un 'Erpetologia popolare, p. 25, 36. Verona 1854. (var. albiventris, flaviventris, cupreicentris). - De Betta, Erpetol. Prov. Venete etc. in: Atti Accad. Agricolt. Arti e Comm. di Verona XXXV, p. 152 (var. campestris). - Fitzinger, Systema reptilium p. 20. Wien 1843. - De Betta, Nuova, serie die note erpetologiche in: Atti del R. Ist. Yen. Sc. e Lett. Ser. V. T. V. - Fitzinger in: Abh. 
Böhm. Gesellsch. d. Wissensch. I. Bd. (neue Folge) S. 324. Prag 1829. - Wiegmann, Herpetologia mexicana. Berlin 183t. - Camerano, Considerazioni sul Gen. Lacerta Linn. in: Atti Accad. Sc. di Torino. XIII. 1877. - Vlieninger, Verzeichnis Rept. Württemb. in: Jahreshefte f. vaterländ. Naturkunde 1847.

Lacerta podarcis var. Cettii, var, Genei Ca l'a, Monogr. della Lacertula comune di Sardegna p. 23. Cagliari 1872.

$L$. olivacea, Rafinisque Schmalz, Caratt. di alcuni nouvi gen. e nouv. spec. di animali e piante della Sicilia. 1810, Palermo.

L. puccina, Rafinisque Schmalz, !. c.

? L. bifasciata, Risso, Hist. nat. princip. product. de l'Europe etc. III. p. 87. Paris 1826.

L. maculatu, Merrem, Versuch eines Systems d. Amphib. Marburg 1820 (S. 63).

L. hieroglyphica Berthold, Üb. verschied, neue od. seltene Amphibienarten in: Act. soc. reg. Goetting. VIII. 1842.

? L. Laurenti (Daud.) Ménétries, l. c.

Lézard gris des murailles Cuvier, Le Règne animal, 2. édit. t. II., p. 31 ; 3. édit. t. II. pag. 29.

Lacerta muralis, Fitzing er, Neue Klassifikation d. Reptilien. Wien 1826 (S. 51. var. maculata, lepida, Brongniardii). - Milne Edwards, Recherches zoolog. pour servir à l'hist. des Lézards in: Ann. sc. nat. XXII. 1829. - Schinz, Fauua Helvetica in: Nouv. mém. Soc. helvet. Sc. nat. t. I. p. 138, 1837. - G Gené in: Mem. delle Sc. di Torino, t. 36, p. 302. 1833. - Duméril et Bibron, Erpétologie générale V, p. 228. Paris 1839. - Latreille, Hist. nat. Salamandres de France, P. XVI, 2a. Paris 1800. - Latreille et Sonini, Hist. nat. des Reptiles. Paris 1802. - Dugès in: Ann. sc. nat. XVI (mars), p. 337. 1829. - Crespon, Faune méridionale, p. 202. Nimes 1844. - De Filippi, Regno animale, p. 258. Milano 1852. - Schinz, Naturgeschichte und Abbildungen, S. 101, Taf. 39, tig. 1 u. 2. - Merrem, Versuch eines Sytems d. Amplibien, S. 67. Marburg 1820. - Tappe, Die einheim. Eidechsen. S. 36. Oberhausen 1868. - Stra u ch, Essai d'une erpétologie in: Mém. Acad. Imp. des Sc. de St. Petersb. t. IV. 1862. - Fatio, Faune des Vertébrés de Ia Suisse III, pag. 92. 1872 (var.albicentris, faviventris, mbriventris). - Leydig, Die in Deutschland lebend. Arten d. Saurier, S. 225. Tübingen 1872. - S chreiber, Herpetologia europaea, S. 408. Braunschweig 1875. - J. v. Bedriaga, Üb. die Entstehung d. Farben bei d. Eidechsen. Jena 1874 (var, neapolitana). - F. Lataste, Essai d'une 
Faune lerpétologique de la Gironde in: Act. Soc. Linn. Bordeaux XXY, p. 71. Bordeaux 1876. - Braun, Lacerta Lilfordi etc. in: Arb. aus d. zool. zoot. Institut Würburg, Bd. IV. Taf. 1, fig. 4, 5, 7, 8. Taf. II, Fig. 2. - v. B edriaga, Herpetolog. Studien in: Archiv f. Naturgesch. 1878 u. 1879. - Boulenger, in: Proc. Zool. Sac, of London 1851, pag. 743. - v. Bedriaga, in: Bull. Soc. Zool. de France IV, pag. 19t, pl. IX. Paris 1879; Bull. de Moscou 1881, Nr. 3, p. 101. $L$. vulgaris Aldrovandi, De quadrupedibus digitatis oviparis, pag. 625. Bononiae 1663.

Yon den meisten anderen Herpetologen abweichend, habe ich in meinen in letzterer Zeit erschienenen Schriften zu zeigen versucht, daf der Formenkreis der »L. muralis Laur.«, wegen der ihr eigenen unbegrenzten Variabilität, sich keineswegs vollkommen präcis umschreiben läfat und daf man lediglich der Systematik zuliebe zur Aufstellung eines Typus, der den gesamten Formenkreis der Species repräsentieren soll, seine Zuflucht genommen hat. Bei den allermeisten Eidechsen unfalit der Speciesbegriff allerdings eine einzige Form oder Hauptform, deren wesentliche Charaktere sich verhältnismäßig durch eine Beständigkeit auszeichnen, und eine mehr oder weniger große Anzahl von Varietäten, deren Merkmale einen geringeren Grad von Beständigkeit aufweisen. Anders verhält es sich mit der uns hier interessierenden Art. „L. muralis Laur。 umfafit nämlich eine ganze Entwickelungsreihe verschiedener Formen, die in vielen Fällen in allen wesentlicben Merkmalen übereinstimmen und deren Verbreitungskreise übereinander greifen, in anderen Fällen aber unterscheidende Charaktere in sich bergen und geographisch getrennt erscheinen; ja diese Charaktere sind bisweilen, wie es namentlich bei den insulanischen Mauereidechsen öfters der Fall zu sein pflegt, dermaßen scharf prononciert und durch ihre Stabilität ausgezeichnet, daß3 ihre Zusammengehörigkeit nur auf Grund minutiöser Untersuchung nachgewiesen werden kanu. Das Erkenntnis der Beziehungen zwischen den binnenländischen Formen hat übrigens auch seine Schwierigkeiten, namentlich in denjenigen Fällen, wenn auf die Beibehaltung nur einer einzigen typischen Form Gewicht gelegt wird. Die Art »muralis besteht nämlich aus mehreren Formenkreisen, deren gemeinsame Stammform unbekannt ist; die Formenkreise aber, welche oftmals cine zusammenhängende Reihe fein abgestufter Zwischenformen umfassen, werden meistens durch eine Haupt- und zugleich Mutterform repräsentiert, welche als Typus oder Subspecies bezeichnet werden kann. Behufs Erleichterung des Studiums und der Bestimmung der Mauereidechsen, will ich eine Z̈bersicht der in beifolgenden Blattern beschriebenen oder nur kurz erwähnten Formen geben. Diese tabellarische Zusammenstellung entspricht im grofen und ganzen der, von mir in meinen herpetologischen Arbeiten angedeuteten und noch kürzlich ausführlich erläuterten Methode bezüglich der Einteilung der Species in Subspecies, 
Varietiten und Untervarietäten. Ich will nur noch ausdrucklich bemerken, dats ich den Artnamen »muratis La ur.« als liollektiv-Bezeichnung für Subspecies sowie auch für sämtliche suborlinierte Kategorien betrachte.

\section{Lacerta muralis $\mathrm{L}$ a $u \mathbf{r}^{\circ}$. sp.}

lïrpergestalt.

Der lörper ist bald mehr, bald weniger schlank und gestreckt, der Rumpf entweder von oben leicht niedergedrückt oder gerundet und in der Mitte schwach bauchig verdickt. Der rom lumpfe durch eine schwache Einschürung gesonderte, oder durch den sehr breiten, mit Falten verschenen Hals geschiedene Kopf ist flach und breiter als hoch oder im ganzen ron vierseitig pyrmidenförmiger Gestalt und nahezu ebenso hoch wie breit. Die Schnanze ist abgerundet und zeigt fast senkrecht abfallende Seiten; über den Augen erscheint die Schädeldecke meist schwach gewölbt, nach rom zu sanft abwärts geneigt; die Temporalgegend ist leicht backenartig aufgetrieben. Die Rumpfunterseite ist flach. Die Vorderbeine reichen bis zum vorderen Augemrand oder bis zu den Nasenlöchern, ja bisweilen selbst bis zur Schnauzenspitze; die Hinterbeine reichen bis zu den Achseln, bisweilen auch darüber hinaus, nur in einzelnen Fällen erreichen sie dieselben nicht. Der cycloidal-tetragonale, dünn auslaufende Schwanz ist stets länger als der übrige Körper. Das Weibchen ist immer kleiner, schlanker und zarter gebaut als das Männchen. Del Kopf besitzt einen depressen Charakter; die Supraorbitalregion ist ziemlich flach. Der Kopf des Weibchens ist kürzer und schmäler; besonders geht die Schnauze spitzer zu als es beim Mânnchen der Fill zu sein pHlegt. Der ziemlich flache, nach rïchwärts an den Seiten mäbig bauchig aufgetriebene Rumpf ist verhältnismäbig länger und die Beine schmächtiger gebaut als beim Männchen. An der Schwanzwurzel wird die dem Männchen eigentümliche Verdickung vermilst.

1. Gruppe:

Subsp. fusca de Bedr. 1878.

Dic hierher gehörenden Mauereidechsen sind durch ihre geringe Körpergröße, durch flacheren Kopf, rundum gewöhnlich etwas eingeschourten Hals und bei den auf dem hontinent lebenden Formen durch die vorherrschend braune Grundfärbung gekennzeichnet. 4 vordere Supralabiala; das Massetericum fehlt bei den in Persien einheimischen Individuen.

Varietäten: flaviundata m., corsica m., Rasquineti m., milensis m., Erhardii m., saxicola Eversm., persica m., melisellensis Braun, etc. 
2. Gruppe: Subsp.neapolitana de Bedr. 1874.

Diese Unterart unterscheidet sich von Subsp. fusca durch ihre bedeutendere Körpergrölie, ihren vierseitig pyramidenförmigen Kopf, der nahezu oder ebenso breit ist wie hoch, sowie auch durch die vorherrschend grüne Rückenfarbe. 4 vordere Supralabialia; das Massetericum fehlt nur bei einigen insulanischen Formen.

Varietäten und Subvarietäten: Latastei $\mathrm{m}$., filfolensis $\mathrm{m}$., coerulea Ei m., viridiocellata m., coentescens-monaconensis Eim., coerulescens gallensis Eim., Cettii Cara, olivacea Raf., livorniensis m., albiventris Bonap., campestris De Betta, olvacea albiventris Bonap., reticulata Schreib, nigriventris Bonap, lineata De Betta, sicula Doderleinii de Betta, roseiventris Massal. etc.

3. Gruppe.

Subsp. Bruggemanni de Bedr. 1879.

Diese Unterart ist gewissermaken ein Verbindungsglied zwischen Subsp. fusca und Subsp. neapolitana. In Hinsicht der Körpergestalt und Körpergröße stimmt sie mit der ersteren überein. Die Grundfarbe ist wie bei Subsp. neapolitana. 4 vordere Supralabialia; Massetericum vorhanden.

4. Gruppe.

Subsp. balearica de Bedr. 1879.

Diese den Balearen eigentümliche Gruppe umfaft eine Anzahl Formen, welche an ihrem breiten Halse und dicken, verhältnismäligig kurzen Rumpfe gut kenntlich sind. The Kopf ist pyramidal, mit ziemlich stark zugespitzter Schnauze. Ihr an der Basis, besonders bei den Männchen verhältnismälig breite Schwanz ist in eine kurze Spitze ausgezogen und erscheint oftmals wenig länger als der Körper. Die Grundfarbe des Oberkürpers ist vorherrschend braun. 4 vordere Supralabilia, Massetericum vorhanden.

Varietäten: Lilfordi Günth., Gigliolii de Bedr., pityusensis Boscà.

5. Gruppe.

Subsp. Steindachneri m.

Der stark abgeplattete, in der Wangengegend sehr breite Kopf nimmt von den Augen an rasch nach vorn zu ab; die Schnauze ist stark zugespitzt. Der Rumpf ist plattgedrückt, namentlich bei den Weibchen. Die Vorderbeine reichen bis zum Vorderrande der Orbitalhöhle, obwohl sie zuweilen hinter dieser Länge etwas zurückbleiben; die Hinterbeine erreichen beim Männchen die Achseln, oder reichen auch etwas darüber hinaus; beim Weibchen urreichen sie die Achseln nicht. 4 bis 5 vordere Supralabialia, das Missetericum ist meistens nicht vorhanden. 
A u fere Körperbedeckung.

Die Beschildung und Beschuppung zeigt bei der muralis viele Unbeständigkeiten. namentlich sind Abweichungen rom »Typus bei den isoliert lebenden, beispielsweise bei den insulanischen Formen lionstatierbar. Das trapezförmige Oecipitale ist in der Regel kleiner, d. h. schmäler und kürzer als das nach hinten verschmälerte, manchmal, aber selten, spitz auslaufende, gewöhnlich abgestutzte, vorn recht- odel" stumpfwinklig endende Interparietale; in Ausnahmsfällen, so beispielsweise bei den balearischen Manereidechsen, sind diese beiden Tafeln gleich grof, mir liegen sogar Exemplare vor, bei denen das Hinterhauptsschild etwas länger ist als das Interparietale. Die grolien Sc. Parietalia lassen an ihren leicht abgerundeten seitlichen Außenränderu schmale, längliche Saumschilder erkennen, welche bedeutend gröber erscheinen als die übrigen Schuppen, welche die Schläfe bekleiden; die hinteren Parietalkanten sind gleichfalls, und sogar ziemlich deutlich, abgerundet, während die nach innen gekehrten Rinder aus etwa vier, unter äuljerst stumpfen Winkeln zusammenstoßjenden Kanten gebildet werden. Die pentagowalen Frontoparietalen, die, nebenbei bemerkt, länger als breit sind, stofen mit ihren längsten Kanten in der Mittellinie des Kopfes aneinander, während ihre geraden oder bogenförmig gekrümmten vorderen Kanten sich an die Stirntafel anfügen und ihre ebenfalls kurzen hinteren Kanten einen einspringenden Winkel bilden, der zur Aufnahme der vorderen Partie des Interparietale dient; die zwei lateralwärts und nach auŁen liegenden Seiten endlich sind entweder mehr oder weniger stark ausgeschnitten, abgerundet, oder vollkommen gerade. In ersterem Falle erscheint der Seitenteil der Frontoparietaltafel als ziemlich lange Spitze zwischen das Parjetale und das Supraoculare III. eingeschoben, in letzterem stofen die erwähnten Kanten unter stumpfem Winkel zusammen, dessen Spitze das vierte kleine, vier- oder fünflantige Oberaugenschild berührt. Der in der Regel, usd namentlich beim Männchen, gewölbte, seitlich durch eine feine Schuppenreihe umsäumte und von den schmalen, länglichen 5 Supraciliaren getrennte Discus palpebralis besteht aus einer gröliseren, nach vorn zugespitzten, seitlich leicht abgerundeten, hinten meistens geradekantigen Tafel und aus einem etwas kleineren, dahinter liegenden Schilde, das breiter als lang ist und nach rückwärts winkelig ausgezogen oder bogenförmig gekrümut erscheint. Das nach hinten sehr stumpfwinklig oder fast gerade abgestutzte, in der Regel aber in eine dreieckige Spitze ausgezogene, nach vorn bald stumpfwinklig, bald spitzwinklig endende Frontale ist das zweitgrößte Kopfschild; seine Seiten sind selten parallel, in der Regel aber deutlich ausgebuchtet und nach vorn zu divergierend. Infolgedessen erscheint der mittlere 'T'eil dieses Schildes am schmälsten, während die vordere, oftmals vorspringende Partie bedeutend breiter ist; in seltenen Fällen zeigt letztere zwei geradlinige Kanten, welche 
unter stumpfem, zwischen den beiden zunächst liegenden Frontonasalen eingefügtem Winkel zusammenstofen; in den meisten Fällen sind diese Kanten stark ausgerandet, wodurch das Frontale mit einer medianen, dreieckigen oder leicht abgerundeten, zwischen die Frontonasalen eingeschobenen Spitze und mit zwei seitlichen, zwischen den Supraorbitalen und den Frontonasalen sich einfügenden Spitzen versehen ist. Der hintere, bedeutend schmälere Teil des Stirnschildes zeigt zwei mehr oder weniger deutlich ausgerandete Seiten und eine kurze Spitze, welche zwischen die Parietalen hineinragt. Die stets längeren als breiten Frontonasalen zeichnen sich durch die Unbeständigkeit ihrer Gestait aus; sie sind meist sechsseitig und nach auben hin länger als nach innen zu, weshalb auch ihre, an die Freno-ocularia angrenzenden geraden Ränder die längsten von allen sind. Die Länge ihrer medianen Berührungslinie hängt übrigens von der Entwickelung des vorderen Teils des Frontalschildes ab: ist letzteres ausgezogen, so erscheinen die Frontonasalen nach innen zu schmal und mit kurzen Rändern versehen, ja bisweilen treten sie auch gar nicht in gegenseitige Berührung, indem die lang ausgezogene Frontalspitze mit dem nahezu rhombischen, oder einem Kreisausschnitt ähnlichen Internasale in Kontakt tritt. Die übrigen kürzeren Frontonasalkanten stofien unter stumpfen oder spitzen Winkeln zusammen und berühren hinten das Frontale und das erste und zugleich kleinste, meist drei- oder vierseitige Supraorbitale, vorn das Internasale sowie auch das Frenale; diese Kanten hängen vollständig von der Konfiguration der ihnen angrenzenden Schilder ab und erscheinen bald gerade, bald ein- oder ausgebuchtet. Auf die Konturen dieser Schilder, sowie auch auf diejenigen der längeren und breiteren Frontoparietalen wird mit Recht kein Gewicht bei der Unterscheidung der Species gelegt. Die trapezförmigen oder dreieckigen, seitlich ausgerandeten Supranasalia berühren sich in einer sehr kurzen Naht (in diesem Falle ist das Supranasale trapezförmig) oder mit ihren Spitzen; in einigen Fällen aber erscheinen sie durch das nach vorn stark vorragende Zwischennasenschild und das nach oben schwach ubergewölbte, beinahe doppelt so grolie als lange Rostrale, welches das Vorderende des letztgenannten Schildes berührt, voneinander getrennt. Seitlich vom Rüsselschilde befindet sich das erste ziemlich lange, viereckige Oberlippenschild, das unter Beteiligung des gegen die Basis erweiterten, nach oben verengten und hohen Nasofrenale sowie auch des Supranasale zur Begrenzung des Nasenloches und auch zur Stütze des Nasofrenale dient. Das Vorhandensein nur eines Nasofrenale habe ich unter die Hauptcharaktere der muralis aufgenommen, denn zweifelsohne muls das von F. Müller bei einigen korsikanischen Mauereidechsen konstatierte Vorhandensein von 2 Nasofrenalen lediglich auf Verstümmelung oder angeborene Milbildung zurückgefuhrt werden. Auf das Nasofrenale folgt das leicht auf den Pileus übergewölbte, schmale, höhere als lange. 
fünf Ränder aufweisende und dem zweiten Supralabiale aufliegende Frenale; zwischen diesem und der Orbitalhöhle befindet sich das ansehnliche, hinten ziemlich hohe und mit drei kurzen, ausgerandeten Kanten versehene lireno-oculare, welches abbr dem dritten, schmalen und uiber dem vierten, gegen seine Basis stark erweiterten und nach hinten $z u$ in eine ziemlich lange Spitze ausgezogenen Oberlippenschilde gelegen ist. Das erste vorlere und zugleich das gröbte Supraciliare legt sich an das freno-oculare oben an, während das kleine Praeoculare den unteren Teil dieses Schildes vom langen, oben bogenfömig ausgerandeten und seitlich Fortsätze entsendenden fünften Supralabiale oder Suboculare trennt. Supralabialia posteriora finden sich jederseits 1 bis 2. Die Schläfe sind mit körnerartigen Schuppen oder mit schilderährilichen, aber äuferst kleinen Schupen bedeckt, die gewöhnlich ein größseres Massetericum zwischen sich einschlielien; dieses Schild feht nur bei einigen insulanischen, ferner bei den persischen, algierischen und spanischen muralis. Ein längliches, etwa bohnenformiges Tympanalschildchen umgiebt zum Teil den Vorderrand der ziemlich großen, nahezu ovalen Ohröffinung. Sublabialschilder finden sich jederseits 6-7, von denen die vorderen durch das ziemlich grofie Mentale von einander getrennt werden. Submaxillaren sind in der Regel 6 , seltener 5 vorhanden; die vordersten 3 Pare stof̉en in der Mittellinie zusammen; nach rüchwärts nehmen sie bis zum vierten Paare allmählich an Grölse zu. Zwischen den Submaxillaren sind die, die Kehle bekleidenden Schuppen länglich und schmal; sie werden von den dahinter liegrenden breiteren Halsschuppen durch eine äulierst fein beschuppte Querfurche getrennt, welche gewöhnlich von einer Querfalte begleitet und überdeckt erscheint.

Das nicht gezähnelte, ausnahmsweise mit spurweise zackigem freien Rande versehene Halsband besteht aus 9 bis 13 Tafeln; die mittlere dieser Tafeln ist stets vergrößsert, während die

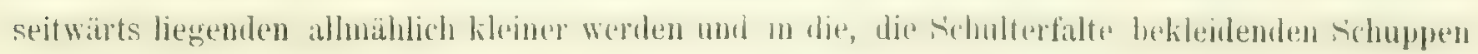
übergehen. Das Brustdreieck ist sehr deutlich ausgeprägt und aus 5 bis 11 Schildern zusammengesetzt. Die Bauchschilder stehen in 6 Längsreihen, von denen die der mittleren Reibe schmäler sind als die der begrenzenden; ausnahmsweise (mir sind nur zwei Fälle bekannt) sind 8 Reihen konstatiert worlen, was aber auf eine Abnormität zurückzufuhren sein dürfte. Die Randschildchen, d. h. jene, den äußjeren Ventralschildern angrewzenden T'äfelchen erreichen mitunter eine ziemlich ansehnliche Gröbe und sind oftmals als ein viertes Paar longitudinaler Schilderreihen betrachtet worden. Die Anzahl sämtlicher Qnerbauchschilderreihen beträgt 25 bis 30 ; die zwei letzten Reihen, welche an die Praeanalschilder grenzen, bestehen aus 6 kurzen Schildchen. Die Aftergegend ist von einem groben fünfseitigen, an seinen bcken gewöhnlich leicht abgerundeten Anale bekleidet, dessen freie, der Spalte zugekehrte Kante die längste ist; 
vorn und seitlich erscheint dieses Schild von 2 Bogenreihen kleiner Schildchen begrenzt; die dem Anale zunächst liegenden sind stets grölier als diejenigen, welche sich mehr nach vorn an der Grenze der Ventraltafeln befinden. Die 40 bis 67 Längs- und in 125 bis 168 Querreihn angeordneten libckenschupen sind stets gewölbt und fast immer, wem anch nur schwach gekielt. In Bezug auf ihre Gestalt und Größe zeigen sie eine große Mannigfaltigkeit: bisweilen sind sie äufserst klein, rundlich körnig und ziemlich stumpf oder deutlich gekielt, mitunter erscheint die nach aufen zu gelegene Fläche der Körnerschuppen dreieckig, indem die erhabene Spitze der Schuppe sowie auch der Kỉel gegen den Rand der Schuppen zu liegt und die beiden nach der Spitze gehenden Seiten etwas konvex gebogen erscheinen. In letzteren Fällen ist der allgemeine Umrib und namentlich die Basis der Schuppen undeutlich; in anderen Fällen aber erscheinen die Schuppen ziemlich grok, so namentlich bei den im Gebirge, wie Z. B. in den Pyrenäen, im Kaukasus, und auch auf einigen Inseln, beispielsweise auf der Insel Glenan (an der Bretagner Küste) lebenden Mauereidechsen. Auch büßen sie sehr oft ihren rundlichen Umrís ein, indem sie rundlich regulär-hexagonal oder länger als breit und mehr scharfeckig erscheinen. Bei einigen muralis, wie $z_{*}$ B. bei den kaukasischen saxicola, entstehen die Kiele auf eine ganz eigentümliche Art: die Schuppen erscheinen nämlich in ihrer Mitte oder gegen den Raud hin schwach der Länge nach eingedrückt und lassen bei stärkerer Vergröferung deutlich eine etwa rinnenatige Vertiefung erkennen, deren einer land hervorragt und den Kiel repräsentiert. Gegen den Nacken hin erscheinen die Schuppen etwas kleiner und rundlich körnig oder rundlich regulär-hexagonal und sind bald gekielt, bald ungekielt. An den Rumpfseiten treten in der Regel nur Spuren von Kielen auf; die an den Bauchgrenzen sich befindenden Schuppen büßen ihre Kiele gänzlich ein und gehen allmählich in die »Randschildchen « über. Die Form der Rumpfseitenschuppen ist länglich abgerundet vierseitig; gegen die Schwanzwurzel hin erscheinen die Schuppen nahezu durchweg länger als breit, hexagonal, meistens scharfeckig und deutlich längsgekielt. 3 bis 4, in seltenen Fällen .5 Schuppengürtel entsprechen der Länge einer Bauchtafel. Querreihen von Rumpfschuppen sind meist 140 bis 150 vorhanden, obwohl diese Zahl sich manchmal auch bis auf 156 steigern, oder auf 135 herabsinken kann. Die Anzahl der longitudinalen Schuppenreihen betrügt 40 bis 60 . Die in 87 bis 110 Quergürtel angeordneten Schwanzschuppen sind oben fast gerade abgestutzt, oder stumpfwinklig ausgezogen, unten erscheinen siv an der vordersten Schwanzhälfte gerade abgestutzt, gegen das Schwanzende hin aber mitunter scharf zugespitzt. Während die oberen gleichseitigen Schuppen am Schwanzanfang in der Regel mit stumpfen Kielen versehen sind und erst gegen das Schwanzende hin scharf gekielt erscheinen, sind die bedeutend kürzeren unteren, an der Schwanzbasis 
gelegenen Schuppen gewöhnlich ganz glatt und erhalten erst gegen die Mitte des Schwanzes ziemlich scharfe, die Schuppe in gleiche Hälften teilende Kiele. An den Schwanzseiten sind die Schmpen ungleichseitig, mehr in diagonaler Richtung gekielt.

Schenkeldrusen und Kähne.

Die Zahl der Schenkeldrüsen schwankt, zwischen 17 und 23 jederseits; z. B. bei den kankasischen Mancreidechsen laun die Zahl bis auf 13 herabsinken oder aber, wie es öfters bei den balearischen formen der lall ist, sich bis anf 24 oder 25 steigern; in selteneren Fällen sind 26 bis 29 (so z. B. bei Var. Latastei) vorhanden. In Zwischenkiefer sind 6, oftmals aber 7 Zähnchen sichtbar; die Zahl der zweispitzigen Yähme im Oberkiefer beträgt jederseits 14 bis 18 , im Unterkieler sitzen im ganzen 38 oder 40 , ebentalls zweispitziger Zähne, nach Leydig sollen sogat 46 konstatiert worden sein. Am Gaumen mangeln die Zähne in der Regel vollständig.

Subspecies und Varietiten.

Subsp. fusce de Bedriaga 1878 (Herpetolog. Studien in: Archiv f. Naturg. 44. Jahrg. I. Bd. S. 267 ; ebendas. 45. Jahrg. 1. Bd. S. 288 ; Bull. Soc. Zool. de France IV. p. 212. - Schreiber, Herpetolog. europ., p. 408. Typus, var. a, e, f, g, m, n, o, J, s. - La taste, Essai d'une Faune de la Gironde in: Act. Soc. Linn. Bordeaux, t. XXX, p. 71 . Duméril et Bibron, Erpétol. gén. V, p. 228, var. b, c, d, f, g, i, k. - Fatio, op. cit., p. 92. - L. Brongniardii Daudin, op. cit. t. III. p. 221. - P. mualis var /laviventris Il assalongo, 1. c. - L agilis Latreille et Sonnini op. cit. $-P$. muralis auctor., $P$. albiventris Massal. (non Bonap.), $P$. flaviventris (Massal.) de Betta, P. cupreiventris Mass., De Betta, Nuova serie di note erpetologiche etc. in: Atti Ist. Veu. Sc. e Lett. Ser. V. T. V. 1879; P. muralis a uct. var. a, b, c, d, e. De Betta in: Atti Accad. di Agricolt. etc. di Verona, XXXV, p. 154. - Leydig, Die in Deutschland lebend. Art. d. Saurier, S. 225. Schlegel, De Dieren van Nederland. Gewervelde Dieren, p. 7. Taf. II, Fig. 1. Haarlem 1862. - L. Merremia, maculata, agilis, fusciata Risso, op. cit. T. III. p. 86. - T'schudi, Monogr. d. schweiz. Echsen, S. 37. - Seps muralis Laurenti, Synops, reptil. pag. 162. ${ }^{1}$ ) - Bekanntlich wurde die in Deutschland in der Rheingegend. und dem Donauthale häufig vorkommende braune Mauereidechse zuerst von A I drov a n d i in seinem, im Jahre 1663 erschienenen Werke »De quadrupedibus digitatis oviparis« beschrieben und Lacerta vulgaris genannt. Diese vorlineische Benennung aber erwies sich schon deshalb unpraktisch, woil der Ausdruck communis

1) Vergl. die Synonymie von muralis fusca in meiner im Bull. Soc. Zool. de France 1879, po 212 publizierten Schrift über die Varietäten von der Mauereidechse. 
oder vulgaris, wie Leydig treffend bemerkt, je nachdem der Forscher im Süden oder Norden lebt, sich auf verschiedene drten bezieht und dadurch zu endlosen Verwirrungen führen würde. Der Nachfolger Aldrovandis, Laurenti, bezeichnete die betreffende Eidechse als Seps muralis, welche postlineische Benennung heutzutage noch freilich in etwas modifizierter Weise - indem nämlich der Gattungsname »Seps in den ihm jetzt entsprechenden Namen »Lacerta« umgeändert worden ist, - die braun gefärbte Nauereidechse bezeichnet. Indem die von Laurenti gegebene Beschreibung zur Diagnose des Tymus von muralis erhoben wurde, gaiten sämtliche ubrigen von jener Beschreibung durch Färbung oder andere Merkmale abweichenden Formen der Nanereidechse fur Abarten und wurden selbst von den kritisch verfahrenden Forschern der L. muralis Laur. untergeordnet. - Als ich die grüne Mauereidechse Italiens, die grölier ist als dic Laurentische Form, kennen lernte, war ich erstaunt, in derselben nur eine Varietät der braunen muralis erblicken zu müssen. Die nähere Betrachtung und Vergleichung des sogenannten Typus und der grünen Abart jedoch erwies, dab beide ebenso gut als Subspecies gelten könnten, und dab̉ die grüne Manereidechse einer besonderen Benennung bedürfe. Sie wurde von mir damals mit dem Namen $L$. muralis neupolitanas belegt. Wenn wir uberlegen, daf $L$. muralis $\mathrm{L}$ a ur. ebenso gut wie muralis neapolitana und so vicle andere in jüngster Zeit bekannt gewordene Eidechsen, echte Mauereidechsen sind, so nüssen wir entschieden dic Laurentische Benennung "Lacerta $(S c p s)$. muralis « bloß als KollektivBezeichnung betrachten, dagegen die bis jetzt unter dem Namen smuralis La ur.« bekannte Eidechse mit einem passenden Subspecies-Namen belegen. Aus Prioritätsrücksichten war ich darauf bedacht, einen älteren, brauchbaren Speciesnamen zu restituieren, stieb jedoch dabei auf unüberwindliche Schwierigkeiten und wurde endlich nach langem Suchen gezwungen, die in Rede stehende Eidechse als subsp. fuscu zu bezeichnen.

Was die Gröfe und Körpergestalt anbetrifft, so weicht die fusca von der Subsp. neapolitana insofern ab, als sie schlanker und in der legel etwas kleiner ist; auch ist ilur Kopf gewöhnlich niedriger als bei der zuletzt genannten Lacerta. Die Details in Mafen der fusca lasse ich hier folgen, indem jeh bemerke, daf No. 1 aus Persien, No. 2 und 3 ans Heidelberg, No. 4 und 5 aus Görz und No. 6 aus Trapezunt (No. 2718 im Mlus. d'hist. nat. in Paris) stammen.

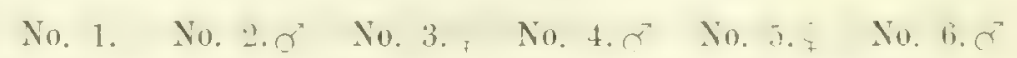

Gesamtlänge . . . $146 \mathrm{~mm} \quad 185^{1 / 2} \mathrm{~mm} \quad 159^{1 / 2} \mathrm{~mm} \quad 189^{1 / 2} \mathrm{~mm} \quad 168^{1 / 2} \mathrm{~mm} \quad 176^{1 / 2} \mathrm{~mm}$

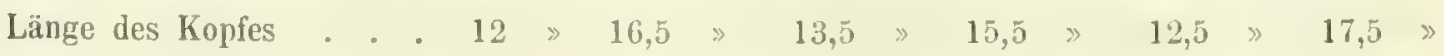
Breite des Kopfes ... 7,3 » 10,5 » 8,5 » 9,7 » 8,3 » 12 » 


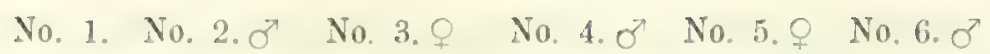

Höhe des Kopfes. . . $\quad 3,7 \mathrm{~mm} 8 \mathrm{~mm} \quad 6 \mathrm{~mm} \quad 7,7 \mathrm{~mm} \quad 6,3 \mathrm{~mm} \quad 9 \quad \mathrm{~mm}$

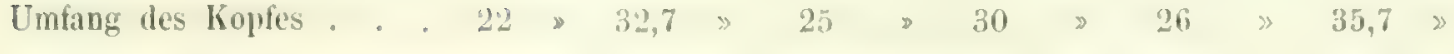

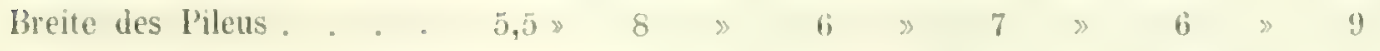

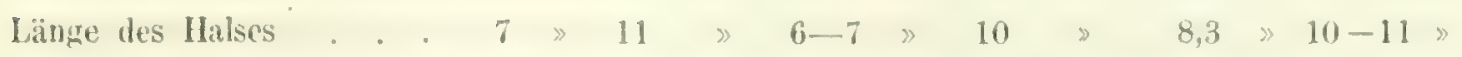
Umfang des llalses . . 21 » 33 》 23,7 » 30 》 $26 \quad 37-38$ 》 Länge des Rumpfes . . 38 》 48 》 40 》 45 》 48 》

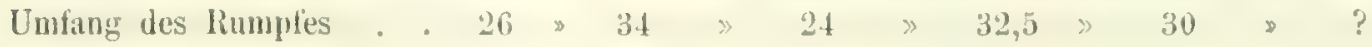

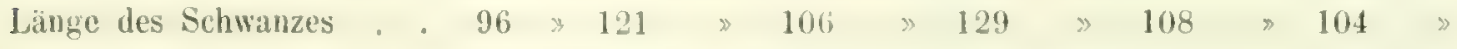

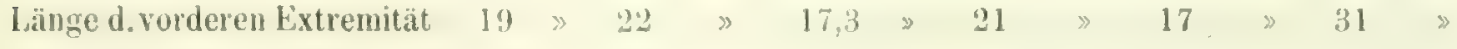

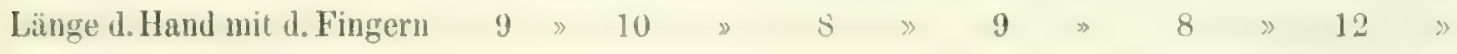

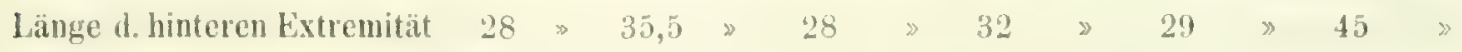
Länge d. Futies mit d. Zehen $14 \geqslant 17$ » 13,5 » $15 \quad$ » $14 \quad$ 》 21 》

Etwa zehn Monate alte fusca aus Heidelberg messen 67 bis $70 \mathrm{~mm}$.

Die Farben und namentlich dic Zeichnungen sind in ein und derselben Lokalitat autserordentlich verschieden, jedoch lassen sich in den meisten Fällen sämtliche Zeichnungsänderungen auf ein Grundschema zurückfuhren, ja selbst bei den nahezu cinfarbigen lichtbraunen muralis Spaniens sind wir in der Lage den der fusca eigentümlichen Zeichnungstypus zu erkennen, und zwar in einem helleren Dorsalband, das jederseits von einer dunkleren Seitenzone umsäumt erscheint. Beståndigere Formen, insofern sie, obschon wieder variierend, doch inmer cine gewisse Stabilität der Merkmale zeigten, habe ich folgende gefunden.

Die breite hellnubiblaune Rückenzone der mir von der Ostküste Syaniens vorliegenden muralis ist von zwei etwas dunkleren Bänlern, welche hinter den Augenhöhlen ihren Ursprung nehmen und an der Wurzel der Hinterextremitäten enden, umsäumt; die Oberseite des Kopfes, der Gliedmatsen und des Schwanzes, ferwer die Bauchgrenze sind hellbraun gefarbt; dic unteren Körperteile erscheinen bläulich- oder grünlichgelb. Diese Heckenlose und nur eine Spur von Bebänderung zeigende Var. hispanica geht in eine deutlich gebänderte und gestreifte Form über, welche sowohl im circummediteranen Gebicte als auch in Mitteleuropa weit verbreitet ist.

Die Farbe der Rückenzone ist bei den ginz jungen Exemplaren dieser gemeinen Form meistens braum mit einen bald mehr grauen, bald mehr olivengrünlichen Anthge versehen, jedoch kommen auch Stücke mit ziemlich dunklem olivenbrïunlichem Rücken vor. An den Rumpfseiten sieht man eiue dunkelbraunc, ja zuweilen selbst schwarzbraune Binde, zu deren beiden Seiten sich äulserst schuale helle Streifen hinziehen; die Bauchgrenzen sind wiederum 
dunkelbraun koloriert. Sowohl der Rücken als auch die Oberseite des Kopfes, der Gliedmafen und des Schwanzes erscheinen meist ungetteckt oder erhalten nur Spuren von dunklen Flecken: die Schuppen an den Seiten und an der Unterseite des Schwamzes aber erscheinen dunkel gezeichnet; bei maherer Betrichtung ergiebt es sich, dab diese Schupen weil grandet und schwarzbran getleckt siud und dals die weiblichen Striche an den Schwanzseiten nichts Anders als die Fortsetzung jener hellen Streifen rorstellen, welche die Rumpfseiten des Tierchens zieren. Die ungezeichneten unteren Körperteile sind gelblich ode1 bläulich überHogen. Mit zunehmendem Alter pHegen die Farben der Lörperoberseite gewöhnlich, aber nicht immer, heller. namentlich grünlich-, gelblich- oder hellnubbraun zu werden, variieren ubrigens in allen möglichen Schattierungen zwischen Gelb- und Olivenbraun, ja gehen zuweilen selbst in tiefes Schwarzbraun über. - Unter den von mir untersuchten fusc stief ich auf folgende Äuderungen der Zeichnung:

a) Dic hellnulabraune, ungezeichnete Rückenzone erscheint jederseits von einer schmalen, weiflichen oder gelblichbraunen Binde umsäumt, welche am äuferen seitlichen Rande der Parietalschilder ihren Ursprung nimmt. Darauf folgen $1^{1 / 2}$ oder $2 \mathrm{~mm}$ breite, dunkelbraune Binden, die an den Wurzeln der Hinterextremitäten enden. Diese Binden werden wiederum von schmalen gelblichen Längsstreifen begrenzt. Als Fortsetzung der letzteren müssen die gelblichen, die supralabialen zierenden Flecken und die hellen Streifen an den Schwanzseiten betrachtet werden. - b) Grundfarbe des Rückens hellnufbraun; die Seitemregionen zeigen eine Tendenz ins Rötliche. In der Mittellinie des Körpers zieht sich eiu, aus weit voneinander entfernten, dunkelbraunen Flecken bestehendes Band hin; auf jeder Seite, oberhalb der Obröffnung nimmt ein Seitenstreifen seinen Anfang, um sich etwa neben dem Vordergelenk in der die Rumpfseiten zierenden Netzzeichnung zu verlieren. - c) Farbe der Oberseite wie bei b); auf der Mittelzone des Rückens ziehen sich 3 zickzackartige braune Fleckenstreifen hin. Die Seitemregionen sind äulierst stark gefleckt; die Grundfärbung erscheint hier als kleine Makeln. Bei näherer Betrachtung dieser Zeichnung kann man deutlich genug sehen, daf dieselbe aus 2 parallelen Streifen besteht und dafi die Streifen gegeneinander Äste bilden und diese sich wieder verbinden. Die Grenze dieser Seitenzeichnung stellt ein rom Auge sich hinziehendes goldgelbes, schmales Band dar, welches sich in der Caudalwurzel verliert. Die Seitenzeichnung ist jedoch nicht ohne Unterbrechungen, die durch einen, sich von der Schnauze und unter dem Auge hinziehenden hellen Streifen verursacht werden. - d) Eine schwach ausgeprägte braune Mittellinie oder Fleckenreihe zieht sich auf dem hellbraunen (café au lait) Rücken hin. Die Seitenteile des hörpers sind dunkel genetzt: die Maschen dieses Jetzwerkes lassen den Grund- 
ton hervortreten; dieser erscheint nicht immere einfarbig, sondern die böher gelengenen Maschen sind öfters kafteebraun, die zu unterst liegenden hellnufbraun. - e) Die Grundfarbe des Rückens ist ein Grün- oder Graubraun, das bein Mïnnchen mehr grün, beim Weibehen mehr gelblich oder auch dunkler ist. Quer über den Rücken laufen zackige dunkelbraune Flecken oder geschlängelte Linien, welche mitunter ineinandertliefien und ein allerdings meistens schwach angedeutetes Netzweri hilden. - f) Der mittlere Teil des Rückens ist dunkel graubraun. mit schwachgrüulichem 'Ton. Z Zu beiden Seiten des Rückgrates ziehen sich wellenförmige, vielfach unterbrochene dunkelbraune Streifen hin; an den Seitenteilen des Rückens sind in Längsreihen angeordnete grüngelbe runde Makeln sichtbar. - g) Die Oberseite des Körpers ist bronzebraun mit einem Stich ins liotbraune. Zu beiden Seiten der Wirbelsäule laufen wellenförmige, dunkelbraune, mitunter fast schwarze, schmale Bänder, welche sich öfters in unregelmäfige Flecken auflüsen; an diese grenzt von auben jederseits ein gelblichgrüner, schmiler Streifen, ler nach hinten sich an die Oberschenkel hinzieht; lerselbe besteht entweder aus einzelnen, oder zuweilen auch aus miteinander verbundenen runden Flecken. Dieses Fleckenband wird von aufien wiederum von dreieckigen, schwarzen Flecken begrenzt. Endlich schliefit sich an dieses letztere auf jeder Körperseite, vom seitlichen Rande der Sc. parictalia anfangend, ein vorn zusammenhängendes, nach hinten aber in einzelne Flecken sich auflösendes gelbes oder gelbgrünes Band. Die übrigen seitlichen Teile des Rückens enthalten auf hellem Braun gelbe, runde Makeln. - h) Die hellbraune oder braungraue Rückenzone ist fleckenlos oder mit wenig abstehenden, schnörkelartigen und deltaförmigen brannen Figuren und einem schmalen, aus dunkelbraunen oder schwarzhraunen Fleckchen bestehenden Ruckenstreifen versehen. Die dunkelbriunen, hinter den Auren berinnenten und die Rumpfseiten zierenden Binden sind unten geaugt und mit brïunlichweiben, weililichen oder scolblichen Punkten betüpfelt, gegen den Rüicken hin erhalten sie einen schmalen hellen Saum und sehen ausgezackt aus. - i) Auf hellnukbrauner Ruckenzone befinden sich :3 dunkelbrame, aus grolien dunkelbramnen, untereinander verbundenen Flecken bestehende Binden; zwischen den seitwärts liegenden Binden und den dunkelbraun genetzten und hell geaugten Rumpfseiten befinden sich die, der fusca ckarakteristischen hellen, oberhalb der Augenhöhle ihren Ursprung nchmenden und sich bis auf den Schwanzanfang hinziehenden hellen Streifen. - (Habitat: Bocognano und Bastelica auf Korsika.) - j) Die schwarze oder dunkelbraune Oberseite des Körpers ist von etlichen blatigelben Längsstreifen Ilurchzogen. - (Fundorte auf Korsika.)

Die Kopflecke und die Oberseite der Extremitäten und des Schwanzes erscheinen bei den üpigg gezeichneten Exemplaren der muralis fusca auf braunem oder olivenbraunem Fond deut- 
lich dunkel geffeckt, bei ilenjenigen Stïcken aber, leren Körperoberseite weniger stark gezeichnet ist, sind Kopf, Schwanz und Beine nur spurweise und hell geatut; die Schwanzseiten sind lellhram oder weiklich mol dunkelhrann gestreift oder mit Makeln versehen, welche in Längsreihen angeordnet erscheinen. Oberhath der Wurmel des Vorderextrenitatenpaares liegen in den meisten Fällen sehr scharf ausgeprägte schwarze Flecken und weifiliche, gelbliche oder bäuliche und grünlichweilie dunkel umrandete Ocelli; diese Zierden kommen allerdings vorzugsweise bei dem minnlichen Geschlechte vor, anch diejenigen schwazen, blauen und grünlichen Flecken, welche oftmals die änfiersten longitudinalen Banchachilderreihen schmücken, sind meistens nur bei den Mämohen vorhanden. Die Männchen sind ferner in der Regel dadurch gekennzeichnet, daß die dunkle unregelmäkige Zeichnung des Oberkörpers schärfer aufzutreten und die oben erwähnten, der muralis fusca eigentümlichen Zonen oder Lüngsstreifen zu verdrängen ptlegt, wïhrend sowohl bei den Weibchen, als auch bei den jungen Stücken die Längsbänder oder Streifen meistens gut nachweisbar sind. Endlich mut noch erwähnt werden, daf3 die Männchen den Weibchen gegenüber auf der Unterseite ofters greller gefärbt und stärker gepunktet erscheinen. Gewisse Farbentöne, so \%. B. Ziegelrot und das intensive Gelb treten vorzugsweise bei dem männlichen Geschlechte auf. Die Farbe der Unterseite kann von einem perlmutterglänzenden Weics einerseits durch Grau in Hellblau oder Ifllgrün, anderseits durch Gelh bis zum Ziegelrot mannigfaltig abändern. Gesättigte Farbentöne kommen namentlich am Banche und in der Kehlgegend zum Vorschein, während die Extremitäten stets etwas heller gefirht und die Schwanzunterseite, mit Ausnahme der in der Regel gelblichen, weiklichen oder rötlichen Mittel\%one, bläulich, grünlich oder grau angeflogen erscheint. Die Kéehlschuppen sind mitunter, wie es $\%$. B. bei den, mir aus Levico (Süd-T'irol) vorliegenden Exemplaren, welche ich der Güte des Herrn Marquis G. Doria verdanke, der Fall ist, abwechselnd schachbrettartig, blan und rot gefärbt und dunkel gepunktet. - Die Unterlippenschilder sind meistens bläulich gefärbt und öfters auch dunkel gefleckt; ebenso Sc. submaxillaria. Die Unterseite des Schwanzes und der Gliedmafen, die Brust und der Bauch mit Ausnahme der stets entweder blau oder schwarz oder blau und schwarz gefleckten äuferen Ventralschilderserien sind fleckenlos oder schwarz gepunktet und gefleckt. Das ursprüngliche Kolorit des Banches und der Kehle wird zaweilen durch eine stark entwickelte und in from von Würfoln auftretende schwarze Zeichnung fast gänzlich verdrängt. Sowohl lionaparte, als auch Massalongo haben sich bei der Unterscheidung der zahlreichen binnenländischen Formen der Manereidechse der Färbung mnd Zeichnung des Bauches als diagnostischer Nerkmale bedient; diese Einteilung haben De Betta, Fatio und Lataste adoptiert und führen in ihren Schriften var. albi- 
ventris, Raviventris, muriventris, nigricentris u. S. W. auf, da jedoch diese angeblichen Varietäten durch unzählige 'Wwischenformen verkettet sind, so glaube ich davon absehen zu müssen, mich der Linteilungsmethode meiner Vorginger anzuschliefsen. - Was den Verbreitungsbezirk ler fusca in Europa, Asien und Afrika anbelangt, so will ich hierüber an Schlusse dieses Alschnittes einige Bemerkungen hinzufigen und gehe vorlüufig zur Beschreibung einiger, mehr oder weniger auffallender Varietiiten dieser Subspecies über.

Var. favinudate in. (Vergl. Hig. 3. 'Taf, XVII im Archiv f. Naturg. 45. Jahrg. 1.Bd.). Die Oberseite des Oberkörpers, des Schwanzes und del Kopfseiten ist rabenschwarz; auf dem Räcken und den Rumpfsciten verlaufen feine wellenförmige, goldgelbe Querstreifen; die Schädeldecke und lichle sind auf schwarzem Grunde gelb gemakelt; gelbe Augenflecken zieren vorzugsweise die hinteren Extremitäten; die schwarzen Schwanzschuppen sind grelb gerändert. Der weibliche Untergrund des Bauches wird durch eine stark entwickelte und in Form von Würfeln auftretende schwarze Zeichnumg verlrängt. Die mach anfen liegende longitudinale Bauchschilderreihe ist intensiv grün; das schwarze gelbumsäumte Afterschild und die schwarze Unterseite der hinteren Gliedmalien lassen die tief gelbkolorierten femoraldrüsenreihen sehr deutlich hervortreten. Die Unterseite des Schwanzes ist stahlgrau, gelb gefleckt. Die 'lotallänge beträgt $173 \mathrm{~mm}$, wovon $16 \mathrm{~mm}$ auf den Kopf und $110 \mathrm{~mm}$ auf den Schwanz kommen; die Kopfhöhe beträgt $7 \% \mathrm{~mm}$; der grö́te Umfang des Kopfes ist $33 \mathrm{~mm}$. - Der Fundort dieser Abart ist Rom.

Var. corsica m. (Vergl. meine Beitr. z. Kienntnis d. Amphibien u. Reptilien d. Fauna v. Korsika in: Archiv f. Naturgesch. 1853. Bd. I. S. 269). Die schwarze Oberseite des Körpers ist von etlichen blabgelben Lüngsstreifen durchzogen. Die erste longitudinale Banchschilderreihe ist grün gefleckt; die übrigen Bauchplatten erseheinen grauweits und sind schwarz punktiert.

- Fundort: Bocognano in Korsika.

Var. Rasquincti m. (Vergl. 'I'af. X, fig. 1, 2 in: Archiv f. Naturg. 44. Jahrg. I. Bil.). Die Grundfarbe der Rückemregion, der Schädeldecke und der Schwanzoberseite bezeichnet ihr Entdecker Dr. E. Rasquinet als dunkel- oller schmutzigülgrün. Das mir im Herbst 1877 übersandte Männchen zeigt ein dunkelbrames Kolorit mit nu äuferst schwacher Tendenz ins Grüne. Aller Wahrscheinlichkeit nach hat das Tier seine ursprüngliche Fürbung eingebülit und stand dem Hiutungsprozesse nahe. Die Mittelzone der Oberseite erweist sich dunkelbraun, die Seitenzonen etwas heller. Die seitlichen Teile des Rumpfes sind prachtvoll himmelblau. Die Schädeldecke dunkelbraun mit einem Stich ins Grüne. In der Mittelzone des Oberkörpers verläuft eine schwarze Fleckenbinde, welche sich etwa hinter der Schwanzwurzel verliert; diesem 
Mittelbande parallel ziehen sich mehr oder weniger regelmälig in Querreihen angeordnete, schwarze, meist zarte Streifen hin; diese Streifenserien nehmen ihren Ursprung hinter den Sc. parietalia; gegen die Seiten des Körpers verästeln sie sich und bilden eine Netzzeichnung. Dabei tritt selbstverständlich die himmelblaue Grundfarbe nur in den Maschen dieses Netz werkes zum Vorschein. Es ist dies eine Erscheinung, die uns öfters zu der irrtümlichen Annahme führt, die Zeichnung sei die Grundfarbe und der zu unbedeutenden Augentlecken reduzierte Grumiton sei das Zeichmungselement. Die gröbiten Maschen liegen oberhalb der Wurzeln der Vorderextremitäten. Die zwei zarten Längsbinden, die an der Ohröflinung ihren Ursprung nehmen und jederseits eng aneinander liegen, sind untereinander durch zahlreiche Querstreifen verbunden. Die Wangen, mit Ausuahme des unter dem Auge liegenden Supralabiale, das schön blaugrün koloriert ist, sind schmutzigrosa mit schwarzen Punkten. Die Kehlschuppen sind abwechselnd schachbrettartig schmutzig weib, schwarz, blau, braun und rot gefärbt; die Unterlippenschilder auf schmutzigrosa Grunde braun gefleckt; ebenso Se. submaxillaria. Besonders schön und grell sind die Farben der Bauchgegend. Die mittleren 4 longitudinalen Bauchschilderreilien und die Brust sind rot, die seitlichen Reihen himmelblau. Letzte Farbe geht teilweise auch auf die daneben liegenden roten Schilderserien über, so dal.s wir Schilder wahrnehmen, die zur Hälfte blau und zur Hälfte rot gefärbt sind. Während das mediane Par der Schilderreihen hier und da spärlich punktiert ist und die blauen, uach außsen liegenden Tafeln jeglicher Fleckungr entbehren, sind die äbrigen, zum Teil blau und rot gefirbten Reihen stark gefleckt. Das Anale und die Preanalen sinl prachtvoll rot. Die Unterseite der Vorderextremitäten ist schmutzig rosa-grau gefleckt, die der Hinterbeine dagegen mamigfaltig koloriert, es wechseln hier mosakartig blaue, schwarze, rote und hellbraune Schilder ab; die Fufsohlen sind schmutzigrosa. Die Beine oberhalb auf hellbraunem Grunde dunkel gefleckt. Der' Schwanz ist oben braun, unten rot gefürbt und spärlich punktiert. - Die Totallïnge von der Schnauzenspitze bis zum Schwanzende beträgt $185 \mathrm{~mm}$, wovon auf den Kopf $18 \mathrm{~mm}$ und auf den Schwanz $18.5 \mathrm{~mm}$ kommen; der grö́te Unfang des Kopfes ist $34 \mathrm{~mm}$, del gröbte Höhendurchmesser des Kopfes $=8 \frac{1}{2} \mathrm{~mm}$, die Breite der Schüdeldecke an ihrer breitesten Stelle 8 mm. - Fundort: La Deva, eine in der Nähe von Arnao (an der cantabrischen Kiuste) ilegende Insel. ${ }^{1}$ )

Var. mitensis m. (Vergl. meine Arbeit üb. die Amphibien u. Reptilien Griechenlauds in: Bull. de Moscou 1881, No. 3, pag. 98). Die Oberseite des Kopfes, die Mittelzone des Rückens und des Schwanzes erscheinen hellnubbraun. Graue Ocelli, oder in selteneren Fällen dunkel-

$\left.{ }^{2}\right)$ Näheres darüber im Archiv f. Naturg. 1878, Bd. 1. S. 260. 
braune Punkte, lassen sich auf der liickenzone unterscheiben; die Seiten des Rumpfes und les lioptes erhalten ant gelbem oder grumgelbem fond schwaze Querbinden. bitliche blatue Ocelli zieren die Seiten und treten ith den Whreln der Vorderextremititen besonders schart hervor. Blane und grüne Flecken bedecken dic äuljersten longitudinalen Bauchschildereihen. Der Batuch und die Kehle erhalten auf bläulichem Grunde cine Anzahl schwarzer wurfelartiger Flecken. Die Unterseite des Schwanzes zeigt einen rötlichen Antlug. Die Körperform und die lö̈rpermalse dieser Form sind ungefihr dieselben wie bei subsp. fusca, nur scheint mir der Lopf etwas höher und cher pyramidenförmig als abgeplattet und der sehwanz etwas küzer zil sein. - Fundort: Insel Milo.

Var. Erhardi m. (1. c. S. 99), - Diese Abart weist oben, auf graubraunem Grunde 3 oder 4 gelbgrume Längsstreifen auf, welche an den Halsseiten aber intensiv citronengelb erscheinen. Die Kehle ist gleichfalls citronengelb, der Bauch schmutzigweifz; die auliersten Jongitudinaleu Batchschildereihen sind blaugrüu. - Sowohl die Halsbandtafeln als anch das Massetericum und das Tympanale zeichnen sich durch ihre geringe Gröbe aus, - Fundort: Insel Seriphos im griechischen Archipel.

Var. saxicole Eversm. (Nouv. Mem. de Hoscou III. p. 349. Tab. XXX. fir. 1. Kessler, Zoolog. Reise durch Transkaukasien im Jahe 1875, 1. c.). - 》Der ganze Oberkörper«, sagt Eversmann, what cine lauchgrune Farbe, uberall mit schwarzen Flecken besetzt; nur die Seiten, in der Dicke des Kopfes, sind stark mit braun tingiert, so daf auf dem Rücken ein breiter grüner Streifen, in der Breite des Kopfes übrigbleibt, der an den Seiten durch die braune Farbe und durch die schwarzen Flecken in denselben zackig begrenzt ist. Die Flecken in den reingrunen Streifen stehen nicht gauz regelmäligig, jedoch lassen sich im allgemeinen zwei Hauptreihen bemerken. Del Banch ist schün weils mit Perlmutterglauz, die äufiersten Bauchschilder sind mehr oder weniger schön himmelblan. Kessler fügt der Eversmannschen Beschreibung ungefïh folgendes hinzu: „Die hellbrane oder blatigrüne mediane Rückenbinde wird fast immer in der Nähe der Wirbelsäule von 2 Reihen schwärzlicher Flecken, welche zuweilen mehr oder weniger zusammenflieben, durchzogen; gegen die Riande' hin erscheint diese Binde etwas heller, ja bisweilen sogar weililich, wodurch sie von den braungrauen Rumpfseiten, welche von 2 festonierten schwilzlichen Bändern, von denen das obere nahezu stets weikliche Augenflecken enthält und breiter und dunkler als das untere ist und öfters durchbrochen erscheint, deutlich abgegrenzt wird. Die Unterseite des Körpers ist blatsgrünlich; an den Rändern der äuferen Bauchtafeln befinden sich mitunter bläuliche Flecken, welche von del unteren Seite durch eine schwärzliche Binde umsiumt werlen«. - Die mir 
vorliegenden, aus Elenowka am Golitsch-See stammenden Exemplare, welche ich der Güte des Herm Dr. Strauch verdanke, zeichnen sich sowohl durch ilne Farbung als auch durch ilure Körpergestalt und Beschuppungr aus. Der Rücken nimmt in der Breite der Kopfschilder eine gelblichbraune gelb, ja bisweilen goldgelb umsäumte Binde cin; die mediane Rückenzone ist mit bald kleineren, bald grölseren umregelmälig oder in mehreren Längsreihen gestellten Klecken oder Punktflecken, odcr aber mit kurzen, querangeordneten Linien und schwarzbramen Flecken besetzt. An jeder Seite des Körpers befindet sich eine, in der 'Temporalgegend begimnende und auf den Schwanzanfang übergehende schwarzbraune Zickzackbinde, welche sich deutlich vom braunen Untergrunde abhebt; gegen die Bauchgrenzen hin sind auberdem öfters hellbraune oder gelblichbrane runde, zum Teil dunkelbraun umrandete Flecken sichtbar. Schwarzbratune Punkte finden sich auf der braunen Kopfobertäche und auf den brïunlichgelben oder graugelben Schnauzenseiten verteilt; sowohl auf der Oberseite der vorderen als auch der hinteren Gliedmalien sind auf hellbraunem Grunde helle, von schwarzbraunen Fleckchen begleitete Ocelli vorhabden. An den Schwanzseiten und längs der Mittellinie des Schwanzes verlaufen bisweilen zickzackförmige schwarzbraune Linien, mitunter aber lösen sich diese Linien schon am Schwanzanfange in einzelne Flecken auf und bilden gegen das Schwanzende hin, indem sie der Quere nach incinandertlietsen, wellenförmige Querbinden; der Scbwanz kann übrigens auch nahezu ungefleckt erscheinen. Die Kehle ist spurweise blaugrün angehaucht oder sie ist gelb mit eingestrenten grünlichen Schuppen; mit Ausnahme der äulseren longitudinalen Bauchschilder, welche blaugrän und dunkelgrau gefleckt erscheinen, ist der Bauch einfarbig hellgelb; die größeren Tafeln an der Unterseite der Extremititen und die unteren Schwanzschuppen sind mit einem grünlichen Anttuge versehen.

Diese Form der muralis unterscheidet sich schon beim ersten Anblick von allen anderen durch ihren langen abgeplatteten Kopf und ihren breiten, stark plattgedrückten Rumpf. Bei den mir vorliegenden weiblichen Exemplaren erreicht der Schwanz die doppelte Körperlänge nicht; der Aussage Kesslers zufolge sollen jedoch Exemplare der saxicole vorkommen, bei denen der sehr dün ausgezogene Schwanz die Länge des übrigen Körpers um melı als $2 / 3$ ubertrift. Var. saxicola zeichnet sich ferner durch ihre äuferst schwach gekielten und spurweise furchenartig eingedrückten grotsen Rückenschuppen aus, namentich an den Leibesseiten erscheinen die etwas breiteren als langen, vierseitigen und mit abgerundeten Ecken versehenen Schuppen sehr groł; genau dieselbe Eigentümlichkeit zeigen übrigens alle mir bekannt gewordenen, im hohen Gebirge einheimischen muralis und ich habe seiner Zeit darauf hingewiesen, daf bei den Manereidechsen in den Pyrenien, so z. B. auf dem 1545 Meter hohen Gebirgs- 
passe Aspin ror allen Dingen die abgeplattete Körnerform und die grobe, der muralis nicht cigene Beschupung des läuckens auffällt. - Das sehr grofe Masseterieum ist von verhältnismälsig sehr kleinen f'emporalschildehen umgeben; die Palpebralscheibe und die Supraciliaren erscheinen durch eine kurze Könncreihe teilweise getrennt. Das ans 7 bis 9 'Tafeln bestehende IIalsband ist kinm merklich gezähnelt. Die Aftergegend ist durch das grobic Anale bedeckt, das von 7 bis S. schmalen l'afeln umgeben ist, von denen die mediane 'Iafel doppelt so grofis ist wie die übrigen. Die Malic dieser, laut Kessler den Kankasus-Lündern eigentümlichen Varietait sind folgende: Totallänge: 1621/2-164 mm; Kopflinge: $12^{1 / 2} \mathrm{~mm}$; grüliste Kopfbreite: $7^{2 / 3} \mathrm{~mm}$; grölite Kopflü̈le: $5 \frac{1 / 1}{\mathrm{~mm}}$; gröfiter Umfang des Kopfes: $23 \mathrm{~mm}$; Breite des Pileus: $5^{3} / 4 \mathrm{~mm}$; Halslinge: $8 \mathrm{~mm}$; Halsumfang: $24^{1 / 2} \mathrm{~mm}$; IRumpflänge: $48 \mathrm{~mm}$; Umfang des Rumpfes: 35-36 mm; Länge des Schwanzes: $103 \mathrm{~mm}$; Lünge der Vorderoxtremität: $20 \mathrm{~mm}$; der Hand und I'inger: $9 \mathrm{~mm}$; Länge der Hinterextremitiat: $291 / 2 \mathrm{~mm}$; de's Futies und der Zehen: 141\% mm. - Schenkeldrisenzahl: 13 bis 16 jederseits.

»Diese schöne Eidechse«, sagt Èversmann (I. c.), shabe ich im Kaukasus erstanden, wo sie an den Sandsteinfelsen, unweit des Saucrbrunnens Nordzana mit grofer Schnelligkeit umherlief«. Neuerdings sind mehrere von der saxicola bewohnte Örtlichlieiten namhaft gemacht worden, so beispielsweise die Umgegend von der Station Kasbek (6t00 Fuls Mecreshöhe), die Strecke zwischen den Stationen Passanuar und Mleti und der Berg Salawat in der Umgebung von Nuchat (Kessler); die mir zu Gebote stehenden weiblichen Stuicke stammen, wie gesagt, aus Elenowka.

Var. melisellensis Braun (Lacerta Lilfordi u. L. muralis etc. in: Arbeiten a. d. zool. zootom. Institut Wurzburg. Bd. IV. 'I'af. 1. Fig. 12. a, b. Taf. I1. Fig. 4. - v. Bedriaga, Local Colour-Yariation in Lizards in: Nature 1879, No. 516, 1. 481). - Die ganze Oberseite des Körpers, Kopf, Schwanz und Gliedmalien inbegriffen, erscheint bei den von Braun untersuchten Exemplaren schwarzbraun. Über den Rücken erstrecken sich 6 hellere Binden, die sich sehr deutlich abheben; das median liegende I'au derselben, das zu beiden Seiten der Wirbelsäule läuft und hinter den Hinterhauptsschildern beginnt, verbreitert sich anfangs, um sich alsbald nach hinten zu ein wenig zu verschmälern und auf dem Vorderteile des Schwanzes zu verlieren; die Ränder dieser Binden sind nach außen hin in der Mitte des Rückens gezackt. Das zweite, vorn ziemlich breite und scharf abgehobene, von der Mitte des Rückens an mit zackigem liande versehene und undentlich werdende Bindenpar beginnt jederseits an der äułeren und hinteren Ecke des Oecipitalschildes, während das dritte äuliere, am schwächsten

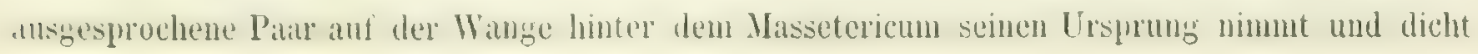




\section{$-12-$}

über dem Arm nach hinten lïuft, wo es sich an einem von Braun untersuchten Stücke bis dicht vor dem Oberschenkelgelenk erkennen läf, an einem anderen aber nur eben angedentet ist. Auf beiden Seiten des Körpers liegen eine Anzahl von rumen, helleren Fleckehen: namentlich tritt diese Flechung zwischen dem innersten und zweiten Bande zu 'Tare. Die Unterseite des Körpers, mit Ausuahne des etwas helleren Kinnes und der etwa blangrauen Schwanzunterseite, ist dunkelblan; die erste Longitudinalreihe der Bauchtafeln ist mit zachigen, leellblauen Flecken geschmückt.

Bei den mir zur Verfügung stehenden melisellensis, welche ich der Freundlichkeit des Herrn Dr. E. Schreiber verdanke, tritt dic helle Streifung spurweise und nur bei den Weibchen hervor, anch habe ich nu 2, oberhalb der Ohröffnung anfangende, leicht geschlängelte, grünlichbraune oder graubraune Streifen wahrnehmen können, welche die Rückenzone von den Rumpfseiten trennen; diese Streifon entsprechen geniu deujenigen bei der fuscu, welche Eidechse, nebenbei benerkt, diu Stammform sowohl der milesellensis als auch der Rasquineti, flaviumdata und milensis repräisentiert. Oftmals werden diese Streifen durch 2 Reilien bräunlicher, grünlichbramer oder graubranner und bläulicher Flecken ersetzt; in diesen Falle aber tritt gewöhnlich in der Nähe des Rückgrates ein Paar nitunter nnterbrochener, selımaler, heller Streifen auf, das am hinteren Rande des Occipitalschildes seinen Ursprungr nimmt und sich vorzugsweise deutlich bei den jüngeren lebenden, und anch bei den älteren, im Weingeist aufbewahrten weiblichen Stücken vom schwarzbramen Grundkolorit abhebt. In anderen Fällen gresellen sich diesen Streifen und Längsteilien vou Flecken noch andere, unregelmäbig auf dem Oberkörper verteilte hellere Flecken hinzu. Diese Fleckung und Streifung tritt selten und weniger scharf ausgeprägt bei den männlichen Exemplaren auf, in den meisten Fällen erscheint ihre Oberseite uniform dunkel, prïchtig blau schillernd oder mit brïunlichen Tinten versehen. Kopf, Gliedmalien umd Schwanz sind bei beiden Geschlechtern oberhalb schwarzbraun, unterlalb blau, graublau vder bleifarbeu; der Batuch ist meistens schön dunkelblau; die änkeren Läingsreihen der Bauchtafeln sind abwechselnd hellblau und schwarzbraun gefärbt; die übrigen Ventralschilder hellblau gerandet. Die Kopfseiten endlich zeigen bisweilen auf bräunlichem oder bläulichew, dunklem Grunde hellblaue Ocolli. Abgesehen von den Körpermąen und der Körpergestalt unterscheidet sich die insulanische Varietät »melisellensis« von den gleichfalls dunkel kolorierten muratis Lilfordi und cocruleu dadurch, dafs bei diesen das Blau prädominiert, währeud bei der uns hier interessierenden melisellensis meistens die schwarzbraune Grundfärbung vorherrscht, auch ist die Stammform der melisellensis die muratis fusca, wälrend die Lilfordi von muralis balearica, einer kräftig gebauten und relativ kurzschwänzigen insulanischen Nauer- 
cidechse, und die coemelea von Subsp. nonpolitanu, der gröf.sten, grünen binnenlïndischen muratis allyulciten ist.

Ich lasse hier einige Körpermalse von beiden Geschlechtern der metisellensis folgen:

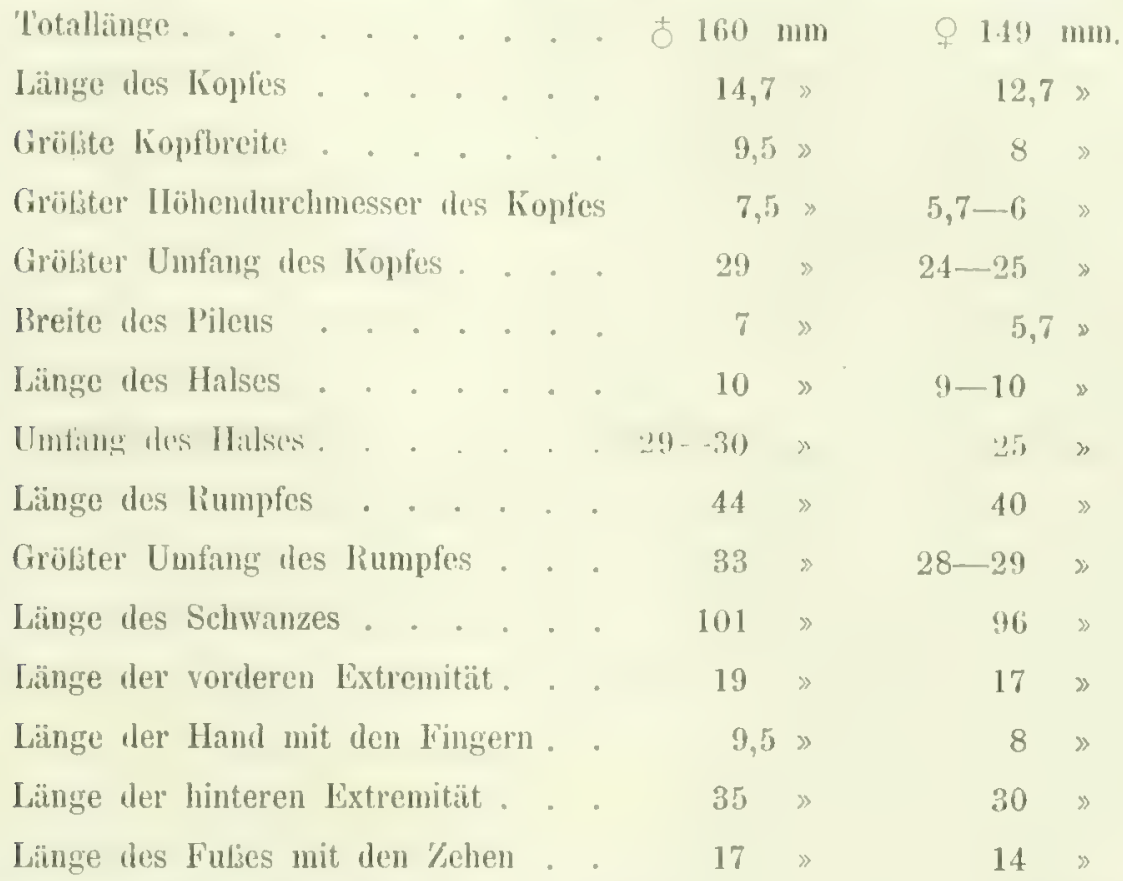

Die Originalexemplare, welche im k. k. zoologischen Kabinett in Wien aufbewahrt werden, stammen aus Melisello, einer Felseninsel bei Lissa in adriatischen Meere; der Güte des Herm Dr. Schreiber in Görz verdanke ich einige melisellensis yon der Insel St. Andrea, östlich von Lissa; auch auf Pelagosa soll diese Abart einheimisch sein; auf St. Andrea lommt die mclisellensis gemeinschaftlich mit der muralis fuscu vor, so dat man hier von ziemlich lichtbraunen bis zu tiefschwarzen Mauereidechsen ganze Reihen zusammenstellen kann.

Var. persica m. (Lacerta muralis M err. und D) e F. - part. - Bla nford, in: Eastern Persia, II. 1\% 361. London 1876). - Von den europäischen muralis fusca weichen die mir vorliegenden Stücke in einigen Punkten recht erheblich ah. Namentlich mufi ich das Fehlen des Massetericum hervorheben, was bereits Blanford aufgefalten ist. Wem Blanford angiebt: "In some specimens I find it (i. e. the usual large mid-temporal shield) entirely wanting, the whole temporal region being occupied by subequal scales«, so glaube ich daraus folgern zu kömnen, dat, das Fehlen des Massetericuns hei den persischen muatis eine nenerworbene Eigentümlichkeit ist. Ferner fallon bei den letzleren die kurzen Hinterextremitäten auf, die die Achsehn nicht erreichen, und endlich die greringen Körpermalie. In Bezugr auf die 
untergeordneten Merkmale dieser Subspecies muf hinzugefügt werlen, daf die Schläfe mit äufserst kleinen, länglichen, hexagonalen Schuppen bekleidet sind, dats die Rückenschuppen rundlich gewölbt und äuferst schwach gekielt erscheinen und dalj der niedrige und flache Kopf einen geringeren Umfang hat als der Hals. Das Halsbaud wird ans 10 bis 12 kleinen Täfelchen gebildet. Das Anale erscheint von 6 gröberen Schildern umgeben. Schenkeldrïsen konstatierte ich 16-16. - No. 10238 ans dem Berliner Universitätsmuseum ist oben hellnufbraun. Pileus und regenerierter Schwanz einfarbig; Rücken mit dunkelbraunen Pünktchen besetzt; Extremitäten graubraun gezeichnet. Auf der Schläfe zwei liurze Längsreihen dunkler Punkte. Zügelgegend fleckenlos, mit Ausnahme des dunkelbraun gefleckten Freno-oculare; die Submaxillaria, die Unterseite der Schwanzwurel und der Extremitäten grünlichgelb, die übrigen Banchteile gelb. - Das in meiner Sammlung befindliche Stuck weicht insofern von dem Berliner ab, als bei ihm die Seiten des Körpers kastanienbraun sind und gegen die Rückenzone hin von gelbbraunen Ocellen begrenzt erscheinen. Auch zeigt das Braun des Rückens cinen Stich ins Olivenfarbene und die Körperunterseite ist grünlichgelb. Beide in Rede stehenden Individuen stammen aus der Naturaliensammlung Gerrard in London. Die genaueren Fundorte habe ich leider nicht verzeichnet gefunden.

Geographische Verbreitung.

Wer L. muralis fusca in Nordafrika zuerst beobachtet hat, ist mir bis jetzt unbekannt geblicben; vielleicht war es Moritz Wagner, der sie auf seinen Reisen in den Jahren 1836-38 anf dem Küstenstriche in der Berberei gesammelt zu haben behauptet (vergl. Schlegels Bemerkungen üb. đo in d. Regentschaft Algier gesammelt. Amphibien in: M. Wag ner, Reisen in d. Regentschaft Algier etc. Bd. III. S. 106. 1841). Doch scheint die Bemerkung Schlegels, dafs die von Wagner gesammelten Exemplare meistens mit den von Prinz von Musignano unter dem Namen albiventris abgebildeten Varietäten übereinstimmen, insofern aufzufallen, als $» P$. muralis albiventris $\mathrm{B}$ on a p.« eine Form der grünen muralis (d. H. der neapoitana) vorstelit, welche Eidechse in den, von Wagner bereisten Gegenden der Berberei gänzlich zu fehlen scheint. Synonym mit muralis fuscu ist woh! L. agilis L. bei Gervais (vergl. seine Enumération de quelques espèces de Reptiles provenant de Barbarie in: Ann. Sc. nat. 1837). - Über die nordafrikanischen Fundorte der braunen Mauereidechse sind erst in neuerer Zeit gentïgende Beobachtungen gesammelt worden; sie zïlilt ebenfalls zu den weit verbreiteten Eidechsen und begleitet. L. pater in einem grofin Trile ihres Verbreitungsgubietes, ist aber melı auf die Küstenstriche und auf den Westen Algeriens beschränkt und dringt allem Auscheine nach weit über die algierisch-tunesische Grenze hinaus. In südlicher Richtung ver- 
breitet sie sich riemlich weit. Herr Simon fand sie bei Tanger in Marokko'), Strauch bei Tlemeen 2); auch auf dem Plateau von Sersou ist sie konstatiert worden (Samml. von IIerrn Lataste, No. 640). In der Umgebung von Algier ist sic sehr gemein, jedoch nicht uberall Glech häufig (I3erl. Mus. No. 1013, St. Petersb. Mus, d. Akad. d. Wissensch. No, 3125); in Ammale umi Oran ist sie von Strauch (St. Petersh. Mus, d. Akal. No. 3126, 3393), in Daya (Prov. von Oran), in Sétif und in Chabet el Akra (Prov. von Konstantine) nenerdings von F. Lataste (Samml.v. Lataste: No. 601, 324, 1249) gesammelt worlen.

Die Fundorte 'Teneriffe ${ }^{3}$ ) und Madeirn ${ }^{4}$ ) sind verdächtig.

Beifolgende lundortsangaben für muratis fuscu in Spanien entnehme ich lauptsichlich Ilen Schriften Ed. Boscìs ${ }^{7}$ ): Siles, Granada ${ }^{5}$ ), Malaga (Ber7. Mus. No. 3399), Cadiz ${ }^{6}$ ), Sevilla, Badajoz an der spanisch-portugiesischen Grenze, Merida, Magacela und Cabeza del Buey in Estremadura, Ciudad-Real, Madrid, Escorial; Gredos, La Granja, San Idelfonso, Valladolid in Alt-Kastilien; Aragon, Arna in Asturien; 'Tuy, Pontevedra, Cuntis (Samml. v. Bedriaga: No. 184, ded.: V. L. Seoane); Santander, Pamplona und Ordura in Viscaya (nach Büttger 1. c.); Logrono; Las Iurdas, Barcelona; Provinz Valencia; Alicante, Morella; Pozo-hondo bei Albacete und die Columbretes-Insel »Montcolibri«. - In Portugal soll die Mauereidechse nach Barboza du Bocage gemein sein. ${ }^{\circ}$ ) Boscà gieht an, daber sie am Bom Jesus do Nonte in Entre Douro e Minho angetroffen habe und hemerkt, dab das Museum zu Coümbra Lxemplare dieser Eidechse, aus Beira stammend, aufweist. Lissabonner braune muratis erinnere ich mich im British Museum gesehen zu haben; endlich besitze ich selbst Exemplare aus der Umgebung von Coïmbra, welche ich der Güte des Hern Prof. A. Giraldes verdanke. Die auf den Balearischen Inseln einheimischen muralis scheinen einer besonderen Subspecies anzugehören, von der weiter die Rede sein wird.

1) Böttger, Jie Reptilien U. Amphitien von Marokko II. Frankfurt a. M. S. 18. (1883).

${ }^{2}$ ) Essai d'une Erpétologic de l'Algéric in: Mém. Acad. Imp. Sc. de St. Petersh. VIIe. Série, t. IV. Nก. 7. 1862.

${ }^{3}$ ) Duméril et Bilron, Erpétologie générale, V. p. 23\%. - C. et A. Dumciril, Cat. méthod. de la collect. lies Reptiles. Paris 1851.

$\left.{ }^{4}\right)$ Fitsch, in: Bericht üb. Senckenberg. naturforsch. Ges. 1869-70. S. 102.

5) Catalogo de los Reptiles y Anfibios observados en España etc in: Annales de la Soc. Esp. de Hist. Nat. VI. 1877; Correcciones y Adiciones al Catalogo de los Reptiles etc iludem, '1. X. 1881; Catalogue liept. ot Amphibiens de la Peninsule Ibérique etc, in: Bull. Soc. Zool. de France 1880.

$\left.{ }^{8}\right)$ Bötger, Liste d. von II. Kobelt in Spanien u. Algerien gesammelt. Kriecht. in: Bericht Senckenb. naturf. Gesellsch. in Frankfurt a. M. 1880-81. S. 144.

${ }^{7}$ ) Nach C. und A. Duméril, 1. c.

9) Liste des Mammiferes et Reptiles ohservés en Portugal in: Revue et. Mag. de Zoologie par GuérinMeneville XVI. 2 sćrie, 1863. 
Auch im benachbarten Frankreich ist sie gemein, namentlich in der südlichen und mittleren Zone desselhen; im Norden und Osten dagegen wird sie weniger häufig angetroffen. Was zuerst ihr Vorkommen im suidlichen Frankreich anbetrifft, so hat man sie seit längerer Zeit in den Pyrenäen beobachtet, wo besonders in der Umgebung von Eaux-bonnes eine grobbeschuppte Form einheimisch ist (F.Lataste); auch bei Luchon (Benqué-le-rlessus) in den IIautes Pyrenées soll sie zu Hause sein (Samml. v. F. Lataste: No. 319). In sämtlichen südlichen Departements ${ }^{1}$ ), namentlich im Hérault ${ }^{2}$ ) (Pic de St. Loup bei Montpellier ${ }^{3}$ )), im

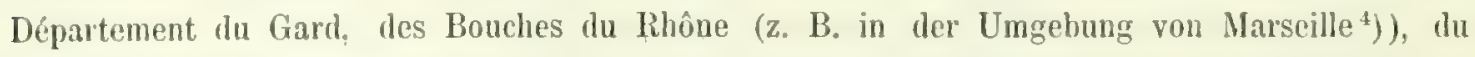
Var und des Alpes Maritimes ${ }^{5}$ ) ist sie ziemlich überall nachgewiesen worden und hat durch ihre unbeständige Zeichnung und Färbung Risso, dem Verfasser des Werkes 》Hist. nat. de l'Europe méridionale«, Anlaß zur Aufstellung von zahlreichen »guten Arten gegeben. In der Gironde ist die durch Lataste als die gemeinste Eidechse angezeigt worden ${ }^{6}$ ); wie mir dieser Forscher mitteilt, enthält seine Sammlung Exemplare aus der Allée de Boutant bei Bordeaux und aus St. Sever (Landes); ferner bewohnt sie nach Ed. Beltrémieux ${ }^{7}$ ) und Lesson ${ }^{8}$ ) das Département de la Charente-Inférieure, findet sich nach De Rocheblune ${ }^{9}$ ) im Département de la Charente vor, ist, wie Mauduyt ${ }^{10}$ ) behauptet, im Dép. de la Vienne beobachtet worden, wird nach Millet ${ }^{11}$ ) im Dép. de Maine-et-Loire angetroffen, lommt nach einer brieflichen Mitteilung von Herru F. Lataste auf den Insch Glenan, sowie auch in der Bretagne, so in Morbihan ${ }^{12}$ ), ziemlich häufig vor und soll im Dép. de la Seine nicht selten sein, ja sogar an gecigneten Lokalitäten, so in Fontainebleau (Bouron) in grofier Anzahl vorkommen und selbst im VI. Arrondissement von Paris konstatiert worlen sein (Collin de Plancy). Bei-

$\left.{ }^{1}\right)$ Crespon, Faune méridionale. Nimes 1844. p. 202. (5 Varietäten!)

2) De Serres, Essai pour serrir à l'hist. des animaux du Midi de la France ctc. - Jumeau in: Bull. Soc. d'études se. nat. de Béziers 1879.

${ }^{3}$ ) Alfred Westphal-Castelnau, Cat. collect. de Reptiles etc. in: Compte-rendu des travanx du Congrès scientifịue de France, tenu à Montpellier, en dlécembre 1868. Montpellier 1870.

') C. et A. Duméril, l. c.

${ }^{5}$ ) Vérany, Zoologie des Alpes Maritimes etc. Nice 1862. p. 25. -- Bei Nizza und in Nizza selhst, ferner in Cannes und in Mentone ist die braune muralis die herrschende Art.

$\left.{ }^{8}\right)$ Essai d'une Faune herpétologique de la Gironde in: Act. Soc. Linn. de Bordeanx 1876.

$\left.{ }^{7}\right)$ Faune du dép. de la Charente-Inférieure in: Acad. de La Rochelle. Sect. Sc. nat. 1862-63. Faune virante 1864 .

") Act. Soc, Linn, de Bordeaux, t. XII. 1841. pag. 55 ( $L$. agilis Daud).

y) Cat. d'une partie des animaux vivant dans le dép. de la Charente, ebendas.

10) Herpétologie de la Vienne. Poitiers 1844.

11) Faune de Maine-et-Loire. 1828, supplément 1868.

${ }^{12}$ ) C. et A. Duméril, op. cit. 
folgende Verbreitung der fusea in der Umgebung von Paris cntnehme ich hauptsiachlich aus Latastes Catalogue des Batraciens et Reptiles des environs de Paris ete. (Act. Soc. Linn. de Bordeaux, t. XXXI, 1876): Argenteuil, St. Germain, Meudon, Issy und Levallois-Perret; nach ciner Mitteilung desselben Gewährsmannes soll sie bei l)e l'Isle und Thomas als in den Dép. de la Loire-Inférieure und Vendée vorkommend verzeichnet sein und auch bei Abbeville im Dép. de la somme nicht mangeln (Baillon, Cat, des mammifères, oiseanx ete. d'Abbeville). Über ihre Verbreitung im Dép. de l'Aube teilt uns Collin de Planey folgendes mit: - Beancoup moins commun qu'aux environs de Paris, si ce n'est dans le sud du département, où il est abondant. Dans le nord, sur la limite de la Marne, où s'étend le terrain crétacé supérieur et où les pierres sont fort lares, nous ne l'avions point rencontréc ${ }^{1}$ ). Nach Bert käme diese Lacertu auch im Dép. de l'Yonne sehr häufig vor ${ }^{2}$ ), hingegen scheint sie im Dép. de la Moselle selten zu sein (Malherbe, Zoologie de la Moselle in: Statistique de la Moselle. Metz 1854). Laut Holandre ist sie atus dem Département de la Meuse signalisiert worden ${ }^{3}$ ). Im Dép. de l'Allier ${ }^{*}$ ) und du Doubs ist sie, wie Girod-Chantrans (Lézard gris $\left.{ }^{5}\right)$ ) und Ernest Olivier ${ }^{6}$ ) übereinstimmend angeben, überall, namentlich aber in felsigen Gegenden

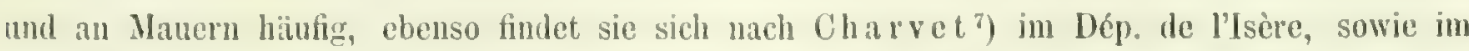
Jura-Département, wo sie nach Ogérien allerorten bis nach Morez und Les Rousses, also bis zur schweizerischen Grenze gefangen worden ist und noch in einer Höhe von $1600 \mathrm{M}$. vorkonmen soll $^{8}$ ).

Über die Verbreitung der fusce in Belrien macht Ed. de Selys-Long schamps ${ }^{9}$ ) folgende interessante Bemerkung: >C'est le plus commun. Il se trouve en grand nombre dans les carrières de pierres calcaires, les vignobles et les vieux murs des bords de la Mense, de l'Ourthe et de la Vesdre; mais il est incomm dans les villages des plaines de la llesbaye et je ne lai pas vu non plus sur les plateaux de l'Ardenner. Man kann somit selr gut die

1) Catalogue des Reptiles et Batraciens du dép. de l'Aube etc. in: Bull. Soc. sc. nat. de Semur 1877.

$\left.{ }^{2}\right)$ Cat. des animaux vertébrés qui vivent à l'état saurage dans le dép. de l'Yonne in: Bull. Soc. sc. hist. et nat. de l'Yonne 186'́, pag. 8 ō.

3) Cat. des animaux observís et recueillis dans le dép. de la Moselle in: Bull. Soc. d'hist. nat. de la Moselle VI. 1851. Metz.

4) E. Olivier, Essai sur la Faune de l'Allier etc. I. Vertébrés. Moulins-Paris 1880 (Bull. Soc. "'Emulation de l'Allier).

$\left.{ }^{5}\right)$ Essai sur la géographie physiqque, le climat et l'hist. nat. du dép. du Douls, vol. I, p. 114. Paris 1850.

$\left.{ }^{6}\right)$ Faune du Doubs etc. in: Mém. Soc. d'Emulation du Doubs 1883. Besançon.

7) Catalogue des animaux uqui se trouvent dans le dép. de l'Isère. 1846.

$\left.{ }^{8}\right)$ Hist. nat. du Jura et des départ. voisins. T. III. pag. 293. Paris 1863.

9) Faune belge, I. pag. 169. Liège 1842 . 
IRichtung verfolgen, welche sie bei ihrel Einwanderung nach diesen Gebiet genommen: dieselbe ging von Süd nach Nord lïngs des Mats-Flusses. - Über die Maucreidechsen in Luxemburg berichtet De La Fontaine ${ }^{1}$ ), dalj das Tier namentlich an den Befestigungen von der Stalt Luxemburg hansen soll. - Dats es in Holland und zwar in der Provinz Gröningen und bei Nimwegen existiert, erwähnt Schlegel in seiner Arbeit über »Die Dieren van Nederland. Gewervelde Dieren (Haarlem 1862. S. 7); der Verfasser fügt hinzu, dab die uns hier interessierende Lacerta auch in den gemälbigten Zonen Sibiriens und in Skandinavien verbreitet sei, dies ist allem Anschein nach eine irtümliche, auf irgend einem Mifsverstindnis beruhende Angabe; das Vorkommen der Mauereidechse in England ${ }^{2}$ ), in den skandinavischen Staten, sowic auch in Norden Rufilands oder in Sibirien ist höchst unwahrscheinlich; und in der That liegen gar keine positiven Nachrichten vor, daf sie bis zur Breite von $56^{\circ}$ (d. h. etwa bis zur Südgrenze Schwedens) hinaufsteige; die Grenzlinie ihrer Verbreitung mach Norden hin erreicht in den Niederlauden den $53^{\circ}$ n. Br. und die Provinz Gröningen muls, meiner Meinungr nach, für unsere Südländerin als ein weit vorgeschobenes und isoliertes Standquartier gelten.

Nach Tschudi ${ }^{3}$ ) kommt die braune muralis in grolser Anzahl in der südlichen, westlichen und nördlichen Schweiz, so in Tessin, Waadt, Bern, Aurgau, Basel und im Jura vor; weder Tschudi, nach Schinz nennen sie aus dem Osten. T'schudi sagt aulierdem, dali sie sder ganzen mittleren Schweiz zu fehlen scheine und im ganzen Kanton Zürich, in den kleinen Kantonen und im südlichen Teil von St. Gallen von $L$. vivipara ergïnzt werde, die da zurücktrete, wo Podarcis muralis vorkommt.« Die Vermutungen dieser Faunisten haben sich insofern nicht bestätigt, als die muralis auch in St. Gallen ${ }^{-1}$, in Chur ${ }^{5}$ ) und an mehreren anderen Punkten in Graubünden ${ }^{6}$ ) beobachtet worden ist. Es ist allerdings richtig, dali diese Form in den, von Tschudi und Schinz genannten Gebieten der Schweiz bedentend häufiger aufzutreten ptlegt. Unter den Fundorten der muratis finde ich ferner die Thäler von Poschiavo (im Süden Grabbindens), das Bergelier Thal bei Cliavenna und das Val Mesocco am S. Bernardino, die Umgrebung von Genf, Umgegend von Lausitune, Vevey, Ouchi und Eclépens (Razoumowsky ${ }^{7}$ ), Bern am Aarziehlirum (Noll ${ }^{5}$ ), die welsen und Mauern des Schlosses

1) Faune du Pays de Luxembourg etc. Reptiles, pag. 8. Luxembourg 1875.

$\left.{ }^{2}\right)$ Merrem, Versuch eines Systems d. Amplibien, s. 67. Marburg 1820.

3) Monogr. d. Schweiz. Echsen in: Nouv. MIém. Soc. Helv. sc. nat. 1837.

9) Fatio, Faune des Vertébrés de la Suisse III, 1. 98. Genère et Bâle 1872.

5) v. Brügger, Naturgeschichtl. Beitrige z. Kennt. d. Umgeb. v. Chur, S. 151. Chur 1876.

6) Fatio, op. cit.

7) Hist: nat. du Jura etc., t. I. p. 103. Lauzaune 1789.

5) Einiges üb. unsere Eidechsen in: Zoolog. Garten VII, S. 312. 
Lenzburg «ei Rupperschwyl und Rheinfelden (Schinz, fauna helvetiea in: Nene Denkschrift. d. allg. schweizer. Gesellsch. f. d. gesammt. Noturwissenschaften. Nenchatel 1537. Bd. I. S. 138), Brugg im Aargau, Arleshem und Schweighof bei Badenweiler ${ }^{-3}$ ) erwïlnt. Über ihre Verbreifung bei Basel teilt M illey folgendes mit: "Sic ist mehr eine Bewolnerin der Stadt selbst, indem sie hauptsächlich in. den nach Ost und Süd gelegenen liesten der Stadtbefestigung rorkommt; doch habe ich sie atuch schon auf der Landstratie vor dem ehemaligen Steinenthor gefangen. Besonders hätig ist sie an der Albanschanze. . » An der Rheinhalde beim Kinderspital bewohnt die Muralis Löcher in der dem nageltuhartigen Geröll aufliegenden Mergelsehicht; sie wird ron dar an lïngs der gauzen Rheiulatde bis nach dem Grenzacherhorn getroffen und ist, wenn ich nicht irre, namentlich an den Rebmancrn zwischen Grenzach und Wiehlen zu

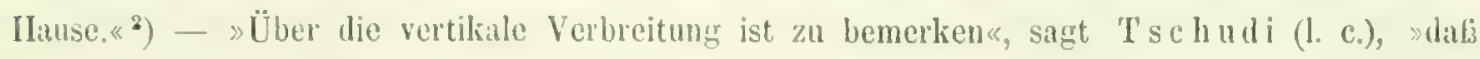
sie bis zu $3800 \mathrm{~F}$. vorkömmt. E' a tio tügt hinzu, dalj sie auf der nördlichen Seite der Mpen selten über 1250 M. angetroffen werde, während sie an Sudabhange des Gebirges bis zu einer Höhe von 1700 M. hinatsteige. Die Nachforschungen Venance Payots ${ }^{3}$ ) haben ergeben, dats im Gebirgstock des Monthlane die weilis- und die rotbäuchige Varietät selten über 1500 M. steigt, dalis aber die total schwarze meralis in dieser Höhe noch konstatiert werde. Ob dies aber wirklich der ball ist, kann ich nicht entscheiden. Derselbe Gewährsmann teilt uns ferner mit, dals das Tier an den südlichen Abliängen des Montblanc weit häufiger sei als an den nördlichen.

Auf der Apenninischen Halbinsel ist sie vorzugsweise auf den Norden angewiesen, wo sie allenthalben sehr gemein ist und öfters mit der grünen Maucreidechse ihren Aufenthaltsort teilt. In anderen Gegenden, z. B. an den Ufern der norditalienischen Seen, kommt ausschlieblich die fusca vor. An der Nordwestküste Italiens erstreckt sich ilı Verbreitungsbezirk ungefahr bis Genua; von Spezia an wird sie z. T. durch andere Formen vertreten. An der Ostküste dringt sie weit südlicher vor und wird sogar in der Calabria ulteriore angetroften; Exemplare der fusca, welche in Arena von Dr. Cavanna gesammelt worden sind, verdanke ich der Liberalitat Prof. Gigliolis. In den Central-Apenninen und dem Sabinergebirge ist sie gleichfalls einheimisch, von dort aus ist sie in die Campagna Roman bis nach Rom eingedrungeu Nach der reichen Reptiliensummlumg des Hern Giglioli in Florenz (R. Museo di Fisica e

1) I. und II. Nachtrag z. Katalog d. herpetolog. Samml. d. Basl. Mus. in: Verhandl. d. naturforsch. Gesellsch. in Basel 1880 u. 185\%. Basel.

2) Mitteilungen aus d. herpetolog. Samml. d. Basl. Mus, ebendaselbst, Bd. VI.

$\left.{ }^{3}\right)$ Erpètologie, Malacologie et l'aléontologic des environs du Mont-Blanc in: Mun. Sc. phys, et nat. de Lyon VIII. Lyon 1864. 
Storia naturale) zu urteilen, kommt sie vorzüglich nördlich von den toskanischen Apenninen, ferner bei Florenz, in Lneca und Rimini vor und schließlich im Modenesischen, in den Ligurischen Apenninen und im P'iemont, wo sie namentlich in sandigen Gegenden von Cambiano, im Valle del Po, ${ }^{1}$ ) di P'inerolo, Sesia, d'Aosta und Lanza einheimisch ist. Das Vorhaudensein von zwei verschieden kolorierten muralis im Valle del Po hat bekanntlich die Aufmerksamkeit De Filippis auf sich gezogen und diesen Forscher veranlalist, beide, d. h. unsere fusca und neupolitana, von einander specifisch zu trennen; erstere ist von ihm einfach als slacerta de' muri« bezeichnet, letztere aber mit dem Cett ischen Namen stiliguerta versehen worden, eine Bezeichnung, welche zum 'Teil auch jetzt noch kursiert. Als »Podarcis muralis auctorum var. cupreiventris « wird unsere fusca von De Betta ${ }^{2}$ ) für Valle di Non im Trentino bezeichnet, als vilr. flaviventris für Verona und Vicenza und endlich als var. rubriventris für das Veronesische und I'adovanische Gebirge aufgefuhrt. In grofer Anzahl habe ich das Tier an den Mauern des Amphitheaters zu Veroila und in Camobbio am Langen-See angetroffen; von hier aus scheint sic nach dem Ticino vorgedrungen zu $\operatorname{sein}^{3}$ ). Auf den, westlich von der Halbinsel liegenden kleineren Inseln scheint sie meistens zu fehlen; ich habe nur die Gewilheit erlangen können, dats sie auf einigen Liparischen Inseln vorkommt und vielleicht auch auf Elba in Gemeinschaft mit der grünen Form gefunden worden sei. Auch auf Sardinien dürte sie gänzlich fehlen, wenigstens ist sie wedel" von Gené noch von Cara angegeben worden.") Auf Corsika hingegen ist sie, wie ich es aus eigener Erfahrung weils, sehr gemein, namentlich im Gebirge ${ }^{5}$ ). Bei Vivarrio habe ich eine Zwergform der fusca konstatiert; bei Bocognano haben die fusca grüne, metallisch glänzende Schwänze; nach F. Müller (op. cit., l. c.) sind die in der Umgebung von Ajaccio einheimischen braunen muratis zuweilen mit cinem doppelten Nasofrentale versehen; aulierdem habe ich das Tier bei Bastia, in Orezza und in Bastelica zu sehen Gelegenheit gehabt. Auf Sicilien kommt die fusea ebenfalls vor, so z. B. bei Messina; ob sie auf dieser" Insel allgemein verbreitet ist, kann ich aus der mil vorliegenden Litteratur nicht ersehen. - Obgleich der Lacerta oder "Podurcis" mualis in beinahe allen italienischen schriften gedacht worden ist, kann der Verbreitungsbezirk namentlich der kleineren braunen

$\left.{ }^{1}\right)$ Nuovi Anali delle scienze naturale dic Bologna, Serie III. Tomo V. pag. 69. Bologna 1852.

2) Verhandl. zool. botan. Ver. in Wien, 1852, S. 153.

3) P'avesi in: Atti Soc. Ital. Sc. nat, Vol. XVI. pag. 21. Milano 1873-74.

$\left.{ }^{4}\right)$ Nachträgl. Zusatz: - Exemplare von muralis fusca aus Sassari sind mir erst zu Gesicht gekommen als die Abschrift meiner Abhandlung fast vollendet war, so daf sie leider nicht mehr berïcksichtigt werden konnten.

$\left.{ }^{5}\right)$ v. B edriaga, Beitr. z. Kenntn. d. Amphibien u. Reptilien d. Fauna v. Corsika in: Archiv f. Naturgesch. XLIX. Jahrg. 1 Bd. S. 268. 
Mauereidechse noch immer nicht sicher festgestellt werden und zwar aus dem einfachen Grunde, weil die Autoren die verschieden kolorierten muralis antweder nicht unterscheiden wollten oder überhaupt nur eine in der von ihnen bewohnten Region vorkommende kannten, die Existenz der anderen aber ignoricrten. Die dadurch entstandene Konfusion wurde öfters durch die vorefühte Diagnose, falls die richtige larbe nicht getroffen wurde, verschlimmert, oder, falls dieselbe in eine andere Sprache übertragen, wurde sie dermafien verunstaltet, dafs cigene Erfiltrungen betreffs des Vorkommens des Tieres sich als erforlerlich herausstellten. Wie sehwer die Aufgabe ist eine geographische Verbreitung der muralis überhaupt festzustellen, ersah ich, als ich meine Bemerkungen über diesen Gegenstand in meiner Schrift »Herpetologische Studien « einschaltete; ich begnügte mich damals, um Irrtümer zu vermeiden, dieselbe in allgemeinen Zügen zu behandeln. Demungeachtet schlichen sich falsche Angaben ein. Die nenerdings im Archiv f. Naturgesch. erschienene voluminöse Arbeit Eimers über die Manereidechsen hat unsere Kenntnisse uber die Verbreitung der zwei Hauptformen vou muralis auch nicht im mindesten gefördert, denn der Verfasser hat die Grundfärbung und die Gröfe der von ihm beschriebenen 'Tiere meistens auker acht gelassen und seine Aufmerksamkeit hauptsïchlich nur auf die Zeichnung gerichtet; 'ob diese allein, oder ob die Zeichnung und lie Kopform genügen, um in Zukunft die Mauereidechsen nach dem Eimerschen Prinzip zu klassifizieren, dürfte sich bald ergeben; was mich anbetrifft, so habe ich beim besten Willen das uns in den Untersuchungen über das Variieren der Mauercidechsen« vom Verfasser gebotene Material in diesem Absehnitt nicht zu verwerten gewufit, denn was hilft es uns z. B. zu wissen, dab die »muratis reticulata« oder "punctata fasciata« von Pianosa und Elba derjenigen von Kiorsika oder Verona, Cleven oder aus dem Schwarzwald ähnlich ist, namentlich da uns oder dem Verfasser jener Schrift die Grundfarbe des Tieres von Pianosa und Elba unbekannt geblieben ist; nur auf indirelitem Wege, d. h., wenn wir die Einteilung der muralis in zwei Hauptformen (i. e. in muralis fusca und m. neapolitana) acceptieren und aus der uns vorliegenden Litterafur erfaliren, dats sowohl in Cleven als auch im Schwarzwald ausschliefilich die klemeren braunen muralis vorkommen, gelangen wir zu der Schluffolgerung, dafis wohl diejenige Mauereidechse, welche sinnerhalb einer Grenze, die von Korsika über Genua und Cleven bis in den Schwarzwald und von da nach Verona, Venedig, Rimini, von hier herüber nach Lucea und über Elba auf die Insel Pianosa gezogen ist « (Eimer, l. co), der muralis fusca angehört. Die von Limer, »um unmotivierter Aufstellung und Benennung von Abarten für die 'dukunft ein Ënde zu machen « und in der lüblichen Absicht »keineswegs die alten Namen durch neue zu ersetzen , proponierte neue Nomenklatur, ohne jedwede Berücksichtigung des 》Prioritätsprinzips «, ist 
schon darum unbefriedigend ausgefallen, weil dieser Autor sden Versuch, die von Duméril und von Schreiber aufgestellten Varietiten auf die scinigen »zurückzuführen « unterlassen hat (l. c., S. A. S. 139. Siehe die Anmerliung). Es ist allerdings wahr, dafis 》auf Grund der Beschreibung« mitunter ein derartiger Versuch nicht gut möglich ist; die Duméril-Schreiberschen Varietäten aber sind meistenteils seh" scharf charakterisiert, auch sind sie in vielen Fällen in den Museen wieder zu finden. Dafs »liese Zurückführung« und Entzifferung der sbisherigen Beschreibungen« nur Wert zu irgend einem »zwingenden Zwecke hätte, sehe ich nicht cin, ich glaube vielmehr, daf eine zZusammenfassung oder Klassifizierung einer Tiergruppe, wie sie uns Kimer mitgeteilt hat nur dann einen Wert hat und nur dann die Berechtigung crhält acceptiert zu werden, wenn sämtliche oder auch nur die meisten Beschreibungen berücksichtigt orler wenigstens entziffert worden sind und die Synonymie uns in ihren Iauptzügen vorliegt. Dats genannter Forscher diese Haupthedingungen nicht erfüllt, oder nur in sehr geringem Ma(ie erfült hat ${ }^{1}$ ), haben wir anch ohne seinen Hinweis zu schliefen vermocht. Beliebe Herr Eimer zu bedenken. daf, falls seine Nachfolger seinem Beispiele folgten und das "Entziffern seiner Beschreibungen unterlassen würden und zur nochmaligen Umtaufe der Mauereidechsen sehreiten sollten, rr sie sicherlich nach der, von ihm üblichen Art und Weise mit den bittersten 'Vorwürfen und Schmähungen überschütten würle. Das Entziffern der »bisherigen Beschreibungen ist ja zu zeitrabend, die '/urückfübrung z. B. von drei bis vicr Trophilosame-Species auf eine einzige, wie 2. B. in betreff der Tropidosaura capensis (non Smith), Burchelli und montana der Fall gewesen ist (vergl. mein Kapitel uber Tropidosaura montame), und die Durchmusterung aller Tropidosaura in nicht weniger als fünf Museen dürfte (nach Eimer's Ansicht) nur zu irgend einem szwingenden Zwecke und nicht aus Interesse und aus PHichtgefüh, das man sich selbst und nicht minder dem Verleger und dem Publikum schuldig ist, dienen und deshalb nicht der Mühe wert sein, und dennoch hat ein Mann wie Leydig es nicht unter seiner Würde gehalten, cben auf dieses Entziffern einzugehen und hat dadurch den Dank sciner Nachfolger und Nachahmer zu ernten; dafí dies auch wirklich der Fall ist, will ich mir erlauben dic Bemerkung einiger meiner Fachgenossen mitzuteilen, daf nämlich gerade die Abschnitte kritischen Inhalts, sei es über die Identifizierung der Arten oder Varietäten, sei es in Bezug auf die künstlerischen Leistungen der verschiedenen Autoren, ilu ganzes Interesse in Anspruch genommen hätten; es ist allerdings wahr, daß nur des Meisters Hand diesem an und für sich vielleicht trockenen

') Var.campestris de Betta 1857 findet sich nämlich in die Synonymie der sstriata s. str. Eimer 1881 versetzt, dic albiventris Bonap. 1832 soll mit smaculata-striata Fimer* 1881 und dic olivacea IRafin. 1810 mit *concolor Eimer* 1881 identisch sein und meine flatiundate 1879 hat ten Namen sigris Eimer 1881 erhalten!! 
Gegenstand derart zu schildern vermag, dak man immer wieder die betreffenden Seiten mit Genuf durchliest.

Was nun den Verbreitungsbezirk der braunen muratis in den österreichischen Staten anbelangt, so muß vor allem erwähnt werden, daf hier die vorherrschende Form der muralis die fusca ist. Über ihre Verbreitung in 'Tirol haben mehrere Forscher, unter ihnen Gredle $\mathbf{r}^{1}$ ), einiges mitgeteilt. »Kein Tier«, sagt er, »dürfte sich dem Auge des Nordländers, der im Vorsommer oder Herbst den Brenner überstiegen, bälder und auffälliger darbieten, als die Scharen von Manereidechsen, die alle sonnigen Stellen, Pfosten und Biame, alte Mauern und Barrieren, Hausmauern, ja selbst Kirchtürme bis zur Spitze belagern«. »Die Art gehört zwar cbenfalls dem wïrmeren Süden an, ontwickelt wenigstens nur hier die audjerordentliche Individuenzahl; verbreitet sich aber doch anch in Pusterthale bis an dic »Windschmur am Fingange des Antholzer Thales, und jenseits der Wasserscheide in Drauthale bei Lienz und Nikolsdorf, - in alle Querthäler des Eisack, und Fisch-Laufes: in Lüsen, Villnöls und Eggenthal, im Sarnthal und Passeier (hier bei Moos, 3060' ü. M., noch ziemlich häufig), auf dem Nonsberge, im Thale von P'rimier, im Valsugana und Sarkathale ete., wo Verfasser selbst sie allenthalben beobachtete; scheint endlich im Vinschgau selbst die Reschener Höhen übersprungen zu haben - wenigstens findet sie sich noch im oberen Teile des Innthales: bei Pfunds und Landeck einzeln wohl die einzigen Standorte Nordtirols. Allein auch vertikal steigt sie in Südtirol bis 4000, ja selbst zu 5000' Meereshöhe auf, z. B. an der Seiseralpe und auf dem Salten, hält sich auf solchen Höhen nur an warme Felsen und nimmt gewöhnlich eine mehr pistaziengrünliche Oberseite an.« - Das Vorkommen an der Seiseralpe ist nachträglich von Leydig (Die in Deutschland lebend. Arten d. Saurier, S. 235), Milde e und Prosslinger ${ }^{3}$ ) bestätigt worden. Leydig, ohne die von Gredler in seiner mir leider nicht zur Verfügung stehenden, bereits im Jahre 1853 publizierten Sichrift »Vierzehn Tage im Bade Ratzes« gemachte Mitteilung im Gedïchtnis zu haben, war, wie er angiebt, nicht wenig überrascht, bei einem Ausfluge ins Tiroler Gebirge im August 1868 »ummittelbar am Rande der Seiseralpe, bei ctwa 5000 Fuk Meereshöhe, ein prüchtiges Männchen mit lebhaft braumotem Bauch unter einem Stein« zu fingen. »Desgleichen «, bemerkt Leydig, »sah ich lebhaft gefärbte Tiere häufig bis zu den Dorfmauern von Oberbozen (3995') und Lengmoos (3796'). Bei Besteigung der Mendel war dlas Tier bis nahe zur Paßhöhe (4787') zu verfolgen, doch auf der Spitze blickte ich mich

1) Fauna d. Kriecht. u. Lurche Tirols in: XXII. Programm d. k. k. Gymnasiums zu Bozen. Bozen 1827.

2) Ein Sommer in Südtirol, 1864.

9) Das Bad Ratzes in Südtirol. 1883. S. 38. 
vergehens darnach um. Nichts ungewühnliches bietet es daher, wenn ich weiter anführe, daf: ich $L$. muralis bei Völs (2145') noch weit hinein in den Wald, am Wege der gegen Ratzes führt, gefangen habe; chenso auch an den Mauern hinter Castelruth (3349') gegen St. Michele zu, und zwar in Menge, während sie an den sonnigen Jauern bei Seis (2960) nur vereinzelt sich blicken lief. « Ferner soll diese Eidechse bei Meran ${ }^{1}$ ), in den Schluchten der DolomitFelsen um den Tobino-See und hinter Vulpian, wo nach $\mathrm{Hartmann}{ }^{2}$ ) recht dunkel-bläulich und briunlich-grün gefärbte Individuen vorkommen sollen und, wie es neuerdings gemeldet. worden ist, auch »an den Abhängen der Brennerstralie zwischen Innsbruck und Schupfen ${ }^{3}$ ) zu Hause sein. Schlieflich muf erwähnt werden, daf bei Schlof Gandegg in Eppan (unweit Bozen), laut Gredle $r^{\&}$ ), eine blafirosa muralis mit lebhaft roten Augen gefangen worden ist; mit lecht bemerkt der genannte Forscher, dak derartige s vollkommene Blendlinge unter Eidechsen »sicher zu den gröften Seltenheiten« gehören. - In Bruhins Schrift über die Wirbeltiere Vorarlberges (Verhandl. zool. botan. Ges. in. Wien 1869, S. 256) finde ich sie für St. Gallen namhaft gemacht.

»Nach Osten hin«, sagt Schreiber (Herpetologia europaea, S. 418), sist muralis bei ihrem Vordringen namentlich der Donau gefolgt, längs deren Laufe sie von Niederösterreich an bis sur Mündung allenthalben ziemlich gemein ist«. In Niederösterreich, und zwar bei Wien, ist sie, wie es scheint, zuerst von Laurenti (Synops. rept. pag. 165) beobachtet und nachträglich von Fitzinger ${ }^{5}$ ) als im Wiener Stadtgraben und bei Baden, von Knaue $\mathbf{r}^{6}$ ) als slängs des Linienwalles und am Gemäuer des Ufers der Wien«, an günstigen Orten in gröŁerer Anzahl vorkommend angegeben worden. Weiter nordwitrts vom Erzherzogtum Österreich scheint sie nicht vorzudringen, wenigstens finde ich sie für Böhmen weder von Glückselig, noch von Schreiber erwihnt; dagegen soll sie in Oberungarn, so bei Kaschaup), ym sürlichen Mähren, an den Grenzen von Ungarn und Österreich $\propto^{8}$ ) und in Siebenbürgen »an steinigen Hügeln und sonnigen Stellen der Vorgebirge bis zu 3000 Fuf Höhe im südlichen Teile des Landes fast überall häufis, z. B. bei Michelsberg; Zoodt, am Rothenturmpasse u. s. W. ${ }^{9}$ ) konstatiert worden

$\left.{ }^{1}\right)$ Milde in: 44 Jahresber. d. schles. Ges. f. vaterländ. Kultur, S. 55.

$\left.{ }^{2}\right)$ Sitzungsber. d. naturforsch. Freunde zu Berlin 1877. S. 207.

$\left.{ }^{9}\right)$ Leydig, Ůb. die Verbreit. d. Tiere im Rhöngeb. etc. in: Verhandl. d. nat. Ver. d. preuss. Rheinl. und Westf. 38. Jahrg. 4. Folge, VIII. Bd.

4) Korrespondenzbl. zool. mineralog. Ver. in Regensburg 36. Jahrg. S. 22. 1882.

5) Abhandl. d. k. böhm. Gesellsch. d. Wiss. Bd. I (neue Folge) S. 324 (Prag 1829).

6) Die Reptilien und Amphibien Nieder-Österreichs. S. 6. Wien 1875.

`) Verhandl. zool. botan. Ges. in Wien XIII. S. 278. 1862.

s) Heinrich, Mährens u. k. k. Schlesiens Fische, Reptilien u. Vögel. S. 38. Brünn 1856.

9) Bielz, Fauna d. Wirbelt. Siebenbürgens etc. S. 152. Hermanstadt 1856. 
sein. In Süd-Ungarn soll sie gleichfalls, und zwar bei Mehadia, vorkommen (L cydig, J. c.); in der Fauna von Béllye und Dátda von v. Mlojsisovics (Bd. II. Graz 1884) finden wir sie snach anderen angegeben. Ob die, „nảichst den Donaumündungen bei Tuldscha« von Graf F'errari und 'Zelebor beobachteten Manereilechsen der Subspecies fusca angehören, ist fraglich, denn bei Tuldscha sollen auch munlis neapolitana einheimisch scin. - Aus Kärnten wird die muralis von Latzel ${ }^{1}$ ) und von $v$. Gallenstein ${ }^{2}$ ) und von den östlichen Abhängen des Reikiofel in den Gaithaler Alpen von Kohlmayer $r^{3}$ ) erwähnt; aus der Umgebung von Gör\% und aus dem Karstgebirge stammende fusca besitze ich in meiner Reptilien-Sammlung. Exemplare aus Spalato enthält das Museum in Berlin ${ }^{4}$ ); auch anderweitig in Dalmatien dürfte das Tier nicht fehlen, jedenfalls aber viel seltener als die grüne neapolitana sein. Von den Inseln im Adriatischen Meere kenne ich sie nur von der Insel St. Andrea, wo sie, wie ich es aus einer, mir von Dr. E. Schreiber zugegangenen Sendung schliefie, gemeinschaftlich mit der schwarzblauen forn mmelisellensis $\mathrm{Braun}$ « lebt.

Das Vorkommen der fusca an gewissen Lokalitäten in Deutschland ist schon vor langer Zeit aufgefallen und hat zu cingehenden Studien über die Ausbreitung der Manereidechse Veranlassung gegeben. Fusca ist, wie gesagt, eine im ganzen mehr südliche und westliche Form als die Smaragdeidechse und sverhält sich mit ihrem Vorrücken nach Norden umgekehrt wie die grüne Eidechse, die im östlichen Europa weiter nach Norden gegangen ist als im westlichen, während die Mauereidechse im Osten weit gegen den Westen in ihrer Nordgrenze zurückbleibt«; man behauptet zwar, letztere an einigen Orten in der Mark und in Schlesien beobachtet zu haben, zahlreich tritt sie aber in Südwestdeutschland auf. So wenig sie nach Norden hin verbreitet ist, geht sie auch in höhere Gebirge hinuf, und ist im ganzen in Deutschland als eine typische Bewohnerin der Thäler zu betrachten, wo sie sich vorzugsweise in der Thalsole oder in deren nächsten Nähe, an, von der Sonne durchwärmten Felsen, Weinbergsmatuern und Geländen aufhält. Sämtliche Naturforscher, welche sich näher mit dieser Eidechse befatist haben, geben übereinstimment an, datls sie bei ihrem Vorrücken nach Norden dem Laufe des Rhein- und Donatustromes gefolgrt sein muls und dats ihre Finwanderung nach Westelentsehlatnd, wohin ihr durch die Gebirgslücke zwischen Jura und den Vogesen der Werg offen stand«,

$\left.{ }^{1}\right)$ Beiträge z. Fauna Kärntens in: Jahresber. d. naturw. historisch. Landesmus. v. Kärnten, Heft 12. Klagenfurt 1876.

2) Die Reptilien von Kärnten in: Canavals Jahrb. d. uaturhist. Landesmus, v. Kärnten. Bd. II. S. 5: - Schr häufig an Mauern und Felsen, auch noch auf höheren Gebirgen«.

3) Jahrb. d. naturw. historisch. Landesmus. v. Kärnten, Heft IV. S. 64. Klagenfurt 1859.

4) Die betreffenden fusca (Nr. 4524) sind als soxycephala bestimmt worden. 
einerseits von der Schweiz, andererseits von Frankreich aus stattgefunden habe. Noch andere Forscher fügten erginzend hinzu, dass die Bodenbeschaffenheit und die klimatischen und Nahrungsverhältnisse bei ihrer Ausbreitung in Deutschland hemmend oder fördernd wirkten. Wenn wir die Thatsache in Betracht ziehen, dass die fusca bis jetzt mit Sicherheit nur in Rheingebiete nachgewiesen worden ist und dass ihre Fundorte auf einen Zusammenhang mit Frankreich und der Sclıweiz deuten, ferner, wenn wir die Angaben Paulus', Leydigs und Welkers berücksichtigen, wornach die murulis den Keuper und die, über denselben lagernden Formationen zu meiden scheint und sich nicht immer, wie es das Experiment Welckersi ${ }^{1}$ ) bewiesen hat, von einem Orte zum anderen erfolgreich verpflanzen läbst, so müssen wir annehmen, dab̉ den Hauptweg zu ihrer Ausbreitung nach Deutschland das Rheinthal bildet und dass das Tier erst nachtriaglich in einige Nebenthäler gelangt ist und sich hier nur an cinzelnen, oft weit auseinander gelegenen Stellen behaupten konnte. Nach Paulus, dem wir eine eingehende Studie über das Vorkommen der muralis im Rheingebiete, namentlich in Wurttemberg verdanken, verbreitet sich diese Eidechse saus dem. ganzen Rheinthal durch das Neckargebiet bis oberhalb Hoheneck, längs dessen Zutlussen aus dem Odenwald, längs der Elsenz bis Sinsheim, der Jagst bis Möckmühl, des Kochers bis Neuenstadt, ferner längs der Enz bis zum Enzklösterle, der Glems bis nahe an Leonberg, der Würm bis über Joüflingen hinaus, der Nagold bis nahe an Wildberg, lïngs einer kurzen Strecke an der Eyach und längs der kleinen Enz bis Faustberg, wo sic sich auf dem Plateau bis nach Neuenbürg ausbreitet, während sieq... »an den bezeichneten Flüssen nur dem engeren Flutithal folgt. Von den übrigen in den Rhein sich ergiebenden Flüsseu des badischen Schwarzwaldes folgt sie dem Schwetzinger Bach bis in die Nähe von Sinsheim, der Kraich, der Salza bis Bretten, der Pfinz, der Alb bis Herrenalb, der Murg mit deren Zufüssen bis Freudenstedt und Umgebung, der Rench bis Oppenau, der Kinzig bis nahe an Loliburg, der Gutach bis Triberg und der Wutach und deren Zuflüsse bis über Waldshut hinaus«. Paulus fügt dieser reichhaltigen Aufzählung der Fundstellen für die uns hier interessierende Lacerta die Bemerkung hinzu, dak sie, mit Ausnahme der Gegenden von Freudenstedt und Neuenbürg, auf dem Plateau bis 1857 nicht beobachtet wurde und dafis sie sich nur auf die Gebirgsformationen von dem Urgebirge aufwïrts bis zu dem Muschelkalk beschränke (Jahreshefte d. Ver. f. vaterländ. Naturkunde in Württemberg XIII. Jahrg. 1857. S. 54). Die

1) Welcker hat bekanntlich L. muralis um einen Breitengrad nordwärts, und zwar aus Heidelberg nach der Haardtburg am Fufe des Gleiberges in der Nähe von Giefsen, versetzt, welcher Versuch der Akklimatisierung ihm aber nicht gelang (siehe Zoolog. Garten VII, S. 210). 
Fundorte bei Neuenbürg $\left.{ }^{2}\right)$ und Lanfien an Neckar ${ }^{2}$ ) sind schon laugst bekannt; die übrigen

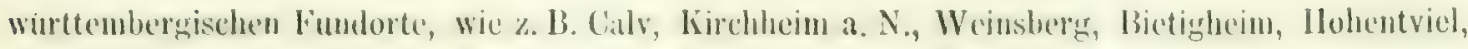
das Gebiet der 'Zaber (Nordscite des Michelberges), Wartberg bei Heilbronn sind von Krauls (Württembergische Fauna in: Das Königreich Wättemberg, S. 497), Leydigr (op. cit.) und dem mir leider unbekannt gebliebenen Beabeiter der Tierwelt in dem Werke shas lïnigreich Württemberg«, herausgegeben von dem k. statist. lopogr. Bureau (Stuttgart 1863. S. 291), nachtraglich hinzugefügt worden. Nach den übereinstimmenden Angaben mehrerer Faunisten und nach den im Senckenbergischen Museum aufbewahrten Stücken zu urteilen, kommt die muralis sowohl im württembergischen als anch im badischen Schwarzwald vor; als specielle Fundorte finde ich Teinach, die Abhänge des Teinachthales, das hinzigthal sbis gergen den Ursprung der Kinzig«, die Ufer der Gutach »bis Triberg« und Freiburg genannt, wo sic übrigens selten vorkommen soll. Nüblin, welcher zuletzt die Fauna des Grobherzogtums Baten durchforscht hat, bezeichnet die witrmeren Seitenthäler in der liegion der forberge, so das Murgthal, Neckarthal u. a., als die von der Minnereidechse bevorzugten Wohngebiete und fügt ergäinzend hinzu, dałs sie den selteneren Arten ingehöre. ${ }^{3}$ ) Das Vorkommen bei Heidelberg hat Welcker angezeigt, und dals unser Tier sich noch daselbst findet, weil ich aus cigener. Erfahrung. In früherer Zeit wa die fusca in Heidelberg, und zwar an der Neuenheimer Seite an den Mauern dicht am Neckarufer, überaus häufig, nach den letztjährigen Überschwemmungen aber ist sie äuferst selten geworden. - Koch ${ }^{4}$ ) und Medicus ${ }^{5}$ ) exwähnen sie für die Rheinpfalz »wo sie häufiger als jede audere Eidechse vorkommt . Glase ${ }^{\circ}$ ) verzeichnet sie für Hessen (Umgebung von Worms, Heppenhein an der Bergstralse). Jäickel und Römer-Buchner giebt in dem, im Jahre 1827 in Frankfurt a. M. erschienenen 》Verzeichnis der Steine und Tiere, welche in dem Gebiete der freien Stadt Frankfurt und deren nïchster Umgebung gefunden werden« an, dats das Tier in der Richtung vgegen Darmstadt « vorkommt, wwelche Gegend«, wie Ley dig berichtet, wereits den Vorhügeh des Odenwaldes

$\left.{ }^{1}\right)$ Memminger, Beschreib. v. Württemberg 1820. - G. v. Martens, Üb. württemberg. Fauna in: Korrespondenzbl. d. landwirtschaftl. Ver. I. S. 155. Stuttgart 1830. Der Verfasser bezeichnet unsere Art mit dem D a udinschen Namen >agilis«.

2) Leydig, Die in Deutschland lebend. Arten d. Saurier, S. 237.

$\left.{ }^{8}\right)$ Tierwelt in: Das Grofherzogtum Baden. Karlsruhe 1883.

4) In Sturms Deutschlands Fauna, 1828 (nach Leydig). - In der mir zu Gebote stehenden Ausgabe von Sturms Fauna findet sich Seps muralis Laurenti in die Synonymie ron der »kleinäugigen Eidechse. versetzt; auch ist diese Eidechse durch Wolf und nicht von $\mathrm{Koch}$ beschrieben.

s) Tierwelt d. Rheinpfalz. Bavaria, Landes u. Volkeskunde von Bayern, 1867.

8) Allerlei Beobachtungen a. d. Tierleben etc. in: Zoolog. Garten XI. S. 157. 
und der Rhcinebene zugezithlt wird«. Leydig fügt hinzu, daf̉ $L$. muralis im Maingebiete mangelt. ") Vou Bingen rheinabwärts bis Nimwegen in Holland hat man sie nicht nur in dem Thale des liheins selbst, sondern atuch in cinigen Nebenthälern, wie z. B. bei Kreuznach und in der Lbernburg im Nahethate (Leydig, v. Bedriaga), an der Lahn bis Ems (Nol1²)) bei Hohenrhein und Ems (Kirschbaum ${ }^{3}$ )), im Moselthale, bei Altenahr im Ahrthale (Leydig, 1.c.) vielfach gefunden. Über das Vorkommen der fuscu im Rheinthale liegen mir noch die Angaben von Leydig vor, wonach sie am Rochusberry und Scharlachskopf bei Bingen, in Hönningen, an Drachenfels, an somnigen Matuern der alten Anatomie, am salten Zolk und an der Mauer der gyualkologischen Klinik in der Stadt Bonu beobachtet wurde. Melsheimer ${ }^{4}$ ) fand sie bei Linz a. Ih., Nol! ${ }^{5}$ ) bei Coblenz und zwischen Coblenz und Winningen im Thonschiefer und ich 1879 mehrere Exemplare bei St. Goar an Strafengeländen. Nach Leydig zieht sich die fuseu vom Moselthale, wo sie, beiläufig bemerkt, svon lange her durch Schnur als die gemeinste Eidechse angezeigt worden ist ${ }^{6}$ ) und sin Menge an Felsen und Weinbergen, sowie auch innerhalb der altersgrauen Städtehen, an Kloster- und Bergruinen haust (Leydig), - auch sin die Eifel, ohne aber allgemein verbreitet zu sein«; so fehlt sie z. B. in der Umgebung von Daun und im Lieserthal; serst atuf dem Wege von Manderscheid nach Meerfelden, im tief eiugeschnittenen Thal der kleinen Kyll« traf sie Leydig »an sonnigen Felsen«; bei Manderscheid am Anstieg zum Belvedere, ferner bei Gerolstein, dann im Üsthal bei Bertrich, wo sie ebenfalls bis zum Saume der Hochtläche hinangeht, endlich am Laacher See, an Felsen und Gebiuden, auch an den Steinhalden Niedermendigs wäre diese Eidechse nach Leydig häutig. Einer nachträglichen Mitteilıng ${ }^{7}$ ) desselhen Forschers nach zu urteilen, dürfte die fusca über den Brenner nach Bayern eingewandert sein. Leydig sagt nämlich: »Nach eigenen

2) Üb. d. Verbreit. d. Tỉere im Rhöngebirge etc. in: Verhandl. d. uat. Ver, d. preuf. Rheinl. u. Westf. 38. Jalurg. 4. Folge. VIII. Bu.

$\left.{ }^{2}\right)$ Einige dem Rheinthale von Bingen bis Coblenz eigent. Pflanzen u. Tiere (Jahresb. d. Ver. fo Geographic u. Statistik. Frankfurt a. M. 1878).

$\left.{ }^{3}\right)$ Reptilien u. Fische d. Herzogt. Nassau, 1865.

4) Korrespondenzbl. d. naturhist. Ver. d. preuk. Rheinl. u. Westfal. 1876. S. 90.

${ }^{5)}$ Zoolog. Garten VII. S. 312 .

b) In einem, mir vorliegenden, wohl unvollständigen Auszuge aus der Arbeit Schnurs »Systematische Zusammenstellung $d$. im Regierungsbezirke Trier bisher von mir aufgefundenen lieptilien (Jahresber. d. Ges. f. nützl. Forschungen zn Trier 1857. S. 69. Trier 1858) vermisse ich die Mauereidechse, hingegen finde ich sie, in Schäfers Moselfauna I (Trier 1844), in IIollandres Catalogue des animaux vertébrés observés et recueillis dans le département de la Moselle (Bull. Soc. d'hist. wat. de la Moselle VI. Metz 1851) und in Malherbes Zoologie de la Moselle (in: Statistique de la Moselle. Metz 1854) genannt.

7) Üb. d. Verbreitung d. Tiere im Rhöngebirge u. Mainthal m. Hinblick auf Eifel u. Rheintal (l. c.). Anmerkung 9. 
und fremien Beobachtungen sehien es früher', als ob Lacerta muratis von 'Tirol her die Berge nicht überschreite, sondern nach Deutschland ins Rhcingebiet gelangt sei durch die Schwei\% und ron Frankreich aus; dann dureh das Donathal herauf. Hermann $k$ raufs hat aber die Wahrnehmung gemacht, dabs an den Abhïngen der Brennerstrafie zwischen Innsbruck und Schupfen, teils an Glimmerschieferfelsen, teils am Stein- und Holzgeländer der Strafe L. muralis haiufig vorkommt, sonach ein Einwandern über den Brenner stattgefunden haben mul3 (Verhandlungen der zool.-bot. Ges. in Wien, 1873, S. 8, Anmerkg.) «. - Aus dem Gesagten läßst sich mit Evidenz schliefsen, dafs die Verbreitung der in Rede stehenden Eidechse vom Süden nach Dentschland und Österreich nicht nur durch das Iihein- und Donauthal, sondern auch über das Tiroler Gebirge, sowie auch, wie ich gleich hinzufügen möchte, durch das Moselthal möglich gewesen. - Vielleicht mag es gröferer Aufmerksamkeit gelingen, das Tier auch im südlichen Bayern nachzuweisen; so viel ich weif, ist dies noch nicht geschehen. $\gg I m$ diesseitigen Bayern«, sagt Jäckel, der Verfasser einer Schrift über die Kriechtiere Bayerns, ${ }^{1}$ ) skommt sie nicht vor«, sondern nur »im Kanton Dürkeim bei Freiusheim, bei Grünstad, bei Duttweilen am sogenannten brennenden Berg in der Pfalz«. - Was nun das Vorkommen dieser Form im äufersten Westen und Osten Deutschlands anbetrifft, so läft sich nichts Bestimmtes darüber sagen. Das Senckenbergsche Museum in Frankfurt a. M. besitzt ein Exemplar. das Herr Simon in den Vogesen, wohl auf deutschem Boden, erbeutet haben soll und im Buche Godrons 》Zoologie de la Lorraine« (Paris 1863, pag. 22) finde ich sie als strès commun sur les vieux murs angegeben; genaneres über" die Fundstellen fehlt aber. - Lichtenstein erwähnt das Vorkommen der muratis in Schlesien ${ }^{2}$ ) und in der Mark ${ }^{3}$ ) und Tobias (1. c.) giebt die Möglichkeit zu, daß sie auch bei Görlitz einheimisch sein könnte. Die.Angabe Lichtensteins dürte aber wohl auf Verwechselung beruhen, jedenfalls ist sie, wie ich mich nenerdings bei der Durchmusterung der Berliner Sammlung zu uberzeugen Gulenenheit gehaht habe, durch keine Belegstücke erhärtet.

Während das Wohngebiet der muratis fusca in Spanion und Italien ziemlich genau aus der herpetologischen Litteratur ersichtlich ist, sind wir nur wenig über ihre Verbreitung auf Iler Balkan-Haibinsel unterrichtet, namentlich bezüglich der Türkei läßst sich zur Zeit nur sagen, dafs das Tier in der Umgebung von Serajewo, bei Travnik, in Herzegovina ${ }^{4}$ ) und bei Konstan-

1) Korrespondenzblatt d. zool, mineralog. Ver. in Regensburg, No. 6. 7. XXV. Jahrg. 1871. S. 81.

2) Nomenclator reptilium et amphibiorum etc, pag. 15.

$\left.{ }^{3}\right)$ Siehe Tobias, Die Wirbelt. d. Oberlausitz in: Abhandl. d. naturforsch. Ges. zu Görlitz, XII. S. 92. (iôrlitz 1865.

4) Da v. Möllendorf in seinen Beiträgen z. Fauna Bosniens (Görlitz 1873) üher Podarcis muralis 
tinopel beobachtet oder erbeutet worlen ist. 1) Auf dem Festlande Griechenlands scheint unsere Lacerta ziemlich bherall, aber nirgends in urofier Anzahl vorzukommen und wenn die Mitglieder der franzisischen Morea-Expedition das Gegenteil angeben, so ist dies einfach dadurch zu erklïren, daf: die Bearbeiter des herpetologischen Abschnittes des Werkes Expédition scientifique de Morée« die grüne Mauereidechse, L. taurica und L. pelopomesica mit der muralis fusca zusammengeworfen haben. Braune muralis kommen einzeln sowohl im Norden als auch im Süden, sowohl im Gebirge, beispielsweise auf dem Parnak, als auch in der Ebene, z. B. in der Eleusischen vor. Prächtige Stücke mit feuerroter. Unterscite habe ich am håufigsten am Fube des sogenanten Turkovun bei Athen gesehen; im Berliner Museum habe ich gleichfalls die fusca aus »Attika vorgefunden (No. 6973). Von den Jonischen Inseln kenne ich sie nur aus Cephalonia (Mus, in Halle: No. 139). Auf den Cykladen gehört sie zu den ziemlich weit verbreiteten Saurier-Arten. Auf Syra, Tinos, Mykonos, Phanar, Seriphos und Milo habe ich sie in grofiser Menge gesehen; die von der Insel Andros stammenden, im Museum zu Athen konservierten Individuen zeichnen sich durch ihre bedeutende Größe und durch ihre groken Schlafenschuppen aus. In grojer Anzahl ist die loraune muralis auch auf den kleinen, zwischen Attika und Negroponte liegenden Inseln Petali anzutreffen; die mir durch Herrn Inspelitor Münter zu Tatoï von dort zugesandten Stücke haben auf ihrer Bauchseite entweder einen gelblichen oder rötlichen Anflug oder sind orangerot koloriert. Die auf Mykonos einheimische fusca erscheint punktiert und gestreift oder nur punktiert. Auf Kreta kommt eine rubriventris mit schön ausgeprägten Linien auf den Rumpfseiten und üppig gezeichnetem Riickeu in Gemeinschaft mit der typischen fusca vor (Berl. Mus., No. 1052); Raulin hat letztere bei Khalepa beobachtet (Vergl. Ile de Crète. Vol. II. p. 1024. 1869).

Aus den Schriften A. Günthers ${ }^{2}$ ) und L。 Lortets ${ }^{3}$ ) über die Kriechticre Palästinas und Syriens erfahren wir, dafs die Mauereidechse in Beyrut, Saida, Tyrus, Hanaoueh und am See Hule gefunden wurde; auch in Gollu und in Mesopotamien soll sie beobachtet worden sein (X. Rapport du Mus. d. Sc. nat. Lyon, pag. 15); jedoch ist aus diesen Arbeiten nicht ersichtlich, ob unter smuralis« die grüne oder die uns hier interessierende braune Mauereidechse gemeint ist. Aus Klein-Asien kennt man sie bis jetzt nur aus türkisch Armenien ${ }^{4}$ ), Brussa

Wagl., Meremmii Wagl, und olivacea Schinz spricht, so bätten wir Grund zur Annahme, dafs unter der zuerst genannten unsere fusca gemeint ist.

1) Böttger, Herpetolog. Mitteilungen in: XXII. u. XXIII. Bericht. d. Offenbacher Ver. f. Naturkunde.

$\left.{ }^{2}\right)$ Report on a collection of Reptiles and Fishes from Palestine in: Proc. Zool. Soc, of London 1864, p. 488.

3) Poissons et Reptiles du Lac de Tibériade etc. in: Archives du Mus, d'hist. nat. de I.yon III. Lyon 1883.

4) Nach Kessler. 
und aus Trapezunt (Mus. d'hist. nat. in P'uris, No. 2718; var. D. in: Duméril und Bibrons Erpétologie générale, t. V, P. 233). Was den Verbreitungsbezirk der fusca in Persien anbelangt, so läbt sich zur Zeit nur wenig darüber sagen. De Filippi ${ }^{\mathbf{1}}$ ) traf sie im Norden und zwar in der gebirgigen Gegend von Demavend, ferner in der im südlichen 'leile Persiens gelegenen Provinz Laristan ( Vale der Lar ). Blanford ${ }^{2}$ ) traf sie auferlem im ElburzGebirge. „L. muralise, sagt dieser Forscher, winhabits the higher parts of the Elburz mountains. I only saw it on the south side of the hills, close to their summit, but it abounder on the north side, in the forest region, as low as 5000 feet above the sea, and perhaps lower, and was met with, rather less abundantly, up to an elevation of at least 10,000 feet«. Das British Museum enthält eine fusca aus Mâzanderan (ded. Blanford). Sämtliche von mir untersuchten braunen muralis aus Persien zeichnen sich, verglichen mit den großen Stiicken aus Traplezunt, durch ihre geringe Grobe, durch die feine Beschuppung der Temporal-Gegend, sowie auch durch die Abwesenheit des Massetericum aus.

Ibre Verbreitung im Kaukasus und in Transkaukasien ist ziemlich genau bekannt; sie wurde an den Sandsteinfelsen, unweit des Sauerbrunnens Norlzana, bei Tarki (IVestufer des Kiaspisees), in Elenowka, in Daratschitschak, im Kasbekgebirge, uuweit der Station Kasbek, zwischen den Stationen Passanaur und Mleti, in Mleti in Aragwathal, in Bad Abastuman und auf dem Berge Salawat (Umgebung von Nucha) konstatiert. Erstere zwei Fundorte sind schon längst bekannt ${ }^{5}$ ), die letzteren von $K_{\text {essler }}^{4}$ ) und $\mathrm{B} \ddot{\operatorname{tg} g e \mathrm{r}^{5}}$ ) beigefügt. Nach Kessler soll die typische fusca überall im kaukasischen Gebiete verbreitet sein, namentlich aber am Südabhange des Hauptgebirgstückens vorkommen und sich noch in einer Ilöhe von 6500 Ful:s finden, während die Var. saxicola Eversm. vorzugsweise den nördlichen Abhang des kaukasischen Gebirgszuges bewohnt und bis z.u 6400' Meereshöhe hiniufsteigt (Haltestelle Kashek). Das zoologische Museum der k. Akademie der Wissenschaften zu St. I'etersburg enthïlt Stucke aus Borschom (No. 3139), aus Achty (No, 5760) und Nowo-Bajazet am Goktscha-Sec, aus Temir-Chan-Schura (No.5759), von den Ufern des Flusses Belaja (Kuban) und aus Lenkoran.

$\left.{ }^{1}\right)$ Note di un Viaggio in Persia nel 1862. p. 354. Milano 1865. Vergl. auch: Camerano, Considerazioni sul Genere Lacerta L. etc. in: Atti. R. Accad. Sc. di Torino, Vol. XIII. 1877.

2) In: Eastern Persia, vol. II, p. 361. London 1876.

$\left.{ }^{3}\right)$ S. L. saxicola in: Eversmann, Lacertae imperii rossici etc. (Nouv. Mém. Soc. Imp. natur. de Moscou III. p. 349. 1834. - Eichwald, Reise auf d. Kaspischen Meere u. in d. Kaukasus, I. S. 97. Stuttgart u. Tübingen. 1834.

4) Zoolog. Reise durch Transkaukasien im Jahre 1875 in: Arbeiten d. St. Petersl. naturw. Gesellsch. VIII. Beilage. St, Yetersburg 1878 (russisch!).

5) Studien an palaearkt. Reptilien u. Amphibien in: Bericht d. Ofienbach. Ver. f. Naturkunde 1880. 
I. agitis L. aus Lenkoran und L. Laurenti Daud. bei Ménétries') gehören höchst wahrscheinlich zu muralis fusca. Der Güte des Akademikers Dr. Strauch verdanke ich Exemplare der typischen fusca aus Elenowka am Goktscha-See, aus Helenendorf bei Jelizawetpol (gesammelt (urch Iohenacker) und aus dem Aragwathal. Eichwald, der Verfasser des Werkes "Fauna caspio-caucasia», giebt folgendes über das Wohngebiet sciner Zootoce rlulybldra (= saxicola Eversm.) an: „Hab. in Caucaso, Iberia, ar 'Tiflisios urbem, Somchetia; etiam ad aquas carbonicas Kislawodskienses«. El behauptet ferner die murulis in Volhynien gefunden zu haben ${ }^{2}$; da jedoch später dort niemand weiter sie gesehen hat, darf, auf diese Angabe kein Gewicht gelegt werden. Obschon wir nur wenig über ihre Verbreitung im europäischen Ruf3land unterrichtet sind, kümnen wir dennoch nahezu mit Sicherheit atnnehmen, dals sie sich nicht über den Norden von Rufland verbreitet. Nach Seidlitz ${ }^{3}$ ) soll sie von Dr. $\Lambda$ smuf in Livland beobachtet worden sein, eine Angabe, die wohl anf einem Irrtum beruhen dürte; jedenfalls ist sie in einem älteren Verzeichnis über die Fauna Livlands ${ }^{4}$ ) und in einer kürzlich publizierten Schrift über die Reptilien in den Ostsecprovinzen nicht genannt. ${ }^{5}$ ) Auffillend und für unser Verständnis unerklärlich erscheint der von Pallas »nachgewiesene« Fundort von L. muralis in Sibirien. ${ }^{6}$ ) Die angeblich in Sibirien von Pallas gesammelten muralis befinden sich im zoologischen Museum zu Berlin und sind als smeralis" und zugleich als soxycephala « bezeichnet (No. 1015, 1020); höchst wahrscheinlich liegt hier ein Fehler in der Fundortsangabe vor. Ebenfalls nicht authentisch scheint mir die Vermutung Sabanejews zu scin, wonach diese Fidechse nicht nur im Kaslinski-Ural, sondern auch allerorten im Uril-fiebirge vorkommen soll. $\left.{ }^{7}\right)$ Das Verbreitungsgebiet der Mauereidechse im russischen Reiche beginnt, meiner Ansicht nach, in den südlichen Gouvernements, etwa vom $50^{\circ} \mathrm{n}$. Br., uud reicht nach Süden bis zur Südküste Tauriens, nach Osten bis zu dem Ostufer des Kaspisees und begreift auch das kaukasische Gebiet und Russisch-Armenien in sich. In der Krim fehlt sie an vielen Orten; namentlich im Norden findet man sie nur ganz vereinzelt vor, so nach Kessler im oberen Salgir-Thale, »aber nur in zwei bis drei, von Kalkfelsen eingefafiten Klüften «。 ${ }^{8}$ ) $\Lambda$ n der Suid-

1) Catalogue raisonné etc. pag. 60, 62.

$\left.{ }^{2}\right)$ Naturhistorische Skizze von Lithauen, Volhynien u. Podolien etc. S. 233. Wilna 1830.

$\left.{ }^{3}\right)$ Verzeichnis d. Såugetiere, Vögel, Reptilien u. Amphibien d. Ostseeprovinzen, S. 45.

4) Fischer, Versuch einer Naturgeschichte von Livland. S. 237. Königsberg 1791.

3) 0. v. Löwis, Die Reptilien Kur-, Liv- und Estlands. Riga 1884.

$\left.{ }^{6}\right)$ Lichtenstein, Nomenclator reptilium et amphibiorum etc. pag. 15. Berlin 1856.

7) Bulletin de Moscou XLIV. P. II. p, 273. Moscou 1871.

${ }^{8}$ ) Köppen, Zur Herpetologie d. Krim in: Beitr. z. Kenntnis d. russischen Reichs u. d. angrenzend. Länder Asiens. I. Folge. Bd. VI. S, 63. St. Petersburg 1883. 
kisste der Hallhinsel scheint sie hïutiger zu sein, obschon weniger häufig als die taurica. Kessler führt sie aus Jalla an; die zoologische Universitätssammlung in Kiew enthält eine fusca vom Georgenkloster bei Balaklawa (No, 1967). Die in derselben Sammlung sich befindende, als muralis bezeichnete Lacerta (No, 1966) scheint mir eine neue Form zu scin. Die von vielen Autoren als synonym hierher gezogene $\gg L$. grammica Lichtenstein meiner Veinung nach, zu einer spitzköpfigen Form oder zu depressa Camerano gehören liathke sagt von ihr unter anderem: „Sie ist sehr schlank und hat cinen verhailtnismäbig viel längeren Schwanz als selbst $L$. taurica. Im Vergleich zu dieser Eidechse ist jedoch ihr Kopf viel breiter und oben nicht gewölbt, sondern platt«... »Die Schuppen des Rumpfes sind alle glatt und ohne Spur cines Kieles, erscheinen zum 'l'eil als unregelmäligige Fünfecke, zum T'eil als kreisrunde Scheiben und sind verhältnismäßrig sehr klein, so dafs in der Mitte des Rumpfes jederseits bis 35 Stiick in einer senkrechten Reihe stehen« ... »es befindet sich«... vein ziemlich grofies Scutum massetericum, um das herum eine Menge zwar verschiedentlich grolier, doch in ganzen nur sehr kleiner Schildchen gelagert ist «... sDie wirbelförmig aneinander gereihten Schilder des Schwanzes sind aber stark gekielt und ihre Kiele springen nach hinten in eine Art von Spitze viel stärker vor als bei vielen anderen Eideclssen, weshalb denn auch der Schwanz von L. grammica sehr rauh anzufühlen ist. In Hinsicht des Scutum massetericum, der vor dem After liegendeu Schilder, und der Länge der Hinterbeine ist diese Art sehr ähnlich der L. muralis.. ${ }^{1}$ ) - Diese Beschreibung paßit aber eher auf Lacerta depressa Cam. oder die oxycephale. Ich brauche hier wohl kaum besonders hervorheben zu müssen, daki der von Rathle für seine Krimer Echse proponierte Namen »L. grammica Licht.« schlecht gewählt ist, denn diese Bezeichnung bezieht sich nicht auf eine echte Lacerta, sondern vielmehr auf eine pristidactyle Saurier-Art, welche, wie Rathke selbst angiebt, sbis dahin nur in Egypten, Nubien und der 'Tartarei gefunden worden war», - Nach Czernay kommt die Var. saxicola Eversm. im Charkowschen Gouvernement snicht selten vor ${ }^{2}$ ) und nach Kessler findet sich die muralis im Gouvernement von Kiew (siehe Leydigs Werk über die deutschen Saurier). Exemplare atus der Umgebung Odessas habe ich im zoologischen Museum der K. Akidemie zu St. Petersburg vorgefunden (No.3136). Tardent führt die Mauereidechse aus Bessarabien an, wo sie häufig vorkommen soll. ${ }^{3}$ )

Nachdem ich nun möglichst vollständig die Verbreitun!r der" fusca in den einzelnen Ländern

1) Beiträge z. Fauna d. Krim, 1. c.

$\left.{ }^{2}\right)$ Bulletin de Moscou 1851. Bd. I, pag. 269.

3) Essai sur l'hist. nat. de la Bessarabie, p. 12. Lauzanne 1841. 
besprochen, will ich noch die Grenzlinie ihrer allgemeinen Verbreitung ziehen. Die Nordgrenze ihrer Verbreitung hat folgenden Verlauf: von der Nordküste Frankreichs geht sie über den nördlichen Teil Hollands (Provinz Groningen), anfangrs dem Rhein-, damn dem Neckarufer folgend, bis ins Württembergische über; von hier tritt sie, fast steil nach Sülen gehend, nach Tirol hinuiber, dann wendet sie sich wieder nördlich, den Gebirgszügen folgend, in der Richtung nach Wien und von hier längs del Grenze Mäbrens und Ungarns nach Kaschau in Oberungarn; üstlich scheint die Grenzlinie längs del Karpaten zu verlaufen, die Gouvernements von Kiew und Charkow zu berühren, um sich wiederum bis zum $44^{\circ} \mathrm{n} . \mathrm{Br}$. (Piatigrorsk) und zum $43^{\circ} \mathrm{n}$. Br. (Tarki) zu senken und ihren Endpunkt am Sülufer des Kaspisees in der Provinz Mâzenderan zu erreichen. Einerseits Matzenderan, andererseits das Larthal in Laristan scheinen die am weitesten östlich vorgeschobenen, von der fusca bewohnten Gebiete zu sein. Daßs die unwirtlichen, südlich von Kurdistan liegenden Gebiete von unserer Eidechse gemieden werden, steht auljer Frage, wir können folglich annehmen, dafs die südgrenze ihrer Verbreitunğ in TürkischArmenien zu suchen ist und daf sie sich möglicherweise von da längs der syrischen Küste verbreitet habe. Die südliche Grenze ihrer Verbreitung ist mir nicht möglich festzustellen, denn aus den mir vorliegenden Angaben ersehe jch nur, daf die südlichsten Punkte, wo sie bis dato gefunden worden ist, weit voneinander entfernt liegen; es sind Kreta, Sétif, Plateau de Sersou, Tlemcen und Tanger. Die atlantischen Küsten Portugals, Spraniens und Frankreichs bilden die westlichen Schranken ihrer Verbreitung. Die angeblichen Fundorte in Schlesien und in der Mark habe ich aus den oben angeführten Gründen auker acht gelassen.

Über ihre senkrechte Verbreitung hätte ich noch folgendes zu bemerken: in Suidtirol steigt sie bis 4000, ja selbst zu 5000 Fuf Meereshöhe hinauf (Gredler, Leydig), im Gebirgsstock des Montblanc, wie es Venance Payot behauptet, ist sie in den Höhen von etwa über 6500 Fuß gefunden worden und im Kaukasus soll sie, laut Kessler, bis zu einer Höhe von 6500 Fußs hinaufsteigen. Dafs das Tier in Höhen von über 5000 Fuf selten ist, brauche ich wohl kaum hinzuzufügen.

Subsp. neapolitana de Bedriaga 187.4 (Über die Entstehung d. Farben bei d. Eidechsen. Jena 1874; Herpetolog. Studien in: Archiv f. Naturgeschichte, Jahrg. 44, Bd. I, S. 285; Jahrg. 45, Bd. I. S. 274; Bull. Soc. zool. de France IV, p. 202. - L. serpa Rafinisque, L. Camerano, Monografia dei Sauri Italiani in: Zoologischer Anzeiger. VIII. Jahrg. 1885. S. 418. - Lézard des murailles Milne Edwards, Recherches zool, pour servir à l'hist. des Lézards etc. 1. c. - Podarcis Merremii, var. maculatus Fitzinger, Versuch einer Geschichte d. Menagerie d. öster. k. Hofes in: Sitzungsber. d. k. Akad. d. Wiss. Math. naturw. 
K1. 1885. S. 652. - L. muralis vilt. c, d, e, h, i, j, k, 1, q. r, t, u (?), v, Schreiber, Uerpetologia europaca, S. 408-410. - Vergl. die Synonymic von neapolitana in Bull. Soc. zool. de France, t. IV, 1). 202).

Mit diesem Namen belegte ich eine grüne Form der Mauereidechse, welche grölier ist als die fuscu und vorzugsweise in Italien, Sicilien, Sardinien, Dalmatien und auch in Griechenland vorkommt. Das endlose Variieren der fusca finden wir in noch grötierem Mafsstabe bei unserer neapolitana. Wie dort, so auch hier wurde letztere in zahlreiche, möglichst voneinander geschiedene Abarten zergliedert und mit den verschiedensten Namen belegt. Den SubspeciesNamen meapolitana bitte ich als Kollektiv-Bezeichnung für die meisten, oberhalb melr oder weniger grün gefirbten und auch sonst durch ihre bedeutenden Körpermafe und die eher pyramidale Kopfform gut kenntlichen Matuereidedsen zu betrachten. Mit Ausmahme der Zeichmug sind die neapolitunae, was den Bau des Körpers und die Grundfärbung anbetrifft, ziemlich beständig; nachfolgende Zeichungsvarietäen fielen mir ander manchen anderen besonders auf:

a) Der ganze Rücken, oder blof der vordere Rückenteil, sowie auch der Nacken erscheinen entweder gras- oder olivengrün, oder hell-, fast gelbgrün. Bei der italienischen Form prädominiert das Grasgrün beim Männchen und das Zimtbraun und Gelbgrün beim Weibchen (rlegans, modestu Eimer ${ }^{1}$ ), während bei den in Dalmatien und atuf einigen dalmatinischen Eilanden eimheimischen Eidechsen die olivengrunen und olivengranen Farben auf der Rückenobertläche vorherrschen. Sowohl bei diesen, als auch bei jenen nehmen in der Regel die grünlichen Tüne gegen die liumpfseiten und gegen den Schwanzanfung zu allmählich ab; in den meisten Fillen erscheinen diese Körperpartien, sowie auch die Oberseite des Kopfes, der Gliedmafien und des Schwanzes fahl- oder zimtbraun, bronzebraun, olivengrün oder olivengrau. Bei den italienischen männlichen Individuen sind die Rumptseitun mitunter auf hellbraunem irunde dunkel gefleckt, während bei den dalmatinischen Individuen die brïunlichen Rumpfseitenbinden nur in seltenen Fällen eingestreute gelblich-oder grunlichbraune Schupen autzuweisen haben; auberdem unterscheiden sich die Italiener insufern von den Dalmatinern, als sich bei ersteren, und zwar vorzugsweise bei den Männchen, über der Wurzel der Vorderextremität blaue Augenflecken befinden; bei den mit ähnlichen Zierden versehenen Weibehen sind die Ocelli stets lilein und gelbgrün gefürbt. In cingen Fällen heben sich aulierdem bei den italienischen männlichen Individuen hellbraune Ocellenflecken vom braunen Fond auf der Oberseite der hinteren Gliedmafien ab. Die Fürbung der Unterseite ist manchen Verimlerungen unterworfen; in den meisten Fillen zeigt die Bauchseite ein gelbliches Weif ( $L$. puccina Raf.), das aber einerseits durch Blau ins Grünliche, 
anderseits durch Gelbrot bis ins Ziegelrot übergehen kann. Lebhaft kupferfarbene Stücke (I. cumpeiventris Massal.) scheinen vorzussweise auf einigen dalmatischen Inseln, so beispielsweise auf Lussin einheimisch zu sein; sie kommen übrigens auch in Italien vor. - Dicse nahezu unisono gekleidete und ungefleckte murclis ist bereits im Jahre 1810 von Rafinisque Schmalz als $L$. olivacea beschrieben worden. ${ }^{1}$ ) - Die Mafise, deren Details ich hier folgen lasse, sind von italienischen und dalmatinischen Nännchen und von einem dalmatinischen Weibchen genommen worden; die dalmatiner Stücke stehen in Bezug auf die Körpergrößie den italienischen nach.

Neapel. Lussin.

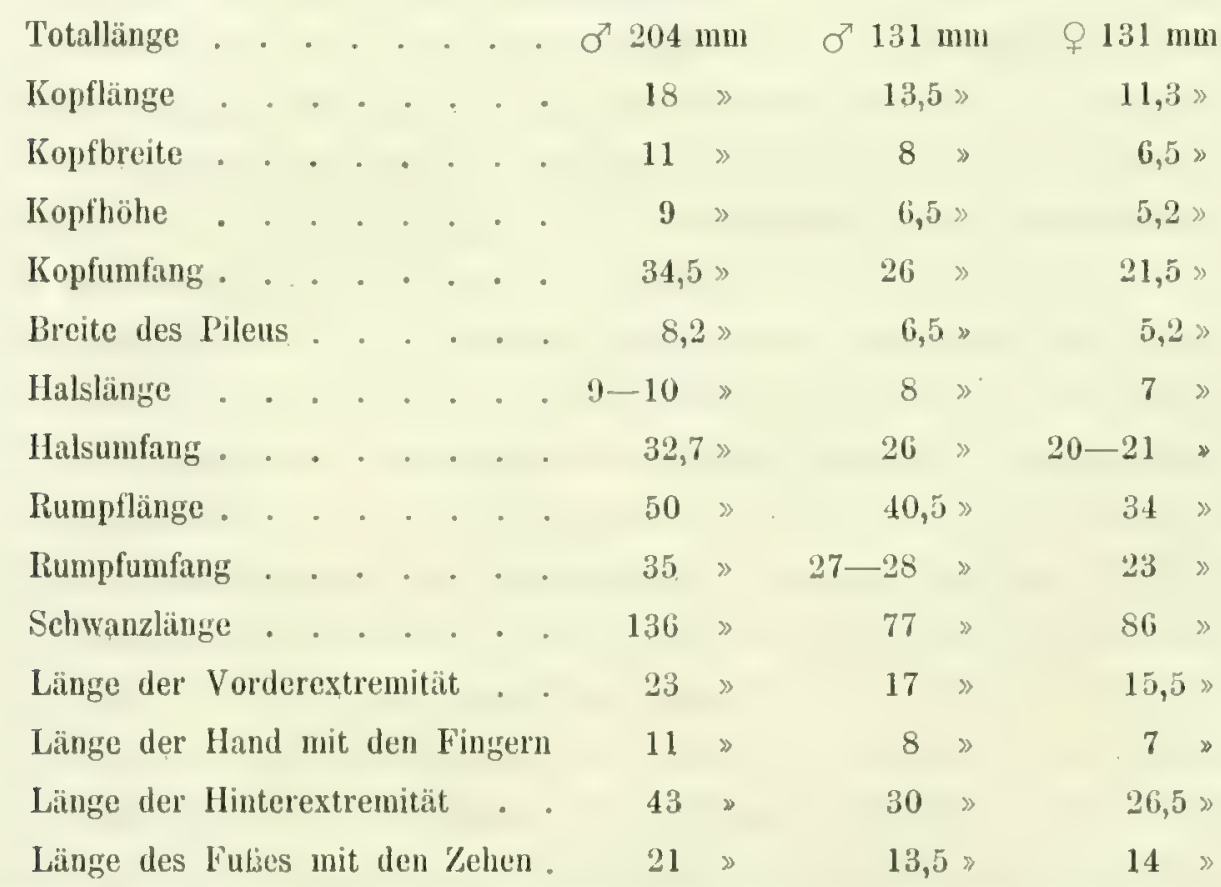

b) Die Farbe dẹ breiten Mittelzone des Rumpfes ist grasgrün umsäumt vou aus größeren schwarzen Flecken bestehenden Binden, welche hinter den vorderen Extremitäten ihren Ursprung nehmen und in der Wurzel der Hinterextremitäten enden. Etwas vor der Schwanzbasis fängt oben eine, ebenfalls aus schwarzen Makeln bestehende, mediane Binde an und geht in den braun kolorierten Schwanz über. Vom äußeren Rande der Parietalia gehen jederseits, einen Saum der schwarzen Binde bildend, mitunter nur spurweise angedeutete hellgrüne Streifen alus. Kopfdecke und Schliafe sind grasgrün; Massetericun und Tympanale braun, schwarz junktiert; Supralabialia sind hellgrün; die unteren Seitenteile des Halses sind hellila oder bläulich.

1) Caratteri di alcuni nuovi generi e nuove specie di animali e piante della Sicilia. Palermo 1810. 
Die Seiten des Rumpfes orseheinen mannigfaltig koloriert; es wechseln hier grine, hellbraune, rötliche und lilafarbene Schuppen untereinander $a b$. Auf beiden Seiten hinter den Achseln sind zwei blaue Ocelli vorhanden, von denen das eine, unmittelbar an der Wurzel der Gliedmafien liegende, von einem breiten schwarzen linge umrandet ist. Nahe der ersten longitudinilen Bauchschilderreihe crhalten die Rumpfseiten eine zweite, aus kleineren schwarzen oder braumschwarzen Flecken bestehende Binde. Die Oberseite der Vorderextremitaten trïgt grume und schwarze Flecken, dic Oberseite der Hinterextremitäten ist grünlichbraun und nur vorn (auf den Schildern) dunkel gefleclit. Die äulicren Längsreihen der Bauchtafeln sind blau, schwarz gefleclit; die übrigen Schihler haben entweder eine rötlichgelbe oder bliuliche Farbe oder sie sind grünlich, weiligelb geranlet; die Brustgegend ist stellenweise blan gefleckt; die Kieferschilder haben gleichf:lls einen blüulichen Anflug. - I)iese, hinsichtlich ihrer KürrergröLe sich der olivacea nühernde Zeichnungsform kommt in Colambrone, einer morastigen Gegend bei Livorno und auf Sicilien vor und reprisentiert eine echte Feldbewohnerin; sie ist von mir im Jahre $1879 \mathrm{im} \mathrm{Archiv} \mathrm{f.} \mathrm{Naturgesch.} \mathrm{45.} \mathrm{Jahrg.} \mathrm{I.} \mathrm{Bd.} \mathrm{S.} 279$ als Untervarietät »7ivornensis« oder als »sous-varieté g.«(Bull. Soc. 200l. de France IV, p. 205) verzeichnet worden.

c) Die neapolitana albiventris weicht in einigen Punkten von der vorigen ab. Die Grundfarbe des Rückens ist im vorderen Teile vorherschend grün, von grasgrün (o) bis olivengrün (f), selten graugrün. Gegen die Schwanzwurzel hin nimmt die grüne Fïrbung allmählich ab und geht in Braun, Fahlbraun oder '/imtbraun über. Die seitlichen Teile des Rumpfes sind selten reingrün, und zwar nur bei den grasgrünen Exemplaren, dagegen entsprechen sie in der Regel den hinteren Partieen des Körpers in ihrer Färbung. Die Rücken- und Seitenzeichnung ist sehr mannigfaltig; bei einigen z. B. zieht sich in der Vertebrallinie eine ununterbrochene, schwarze oder schwarzbraune, zicmlich breite Zickzackbinde oder bloL eine Zickzacklinie hin, die sich in der Schwanzwurzelgegend in einzelne Makeln auflöst, bei anderen besteht dieses Band selbst im vorderen Teile des Rumpes aus vollkommen getrennten oder nur durch feine Veriistelungen untereinander zusammenhïngenden, mitunter hellbraun, weililich oder grünlich geaugten und spurweise mit hellbraun umsïumten quadratischen oder delta- und schnörkelfürmigen Flecken. In nur geringer Entfernung von dieser Vertebralfleckenserie liegen wiederum dunkle Fleckenreihen, so dals nur je eine schmale ungezeichuete Binde Grundfarbe zwischen ihnen übrig bleibt. Dabei sind die Rumpfseiten mehr orler weniger stark schwarz oder schwarzbraun gefleckt; im letzteren Fall zeigen die Flecken eine Neigung zusammenzufliefien und sich zu verspinnen, wodurch geschlïngelte, vielfich unterbrochene und ungleich breite Querbinden entstehen, welche bisweilen durch hellbraune oder weibliche strich- oder aurenartige, reihen- 
weise angeordnete Flecken getrennt erscheinen; diese Fleckenreihen fangen oberhalb der Ohröffnung an, um sich über die Achseln, häufig bis zum ersten Schwanzdrittel fortzusetzen. In selteneren Fällen verspinnen sich die Flecken auf den Flanken zu einem Netzwerk; minder hâufig scheinen albiventris Bonap. vorzukommen, bei denen die Zeichnung der Oberseite nur spurweise, etwa in Form von Punktflecken oder Strichen, geschlängelten Linien oder Ringen, angedeutet ist; in diesem Falle ptlegen sowohl die längs des Rückgrates als auch längs der Rumpfseiten sich befindlichen Flecken auf grülichbraunen Binden angeordnet zu sein; diese Binden scheinen nichts Anderes zu sein als jene, bei den grobgefleckten albiventris erwillinten Fleckensäume, welche sich hier vereinigt und auf diese Weise Binden gebildet haben mögen. Über den Wurzeln der Vorderextremitäten ist jederseits ein meistens schön ausgebildeter, blauer, runder Fleck sichtbar, der ofters dunkel umrahmt erscheint; auch die ersten Longitudinalreihen der Ventralia sind blau, wobei die Schienen dieser Reihen zuweilen schwarz und weif punktiert oder gestreift sind; blälich-grunlichweifse oder weilse, mit brïunlichem Anfluge versehene Ocellen zieren mitunter und zwar vorzugsweise bei den Männchen die hintere Partie des Unterschenkels, oberhalb des Fuligelenkes, des Oberschenkels und des Kniegelenkes; an den Seiten der Schwanzbasis kommen dergleichen Zierden nur selten vor. Die Kopflecke ist auf duukelbraunem, zimtbraunem oder grünlichgrauem Grundton schwarzbraun gezeichnet; die Wangen und Unterkiefer sind häufig hellgrün oder blïulich gefärbt, wobei die Schläfengegend in der Regel oben auf bräunlichem Grunde dunkelbraun gefleckt erscheint. Die Zeichnung des Oberkörpers wiederholt sich insofern auch auf dem Schwanze, als die Vertebralfleckenreibe und die Flankenflecken bis gegen das Schwanzende hin sich fortsetzen, hier aber bedeutend schwiicher auf grau- oder braungrünem Grunde ausgeprägt zu sein ptlegen; auf den Schwanzseiten gesellen sich je eine Reihe weißlicher Flecken hinzu. Die Bauchseite und die Unterseite der Extremititenpare sind vollkommen weif oder mit nur äulierst schwachem gelben, blauen oder graublauen Anfluge; die Unterkiefer erscheinen ziemlich stark bläulich angehaucht.

Neapolitana albiventris ist in der Umgebung von Neapel, auf Capri, in Toskana, so z. B. bei Florenz, sogar in Florenz selbst und auf Sicilien einheimisch; die lateralwärts genetzten albiventris habe ich besonders häufig in der Nähe von Messina, auf dem sandigen Boden und an den Mauern dicht am Meere getroffen. Wenn De Betta angiebt, daf diese Eidechsenform die gröften Mafe unter den neapolitanae erreicht, so stimme ich mit ihm darin überein, denn die männlichen Individuen erreichen gewöhnlich $230 \mathrm{~mm}$, die Weibchen $195 \mathrm{~mm}$ an Länge. Die Details der Mafe sind folgende:

$$
\text { ऊ aus Capri: - Totallänge: } 236 \mathrm{~mm} \text {; Kopflänge: } 19 \mathrm{~mm} \text {; Kopfbreite: } 12 \mathrm{~mm} \text {; Kopf- }
$$


höhe: $10^{1 / 2} \mathrm{~mm}$; Unfing des Kopfes: $42 \mathrm{~mm}$; Breite des P'ileus: $9^{11 / 2} \mathrm{~mm}$; IIalslïnge: $10 \mathrm{~mm}$; Umfang des IIalses: $42 \mathrm{~mm}$; Rumpllinge: $61 \mathrm{~mm}$; Umfing des Rumpfes: $51^{1 / 2} \mathrm{~mm}$; Schwanzlänge: $156 \mathrm{~mm}$; Lïnge der vorderen Extremität $27 \mathrm{~mm}$; der Hand und Finger: $12 \mathrm{~mm}$; der hinteren Lxtremitä: $45 \mathrm{~mm}$; des liufies and der /chen: $22 \mathrm{~mm}$.

q. aus Neapel. - Totallänge: $153 \mathrm{~mm}$; Koflinge: $14 \mathrm{~mm}$; Kopfbrcite: $9 \mathrm{~mm}$; Kopfhöhe: $7 \mathrm{~mm}$; Umfang des Kopfes: $27 \mathrm{~mm}$; Breite des Pileus: $7 \mathrm{~mm}$; IIalslänge: $9 \mathrm{~mm}$; Unfang des IIalses: $27 \mathrm{~mm}$; Rumpflänge: $45 \mathrm{~mm}$ : Unfang des Rumpfes: 32-33 mm: Schwanzlänge: $94 \mathrm{~mm}$; Länge der vorderen lixtremität: $21 \mathrm{~mm}$; ler Hand und Finger: $9 \mathrm{~mm}$; der hinteren Extremitait: $34 \mathrm{~mm}$; des Fulses und der Zehen: $16^{1 / 2} \mathrm{~mm}$.

d) Eimer führt uns, statt sich an die Originalbeschreibung der campestris de Betta zu halten, eine Form der Genci Cara oder lineata d e Betta als echte campestris de Betta vel striata s. str. Eimer vor. Um weiteren Milsverstïndnissen vorzubeugen, will ich versuchen, die von de Betta in seiner Erpetologia delle Provincic Venete e del Tirolo Meridionale pag. 152 gegebene Diagnose der compestris ins Deutsche zu übertragen: „Der gleichmäligig schün, melr oder minder lebhaft grün grefärbte Rücken ist mit einer breiten, meist brïunlichen ununterbrochenen und mit einer bald mehr, bald minder grofien Anzahl schwärzlicher oder schwarzer, bald grögerer, bald kleinerer und von einander entfernten Flecken besetzten Binde versehen. Diese Binde erscheint zuweilen nur schwach markiert und schwarz gefleckt; mitunter wirl sie blof durch kleine schwarze Fleckchen gebildet, welche an Halse unterbrochen erscheinen und am ganzen Rücken ziemlich spärlich verteilt sind. Zwei ähnliche Linien an den Kürperseiten lassen das zwischen diesen und der dorsalen Reihe sich befindende lebhafte Grün in Gestalt von 2 breiten Binden stark hervortreten; diese Linien an den Körperseiten sind oben und unten weifs umsäumt, wobei der obere Saum als ununterbrochener weifer Streifen auftritt und sich deutlicher als der zu unterst liegende abhebt; auf den Binden sieht man hier und da verteilte weifse Flecken. Der Kopf hat cine bald mehr, bald weniger gesättigte braune Furbe und ist mehr oder minder mit kleinen schwarzen Fleckehen und Punkten besetat. Die unteren Körperteile sind gleichmäbigr weiflich, gelblich, gelblichgrün oder auch rötlich koloriert«. In betreff des Wohmbezirks der neapolitanu campestris berichtet De Betta folgendes: (Cosi nel basso Veronese, nel Padovano, e presso Venezia soltanto, e sempre esclusivamente nelle campagne o sulle siepi verdi, può dirsi frequente la var. campestris, che in Tirolo scontrai solo e rarissima presso Ala e Rovereto«. - Die campestris soll ferner auch auf Korsika einheimisch sein; sie ist, wie De Betta behauptet, identisch mit der tiliguertu De Filippi (non Cetti! non Camerano!). 
e) As Subvar. Alememii Fitz. (non Risso!) bezeichne ich die in Dalmatien verbreitete und auch im Kiarstgebirge vorkommende, von Bonaparte als $P$. olivacens albiventrise und von Eimer als "punctato-striatak und "punctato-fasciata benannte, mehr oder weniger deutlich zweifach weíl gestreifte neapolitana. Die Grundfarbe des Rückens dieser Untervarietät (Vergl. meine Fig. 5 auf Taf. IX im Bull. Soc. zool. de lrance, vol. IV) ist rorherrschend grün, selten und, wic es scheint, nur bei den Weibchen in Braun oder Olivenfarben getrübt: in der Mittellinie des Rückens zicht sich ein aus schwarzen oder schwarzbraunen Flecken bestehendes Band hin, das mitunter etwas vor der Schwanzwurzel beginnt und in den bräunlichgrün kolorierten Schwanz übergeht; bisweilen sind die Dorsalpunkte nur spurweise angedeutet. (Vergl. Bonapartes $P$. olvaceus albiventris in: Iconografia della Fauna italica, Fig. a); vom äuferen seitlichen Rande der Parietalia gehen jederseits ganz hellgrüne ( $\left(\right.$ ) oder weiß́liche ( $\left.\sigma^{7}\right)$, schmale ununterbrochene Streifen oder Längsreihen von ebenfalls hellen, länglich schmalen, mitunter leicht geschlängelten Fleck̉en, welche von melır oder weniger zusammenhängenden, bei den Weibchen auf hellbraunen Binden angeordneten, bei den Månnchen hingegen nur hellbraun umsïumten schwarzbraunen oder schwarzen Flecken und schnörkelartigen Figuren beiderseits begrenzt erscheinen; in einigen Fällen vermissen wir diese dunkle Umsäumung am oheren Rande der hellen Streifen oder der hellen Fleckenreihen entweder gänzlich, oder sie tritt nur spurweise angedentet auf; in anderen Fällen wiederum und zwar bei den weiblichen Individuen sind die unteren, als Säume dienenden dunklen Flecken nahezu gänzlich durch ziemlich breite nußbraune Binden ersetzt, die bereits am Nasenloch entspringen, sich durch das Auge und die Temporalregion auf die Rumpfseiten fortsetzen, um sich am Schwanzende $z u$ verlieren. Diese Binden sind noch einmal gegen die Bauchseite hin von einem hinter dem Auge beginnenden und am ersten Schwanzdrittel noch nachweisbaren hellen Streifen begrenzt, der sich allerdings schon deswegen viel schwächer als der.obere Streifen abzuheben pflegt, weil die Bauchgrenze bedeutend heller bräunlich, grau oder grünlichbraun koloriert erscheint. Bei den ơ setzt sich der untere helle Streifen selten scharf $a b$, in den meisten Fällen ist er durch eine longitudinale helle Fleckenreihe, oftmals nur spurweise angedeutet; auf diesen folgen joderseits je eine Reihe kleiner brauner Flecken, welche sich. mitunter verästeln und verspinnen, aber nicht in dem Mafe, wie es von dem Koloristen auf meiner in Bull. Soc. zool. de France IV, Taf. IX erschienenen Fig. 5 wiedergegeben worden ist; auch die zahlreichen weifen und blauen Punkte auf den Rumpfseiten muß man sich hinweg denken. Über den Vorderextremititen befinden sich bisweilen bei beiden Geschlechtern runde Flecken, welche bei den Männchen schön blau und grob, bei den Weibchen, aber grünlichweif oder bräunlich und klein erscheinen; die bellbraune Ober- 
seite der Gliedmalien ist gränlich geaugt; die äuferen Längsreihen von Batuchtafeln und die Submaxillaren sind bronzebraun $(\varphi)$, grünlich oder blitulich $\left(\sigma^{7}\right)$ angehacht; dic Kopfdecke endlich ist auf grüulichgrauem, grünlichbramem, olivengrünem oder auch, obschon weniger häufig, auf grasgrünem l'ond dunkelbraun gezeichnet. Die Unterseite des Schwanzes ist mit einem gelblichen Authge versehen, während alle übrigen unteren Körperteile weiß̧ sind oder bald gelblich oller rosi, bald grünlich oder bläulich angehaucht und perlmutterglänzend erscheinen. - Ich lasse hier die Malise der gröfiten, mir aus dem Karstgebirge zur Verfügung stehenden Stücke folgen:

Männchen. - 'Totallänge: $190 \mathrm{~mm}$; Kopflänge: $15 \mathrm{~mm}$; Kopfbreite: $9 \mathrm{~mm}$; Unfang des Kopples: $29 \mathrm{~mm}$; Kopfhöhe: $7 \mathrm{~mm}$; Breite des Pileus: $5-6 \mathrm{~mm}$; IIalslängre; $9 \mathrm{~mm}$; Halsumfang: $28^{1 / 2} \mathrm{~mm}$; Rumpflänge: $49 \mathrm{~mm}$; Rumpfumfang: $30-32 \mathrm{~mm}$; Schwanzlänge: $126 \mathrm{~mm}$; Länge der vorderen Lxtremität: $201 / \mathrm{mm}$; der Hand mit den lingern: $8-9 \mathrm{~mm}$; der hinteren Extremitit: $36 \mathrm{~mm}$; des Fufses mit den Zehen: $16^{1 / 2} \mathrm{~mm}$. - Weibchen. 'Totallänge: $184 \mathrm{~mm}$; Kopflänge: $12^{1 / 2} \mathrm{~mm}$; Kopfbreite: $8 \mathrm{~mm}$; Umfang des Kopfes: 25-26 mm; Kopfhöhe: 6-61/4 mm; Breite des Pileus: $5-6 \mathrm{~mm}$; Halslänge: $8 \mathrm{~mm}$; Halsumfang $24-24^{1} / 2 \mathrm{~mm}$; Rump̧fänge: $45 \mathrm{~mm}$; Rumpfumfang: $34^{1 / 4} \mathrm{~mm}$; Schwanzlänge: $120 \mathrm{~mm}$; Länge der vorderen Extremität: $16 \% \mathrm{~mm}$; der Hand mit den Fingern: $7-8 \mathrm{~mm}$; der hinteren Extremität: $29 \mathrm{~mm}$; des Fulses mit den Zehen: $14 \mathrm{~mm}$.

f) Das Gewand der mir von der Insel Pelagosa im Adriatischen Meere seitens Prof. Stossich im Jahre 1881 und seitens Dr. E. Schreiber in Jahre 1882 zugesandten neapolitana erinnert uns im allgemeinen an die albiventris Bonap. Sobald man aber auf die nähere Betrachtung dieser Eidechsen eingeht, so ergeben sich bedentende Unterschiede. Die bei den Männchen bald grüne, bald dunkelgrüne oder bräunlichgrüne, bei den Weibchen meistenteils hellgriune Grundfarbe tritt bei den Pelagosa-M Muralis in Form von schmalen, an ibren Rändern leicht gezähnelten Binden auf, welche stets schmäler als die 3 den Rücken zierenden schwarzbraunen Fleckenbänder erscheinen; das mediane Fleckenband ist in der Regel genau so breit wie die hintere Kante des Occipitale, am Nacken und am Vorderrücken verfliefsen die Flecken vollkommen ineinander und bilden ein nahezu überall gleich breites, ununterbrochenes Band, welches sich erst gegen die Mitte des Rückens in cinzelne, untereinander zusammenhängende und dicht aneinander gestellte Flecken auflöst; die darauf folgenden schmalen helleren Streifen Grundfarbe werden gegen die Caudalwurzel allmählich schmäler und verlieren sich meistenteils auf der Schwanzbasis, waihrent das dunkle mediane Vertebralband und die diesem parallel liufenden, von den hinteren P'arietallkinten entipringrnden, ziemlich breiten schwarbrauncn Fleckenbänder in der Regel auch auf dem Schwanze deutlich sichtbar zu sein pflegen. Die zuletzt erwähnten 
Parictal-Fleckenbinder werden nun von schmalen, leicht geschlängelten, an äuberen seitlichen liande der Parietalen beginnenden und etwa oberhalb der Ansatzstellen der Hinterbeine endenden, vorn grünlichweisen, hinten mitunter brïunlichweilsen Streifen oder Argustlecken begrenzt; im ersteren Falle crscheinen die Rumpfseiten von jelerseits je zwei dunklen Fleckenbänder geziert, welche durch cinen hellen Streifen getrennt siut, während im letzteren Fall die Rumpfseiten üppig schwarz genetzt und bräunlich und grünlich geaugt erscheinen. Die Gliedmatien sind oben mehr oder weniger stark dunkel gezeichnet und bell gefleckt; bei den seitwäts genetzten Stücken nimmt die schwarzbraune Zeichnung dermatien zu, datis die Grundfarbe nur in Form von kleinen runden Fleckchen zutage tritt. Die Kopfdecke und die Zügelgegend ist auf braunem oder olivengrünem Fond dunkel gezeichnet. Die Unterseite des Körpers beim Männchen ist bläulich; das Blau gewinnt zuweilen an den Bauchseiten und in der Kehlgegend an Intensität. Bei den Weibchen erscheinen Kehle und Bauch blau oder gelblich angehaucht. Mit dieser neapolitana aus Pelagosa, welche ich, nebenbei bemerkt, mit dem ihr von Dr. L. Schreiber verliehenen Namen »pelagosae« bezeichnen möchte, scheint die bisweilen prachtvoll dunkelgrüı gefärbte muralis von der Insel Montecristo nahe verwandt zu seiv. Neapolitana var. pelagosae gehört einer ziemlich kleinen Rasse an; nach den mir zu Gebote stehenden Stuchen zu urteilen, erreichen die Männchen $155 \mathrm{~mm}$, die Weibchen $145 \mathrm{~mm}$ an Länge, wovon bei den ersteren $15 \mathrm{~mm}$ auf den Kopf und $100 \mathrm{~mm}$ auf den Schwanz, bei den letzteren $11^{3 / 4} \mathrm{~mm}$ auf den Kopf und 96 mm auf den Schwanz kommen.

g) Sowohl beim Männchen als auch beim Weibchen zeigt die mehr oder weniger intensive grüne, bräunlich- oder graugrune (z) Oberseite des Rumpfes eine üppig schwarze oder schwarzbraune Zeichnung, welche in Form von meistenteils ziemlich schmalen, transversalen, vielfach geschliangelten, sowie auch unterbrochenen Linden auftritt. Die Schädeldeche ist auf helluufbraunem (rrunde dunkelbraun punktiert, die Schilder und Schuppen auf der Kiehle abwechselnd blau und weils. Die äulieren blauen seitlichen Ventralia enthitten schwarze oder dunkelbraune Makeln, das Anale einen bläulichen Fleck in der Mitte: Junge Stücke sind oben braungrün, dunkelbraun gezeichnet. Diese von Schreiber als reticulata, von Eimer als maculata (vergl. Archiv f. Naturgesch. 1881. Taf. XIV, Fig. 19, 20) und vou mir als insulanica benannte Form kommt vorzugsweise auf den italienischen Inseln Planosil, Giglio, Ventotene und weniger häufig auf dem Festlande Italien vor. Was ihre Körpergestalt anbelangt, so muß erwälınt werden, dafs ihr Kopf einen geringeren Höhendurchmesser aufzuweisen hat, dafis ihr Rumpf ziemlich plattgedrückt und dafi ihr Hals breit ist. Die auf Pianosa einheimischen reticulatae zeichnen sich durch ihren kräftigen Körperbau aus. 
h) Dicht an der Insel l'ianosa liegt eine klemere Felseninsel pha Scuola di Pianosa genant, welche von der nigrizentris bonat pate (Vergl. Var. t bei Schreiber l. c. S. 410) bewohnt wird. Nach den mir vorliegenden Strieken, welehe ich durch die Giute des Herrn Prof. Giglinli erhalten labe, zu urteilen, ist diese Insulanerin eine veränderte neapolitana von der Nachbarinsel. Ihre Grundfirbung wird durch die uppig entwickelte schwarze oder schwarzbrane Keichnung dermatien verdrängt, dats sie in form von zahlreichen grünlichen Augenflecken (nigriventris Bonap., De Betta) oder als feine wellenförmige Querstreifen zuftritt; die Verdunkelung des ursprünglichen Grundliolorits findet auch auf der Schüdeldecke statt, indem letztere schwarz oder dunkelbraun, braun und hellnubbraun gefleckt erseheint. Die Unterkiefer sind anf grünlichgrauem orlex blïulichem Grunde dunkel gezeichnet. Der Batuch ist bläulich mit zahlreichen dunkelgrauen oder schwarzon Flecken bedeckt; die äulieren Reihen der Ventralen erhalten grolse blane und schwarze Makeln. Der Schwanz ist oben bräunlich, unten hellgrau vder bläulich mit Ausnahme der gelblich geränderten hinteren Schuppenränder. Die Länge der mir vorliegenden Stücke von »La Scuolae beträgt $168 \mathrm{~mm}$, während das in Bonapartes Iconografia abgebildete Exemplar ungefihr $200 \mathrm{~mm}$ milit. Nigriventris kommen, obschon selten, auch auf der apenninischen Halbinsel, so z. B. in Rom und Neapel und auf Sicilien (Duméril et Bibron, 1. c.) ver und sehen im allgemeinen der Var. filfolensis etwas ähnlich. - Als nigriventris Massalongo-De Betta wird ferner cine neapolitana bezeichnet, deren Rücken sehr stark schwarz gefleckt und genetzt und deren weißliche Bauchseite mit schwarzen Flecken besetzt erscheint, während bei den typischen nigrivcntris Bonap. aus den Umgebungen Roms die schwarze Bauchzeichnung die helle Grundfürbung zu verdrängen ptlegt. Schreiber sagt sogar: „subtus atra, aut concolor aut passim albo-punctulata«. - "Nigriventres« mit ygrünem IRücken« sollen auf den Inseln Palmajoli, und Salina, einer der Liparischen Inseln, vorkommen; ich kenne sie von diesen Fundorten leider nicht.

i) Mit dem Namen stineatas de Betta (1874), Genei Cara (Monografia della Lucertolit comune di Sardegna. Cagliari 1878), wird allem Auscheine nach diejenige neapolitana bezeichnet, welche neuerdings als striatas.str. (=campestris non De Betta!) und maculatu-striatu (=ulbiventris non Bonap.!) im Archiv f. Naturg. 1881 'Taf. XIII. Fig. 1, 2, 3. Taf. XIV. Fig. 13, 14 abgebildet worden ist. Da diese Subvarietit mir z. Z. nicht vorliegt, so ziehe ich vor, die von De Betta ${ }^{1}$ ) in italienischer Sprache abgefabte Beschreibung hier zu wiederholen: „Der Rücken ist mehr oder weniger intensiv grün koloriert. Die braune Farbe des Kopfes zeigt eine

$\left.{ }^{1}\right)$ Rettili ed Anfibi in: Fauna d'Italia IV. Milano 1874 (L'Italia sotto l'aspetto fisico, storico etc.). 
Neigung ins Rötliche, welches mehr oder minder stark nuanciert ist; eine breite Binde von derselben Farbe, mit schwarzen, in regelmäligen Serien angeordueten Flecken, zieht sich längs der ganzen medianen oberen Partie des Köryers hin und erscheint hie und da durch eine sehr zierlich augeprïgte, am Auge entspringende und sich bis zum Schwanz hinziehende weilie Linie vom Grundtone des Rückens getrennt zu sein. Die Leibesseiten sind verschiedenartig schwarz gefleckt und oftmals durch cine andere weilse Linie durchzogen, welche parallel derjenigen des Rückens läuft. Die weikliche Unterscite ist himmelblau oder mit blafigelbem Anfluge versehen. Bei den jungen Individuen treten die weifen Linien mehr zum Vorschein, denn das breite mediane Rückenband ist rötlich, fleckenlos und nahezu gleichmälig kolorjert und die erwälnten Linien auf den Leibesseiten zeigen schwarze Umsäumungen. Diese von mir nach denjenigen Exemplaren, welche ich im Juli 1870 durch Prof. Targioni-'Tozzeti erhalten habe, als slincute* benannte Varietait ist nachträglich und zwar kürzlich von Cara unter dem Namen Lacerta podarcis var. Genei (Monografia della lucertula comune in Sardegna) beschrieben und mir lebend und in mehreren Stücken unter vielen anderen sardinischen Reptilien freundichst zugeschickt worden. Bis jetat ist es mir nicht gelungen ihr anderswo als auf dieser Insel zu begegnen, wo sie, wie Car a mitteilt, sich gewöhnlich in felsigen Gegenden unter Gebirgspflanzen, unter Steinen und in Felsenspalten aufhält. — De Bet a identifiziert seine lineata mit der tiliguerta Camerano (Vergl. seine Schrift: Sulla Tiliguerta ctc. in: Atti R. Istituto Veneto, Serie V, Tomo IV.), scine campestris mit der tiliguerta De Filippi ') und die tiliguerta Cetti mit seiner lokalen larbenvarietät der allergenreinsten Manereidechse (Podarcis muralis)«, worunter eine lokale Zeichnungsform unserer fusca zu verstehen ist.

Wenn die Mauereidechse den Herpetologen durch ihre grenzenlose Variabilität in der Größe, der Körpergestalt, Zeichnung und Färbung, aufierdem durch ihre Verwandtschaft mit anderen Arteu ofters Anlaßs zu Meinungsverschiedenheiten giebt, so gilt dies insbesondere von der sardinischen muralis, welche Cetti in Jahre 1777 (Anfibi e pesci di Sardegna IV, 1) 15. Sassari) als Tilignerta und nachträglich $\mathrm{M}$ e yer als Ameiva tiliguerta benannt haben ${ }^{2}$ ). Di ese

1) Nuovi Annali delle scienze di Bologna, Ser. III. Tom. V. p. 69. Bologna 1852.

*) Synops. rept. etc. Göttingen 1795. - Auch Latreille, Shaw, Daudin, Merrem und Dugés er"ähnen der tiliguerta in ihren Werken; die zuletzt genannten Autoren verwechseln sie aber mit der zweifach gestreiften viridis. Meyer, wie ich hier hinzufügen möchte, hat wohl kaum selbst eine >titiguerta zu untersuchen Gelegenheit gehabt, sondern blow die Cettische Beschreibung dieser Eidechse gekannt und auch infolgedessen aus der Bemerkung Cettis, die titigucrta könne mit der Smaragdeidechse oder der amerikanischen Ameiva verglichen werden, den Schluf gezogen, die tiliguerta müsse der Gattung Ameiva angehören' Die Diagnose, welche Cetti uns von seiner tiliguerta hinterlassen hat, ist allerdings inexakt und vague und wir können uns kaum bei etwaiger Aufstellung einer Tiliguerta-Abart nach ibr richten; ich habe infolgedessen vermieden in der vorliegenden Arbeit von dieser Bezeichnung irgend welchen Gebrauch zu machen. 
Benennung wurde seitdem entweder einfach in die Synonymie der muralis versetzt oder sie reprisentierte eine Abart oler sogar eine Art. Trotzlem letateres aufs energischste von De Betta bestritten wurde, tauchte die "Titiguertak von nenem auf. In der sich nur wenig mit den italienischen Reptilien befassenden deutschen Litteratur finden wir im Werke Leydigs ebenfalls einen I'latz für die tilignente cingerïunt. Der Grund dafür liegt wohl darin, daßs der Verfasser, wie er selbst zugiebt, damals die neapolitanische Mauereidechse nicht kannte und Schluffolgerungen aus der Vergleichung der sardinischen muralis mit jenen aus Norditalien (Subv. campestris de Betta) und Deutschland (Subsp. fusca) gezogen hat.

Unter den weniger häufig vorkommenden Formen der neapolitana verdienen folgende, von Schreiber und De Betta beschriebenen und von Bonaparte abgebildeten einer besonderen Erwåhnung:

1) „Supra pallite grisescens, fasciis regularibus nigro-marmoreis 5-8 per dorsum decurrentibus. Subtus albida, concolor (Sardiu.) Schreiber, l. c. var, j.

2) Supra cinerea, virens vel coerulescens, maculis quadratis interdum seriatis, lateralibus saepe per longitudinem confluentibus; subtus albida vel rubescens, (Eur. merid.) Schreiber, var. 1 .

3) "Supra virens, maculis atris seriatis; subtus rubescens, concolor (Sicil.) Schreiber, var. $k$.

Die Sub. Nr, 2 erwähnte „Varietiat \& dürfte diejenige sein, welche in der Iconografia della Fauna italica abgebildet und als $\gg$ Podarcis muralis siculus maculatus muriventris" angeführt und bei De Betta (Nuova serie di note erpetologiche etc. in: Atti R. Istituto Ven. sc. e. lett., Ser. V, T. V. 1879) als $\gg$ P. sicula muriventris Bonap.« erwähnt worden ist.

4) »Supra pallide cinerea vel coerulescens, maculis atris creberrimis et confluentibus dense reticulata; subtus atra, aut concolor aut passim albo-punctulata (Ital. merid. Sicil.). Schreiber, var. u. - Diese nuratis, sowie auch diejenige, welche Costa in seiner »Fana di Aspromonte e sue adiacenze ( $\mathrm{pag}$. 75. 1828) als $\gg L$. acrolampra« benennt und beschreibt, erregen insofern unser Interesse, als sie der dunkelfarbigen muratis vom Faraglioni-Felsen bei Capri in allgemeinen ähnlich sehen dürften. Namentlich. scheint $\gg L$. acrolampras an letztere zu erinnern. Costa giebt ungefähr folgende Charakteristik seiner »kalabresischen« (?), zweifelsohne mit der muralis identischen Eidechse: »Der Körper ist oberseits bläulich-schwarz mit unregelmäßigen, etwas helleren Flecken besetzt; die Unterseite ist. himmelblau mit etwas rot an den Rändern der Schilder, namentlich an denjenigen der Kichle, der Beine, der Füise und der ersten Caudalringe. 2 hexagonale, lange Schilder glänzen am Hinterkopf wie Bleiplatten. Von den 
7 gröferen Halsbandschildern ist das mittlere das gröbte, während die ubrigen gegen die Sciten hin an Gröfse abmehmen.« - Es ist mir leider nicht gelungen von den neapolitanischen Universitäts-Behörden Näheres äber diese Lacerta von Costa zu erfahren, namentlich in betreff des angeblichen Fundortes habe ich nicht die erwünschten Aufklärungen erhalten können und

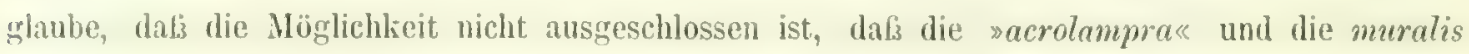
vom Faraglioni ein und dasselbe Tier sein könnte. Jedenfalls, sollte es sich bestätigen, daL, erstere in der 'That cine auf dem Festlande Kalabrien einheimische Form reprüsentiert, ist es interessant, dak auch auf dem Festlande dunkel gefärbte muralis vorkommen, bei denen die blaue Färbung prädominiert. - Aus der neuen Serie der herpetologischen Notizen von De Betta (l. c.) entnehme ich folgende Beschreibungen einiger mir nicht näher bekannten neapolitana:

A) Sicula Doderleini De Betta mit selır wenigen schwarzen, in longitudinalen Serien angeordneten Punkten auf dem Rücken; die der ssicula albiventris Bonap. eigentümlichen weiflichen lateralen Binden fehlend; eine ins Grau spiclende, braun gefleckte Binde auf den Leibesseiten. Unterseite weililich mit grünem Anfluge. - B) rosciventris Mass al. mit grünem oder bliulichgrünem, unregelmälisin schwitz gesprenkeltem laücken und fleischfarbener Unterseite. - C) Cettii. Diese von Cara mit muralis albiventris verglichene und vielleicht identische Manereidechse wird von De Betta mit der tiligucrta Camerano citiert und als mit unregelmäfsigen, schwarzen oder schwärzlichen, in Längsstreifen angeordneten Flecken, welche mehr oder weniger getrennt erscheinen oder sich gegenseitig berühren und cin Netzwerk bilden, und cinem bläulichweifsen Unterkörper versehen, beschrieben.

Hinsichtlich der Färbung und Zeichnung sowie auch im ganzen in Bau und Körpergröfse findet sich bei den insulanischen Formen der muralis neapolitana weniger Abwechslung als bei den binnenländischen; infolgeciessen können melurere Inselbewohnerinnen als ziemlich beständige I.okalvarietïten betrachtet werden. Unter diesen sind kürzlich folgende beschrieben worden:

1. Var. Latastei m. (Herpetolog. Studien im: Archiv f. Naturg. 1879. Bd.45 S. 264.Mém. sur. les variétés europ. du Lézard des murailles in: Bull. Soc. zool. de France IV, pag. 209. Pl. IX, fig. 4. - Local Colour - variation in Lizards in: Nature, vol. XX, Nr. 516, pag. 481). - Die Grundfarbe der Oberseite des Körpers ist im allgemeinen hell oder dunkelbraun; in der Halsregion kommt noch gewöhnlich zum Braun Grün hinzu; es entsteht infolgedessen ein olivengrüner Ton. Die Mitte des Rückens ist rein braun, die Schwanzwurzelgegend rotbraun koloriert. Die schwarze Zeichuung der Oberseite variiert ebenso stark, wie bei der binnenländischen neapolitana; es sind meistens in Binden angeordnete Makeln, zuweilen aber 
nur schmale Streifen. Sobald die Zeichnungselemente durch ihre Ausdelınung in Kontakt treten, erhalten die Tiere ein Netzwerk. Endlich kann die Zeichnung nur spurweise und zwar auf den Seiten angedeutet erscheinen; sie tritt in Gestalt von Hablireisen auf, welche die bei den gleichmäßig hellbraun (café au lait) gekleideten, auf den Körperseiten befindenden blïulichen und hellgrünen Ocellen umgehen. Dic kleinen Argusflecken, welche nur eine meiner weiblichen Latastei zieren, sind in 2 parallelen Reihen angeordnet; dabei ist der oberhalb der Wurzel der Vordergliedmatien liegende runde Fleck bedeutend größer, als die übrigen; er erscheint blat oder grünblat und ist in den meisten Fïllen schwarz umrahmt. Die Kopfdecke dieser Ponza-Rasse ist einfarbig braun; die Unterseite des Kopfes ist weib, die Bauchseite schwach rötlich, die ersten longitudinalen Ventralreihen sind blaugrün koloriert. Die Mämnchen sind viel dunkler nuauciert als die Weibchen, auch ist die Zeichnung weit weniger ausgesprochen; es werden hier vielmehr einzelne ordnungslos verteilte, beinahe schwarze Schuppen angetroffen. Die Kopfdecke ist dunkelbraun. Der Argusfleck an der Schulter wird mitunter vermißt. Die Rückenschuppen sind sowohl bei der vou einer bei Ponza liegenden Felseninsel stammenden Latastei als auch bei den Individuen von Ponza selbst kleiner als bei der binnenländischen neuzolitana, in der Halsgegend abgerundet, in der Rückemmitte fünfeckig und an den Rumpfseiten verschieden gestaltet, meist abgerundet vierseitig. Das Massetericum fehlt öfters. Die Zahl der Femoraldrüsen scheint beträchtlicher zu sein, als es in der Regel bei den kontinentalen Formen der Fall ist; meine müunlichen Latustei weisen jederseits 26 bis 29 Drüsen, die weiblichen nur 24 auf.

Ihre Gesantkörperlänge beträgt $205 \mathrm{~mm}$, wovon 19 auf den Kopf und 131 auf den Schwanz kommen. Der gröbte Breitendurchmesser des Kopfes beträgt $14 \mathrm{~mm}$. Gröbter Höhendurchmesser des Kopfes $=9 \mathrm{~mm}$. Die Ansatzstelle des Pileus an den Rumpf zählt $8 \mathrm{~mm}$. Der größte Umfang des Kopfes beträgt $39 \mathrm{~mm}$, der Umfang des Halses $40 \mathrm{~mm}$.

Die in meinem Besitz sich befindenden Latastei-Eidechsen stammen aus zwei Lokalitäten. Eine Anzahl hatte ich eigenhändig auf der Insel Ponza erbeutet und ein Exemplar wurde mir von einem westlich von Ponza gelegenen, im Meere isoliert stehenden Felsen zugestellt. Während die, von der Insel selbst stammenden Exemplare in ihrer Körpergestalt und in ihren MaEen so gut wie gar nicht von der neapolitana abreichen, weist die eben erwähnte FelsenEidechse männlichen Geschlechts einen kräftigeren Bau und erinnert im allgemeinen an die Faraglioni-Lacerta.

Auf der unweit von Ventotene liegenden kleinen Insel Santo Stefano und auf der Felseninsel Scoglio di Mezzogiorno bei Palmarola sollen die Mauereidechsen dunkel, ja sogar, 
wie es neuerdings behauptet worden ist, oberseits fast schwarz, mit grün geflecktem Rücken und blauem Bauche versehen sein.

2. Var. filfolensis m. (v. Bedriaga, Die Faraglioni-Eidechse und die Entstehung der Farben bei den Eidechsen. S. 18. Heidelberg 1876; Local Colour-Variation in Lizards in: Nature XX, 1. 481; Herpetolog. Studien in: Archiv f. Naturg. 44. Jahrg. Bd, I. S. 316. 45. Jahrg. Bd. I. S. 256; Mém. sur les variétés europ. du Lézard des murailles in: Bull. Soc. zool. de France IV, 1. 210. - Zootoca Lilforli Güther in: Ann. and Mag. nat. hist. XIV, p. 159. - Lacerta filfolensis Bedriaga, Braun, Lacerta Lilfordi etc. in: Arbeiten aus d. zoolog. zootom. Institut in Würzburg IV. - Podarcis filfolensis B edriaga, de Betta, Nuova serie di Note erpetologiche etc. 1. c.). - Diese Inselbewohnerin ist, wie ich es vorausgesehen hatte (vergl. meine Herpetolog. Studien 1878 l. c.), eine veränderte neapolitana. Auf tiefschwarzer Rumpfoberseite sind zahlreiche grüne und blaue runde Flecken und Punktflecken, Überbleibsel der ursprünglichen Grundfarbe, verteilt, welche durch die, sich üppigr entwickelnde und jetzt als Grundton figurierende schwarze Zeichnung verdrängt werden. Die mediane Iiückenzone ist meistens mit grünlichgelben Punktflecken besetzt; diejenigen Fleckchen, wulche den der Mauereidechse im allgemeinen zukommenden helleren, die Rückenzone begrenzenden Oberaugenstreifen ersetzen, sind zuweilen innen gelb, nach aufen zu blau gefärbt, die Rumpfseiten und die Kopfseiten erscheinen mit gröferen blauen Flecken oder blok mit Punlittlecken geschmückt. Derjenige Augenfleck, welcher oberhalb oder hinter der Wurzel der vorderen Extremität liegt, ist gewöhnlich größer als die übrigen und erscheint kobaltblau koloriert. Die Oberseite der Gliedmafen ist weniger intensiv schwarz gefärbt, mit Neigung zu Braun oder Braunrot; einige grünliche, bläuliche und bellbraune Punktflecken heben sich vom dunklen Tntergrunde im Leben deutlich ab. Die ungezeichnete, oder an der Wurzel mit grünlichblatueu, lateralwärts mit bläulichweißen Fleckchen versehene Schwanzoberseite ist anfanıs schwarzbraun, nach hinten mehr und mehr grau oder hellbraun. Die Kopfdecke ist entweder ungefleckt schwarz oder auf schwarzbraunem Grunde braun gezeichnet; bei dem mir vorliegenden Exemplare ist das Interparietale mit einem centralliegenden bläulichen Punkte, die Parietalia an ihren seitlichen Aufenrändern mit blïulichen Streifen geziert; auch die Schläfe und die Oberlippenschilder sind auf schwarzbraunem Fond spärlich blau gefleckt. Die Submaxillaren sind entweder bläulich-schwarz, rotbraun gescheckt oder hellblau gefleckt und umsäumt; an der Kehle nimmt man auf schwarzblauem Grunde etliche hellblaue Schuppen wahr; die schwärzlichen Halsbandschilder sind an ihren freien Rändern hellblau umsäumt. Die dunkelblauen, in der Bauchmitte braun angehauchten, oder die vorderen »braunroten«, die hinteren »schwarz- 
grauene, blau überflogenen Flankenschuppen sind prachtvoll blau gemakelt oder gepunktet. Die Unterseite des Schwanzes ist hrammot oler stahlerau; die Unterseite der Beine dunkelgrau mit einer Neigung ins Blaue und mit gelblichen Säumen an den gröfseren Schildern. Das Weibchen ist in einigen Stücken vom Männchen verschieden: dasselbe soll netwas Violettbraun im Schwarz der Oberseite des Rumpfes« zejgen, insbesondere soll »ein in dieser Weise gefärbter Streif vom ersten Drittel « der Rumpfoberseite an bis zur Schwanzbasis in der Mittellinie sich erstrecken. „Jederseits vom Kopf an bis zur Schwanzwurzel ist das Schwarz $2 \mathrm{~mm}$ breit durch ein schwaches Grün teilweise verdrängt, unmittelbar hinter dem Kopfe auch in der Mittellinie. Nach außen von dieser Zone finden sich im Schwarz kleine, meist annähernd runde, blaugrüne oder blaugrüngelbe Fleckchen. Auch die Oberseite von Kopf, Schwanz und Extremitäten war etwas heller als beim Männchen, die erstere mit Grünlich und Rostbraun.« Der Bauch soll leicht roströtlich, die Unterseite der Extremitäten und des Schwanzes rötlich. hrau bis fleischfarben, die Kehle und die Unterkiefer hellhliu gefüht und mit groben, schwarzen, mit Rotbraun (namentlich an den Randpartien) gemischten Flecken geziert sein. Die Kopfseiten (bis zum Unterkiefer) sollen endlich schwarz mit drei kleinen blauen Flecken versehen sein.

Was nun die Körperbedeckung anbetrifft, so muf3 bemerkt werden, daßs die Rückenschuppen etwas kleiner sind als bei den süditalienischen, sicilianischen oder selbst maltesischen muralis, denn es gehen bei der filfolensis 4 bis 5 Schuppen auf eine Bauchtafel, während bei der neapolitana subsp. etwa 4 und bei der fusca subsp. 3 bis 4 Rückenschuppen der Länge eines Bauchschildes entsprechen. Es ist behauptet worden, daß die Dorsalschuppen bei der uns hier interessierenden filfolensis ungekielt erscheinen, dessenungeachtet finde ich bei der mir zur Verfügung stehenden männlichen Eidechse deutliche Spuren von Kielen. Es ist ferner behauptet worden ${ }^{1}$ ), daßs als Auktor von filfolensis »Günther zu setzen ist und kein anderer«. Darauf hin mufs ich bemerken, daf $\mathrm{Dr}$. G ü nther allerdings der erste gewesen ist, welcher der dunkelgefärbten Filfola-Lacerta Erwähnung gethan hat, daß ich aber insofern auf die Bezeichnung "filfolensis" Anspruch haben dürfte, als ich meinerseits der erste gewesen bin, der die Litfordi- sowie auch die Filfola-Eidechse aus dem Genus »Zootoca« entfernt hat; ferner habe ich die Unterschiede beider erkannt und endlich die Filfola-Abart mit dem Namen "filfolensis« $(1876)$ bedacht, sie in meinen, Herpetologischen Studien beschrieben und von der neapolitana abgeleitet. Günther hat bekanntlich $L$. muralis var. Lilfordi als $\gg$ new

1) Eimer, Untersuchungen üb. d. Variieren d. Mauereidechse etc. Berlin 1881. S. 182. - Vergl. meine Ermiderung im Archiv f. Naturg. XxxxVIlI. Jahrg. 1. Bd. S. 307. 
European Species of Zootocas beschrieben und folgendes hinzugefügt: "To this species ("Zootoca Lilfordic) I refer also the lizard which is so common on the Filfola Rock, a very small island south of Malta๔. - Die Größenverhältnisse bei der filfolensis sind folgende: Männchen. - Totallänge: 181,5 mm (Weibchen: $150 \mathrm{~mm}$ ); Kopflänge: $16 \mathrm{~mm}$ (q 13,5 mm); größte Kopfbreite: $10 \mathrm{~mm}$; Kopfhöhe: $8 \mathrm{~mm}$; Kopfumfang: $32 \mathrm{~mm}$; Breite des Pileus: $7 \mathrm{~mm}$; Halslänge: $8-9 \mathrm{~mm}$; Halsumfang: $33 \mathrm{~mm}$; Rumpflånge: $51.5 \mathrm{~mm}$ ( $42 \mathrm{~mm}$ ); Rumpfumfang: $38 \mathrm{~mm}$; Schwanzlänge: $114 \mathrm{~mm}($ q $95 \mathrm{~mm})$; Länge d. vorderen Extremität: $25 \mathrm{~mm}$; der Hand mit d. Fingern: $12 \mathrm{~mm}$; d. hinteren Extremität: $42 \mathrm{~mm}$; d. Fufses mit d. Zehen: $20,5 \mathrm{~mm}$. - Die Gesamtlänge der männlichen filfolensis von der Schnauzenspitze bis Schwanzende kann auch bis $222 \mathrm{~mm}$ betragen, wovon $20 \mathrm{~mm}$ auf den Kopf, $70 \mathrm{~mm}$ auf den Rumpf und $132 \mathrm{~mm}$ auf den Schwanz kommen, die gröfite Kopfbreite soll 13 und die gröfte Kopfhöhe $11 \mathrm{~mm}$ betragen.

Der Fundort dieser schönen, im Archiv f. Naturg. 1881, Bd. I. Taf. XV. Fig. 24 und 25 abgebildeten Abart ist die südlich von Malta gelegene Felseninsel Filfola.

3. Var. coerulea Eimer. - Während die ursprüngliche, der Stammform von filfolensis, d. h. der Subspecies neqpolitana zukommende grüne Grundfärbung bei der Filfola-Varietät in Gestalt von kleinen Flecken zu Tage tritt, ist sie bei der auf dem dicht bei Capri gelegenen Faraglione-Felsen lebenden, von Eimer als var. coerulea (Verhandl. d. physikal.-medizin. Ges. in Würzburg Bd. III. - Zoolog. Studien auf Capri II. Taf. I. Leipzig 1874), von Braun (Lacerta Lilfordi etc. in: Arbeit. zoolog. zootom. Inst. Würzburg IV) und von mir als var. faraglioniensis, von $\mathrm{Schreiber}$ als var. b. und vielleicht bereits von Costa als L. acrolampra (Fauna di Aspromonte e sue adiacenze. Napoli 1828) beschriebenen meralis fast gänzlich verschwunden. Die Grundfarbe des Rückens bei beiden Geschlechtern ist in der Regel schwarz, bei den weiblichen Individuen tritt in seltenen Fällen ein grünlicher, bei den jungen Exemplaren beiderlei Geschlechts ein bläulicher Schimmer hinzu, wobei man gewöhnlich eine schwarze Zeichnung wahrnehmen kann. Letztere ist übrigens auch bei den weniger intensiv, etwa grauschwarz kolorierten älteren Stücken bei Sonnenbeleuchtung ziemlich gut sichtbar. Gegen die Schwanzwurzel und die Rumpfseiten zu nimmt das Schwarz oder Grauschwarz allmählich ab und weicht einem dunklen Blau, welche Farbe sich auch auf die Extremitäten und den Schwanz ausbreiten kann; in anderen Fällen haben der Schwanz und die Gliedmatien, namentlich die hinteren, oberseits einen bronzegrünen Anflug, der zur schönen Jahreszeit den höchsten Grad der Sättigung zu erreichen pflegt. Mit Ausnahme des oberhalb der Wurzel der Vorderextremität gelegenen bronzegrünen, oftmals deutlich schwarz eingefaften Augenflecken und zwei ähnlich 
grefärbten Ocellen an der oberen, nach hinten zu gekehrten Partie des Ober- und Unterschenkels, sowie auch einiger schwarzer. Flecken, welche oftmals auf der Oberseite der Hinterbeine ineinander flielien und ein Netzwerk bilden, erscheinen die scitlichen Körperteile sunst selten gezeichnet; auch treten sowohl die grünen Ocellen als auch die schwarze Zeichnung nur bei den Mämnchen deutlich hervor; bei den Weibchen bleiht letztere gewöhnlich gänzlich aus, während die dugenflecken matt, grünlichbraun, blau oder grau erscheinen und der dunklon Umrahmung entbehren; diese Flecken fehlen übrigens an den hinteren Gliedmalien meistens gänzlich. Der Kopf, mit Ausnilhme der tief himmelblauen Kehle und der Unterkiefertafelu, ist pechschwarz mit schönem Glanz. Die ganze Unterseite des erwachsenen Tieres ist, mit Ausnahme der gelben oder weiblichen Femoraldrüsen und der grau- oder gelblichweilien Sohlen, schön tief meerblau; jedoch nicht ganz einfurbig, denn die Schilderrïnder erscheinen in der Regel etwas heller koloriert. Auch die mediane Partie des Bauches zeigt zuweilen eine lichtere oder hellblaue ins Grüne übergehende Fürbung, während die äuLeren lateralen Ventralia indigo oder schwärzlich koloriert erscheinen. - Die Faraglione-Eilechse variiert nur in geringem Grade; mir sind nur Individuen mit tief schwarzen, blauschwarzem, graublauem und grünlichschwarzem Rücken bekannt; im Winter kommen diese Tinten weniger zur Geltung; das Tier erscheint zu dieser Jahreszeit trübe und einförmig gefärbt; auch im Weingeist aufbewahrt verliert es alsbald seine schönen Farbentöne, es wird nämlich bläulich oder graublau, ja sogar »himmelblau und die seiner Stammform eigentümliche schwarze Zeichnung tritt dann dentlich zum Vorschein; solche verfärbte, oftmals perlmutterblau aussehende Stücke künnen keinen Begriff von der Farbenpracht der Faraglione-Lacerta geben.

Hinsichtlich der Schilder und Schuppen ist zu erwälnen, daf das Massetericum fehlen kann, dafs die Ventralia in einigen Fällen, obschon selten, in 8, anstatt in 6 Längsreihen angeordnet erscheinen, ferner, dals diejenigen Randschildchen, welche die äuljersten Ventraltafeln begrenzen, oftmals sehr groß auftreten können und endlich, dafỉ die Rückenschuppen eher rundlich reguär-hexagonal geformt sind und sich somit, bei näherer Untersuchung, von den in der liegel längeren als breiten und mehr scharfeckigen Schuppen bei der necupolitanu subsp. unterscheiden. - Die Faraglione-Eidechse ist, wie ich glaube, die größte und stärkste muralis, indem sie bei einer Länge von 220 bis $250 \mathrm{~mm}$ einen Rumpfumfang von $42 \mathrm{~mm}$ erreichen kann. Die beifolgenden Maß̉e beziehen sich auf Exemplare von der gewöhnlichen Größe:

Männchen.- Gesamtlänge: $217 \mathrm{~mm}$; Kopflänge: $20 \mathrm{~mm}$; größte Kopfbreite 12,3 mm; größte Kopfhöhe: 10,3 $\mathrm{mm}$; größter Kopfunfang: $39,3 \mathrm{~mm}$; grölite Breite des Pileus: 9,3 mm; Halsumfang: $40 \mathrm{~mm}$; Rumpflänge: $64 \mathrm{~mm}$; Schwanzlänge: $133 \mathrm{~mm}$; Länge der vorderen 
Extremität: 26. $\mathrm{mm}$; der Hand mit den Fingern: $11 \mathrm{~mm}$; der hinteren Extremitåt: $45 \mathrm{~mm}$; des Fußes mit den Zehen: $22 \mathrm{~mm}$; Halslänge: $9 \mathrm{~mm}$.

Weibchen. - Gesamtlänge: $188 \mathrm{~mm}$; Kopflänge: 15,2; Kopfbreite: $9 \mathrm{~mm}$; Kopfhöhe: $8 \mathrm{~mm}$; Kopfumfang: $30 \mathrm{~mm}$; Breite des Pileus: $7 \mathrm{~mm}$; Halslänge: $9 \mathrm{~mm}$; Halsumfang: $29 \mathrm{~mm}$; Rumpflänge: 56-57 mm; Rumpfumfang: $39 \mathrm{~mm}$; Schwanzlänge: 116,5; Länge der vorderen Extremität: $22 \mathrm{~mm}$; der Hand mit den Fingern: 10,5; der hinteren Extremität: $37 \mathrm{~mm}$; des Fufses mit den Zehen: $19 \mathrm{~mm}$. - Die Eier sind 151/2 mm lang.

Die muralis von der Insel Capri wird von Schreiber (l. c.) zugleich mit einer auf den Cykladen vorkommenden Abart mit schwarzem Bauche und Schwanze, schwarzen, grüngefleckten Schenkeln und schwarzem Rücken mit grünen Fleclienreihen citiert, jedoch, wie ich glaube, mit Unrecht. Diese von mir auf den Cykladen allerdings nicht beobachtete Varietät habe ich seiner Zeit als archipelagica bezeichnet. Erhard erwähnt außerdem noch zwei auffallend grefärbte Varietäten, welche auf den Inseln des griechischen Archipels leben; es sind: »Die Varietät mit grasgrünem Rücken und Seiten und 5 Längsreihen schwarzer Flecken. Bauch und Brust sind orangerot, Kehle und Hals grau, untere Kinnlade gummiguttgelb. 3 weilie Bindẻn laufen über den Bauch, über die Seiten orangerote, blaue und gelbgrüne Flecken«, ferner »eine Varietät mit rotbraunem Rücken und Schwanze, grünem Hals und Kopfe, gelber Unterseite; an jeder Seite des Leibes mit 5 sehr grofen kobaltblauen Tropfen geziert, die beim Atmen des erregten Tieres eine brennende Azurfarbe annehmen. Diese Varietät ist die größte und erreicht bis 10" Länge. (Fauna d. Cykladen, I. s. 80. Leipzig 1858).

4. Var. coeruleo-coenulescens Eimer. - Während die coerulea vel furaglioniensis auf dem südlichst gelegenen Faraglione-Felsen lebt, soll auf dem mittleren, also der capresischen Kü̈ste nüher liegenden, ebenfalls im Meere isoliert stehenden Felsen eine bedeutend hellere und eher der Stammform »neapolitana« ähnlich sehende Form der muralis hausen. Ihr Rücken soll tief blau, etwa kornblumenblau erscheinen, welche Farbe nur auf der Rückenhöhe durch Beimischung von Grau gedimpft wird; ihr Bauch ist wenig heller blau gefärbt. Gegen die Schwanzwurzel hin geht das Blau oben in ein Blaugrün über, das sich weiter auf die Oberfäche des Schwanzes und der hinteren Extremitäten verbreitet. Dieses Grün, durch die zartesten Übergänge mit dem Blau verbunden, soll bei beiden Geschlechtern vorhanden sein und sich auch nach vorn über die Rumpfseiten mehr oder weniger ausdehnen. Diese Beschreibung wird man in der Eimerschen, oben citierten Schrift im Archiv f. Naturg. 1881 vorfinden.

5. Var. coerulescens-monaconensis Eimer. - Derselbe Autor beschreibt ferner unter dem Namen »coerulescens-monaconensis eine Form vom Monacone-Felsen, der ostnordöstlich von 
den übrigen Felsen und in einer Entfernung von $140 \mathrm{~m}$ von der Insel Capri liegt. Diese Form, wohl Varietät, zeigt deutlicher als die zuletzt beschricbene coemleo-coemulescens die Zeichnung der capresischen neapolitana, sie hat aber eine höchst eigenartige Rückenfarbe und zwar ein sMattgrün mit nach den Seiten zunehmendem, bliulichem Ton, auf der Rückenhöhe und auf den Kopfschildern bei vielen Individuen mit ausgesprochener Mischung von Braun.« „Diese bescheidene Färbung", bemerkt der Autor, serhält bei gewisser Beleuchtung aber eine höchst auffallende und wichtige Veränderung: lält man das Tier so zwischen die Sonne und das Auge, dafs dieses über seinen Rücken hinblickt, so erscheint letzterer prachtvoll dunkelblau, ähnlich der Rückenfarbe der coeruleo-coemulescens, ähnlich dem Schimmer, welcher am Rücken der coerulea bei Einwirkung des Sonmenlichtes zu beobachten ist«, »auch die Unterseite unseres Tieres ist nicht wie bei der gewöhnlichen Maureidechse weif, sondern sie hat einen blanen Ton, der sich zuweilen bis zu einem schönen Blau steigern kann und der sich vom Unterkieferwinkel bis zur Schwanzwurzel erstreckt. Diese blaue Färbung der Unterseite setzt sich über die Bauchschilder nach den Seiten der Eidechse hin fort in das Blau des Rückens.\& Obschon mir diese Beschreibung mit der 1. c. beigefügten Figur (Vergl. Taf. XV, Fig. 23) nicht durchweg ubbereinzustimmen scheint, so verweise ich democh den Leser auf dieselbe. Beide, sowohl die coeruleo-coemlescens, als auch die coerulescens-monaconensis kenne ich aus eigener Anschaunng ebenso wenig wie folgende Form:

6. Var. coerulescens gallensis Eimer, welche vom Auktor folgendermaßen charakterisiert worden ist: „Im August, als ich den Felsen (d. h. Galli, eine zwischen Capri und Amalfi, im Meere gelegene Felsen-Gruppe) besuchte, traf ich die Bauchfarbe dieser Lac. muralis coerulescens gallensis blau angehaucht, der Rücken was entweder vollkommen grün wie bei L. muralis elegans oder grün mit einer Spur von Blau; besonders die Seiten zeigten letztere Farbe ausgeprägter. Manche Individuen hatten auch Braun im Rückenkleide; die Jungen Latten am meisten Braun, am wenigsten Blau. Bei den Männchen war das blaue Auge hinter der Wurzel der Vorderextremitäten außerordentlich grof; bei einzelnen beobachtete ich mehrere solcher Flecke in einer Linic hintereinander. Bei den Männchen war die blaue Färbung von Bauch und Rücken viel satter als bei den Weibchen, besonders war bei jenen auch die äuferste Bauchschilderreihe jederseits mit einem satten blauen Fleck versehen, an dessen Stelle bei den Weibchen ein grüner trat. - Ob diese Form der muralis eine Varietät oder blob Untervarietät der neapolitana repräsentiert, kann ich aus dem einfachen Grunde nicht entscheiden, weil mir das 'lier bis jetzt nicht zu Gesicht gekommen ist. 
7. Var. viridiocellata m. ${ }^{1}$ ) - Die Grundfarbe des Rückens ist braun, und zwar etwas lichter an dem vorderen Abschnitte des Rückens, dunkler aber gegen die Schwanzwurzel und die Seiten zu. An der Mittellinie des Rückens zieht sich eine schwarze Fleckenbinde hin und verliert sich in der Schwanzwurzel. Diese Fleckenbinde besteht aus voneinander getrennten größeren Makeln. Eine jede dieser Makeln ist in ihrer Mitte eingeschnürt. Diese Einschnürungen deuten möglicherweise auf 2 ursprünglich parallele und nachträglich in Kontakt getretene Fleckenbinden. Parallel mit der eben erwïhnten Mittelbinde laufen jederseits schwarze Binden, welche wiederum durch einzelne nacheinander gereihte Makeln repräsentiert werden, nur mit dem Unterschiede, dals sie weniger nebeneinander gedrüngt liegen und somit die braune Grundfarbe schärfer hervortreten lassen. Aus jeder Makel dieser Seitenbinden entspringen breite schwarze Streifen, welche sich nach den Bauchgrenzen zu etwas seitwärts, nach vorne gerichtet, hinziehen. Die Makeln der Vertebrilbinde sind anfangs, also am Kopfe, verhältnismäligig nur schwach angedeutet, werden aber nach und nach ausgeprägter in Tinte und Gröbe. Überhaupt ist die schwarze Zeichnung dieser Form eine regelmäßige zu nennen. Die Oberseite des Kopfes ist dunkelbraun. Wangen und Unterkiefer sind weißhich mit einer Tendenz zu Blaugrau; die Farbe des Bauches ist weiklich, ohne jegliche dunkle Pigmentierung; die erste longitudinale Bauchschilderreihe ist hellgrün gefürbt. Die oberen Flächen der Extremitätenpaare sind auf braunem Grunde spärlich schwarz gestreift und punktiert; etwa oberhalb der Wurzeln der Vorderextremitäten befindet sich jederseits ein Ocellus, der vorhin bei der muralis nectiolitana und der Faraglioni-Eidechse beschrieben wurde, nur mit dem Unterschiede, dafi derselbe bier hellgrün erscheint, während die Augenflecken bei der neapolitana blau und bei muralis vom Faraglione dunkelgrün koloriert sind. - Diese in Bezug auf die Körpermaße von muralis neapolitance nicht abweichende Varietät habe ich bei Messina, auf Capri und auf Korsika, so z. B. bei Bastia ziemlich häufig beobachtet.

Greographische Verbreitung.

Vor allem muf ich das Vorkommen der muralis neapolitana auf der Pyrenäischen Halbinsel in Abrede stellen. Zwar erfahren wir aus den Schriften Barboza du Bocages und Boscas darüber nichts Sicheres, aber die Thatsache, daf ich die neapolitana in Katalonien, Aragonien, Valencia, Neu-Kastilien und Murcia nirgends getroffen habe, bestimmt mich zu der Annahme, dał sie in ganz Spanien fehlt. Gemäf der Thatsache, daß die Fauna Nordafrikas

1) จ. Bedriaga, Beiträge z. Kenntnis d. Nauereidechsen in: Archiv f. Naturg. 1877. Bd. 1. S. 115. - Bull. Soc. zool, de France IV. pag. 211. 


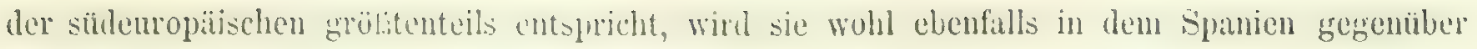
liegenden Marokko vermilst. In den Arbeiten Böttgers über die Kriechtiere von Marokko finde ich sie nicht genannt. Dasselbe gilt für Frankreich. In betreff Korsikas und Algeriens ist mit Gewifheit anzugeben, flafs die muralis neapolitana auf Korsika einheimisch und sogar stellenweise die gemeinste Fidechse ist, dalt; sie dagegen in Algerien nicht angetroflen wird; die von Duméril und Bibron, von Strauch, Lallement und anderen Faunisten erwihnten Mauereidechsen stellen zweifulsohue die murolis fuscu vor. Die eigentliche Heimat der grünen muralis ist entschieden die Apenninische Halbinsel und die anliegenden Inseln. Sowohl in Inneren Italiens, als auch an den Küsten und auf den Inseln tritt sie ungemein läufig in allen möglichen Tiariationen auf und scheint beinahe alle anderen Arten verdrïngt zu haben. Verfolgen wir ihre Ausbreitung nach Norden zu, so sehen wir alsdann, dał sie im Inneren der Halbinsel bis etwas über den $450^{\circ} \mathrm{n} . \mathrm{Br}$, an der Ostküste bis etwa zum $46 .^{\circ}$ и. Br., dagegen an der Westküste nur bis zum $440^{\circ} \mathrm{n}$. Br. vordringt. In den gemäßjigten Teilen Piemonts, so nach De Filippi (Cenno sulla Tiliguerta di Cetti in: Nuovi Annali sc. nat. di Bologna, Serie 3. Tomo V. pag. 69) im Thale des Po, in den sandigen Gegenden von Cambino bei Turin, in der Lombardei und in Venezien ${ }^{1}$ ) kommt sie, mit Ausnahme der gebirgigen Gegenden, überall und stellenweise, wie z. B. bei Turin und Verona, gesellig mit der muralis fusca vor; auffallenderweise aber hält sich erstere in diesen Gegenden lieber in sandigen oder mit grasbewachsenen Ebenen auf und uberläst die Weinberge und Ifermanern der braunen Mauereidechse zum Aufenthaltsorte, während dagegen im Süden Italiens die neapolituna buchstäblich von allen Ifauern Besitz genommen und die fusca ins Gebirge verdrängt hat. Ebenso auffallend und für unser Verständnis noch rätselhaft erscheint es, daf̉ die in Rede stehende murulis, eine Küsten- und Inselbewohnerin par excellence, aus dem Piemont oder aus dem Süden entlang der Küste nicht bis zur Riviera vorgedrungen ist, denn sowohl in Mittel- als auch in Süd-Italien scheint sie am Meeresgestade nicht nur nirgends zu fehlen, sondern überall, inmitten großer und volkreicher Städte, ja sogar in Venedig zu hausen. De Filippi (l. c.) führt die »Tiliguertas (neapolitana nobis) für Ligurien an, ohne etwas Genaueres über die Fundstellen zu sagen, mir aber ist das Tier von Nizza an bis Genua nirgends zu Gesicht gekommen; auch südlich von Genui, so bei Spezia und Viareggio ist es mir aufgefallen, wie selten man der neapolitana begegnet. Jedenfalls dürfte sie in Ligurien nur in geringer

1) G. v. Martens, Reise nach Venedig. Bd. I. S. 32; Bd. II. S. 405. Ulm 1824. (L. arenicola

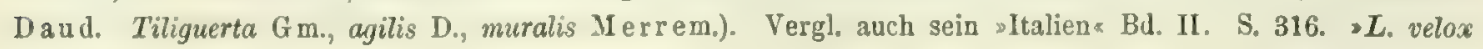
Pallas." Stuttgart 1844. 
Anzahl vorkommen, etwa wie im italienischen Tirol, wo sie bei Ala und Rovereto nach De Betta (l. c.) anzutreffen ist. Südlich der Apenninen in Toskana tritt sie von Livorno an längs der Küste in unzähliger Menge auf und ist auch im Inneren, so bei Florenz, bei Arezzo und in Umbrien gemein. Auch in Marken und in den ämilischen Provinzen ${ }^{1}$ ) sind die Fundorte der neapolitance so zahlreich, dafs es bei weitem leichter sein würde diejenigen Orte namhaft zu machen, wo sie gånzlich fehlt oder wo sie seltener vorkommt, wie es z. B. am östlichen Abhang des Apenninen-Gebirges der Fall ist. In den Abruzzen soll sie nicht fehlen; ich finde sie für Caramarico angegeben. In der Umgegend von Rom und im Süden der Halbinsel ist sie ebenfalls gemein und tritt in vielen Spielarten auf. Auf den Inseln des 'Tyrrhenischen Meeres - auf Giglio, Pianosa, La Scuola bei Pianosa, Montecristo, Formica di Grosseto, Palmajola, Elba, Tinetto, ferner auf Ischia, Capri ${ }^{2}$ ) und auf den Inseln Ponza, Ventotene, S. Stefano - erleidet sie zahlreiche und interessante Modifikationen und tritt oft auffallend gekleidet auf. Auf allen diesen Inseln repräsentiert sie die Lacerten und in den meisten Fällen die alleinige Bewohnerin unter den Reptilien. Nach den im neuen nationalen Museum zu Florenz aufbewahrten Exemplaren der grünen muralis zu urteilen, fehlt sie auf den Liparischen Inseln nicht; aus einer in der "Nature (Nr. 475. 1878) erschienen Schrift Gigli o lis erfahreu wir, daf3 sie auf den Inseln Lisca nera, Lisca bianca und Bottaro neben Panuria, einer der Liparischen Inseln vorkommt ${ }^{3}$ ); wir wissen auch, daf auf Stromboli »auffillend dunkel« kolorierte Mauereidechsen einheimisch sind, ob sie aber der Form neapolitana oder fusca angehören, ist uns unbekannt. Über ihr Vorkommen auf den Ägatischen Inseln liegen mir keine Daten vor; da sie auf der gegenüber liegenden sicilianischen Küste, so nach Böttger ${ }^{4}$ ) bei Marsala (Villa Sophia bei Sampolo), einheimisch ist, dürfte sich ihr Verbreitungsbezirk auch auf diese erstrecken. An allen übrigen Küsten Siciliens, und stellenweise

1) Carruccio, Importanza ed utilita delle collezioni faunistiche locali etc. Ann. sc. nat. Serie II. Modena 1880.

$\left.{ }^{2}\right)$ Allem Anscheine nach ist die Mauereidechse für Capri zum ersten Male vom Verfasser der interessanten Schrift „Statistica fisica ed economica dell' Isola di Capri (Esercitazioni accademiche degli Aspiranti naturalisti etc., vol. II. Parte I, pag. 62. Napoli 1840) erwähnt worden. Der Autor giebt auch an, daf Bufo variabilis, Coluber atrovirens und der Gecko auf dieser Insel vorkommen. - Der Tarentola mauritanica L. wird allerdings sehr häufg sowohl auf der Insel selbst, als auch auf dem Faraglioni-Felsen angetroffen; Bufo variabilis aber gehört jetzt zu den größsten Seltenheiten und Zamensis atrovirens scheint ron dieser Insel gänzlich verschwunden zu sein.

3) Vergl. auch: Spalanzani, Viaggio alle due Sicilie. Pavia 1792 ("L.agitis «).

$\left.{ }^{4}\right)$ Liste von Reptilien und Batrachiern gesammelt 1881-82 etc. in: Bericht über die Senckenberg. naturf. Gesellsch. in Frankfurt a. M. 1880-81. Zweite Liste von Reptilien und Batrachiern etc. ibidem, Jahrg. 1881-82. 
im Inneren der Insel, wird die Eidechse allenthalben angetroffen ${ }^{1}$ ). Min à P a l um b o ${ }^{2}$ ) kennt sie aus Iadonie, Caltanisetta, Catania und Girgenti, Böttger erhielt mehrere Formen dieser Subspecies aus den Umgebungen Palermos (Mte. So. Cirro, Nte. Cuccio, Solanto bei Bagheria, Giardino inglese, Monreale, Partinico, Acqua Santa, Capo di Gallo, Bagheria etc.) von Syrakus Taormina und Termini und ich selbst sammelte sie bei Messina. Auch auf den grofen Lavafeldern des Ätna ist sie ebenso wie auf denjenigen des Vesuvs beobachtet worden. Unter den zwischen Sicilien und Afrika liegenden Inseln sind Malta, Linosa und, wie es scheint, auch Gozzo und Comino von ihr bewohnt. Sowohl auf Linosa, als auch auf Filfola, der südlich von Nalta gelegenen Felseninsel, weichen die Eidechsen insofern von der Stammform (i. e. der neapolitana) ab, als sie dunkel gefärbt erscheinen. - Daß3 die neapolitana in Tunis einheimisch Ist, wissen wir aus den Schriften $\mathrm{C}$ a fmeranos ${ }^{3}$ ). - Auf Korsika habe ich sie vorzugsweise an den Küsten, so in der Umgebung von Bastia, am Kap Corso, bei Ajaccio und ausnahmsweise im Gebirge, z. B. in Orezza in kleiner Anzahl gesehen. Daßs diese Form in Sardinien zu Hause sei, ist schon aus den älteren Schriften der dortigen Zoologen bekannt. Cetti, der Verfasser der auch in deutscher Sprache in Leipzig im Jahre 1799 publizierten Naturgeschichte von Sardinien, ferner Azuni, der Bearbeiter von »Histoire géographique, politique et naturelle de la Sardaigne« (vol. II, p. 67. Paris 1802), endlich Ge ué (l. c.) und Cara (Monografia della Lucertola commune di Sardegna. Cagliari 1872) führen sie für Sardinien unter verschiedenen Namen auf, bald als »Tiliguerta«, „Caliscertula", bald als »Lézard vert« oder als »L. podarcis var. Cettii« und »var. Genei«. Nach Gené soll sie auf dieser Insel allenthalben anzutreffen und nach Giglioli (1. c.) auch auf der kleinen, südlich von der Insel Vacca grelegenen Insel Torro, im Südwesteu von Sardinien (bei St. Antiocho), einheimisch sein und auf Torro ein nahezu schwarzes Kleid aufweisen. Daf3 die neapolitana oder deren Spielarten die fusca von Sardinien gänzlich verdrängt habe, wie es behauptet worden ist, bezweifle ich sehr, umsomehr da ich im Berliner Museum eine angeblich aus „Sardegna« stammende, als $\gg L$. tilignerta《 bezeichnete braune nuralis entdeckt habe.

Aus Venezien dringt sie in den Karst und uach Dalmatien ein, von wo aus sie durch

1) Doderlein, Revista della Fauna Sicula dei Vertebrati in: Nuove Effemeridi Siciliani XI.

$\left.{ }^{2}\right)$ Prospetto degli Studi di Erpetologia in Sicilia. Palermo 1863.

3) Considerazioni sul Genere Lacerta Linn. etc. in: Atti Accad. Sc. di Torino XIII. 1877. Cameranos Abhandlungen $\gg$ Monografia dei Sauri italianic (Zoolog. Anzeiger VIII. S. 417; Mem. K. Accad. Sc. di Torino, Serie II, Tom. XXXVII) und "Della Lacerta taurica Pall. in Italia (Bollet. dei Mus. di Zoologia ed Anat. comparata della K. Universita di Torino. No. 7, 1886) sind mir erst zu Gesicht gekommen, als der Druck meiner Arbeit bereits hegonnen war, so das beide nicht mehr berücksichtigt werden konnten. 
das montenegrinische Gebiet ${ }^{1}$ ) sich einen Weg in die Balkanhalbinsel gebahnt hat. Über das Vorkommen der Mauereidechsen im Karste macht"mir Dr. E. Schreiber in Görz folgende interessante Mitteilung: „Das Tier kommt bei uns in der grünen Form im Karste, in der braunen Form am Meeresufer sehr häufig vor:« Nach den übereinstimmenden Zeugnissen von Germar ${ }^{2}$ ) und Erber kommt sie in großer Anzahl und in vielen Abänderungen in Dalmatien vor. Jan ${ }^{3}$ ) führt sie unter dem Namen silignerta $\mathrm{C}$ etti« aus Zara an und nach den Exemplaren im Berliner Museum zu schlielien, ist sie auch im Süden Dalmatiens, z. B. bei Cattaro erbeutet worden. Nicht minder sind die meisten Inseln des Adriatischen Meeres reich an diesen Tieren, so kenne ich', sie von Lussin, Lesina ${ }^{4}$ ) und Pelagosa ${ }^{5}$ ); die adriatischen neapolitana haben allerdings mit manchen binnenländischen Formen viele Ähnlichkeit, besitzen aber doch immerhin so manche Eigentümlichkeiten, dafs sie bisweilen einen, von der italienischen oder dalmatinischen neapolitana ganz verschiedenen Eindruck machen und sich öfters durch ganz gewaltige Gröbe auszeichnen; namentlich soll die Olivacea-Form verhältnismäßig häufig sein. Aus der mir yor einigen Jahren von Dr. Rey in Leipzig zur Bestimmung anvertrauten Sendung von Reptilien habe ich zu schließen vermocht, daf die türkischen neapolitana ebenfalls hedentende Längenmafie erreichen, dabei aher sich durch cine konstantere Zeichnung auszeichnen; namentlich scheint die Mittelregion des Rückens beim Männchen ziemlich beständig drei, aus eng aneinander liegenden schwarzen Flecken bestehende Reihen aufzuweisen.

Die von Berthold ${ }^{6}$ ) für Konstantinop̣el erwähnte $L$. hieroglyphica dürfte unsere neapolitana vorstellen; die auf Korfu einheimische, sogenannte L. Merremii Schinz (Vergl. Erbers Ergebnisse d. diesjährigen Reise nach Griechenland in: Verhandl. zool. botan. Ges. in Wien, Jahrg. XVI, S. 825) ebenfalls. Aus Cephalonia stammende Exemplare enthält die zoologische Universitätssammlung zu Halle (Nr. 138). Auf dem Festlande Griechenlands und auf den Cykladen wird sie mit alleiniger Ausnahme der Insel Milo ebenso häufig angetroffen wie die fusca. In Bezug auf die Färbung hätte ich nur zu bemerken, daßs bei der auf Tinos, Syra und Phanar lebenden neapolitana der vordere Rückenteil, und zwar meistens nur in der Halsgegend, grün koloriert ist, während die hinteren Teile graubraun oder graugrün gefärbt

1) Erber, Die Amphibien d. österreich. Monarchie in: Verhandl, zool. botan. Ges. in Wien, XIV, 1864. -- v. Möllendorf, Beitr. z. Fauna Bosniens. Görlitz 1873.

$\left.{ }^{2}\right)$ Reise nach Dalmatien, 1817.

3) Cenni sul Museo Civico di Milano etc. pag. 40. Milano 1857.

4) Botteri, Notizen in: Verhandl. zool. botan. Ver. in Wien III. S. 129. 1853.

5) Stossich in: Bollet. Soc. Adriatica Sc. nat. in Trieste 1877, p. 184.

$\left.{ }^{6}\right)$ Über einige neue oder seltene Amphibienarten in: Akten d. k. Gesellsch. d. Wissenschaften VIII. Göttingen. 
erscheinen. Davon, daf diese Form auch in Attika vorkommt, habe ich mich vor kurzem überzeugen können: das Universitätsmuscum zu Berlin enthült vämlich ein Stück (Nr. 6982) mit der Etikette " $L$. faurica vom Olymp in Attika». Mauereidechsen, welche sim feurigen Azurblau prangen«, wie es Erhard (Fauna (l. Cyklaten, S. 80) angiebt, habe ich auf den größseren Cykladen, so auf Syra, Andros, Tinos, Mykonos, Seriphos, Milo und endliclı auf Phanar bei Syra, nicht zu sehen beliommen. Möglicherweise bewolnen diese Erhardschen maralis, wie wir es anderswo kennen gelernt haben, auch hier nur kleine Felseninseln, die ich leider im Jahre 1880 nicht alle erforschen konnte. Auch die kornblumenblaue, von Schreiber (l. c. S. 408, 419) citierte und von mir als sarchipelagica« benannte Form habe ich nirgends aufzufinden vermocht und glaube mir hier die Bemerkung erlauben zu dürfen, dafs Dr. E. Schreiber, wie et es mir selbst mitgeteilt hat, die betreffende muralis nur aus der Beschreibung Erhards kennt. Auch ist der rasche Farbenwechsel, den der Verfasser der "Fauna der Cykladen« bei seinen muralis beobachtet haben will, eine bei den Lacerten nicht bekannte und wenig glaubwürdige Erscheinung. Es wäre jedenfalls eine dankbare Aufgabe, lie unzähligen kleineren Cykladen in Bezug ihrer Eidechsenfauna zu erforschen.

Unter den von Unger und Kotschy (Vergl. Die Insel Cypern. Wien 1865) auf Cypern beobachteten Reptilien figuriert $L$. muratis, leider aber ohne nähere Angabe über ihre Färbung, jedoch glaube ich im Jahre 1878 die neapolitana aus Cypern im Mailänder Museo Civico (Nr. 342) als »L. cypria aufgestellt gesehen zu haben; auch vermute ich, dals die mir neuerdings freundlichst von Dr. L. Camerano zur Ansicht übersandte, zu meinem Bedaueru sehr mangelhaft konservierte Eidechse aus Cypern (Mus. Turin: Nr. 22) die neapolitana vorstellen dürfte. Erber giebt sie ("L. Merremii巛) in einem seiner Reiseberichte für Rhodus an (Verhandl, zool. botan. Ges, in Wien XVIII, S. 904). Ihr Vorkommen in Syrien und zwar bei Jerusalem, ist nur von F. Müller mit Bestimmtheit behauptet worden (III. Nachtrag $z$. Katal. d. herpetolog. Sammlung d. Baseler Mus, in: Verhandl. d. naturf. Ges, in Basel 1883). Die Mauereidechse ist allerdings schon längst und noch neuerdings von Loltet als in Syrien und Palästina vorkommend angegeben worden, jedoch sind diese Angaben für das Vorkommen speciell der netıolitana nicht mafgebend. weil weder von ihrer Färbung noch ihrer Gröfe auch nur eine Silbe erwähnt worden ist. Nach dem mir im Jahre 1878 zur Ansicht und Bestimmung von Dr. Rey in Leipzig zugesandten Material zu schließen, kommt die neapolitana auch in Kilein-Asien vor; sonst sind, so viel ich weit;, kleinasiatische Fundorte durch keine Belegstücke bekannt. Das Museum in Halle enthält ein Stück dieser Form aus »Aegyptia\& (Nr. 405), das als $" L$. oxycephala bestimmt worden ist! Daf diese Fundortsangabe auf Verwechslung 
beruht, brauche ich wohl kaum hinzuzufügen; in Ägypten kommen sicherlich keine echten Eidechsen, geschreige denn europäische Arten, vor.

Über die Verbreitung der grünen muratis in Südruf̧land kann z. Z. nichts angegeben werden. Unsere Kenntnisse über die russischen Saurier sind noch sehr mangelhaft, nur insofern kanu ein Fortschritt verzeichnet werden, als einige mit $L$. muralis oder $L$. taurica zusammengeworfene Species sich als gute Arten erwiesen haben und andere fragliche Formen, wie beispielsweise L. chalybdea E ichw. und L. saxicola Eversm., ihren definitiven Platz in der Synonymik gefunden haben. Wie willkürlich und unkonsequent wir mit der saxicola verfahren sind, mügen hier einige Beispiele illustrieren: Duméril und Bibron gaben auf S. 218 ihrer generellen Herpetologie (Bd. V.) an, Eversmann hätte eine junge viridis als saxicola beschrieben; auf S. 230 desselben Werkes aber ist die saxicola einfach in die Synonymie der muralis versetzt worden. Krynicky ${ }^{1}$ ) nahm an, die saxicola sei mit taurica identisch und behielt Eversmanns Benennung. Die Verfasser der Erpétologie générale bemächtigten sich nun der saxicola Krynicky, um sie ebenfalls in die Synonymie der Mauereidechse zu stecken. Eichwald nennt die saxicola gleichbedeutend mit seiner chalybdea. Schreiber ist geneigt, erstere mit der taurica zu identifizieren, spricht sich aber nicht bestimmt darüber aus, weil, wie er auf S. 419 seiner Herpetologia europaea angiebt, Eversmann nur das Farbenkleid dieser Lacerta beschrieben habe. Meines Wissens nach trafen Bonaparte (Iconografia della Fauna italica II), Czernay (Bulletin de Moscou 1851. I) und Kessler (Zoolog. Reise durch Transkaukasien etc. 1. c. das Richtige, indem sie die saxicola Eversm. mit der muralis als gleichbedeutend erklïrten, oder aber als Varietit der braunen Mauereidechse betrachteten. Die angeführten Beispiele werden genügen, un zu zeigen, dafs die Lacertiden-Familie und namentlich die etwas stiefmütterlich behandelte »Lacerta«, einer gründlichen, auf authentischen Exemplaren basierten Revision bedurfte.

Zur Zeit können wir mit Bestimmtheit angeben, dafs das eigentliche Wohngebiet der neapolitana sich vom $60^{\circ}$ o. L. von Paris bis etwa zum $33 .^{\circ} 00$. L. von Paris (Jerusalem!) erstreckt; daf3 sie nördlich von den Alpen nicht angetroffen wird, überhaupt den $460^{\circ} \mathrm{n} . \mathrm{Br}$. nicht überschreitet, und daß die Südgrenze ihrer Verbreitung zwischen dem $35 .^{\circ} \mathrm{n}$. Br. und dem $37 .{ }^{\circ}$ n. Br. liegt (Küste von Tunis, Cypern und Rhodos!). - Fassen wir das über die Verbreitung der grünen und braunen Mauereidechse (subsp. fiesca, subsp. neapolitana) Gesagte zusammen, so werden wir zu einer höchst interessanten Schluffolgerung gelangen. Der bekannten Thatsache entsprechend, daj die Kriechtiere Südeuropas gröbtenteils auch der nord-

1) Bulletin de Moscon 1837, Nr. 3. 
afrikanischen Küste angehören, treffen wir die muralis in Afrika an und zwar ähnlich wie an den südeuropäischen Küstengebieten verteilt. Ich hatte vorhin gezeigt, daßs die fusca auf dem europäischen Kontinente bis zum $60^{\circ}$ o. L. von Paris die alleinige Repräsentantin der Mauereidechsen ist. In Nordafrika, wie es sicher konstatiert worden ist, gehört sie hauptsächlich der Litoralfauna Algeriens an, deren Grenze sich bekanntlich ungefähr bis zum $60^{0}$ o. L. von Paris erstreckt. Vom $6.0^{\circ}$ o. L. an tritt die neapolitana auf und verdrängt die fusca größtenteils aus Italien, Sardinien und Sicilien. Korsika und Norditalien bilden so zu sagen eine Versuchsstation oder kosmopolitische Zone, denn sowohl hier als dort sind beide Subspecies einheimisch und treten ziemlich gleich häufig auf. In dem südlich von Sardinien und Sicilien liegenden Tunis wird wiederum die neapolitana vorgefunden; die zwischen den tunesischen und sicilianischen Küsten liegenden Inseln beherbergen sie ebenfalls. Tunis dürfte die äufierste Grenze ihrer westlichen und gleichzeitig östlichen Ausdehnung auf afrikanischem Boden in sich begreifen. Somit würde die muralis vom $80^{\circ} 0 . \mathrm{L}$. von Paris in der Richtung nach Osten hin nur Süd-Europa und einem sehr beschränkten Teile Vorder-Asiens angehören.

Subsp. Brugemanni de Bedriaga 1879 (Herpetologische Studien im: Archiv f. Naturg. 45. Jahrg. Bd. I. S. 304. Taf. XVII. Fig. 1. - Bull. Soc. zool. de France IV, pag. 219). Auf der hohen Mauer des Arsenals zu Spezia und in dem diese Mauer von der Landstrafe trennenden Graben kommen zweierlei grestaltete und gefïrbte Nauereidechsen vor, von denen die eine, die neapolitana ist, die andere aber eine kleinere, in ihrer Körpergestalt an die fusca lebhaft erinnernde, eigentümlich gezeichnete, hellgrüne morulis. Ihre Färbung und Zeichnung sind so auffallend und so sehr von den bekannten Formen der Mauereidechse verschieden, dats man sie schon aus der Ferne zu erkennen vermag. Auf gelbgrünem oder hellgrünem Fond verlaufen beim Männchen feine wellenförmige schwarze Querstreifen, welche sich an den Kürperseiten verästeln, ineinander verschmelzen und ein Netzwerk bilden, deren kleive Maschen öfters hellblau erscheinen; dabei ist zu bemerken, daß die an der Schulter liegenden Maschen bedeutend grö[ier sind, besonders schön hervortreten und die bekanuten Ocelli der neapolitana vorstellen. Die Schädeldecke ist braun, grün gefleckt. Auf der zum T'eil grau und grün gefärbten Oberseite der Extremitïten sind hellgrüne Ocelli zerstreut. Der Schwanz erhält an oberen Teile auf grünbraunem Fond dunkelbraune Zickzacklinien. Die Bauchseite ist auf weiblicheın Grunde schwarz gemakelt; jede Ventraltafel erhält einen schwarzen Würfel; die erste longitudinale Reibe erscheint total blau. Der Unterkopf zeigt weiße, schwalz umrandete Ocellen. Die von mir erhaltenen Weibchen waren meistens einfacher koloriert, als die Männchen; die Grundfabe des Rückens war grünlich braun. - Die Kopfform ist bei beiden Geschlechtern 
abreplattet; der liumpf ehenfills. Dic Mafe, deren Details ich hier folgen lasse, sind gröbtenteils mit jenen der subsp. fusca identisch.

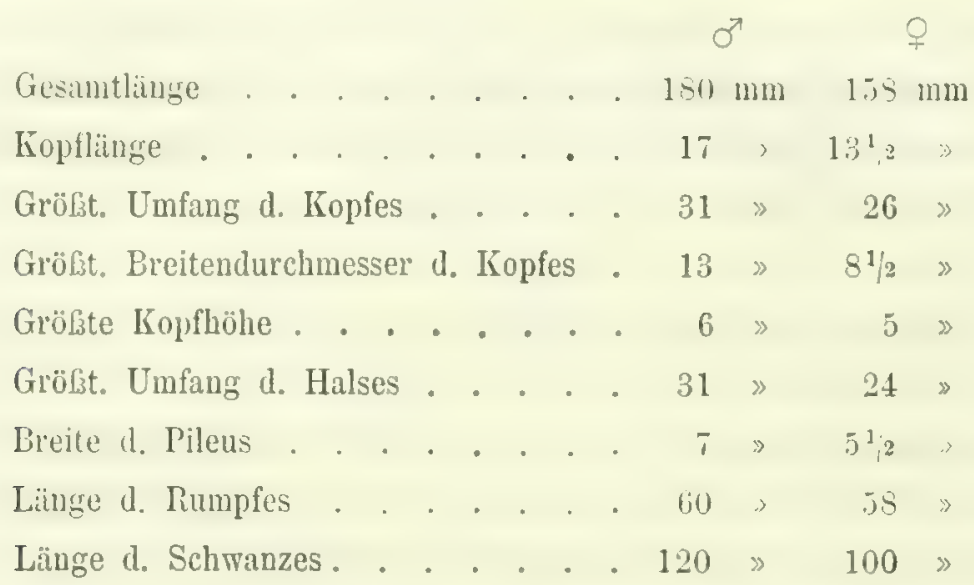

Die Schilder und Schuppen sind denen der anderen Mauereidechsen ziemlich gleich; es bliebe daher nur noch zu bemerken, daß das Massetericum klein, oder gar nicht vorhanden ist, ferner, dab die Oberschildchen nicht grol; erscheinen, endlich, dals die Schwanzschuppen leicht zugespitzt cuden. Beim Männchen zählte ich jederseits 2:3 Femoraldrüsen, beim Weibchen dagegen nur 20. - Über die Lebensweise dieser wohl den Übergang von fusca zur neapolitana bildenden muralis hätte ich zu bemerken, dafs sie viel behender als die neapolitana und daher am schwierigsten zu erhaschen ist. Sie bewohnt außel der erwähnten Arsenal-Mauer die Brückenpfeiler, auf deren ghatt bcarbeiteten Steinen sic mit wunderbarer Gewandtheit herumklettert.

Subsp. balearica de Bedriaga 1879 (Bull. Soc. zool. de France IV, 1879. pag. 221, Pl. IX, Fig. 3. - Bull. de Moscou 18s1, No. 3, pag. 103). - Diese Unterart sowie auch ihre Tochterformen, wie z. B. die Lilfordi Günth., die Gigliolii de Bedr. und die pitynsensis Boscà, sind ausschlieflich insulanische Mauereidechsen; sie leben auf den Balearen uncl zeichnen sich durch ihren kräftigen Körperbau, durch ihren verhältnismäligig kurzen Schwanz und breiten Hals aus. Auf dem Kople, Rücken, Beinen und Schwanze herrscht bei der baleurica die bräunliche Farbe vor, mit eingemischten dunkelbraunen Schuppen; letztere sind unregelmäßig verteilt oder bleiben gänzlich aus, in diesem Falle aber ist die Grundfarbe entweder graubraun mit schwarzgrünlichem Ton oder bronzebraun mit einem Stich ins Rotbraune. An den Rumpfseiten sind etliche zerstreute helle, etwa bräunlichweilie, ziemlich runde Flecken sichtbar, welche mitunter eine von dem hinteren Augenwinkel ausgehende Längsreihe bilden, welche sich über der Wurzel der vorderen. Extremität hinweg an den Seiten des Rumpfes 
hinzieht und sich am Schwanzanfange fortsetzt, wo sie allmïhlich undeutlicher wird und gianzlich verschwindet. Eine zweite ähnliche und mit jener genau parallel latufende Fleckenreihe geht vom hinteren Ohrrande aus, läuft zwischen der Bauchgrenze und der oberen fileckenreihe hin und setzt sich in einer schwachen Spur an der Seite des Schwanzes noch eine Strecke fort. Bei den deutlich hellgefleckten Individuen pflegen die dunkelgefärbten Schuppen sich limgs der Wirbelsiule zu konzentrieren und auch die oberen fleckenreihen zu umsïumen; jedoch ist dies nur in seltenen Fällen von mir konstatiert worden. Die Kopfdecke ist dunkelbraun, die Kopfseiten und die Gliedmafien sind oberseits spärlich dunkelbraun und bräunlichweif. grefleckt. Die Kehle und der Hals sind auf schmutzigweifem, bläulichem oder rötlichem Grunde grau gemarmelt; der Bauch und die Unterseite der Beine sind bläulich oder ziegelrot spärlich dunkel punktiert oder fein gestreift. Der groibte 'Teil des Schwanzes ist oberseits einfarbig hellbraun, unten bläulich. - Subsp. balcarica kommt auf Menorka, Mallorka und höchst wathrscheinlich auch auf den kleinen Inseln del Colon und del Rey vol (Vergl. Braus Arbeit üb. L. Lilfordi und L. muralis in d. Arbeiten a. d. zool. zootom. Inst. Würzburg IV. 1877).

Die Details der Mafe einer mir vorliegenden männlichen balearica von Menorka sind folgende: Totallänge $143 \mathrm{~mm}$; Kopflänge $17 \mathrm{~mm}$; grölit. Breitendurchmesser d. Kopfes 10,7 mm; größst. Höhendurchmessel 7,5-8 $\mathrm{mm}$; grölat. Umfang d. Kopfes $32,3 \mathrm{~mm}$; Breite des Pileus $7 \mathrm{~mm}$; Halslïnge $9 \mathrm{~mm}$; Umfang d. Halses $34,3 \mathrm{~mm}$; Rumpflänge $45 \mathrm{~mm}$; Rumpfunffung $38 \mathrm{~mm}$; Schwanzlïnge $81 \mathrm{~mm}$; Länge d. vorderen Extremität $22 \mathrm{~mm}$; d. Iland m. d. Fingern 10,3 mm; d. hinteren Extremität 37,3; d. Fulies m. d. Zehen $18 \mathrm{~mm}$.

Var. Gigliolii de Bedriaga 1879 (Herpetolog. Studien, 1. c.-- Bull. Soc. zool. de France IV, p. 223). Die Grundfarbe des Männchens ist vorwiegend hellnufibraun, nur gegen den Schwanz zu wird sie dunkelblau. Aus diesem blauen Felde nelimen 4 parallele, anfangs ebenfalls dunkelblaue, dann aber grünblaue ununterbrochene Streifen ihren Ursprung; in der Halsgegend verfärben sie sich jedoch und sind kaum von der Grundfarbe zu unterscheiden. Die braun kolorierten Teile des Rückens werden durch eine, meistens stark entwickelte schwarze Zeichnung durchzogen; diese Zeichnung tritt besonders in der Mittellinie der Oberseite hervor. Die dunkelbraunen Körperseiten werden von grüngelben Ocellen geziert. Die Oberseite des Schwanzes ist schön blau, die des Kopfes braun und dunkelbraun gefleckt; an den Seiten und der Unterseite des Schwanzes wechseln metallisch grüne und blaue Schilder miteinander ab. Die untere Körperseite, also die mittleren Ventralreihen, der. IIals und die Extremitäten sind graurötlich; die erste und die nach auben liegende Iälfte der zweiten longitudinalen Bauchschilderreihe sind dunkelblau, die übrigen lieihen sind zart dunkelblau gestreift. Auf dem 
Anale finden wir einen lilablauen Flecken; eine Anzahl von Halsschuppen und Schilder der Unterseite der Extremitäten sind blaugrün. - Die übrigen von mir gesammelten Männchen dieser Form sind einfacher gekleidet. Die soeben erwähnten blaugrünen Streifen sind bei ihnen nur spurweise angedeutet; am schärfsten tritt das blaue Kolorit in der Schwanzwurzelgegend hervor. Die Oberseite der Gliedmaßsen und die Seiten des Körpers sind einförmig hellnubibran; die Schädeldecke erscheint dunkelbraun; die Wangen sind spärlich gefleckt; die blaue Streifung der einzelnen Tafeln ist hier nur spurweise vorhanden, das Anale enthält in den meisten Fïllen einen bläulichen Flecken in der Mitte. Die Schwanzschilder sind abwechselnd rötlichbraun und grün koloriert.

Die mir vorliegenden Weibchen der Gigliolii sind brillanter nuanciert als die Männchen. Die Grundfarbe des Rückens ist dunkelblau oder bläulichgrün; im ersteren Falle wird der Untergrund von 5, am Hinterrande des Pileus und oberhalb der Ohröffnung beginnenden und am Hinterrücken endenden schmilen, metallisch glänzenden und mit dunklen Punkten besäten Streifen unterbrochen, im letzteren Falle erblickt man 4, aus kleinen Flecken bestehende, braune Streifen, welche die Mittelzone des Rückens einnehmen. Auf hellnuGbraunem Grunde der Seiten nimmt man blaugrüne Augenflecken wahr, welche in 3 bis 5 parallele Längsreihen angeordnet zu sein pflegen; eine dunkelbraune Zickzackzeichnung, welche die Ocellen zum Teil umgiebt, hebt letztere schärfer hervor. Die Schädeldecke ist hellnulbbraun, mit kleinen schwärzlichen oder dunkelbraunen Flecken geziert; hie und da treten auferdem noch blaugrüne Makeln zum Vorschein; dieselben sind auf den Wangen und an der Schnauze gut ausgeprägt. Die Schläfenschilder sind abwechselnd grün, blau, schwarz und braun koloriert; die Kehle ist auf orangerotem Fond blaugrün gespritzt. Die Farbe des Bauches mit Ausnahme der äußeren saphirblanen longitudinalen Schilderreihe, ist ziegelrot ouler rot, stellenweise mit einem Stich ins Graue; die zweite Reihe der Ventralen ist blau gefleckt, das mittlere Paar aber erscheint fein gestreift (Vergl. meine Taf. XVII, Fig. 4, 5 u. 2 im Archiv f. Naturg. 1879). Das Anale trägt in der Mitte einen grolien lilablauen Flecken, welcher blaue Verästelungen nach außen zu sendet; die winzigen Schuppen, welche dicht an der Afterspalte liegen sind helllila. Der oberhalb zum Teil blaugrüne, z. T. saphirblaue Schwanz ist unten café au lait oder rötlich angrehaucht mit einer Andeutung von metallisch Grün. Die Oberseite der Gliedmaßen erscheint hellnubbraun, dunkelbraun und blaugrün gefleckt; letztere Tinte erscheint in der Ocellenform und wird gewöhnlich von einem dunkelbraunen Ringe umgeben. - Die Färbung der Jungen ist kaum von der der Alten abweichend, nur fallt bei ihnen der metallischgrüne Schwanz auf, der bei den ausgewachsenen Exemplaren zum größten Teil blau ist; auch ist ihre Bauchseite 
weniger intensiv koloriert. - Var. Gigliolii variert selur stark in ihrer Fürbung und steht infolgedessen im Gegensatze zu jenen lionstanten Formen, wie z. B. der muralis vom fararlioni-Felsen bei Capri und der Lilfordi von der Insel Ayre. Der Fundort dieser schönen Abart ist die Insel Dragoneras an der Westküste von Mallorkil. Auf der Südseite dieser Insel trift man sie mit saphirblauen und grünblauen Rä̈ckenstreifen. Ls kommen aber darunter auch Stücke vor, denen diese Streifung fehlt, oder solche, die nur eine kaum merkliche Spur derselben besitzen.

lhr Körper ist im allgemeinen schlanker und gestreckter als bei der Lilfordi. Die Gesamtlänge meines grölaten Männchens beträgt $17^{1 / 2} \mathrm{~cm}$, dabei ist aber zu bemerken, dąs das betreffende stück zweifellus einen regenerierten, $10^{1 / 2}$ cm langen schwanz besitat und dills ich mehrere Eidechsen dieser Varietit mit lingeren Schwänzen gesehen habe, deren ich jedoch leider nicht habhaft werden konnte. Die Länge des Kopfes beim Nännchen betrïgt $17 \mathrm{~mm}$; die gröfte Kopfbreite $=9^{1 / 3} \mathrm{~mm}$, grö́ste Kopfhöhe 8 bis $9 \mathrm{~mm}$. Die mir zu Gebote stehenden Weibchen sind $156 \mathrm{~mm}$ lang; ihr Kopf mist $14 \mathrm{~mm}$, ihr Schwanz $100 \mathrm{~mm}$.

Var. Lilfordi Günther 1874 (Ann. and Magaz. nat. hist. Ser. IV, vol. XIV, p. 158. v. Bedriaga, Herpetolog. Studien 1878, l. c.; Mém. sur les variétés curop. du Lézard des murailles, 1. c., p. 225. Pl. IX. Fig. 1, 2. - Braun, Lacerta Lilfordi etc., l. c., 'Taf. I, Fig. 1, 2, 3 u. 4). - Folgende Beschreibung des Farbenkleides entlehne ich gröfatenteils aus der citierten Schrift von Braun: „Die Oberseite und der gröbte Teil der Seitenflächen des Rumpfes, die Wangengegend, die Oberseite der Extremitäten, mehr nach hinten als nach vorn reichend, und die Oberseite des Schwanzes ist ganz schwarz, selbst ganz frisch nach der Häutung ohne eine Spur einer anderen Färbung.\& Die der Faraglioni-Muralis und anderen Formen zukommenden grünen oder blauen Augenticken hinter der Achsel und an den hintereu Gliedmafen werden bei der Lilforli gänzlich vermilit. "Nur an den Seiten des Rumpfes findet sich bei den größten Exemplaren dicht an der Grenze gegen die Bauchschilder eine unregelmäßige Reihe von 3 bis 5 ganz dunkelblauen, runden, ziemlich kleinen Flecken, die für gewöhnlich nicht ins Auge fallen, weil sie fast schwarz zu nennen sind. Bei etwas jüngeren Tieren sind 2 Reihen solcher schwarzblauer Flecken vorhanden, wobei die dem Bauche näher liegende Reihe etwas heller erscheint, als die entferutere; diese Flecken beginnen erst eine Strecke hinter der Achsel und hören vor der Hüfto wieder auf. Die Schädeldecke ist ziemlich dunkelbraun mit helleren kleinen Sprenkein besetzt, oder ganz schwarzbraun ohne jegliche Fleckenzeichnung, oder, wie ich hinzufugen will, tief schwarz und im Sonnenlicht deutlich irisierend. "Die Schilder an der Schnauze und dem Oberkicfer sind dunkelblau gefübt, mit ein- 
zelnen, sehr unregelmälligg zackigen, metallisch oder mehr grünlich glänzenden Flecken besetzt.« 》Der Bauch ist saphirblau; immer tragen die Schilder, welche die erste seitliche Longitudinalreihe bilden, schwarze Flecken, die einen grofen 'Teil des einzelnen Schildes besctzeu. Mitunter sollen auch die mittleren Bauchschilder kleine, schwarze Flecken tragen. Der Ifals ist manchmal einfarbig blau, meist litht er namentlich an den Seiten zu schwarze, mehr oder weniger vollstïndige Ringflecke (schwarzer Kreis auf blauem Grunde), von diesen ausgehende Spangen oder einfache Flecken erkennen; nach der Mittellinie zu verschwinden dieselben gewöhnlich.« Die Unterkiefer sind ebenfalls etwas heller als der Banch und dic unterseits dunkelblauen, oft mit kleineu schwarzen Sprenkeln besetzten Extremitäten; an den Unterkieferschildern sind feinzackige, sternförmige Bronzetlecke konstatierbar. Die Aftergegend und die Schwanzunterseite sind dunkelblau; gegen das Schwanzende zu geht das Blau in dunkles Graublau und endlich in Rauchgrau über. Bei Exemplaren von 45 bis $51 \mathrm{~mm}$ Körperlänge excl. Schwanz ist die Kopfoberseite braun nit unregelmäß̊gen dunklen Linien, Tupfen und Flecken besetzt, während die Schläfe kaffeebraun, die Supralabialia schwarz mit blauen, oder blau mit grünen, braunen, gelben und schwarzen Sprenkeln geschmückt erscheinen. Der Hals zeigt auf dunkelblanen Grunde brame Ringe und Streifen. Der Rücken ist braun, heller als der Kiopf, wach hinten zu dunkler werdend; zu beiden Seiten des Rückgrates ziehen hinter dem Kopf begiunend, 2 dunkelbraune, fast schwarze geschlängelte Streifen nach hinten, die sich in der Höhe der Hinterextremitäten allmählich verlieren. »Ein zweites Linien- oder Bindenpaar faillt in die Verlängerung der Verbindung von Nasenloch und Ange und beginnt seitlich am Sc. parietale nach hinten sich allmählich verlierend; Farbe und Gestalt ist gleich dem ersten Pare. Der Streif, der auf jeder Körperseite zwischen der einen und der auderen Binde übrig bleibt, ist meist braun gefärbt, nach hinten dunkler, resp. schwarz werdend; mitunter ist er jedoch duvkelgrün, das Grün fällt leichter bei auffillendem Sonnenlicht in die Augen und glänzt danı stark metallisch. Seitlich nach dem Bauche zu wird die braune Farbe dunkler und ist von zahlreichen runden, blauen Flecken unterbrochen, die hinter der Achsel beginnen, « Die Bauchschilder sind an den Seiten schwarz mit blauen Flecken, in der Mitte stark grünlich, oder mehr gelbgrün gesprenkelt. Die Falte hinter dem Halsband ist gelblich, mitunter hellgrün und gelb; bei den ausgewachsenen Individuen ist diese Falte mit hellblauen Schuppen bekleidet, welche gewöhnlich einen mehr oder weniger breiten Streifen Gelblichgrün erkennen lasscn. Der Schwanz ist bei den Jungen oben dunkelgrün, unten hellblau mit grünen Sprenkeln besetzt, also ähnlich wie am Bauch; nach hinten zu wird er rötlichgrau. Die Gliedmaßen sind oben dunkelbraun, nach hinten und unten zu heller; sie hekommen mitunter grüne Sprenkeln wic 
die Hanchtafeh. Bei 55 bis $6.3 \mathrm{~mm}$ langen Individuen ist die Farbe des l'ileus bald heller braun mit dunklen Sprenkeln, balıl dunkler mit helleren Flecken; die Temporalgegend beginnt in Schwarz überzugehen. „Der Rücken«, sagt $\mathrm{Bra \textrm {n }}$, „zeigt die weitgehendsten Änderungen: Das Schwarz, welches oben auf dem Rücken bei den mir zu Gebote stehenden jüngsten T'ieren auf die Gegend zwischen den beiden Hinterbeinen beschrinkt war, hat sich als sehr dunkles Braun weiter nach vorn verbreitet bis an die Vorderbeine, die 2 Pxar Binden sind nicht mehr kenntlich, höchstens bei einigen rorn schwach angedeutet; diss Dunkeln des Rückens hat auch die his an die Binden reichenden blauen Flecke verdeckt, doch sind noch 2, manchmal auch 3 Reihen derselben vorhanden. Der Bauch ist dunkler blau geworden, bei den seitlichen Schildern, die bei jüngeren Tieren mehr schwarz als blau waren, hat das Blau auf Kosten des Schwarz zugenommen; während früher die vier mittleren Reihen grünlich waren, beschränkt sich jetzt diese Farbe fast allein auf die beiden mittelsten. Die Unterseite des Halses weicht jetzt nicht mehr von den ausgewachsenen ab, die Flecken, Binden und Ringe auf denselben sind schwarz geworden. Auch die Extremitäten dunkeln, die runden Flecke verschwinden... Der Schwanz verliert seine grüne Färbung, wird oben schwarz, unten nach hinten fortschreitend dunkelblau. »Bei noch größeren Tieren, die ich als zweijährige, resp. im zweiten Jahre stehend betrachte, von der Körperlänge bis etwa 65 bis $70 \mathrm{~mm}$, ist fast überall schon die Färbung der ganz ausgewachsenen Exemplare aufgetreten; mitunter erhält sich bei diesen ein in der Sonne goldig glänzendes Braun auf dem Nacken und in der Achsel, dicht hinter den Oberamen, doch auch dieses schwindet.

Iabie beim $\sigma^{7}$. - Gesamtlänge: $161 \mathrm{~mm}$; Kopflänge: 18,3 $\mathrm{mm}$; Kopfbreite: $12 \mathrm{~mm}$; Kopfhöhe: $10 \mathrm{~mm}$; Kopfumfang: $39 \mathrm{~mm}$; Breite d. Pileus: $7-8 \mathrm{~mm}$; Halslänge: 10,5 mm; Halsumfang: $41 \mathrm{~mm}$; Rumpflänge: $53 \mathrm{~mm}$; Rumpfumfang: 43-44 mm; Schwanzlänge: $\$ 9,5 \mathrm{~mm}$; Länge der Vorderextremität: 23,3 mm; d. Hand m. d. Fingern: 10,3 mm; der Hinterextremität: $36 \mathrm{~mm}$; d. Fußes $\mathrm{m}$. d. Zehen: $16 \mathrm{~mm}$. - Maße beim $q$. - Gesamtlänge: 150-151 mm; Länge d. Kopfes: 14, $5 \mathrm{~mm}$; Kopfbreite: $8,3 \mathrm{~mm}$; Kopfhöhe: $7 \mathrm{~mm}$; Kopfumfang: $27 \mathrm{~mm}$; Breite d. Pileus: $6,3 \mathrm{~mm}$; Halslänge: $8-8,5 \mathrm{~mm}$; Halsumfang: $27,5 \mathrm{~mm}$; Rumpflänge: $45 \mathrm{~mm}$; Rumpfumfang: $31,5-33 \mathrm{~mm}$; Schwanzlänge: $91 \mathrm{~mm}$; Länge der Vorderextremität : $19 \mathrm{~mm}$; d. Hand $\mathrm{m}$. d. Fingern: $9 \mathrm{~mm}$; d. Hinterextremität: $31 \mathrm{~mm}$; des Fukies m. d. Zehen: $15 \mathrm{~mm}$.

Diese schöne Varietät findet sich auf dem südöstlich von Menorka liegenden Eiland \$Isla del Ayre.

Nach einer im Bull. Soc. zool, de France, V, erschienenen Mitteilung von Boscà kommt 
sie auch auf den kleinen Inseln »La Moltona, La Guardia« und »Frares« vor. Boscà sagt ferner, datis nach den von ihm eingezogenen Erkundigungen, auch auf der Insel Cabrera sowie auch auf den bei Cabrera liegenden kleineren Inseln schwarze Eidechsen vorkämen.

Var. pityusensis Ed. Boscà 1883 (Exploracion herpetológica de la Isla de Ibiza in: Anal. Soc. Esp. de Hist. Nat., tomo XII). - Obschon diese Eidechse in betreff ihrer Grölie und Körpergestalt zweifelsohne der Gruppe sbalearica« angehört, ist sie doch auf eine ganz eigenartige Art und Weise gekleidet. Die Rückenfarbe der pityusensis hat allerdings einige Ähnlichkeit mit der neapolitana, indem sie vorherrschend grün ist, aber dies Grün ist bei der zuerst genannten ganz hell und häufig mit Gelb stark vermischt, so dal’ man sie geradezu als eine gelbrückige Lacerta bezeichnen könnte; nur in seltenen Fällen tritt eine Verdunkelung, d. h. eine Neigung zu Braun auf. Die schwarze oder schwarzbraune Zeichnung variiert auliserordentlich. Bei einigen, hauptsächlich bei den weiblichen Individuen, ziehen sich über den Rücken hin 5, zum Teil kontinuierliche, zum Teil aus losen, kleinen, dunklen Strichen bestehende Streifen, welche bedeutend schmäler sind als die zwischen ihnen sich befindenden fleckenfreien Streifen der Grundfarbe. Bei anderen Exemplaren entsenden die vertebralen strichartigen Flecken feine Verzweigungen und bilden S-förmige und schnörkelartige Figuren, welche beim Männchen ziemlich stark ausgeprägt erscheinen und etliche grüne runde Flecken einzufassen pflegen. Beim Männchen ist auberdem die Zahl der longitudinalen Fleckenserien auf dem Rücken geringer; meistens sind nur 3 vorhanden, wobei die Streifen Grundfarbe mit hin und wieder zerstreuten dunklen Punktflecken versehen erscheinen. Rücken und Rumpfseiten sind durch einen breiteren, fleckenlosen Streifen Grundfarbe abgegrenzt; die Kopf- und Rumpfseiten erhalten eine, aus Ringflecken bestehende Fleckenbinde und gegen die Bauchgrenze hin noch eine andere, aus kurzen, mehr oder weniger ausgeprägten Querlinien, Flecken und schriftartigen Figuren ( $q$ ), dic öfters von rostbraunen, orangeroten oder gelbeu Flecken begleitet werden; bei derart gefleckten Individuen ist die gelbe, grünlichgelbe oder orangerote Färbung am Bauche vorherrschend; namentlich erscheint die Schwanzunterseite sowie auch die Kehle prachtvoll orangerot oder ziegelrot koloriert, dabei ist das äufere longitudinale Bauchschilderpaar entweder bräunlich und grünlich oder einfach blaugrün gefärbt; bei cinigen Exemplaren, namentlich bei den weiblichen dehnt sich das Blaugrün auch auf alle übrigen unteren Köperpartien aus. Exemplare, bei denen die Körperunterseite rosa oder gelblichweiß̧, grau gefleckt erscheint, kommen gleichfalls vor. Die Kopfoberseite und die Oberseite der Extremitäten erscheinen selten ungezeichnet; meistenteils ist der Kopf oben, sowie auch seitwärts auf hellbräunlichgrünem Grunde, üppig schwarzbraun gezeichnet; die Oberkieferschilder crhalten aulierdem 
orangerote Ränder und orangerote und blaugrïne Flecken, während die blaugrünen, rosagelben oder rötlichen Submaxillaren in den meisten Fällen vorn und hinten dunkelbraun gerändert zu sein pflegen; die Kehle ist manchmal jederseits von einer Reihe runder dunkler Flecken begrenzt und auch in der Mitte dunkel punktiert; bei den auf dem Rücken mehr dunkelfarbigen männlichen Individuen sind die kiehlschuppen abwechselnd mosaikartig, weiflich, dunkelgrau, blau und ziegelrot gefärbt. Die stets hellere Schwanzoberseite ist unregelmäfigig dunkelbraun punktiert und gefleckt, während die Unterseite ungezeichnet ist. Oberhalb der Wurzel der Vorderextremitäten befindet sich öfters ein grünlicher, runder Flecken und um diesen herum eine schwarzbraune Umrahmung. - Die pityusensis ist im Durchschnitt etwas größer und kräftiger gebaut als die übrigen balearischen Mauereidechsen, ohne daß ihr Schwanz verhältnismäßig länger wäre; sie erreicht einen relativ bedeutend größseren Körperumfang als wie Subsp. neapolitana und kann zugleich mit der dunklen Faraglioni-Eidechse als die kräftigste muralis gelten. Die Maße der pityusensis sind:

Männchen. - Totallïnge: $185 \mathrm{~mm}$; Länge des Kopfes: 17,5 mm; des Halses: $11 \mathrm{~mm}$; des Rumpfes: $56,5 \mathrm{~mm}$; des Schwanzes: $111 \mathrm{~mm}$; der Vorderextremität: $25,5 \mathrm{~mm}$; d. Hand m. d. Fingern: $11 \mathrm{~mm}$; der Hinterextremität: $44,5 \mathrm{~mm}$; des Fubes m. d. Zehen: $21 \mathrm{~mm}$; grų̈te Kopfhühe: 10,2 mm; grölite Kopfbreite: 12,7 mm; größte Breite d. Pilens: $9 \mathrm{~mm}$; grölit. Umfang des Kopfes: $40 \mathrm{~mm}$; des Halses: $41 \mathrm{~mm}$; des Rumpfes: $45 \mathrm{~mm}$.- Weibchen. — Gesamtlänge: 143-144 mm; Lünge des Kopfes: $14,5 \mathrm{~mm}$; d. Halses: $6-7$; d. Rumpfes: $46 \mathrm{~mm}$; des Schwanzes: $83 \mathrm{~mm}$; der Vorderextremität: $17 \mathrm{~mm}$; der Hand $\mathrm{m}$. d. Fingern: $8 \mathrm{~mm}$; der Hinterextremität: $27,5 \mathrm{~nm}$; d. Fulies m. d. Zehen: $14 \mathrm{~mm}$; grölite Kopfhöhe: $6,7 \mathrm{~mm}$; größte Kopfbreite: $9 \mathrm{~mm}$; größte Breite des Pileus: $6,5 \mathrm{~mm}$; größster Umfang des Kopfes: $27 \mathrm{~mm}$; d. Halses: $28,5 \mathrm{~mm}$; d. Rumpfes: $35 \mathrm{~mm}$.

Die Schenkeldrüsen sind meist groß, in ihrer Zahl von 20 bis 24 ändernd. - Ed. Boscà fand diese Varietät auf Ibiza, sowie auch auf den kleinen bei Ibiza liegenden Inseln „La Grosa und »La Redonia bei Santa Eulalia, auf »El Malvi Gros« und »Malvi Pla y La Grosa gegenüber der Stadt Ibiza. Hinzufügen möchte ich noch, daf ich die pityusensis oder eine dieser Varietiit ähnlich sehende Form aus Tunis stammend gesehen zu haben glaube (Mus. in Turin). Eine Übergangsform, welche die pityusensis und die fusca verkettet, ist mir neuerdings aus der spanischen Provinz Galizien zugestelit worden, doch verzichte ich zu Gunsten des Entdeckers dieser Form auf ihre Beschreibung.

Aus der Ende November 1885 erhaltenen Schrift $\rightarrow$ V. L. Se o a ne, Identidad de Lacerta Schreiberi (Bedriaga) y Lacerta viridis var. Gadovii (Boulenger) é investigaciones herpe- 
tológicas de Galicia. La Coruña 1884 * ersehe ich, dak letztere den Namen war. Bocagei erhalten hat. In dieser Schrift werden aufierdem $L$. Schreiberi Bedr. und $L$. ocellata var. iberica Se o a ne aufgeführt. ${ }^{1}$ )

Subsp. Stcindachneri mihi ( $L$. oxycephala Schleg., Steindachner, Herpetolog. Notizen II. in: Sitzb. d. mathem. naturw. Cl. LXII. I. Abt. S. 336, 'Taf. I. Fig. 3-6. Wien.? L. oxycephala, Schreiber, op. cit. S. 404, 407. - L. oxycephala var. hispanica Steind, v. Bedriaga in: Bull. de Moscou, No. 3, 1881. S. 82 ; Böttger in: Abhandl. d. Senckenberg. naturf. Gesellsch. XIJ. Bd. S, 371; Boscà in: Bulletin Soc. zool. de France V, pag. 274). - Der stark abgeplattete, in der Wangengegend sehr breite Kopf nimmt von den Augen an rasch nach vorn zu ab; die Schnaze ist sehr stark zugespitzt verschmälert; die vollkommen platte Oberfiache des Kopfes ist sanft von hinten nach vorn abwïlts geneigt, nul spurweise angedeutete IVülbungen treten zuweilen bei alten Männchen über den Augen auf; die vorn fast senkrecht abfallenden Seiten sind an der Grenze der Labial- und Frenaltafeln deutlich vertieft. Der Rumpf ist platt gedruckt, namentlich beim weiblichen Geschlechte. Die Vorderbeine reichen bis zum Vorderrande der Orbitalhöhle, obwohl sie zuweilen hinter dieser Länge etwas zurückbleiben; die Hinterbeine erreichen, an den Körper angelegt, beim Männchen die Achseln, oder reichen auch etwas dariber hinaus; beim Weibchen erreichen sie die Achseln nicht. Der düun auslaufende an seiner Basis breite Schwanz betrigt etwa zwei Drittel der Totallänge, obwohl er diese Länge bisweilen etwas überschreiten, oder auch dahinter zurückbleiben kann. - Subsp. Steindachneri unterscheidet sich von der oxycephala sowohl durch die Beschilderung der Nasofrenalgegend, als auch durch die Bekleidung der Schläfe. Bei oxycephala stehen bekanntlich 2 Nasofrenalia genau übereinander, bei Steindachneri dagegen findet sich hinter dem Nasenloche nur ein solches Schildchen, welches sich nach oben zu ziemlich stark verschmålert. Bei der zuerst. genannten Eidechse sind die Temporalia um ein grofes Scutum massetericum gruppiert, bei der zuletzt erwähnten aber wird dieses vermifit, was bereits von Böttger (l. c.) hervorgehoben worden ist. Auch Schreiber, rer bekanntlich die oxycephala mit unserer Steindachneri vereinigt, gicbt in betreff der Beschildung der Temporalregion folgendes an: »scuto masseterico plerumque nullo» Die Zahl der vorderen Supralabialia ist 4 bis 5 , welch letztere Zahl an die oxycephala aus Dalmatien erimert. Das Occipitale ist trapezförmig und kleiner als das längere als breite Interparietale. Das Collare besteht aus 9 bis 13 sehr kleinen Schildchen. Die kleinen glatten, ziemlich flachen, nur nach hinten zu mit

1) Nicht genügend bekannt sind die dunkelen muralis von Stromboli und von Tinetto bei Splezia, sowie auch die intensiv schwarzrückigen und mit gelbem, schwarz geflecktem Bauch versehenen muralis von der Isola del. Toro' (Sardinien) und die' schwarzen muralis von Linosa. 
einer spurweise emporragenden Spitze versehenen Rumpfschuppen sind linglich hexagonal und fünfeckig mit abgerundeten Ecken, an den Rumpfseiten etwa abgerundet vierseitig und am Nacken rundlich oder rundlich hexagonal. Die Schwanzschuppen tragen sowohl oben als auch unten Kiele, jedoch sind dieselben auf der Unterseite viel schïrfer ausgeprägt, auch sind die unteren Schuppen, mit Ausnahme derjenigen, welche an der Schwanzwurzel liegen, spitz ausgezogen, während die oberen Schuppen hinten gerade abgestutzt erscheinen und nur am Schwanzende in eine kurze Spitze endigen. - Jederseits sind 14 bis 18, meistens aber 17 Schenkeldrüsen vorhanden.

Auf bräunlichweifiem, bleigrauen oder grünliclıgrauem Grunde ziehen sich bei den jungen Stcindachneri meist 5 unterbrochene, schmale schwärzliche Streifen hin; der Jittelrückenstreifen besteht anfangs am Nacken aus 2 äuferst feinen dunklen Linien, welche gegen die Mitte des Rückens zusammenfliefen und einen einzigen Streifen bilden. Dieser Streifen sowohl als auch der 6. und 7., welche an den Bauchgrenzen liegren, stehen in der Intensität der Farbe gegen die übrigen zurück. Die nächst folgenden fangen schon am Aufenrande der Parietalia an und zichen sich teilweise auf den Schwanz hinüber. Das an den Schläfen seinen Ursprung nehmende Streifenpaar wird von den Hinterextremitäten unterbrochen, um schlieflich teilweise in den Schwanz überzugehen. Der Grundton des Oberkörpers, der zwischen den Streifen zu Tage tritt, erscheint ebenfalls in Gestalt von schmalen Binden. In der Halsgegend wird die Grundfürbung heller, in der Schwanzwurzelgegend dagegen etwas dunkler und zeigt eincn suünlichen Ton. Die Kopfdecke ist graugrün, schwarz punktiert. Die Vorder- und Hinterextremitäten haben auf schwarzem Grunde zahlreiche grüngelbe Ocellen. Der Schwanz ist oben metallischgrün quergestreift; die Unterseite des Schwanzes ist grünlich, diejenige des Bauches, Kopfes und der Gliedmaßen kreidervei£. Die von Böttger untersuchten jungen Stücke sind etwas anders gefürbt; sie zeigen »7 schwarze Längsstreifen, deren äufere Zwischenräume von je 2 weißen und deren 2 innere Zwischenräume von 2 olivenbraunen Längsstreifen eingenommen werden. Der obere der beiden seitlichen weißen Längsstreifen zieht über die Seiten der Parietalia und wird hier stets nach innen von einer schwarzen Längsbinde begrenzt.« - Die Alten sind in vielen Fällen im allgemeinen von den Jungen nicht verschieden, nur daks die Zeichnung fast immer weniger scharf, weniger regelmähig und mehr braun ist; in anderen Fällen aber verschwinden die schwarzen Streifen der Rückenmitte entweder vollständig oder sie werden successive von unten nach oben schwächer, und die grüne, olivengrüne oder braune Mittelzone des Rückens wird breiter, die weiben Seitenstreifen aber wandeln sich in weilsgraue, bläulichgiüne oder olivenblaue streifen um und verlieren mit dem Alter an Intensität. 
1) Ko Kopf ist stets mit sehr regelmäbigen, symmetrischen, schwarzen Zeichnungen grefleckt, die Halsseiten sind schwarz gepunktet. $\Lambda$ uf jedem Schilde der äulieren Bauchschilderreihe befindet sich ein schwärzlicher Mittelflecken. Die Bauchseite ist meist einfarbig grünlichweili, bein Weibchen zuweilen rötlich irisierend; die Kopfunterseite beim Mänuchen mitunter schön himmelblau. Nach Steindachner (I. c.) sollen auferdem Weibchen und Männchen sich insofern voneinander unterscheiden als beim ersteren in der Regel 4 bis 6 helle Längsbinden vorkommen, welche zuweilen an den Rändern schwärzlich gesprenkelt oder gesäumt sind, während beim letzteren meisteus 3 schwarze Längsbinden am Rücken und jederseits 2 an den Rumpfseiten vorhanden sind; sdie Binden sind nahezu stets durch sehr kleine, unregelmäligige Zwischenräume schwach und unvollständig unterbrochen.« Die mir vorliegenden ausgewachsenen Stücke sind entweder mit 6 bis 7 dunkelbraunen, auf den Seiten hellgeaugten und ausgezackten Oberrumpfstreifen versehen oder zeigen blok an den Rumpfseiten ein Paar dunkler, schmaler Streifen, welche den einfarbigen oder aber spärlich dunkel punktierten, hellnubbraunen Rücken umsäumen; letztere können übrigens auch gänzlich fehlen. Der weitere Unterschied in der Grundfarbe besteht ferner darin, dafis das Rückenfeld sich jederseits von den Seitenfeldern durch einen schmalen lichten, etwa grünlichweißen Streifen absetzt, was sich, wenn auch um vieles schwächer, noch einmal gegen den unteren Rand des oberen Seitenfeldes wiederholt. Am Nacken sind zuweilen Andeutungen von 3 dunklen Streifen konstatierbar; die Bauchseite bleibt bei diesen, hinsichtlich ihrer Zeichnung und Färbung der muralis fusca sehr ähnlich stehenden Stücken durchweg bläulich oder grünlich und fleckenlos.

Subsp. Steindachneri scheint nur auf der pyrenäischen Halbinsel vorzukommen. Steindachner fand sie in sehr bedeutender Anzahl am Monte Agudo bei Murcia und in der Umgebung von Alicante an felsigen Orten; ebenfalls zahlreich ist sie laut Böttger bei Almeria und Cartagena beobachtet worden. Die für Neu-Kastilien (Navacerrada) und Alt-Kastilien (Basco de Avila) bei Boscà (l. c.) angeführte soxycephala sowie auch die von mir bei Alicante beobachteten und in meinen Herpet. Studien (Archiv f. Naturg. 1879, Bd. I, S. 293) beschriebenen jungen Eidechsen dürften zu Subsp. Steindachneri gehören. Nach meinen und anderer Beobachtungen findet man sie stets in ausgedörrten, unwirtlichen Örtlichkeiten, so in den steinigen Bergen, an sandigen Orten oder im trockenen felsigen Bett eines Baches. Subsp. Steindachneri unterscheidet sich somit auch hinsichtlich ihrer Lebensweise von der auf Korsika lebenden »Bedriagae« sowie auch von der dalmatinischen oxycephala.

Maß3e. - Totallänge: $127 \mathrm{~mm}$; Länge d. Kopfes: $10 \mathrm{~mm}$; des Halses: 5-6 $\mathrm{mm}$; des Rumpfes: $30,5 \mathrm{~mm}$; des Schwanzes: $86 \mathrm{~mm}$; der Vorderextremität: $14 \mathrm{~mm}$; der Hand $\mathrm{m}$. d. 
Fingern: $6 \mathrm{~mm}$, der Hinterextremität $22 \mathrm{~mm}$, des Fußes m. d. Zehen: $11 \mathrm{~mm}$; gröbte Kopfhöhe: $3,3 \mathrm{~mm}$; grüßte Kopfbreite: $6,5 \mathrm{~mm}$; Breite d. Pileus: $4,5 \mathrm{~mm}$; grö̉ster Umfang des Kopfes: $17,7 \mathrm{~mm}$, d. Halses: $18-18,5 \mathrm{~mm}$, des Rumpfes: $23 \mathrm{~mm}$, des Schwanzes an seiner Wurzel: $16 \mathrm{~mm}$, in der Mitte: $6 \mathrm{~mm}$.

\section{Lacerta Danfordi Guinth. 1876.}

Char. - Scutum occipitale interparietali minus. Scutum frontale longum. Nasofrenalia duo, superposita. Supralabialia anteriora 5. Discus palpebralis in margine externo serie granorum limbatus. Sc. parietalia in marginibus scuto oblongo maiore nonnullisque squamis limbata. Tempora squamata, scutum tympanicum; scutum massetericum parvum. Sulcus gularis nullus, collare fere integrum. Scuta abdominalia per series 6 disposita. Squamae dorsi quadrangulares, angulis rotundatis, pone vix carinatae et ante laeves. Pori femorales utrinque 19. Dentes palatini nulli. - Corpus satis gracile; caput pyramidale latius quam altius. Jaris cauda interdum corpore duplo longior, feminae minor. - Longitudo: 144-227 mm.

Synonymie.

Zootoca Danfordi Gunther, Description of an new Species of Lizard from Asia Minor in: Proc. Zool. Soc. of London 1876, pag. 818.

Podarcis Danfordi (Günth.) Camerano, Considerazioni sul Genere Lacerta etc. in: Atti Accad. Sc. di Toring, vol. XIII. 1877.

Lacerta Danfordi (Günth.) v. Bedriaga, Verzeichnis d. Amphibien u. Reptilien VorderAsiens in: Bull. de Hoscou, No. 3 (1879), S. 30. - Boulenger, On the Lizards of the Genera Lacerta and Acanthodactylus in: Proc. Zool. Soc of London 1881, p. 741,743 .

Körpergestalt, Schilder und Schuppen.

Von L. muratis, mit der sie in Hinsicht der Körpergestalt im allgemeinen übereinstimmt, unterscheidet sie sich durch die Beschildung der Nasalregion und stimmt in dieser Beziehung mit $L$. laevis überein; von beiden Arten aber unterscheidet sie sich durch die Rückenschuppen.

Das Weibchen ist von dem Mämmchen schon durch die Körperform ziemlich leicht zu unterscheiden. Der Leib ist bei ihm bedeutend gestreckter, der Bauch mehr aufgetrieben, abgerundeter und dicker, der Kopf platter und schmäler, besonders die Schnauze spitzer zugehend als beim Männchen und auch zugleich etwas spitzer als bei den vorhergehenden Arten. Die Vorderbeine reichen bei beiden Geschlechtern bis zum Frenalschild, die Hinterbeine aber sind 
beim Männchen verhäitnismäkig etwas länger als beim Weibchen, denn bei ersterem reichen sie etwas uiber die Achseln, während sie beim Weibchen die Achseln in der Regel nicht erreichen oder kaum zu berühren pflegen. Der beim Männchen ziemlich dünn auslaufende Schwanz ist lang, das Körpermafs oft mehr als um das Doppelte überschreitend. Das Weibchen Iat einen viel kürzeren Schwanz als das Männchen. Der rom Kopfe durch eine schwach ausgeprägte Finschnürung gesonderte Hals ist bei beiden Geschlechtern breiter als der Kopf.

Approximative Mafe:

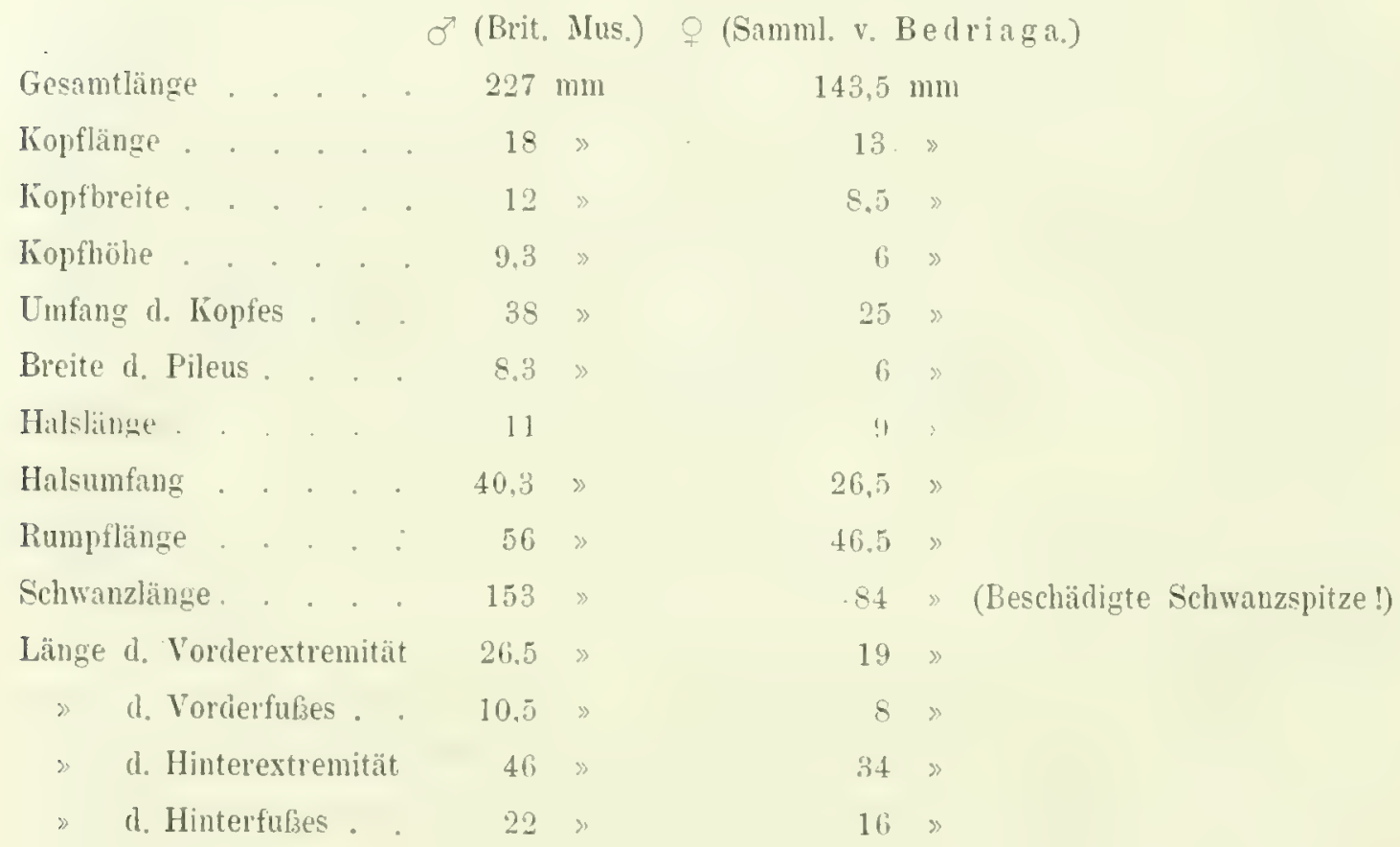

Schilder und Schuppen der Kopfseiten sind wie bei L. laevis, nur mit dem Unterschiede, daß3 das ron körnerartigen, leicht gewölbten, polygonalen und hexagonalen Schuppen umgebene Massetericum bedeutend kleiner erscheint. Zwischen dem kleinen, seitlich liegenden Nasenloche und dem Augenwinkel sind 4 Schider: 2 winzig kleine ïbereinanderstehende und dem Supralabiale I aufliegende Nasofrenalia, welche zur hinteren Begrenzung des Nasenlochs dienen, 1 vierseitiges, vorn abgerundetes, wahezu ebenso hohes als breites Frenale und 1 bedeutend grölieres Freno-oculare, das länger als hoch ist und das rom oben erweiterten Suboculare durch ein längliches, schmales Praeoculare getrennt wird. Die Zahl der vorderen Supralabialen schwankt zwischen 4 und 5 (nach Günther!). An das Suboculare schliefen sich nach rückwärts zu noch 2 kleinere Supralabialia posteriora an. Das schmale, gebogene Tympanale ist nach hinten zu ron körnerartigen, wenig sichtbaren Schuppen umsäumt. Die Parietalen, die 
bedeutend länger als breit sind, werden am Aulienrande nur vorn von einer linglichen schmalen Tafel begrenzt; der lintere Parietalrand ist ziemlich gerade abgestutzt; nach innen zu zeigt jede Parietaltafel 3, unter stumpfem Winkel zusammenstoßende Kanten. Was die Bekleidung der Lopfoberfläche anbetrifft, so zeigt L. Danfordi mehr Ähnlichkeit mit der muralis als mit L. lacris. Vor allem fällt uns das kleine Occipitale auf, das etwa halb so lang und in der Regel schmäler ist als das vorn erweiterte, hinten verschmälerte fünfseitige Interparietale; daf das Occipitale bei laevis eine bedeutende Ausdehnung sowohl in der Breite als Länge zeigt und dafs das Interparietale im Vergleich zu dieser Tafel als ein unansehnliches Schildchen erscheint, werde ich im nächsten Kapitel erwähnen. Sowohl die paarig angeordneten Frontoparietalia und Frontonasalia als auch die Supraorbitaltafeln zeichnen sich durch ihre geringe Längenentwickelung aus und sind nahezu ebenso breit und sogar breiter als sie lang sind. Zwischen den länglichen, schmalen 6-T Supraciliaria und dem ziemlich flachen (ס) oder ganz Hachen () Discus palpebralis sind äuberst kleine, reihenweise angeordnete Kornschuppen eingeschoben. Das mäßig lange Stirnschild ist rorn abgerundet, seitlich leicht ausgerandet und am hinteren etwas verschmälerten Teile mit gerade abgestutzter Hinterseite oder mit äußserst stumpfem, fast undeutlichem Hinterwinkel versehen. Das ziemlich gewölbte Rostrale ist mit seinem spitzen Hinterende z. T. zwischen die äußerst kleinen, in der Mittellinie zusammenstofienden und das Rüsselschild rom etwa rhombischen Iutermasale trennenden Intermasalia eingekeilt. Das mir vorliegende Exemplar der Danfordi besitzt 6 Sublabialia, ein ziemlich langes Mentale und 5 Paar Submaxillaria, wovon die 3 vordersten Paare zusammenstoken und das rorletzte Par das gröbte ist. Die Kehlfurche ist nur durch eine transversale Reihe kileinel Schuppen, welche die mehr länglichen liehlschuppen von den breiteren Halsschuppen trennt, angedeutet. Das aus 11 Tafeln bestehende Halsband ist ganzrandig; bei näherer Betrachtung erscheinen allerdings die freieu Hinterränder der Tafeln etwas abgerundet zu sein, jedoch kann dieses nicht in Betracht gezogen werden. Die Rückenschuppen zeigen nur gegen die Schwanzwurzel zu äuf̉erst schwach ausgeprägte Kiele, sonst sind sie glatt, gewölbt und namentlich nach hinten zu an ihrem Hinterrande ziemlich stark emporgehoben. Am Nacken erscheinen die Schuppen etwa rundlich hexagonal, an Rücken hingegen rund vierseitig und nach hinten zu etwas breiter als lang und endlich gegen die Rüickenseiten zu rhombenförmig; etria 2 bis 3 Querreihen entsprechen der Länge eines.Bauchschildes. Die Zahl der longitudinalen dorsalen Schuppen wechselt zwischen 120 und 125. die Zahl der Querreihen beträgt gewöhnlich 54. Die in etwa 31 Quer- und 6 Längsreihen angeordneten Bauchtafeln sind an den Rumpfseiten von ziemlich großen Randschildchen begrenzt; das Brustdreieck besteht aus $\tau$ 
his 11 Schildchen. Das Sc, anale, das mit Ausnahme des freien Hinterrandes rund herum von 2 Bogenreihen kleiner Tafeln umgeben ist, soll mitunter in zwei Tafeln geteilt auftreten (Günther). Die oberwärts deutlich dachartig gekielten Schwanzschuppen sind fast gerade abgestutzt; die unteren, nur hinten schwach gekielten Caudalschuppen sind vorn an ihrem Hinterende abgerundet, hinten etwas stumpf- oder sogar spitzwinkelig ausgezogen.

Schenkeldrüsen und Zähne. - Die Anzahl der Schenkeldrüsen beträgt gewöhnlich gegen 19-19. - Zähne in den Kinnladen, im Gaumen keine.

Färbung und Zeichnung.

Die Farbe der Oberseite ist hellnulabraun oder ein Gemisch von Olivengrün und Braun; mehrere Schuppen sind dunkelbraun oder fast ganz schwarz und auf dem Rücken zu gröberen schürkelartigen Flecken oder kurzen zezackten Querbinden zusammengestellt. Ähnliche dunkelgefärbte Schuppen sieht man auch auf den Rumpfseiten und auf den Beinen, wo sie ebenfalls in Flecken vereinigt sind; durch ihre teilweise Verbindung entstehen viele krumm gezackte und manuigfaltig zusammenlaufende Linien oder Kreise, wodurch eine marmorierte oder genetzte Zeichnumg grehildet wird; hesonders lleutlich tritt sie bei den Mïnnchen hervor; mitunter gesellen sich dieser Zeichnung auch noch weife Punkte hinzu. Die Oberseite des Kopfes, des Schwanzes und der Schwanzseiten ist mit dunkelbraunen Punktflecken spärlich versehen. Dic Unterseite sïmtlicher Körp̣erteile, mit Ausnahme der gelblich gefürbten Praeanalgegend, ist grünlich mit, wie es scheint, stets am Unterkopf und an der Vorderbrust zerstreuten, dunklen Punktfleckchen. Die Kopfseiten sind dunkelbraun auf hellgrünbraunem Grunde gefleckt; die äub̉ersten Bauchschilder haben auferdem einen gräulichen oder bräunlichen Antlug. Obschon L. Danfordi in betreff der Färbung und Zeichnung der laevis ähnlich sieht, ist letztere dennoch schon an ihrer ungefleckten Kehle und an den neben den Ohröffnungen beginnenden und auf die Rumpiseiten sich fortsetzenden (dunkelbraunen Binden gat $2 u$ unterscheiden ${ }^{1}$ ). Die jungen Tiere sollen schwarz genetzt sein (Günther).

Vorkommen.

Zebil Bulghar Dagh (Cilicischer Taurus) in einer Höhe von 4000 Fuß über dem Neere.

1) Nachträgl. Zusatz. - Da man kürzlich versucht hat $L$. Danfordi mit $L$. graeca zu vereinigen, so will ich hierselbst auf die Hauptunterschiede, welche ich zwischen de m mir vorliegenden Exemplar von $L$. Danfordi und den graeca gefunden zu haben glaube, binweisen: L. Danfordi. Kopf pyramidal, Rumpf nahezu walzenförmig. Occipitale kleiner als das Interparietale, Massetericum vorhanden; gewölbte, gegen den Schwanz hin gekielte Rumpfschupnen. 19 Schenkeldrüsen. L. graeca. Kopf und Rumpf abgeplattet. Occipitale größer als das Interparietale, Massetericum fehlend; ziemlich flache, gegen den Schwanz hin schwach eingedrückte Rumpfschuppen. 22-24 Schenkeldrüsen. 


\section{Lacerta laevis Gray 1838.}

Char. - Sc. occipitale maximum, scuto interparietali multum latius longiusque, scuto frontali lougo latius. Sc. nasofrenalia duo, superposita. Discus palpebralis a scutis supraciliaribus squamis seiunctus. Scuta parietalia in margine externo scuto oblongo maiore nonnullisque squamis limbata. Tempora squamata. Sc. massetericum maximum, sc. tympanicum. Supralabialia anteriora 5. Sulcus gularis interdum distinctus. Collare fere integrum. Sc. abdominalia per series 6 disposita. Squamae dorsi oblongo sexangulares, angulis rotundatis, vel ovatae, vix carinatae. Dentes palatini. Pori femorales utrinque 18-20. - Caput pyramidale, elongatum. Corpus satis robustum, latum, paulo depressum; pedes postici robusti, axillas superantes. Cauda longissima. - Longitudo: 168-230 $\mathrm{mm}$.

Synonymie.

Lacerta laevis Gray, in: Ann. Nat. Hist. 1838. I, pag. 279; Cat. Liz. Brit. Mus. pag. 31. London 1845. - Günther, in: Proc. zool. Soc. of London 1864, p. 488. - Boulenger, in: Proc. zool. Soc. of London 1881, p. 742.

Lac. mualis var. judaica Müller in: Verhandl, naturforsch. Gesellsch. Basel 1881.

Podarcis judaica Camerano, Considerazioni sul Genere Lacerta Linn. etc. in: Atti I. Accad. Scienze di Torino XIII, 1879. Tab. II. Fig. 2, 5.

Lacerta judaica (Cam), r. Bedriaga, in: Archiv f. Naturg. 1879, Bd. I. S. 270; Bull. de Moscou 1880, No. 3, S. 30. - Böttger, Rept. u. Amphibien von Syrien, Palästina und Cypern in: Jahresbericht d. Senckenberg, naturforsch, Gesellsch. 1879-80. Frankf. a. M.

Die ersten Exemplare dieser Species, die nach Europa kamen, waren diejenigen, welche von Gray zur Aufstellung der Art »laevis« benutzt worden sind. Da diese Exemplare sich im British Museum befinden und dem Publikum weniger zugånglich sind, so gerieth alsbald die Graysche Eidechse beinahe in Vergessenheit und tauchte nur selten als Synonym mit irgend einer anderen Art auf bis es nun endlich Boulenger gelang, sie der Vergessenheit zu entreißen und zugleich mit einer inzwischen kreierten Species sjudaica Camer.«zu identifizieren.

Körpergestalt und Ma ảe.

Obschon die laevis der Mauereidechse recht nahe steht, so kann sie, meiner Ansicht nach, dennoch nicht als eine Abart von Lacerta muralis gelten ${ }^{1}$ ), denn sie zeigt mehrere Charaktere,

1) Vergl. F. Müllers »I. Nachtrag z. Katalog d. herpetolog. Sammlung d. Basl. Mus, in: Verhandl. d. naturforsch. Gesellsch, in Basel 1881, wo sie als »muralis var. judaica Cameranos angeführt worden ist. 


\section{$-248-$}

welche sich durch ihre Konstanz auszeichnen. Die Kopfform ist im allgemeinen ähnlich wie bei muralis ncapolitana, nur ist der Hals bei letzterer meistens schmäler als der Kopfumfang, während bei laevis $\sigma^{7}$, ähnlich wie bei muratis Lilfordi $\sigma^{7}$, der Umfang des Kopfes, jenem des Halses nachsteht; auch ist der Breiten- und Höhendurchmesser des Kopfes bei laevis bedentend größcr als dies bei neapolitana der Fall ist. In der Scheitelgegend erscheint der Kopf am breitesten; in der Frenalgegend nimmt der Breiten- und Höhendurchmesser merklich ab. Dadurch, daf der Palpebraldiscus, namentlich bei den Weibchen, beiderseits sehr stark erhoben ist, kommen die Frontonasalen und das Frontale tief zu liegen. Die Schnauze ist mäßig zugespitzt. Die Nasenlöcher sind bei der Betrachtung des Kopfes von oben gut sichtbar, d. h. sie erscheinen etwas nach oben gerückt. Die Augen sind sehr grof. Mit Bezug auf die Gestalt des Rumpfes sieht laevis eher der oxycephala oder der Bedriagae ähnlich; der Rumpf erscheint nämlich abgeplattet und breit; die Entfernung der einen freien Rippenspitze von der ihr entgegengesetzten miß̧t 16,5 bis $20 \mathrm{~mm}$ und sogar darüber bei Exemplaren, deren Totallänge 191 und $230 \mathrm{~mm}$ beträgt. Der am Anfang, besonders beim Männchen, sehr verdickte lange Schwanz ist bei einem $191 \mathrm{~mm}$ langen Exemplar $9 \mathrm{~mm}$ breit. Die Beine sind Eräftig entwickelt, die vorderen erreichen die Vorderkanten der Freno-ocularia, die hinteren ragen über die Achseln binaus. Die Kehle zeigt stark ausgeprägte Falten, die beim Männchen auch auf den Seiten wahrnehmbar sind.

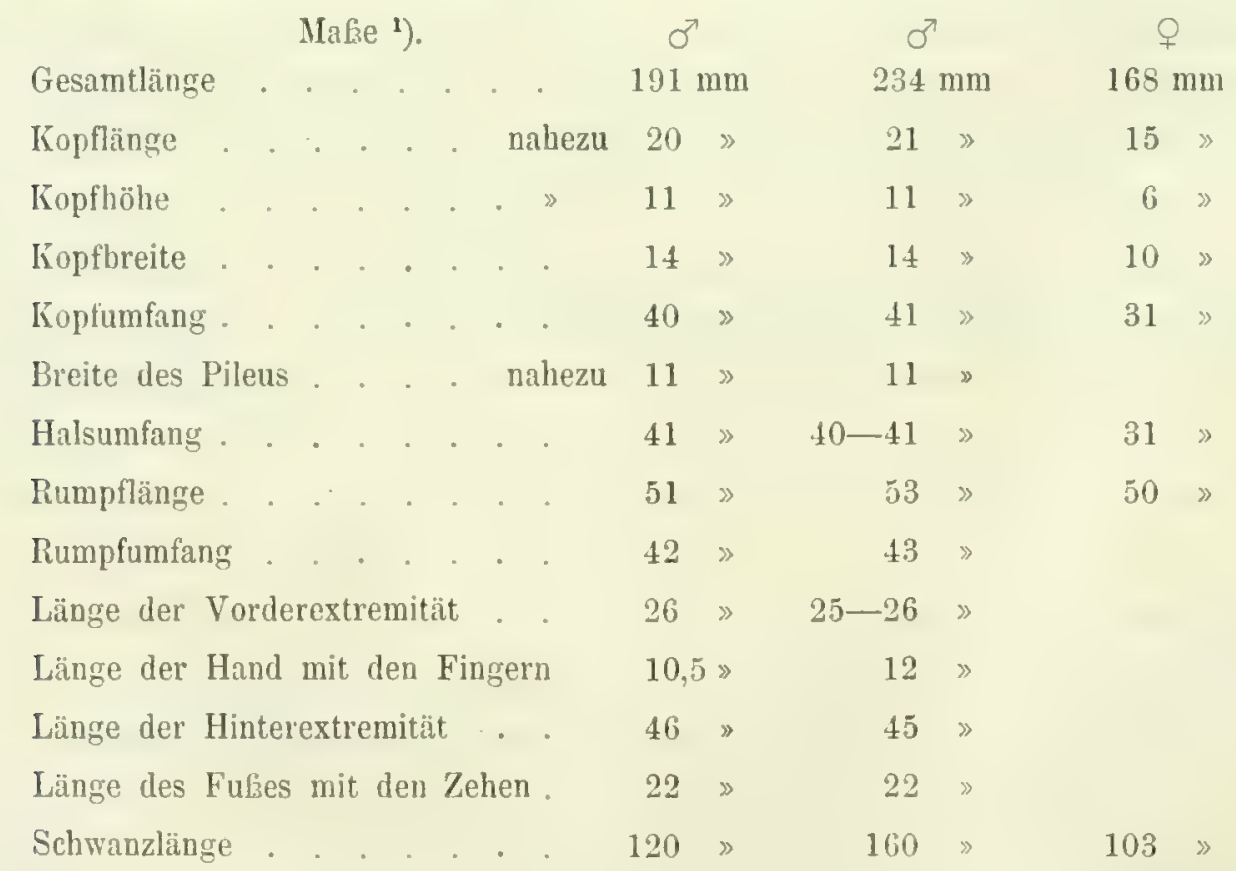

1) Das erste Stück gehört dem Züricher Museum, das zwreite und dritte meiner Sammlung an. 
Schilder und Schuppen (Vergl. meine Taf. Fig. 18 und 22).

Das Occipitale ist auffallend grok3, meistenteils bedeutend länger und breiter als das daror liegende fünfeckige Interparietale; es ist trapezförmig oder tribuguliu mit abgerundeten Ecken und leicht bogenfürmigg gelirummten seitlichen Rändern. Die großen Parietalia sind gewölbt und biegen sich zum Teil nach unten, d. h. auf die Schläfenregion über; nach außsen vorn sind sic von dolchfürwigen Schildern begrenzt, dagegen nach rückwärts legen sich ihnen die Temporalia direkt an. Die Frontoparietalia erscheinen an ihren hinteren seitlichen Kanten ausgerandet und schieben sich mit ihren ziemlich spitz ausgezogenen Hinterenden zwischen das Interparietale und die Parietalia ein. Letztere werden von den größeren, hinten abgestutzten Supraocularia durch vier- oder dreieckige Plättchen getrennt. Die am Aufsenrande durch eine Reihe feiner Körnerschuppen vollkommen gesiumte Palpebralscheibe ist sehr stark gewölbt. Das grolje in seiner Mediaulinie dentlich gefurchte Stirnschild endet vorn in einer abgerundeten stumpf ausgezogenen Spitze; zu beiden Seiten dieses Vorsprungs sind die an die Frontonasalia anstoßenden Kanten ausgerandet; die Seitenränder erscheinen gleichfalls leicht eingebogen. Die Frontonasalia zeigen bei nïherer Betrachtung vorn und hinten wellig gebogene Ränder; dagegen nehmen diejenigen Ränder, welche aneinander stoßen und an die Frenoocularia grenzen, einen geraden Verlauf. Dis Internasale ist grol, vorn abgerundet. Das Rostrale und die Supranasalia sind verhältnismälijig schwach entwickelt. Sämtliche Schilder des Pileus sind gewölbt und durch sehr tiefe Furchen voneinander getrennt; auch sind an denselben, und namentlich bei den alten Männchen zahlreiche Vertiefungen und Erhabenheiten wahrnehmbar. Die Beschilderung der Kopfseiten, namentlich der Schläfe und der Frenolabialgegend weist die hauptsüchlichsten specifischen Merkmale auf. Besonders hervorheben will ich, daf in allen untersuchten Fällen, selbst auch bei den jungen Stücken, sich ein auffallend großes, ovales, oder geniuer gesagt, vielliantiges Massetericum abgrenzte; dasselbe liegt in der Nähe der Parietalia und ist von zahlreichen, kleinen, meistens oval-hexagonalen Schildchen umgeben. Der vordere obere Rand der relativ kleinen Ohröffnung wird von einem länglichen stark gebogenen Tympanicum begrenzt. In betreff der Frenolabialregion ist anzugeben, daß dieselbe 2 übereinanderstehende Nasofrenalia zeigt, von denen das untere und grölite unten breiter als oben und etwa trapezförmig gestaltet ist. Das Rüsselschild nimmt an der Umrandung der Nasenöffnung teil. Die stets koustante Fünfzabl der Supralabialia anteriora ist gleichfalls ein gewichtiges Kennzeichen für die zlucris", denn ; Oberlippenschilder kommen nur ausnahmsweise bei der muralis vor. Auf die vorderen Supralabialia folgen nun das grofe, oben sehr breite, unten verschmälerte Suboculare und 1 bis 2 kleinere Supralabialia posteriora. 
An den hintcren iuliersten Rand des Suboculare legen sich 2 Reihen, den hinteren Augenhöhlenrand umsäumende, nach oben immer kleiner werdende Schildchen an, von denen die gröberen unteren als Postocularia angesehen werden können. Vorn legt sich an das nämliche Schild ein unteres Praeoculare an, das von einem zweiten zwischen dem Auge und dem Frenooculare eingeschoben ist. Der obere Augenrand wird von einem ansehnlichen, vorn breiten, linten verschmälerten Supraciliare und von etlichen schmalen, lïnglichen Schildchen umgeben. Das über dem Supralabiale IV stehende Freno-oculare hat eine dreifach ausgerandete Hinterkante. Endlich schiebt sich das oben relativ schmale, vorn mit bogig gekrümmtem Rande versehene Frenale mit seiner hinteren, in cine Spitze ausgezogenen Partie zwischen das Frenooculare und das dritte Supralabiale ein. Es sind 6 bis 7 relativ hohe Sublabialia und 5 Submaxillaria vorhanden. Auf das fünfte Unterkieferschilderpaar folgen nun jederseits 4 oder 5 sechseckige längliche Schilder. Die Kehle ist vorn von sechsseitigen Schuppen bekleidet, die länger als breit sind; hinten hingegen sind die Schuppen bedeutend breiter aber weniger lang. Der Sulcus gularis ist mitunter deutlich ausgeprägt. 7, 8 oder 9 Tafeln konstituieren das ganzrandige Halsband.

Das Brustdreieck ist vorbanden. 24 Quer- und 6 Längsserien von Tafeln und jederseits eine aus kleinen Schildchen bestehende Pseudogastrostegal-Reihe bekleiden den Bauch. Die mittleren und äufiseren Reihen werden von den kleinsten Schildern gebildet. Abwechselnd 2 und 3 Querschuppenreihen gehen auf die Länge cines Canchschildes. Bei oberflïchlicher Betrachtung scheinen die Rückenschuppen glatt und sechseckig zu sein. Bedient man sich aber der Lupe, so nimmt man alsbald wahr, daf die Schuppen rundlich oder oval sind, daßs sie deutlich ausgeprägte Kiele tragen und endlich, dats sie zwischen sich mikroskopisch-kleine Schüppchen einschliefen, welche dazu beitragen, dafs die Rückenschuppen, mit unbewaffnetem Auge gesehen, hexagonal erscheinen. Gray, welcher bekanntlich behauptet, daf die laevis »dorsal scales roundish, 6-sided, convex « aufweist, hatte mutmaflich die Lupe nicht in der Hand gehabt. Dieser Umstand war wohl der Hauptgrund, weshalb man längere Zeit hindurch nicht mußte, was die slurvisu eigentlich vorstellen sollte. Die approximative Zahl der longitudiualen dorsalen Schuppenreihen ist 55, diejenige der transversalen, regelmäfig angeordneten Serien ist 123. Die Schwanzschuppen sind an ihren freien Kanten meistens abgerundet, selten abgestutzt und mit ziemlich stumpfen Kielen versehen. Wenn auch die Seitenränder dieser Schuppen keinen ganz geraden Verlauf nehmen, so sind die Schuppen dennoch überall ziemlich gleich breit, was ich herrorhchen möchte, denn gewöhnich sind bei den, der laevis nahe verwandten Arten die Schuppen am freien Rande hreiter als an den angewachsenen Kanten. Ich zähle $92-100$ Schwanzringel. Das 
sehr grofe Anale scheint, weil es an seinen Riudern vorn und seitlich von 7 bis 8 grölieren, länglichen, etwa sechsseitigen Schildchen zum 'Teil verdeckt ist, fünfeckig zu sein.

Schenkeldrïsen und Zähne.

Die Zahl der Schenkeldrüsen wechselt zwischen 18-18 und 20-20. Nach Böttger kann die Zahl sich bis auf 22 steigern. - In Oberkiefer sitzen jederseits 17 stumpfe, zweispitzige Zähne; im Zwischenkiefer 7 einfache, gebogene und im Unterkiefer im ganzen 44 stumpfe, zweispitzige Zühne. Der Gaumen ist bezahnt.

Färbung und Zeichnung.

Die Grundfarbe des Oberkörpers ist dunkel- oder hellbraun. Die mediane Rückenregion erscheint höchst selten dunkelbraun oder schwarz gespritzt. Auf den Seiten befinden sich breite, braune Binden, welche stets dunkler siud, als die fundamentale Farbe; sie nehmen ihren Ursprung am hinteren Ohrrande und verlieren sich in der Schwanzgegend. Eine größere Anzahl kleiner, weißlicher Augenflecken zieren diese Binden und verleihen dem Tierchen ein reizendes Aussehen, besonders entwickelt und zahlreich kommen sie bei den Männchen vor. Der oben braune Schwanz ist öfters dunkelbraun punktiert. Die Kopfdecke und Seiten sind braun, selten dunkelbraun gefleckt. Die Kehle erscheint blau, die Unterseite der Extremitäten und die Bauchseite sind bläulich-weif. Blüuliche schwarzumrandete Ocelli zieren die ersten longitudinalen Ventralschilderreihen. Die Seiten des Schwanzes sind unten blaugrau. Die Unterseite des Schwanzes ist weiblich. Das mir zu Gebote stehende Weibchen ist weniger schön gezeichnet. Die am Auge jederseits beginnenden, dunkelbraunen, ausgezackten und vorn gelbweis eingefaliten Seitenbinden sind sehr spärlich gelblichweif punktiert. Gegen die Bauchgrenze hin findet sich jederseits noch eine, der ersten parallel laufende, aber weniger deutlich ausgeprägte graubraune, von weißlichen Ocellen unterbrochene Lüngsbinde. Die im Berliner Museum aufgestellten Exemplare aus Jerusalem (No. 6563) zeichnen sich dadurch aus, daf ihre Bauchteile einen schönen Perhmutterglinz, ihre Kehle, Cnterseite der Extremitiiten und die Schwanzwurzel einen grünen Anflug haben. Auch spielt das Braun des Kopfes und des Nackens bei diesen Individuen ins Grüne über. Einige $L$. laevis von Beyrut im Senckenbergischen Museum sollen nach Böttger (1. c.) höchst elegant koloriert sein; sie sind nämlich oben einfarbig hell spangrün mit tiefschwarzer, hellumrandeter Längsbinde an den Seiten versehen. "Andere der zahlreich von Beyrut vorliegenden Exemplare«, fügt Böttger hinzu, »sind auf dem Rücken grau, oft mit einem Stich ins Kupferrote, einfarbig oder verloschen schwarz gepunktet oder gefleckt. Das dunkle Seitenband ist aber allen vorliegenden Stücken gemeinsam.« 
Habitat.

Mlan kennt diese Art aus Syrien, wo sie in Beyrut und auf dem Libanongebirge (Mus. in Turin) gefangen wurde, von Jerusalem (Senckenberg. und Berl. Mus.), vom Toten Meere (Brit. Mus.) und von der Insel Cypern (Mus. in Turin, nach Camerano!). Der angebliche Fundort »Ägypten« im Züricher Museum (c. đ. 577. t.) für di̊ laevis dürfte vorläufig noch bis auf weitere speciellere Bestïtigung hier zu beanstanden sein. Auch das Original-Exemplar in British .Museum ist sonderbarerweise mit der sicht glaubwirdigen Fundortsangabe $\cdots$ Europe* bedacht worden. Die sub No. 6563 im Berliner Museum aufgestellten, aus der Petermannschen Ausbeute stammenden Jerusalemer Exemplare sind lichtig etikettiert; dasjenige Stüch »sine patria« aber, das in der Büchse No. 1008 sich befindet ist sonderbarerweise als »L. muralis Merr.« benannt. Die Büchsen 1009,1010 und 1030 enthalten ebenfalls laevis unter falschen Namen. Die von mir in dem Wiener Hofnaturalienkabinett untersuchten Stücke sind von Fitzingers Hand als »Podarcis syriaca — also wiederum ein Museal-Name, der vielleicht älteren Datums ist als derjenige von Gray - bezeichnet.

\section{Lacerta Brandti De Filippi. 1863.}

Char. - Scutum occipitale interparietali minus. Sc. frontale longum. Scuta nasofrenalia duo, superposita. Discus palpebralis in margine externo serie granorum limbatus. Supralabialia anteriora 5. Sc. parietalia in margine externo tribus scutellis maioribus limbata. Tempora squamata. Sc. massetericum satis longum, sc. tympanicum. Sulcus gularis distinctus. Collare integrum. Scuta abdominalia per series 8 disposita. Squama dorsi granosae, vis carinatae vel laeves. Dentes palatini. Pori femorales utrimque 19. - Caput pyramidale, paulo latius quam altus. Corpus gracile. Pedes postici axillas fere attingentes. Cauda mediocriter longa, semper corporis longitudinem superans. - Longitudo: $147 \mathrm{~mm}$.

Synonymie.

Lacerta Brandtii De Filippi, in: Arch. per la Zoologia, l'Anatomia e la Fisiologia II. p. 387. Modena 1863; Note di un viaggio in Persia nel 1862, p. 353. Milano 1865. Blanford, The Zoology and Geology in: Eastern Persia, vol. II. p. 362, pl. XX, fig. 1. - - Bedriaga in: Bull. de Moscou 1879, No. 3, S. 29. - Camerano Considerazioni sul Genere Lacerta Linn. etc. in: Atti Accad. Sc. di Torino, vol. XIII. 1877. Boulenger in: Proc. Zool. Soc. Lond. 1881, pag. 743. 
Körpergestalt und Maßse.

Bringt man bei dieser Eidechse die Profillinien und die Zahl der Bauchschilderreihen, der Nasofrenalia und der vorderen Supralabialia nicht in Anschlag, so unterscheidet sic sich nur in geringem Mafse von der muralis. Die Brandti ist nämlich von sehr schlanker, gestreckter Gestalt; der ziemlich kurze Kopf ist nach vorn allmählich verschmälert. Diejenige Linie, welche von den äufseren Parietalrändern anfangend, sich zu den Supraciliaren und von da zu den Nasenlöchern binzieht und als Profillinie bezeichnet werden könnte, senkt sich nach vorn zu bogenförmig und, da kein winklig erhobener oder auch nur äuferst schwach gewölbter Discus palpebralis vorhanden ist, ohne Unterbrechungen. Canthus rostralis abgerundet. Der Rumpf erscheint oben leicht abgeplattet und um etwas länger als es bei der muralis der Fall ist; er mifst bei dem von mir untersuchten Original-Individuum volle $53 \mathrm{~mm}$. Die Vorderbeine reichen bis zu den Nasenöffnungen, die hinteren beinahe bis zu den Achseln. Der Schwanz ist mäßig laug.

Maße des Originalexemplares aus dem Turiner Museum: Gesamtlänge $147 \mathrm{~mm}$; Kopflänge 13,7; Kopfbreite 8; Konfhöhe 7 ; Rumpflänge 53 ; Schwanzlänge 80 (regren. Schwanz!); Umfang des Kopfes 25,5-26, des Halses 26; Länge der Vorderextremität 22, der Hinterextremität $26 \mathrm{~mm}$.

Schenkelporen und Zähne.

Schenkelporenzahl: 19-19. Zwischenkieferzähne: 7; 18-20 Oberkieferzähne jederseits; Unterkieferzähne im ganzen: 40. Letztere scheinen mir zweispitzig zu sein. Der Gaumen ist bezahnt.

\section{Schilder und Schuppen.}

Das nach oben schwach übergewölbte Rostrale ist lilein, breiter als lang. Die gleichfalls unansehnlichen Supramasaltafeln treten wur auf eine sehr kurze Strecke in Kontakt; seitlich unten sind sie durch die stark auf die Kopfseiten gerückten Nasenlöcher nach einwärts stark gebuchtet. Mit Bezug auf seine Gestalt zeigt das Zwischennasenschild gerade das Gegenteil dessen, was wir sonst bei $L$. murulis gesehen haben: es crscheint nümlich vorn etwa dreieckig ausgezogen, hinten aber abgerundet; seine seitlichen Kanten stofien jederseits an das kleine trapezförmige Frenale. Den Raum zwischen dem zuletzt genannten Schilde und dem Nasenloche nehmen jederseits 2 übereinander stehende Nasofrenalia ein. Die Frontonasalia sind beinahe ebenso breit wie lang. Die grolie Frontalplatte ist mit Bezug auf ihre Konturen ähnlich wie die bei der Mauereidechse; die Frontoparietalia weisen ebenfalls nichts Nennenswertes auf. 
Die fünfseitigen Parietalia schlielæen zwischen sich das länglich-fünfeckige Interparietale, das vorn breiter als hinten ist, und das kleine trapezförmige Occipitale ein; seitlich stofien an die l'arietalia 3 , bereits in der Temporalregion sich befindliche, ziemlich breite Plättchen, von deneu das nach vorn liegende, die Supraciliarreihe berührende, das läugste ist. Das zweite und dritte Supraculare werden äulierlich von mehreren mikroskopisch kleinen Schupyen umsäumt und auf diese Weise von den Oberciliarschildchen getrennt. Längliche hexagonale und pentagonale Schuppen bekleiden die Schläfe; in deren Mitte liegt ein gröberes, etwa achthantiges Schild (Sc. massetericum); der obere vordere Ohrrand wird von einem länglichen, bohnenförmigen Tympanicun eingenommen. Ähnlich wie es bei L. luexis Gray und bei $L$. depressa C a mer. der Fall ist, sind auch hier 5 vordere Supralabialia, worauf dann ein breites nach vorn und oben zu ziemlich stark ausgezogenes Subocularschild folgt, an das sich endlich 3, nach hinten kleiner werdende Supralabialia posteriora anfügen. Jedes Zugelschildchen grenzt zugleich an 2 Oberlippenschilder, so z. B. kommt das untere Nasofrenale zum T'eil mit dem ersten, z. T. mit dem zweiten Supralabiale in Berührung; das Frenale stützt sich auf das zweite und dritte, das Freno-oculare stöft an das dritte und vierte und endlich das längliche schmale Praeoculare grenzt an das vierte und fünfte Supralabiale. Es sind 7 Sublabialia und 5 Submaxillaria auf jeder Seite. Die Kehle ist vorn von ovalo-hexagonalen, hinten von verhältnismäkig breiteren Schuppen bekleidet; die Kehlfurche ist sehr deutlich; dis ganzranlige Halsband aus 9, meistens trapezförmigen Schildern gebildet; die sogenannte Plica gularis ist vorhanden. Das Brustdreieck wird aus etwa 14-17 Tafeln gebildet. Die Ventralen sind in 8 Längs- und 29-31 Querreihen angeordnet; auferdem kommen noch seitliche, den äußersten Serien anliegende kleine Schildchen, die sogenannten Pseudogastrostega hiwzu. Die Analregion zeigt ein gröferes, vorn und seitlich von 6-8 Schildchen umgebenes Anale. Die Rückenschuppen sind klein, rund und konvex; deutlich ausgeprägte Kiele hahe ich nicht entdecken können. Es stoben drei Schuppen an jedes Banchschild; 135 Quer- und etwa 51 Längsschuppenreihen. Gegen die Flanken hin werden die Schuppen etwas gröber und büfen ihre regelmiigige Gestalt ein; gegen den Schwanz erscheinen dieselben eher oval als rund und gehen allmählich in längliche, hinten gerade abgestutzte, oder stumpfwinklig endende dachförmig gekielte Caudalschuppen über; die unteren Schwanzschuppen sind ziemlich flach.

Färbung und Zeichnung.

Die Farbe des mir vorliegenden Originalstückes der Brandti ist auf dem Rücken grünlichgrau, auf dem Kopf olivengrün. Auf jeder Körperseite befinden sich 2, stellenweise unterbrochene, d. b. in runde Fleckchen sich auflösende weifliche Binden, von denen die höher- 
liegenden in gleicher Höhe mit dem seitlichen Rande der Parietalia beginnt, während die untere an der Unterseite des hinteren Ohrandes ihren Ursprung hat. Diese hellen Binden erscheinen nun von feinen, schwarzen, etwa haken- oder deltaförmigen Flecken - gegen die Flanken zu nur von Punkten - begleitet. Das der Vertebrallinie zunächst liegende, eben erwähnte Fleckenpaar geht auch auf den hintersten Rumpfteil, also auf die Schwanzwurzel über. Die Schwanzoberfliche ist einfarbig grünlich-grau; die unterste helle Rumpfbinde setzt sich an den Schwanzseiten fort und wird hier von kurzen, feinen, strichartigen dunklen Flecken begrenzt. Dic Oberseite der Extremitäten, namentlich der vorderen - zeigt zahlreiche graubraune, wellenförmige, schwach ausgeprägte Streifen, die sich zu einem Netzwerk vereinigen, welches kleine Maschen der bläulich grauen Grundfarbe übriçlïst; aulierdem sind spärlich zerstreute, schwarze Punkte sichtbar. Hinter den Schultern befinden sich blaue Augenflecken. Die Pileustafeln sind spärlich dunkel gepunktet; die Schlife zeigen etliche schwarze und weisliche Flecken; die übrigen seitlichen Kopfschilder - mit Ausnalme des dunkel gepunkteten Freno-oculare - sind fleckenlos. Die Farbe des Banches, wie der Unterseite der Extremitäten und des Schwanzes ist mattglänzend weif; die erste Longitulinalreihe der Ventralen ist blüulich mit schwarzen Flecken geziert; die übrigen Tafeln - mit Ausnahme des medianen schmäleren Paares - haben an ihren seitlichen Kanten schwarze Säume. Supramaxillaria, Kehle, Halsband sind weils mit einem Stich ins Gelbe.

Das eben beschriebene, von De Filippi im Jahre 1862 yon seiner Reise nach Persien mitgebrachte Stück der Brandti mag wohl ein leicht verblichenes sein, denn die leider sonst beschädigten und für eine eingehende Beschreibung untauglichen Exemplare aus meiner Sammlung sind bedeutend dunkler koloriert und sehen mit Rücksicht auf die Farbenauswahl als auch Farbenverteilung der Mauereidechse und zwar der fusca täuschend ähnlich. Die ganze Oberseite des Rumpfes bis gregen die Bauchtafeln, ebenso der Kopf bis an die Oberlippenschilder, ist nuß3- oder olivenbraun. Vom Hinterteile des Parietale, und zwar an dessen Seitenrande, entepringt jederseits eine helle, grünlich-weilie, beiderscits durch schwarze Zeichnungen gesïumte Binde, deren Fortsetzung auch auf der Schwanzwurzel angedeutet erscheint. Mitunter tritt das grünlichweitie Kolorit nur in Form von länglichen, voneinander entfernten Flecken auf, Auf dèn Halsseiten sind aulierden noch mehrere grünliche oler bräiunlich-gelbe Occlli wahrnehmbar. Der Kopf, die Schwanzoberfäche und die Flanken sind dunkel gepunktet. Schwarze Flecken zieren die äufiersten Längsschilderreihen am Bauche; auf den Extremitïten breitet sich ein dunliles Netzwerk aus, dessen Maschen helle Ocelli zwischen sich einschliefen. Die Kinnladen, die Kehle und der Bauch sind gribbtenteils blitulich; die Aftergegend, die Unterseite der Beine und des Schwanzes hingegen gelblich. 
Vorkommen.

Beide Originalexemplare dieser Species (No. $13 \mathrm{im}$ Turiner Museum) sind von De Filip pi in Baschmidj (od. Basminsk, erste Station auf dem Wege von Tebriz nach Teheran) erbeutet worden. Diejenigen Stücke in meiner Reptilien-Sammlung, welche ich der Vermittelung Dr. O. Böttgers verdanke, stammen von Rasano in Talysch, dicht an der persischen Girenze nächst dem Kiaspisee.

\section{Lacerta depressa Camerano 1878.}

Char. - Scutum occipitale interparitali minor. Sc. nasofrenale unicum. Supralabialia anteriora 4. Discus palpebralis in margine externo serie granorum limbatus. Parietalia in margine externo ante scuto maiore limbata. Tempora squamata. Sc. massetericum plerumque adest; tympanicum adest. Sulcus galaris indistinctus, collare fere integrum. Scuta abdominalia per seris sex disposita. Squamae dorsales parvae vel maiores rotundulae, vix carinatae vel laeves, convexae. Squamae caudales valde carinatae, ad originem tuberculatae quasi carinatomucronatae. Dentes palatini nulli. Pori femorales utrinque 17-22. - Caput elongatum depressum; corpus depressum; cauda in basi late depressa, dupla corporis longitudine minor; pedes postici axillas contingentes $\left(\sigma^{\top}\right)$ vel non contingentes (f). - Longitudo: 134-180 mm. Synonymie.

Lacerta taurica De Filippi in: Arch. per la Zoologia, l'Anat. e la Fisiol., Vol. II. 1863; Note di un viaggio in Persia etc. p. 354. Milano 1865. (part.)

Podarcis depressa Camerano, Descrizione di una nuova specie del Genere Podarcis Wagl. in: Atti della R. Accad. delle Scienze di Torino, vol. XIII.

Körpergestalt und Ma B̉e.

In meinen »Herpetologischen Studien« $(1879,1$. c.) habe ich die Vermutung ausgesprochen, dals Lac. depressa mit L. Portschinstii Kessl. gleichbedeutend sei und dafs sie wohl nur eine Lokalvarietät der Maurereidechse vorstellen könne. Seitdem habe ich sowohl Cameranos als auch Kesslers Species in Augenschein genommen und mich überzeugen können, daß meine Vermutungen mit Bezug auf die Identifikation der depressa mit »L. Portschinshii« und muralis irrig gewesen sind und dab $\mathrm{Camerano}$ vollkommen recht hatte, als er die von $\mathrm{De}$ Filippi in Trapezunt erbeutete und als taurica bestimmte und beschriebene Eidechse mit einem neuen Namen belegte. Nur insofern stimme ich auch jetzt nicht mit Camerano überein, als ich zwischen seiner neuen Species und der muralis wenig Ähnlichkeit finde und eher geneigt bin, die depressa als eine der oxycephalen Eidechsengruppe verwandte Form zu betrachten. Namentlich was die Körperform anbetrifft, nähert sich $L$. depressa der oxycephala oder 
der Bedriagae; so ist z. B. ihr Kopf und Rumpf, wie es bereits Camer a no hervorhebt, starle abgeplattet; der Kopf erscheint in der Schlifengegend an breitesten, verschmälert sich nach vorn allmählich olıne Unterbrechung und weist im Vergleich zur L. oxycephala eine kurze, eher stumpf abgerundete, mit nabezu senkiechten Seiten versehene Schnauze auf. Der Durchmesser des Halses ist demjenigen des Kopfes - in der Temporalregion - gleich. Die Vorderbeine reichen bis zum Nasenloch, das seitlich liegt; die hinteren, an den Körper angelegt, erreichen bei den männlichen Individuen die Achselgegend; bei den Weibchen sind die hinteren Gliedmaßen etwas küzzer, der Schwanz hingegen scheint lünger zu sein, denn er übertrifti bei den mir vorliegenden weiblichen Stücken um einige mm die doppelte Rumpflänge, was bei den Männchen, wenigstens bei denjenigen, welche mir zur Verfügung stehen, nicht der Fall ist. An seiner Basis erscheint der Schwanz bei beiden Geschlechtern breit, niedergedrückt und in der longitudinalen Medianlinie vertieft; nachher wird er drehrund und läuft allmählich dünn aus.

Approximative Mabe in $\mathrm{mm}$.

\begin{tabular}{|c|c|c|c|c|c|c|c|c|c|}
\hline Gesamtlänge . & . & . & . & . & . & . & 178 & 176 & 134 \\
\hline Kopflänge . . & . & . & . & . & . & . & 16,7 & 15 & 11,7 \\
\hline Kopfhöhe & . & . & . & . & & hezu & 7 & 6 & 5,5 \\
\hline Kopfbreite (in der & Temp & oralg & rege & end) & . & & $11-11,5$ & 10,5 & 8 \\
\hline Kopfumfang . . & . & . & - & . & . & . & 32 & 28 & 23,5 \\
\hline Breite des Pileus & . & & . & . & . & . & 8 & 7,5 & 6 \\
\hline Halsumfang & . & . & . & . & . & . & 32 & 30 & 23,5 \\
\hline Rumpflänge & . & . & . & . & . & . & 49 & 55 & 40 \\
\hline Schwanzlänge. . & . & . & • & - & - & . & 112 & 106 & 82 \\
\hline Breitendurchmesser & der & $\operatorname{Sch} \pi$ & & ewurz & & . & $9-9,5$ & 8 & \\
\hline Länge der Vordere & extrem & ität & . & . & . & . & 24 & 24 & 16 \\
\hline Länge der Hinteres & xtremi & & , & . & . & . & 39 & 36 & 29 \\
\hline
\end{tabular}

Schilder und Schupper.

Das Oceipitale ist stets kleiner als das Interparietale. Ersteres ist gewöhnlich trapezisch, letzteres lang, breit, fünfeckig. Die vorn ausgerandeten Parietalen haben hinten und seitlich abgerundete Rinder; ibren seitlichen Aubentudern schlielien sich ein vorderes, langes, schmales Täfelchen und mehrere schuppenartige Schildchen an, welche den Temporalia sehr ähnlich sehen. Die 2 mittleren, den Discus palpebralis bildenden Supraocularia sind nach außen zu von den Supraciliaria durch eine Reihe winzig kleiner Schildchen getrennt. Die hinten abge- 
siulzte Palpebralscheibe ist meist flach. Die Frontoparietalia sind nicht viel grobler als die Frontonasalia; hinteu erscheinen sie spitz ausgezogen oder leicht abgerundet; im ganzen zeigen sie fünf Kanten. Das Stirnschild ist gestreckt, vorn abgerundet oder spitz endend, im hinteren Teile etwas verengt, im allgemeinen von breiter Gestalt. Mit Ausnahme seiner, öfters gerade verlaufenden vorderen Ränder sind sämtliche übrigen Kanten leicht ausgerandet. Die aneinanderstolienden Ränder der Frontonasalia sind meistenteils ziemlich lang; in selteneren Fällen werden sie dadurch abgehtirzt, daf3 das Internasale hinten in eine längere Spitze ausgezogen erscheint, welche sich zwischen die Frontonasalia einkeilt. Das Internasale ist eine ansehnliche, leicht gewölbte, aber nicht auf die Kopfseiten sich herunterbiegende Tafel; manchmal entsendet es nach vorn zwischen die beiden Supranasalia einen kleinen Fortsatz. Das Rostrale ist mäfaig entwickelt und leicht nach oben übergerölbt. Die Nasenlöcher liegen seitlich. Das Nasofrenale ist einfach; das Frenale ist blein und meist trapezförmig; das gröbere Freno-oculare erscheint hinten vielfach ausgeschnitten. In den oberen bogenförmigen Ausschnitt legt sich die vordere Partie des ersten grofen Supraciliare, in die unteren, 2 kleine Praeocularia hinein, von denen das eine, und zwar das zu unterst liegende, an das Suboculare grenzt. Das zuletzt genannte Schild hat eine eigentumliche Gestalt: es ist nämlich sehr niedrig und oben nahezu ebenso breit wie unten, während bei den meisten Eidechsen-Species es nach unten stets verengt erscheint und seitlich stark eingebogene Ränder zeigt, bei der depressa hingegen laben diese Ränder einen geraden Verlauf. Vor dem Suboculare befinden sich 4 Supralabialia, von denen das vierte (von vorn gerechnet) nahezu doppelt so breit ist wie die ubrigen. Auf das Unteraugenschild folgt ein gröferes und ein sehr kleines Supralabiale und endlich ein ansehnliches, fünfseitiges Postoculare. In der Schläfengegend finden sich vorn schmale, äußerst kleine, hexagonale Schuppen, hinten aber größere, konvexe, ebenfalls sechseckige Schildchen, welche in der Ohrgegend durch ein ansehnliches, längliches Tympanale begrenzt werden. Das Massetericum ist meistens vorhanden; es ist eiförmig oder sechskantig. 6 Sublabialia. Die Zahl der Submaxillaria variiert, bald sind es 5 bald 6 . Bei deu sieben von mir untersuchten Individuen febit die Kehlfurche nahezu gänzlich. Die vorn länglichen Kehlschuppen werden nach hinten rundlich oder breiter als lang und leicht äbereinandergreifend. Das ganzrandige, gerade oder leichtgebogene Collare besteht aus $\tau$ bis 9 Tafeln, deren freie Ränder äuferst leicht abgerundet erscheinen; die mittlere Tafel ist - wie es auch sonst meist der Fall ist - breiter als die inr benachbarten. Die Baucbschilder sind in 25-26 Quer- und in 6 Längsreihen geordnet, deren äußerstes und mittelstes Par nur halb so breit ist, als das daranstoGende; uach vorn werden sowohl die äufersten als auch die mittelsten Ventralia bedeutend kleiner. Die Oberschildchen 
sind bald gröfser, bald lileinel. Das Brustdreieck wird aus 8-9 Täfelchen gebildet. Die Aftergegend ist von einel grofien, vorn und seitlich von 2 bis 3 Reihen kleinerer Schildchen umgrebenen Analtafel bekleidet; das dem Sc. anale vorn zunächst grelegene Schild ist stets größer, als die ihm benachbarten, zuweilen erscheint es beinahe ebenso grof wie das Anale seibst. Was die Beschuppung des Oberkürpers anbelangt, so variiert die depressa in sebr betrïchtlichem Grade und ich glaube nicht zu irren, wenn ich die sieben mir von Dr: L. Camerano zur Verfügung gestellten Individuen als zweien Abarten angehörend betrachte. Die eine dieser Abarten - ich will sie als »rulis« bezeichnen - hat große rundliche Rückenschuppen und sehr stark gekielte Schwanzschuppen. An der Caudalwurzel oberwärts und seitwärts treten die Kiele sehr stark hervor; diese Höclierschuppen bilden öfters dornige Quergürtel. Die andere Form der Lacerta depressa, die ich mit dem Varietäts-Namen »modesta« belegen will, zeichnet sich durch ihre kleinen Rückenschuplen und durch ihre weniger scharf gekielten Schwanzschuppen aus. Bei der ersten grobgekörnten Unterart sind die Ventralen etwas gröfer, als bei der feingekörnten Subspecies, so dą̧ die Zahl 3 der auf die Länge eines Bauchschildes gehenden Rückenschuppen bei beiden ziemlich gleich ist. Mit Bezug auf die Bekleidung der Hinterextremitäten bieten diese Formen einige Unterschiede dar: so sind z. B. bei der sructis« die Schuppen am Unterschenkel viel größer und stärker gekielt als bei der smodesta«. Die unregelmäßig rundlichen Dorsalschuppen sind bei beiden stark gewölbt, namentlich tritt die Wölbung an der hinteren Partie der Schuppen auf; gegen die Seiten hin werden die Schuppen etwas größer und nehmen etwa die Gestalt eines Kegels an; gegen die Candalwurzel flachen sich die Schuppen ab, erhalten freie Kanten und nehmen an Größse zu; zwischen den Ansatzstellen der Hinterbeine erscheinen sie hexagonal und weisen deutliche Kiele auf. Die übrigen Rückenschuppen - mit Ausnahme der stets ungekielten Nackenschuppen - sind bald glatt, bald schwach gekielt; die Kiele sind allerdings nur bei günstiger Beleuchtung und unter der Lupe deutlich wahrnehmbar. Bei der Betrachtung unter der Lupe findet man auterdem noch, daf die Schuppen an Hinterrücken nach hinten zu in eine abgerundete Ecke ansgezogen erscheinen. Die oberen Schwanzschuppen sind nach hinten entweder vollkommen abgestutzt oder leicht gerundet; die hinteren winkelig ausgezogen. Sowohl oberwärts als auch unterwärts sind diese Schuppen gekielt. Die Zahl der transversalen Rückenschuppenreihen beträgt bei der depressc mulis 116, bei der modesta 122-135; bei der ersten sind ungefähr 47 , bei der zweiten 57 longitudinale Schuppenreihen an Rücken. Querringel am Schwanze zähle ich bei der mudis 91 , bei del moclesta 80. 
Schenkeldrüsen und Zähne.

Schenkeldrüsen sind meist 17 bis 22 vorhanden; bei var. rudis finde ich 18 Drüsen oder Poren jederseits. Gaumenzähne fehlen. Im Oberkiefer sitzen jederseits 15 Zähnchen, im Zwischenkiefer 6 und im Unterkiefer im ganzen 28.

F arbenkleid.

Die Färbung und Zeichnung ist manchen Veränderungen unterworfen. Einige von den mir vorliegenden Stücken sind oben entweder perlgrau oder grünlichgrau, gefleckt oder einfarbig. Bei den gefleckten Stücken ist der Rücken entweder von dunkelbraunen oder schwarzen Flecken durchzogen, die in parallelen Längsreihen angeordnet sind, oder von unregelmäßjig verteilten Flecken und Punkten besäet; im letzteren Falle tritt auf jeder Seite der Flanken eine am Hinterrande des Auges oder am Freno-oculare beginnende, ziemlich breite, vielfach ausgezackte und unterbrochene Binde auf; oberhalb der Achseln nimmt man auferdem einen hellen Augenfleck wahr. Bei anderen Exemplaren, wie es scheint vorzugsweise bei den weiblichen, verschmelzen die Rückenflecken zu einem Netzwerk, dessen Maschen auf der Mittelzone des Rückens durch die übrig gebliebene bräunlich-graue Grundfarbe, - und auf den Rumpfseiten durch zahlreiche helle Ocelli ausgefüllt werden. Andere wiederum zeigen schnörkeloder linienartige, in die Quere sich hinziehende, dunkle Zeichnungen. Die Kopfschilder sind stets heller koloriert als die übrigen Körperteile; sie sind einfarbig oder dunkel gepunktet Die Oberseite der Extremitäten erscheint dunkel geflecht oder nur gepunktet. Auf den unteren Kinnladen, auf der Brust und in der Aftergegend tritt ein bläulicher oder grünlicher Ton auf; die erste longitudinale Bauchschilderreihe ist meistenteils blau oder rostbraun getleckt; alle übrigen unteren Teile sind weiflich.

Vorkommen.

Bis jetzt scheint diese Art nur in Trapezunt konstatiert worden zu sein (Mus. Turin. und Sammlung v. Bedriaga); sie vertritt hier allem Anscheine nach die oxycephalen Eidechsen. sLacerta oxycephala soll allerdings laut Wa g $\mathrm{n}$ er und Berthold in Transkaukasien gefangen worden sein, woran ich aber stark zweifle; die angebliche Bertholdsche oxycephala dürte wohl mit Lac. depressa C amerano identisch sein.

12. Lacerta oxycephala D. B. (part.) 1839.

Char. - Sc. occipitale interparietali minus. Scuta nasofrenalia duo. Supralabialia anteriora 5. Discus palpebralis in margine externo serie granorum limbatus. Parietalium margines externi $1-3$ scutis maioribus, oblongis, angustis circumdati. Sc. massetericum sat 
magnum; sc. tympanicum oblongum, angustum. Sulcus gularis praesens vel nullus, collare integrum. Scuta abdominalia per series 6 disposita. Squamae dorsales parvae, laeves, sat planae, oblongo-sexangulares angulis rotundatis. Dentes in palato nulli. Pori femorales utrinque 22. - Caput ante acuminato-attenuatum, humile, planum, in regione temporali paulo amplificatum. Truncus abbreviatus, latus, depressus. Pedes postici axillas contingentes vel vix superantes. Cauda hemiola, apicem versus valde attenuata. - Longitudo: $160 \mathrm{~mm}$.

Synonymie.

Lacerta oxycephala Duméril et Bibron, Erpétologie générale, vol. V, pag. 235 (part.). Schreiber, Herpetologia europaea. p. 404 (part.). - Camerano, Monografia dei Sauri italiani. Mem. I. Accad. Sc. di Torino, Ser. II. T. 37 ; Zoolog. Anzeiger 1885, S. 418. Podarcis oxycephala Bonaparte, in: Mem. R. Accad. Sc. di Torino, Serie II. Tom. II. p. 385 (part.); Iconografia della Fauna italica. Roma 1832-1841 (part.). - De Betta Rettili ed Anfibi in: Fauna d'Italia IV. Milano 1874 (part.).

Die Benutzung eines, renngleich wenig erschöpfenden, nichts destoweniger aber zu meinen Zwecken hinreichenden Materiales hat mich zur Überzeugung geführt, daßs $L$. oxycephala der Autoren sich in vier, ziemlich scharf geschiedene Formen trennen läßst, und zwar je nachdem ob das Sc. massetericum vorhanden ist oder nicht und ob die Nasofrenaltafel einfach oder geteilt erscheint. Gegenwärtige, von mir als $L$. oxycephala D. B. (part.) bezeichnete Eidechse aus Dalmatien ist diejenige, welche Schreiber eingehend als $L$. oxycephala in seiner Herpetologia europaea S. 406 beschrieben hat. Sie besitzt ein ziemlich grofies, ron sehr kleinen kübnerartigen Schuppen umgebenes Massetericum mil ist auberdem dadurch charakterisiert. dati ihr Nasenloch nach rückwärts in der Regel von 2 übereinanderstehenden Nasofrenalen begreuzt wird. Die auf Korsika lebende, von Duméril und Bibron und von mir beschriebene soxycephala hat den Namen $\gg L$. Bedriagae Camerano" erhalten; sie unterscheidet sich vou der oxycephala aus Dalmatien, abgesehen ron der abweichenden Zeichnung und Färbung hauptsächlich durch inre Körpermaße und durch die Beschildung der Nasofrenal- und der Temporalregion; sie ist nämlich bedeutend größer und kräftiger gebaut und besitzt nicht, wie jene 2 , sondern nur 1 Nasofrenalschildchen; von einem Massetericum ist mitunter keine Spur zu sehen. Unter die Kennzeichen der griechischen angeblichen oxycephala oder der $L$. graeca habe ich folgende aufgenommen: 2 ubereinanderstehende Nasofrenalia, Massetericum fehlend. Was die von Steindachner als spanische oxycephala und von mir als $L$. muratis subsp. Steindachneri bezeichnete Eidechse anbetrifft, so zeichnet sie sich durch eine einzige Nasofrenaltafel, sowie durch den Mangel des Massetericum aus. Aus dem Gesagten ist ersichtlich, daf der Name 
soxycephalce als liollektivbezeichnung für nicht weniger als vier zusammengeworfene, geographisch getrennte Formen gelten kann.

Aus der Fauna italica des Prinzen von Canino ersehen wir, dak Fitzinger eine dieser Arten zum erstenmal mit dem Namen oxycephlala versab. Daraufhin soll Schlegel eine Anzahl dieser Tiere aus Dalmatien erhalten, als $\gg$. oxycephala im Museum zu Leyden etikettiert und 2 Exemplare an Duméril und Bibron übermittelt haben. Die zuletzt genannten Forscher untersuchten nun sowohl diese, als auch noch andere aus Korsika stammende, spitzkönfige Eidechsen näher und liefen eine ziemlich ausführliche Diagnose in der generellen Herpetologie erscheinen. Daf der Duméril-Bibronschen Diarnose eine andere von seiten $\mathrm{Fitzingers} \mathrm{oder} \mathrm{Schlegels}$ vorangegangen ist, glaube ich nicht, wenigstens wollte es mir nicht gelingen, in den mir zur Verfügung stehenden herpetologischen Schriften eine ältere Beschreibung der in Rede stehenden Art ausfindig zu machen. Die Fitzinger-Schlegelsche Bezeichnung muß ledighich als Musealname aufgefafist werden. In seiner ein. Jahr nach dem Erscheinen des fünften Bandes der Erpétologie générale, in den Mem. della Accad. di Scienze di Torino, Ser. II. Tomo II publizierten Übersicht der Kriechtiere Europas führt Bonaparte L. oxycephala mit Bedenken an; erst in der Iconografia della Fauna italica wird sie von ihm als gute Species anerkannt und zwar auf Grund seines Bekanntwerdens mit dem aus Korsika stammenden Tiere (d. H. L. Bedriagae Cam.). Die ziemlich dürftige Beschreibung Bonapartes ist von einer Abbildung und einem zum Teil mifratenen Versuch Symonyme zu entdecken, begleitet. Im Jahre 1874 wurde die oxycephala wiederum in italienischer Sprache und zwar von de Betta nach dalmatinischen Exemplaren kurz beschrieben. Viel präciser behandelt sie dagegen Schreiber in seiner, ihrer Ausführlichkeit wegen, einzig und allein dastehenden Beschreibung. Dem Verfasser der Herpetologia europaea stand, wie wir es seinen eigenen Worten entnehmen, ein reiches, aus Dalmatien und »Spanien« stammendes Material zu Gebote. Was nun das Vorkommen der oxycephala der Autoren oder meiner L. oxycephala D. B. (part.) und L. Bedriagae anbelangt, so habe ich ganz neuerdings Gelegenheit gehabt, die Steindachnerschen Originalexemplare seiner »oxycephala var. hispanica《 im NaturalienKabinett in Wien zu sehen und bin daher in der Lage, folgendes Urteil fällen zu können: sowohl die Steindachnerschen »oxycephata« vom Monte Agudo bei Murcia (Sitzungsber. d. k. Akad. d. Wiss. Math. naturw. Cl. LXII Bd., 1. Abt. 1870, S. 336. Wien), als auch die Böttgerschen aus der Umgebung von Cartagena und Almeria (Abhandl. d. Senckenberg. naturforsch. Ges. XII. S. 376) gebören nicht der Duméril-Bibronschen oxycephala (= Bedriagae + oxycezhala D. B. part.), sondern der Gruppe von Mauereidechsen an. Dak eine oxycephale 
Eidechse in Spanien vorkomme, hat bereits Gray vermutet, jedoch können wir nicht mit Sicherheit anmehmen, dals die unter dem Namen "Zootoca oxycephalas im Cat. Liz. Brit. Mus. figurierende Eidechse wirklich eine der spitzliöpficen Lacerten ist. Ich führe hier Grays eigene Worte an, um zu zeigen, dals meine Zweifel nicht unbegründet sind; Gray sagt: ¿Z. oxycephala. Spain or Malleira? 'Temple covered with small swollen scales with a large central one; dorsal scales oval rather convex; ventral shields 6- rowed." Eine aus Madeira stammende, als soxycephala bestimmte Lacerta habe ich allerdings im British Museum in Augenschein genommen; obgleich das betreffende Stück sich schlecht erhalten hat, - es stammt aus der Ausbeute ron P. B. Web b - so ist demnoch leicht zu konstatieren, dafis ein Bestimmungsfehler vorliegt.

Körpergestalt und Gröbỉe.

Der mehr (beim o7) oder weniger (beim q) abgeplattete Kopf ist vorn zugespitzt verschmälert; die Schläfengegend ist schwach aufgetrieben, wältend die Seiten am vorderen Kopfteile steil sind; die Schädeldecke neigt sich von den Augen an gegen die zugerundete, oberseits leicht aufgetriebene Schnauzeuspitze ganz allmählich uach abwärts zu. Der Discus palpebralis ist schwach gewölbt; die großen Nasenlöcher liegen seitlich. Der Hals scheint in der Regel etwas breiter als der Kopf oder wenigstens ebenso breit zu sein. Der Rumpf ist kurz, ziemlich breit und abgeplattet; die Vorderbeine (mir stehen leider nur männliche Individuen zur Verfügung) reichen bis zu den Frenalen oder nut etwas über die Augen hinaus; die Hinterbeine erreichen die Achseln oder können auch etwas über dieselben hinausragen. Der dünn auslaufende Schwanz ist etwa auderthalbmal so lang als der Körper; die Caudalwurzel erscheint breit und plattgedrückt.

Totallänge: $160 \mathrm{~mm}$; Länge des Kopfes: $14 \mathrm{~mm}$, d. Halses: 10-11 mm, d. Rumpfes: $46 \mathrm{~mm}$, d. Schwanzes: $100 \mathrm{~mm}$, der Vorderextremität: $21 \mathrm{~mm}$, d. Hand $\mathrm{m}$. d. Fingerm: $9 \mathrm{~mm}$, der Hinterextremität: $31^{1 / 2} \mathrm{~mm}$, des Fufies m. d. Zehen: $15 \mathrm{~mm}$; Breite des Kopfes: $9 \mathrm{~mm}$, d. Pileus: $6 \mathrm{~mm}$; Höhe d. Kopfes: $6 \mathrm{~mm}$; Umfang des Kopfes in d. Temporalregion: $26 \mathrm{~mm}$, des Halses: $27 \mathrm{~mm}$, des Rumpfes: $33 \mathrm{~mm}$, des Schwanzes an der Wurzel: $21^{1 / 2} \mathrm{~mm}$, in der Nitte: $10 \mathrm{~mm}$.

Äufore Körperbed eckung. (Vergl. meine Tafel Fig. 16 u. 29.)

Die binten und seitlich abgerundeten Parietalia berühren mit dem gröbten Teile ihres Innenrandes, welcher aus 3, unter stumpfem Winkel zusammenstokenden Kanten besteht, das kleinere trapezförmige Occipitale und das grötsere, namentlich bedeutend längere, vorn erwei- 
terte und mit stumpfem Winkel zwischen die Frontoparietalia eingeschobene, hinten aber verschmälerte und abgestutzte fünfeckige Interparietale. Beide Frontoparietalen sind von gewöhnlicher Bildung; sie berühren einander mit ihrer längsten Innenseite und lassen sich am besten mit zwei ungleichschenkligen, mit der Spitze nach aufen gerichteten Dreiecken vergleichen, an deren jedem die innere Basalecke schräg abgestutzt ist; in dem dreieckigen, kaum bemerkbaren vorderen Ausschnitr, der durch die Abstutzung der nebeneinander gelegenen Basalecken dieser beiden Schilder entsteht, liegt die hintere kurze Spitze des hinten schmalen, vorn hingegen stärker erweiterten Frontale, weiches mit einem unter stumpfem Winkel zusammenstobenden Vorderrande versehen ist. Die aus ziemlich gleichgrolsen, vorn und hinten abgestutzten, seitlich abgerundeten Tafeln bestehende, schwach gewölbte Palpebralscheibe grenzt nach innen an die ausgerandete laterale Frontalseite; nach auken hin werden die beiden Supraciliaria durch eine feine Körnerreihe begrenzt und erscheinen auf diese Weise von den 6 länglichen und schmalen Supraciliaria getrennt. Das Supraoculare IV ist gut doppelt so grof wie das vorderste erste. Die Frontonasalia sind nahezu ebenso grofis wie die Frontoparietalen; sie berühren sich gegenseitig und repräsentieren etwa zwei Dreiecke, deren sämtliche Ecken abgestutzt erscheinen. Bei den mir vorliegenden Exemplaren der oxycephala ist das rhombische Internasale etwas länger als breit; es erscheint von dem breiten, hinten scharf zugespitzten und übergewölbten Rüsselschilde getrennt. Unter den Schildern, welche die Kopfseiten bekleiden, sind zunächst die 2 kleinen, genau übereinauder gestellten Nasofrenalia zu erwähren, von denen das zu unterst liegende ein Trapez darstellt und zum größten Teil das verhältnismäßig ziemlich großje Nasenloch begrenzt. Der Raum zwischen diesen beiden Tafeln und der Orbitalhöhle wird von 2 Schildern ausgefüllt, von denen das vordere kleinste, vier- bis fünfseitige auf dem zweiten Supralabiale liegende, das Frenale, das hintere gröfere, nach rückwärts etwas erweiterte Schild, das Freno-oculare repräsentiert; zwischen diesem Schilde und dem oben erweiterten und ausgerandeten Supralabiale VI oder Suboculare liegt nur ein längliches schmales Schildchen, das man als Praeoculare zu bezeichnen pflegt; nach hinten zu ist ein ähnliches, aber etwas breiteres Postoculare sichtbar. Das hintere Supralabiale ist in der Regel von 3, uach hinten zu immer kleiner werdenden Tafeln begleitet. Die Schläfe sind mit winzigen körnerartigen Temporalia bekleidet, in deren Mitte sich ein verhältnismäk̊ig grob̉es Massetericum befindet; vor und über dem Rande des großen Ohrloches liegt das längliche, schmale Tympanicum, dessen Vorderrand von 2 größeren Schläfenschuppen begrenzt wird; die äuferen Parietalseiten erscheinen gleichfalls von 1 bis 3 größeren, länglichen und schmalen Tafeln umgeben. Die Unterseite des Kopfes zeigt ein grobes, vorn abgerundetes, hinten geraderandiges Mentale, auf welches jeder- 
seits 6 Sublabialia und 5 Submaxillaria folgen. Die vorderen 2 Submaxillarpaare stoben ilhrer ganzen Länge nach in der Mittellinie zusammen, während die Schilder des dritten Paares z. T. Jurch dazwischen eingeschobene längliche, etwa hexagonale Schuppen voneinander getrennt werden. Der übrige Raum der Kehle wird von Schuppen eingenommen, welche' eine längliche sechseckige Form haben und allmählich in die etwas breiteren Halsschuppen übergehen. Die Kehlfurche soll laut Schreiber kaun wahnehmbar sein, bei den mir vorliegenden Stücken vermisse ich sie gänzlich; dagegen scheint die Querfalte in der Regel vorhanden zu sein. Das aus 11 bis 13 kleinen, gewöhnlich längeren als breiten Schildchen bestehende und wie es scheint, kein gröferes Mittelschild aufweisende ganzrandige Halsband setzt sich seitlich als Falte eine kurze Strecke nach oben fort und vereinigt sich mit einer Längsfalte, die sich vom hinteren Ohrrande nach hinten gegen die Ansatzstellen der Vorderbeine hinzieht. Das Brustdreieck enthält 13 bis 15 Tafeln. Am Bauche zähle ich 6 Längs- und im ganzen, also die Brusttafeln mitgerechnet, etwa 29 Querreihen von Ventralia; sämtliche hinteren Schilder sind ziemlich gleichgrof, wälrend vorn die mittlereu und äußeren Tafeln etwas kleiner sind als die dazwischen liegenden. Die Praeaualgegend ist mit einem, voru von 2 Bogenreihen kleiner Schildchen umgebenen, breiteren als langen Sc. anale bekleidet. Mit Ausnahme einiger spitz ausgezogener Schuppen am Schwanzende, die gekielt erscheinen, sind sämtliche unteren Caudalschuppen glatt, viereckig, hinten vollkommen abgestutzt; auch auf der Schwanzoberseite erscheinen die Schuppen gerade abgestutzt; nur die vorderen sind deutlich stumpf gekielt, die übrigen aber sind spurweise gekielt oder sehen wie gewölbt aus; es sind ungefähr 92 Quergürtel vorhanden. Die Rumpfschuppen sind durchweg glatt und ziemlich flach, nur gegen ihren hinteren Rand ist eine schwach ausgeprägte Wölbung sichtbar. Am Nacken sind die Schuppen rundlich, an den Halsseiten körnig und an liücken länglich hexngonal mit abgerundeten Ecken; die Schuppen an den Rumpfseiten sind kleiner als diejenigen am Rücken; 3 bis 4 dieser Schuppen entsprechen der Länge des Bauchschildes; in del Mitte des Rumpfes zähle ich ungefähr 61 Schuppen in einem Quergärtel und etwa 13 Schuppen in einer Lüngsreihe.

Schenkeldrüsen und Zähne.

Es sind hier jederseits 22 äukerst kleine Schenkeldrüsen vorhanden. Die Flügelbeine entbehren der Bezahnung.

\section{F a rbenkleid.}

Die Grundfarbe der Oberseite liumn von Grau einerseits durch Grünlichgrau bis ins Olivenfarbene, andererseits durch Gelbgrau oder Braun selbst bis zu tiefem Schwarz mannigfaltig ab- 
ändern. Der Körper ist oben entweder einfarbig, oder durch dunkle Flecken verschiedenartig gezeichnet. Vollkommen einfarbige Stücke kommen übrigens selten vor; in den meisten Fällen sind über den ganzen Oberkörper dunkelbraune oder schwärzliche Makeln verteilt, die weder in Form noch in Anordnung beständig erscheinen, sondern bald als isoliert stehende Punkte auftreten, bald wieder linien- oder schnörkclartige Figuren bilden. Da nun diese Flecken nicht selten zusammenstolien oder teilweise verschmelzen, so wird dalurch häufig ein bald mehr, bald weniger regelmäßiges Netzwerk hervorgebracht, in dessen Maschen die Grundfarbe etwa in Form von kleinen Ocellen zum Vorschein kommt. Das Überhandnehmen der dunklen Zeichnung kann nach Schreibel so weit gehen, dafs das Schwarz zur Grundfarbe wird, auf welcher dann der Rest der einstigen Färbung nur noch als helle Puderung zu erkennen ist. »Bei manchen Varietäten«, fügt Schreiber hinzu, streten die Flecken auch zu unregelmäßigen Längsbinden zusammen, was namentlich gern an den Seiten des Rückens, oft aber auch am ganzen Körper der Fall ist, der dann von 3 bis 7 schwïrzlichen Fleckenstreifen durchzogen erscheint. Doch sind diese Binden wohl niemals voll und ganz ausgefüllt, sonderm stets melur oder weniger von der helleren Grundfarbe geteilt oder unterbrochen, so dafỉ sie immer wie zerfressen, gezackt oder gemarmelt aussehen. Aufser diesen schwärzlichen Zeichnungen sind der Oberseite nicht selten auch mehr oder weniger weibliche Flecken eingestreut, die aber meist wenig deutlich und nicht scharf abgegrenzt sind und am häufigsten in der Form von ziemlich rundlichen Tupfen auftreten.« — Die mir vorliegenden Exemplare der oxycephala aus der Umgebung von Scardona (Fluss Kerka), welche ich der Güte des Dr. F. Steindachner verdanke, sowie auch diejenigen Originalindividuen, welche ich in den IIuseen zu Leyden und Berlin zu untersuchen Gelegenheit hatte, gehören der genetzten Form an. Ihre Unterseite ist bläulichweiß; nach Schreiber (1. c.) sollen die unteren Körperteile auch perlgrau oder bleifarben sein, wwelche Färbung aber in manchen Fällen bis zu tiefem Eisengrau, ja fast bis zu Schwarz gesteigert erschein«. Nach dem Material zu urteilen, das ich schon vor mehreren Jahren bei Herrn De Bett a in Verona gesehen habe, kommt in Dalmatien eine Form mit total schwarzem Bauche vor. - Die Bauchseite zeigt mitunter dunkle Flecken. Die meist bläulichgrünen oder grauen Kopfschilder sind mit dunkelbraunen, delta- und schnörkelförmigen Zeichnungen besetzt; die Zügelgegend erscheint mit verloschenen, dunkelgrauen Makeln, die Schläfe mit dunklen Ringflecken versehen. Die Extremitäten sind oberwärts auf grauem oder brüunlichgrünem Grunde dunkelbraun gemarmelt oder genetzt. Auf der Scliwanzoberfläche und auf den Schwanzseiten stelen dunkelbraune, dicht aneinander grenzende Längsstriche, welche meistenteils halb so lang sind wie die Schuppe selbst. 
Das Museum in Paris besitzt zwei auffillend kolorierte oxycephata (No. 2738, dedit: Musée de Leyde); diese Exemplare sind nümlich oben einfarbig schwarz oder ganz dunkel braun. Die Schädeldeclie erscheint dunkelbraun, die Unterseite des Körpers, mit Ausnahme des heller grefürbten Schwanzes und der Hinterbeine, eisengrau. Bei einem Individuum sind die Kiele auf dem Schwanze gut, bei dem anderen hingrgen schwach ausçeprägt. Höchst wahrscheinlich stammt diese oxycephalc var. atre von einer Insel in Adriatischen Neere.

Vork o mmen.

- Sowohl die Originalexemplare im Museum zu Leyden als auch diejenigen, welche das Muséum d'histoire naturelle in Paris und das Berliner Museum (No. 1039) besitzen, stammen aus Dalmatien, wo diese Species, nach einer mündlichen Mitteilung des Herrn Dr. Steindachner, an Flusse Kerka unweit von Sebenico und Scardona angetroffen worden ist. In der Sammlung des Cav. Ed. de Betta in Verona sah ich ferner ein Stück, das, wenn ich nicht irre, sehr dunkel koloriert war, mit der Etikette „presso Lissa«, d. h. „neben Lissa«, versehen; da Lissa eine von der Küste Dalmatiens in ziemlich grolier Eutfernung liegende Insel ist, so muk darunter ein, sich in der Nähe Lissas befindendes Eiland gemeint sein. L. oxycephala scheint überhaupt die dalmatischen Inseln nicht zu meiden, denn Exemplare aus Curzola sind im Museum zu Leyden (ded. Giglioli) aufgestellt. Sicilianische Fundorte sind, so viel ich weif, noch nicht erwähnt worden und dennoch befindet sich das Museum zu Leyden im Besitze einer angeblich aus Sicilien stammenden oxycephata; die Etikette lautet närnlich: »L. oxycephala. Sicile. Voyage Cantraine. Es sei mir aber hier die Bemerkung gestattet, dak mir die Fundortsangaben mehrerer sich in diesem Museum befindender aus der Reise von Cantraine stammender Objekte sehr zweifelhaft erschienen sind. Was das Vorkommen der oxycephala in Italien anbelangt, so wäre es leicht möglich, dafs sie oder die Bedriagae in den Abruzzen zu Hause ist ${ }^{1}$ ). Das Museum zu Halle besitzt eine als "L. oxycephala determinierte angeblich aus Spezia stammende (No. 433) und eine andere als soxycephala aus "Aegyptia« bezeichnete Eidechse (No. 405̃). Beide Bestimmungen sind aber falsch, denn erstere ist in Wirklichkeit eine L. Galloti, während letztere der Art »L. muralis subsp. neapolitana« angehört. Unter den sechs im Berliner lluseum sich befindenden, mit der Etikette $» L$. oxyce1)hula versehenen Büchsen, habe ich nur eine, und zwar No. 1039 ausfindig machen liönnen, deren Inhalt sich als richtig bezeichnet erwiesen hat; alle übrigen dagegen, wie No. 4524, 1041 , 1036, 1021 und 1026, enthalten Mauereidechsen. Aufer diesen falsch bestimmten Tieren sind

1) Vergl. Dehne, Verzeichnis derjenigen Reptilien, welche Dr. Rabenhorst im Jahre 1847 in Italien gefunden, in: Allg. deutsche naturhist. Zeit. Bd. II. 1856. 
mir in diesem Museum noch zwei andere Etiketten aufgefallen; die Büchsen No. 1015 und No. 1020 enthalten nämlich allem Anscheine nach L. muralis (angeblich aus Sibirien!); auf den Etiketten steht der Speciesname $\gg$ L. muratis, ded. Pall as sedruckt und darunter die Korrektur mit der Feder: „L. oxycephaln«!

\section{Lacerta Bedriagae Camerano 1885.}

Char. - Sc. occipitale interparietali multum brevius, interdum paulo latius. Sc. frontale longum. Sc. nasofrenale unicum. Discus palpebralis in margine externo serie granorum limbatus. Supralabialia anteriora 5. Tempora squamata, media plerumque scuto masseterico. Tympanicum adest. Scuta parietalia in margine externo $3-4$ scutis longioribus limbata. Sulcus gularis distinctus. Collare integrum. Scuta abdominalia per series ser disposita. Squamae dorsales sat planae, laeves, saepius parva foveola impressae, quinquangulares vel quadrangulares vel irregulares. Dentes palatini nulli. Pori femorales utrinque 17-27. - Corpus latum, depressum. Caput latum, planum, humile, in regione temporali in genarum modum amplificatum et latissimum. Cauda in basi incrassata, depressa, paulo longior quam $2 / 3$ totius corporis. Pedes postici axillas attingentes. - Longitudo: $226 \mathrm{~mm}$.

Synonymie.

Lacerta oxycephala Duméril et Bibron, Erpétologie générale, vol. V, p. 235 (part.). Giglioli, in: Archiv f. Naturgeschichte 1879. Bd. I. S. 93. - v. Bedriaga, ebendas. Jahrg. 1880, Bd. I. S. 250. Taf, XI, Fig. 2,5,6 und 8; Jahrg. 1883, Bd. I. S. 260. - Camerano, Monografia dei Sauri italiani, in: Mem. R. Accad. Sc. di Torino. Serie II, T. 37 und in: Zoolog. Anzeiger 1885, S. 418 (subsp. Bedriagae).

Podarcis oxyccphala (Schlegel) De Betta, Rettili ed Anfibi in: Fauna d'Italia IV. L'Italia sotto l'aspetto fisico, storico, artistico e statistico. Milano 1874. (part.). - Bonaparte, Amphibia europaea in: Mem. R. Accad. Sc. di Torino, Serie II. Tom. II. pag. 385 (part.); Iconografia della Fauna italica. Tab. fig. 3 (part.).

Körpergestalt und Grö lae.

Unterwirft man die Körpergestalt nur einer oberflächlichen Betrachtung, so kann man allerdings zu der Annahme gelangen, daf $L$. Bedriagae und $L$. muratis specifisch nicht verschieden sind; geht man aber näher ein, so stöfat man sofort auf Differenzen, die für die Unterscheidung dieser zwei Arten von Gewicht sind. Vor allem imponiert der hinten, also in der Temporalgegend, sehr breite, backenartig aufgetriebene, von den Augen nach vorn aber stark verschmillerte, mit morn abgerundeter und seitlich zusammengedrïclter schnauze versehene lange 
Kopf. Die Kopflänge übertrift den gröliten in der Hinterhauptregion sich befindenden Höhendurchmesser zweiundeinhalbmal; eine Queraxe, mitten durch die Temporalregion gezogen, stellt die gröbte Breitenausdchnung des Kopfes dar. Der Breitendurchmesser des Kopfes in der Praeoculargegend entspricht nahezu demjenigen in der Frenonasalregion. Das Schnauzenende, von der Seite betrachtet, ist oben wie aufgetrieben, der Kopf erscheint sonst stark niedergedruckt und - namentlich beim Weibchen - abgeflacht. Beim Månnchen treten die Augenbulbi ziemlich stark hervor, wodurch die Palpebralscheibe erhoben erscheint, während die Frontonasalen ziemlich tief liegen; beides bewirkt eine rasche Verschmälerung des Kopfes, aber speciell nur in der bezeichneten Region. Vorn fallen die Kopfseiten steil ab; die Schidldedece senkt sich ganz allmählich nach vorn zu; in der Hinterhauptsregend ist sie vollkommen horizontal. Der obere lieferrand erscheint boyenförmig geschwungen. Die grolien, ziemlich rundlichen Nasenlöcher sind nach oben geriickt. Der Rumpf ist seh breit, wie plattgedrückt und rom Kopf durch keine halsartige Einschnürung abgesetzt; der Halsumfung ist dem Kopfumfung gleich, übertrifft ilm sogar manchmal. Ier krïftige, namentlich heim Männchen an der Wurze] stark verdickte, oben plattgedrückte schwanz ist in eine verhältnismäßig kurze Spitze ausgezogen; er nimmt etwas mehr als zwei Drittel der ganzen Länge des Tieres ein. Die Vorderbeine ragen stets über die Augen hinaus, sie reichen gewöhnlich bis zur Schnauzenspitze, die Hinterbeine erreichen, an den Körper angelegt, die Achseln. Beim Weibchen sind die Gliedmatsen in der Regel etwas kürzer als beim Männchen. Der Kopf ist bei ersterem kürzer und niedriger, der Rumpf relativ breiter als bei letzterem.

Maße. - б. Gesamtlänge: $226 \mathrm{~mm}$; Länge des Kopfes: $22 \mathrm{~mm}$, d. Halses: $11 \mathrm{~mm}$, d. Rumpfes: $61 \mathrm{~mm}$, d. Schwanzes: $143 \mathrm{~mm}$, der Vorderextremität: $31 \mathrm{~mm}$, d. Hand m. d. Fingern: $13 \mathrm{~mm}$, d. Hinterextremität: $47 \mathrm{~mm}$, des Fulses m. d. Zehen: $22^{1 / 2} \mathrm{~mm}$; gröbit. Breitendurchmesser d. Kopfes: $15 \mathrm{~mm}$; größte Kopfhöhe: $9 \mathrm{~mm}$; gröbt. İopfunfang: $42 \mathrm{~mm}$; Breite des Pileus an seiner Ansatzstelle: $10 \mathrm{~mm}$; Unfang d. Halses: $44 \mathrm{~mm}$, des Rumpfes: 46-48 mm, d. Schwanzes an seiner Wurzel: $30 \mathrm{~mm}$, in der Mitte: $14 \mathrm{~mm}$. - - Gesantlänge: $170 \mathrm{~mm}$; Länge des Kopfes: $15 \mathrm{~mm}$, d. Halses: $10^{1 / 2} \mathrm{~mm}, \mathrm{~d}$. Rumpfes: $50 \mathrm{~mm}, d$. Schwanzes: $105 \mathrm{~mm}$, d. Vorderextremität: $23 \mathrm{~mm}$, der Hand m. d. Fingern: $11 \mathrm{~mm}$, der Hinterextremität: $34 \mathrm{~mm}$, des Fuß̉es $\mathrm{m}$. d. Zehen: $17 \mathrm{~mm}$; Kopfbreite: $10 \mathrm{~mm}$; Kopfhöhe: $6 \mathrm{~mm}$; Breite des Pileus: $6^{1 / 2} \mathrm{~mm}$; Umfang d. Kopfes: $28^{1 / 2} \mathrm{~mm}$; d. Halses: $27-27^{1 / 2}{ }^{\circ} \mathrm{mm}$, d. Rumpfes: $32 \mathrm{~mm}$, des Schwanzes an seiner Wurzel: $22 \mathrm{~mm}$, in der Mitte: $11 \mathrm{~mm}$. Äu fiere Körperbedeckung (Fig. 6 und 20).

Unter den Pileusschildern ist zunächst das Occipitale zu nenuen, das bald trapezförmig und kürzer, bald dreieckigr ausgezogen und ebenso breit ist wie das fünfeckige, nach vor'u zu 
in einen stumpfen Winkel erweiterte, nach rückwärts verschmälerte und gerade abgestutzte Interparietale. Auf dieses Schild folgt ein Paar langer, mit fünf Seiten versehener und in der Mittellinie zusammenstofiender Frontoparietalen; nach vorn zu ersclieinen diese Tafeln abgerundet, hinten stoßen ihre kürzesten Seiten, je nach dem das Interparietale gestaltet ist, entweder in stumpferem, oder spitzerem Winkel zusammen. Die seitlich liegenden vorderen, meistens leicht eingebogenen und die hinteren meistenteils geschweiften Frontoparietalkanten bilden einen spitzen Winkel, welcher zwischen das drei- oder viereckig gestaltete Supraculare IV und das Parictale eingeschoben ist. Die Parietaltafeln zeichnen sich durch ihre Länge aus; sie erscheinen nur äutserst schwach gewölbt und zeigen hinten eine abgerundete, seitlich eine gerade verlaufende, von 3 grölseren, länglich-hexagonalen Schläfenschildern begrenzte Kante; der Innenrand zeigt 3, unter stumpfem oder fast verschwindendem Winkel zusammenstoliende Kanten, deren vordere geradlinig oder bogig verlüuft und sich einerseits an das Supraoculare IV anlegt und andererseits mit dem Vorderrande unter stumpfem Winkel zusammenstößt, dessen Spitze abgerundet eischeint. Die den Palpebraldiscus bildenden, ziemlich gleich großen, oberen Augenschilder sind hinten und meist auch vorn abgestutat; vorn fügt sich ihnen noch ein drei- oder viereckiges Schildchen an; am Aufenrande werden sie von einer feinen Körnerreihe begrenzt, welche somit die Supraocularia von den länglichen schmalen Supraciliaria trennt. Das Stirnschild ist grok, nach vorn deutlich erweitert, nach hinten etwas schmäler werdend, mit leicht ausgebuchteten Seitenrändern und ziemlich stumpfem Hinterwinkel; vorn endet es in einer ziemlich langen, abgerundeten Spitze, welche sich zwischen die sechskantigen langen Frontonasalia einschiebt. Letztere sind länger als breit, seitlich mit geraden, parallel gestellten Kanten, vorn meistenteils mit unter stumpfem, hinten unter stumpfem oder spitzem Winkel zusąmmenstoßenden Rändern versehen; der nach innen zu gekehrte Hinterrand ist bogig geschwungen. Zwischen dem bisweilen ebenso langen als breiten, großen rhombischen, seitlich abgestutzten Internasale und dem nach oben ziemlich stark übergewölbten fünfseitigen Rostrale befinden sich die in der Mittellinie der Schnauzenspitze verengten und zusammenstofenden, lateralwärts erweiterten und stark ausgeschnittenen kleinen Supranasalia. Hinter dem ziemlich grofen, rundlichen, vorn vom Supranasale, unten vom Supralabiale I umgebenen Nasenloche befindet sich eine einzige hohe, das Internasale erreichende Nasofrenaltafel; auf diese folgt nun das ziemlich grofe, trapezförmige, vorn öfters mit einer abgerundeten, hinten leicht ausgerandeten Kante versehene Zügelschild. Das bedeutend größere, fünfseitige Freno-oculare erscheint nach vorn verschmälert; sowohl sein vorderer kurzer, als auch sein oberer, an das Frontonasale grenzender und sein unterer an das Supralabiale III und IV sich 
anlegender Rand verläuft geradlinig, wälrend sein hinterer Rand zwei- bis dreimal ausgeschnitten erscheint; in den untersten dieser Ausschnitte pabit das abgerundete Vorderende les kleinen, länglichen, vorn breiter als hinten gestalteten Praeoculare hinein; nach rückwirts hin kommt dieses Schildehen mit dem oben leicht ausgerandeten Suboculare, das oben nur wenig breiter wird als unten, zusammen. Selne oft sind zwei Pracocularia vorhanden. Auf das Unteraugenschild folgt eine hintere, von 2 bis 3 kleinen Schildchen begleitete Supralabialtafe\}. Es ist erwähnenswert, dafs das Suboculare in der Regel die sechste Oberlippentafel repräscntiert, während bei den meisten anderen Eidechsen die Zahl der Supralabialia anteriora eine Tafel weniger beträgt. Sublabialen sind gewöhmlich 6 , Submaxillaren 5 vorhanden; die 3 vorderen Submaxillarpaare berühren sich in der Mittellinie der Kehle ihrer ganzen Långe nach. Die Schläfe sind mit kleinen hexagonalen oder fünfseitigen Schuppen bekleidet. Das Massetericum kann fehlen; ein längliches schmales Tympanicum ist vorhanden; die grofe Ohröffnung ist vorn mit einer Reihe winziger Körnchen besetzt. Kehlfalte und Kehlfurche sind deutlich unterscheidbar; in einigen Fällen ist letztere allerdings nur von einer transversalen Reihe kleiner Schuppen angedeutet. Zwischen den kleinen hexagonalen Kehl- und Halsschuppen ist kein großer Unterschied wahrnehmbar, denn die Kehlschuppen sind nur etwas länger als die dahinterliegenden Halsschuppen. Das vollkommen ganzrandige und nur äuferst schwach bogige Halsband besteht aus 9 bis 11 mittelgrolien Tafeln, von denen die mittlere etwas gröfer erscheint als die übrigen. Das Brustdreieck enthält 3 bis 8 Schilder. Die Bauchtafeln stehen in 6 Längs- und in etwa 25 Querreihen angeordnet; dic Randschildchen sind bisweilen sehr klein. Die grofe Analtafel ist mit Ausnahme des Hinterrandes rund herum von 2 Reihen Schuppen umgeben, von denen die dem Anale näher liegende Bogenreihe aus 6 bis 8 gröferen Schuppen besteht. Die Rückenschuppen sind glatt, öfters mit einem kleinen Grübchen versehen. Die Konfiguration der Schuppen ist variabel; sie erscheinen sechs-, fünf- und vierecking und außserdem unregelmäßig geformt. In der Nackengegend sind sie mehr rund, klein und körnig, gegen den Schwanz zu länglich, sechseckig und spurweise gekielt; 3 bis 4 Querreihen von Dorsalschuppen gehen auf je ein Bauchschild; ich zähle in der Mitte des Rückens etwa 71 Lïngs- und bis 142 Querreihen von Schuppen. Die hinten vollkommen gerade abgestutzten, oder äufäst schwach gerundeten, länglichen, vicreckigen Schwanzschuppen sind oberhalb stumpf gekielt, unterhalb vorn glatt, hinten spurweise gekielt. Die Zahl der Caudalschuppengürtel variert zwischen 74 und 90. Die Unterseite der längsten Zehen sicht zuweilen wie gekielt aus, bei näherer. Untersuchung nimmt man aber wahr, dalis dies lediglich nur durch Abnutzung der einen Seite der Schuppe verursacht wird. 


\section{$-272-$}

Femoraldrüsen und Zälıne.

Die Zahl der Schenkeldrüsen varijert zwischen 17 und 27. - Der Oberkiefer hat jederseits 17 Zähne, der Unterkiefer 24; am Zrischenkiefer zähle ich 7 bis 8 Zähne. Die vorderen Zähne sind stumpf-kegelförmig, die hinteren zeigen eine schwache Einkerbung. Die Pterygoïdea entbehren der Bezahnung.

Farbenkleid.

a). - Den hellgrïnen Fond durchziehen beim $20 \mathrm{~cm}$ langen Männchen breite, geschlängelte, schwarze Querstreifen, welche sich namentlich an den Körperseiten verästeln, incinander verschmelzen und ein Netzwerk bilden. Zuweilen findet cin gegenseitiges Zusammenfließen der Querbinden vermittelst sehr feiner Verzweigungen der Länge nach statt. Auf den Rumpfseiten, wo die schwarze Zeichnung üppig entwickelt ist, tritt der Untergrund in Form von kleinen, unregelmälig gestalteten Flecken oder Ocellen auf, welche von Helloraun umrandet erscheinen. Gegen den Bauch zu, auf den Flanken verdrängt das Hellbraun die schwarze Zeichnung gänzlich. Eine Längsreihe blauer Augenflecken befindet sich gewöhnlich auf der Bauchgrenze. Besonders intensiv blau gefärbt treten letztere in der Gegend der Hinterbeine beim Männchen auf und stellen wohl sekundäre Sexualcharaktere vor. Seitlich ist die Schwanzwurzel gleichfalls blau gesprenkelt; ferner erhalten die äukeren Ventralia dunkelblaue und schwarze Makeln auf rosaweifem Grunde. Beim Weibehen, deren Grundton aller oberen Körpergegenden dunkelgrün erscheint, fehlt die blaue Fleckung entreder gänzlich, oder sie ist nicht so intensiv als beim Männchen. Dagegen aber ist die Unterseite des Körper's bei ersterem viel schöner koloriert; sie zeigt nümlich eine prachtvolle rosa Tinte, die in der Medianzone des Bauches und auf der Kehle in Mennigrot übergeht. Der Pileus ist bei beiden Geschlechtern mehr oder weniger dunkelgrün, schwarz und braun gesprenkelt; die Schläfe und Kieferschilder sind abwechselnd dunkelbraun, schwarz und grünlich koloriert. Die Oberseite der Vordergliedmafen ist grün mit dunkelbraunen Ringflecken versehen. Das hintere Extremitätenpaar ist gleichfalls oben grün, von schwarzen oder dunkelbraunen Zickzackliuien durchzogen. Die vordere und obere Partie des Schwanzes ist namentlich beim Männchen lebhaft grün gefärbt und mit Blau und Braun betupft. Gegen die Spitze zu nimmt das Braun überhand. Die Schwanzunterseite ist rosaweif, rosa oder mennigrot. - Diese Farbenvarietät ist im VizzavonaWalde auf Korsika gefunden worden.

b) - Eine in der Focce di Vizzavona seln selten vorkommende Form ist diejenige, bei welcher der grüne oder dunkelgrüne Untergrund dermaken durch die üppigr entwickelten Zeichnungen verdrängt wird, daß er in Gestalt von kleinen Augenflecken zum Vorschein kommt. 
c) - Bei den auf lem Mite. Renoso bei Bastelica cinheimischen $L$. Bedriagae ist die Grundfarbe hellnubibraun; sie tritt entweder in Gestalt von augenartigen Flecken auf, welche von einem auf der Rïckenzone schwarzen, auf den Seiten aber dunkelbraunen Netzwerke eingeschlossen erscheinen, oder in Form von unregelmäligen, die Breite durchziehenden Binden, welche durch öfters ebenso breite schwarze Querbinden voneinander getrennt werden. Bei anderen Stücken ist der Grundton vorn bis auf wenige Ocellen reduziert, während die hintere Partie der Körperoberseite schwarze oder dunkelbraune Zickzacklinien und weniger eng aneinander liegende Hieroglyphen auf braunem Fond zeigt. Das Dessin dieser Form stimmt mit demjenigen überein, welches in Archiv f. Naturg. 46. Jahrg. Taf. XI abgebildet worden ist. Die Oberseite des Kopfes, der Gliedmalisen und des Schwanzes und endlich die Wangen sind auf hellbraunem Grunde schwarz und braunschwarz punktiert und gemarmelt. Der Bauch, die Unterseite der Beinchen und des Schwanzes zeigen einen tiefrostbraunen Anflug. Die Kehle ist gleichfalls rostbraun und mit ringförmigen dunkelgrauen Zeichnungen bedeckt.

Die untersuchten jungen Individuen übertreffen die alten an Schönheit. Ihre Farben sind allerdings nicht so intensiv wie bei deu letzteren, lie Verteilung der Tinten aber und die Zeichnung ist so mannigfaltig und zierlich, daßj man nach dem Pinsel greifen möchte, um die Tierchen abzumalen. Die Jungen der grünen Varietät der Bedriagae kenne ich leider nicht, sie waren zur Zeit, als ich mein Zelt in Bocognano aufschlug und im Walde zu Vizzavona jagte, noch nicht sichtbar. In Bastelica dagegen hatte ich Gelegenheit, etliche junge Stücke der braunen Form im September zu sehen und zu erbeuten. Es sind circa $13 \mathrm{~cm}$ lange Exemplare. Ihre hellbraune Rückenzone tritt in Form von Augenflecken auf; jeder dieser Ocellen faßst ein winziges grüngelbes Fleckchen ein. Gegen die Rumpfseiten hin nehmen die Augenflecken an Größse zu, namentlich werten die grüngelben Fleckchen der Rückenzone auf den Seiten gröfer und erscheinen hier grün; sie nchmen eine runde Gestalt an, verdrängen das auf der Rückenzone vorherrschende Kolorit der Ocellen und werden somit von letzteren nur eingerahmt. Bei oberflächlicher Betrachtung des Tierchens glaubt man, dafi die Augen durch schwarze Zwischenräume völlig voneinander getreunt seien; dies ist aber nicht immer der Fall, bei näherer Untersuchung überzeugt man sich, dafis die Ocellen meistens von einem dunkelbraunen Kolorit, das etwa in halbhreisförmigen Figuren auftritt, unvollständig umrahmt werden, und dafs sie folglich miteinander in Verbindung treten. In der Caudalregion erscheinen die Ocellen weniger zahlreich. Zwischen den hier vorhandenen dunkelbraunen Querstreifen haben die Augenflecken wenig Raum sich auszubreiten; rückwärts von der Schwanzwurzel sind sie nicht nehr sichtbar. Die grüne Farbe ist nur noch auf den freien Rändern der oberen 
Schwanzschilder vertreten. Der Schwanz, mit Ausnahme seiner metallgrünen Spitze, erscheint grün und braun gebändert. Die Schädeldecle ist grünlich braun, braun gezeichnet. Die Zeichnungen sind überhaupt sehr symmetrisch verteilt. Die Hinterbeine sind oben heller gefärbt und weniger scharf gezeichnet als die Vordergliedmaken; sie sind hellbraun mit graugrünen Ocellen bedeckt, während die Vorderbeine auf dunkelbraunem Fond gelbgrüne Augen aufweisen. Die Körperunterseite, mit Ausnahme der Kehle und der Vorderbeine, welche auf grünlichweißem Grunde braun und schwarz gemarmelt erscheinen, ist lebhaft mennigrot, rosa oder grünlichgrau. Die erste und äußerste Ventralschilderreihe ist blau und schwarz gefleckt. Die an die Bauchtafeln grenzenden Schuppen sind öfters blau koloriert.

Vorkommen.

Sicher konstatiert ist die Bedriagae auf Korsika, wo sie vorzugsweise an den Abhängen des Monte Renoso bei Bastelica, im Vizzavona-Walde und auf dem Monte Cinto angetroffen worden ist. In der Umgegend von Bocognano, längs des Gravona-Flusses kommt sie ebenfalls vor, aber viel seltener als im hohen Gebirge. Die grofe Hitze scheint diese Art nicht ertragen zu können, denn sie wird auf Korsika nicht unter 700 M. über Meeresspiegel angetroffen ${ }^{1}$ ), dabei werden kühle und bewaldete Örtlichkeiten von ihr bevorzugt, wo sie nämlich weniger Aussicht hat, im Sommer an Wasser- und Feuchtigkeitsuangel zu leiden. L. Bedriagae mufs als Bewohnerin nördlicher Klimata gelten und könnte wohl in Süddeutschland, wo mir der Winter übrigens milder als in Bastelica zu sein scheint, sehr gut fortkommen.

Über die Lebensweise, sowie auch über das Gerippe dieser Species habe ich unlängst ausführlich berichtet. Zum Schlufs möchte ich bemerken, dą die Bedriagae eine der gröften Seltenheiten in unseren Museen ist; nicht nur wird sic in mancher grofstädtischen Sammlung vermist, sondern auch von vielen gar nicht gekannt.

Auf dem Korsika benachbarten Sardinien ist sie bis dato noch nicht nachgewiesen worden, obschon es leicht möglich ist, daß3 sie dort ebenfalls einheimisch ist.

\section{Lacerta graeca $\mathrm{m}$.}

Char. - Sc. occipitale plerumque longius latiusque scuto interparietali. Sc. frontale satis longum et latum. Scuta nasofrenalia duo, superposita. Sc. supralabialia anteriora 5. Sc. massetericum nullum, sc. tympanicum adest, tempora squamata. Sc. parietalia nargine externo scuto proportionaliter parvo oblongo angusto limbata. Sulci gularis vestigium. Collare inte-

$\left.{ }^{2}\right)$ Nach brieflicher Mitteilung ron Dr. C. Forsyth Major geht diese Art auf Korsika bis zur höchsten Spitze der Insel, so z. B. ist sie auf dem MIte Cinto in der Höhe von $2710 \mathrm{~m}$ erbeutet rorden. 
grum, parvis scutellis compositum. Scutil abdominalia in sex series longitudinales disposita. Squamae dorsales laeves, satis planae, in partem posteriorem subconvexac. Dentes palatini nulli. Pori femorales utrimque 22-24. - Caput satis depressum, in regione temporali amplificatum. Truncus latus depressusque. Pedes postici axillas attingentes vel paulo breviores. Cauda in basj dilatatil, al apicem versus tenuissima, corporis longitudinem plus duplo superans.

- Longitudo: $226 \mathrm{~mm}$.

\section{Synonymie.}

Lacerta oxycephala var. modesta, maculata v. Bedriaga, Die Amphibien u. Reptilien Griechenlands in: Bulletin de Moscou, No. 3 (1881), pag. 80.

Körpergestalt und Größre.

Der Kopf ist ziemlich niedergedrückt, seine Breite verhält sich zu seiner Länge fast wie $2: 3$; die Oberfläche ist am Scheitel vollkommen platt, von den Augen nach vorn zu sanft abfallend; in der Backengegend erscheint der Kopf am breitesten, nach vorn zu ist er allmählich (ठ) oder ziemlich rasch (q) verschmälert; dicht vor den Augen, also in der Freno-oculargegend sind die Kopfseiten schwach vertieft, über den Augen ist mitunter eine schwach ausgepräigte Wülbungr konstatierbar. Der Rumpf ist breit und abgeplattet; der Hals gleichfalls breit und sehr lang. Die Vorderbeine sind verhältnismäfßig kurz, die vorderen nie über das Freno-oculare, die hinteren nicht viel über die Achseln hinausreichend. Bei einigen Exemplaren erreichen die vorderen Beine den Vorderrand der Augenhöhle, während die hinteren, an den Körper angelegt, die Achseln berühren. Bei den Weibchen scheinen die Beine, namentlich die hinteren, in der Regel etwas kürzer zu sein als beim IIännchen. Der sehr dünn auslaufende, beim Männchen an der Wurzel ziemlich stark erweiterte Schwanz überschreitet die Körperlänge um mehr als das Doppelte. Ferner ist bei den Männchen der Kopf — namentlich in der Schnauzengegend - bedeutend länger und höher als bei den Weibchen. L. graeca scheint die grökten Lïngenmatie miter allen his jetzt bekimnt gewordenen platycephalen Fidechsen zu erreichen.

Maße in mm. - †. Gesamtlänge: 239; Länge d. Kopfes: 18,3, d. Halses: 14, d. Rumpfes: 55, d. Schwanzes: 166, d. Vorderextremität: 24, d. Hand mit den Fingern: 10, d. Hinterextremität: $40-\downarrow 1$, d. Fufies m. d. Zehen: 17 ; gröfrt. Breitendurchmesser d. Ǩopfes: 11,5; Kopfhöhe 8-8,3; Breite d. Pileus an d. Ansatzstelle: 7,5; Umfang d. Kopfes: 36, d. Halses: 37 , d. Rumpfes: $38-40$, d. Schwanzes an d. Basis: 27,5, in d. Mitte: 11,5. - $q$. Gesamtlänge: 199-200, Längre d. Kopfes: 13,3, d. Halses: 10-11, d. Rumpfes: 46, d. 
Schwanzes: 140 , d. Vorderextremität: 19 , d. Hand m. d. Fingern: 8,5, d. Hinterextremität: 31, d. Fufes m. d. Zehen: 16; Kopfloreite: 8,7, Kopfhöhe: 6,5; Breite d. Pileus: 6,3 ; Umfang d. Kopfes: 26,5 , d. Halses: 27 , d. Rumpfes: 35 , d. Schwanzes an d. Basis: 22 , in d. Mitte: 11. $\ddot{A}$ ufere Körperbedeckung (Vergl. meine Taf. Fig. 12 und 20).

Das Occipitalschild ist in der Regel, namentlich bei den männlichen Individuen, bedeutend länger und auch breitel als das Interparietale; es hat etwa die Gestalt eines Dreiecks, dessen nach vorn gerichtete Spitze gerade abgestutzt ist. Auf das Occipitale folgt das kleine, fünfeckige, hinten gerade abgestutzte, vorn in stumpfem Winkel zwischen die langen, fünfeckigen Frontoparietalia eingeschobene Interparietale. Die diese Schilder seitlich umgebenden Parietalen sind hinten und vorn gerade und an den seitlichen äuferen Rändern abgerundet; ihr Innenrand besteht aus 3, unter stumpfem Winkel zusammenstobenden geraden oder äuferst schwach abgerundeten Kanten. Die 4 über den Augen liegenden Tafeln sind leicht emporgehoben und durch eine feine Körnerreihe von den sieben kleinen Supraciliaren getrennt. Was nur die einzelnen Schilder anbetrifft, so haben die beiden mittleren, den Palpebraldiscus bildenden Tafeln etwa die Gestalt zweier Dreiecke, an deren jedem der nach vorn und hinten gerichtete Winkel abgestutzt ist; zwischen diesen beiden Schildern und einerseits der Parietal- andererseits der Frontonasal-Tafel liegen die äufaeren, schmalen Supraocularia, von denen die hintere etwas größer ist als die vordere. Das frontale ist vorn ziemlich breit, nach rückwärts verengt und in eine kurze, zwischen die Frontoparictalia eingeschobene Spitze ausgezogen; seine seitlichen Kanten sind bogenförmig ausgerandet, seine vorderen, an die sechseckigen Frontonasalen greuzenden Ränder vereinigen sich im Bogen oder stoßen unter stumpfem oder spitzem Winkel zusammen. Das Internasale ist entweder rhombisch oder gleicht etwa einem Kreisausschnitte, dessen Spitze uach hinten gerichtet ist. Das ziemlich grofe, seitlich liegende runde Nasenloch ist vorn und oben vom Sc. supranasale, hinten und oben von 2 übereinander gestellten Nasofrenalia und endlich unten vom ersten Supralabiale umgeben. Auch das Rostrale beteiligt sich öfters an der Imrandung des Nasenloches. Auf die Nasofrenalia folgt das vier- his fünfseitige kleinere Frenale sowie auch das größsere, vorn verschmälerte, hinten erweiterte Freno-oculare. Supralabialia finden wir 7 bis 8 jederseits, von denen das fünfte (von vorn gerechnet), breiteste und oben ausgerandete Schild das Suboculare repräsentiert, welches, nebenbei bemerkt, vorn durch eine långliche schmale Tafel vom Freno-oculare getrennt ist; auch nach rückwärts erscheint es von einem, als Praeoculare bezeichneten Schildchen begrenzt, das sich durch seine Grötie von den kleinen, meistens sechskantigen Temporalia unterscheidet. Das Massetericum fehlt; das große, länglich eiförmige, hinten und vorn bogige Ohr ist vorn oben von einem länglichen Tympanicum 
begrenzt; am äußeren Parietalrand ist meistens nur vorn cine gröbere länglich schmale Tafel sichtbar; der hintere Augenrand ist ron einer Bogenreihe allmählich nach unten kleiner werdender schuppenartiger Schildchen begrenzt. Sublabialschilder finden sich jederseits 6 , in seltenen Fällen 7 oder 8; von den 5 P'aar Submaxillaren, zwischen denen die ziemlich grolsen längeren als breiten Kehlschuppen liegen, ist das vierte das gröbte; die vorderen 2 Paare stoken ihrer ganzen Länge nach in der Mittellinie des Unterkopfes zusammen, während die das dritte Paar bildenden Unterkiefertafeln sich nur partiell gegenseitig berühren. Die Kehlfurche ist durch 1 bis 3 transversale Reihen winziger Schüppchen angedeutet; die dahinter liegenden Halsschuppen sind rundlich hexagonal und werden nach rückwärts zu gröfer. Die Anzahl der meistens etwas längeren als breiten Tafeln am ganzrandigen Collare variiert von 9 bis zu 13; ein mittleres grölseres Schild fehlt in der Regel. Auf der Unterseite des Rumpfes finden sich 6 Längs- und 26-28 Querschilderreihen, von denen die äukeren und mittleren sich durch ihre etwas geringere Größse von den dazwischen liegenden unterscheiden; sämtliche echten Ventralen sind viereckig und nahezu parallelseitig. Das Brustdreieck enthält 6 bis 7 schmale Tafeln. Das doppelt so breite als hohe Anale zeigt einen wenig gekrümmten bogigen Vorderrand und ist durch 2 Bogenreihen von Schuppen begrenzt, von denen die diesem Schilde zunächst liegenden bedeutend gröber sind als die sich dahinter befindenden. Die sogenannten Randschildchen an den äuferen Ventralen fehlen gänzlich oder treten nur als etwas vergrößserte Schuppen auf. Die Oberrumpfschuppen sind ziemlich flach und mit Ausnahme derjenigen am Hinterrücken, welche eine schwach ausgeprägte rinnenartige Vertiefung aufweisen, glatt; längs der Mitte des Rückens sind sie fünf- und sechseckig, länglich schmal, gegen die Rückenseiten hin erscheinen sie hingegen breiter, d. h. ebenso breit als lang und rundlich hexagonal; nuf diese letzteren möchte ich die Aufmerksamkeit des Lesers besonders lenken, denn sie sind die größten Rumpfschuppen; gegen den Bauch hin erscheinen sie bedeutend kleiner und nehmen eine uuregelmäfige Gestalt an. Die Nackenschuppen sind gleichfalls verhältnismäßjig sehr groß3, rundlich hexagonal und leicht gewölbt; es sind im ganzen etwa 132 Quer- und ungefähr 55 Längsschuppenreihen vorhanden. Die Hinterränder der Pileusschilder sind von einer zierlichen perłschnurförmigen Querreihe winziger Schuppen begrenzt. Was endlich dic beim Jännchen in 112, beim Weibchen in etwa 120 Quergürteln angeordneten Caudal. schuppen anbelangt, so sind die oberen gleichseitigen Schuppen nit stumpfen, aber stark hervorragenden Kielen versehen; die Seitenteile der Schuppen erscheinen stark eingedrückt; die unteren Caudalschuppen sind vorn glatt, nach hinten zu gekielt und stumpfwinklig ausgezogen, während alle übrigen Schuppen gerade abgestutzt erscheinen. 
Schenkeldrüsen und Zähne.

Die Anzahl der Schenkeldrüsen beträgt 22 bis 24. Die Zahl der Zähne ist: im Zwischenkiefer 6 oder 7, im Oberkiefer, eine Seite, 15 bis 16, im Unterkiefer, eine Seite, 17 bis 18. Gaumenzähne fehlen.

Farbenkleid.

Vollkommen einfarbige, oberhalb hellbraun oder gelblichbraun kolorierte Stücke sind selten und scheinen vorzugsweise beim weiblichen Geschlecht vorzukommen, während die auf dem Rücken spärlich und an den Seiten üppig dunkelbraun gezeichnete Form häufiger ist. In den meisten Fällen ziehen sich am Rücken entlang 2 bis 4 Reihen runder Fleckchen oder Punkte hin, welche auf graubraunem Grunde in ziemlich grober Entfernung voneinander angeordnet sind. Die Seiten des Kopfes, Halses und Rumpfes, sowie auch die Oberseite der Beine sind auf braunem Fond mit vielen rundlichen und kleinen, dunkelbraun umrandeten, weiblichen oder graubraunen Flecken besetzt. Die Schwanzoberseite ist fast fleckenfrei graubraun, uur an der Caudalwurzel zeigen sich etliche dunkle Fleckchen. Wenn die Rückenflecken sich vermehren und sich der Quere nach anordnen, um teilweise miteinander zu verschmelzen, so entsteht die schöne quergebänderte Form, welche sowohl ihres gesättigten Grundkolorits, als auch der üppigen Zeichnung wegen sofort auffält. Ihre Grundfarbe ist nämlich schön helluufbraun oder kistanienbraun, waihrend die Querzeichnung dunkelbram erscheint. Das Dunkelbraun, das bei der zuerst erwähnten Form blok als schmale Einfassung der hellen Fleckchen an den Rumpfseiten sich bemerkbar macht, verdrängt bei dieser Farbenvarietit nahezu gänzlich den hellen Untergrund, während die in 4 bis 5 Längsreihen angeorlneten Augenflecken sich in bedeutendem Mafe aufhellen und bald weif mit einem Stich ins Braune, bald weif mit einem blauen oder grünlichblauen Anfluge erscheinen und sich auf diese Weise vom dunklen Fond scharf abheben; namentlich nehmen sich die oberhalb der Insertion der Vorderbeine sich befindenden Augenflecken besonders prächtig aus; sie sind nämlich stets hellblau oder blaugrüu und in der Regel grölser als die ihnen benachbarten. Die Kíopfseiten sind gleichfalls, namentlich an den Kieferrändern, auf dunkelbraunem Grunde gelblich oder gelblichgrün gefleckt. Grünlichweibe oder hellbrane, dunkelbrann eingefacte, runde Flecken zicren die Oberseite der Gliedmafen. Dunkelbraune Makeln erscheinen vorn auf der Oberseite des Schwanzes verteilt; auf den Schrranzseiten gesellen sich ihnen grünlichweife Flecken hinzu. Sowohl bei dieser Farbenvarietät als auch bei der vorigen ist die Rückenfläche des Kopfes mehr oder weniger lebhaft hellnubbraun gofirbt, bald einfarbig, bald aber, wenu auch nur spurweise, dunkelbraun gepunktet. IIit Ausnahme der äußersten, blau oder dunkelbraun gefleckten Bauchschilder- 
reihen erseheint der Bauch cinfarbig citronengelb oder bläulichweif, nur die Kehle ist zuweilen mit einigen dunkelbramen Punktflecken besetzt; die Schwanzunterseite ist stahlgrau oder hat einen bläulichen Anflug.

Vorkommen.

Auf der Balkanhalbinsel ist $L$. gracca, wie es scheint, nur auf den Stiden von Peloponnes angewiesen. Meine Excmplare, die ich der Vermittelung Dr. Krüpers verdanke, stammen aus dem Taygetos-Gebirge und zwar aus der Nähe Kalamatas. Ob die in Transkaukasien von Wagner erbeutete und von Berthold als $" L$. oxycephala bestimmte Eidechse auf die uns hier interessierende Species zurückzuführen ist, kann ich nicht entscheiden. Kessler zweifelt an der richtigen Determination des betreffenden Wa gnerschen Individuums einmal, weil seit Wagner es noch niemand geglückt ist, die oxycephala (d. h. die dalmatische) in Transkaukasien zu entdecken und dann weil nichts Nïheres üher den Fundort jener W a gnerBertholdschen Eidechse bekannt geworden ist' ${ }^{1}$.

\section{Lacerta perspicillata D. B, 1839.}

Char. - Sc. occipitale interparietali brevius sed latius. Sc. frontale latum, mediocriter longum. Scuta nasofrenalia duo, superposita. Discus palpebralis in margine externo serie granorum limbatus. Supralabialia anteriora 5. Tempora granosa, disco masseterico nullo, scutis majoribus ad marginem parietalium nullis. Sc. tympanicum parvum. Sulcus gularis distinctus. Collare integrum. Sc. abdominalia per series decem disposita. Squamae dorsi magnae, rotundatae, vix carinatae. Dentes palatini nulli. Pori femorales utrimque 18-19. Caput parvum, posticum latum. Truncus latus et abbreviatus, depressus. Pedes abbreviati, graciles, postici ad axillas non contingentes. Cauda brevis, corpore paulo longior. - Palpebra inferior pellucida. - Longitudo $150 \mathrm{~mm}$. -

Synonymie.

Lacerta perspicillata Duméril et Bibron, Erpetologie générale, t. V, pag. 249. - Gui chenot, Hist. nat. des Reptiles et Poissons in: Exploration scientifique de l'Algérie etc. Zoologie p. 11, pl. I, fig. 3 a, b, c, d. fig. 4. - C. Duméril et A ug. Duméril,

$\left.{ }^{1}\right)$ Eine andere, gleichfalls von Berthold als neue Art, und zwar als L. hieroglyphica bezeichnete und von einigen Fachgenossen in die Synonymie der oxycephala (Schleg. Fitz. D. B.) versetzte Eidechse aus Konstantinopel gehört, meiner Ansicht nach, zu L. muralis neapolitana; auch die von Kessler pait der oxycephala verglichene $L$. Portschinskii hat sich als eine braune Mauereidechse herausgestellt. Die bei R at hke (Bciträge z. Fauna d. Krym, l. c. als L. grammica Licht. beschriebene Eidechse scheint eher einer Art aus der Gruppe der spitz- und plattköpfigen Lacerten anzugehören. 
Catal, méth. collect. Reptiles. Paris 1851. - Gervais in: Anu. des sc. nat. III.

Série, X. p. 204 (1848). - Lallemant, Erpétologie de l'Algérie etc. - Strauch, Erpétologie de l'Algérie in: Mém. de l'Acad. Imp. des Sc. de St. Petersbourg, VII. Série, t. JV. Boulenger, in: Proc. Zool. Soc. Lond. 1881, p. 743.

Thetia perspicillata Gray, Cat. Liz. Brit. Mus. pag. 32. London 1845.

Scelaris perspicillata Fitzinger, Systema reptilium. I. Wien 1843.

Lacerta perspicillata unterscheidet sich bekanntlich von ihren übrigen Geschwistern hauptsächlich durch die Beschaffenheit ihres unteren Augrenlides, das hell und durchsichtig ist und den Augapfel deutlich durchschimmern lälist, also ähnlich wie es bei den Euprepes-Arten der Fall ist. Obschon diese Eigentümlichkeit bei dieser Art anfangs frappiert und manchen Herpetologen bewogen hat, die propricillata als Repräsentantin einer besonderen Sektion zu betrachten ${ }^{1}$ ), so glaube ich dennoch darin nicht etwas besonders Auferordentliches erblicken zu müssen, denn die Untersuchung des Augenlides bei einer ganzen Serie von Eidechsen hat mir gezeigt, daßs bei denjenigen Species, welche einen schwarzen Fleck auf dem unteren Augenlid aufweisen, die Lider dünnhäutig sind, was aber wegen der schwarzen Farbe nicht auffällt. Duméril und Bibron zufolge soll das durchsichtige Lid bei perspicillata und bei anderen Reptilien insofern zweckmälaig sein als die so beschaffenen, geschlossenen Lider das Sehvermögen des Tieres nicht beeinträchtigen, dabei aber die Augen vor dem Eindringen von Sandkürnchen und derartigem schützen; darin muß man den Verfassern der generellen Herpetologie zustimmen, sobald man sich die von diesem 'Tiere bewohnten Lokalitäten vergegenwärtigt. A uf meinen Jagdaustlügen in Spanien hatte ich öfters Gelegenheit, Sandechsen und Amphisbaenen aus dem Sande oder aus Schutt, dessen Aufscharren ganze Staubwirbel verursachte, zu holen und habe mich dabei überzeugen können, daß̧ die durchsichtigen Augenlider bei ersteren und die über die Augen hinwegziehende dünne Körperhaut bei letzteren den Sehorganen dieser Tiere als Schutzmittel dienen müssen.

Körpergestalt und Gröl̉e.

Die Jännchen, namentlich die ausgewachsenen, zeichnen sich durch ihren in der Schläfengegend auffallend breiten Kopf aus; bei den Weibchen hingegen ist der Kopf schmäler und scheint infolgedessen auch länger als beim Männchen zu sein. Die beim Männchen ziemlich

1) So haven z. B. Duméril und Bibron für die perspicillata eine besondere, aber nicht näher bezeichnete »Gruppe aufgestellt. Gra y, welcher bekanntlich eine besondere Vorliebe für die Gartung Lacerta bekundet hat, indem er lieselbe in unzählige Genera zersplitterte, kreierte für die uns hier interessierende Species den Genusnamen o Thetias. 
kurze, beim Weibchen etwas lingere und schmälere schname ist bei beiden Geschlechtern vorn abgerundet. Die Vorderteile der Kopfseiten fallen nahezu steil ab; dabei sind die Nasenöfinungen so weit nach aufwärts gerückt, dafis sic auch auf der Oberseite des Ropfes vollkommen sichtbar sind. Der mit zahlreichen Faltenhildungen versehene Hals hat einen grölseren Umfangr wie der Kopf. Der Rumple ist gleichfalls breit und weniger schlank als e's sonst bei den meisten Eidechsenarten der Fall ist; oben arscheint der liumpf stark abgreplattet allerdings mit Ausnahme der Mittelzone, welche dadurch, dab die oberen Dornfortsiitze an der Wirbelsäule stark entwickelt sind, hervortritt. Ilichst wahrscheinlich verursachen lange, nur schwach bogenförmig gekrummte Rippen die so auffallende Abplattung des Rumpfes. Der allmählich in eine nicht allzu dünne Spitze ausgezogene Schwanz ist an der Wurzel ziemlich dick. Nach den Abbildungen bei Guichenot zu urteilen, erreicht der Schwanz eine unbedeutende Länge; bei der sub. No. 3 bildlich dargestelten prespicillatı ist der Schwanz etwa anderthalbmal so lang wie der Körper; in Fig. 4 hingegen nimmt der Schwanz beinahe die Hälfte der Gesamtlänge des Tieres ein. $\mathrm{Zu}$ meinem Bedauern sind bei sämtlichen mir zur Verfügung stehenden Exemplaren dieser Eidechse, welche aus der Lat asteschen Ausbeute stammen, die Schwïnze abgebrochen. Die Extremititen sind schwach entwickelt; sie sind kurz, namentlich beim Männchen, so reichen z. B. beim Weibchen die Vorderextremitäten bis zu den Nasenüfnungen, bei den Männchen hingegren sind sie kaum im stande die Vorderränder der Augen zu berühren. Die Hinterbeine können bei beiden Geschlechtern die Achseln nicht crreichen.

Nach dem Bilde Guichenots zu urteilen, erreicht die perspicillata ungefähr die Länge von $150 \mathrm{~mm}$, wovon etwa $14 \mathrm{~mm}$ auf den Kopf und etwa $94 \mathrm{~mm}$ auf den Schwanz kommen. Bei dem mir vorliegenden Individuum beträgt dic Länge des Kopfes 10,7 mm, die Höhc 5,7 und die Breite $7 \mathrm{~mm}$. Kopfumfang: $22 \mathrm{~mm}$, Breite des Pileus: 5,2 mm, Halslänge: 5-6 mm, Halsumfang: $23 \mathrm{~mm}$, Rumptlänge: $40 \mathrm{~mm}$, Rumpfunfang: $32 \mathrm{~mm}$, Länge der Vorderextrenitä : $16 \mathrm{~mm}$, der Hand mit den Fingern: 7,2 mm, der Hinterextremität: $23 \mathrm{~mm}$ und des Fulies unit den Zehen: $12 \mathrm{~mm}$.

Schilder und Schuppen.

Das Occipitale ist in der Regel trapezförmig, selten hat es parallele Kanten; es ist kürzer, aber breiter als das stets fünfeckige, langliche uni schmale Interparietale. Die mit vier inneren, geraden und zwei äuferen, leicht abgerundeten Kanten versehenen, länglichen und ziemlich schmalen Pinietalia sind seitlich von etwa 6 klein'n sichuppehen begrenzt. Diese Schuppchen sind nur doppelt oder dreimal so frobs wie die aldrigen schwach gewölbten hexagonalen Temporalia. Die zwei, verhailtnismälijgr kleinen, vorn und hinten abgerundeten und gewölbten mitt- 
leren Supraocularia werden zu beiden Seiten der Parietalia durch ein breites aber kurzes Schildchen, welches dis Supraoculare IV vorstellt, getrennt. Die vordersten ersten Oberaugenschildchen sind hingegen meistens klein und weichen nicht von denjenigen bei anderen LacertenArten ab. Die Palpebralscheibe wird von den länglichen, schmalen Supraciliaria durch eine Reihe winziger Schüppchen getrennt. Das breite Frontale ist nicht viel länger als die Lïngsachse der Frontoparietalia oder des Interparictale; vorn, hinten und seitlich sind seine 6 Kanten leicht ausgerandet. Die Frontonasalia sind hingegen lang und enden vorn und hinten ziemlich spitz; mit den seitlichen längsten Kanten berühren sie die Freno-ocularia; mit den vorderen kurzen und mit den vorderen langen Rändern stofen sie an die trapezförmigen, nach oben leicht äbergewölbten Frenalia und an das ansehmliche, nach vorn und nach hinten spitz endende Internasale; mit den hinteren Rändern grenzen sie an das Frontale und endlich mit ihren inneren, ziemlich langen Kanten treten sie miteinander in Kontakt. Auf beiden Seiten stehen zwei Nasofrenalia übereinander, von denen das obere und zugleich das kleinste, länglich-fünfeckig oder länglich-oval gestaltete Schildchen soweit nach oben gerückt ist, daß3 es zu den Pileustafeln gerechnet werden könnte. Sowohl das kleinere als auch das grölzere Nasofrenalschildchen umranden das Nasenloch von hinten. Der hintere Rand des Sc. supranasale ist stark ausgerandet. Das auf die Kopfoberseite meistens schwach übergebogene Rüsselschild ist nicht sehr breit. Es sind 5 oder 6 schmale, aber ziemlich hohe vordere Sc. supralabialia vorhanden, von denen das erste und letzte am breitesten entwickelt zu sein pflegen. Das Supralabiale I grenzt nicht immer direkt an das Nasenloch an. Das untere Nasofrenale ruht zum Teil auf dem ersten und zum T'eil auf dem zweiten und dritten Supralabiale, wïhrend das Frenale teilweise auf dem zweiten und dritten Oberlippenschilde ruht. Das Freno-oculare ist kleiner, als es sonst bei den Eidechsen. der Fall ist; vorn ist es abgerundet, oben und unten mit geraden Rändern und hinten mit 2 leicht ausgerandeten Kanten versehen, welche unten an das ziemlich anselmliche, vorn abgerundete Praeoculare grenzen, das hinten etwas schmäler ist als vorn. Auf das nicht sehr breite Suboculare folgen nun uach hinten $z u 2$ bis 3 kleine Supralabialia und 2 grörsere, in der Regel gewölbte Postocularia. Lis ist keine Spur von Massetericum vorhanden; das Tympanicum erscheint als eine längliche, schmale und nicht gebogene, am vorderen oberen Rande der Ohröffnung liegende Tafel. Die Ohrrïnder sind nicht gezähnelt. 6 Sublabialia, 5 Submaxillaria und ein grobes Mentale. Die Kehlfurche, begleitet von einer transversalen Kehlfalte, trennt die vorderen, länglichen hexagonalen Kehlschuppen von den breiteren, hinteren Schuppen. Das ganzrandige, nur an den IIalsseiten leicht gebogene IIalsband besteht aus 11 Tafeln, voll denen nur die mitt- 
leren, - etwa 7 an der Zahl - ziemlich grols sind. Der Bauch ist mit kleinen rechteckigen 'Tafeln, welche in 10 longitudinale und 30 oder 31 transversale Reihen angeordnet sind, bekleidet. In der Achselgegend oder dicht hinter derselben beginnen zu beiden siciten 2 äufiere Lüngsreihen, welche in der Regel aus etwas kleineren Schildchen bestehen, von denen diejenigen, welche an die Schuppen grenzen, leicht grewöibt erscheinen. Grofe Randschildchen sind vorhanden. Das Brustdreieck ist ebenfalls konstatierbar. In der legel grenzen 2 transversale Rückenschuppenreihen an jede Banchtafel; eine dritte Querreihe pflegt sich zwischen die Bauchschilder einzuschieben. Bei oberflïchlicher Betrachtung seheinen die ziemlich ansehnlichen, runden, leicht gewälbten Rückenschuppen ganz glatt zu sein, nimmt man aber cin Vergrölierungsglis zur Hand, so bemerkt man alsbald spurweise angedeutete Kiele. Nach den Flanken hin und gegren die Schwanzbasis zu werden die Schuppen etwas gröber und Hachen sich nicht ab. Die Zahl der Rückenschuppen in einer Querreihe schwankt zwischen 136 und 140; die Zahl der Schuppen in einer Längsreihe beträgt 49. Die Schuppen an der Oberseite des Schwanzes sind zum gröfsten Teil ungekielt, gegen ihre freien Kanten hin ziemlich stark gewölbt und zeigen auberdem dentlich abgerundete freie Rïuder. Nur etliche sichuppen auf der Schwanzwurzel sind gekielt. Es sind ungeführ 74 Quergütel vorhanden. Das ziemlich ansehnliche fünf- oder sechsseitige Anale ist vorn und lateralwärts von 6 bis 8 kleinen, meistens hexagonalen Schildchen umgeben.

\section{Femoraldrüsen und $\mathrm{Z} a ̈$ ln $\mathrm{ne.}$}

Die Zahl der Femoraldrüsen beträgt jederseits 18 bis 19. Nach Duméril und Bibron sollen nur 13 Drüsen vorhanden sein. - Die 17 bis 18 Zähne im Oberkiefer sind zwei- vielleicht auch dreispitzig. Im Zwischenkiefer sitzen 5 cinfache Zähne. Am Unterkiefer zähle ich im ganzen 38 zwei- oder dreispitzige Zähne. Am Gaumen sind keine Zähne vorhanden.

\section{F arbenkleid.}

Die Farbe des Kopfes und des Nackens ist bei den mir vorliegenden Stücken grünlichbraun, diejenige der Oberseite des Rumpfes grünlich- oder metallisch-braun. Dieser Metallglanz mufs wohl bei lebenden Individuen recht intensiv sein, da Guichenot und Stra uch dic perspicillata als »uniformement bronzce bezeichnen. Die Oberseite des Schwanzes erscheint olivenf:rrben oder bläulichgrün. Kehle, Unterseite der Extremititen und der Schwanzwurzel weisen einen bläulichen Ton auf; die soustigen unteren Körperpartieen sind gelblich oder weißlich, vorn am Bauche mit einem grünlichen, seitlich mit einem metillischgliuzenden, rötlichbraunen Antluge. Die Unterseite des Schwanzes ist in der Mitte gelblich, an den Seiten grün- 
lichblau koloriert. Die oben graubraunen Extremitäten erlalten öfters kleine, helle Augenflecken; derartige Flecken sind aulierdem zuweilen auf den Flanken erkennbar und treten sogat auf dem Rücken auf. Diese Zierde ist ein Rest des Jugendgewandes, denn bei den jungen Tierchen ist die ganze Rumpfoberseite reichlich mit hellen Ocellen besäet; es mengen sich aufierdem darunter auch schwarze Punkte. Ob diese Ocelli im Leben kupferfarben erscheinen. kann ich nicht entscheiden. Guichen ot beschreibt nämlich eine »bemerkenswerte Varietï « der perspicillata folgenderweise: „Elle présente une variété remarquable par un très grand nombre de petites taches cuivrées repandues sur le corps et les membres.« Fig. 4 bei Gui. chen ot stellt eine perspicillata dar, deren Rücken ein üppig entwickeltes, olivenfarbiges Netzwerk zeigt; rötlichgelbe Fleckchen füllen die Maschen dieses Netzwerkes aus. Gegen die Schwanzwurzel hin geht das Olivengrün in Grau oder Grauschwarz über. Der metallischgrüne Schwanz ist anfangs schwar, gegen das Ende hin weil gepuuktet. Sowohl dic orangegelben und zum Teil rötlich gefärbten Kopfseiten, als auch jene rote Umrandung des Auges, welche auf dieser Figur zu sehen ist, gehören wohl eher der Phantasie des Zeichners an. Höchst wahrscheinlich zeigt diese Art hinsichtlich der Färbung und Zeichnung eine grobe Veränderlichkeit, denn die von Duméril und Bibron beschriebenen Stücke zeichnen sich insofern von den L at ast eschen aus, als bei den ersteren die Kehle weiG und die Bauchteile schwärzlich koloriert erscheinen.

Vorkommen.

L. perspicillata scheint ausschliehlich der Fauna Algeriens anzugehören. Aber auch in Algerien soll ihı Vorkommen nur auf gewisse Lokalitäten beschränkt sein und ich habe Grund, die Angabe Ch. Lallemants - sie sei an Litorale Algeriens gemein - zu bezweifeln, denı in diesem Fall wären ja unsere Museen reichlicher nit dieser Species versehen als sie es bis dato sind. Die perspicillata soll allerdings in den von ihr bevorzugten öden, weniger von Reisenden, als von den Arabern betretenen Gebirgsörtlichkeiten in größerer Anzahl hausen. So teilt mir z. B. Herr Lat aste, welcher vor kurzem Algerien bereist hat, mit, daf er sie aus der Umgebung von Oran nur vom Berge Santa Cruz besitze. Die Exemplare aus Oran von Guichenot und Strauch dürften ebenfalls aus dem nämlichen Orte stammen. Strauch giebt in seiner Herpetologie Algeriens an, dats er ein Individum dieser Species anch in Philippeville gesehen hat. Das Museum zu Paris besitzt Exemplare angeblich aus Algier (No. 1705); es sind dieselben, welche wir in der Erpétologie générale erwähnt finden. Ob diese Fundortsangabe richtig ist, liumn ich nicht mit. Bestimmtheit sagen; jedenfalls aber scheint mir diese Behauptung mit der Angabe, welche im 1851 erschienenen Catalogue méthodique de la collec- 
tion des lieptiles (I'aris) sich vorfindet, nicht ubereinzustimmen. Nach jenem Werke soll die Ileimat der in Rede stehenden Art Algier sein, in diesem heilit es, dals sie 》les endroits arides des environs d'Oran« bewolme und datis dies die sseule contrée» sei, wo sie gefunden worden ist. ${ }^{1}$ )

\section{Lacerta Galloti. D. B. 1839.}

Char. - Sc. occipitale paulo latius, interdumque longius scuto interparietali. Sc. frontale longum. Sc. nasofrenale unicum. Discus palpebralis in margine-externo serie granorum limbatus. Suprabialia anteriora 5. Scuta parietalia in margine externo pone scuto oblongo maiore nonnullisque scutellis parvis limbata. Tempora parvis scutellis vel squamis tecta. Scutum massetericum et tympanicum. Sulcus gularis non distinctus. Collare integrum. Scuta abdominalia per series 12 dispositil. Squamae dorsales longiores quam latiores, multaunulares, sexangulares, obtuso-carinatae. Dentes palatini. Pori femorales utrinque 29.-30. - Lacertac atlanticae non dissimilis, sed multum maior. Caput magnum, in anteriore parte obtusopyramidale; truncus incrassatus, cylindricus, abbreviatus; cauda non raro abbreviata; pedes postici axillas atingentes. - Longitudo: $330 \mathrm{~mm}$.

S y n o n y m i e.

Lacerta Galloti Duméril et Bibron, Erpétologie générale, t. V, p. 238. Paris 1839. P. Gervais in: Bull. Soc. philomat. de Paris 1839; Reptiles des Iles Canaries etc. in: Hist. nat. des Iles Canaries. S. A. pag. 4, tab. I, fig. 1-5. Paris 1811. Böt ger, Reptilien von Marocco u. v. d. Kanarischen Inseln in: Abhandl. d. Senckenberg, naturf. Gesellsch. IX. Frankfurt a. M. 1874 - v. Bedriaga in: Arch. f. Naturg. XXXXV, Bd. 1. S. 325, Taf. XVIII, Fig. 5a,b. - Boulenger in: Proc. 20ol. soc. of London 1881, p. 743.

Zootoca Galloti (D. B.) Gray, Cat. Liz. Brit. Mus. pag. 30. London 1845.

Elaphores (Lac.) Galloti, Fitzinger, Systema reptilium I. Wien 1843.

Zootoca Derbiana Gray, l. c. pag. 29. (Nach Boulenger, 1. c.)

L. Galloti wurde von Duméril und Bibron zum ersten Male einer Untersuchung unterworfen. Die in der generellen Herpetologie niedergelegte Beschreibung dieser sehr charakteristischen und den Kanarischen Inseln eigentümlichen Eidechsenart erhiclt seitdem Er-

1) Auch in Portendik, Gasser-El-Barka und am Kap Mirik würde diese Art, wenu man sich auf den Verfasser der Faune de la Sénégambie (Paris 1883-85) olune weiteres verlassen wollte, cinheimisch sein. 
gänzungen von Gervais, Böttger und von mir selbst. Durch die Liberalität der Herren Cornalia und Dr. Moesch wurde ich in die Lage gesetzt, einige Galloti im Museo Civico zu Mailand und in der Universitätssammlung in Zurich untersuchen zu köunen, auferdem standen mir die im Musée d'histoire naturelle in Paris aufbewahrten Stücke - unter anderem auch die Berthelot und Barker-Webbschen Originalexemplare - zur Verfügung und endlich bin ich selbst in Besitz dieser seltenen Species gekommen. Da ich infolgedessen einige Ergiinzungen zu den bisherigen Beschreibungen zu geben vermag, so will ich im Auschluf an diese einiges über das Tier mitteilen.

Körpergestalt und Gröfe.

Was zunächst die Körperform anbelangt, so haben sowohl die Mailänder, als auch meine Individuen eine Älnnlichkeit mit $L$. viridis; einige grofe Exemplare (wic z. B. No. 5277 im Muséum in Paris) nähern sich dagegen in ihrem Körperbau der Perleidechse; nur scheint mir der Kopf, namentlich bei jüngeren Individuen länger und nach vorn stärker verschmälert zu sein. Bei den ausgewachsenen Stücken und besonders bei den alten Männchen sind die Schläfe stark hervortretend. Die vorderen seitlichen Kopfteile fallen dagegen senkrecht ab; das Schnauzenende erscheint abgerundet. Der Rumpf ist breit, abgeplattet. Die Hinterbeine reichen bis zu den Achseln, die Vorderbeine berühren die Nasenlücher. Der verhältnismäligig kurze Schwanz ist an seiner Basis oben abgeflacht und seitlich mit senkrecht abfallenden Seiten versehen.

Maße. - Exemplar aus dem Museum in Zürich (C. D. 381): Totallänge: $235 \mathrm{~mm}$; Länge d. Kopfes: 23, d. Rumpfes: 67, d. Schwanzes: 145, d. Vorderextremität: 32 und der Hinterextremität: $52 \mathrm{~mm}$; Kopfhreite: 15,5, Kopfhöhe: $13 \mathrm{~mm}$; Breite d. Pileus 10,5-11 mm. Exemplar aus der Sammlung von v. B cdriag a: Totallänge: 203 mm; Länge d. Kopfes: 18,5, d. Halses: $9-10$, d. Rumpfes : 58,5, d. Schwanzes: 126, d. Vorderextremität: 28, d. Hand m. d. Fingern: 14, d. Hinterextremität: 41, d. Fußes m. d. Zehen: $22 \mathrm{~mm}$; Kopfbreite : 13, Koplhöhe: 9,3, Breite d. Pileus: 8,5, Umfang d. Kopfes: 36,5, Umfang d. Halses: 35-37, Umfang d. Rumpfes: $48 \mathrm{~mm}$.

\section{Äubere Körperbedeckung.}

Die Beschildung des Kopfes (vergl. Gervais' und meine Abbildungen, l. c.) nähert sich am meisten der muralis oder laevis. Das sehr grobe, breite Occipitale ist dreieckig oder trapezförmig. Das benachbarte kleinere Interparietale ist breit, fünf- oder viereckig. Die Scheitelschilder stellen an ihren, nach aulien zugekehrten Seiten einen Bogen vor; sie biegen sich auf die Temporalregion über, also ähnlich wie wir es bei der lacvis kennen gelernt haben; nur 
hinten sind sie von den Temporalia durch eine gröfere 'Iafel getrennt; vorn, und zwar zum uräliten 'Teil, arrenzen sie direkt an die Schläfenschildchen an. Die Frontoparietalia sehen denen der muralis ähnlich, nur erscheinen sie länger und breiter als es bei der letzteren der Fall ist. Das namentlich vorn aufallend breite Frontale ist gegen dic Kopfspitze zu einfach hogenfürmig gestaltet. Die 2 mittleren, stark erhobenen Supraocularia sind meistens vorn und linten al)gerundet, in den selteneren Fällen leicht abgestut\%t; sie werden jedoch nicht ihrem ganzen Verlaufe nach von den Supraciliaria durch eine Reihe von 8 bis 9 schuppenartigen 'T'äfelchen getreunt. Das 1. und 4. Supracularschild ist gröfer als bei der muralis, auch erscheint das Internasale gröfer als bei letzterer, es stellt nach vorn einen mehr oder weniger stark ausgeprägten Bogen vor. Dic Supranasalia sind im Verhältnis zu den grofen Frontonasalia klein. Nach Böttger soll sich zuweilen ein accessorisches Täfelchen einschieben, welches er Interfrontonasale nennt. Allem Anschein nach entspricht dieses Schildchen demjenigen, das Braun bei Var. Lilfordi entdeckt hat. Eine im Museo Civico zu Mailand aufbewahrte Galloti (No. 356) zeigt ebenfalls ein abnormes Verhalten der Schilder: die Parietalen erscheinen nämlich zur Hälfte (der Breite nach) geteilt, eine Erscheinung, welche selten bei den Lacerten konstatiert worlen ist. Was die Beschildung der Kopfseiten anbclangt, so finden wir nur ein Nasofrenale vor, das grof und fünfeckig crscheint. Die Frenalia und Freno-ocularia sind ebenfalls ansehnliche Tafeln. Das Nasenloch ist vom Rostrale nicht umgeben. Bei 3 von mir untersuchten Tieren sind jederseits 9 , bei den übrigen nur 8 Supralabialen vorhanden; es stehen 5-6 Tafeln vor jenem gröleren, unter dem Augapfel liegenden Suboculare. Ein grofes, vorn abgerundetes Praeoculare legt sich an das Suboculare an. Es sind 6 oder sogar 7 Submaxillaria vorhanden. Ungefähr in der Mitte der Schläfe ist ein beinahe ovales oder vielseitiges Massetericum vorhanden, um welches kleine, schuppenartige, meist hexagonale Schildchen regelmḯsig angeordnet sind und Kreise bilden. Das Scutum tympanicum ist mitunter in zwei Stücke geteilt. Das eine gröfere Stück, welches das eigentliche Tympanicum repräsentiert, liegt oben am Vorderende der groben Ohröffuung, das zweite kleinere Schildchen liegt unterhalb dieses. Die Beschuppung des Unterkopfes kann als grob bezeichnet werden; die einzelnen Schuppen sind länger als bei $L$. muralis. Das gebogene Halsband besteht aus 10 oder 11 Tafeln; die freien Schilderränder sind leicht abgerundet. Die Gestalt der Schuppen ist vorn an der Halsgegend rund und kaum gewölbt; am Rücken sind sie länger als breit, polygonal, hcxagonal, mit meistens leicht abgerundeten Ecken, sowic auch unregelmäfig gestaltet. Die Kiele erscheinen stumpf und schwach ausgeprägt; sie haben nicht durchweg einen geraden Verlauf, sondern sind öfters lcicht bogenförmig und stets kürzer als die Schuppe selbst, indem 
sie den hinteren Rand derselben nicht erreichen. Auf den Körperseiten erleiden sie eine Umgestaltung und erscheinen länglich viereckig mit nahezu diagonalen, schwach ausgeprägten und stumpfen Kielen versehen. Nach der Bauchgrenze zu nehmen sie wiederum eine andere Form an und werden grölier. Ihr Übergang in die Ventralia ist nicht sehr deutlich ausgeprägt, weil dic Schuppen IIand in Hand mit ihrer Vergröberung gegen die Banchseite abgeplattet erscheinen. Auferdem erhalten sie allmählich durchsichtige Ränder, wie sie nur die Bauchtafeln aufzuweisen pflegen. Im ganzen sind ungefähr 90 longitudinale Schuppenreihen vorhanden. Die Anordnung der 170 bis 200 transversalen Reihen von Schuppen ist eigentümlich; in der Mitte des Rückens närnlich stellt jede Reihe einen stark nach vorn hervortretenden Bogen dar, dabei erreichen einige Reihen nur die Mittelrückenlinie; eine derartige wellenförmige Anordnung der Schuppenreihen kommt übrigens auch bei $L$. muralis vor. Was die Zahl der Bauchtafelreihen betrifft, so ist es schwierig, sie genau anzugeben, da ihre Abgrenzung nach aufien undeutlich ist. Nach Duméril und Bibron sollen. es 12 bis 14 sein; nach Gervais mehr als 6. »Il y a plus de 6 de ces séries«, sagt Gervais, »les unes vont du thorax au bas-ventre, les autres naissent des flancs et sont comme formées par la fusion des squames en pavés des côtés du dos. A vrai dire, ces séries sont aussi bien transversales que longitudinales; et au sixième rang transversal, en partant des membres postérieurs, on compte 13 séries longitudinales: plus près des menbres antérieurs il y en a moins, et leur nombre diminue encore quand elles approchent de l'anus." Meine Exemplare haben 4 vollständige Paare, ferner 2 Paare, welche nur in der Mitte des Körpers vorhanden und als Teile der benachbarten Tafeln zu betrachten sind. Endlich kommen die Oberschilderreihen hinzu, welche Duméril und Bibron mutmalilich als siebentes Paar bezeichnet hatten. Die einzelnen Tafeln, und namenthch die seitlichen, sind länger als breit und wir können daher annehmen, daß3 die Zahl der Tafeln sich auf Kosten der Grölie entwickelt hat. Es sind meistens auf jeder äufiersten Ventraltafel 2 Randschildchen. Falls die transversalen Reihen der Ventralen gyleich nach dem Brustdreieckende gezählt werden, sind es circa 24, sonst aber 30. Die Kehlfurche ist undeutlich. Zwischen dem Anale und den Ventralen ist ein gröferer Raum vorhanden, der mit kleinen Schuppen bedeckt ist. Das ziemlich kleine Anale ist vorn und seitlich von 3 aufeinanderfolgenden, im ITalbkreise stehenden Schildchen umgehen. Die namentlich unten sehr schmalen, in 103 Ringel angeordneten Caudalschuppen sind beinahe ganzrandig mit einer schwach ausgepränten Abrundung an freien Ende; sie tragen stumpfe Kiele ${ }^{1}$ ).

\footnotetext{
1) Vergl. meine Tafel Fig. 36.
} 
Eine gute Abbildungr der Galloti fehlt uberhaupt bis heute noch. Fig. 1 bei Gervais 1. c. ist sehr mangehaft ausgefallen; diejenigen Abbildungen aber, welche die Details, wie 2. B. die Schilder der Oberseite und der Kopfseite veranschaulichen, sind im allgemeinen befriedigend, nur scheint mir in Fig. 2 die Lntfernung zwischen Nasenloch und Auge etwas verkürzt dargestellt zu sein.

Schenkeldrüsen und Zähne.

Die Drüsenzahl 30 oder 29 scheint selten vorzukommen; die Zahl 30 hat Böttger lionstatiert; 29 Drüsen sind mir unter etwa einem Dutzend Individuen nur einmal bei dem von Webb und Berthelot von Teneriffia mitgebrachten Exemplar (No. 2417 in Paris) zu Gesicht gekommen. Die mit doppelter Spitze versehenen stark entwickelten Oberkieferzähne, deren ich auf jeder Seite 16 konstatierte, sind ungleich lang; die vorderen einfachen und hinteren zweiund dreispitzigen Zähne sind länger als die mittleren. Im Zwischenkiefer sitzen 7 bis 9 einfache, nach einwärts gebogene Zühne. Der Unterkiefer enthält im ganzen 40 kräftige doppelspitzige Zähne. Der Gaumen ist bezahnt.

F ärbung und Zeichnung.

In Färbung und Zeichnung ist die Galloti aukerordentlich variabel. Bei den jungen Individuen ist dic Oberseite, soweit ich es nach den mir vorliegenden Spiritusexemplaren beurteilen kann, entweder einfarbig briun, olivenbraun, grau oder graugrün, oder aber mehr oder weniger auffallend hell gezeichnet. Bald tritt die Zeichnung in Gestalt von weiligelben oder grünlichen, dunkelbraun umrandeten Punkten auf, welche eine Neigung zeigen, sich in Längsreihen zu ordnen; bald sind es deutliche Punktstreifen oder transversale, geschlängelte und unterbrochene Binden, welche die Körperoberseite zieren. Bei den etwa $15 \mathrm{~cm}$ langen Gulloti, welche ich im British Museum zu sehen Gelegenheit hatte, ist die braune Rückenzone von dunkélbraunen, vom Hinterrande des Pileus entspringenden Binden umsäumt. Letztere haben ihrerseits nach aufen hin grauweifa, stellenweise bläulichweiß3e schmale Säume, welche sich bisweilen bis zur Hälfte des Schwanzes hinziehen. Die Rumpfseiten erscheinen jederseits mit cinct bläulich- oder grauweißen Binde versehen, welche unten von cinem nach unten zu liegenden dunkelbraunen Streifen begleitet sind. Diese Binden beginnen am Hinterrande der Ohröffnung und schliefzen in sich eine lieihe heller oder blauer Pünktchen ein (vergl. das von Webb und Berthel ot (lem Museum in Paris geschenkte Stück); ähnliche Punktflecken treten auch auf den braunen Zwischenräumen auf, welche die Räckenstreifung von den Seitenstreifen trennen. Gegen die Bauchgrenze hin nimmt der Körper cinen graubraunen 'Ton an und

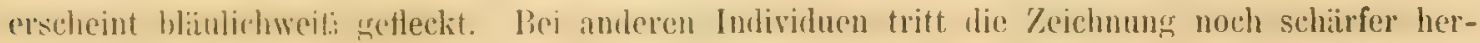


vor. So zcigen z. B. dic sub No. 5276 im Pariser Museum aufgestellten Exemplare deutlich ausgeprägte, an den äuferen Rändern der Parietalia anfangende, vorn weißlich, gegen das Rumpfende zu ureblich aussehende, dunkelbraun umsïunte Streifen. Die Rumpfseiten erscheinen prachtvoll blau und ganz hellblau gefleckt. Diese meist runden Flecken treten dadurch scharf hervor, daf sie dunkelbraun umrandet sind. Auch die Halsseiten haben eine an der Ohröffnung ihren Ursprung nehmende Reihe derartiger Ocellen. Allem Anscheine nach sieht die von Böttger in seiner oben citierten Abhandlung beschriebene Gulloti (No. 15) dem Pariser Exemplar ähnlich, nur ist sie seitlich nicht blau, sondern gelblich weils gemakelt. Auch scheint bei dem Büttgerschen Individuum keine feine dunkelbraune Punktierung vorhanden zu sein, welche bei dem Pariser Stucke auffallt. Auf der gelblichen, gelbgrauen, oder stahlgrauen Kehle laufen jederseits 2 bis 4 , vorn zusammenstofende, nach hinten zu aluseinandergehende parallele, schwarzgraue Lüngsstreifen hin, die meistens schon bei ganz jungen Stücken konstaticrbar sind, bei den alten dagegen vermilit werden. Diese Eigentümlichleit bei den jungen Galloti ist insofern von Interesse, als bei ihrer Mitbürgerin der atlantica Peters, Doria nur die Submaxillaren gestreift sind, währenddem der beschuppte Teil des Kinns cinfarbig dunkel erscheint. Ich möchte auf diese Erscheinung die Aufmerksamkeit des Lesers besonders lenken, weil die Art und Weise wie das Kinn bei diesen Species - ich habe die junge Galloti und die atlantica im Auge -- gezeichnet ist, genügt, um sie sofort voneinander zu unterscheiden. Die Farbe der Bauchteile ist insofern bei den mittelgrofen Galloti von derjenigen bei den jungen verschieden, als sie dunkler erscheint. Bei den letzteren zeigt das hellgelbe Grundkolorit eine Veigung ins Grüne, bei den ersteren hingegen erscheinen die äuferen Ventralen entweder stahlgrau, gelblich und bläulich gefleckt oder braun, gelblichgrau gemakelt; die medianen Reihen aber sind im Gegenteil auf gelblichem oder perlgranem Grunde dunkelgrau oder braun getropft. Bei den gleichfalls halbausgewachsenen Galloti aus dem Züricher Museun ist die Längsstreifung nur äuferst schwach angedeutet; sie erscheint hier nur an Nacken sichtbar, da die hellen Streifen die dunklen nicht schamf begrenzen, oder sie verschwindet iberhaupt; gegen die Mitte des Rumpfes hin zerfallen diese Streifen in einzelne graue Flecken, welche entweder mit dem helleren braunen Kolorit, dis hier die Grundfärbung bildet, zertlielien, oder durch die Rücken und Seiten zierenden, in grołel Anzahl auftretenden, grünlichweißen Flecken, welche nichts Anderes zu sein schein'n, als der Rest der ursprünglichen hellen Längsstreifung, allmählich verdrängt werden. Áuf den Seiten erscheinen diese schwarz und dunkelbraun eingefabten Flecken augenartig, oder ring- und schnörkelförmig, auf dem Rücken hingegen stellen sie kurze, quergestellte Streifen vor, welche manchmal mehr oder weniger in Kontakt treten können und 
auf diese Weise eine deutliche Querzeichmung zu stande bringen. Böttger kennt sogar quergebainderte Formen dieser Art. Der Kopf scheint stets, sowohl bei den jungen, als auch bei den mittelgroben Individuen auf mehr oder weniger dunklen, bramem odor olivenfarbenem Grunde dunkel punktiert oder gespritzt zu sein. Dic durchwegr helleren, offers brïunlichgrauen oder nubbraunen Kopfseiten sind rom bald einfarbig, bald spärlich dunkel gemakelt; hinten in der 'Temporifgegend liommen meistens hellweibliche oder hellyrane Augenflecken oder kurze Lä̈gsstreifen hinzu. Die vorderen Gliedmalisen sind auf dunklem Grunde üplig hell getleckt; lie Grundfarbe entspricht derjenigen des Rückens; das Kolorit der Flecken harmoniert mit dem der Räckenmakeln, nur tritt es intensiver auf. Weniger zahlreich und schwächer ausgepriagte Flecken zicren die Oberseite der Hinterbeine. Der Schwanz ist oben hell- oder dunkelbraun, einfurbig oder dunkelbraun resp. schwarẓbraun gefleckt; die spärlich dunkel gepunktete Schwanzunterseite ist genau von demselben Farbentone wie die hellen Bauchschilderreihen. Nach der Beschreibung des Farbenkleides der grolien, etwa 22 bis $33 \mathrm{~cm}$ messenden Tiere, weiche uns Böttger gegeben hat, zu schlielsen, wird bei diesen die Längsstreifungr mcistens vermilst; die zahireichen Böttgerschen Exemplare sind in den meisten Fällen mit lebhaft grünlichen, hellvioletten, schwarz eingefaßten, mehr oder weniger stark ausgesprochenen Querzeichnungen versehen und besitzen aulierden blaue Seitenmakeln; nur cines seiner grolien Stucke weist 4 besonders deutlich ausgeprärte, bläuliche Längsstreifen auf; ein anderes hat 2 nach hinten schärfer hervortretende, schwarze, unterbrochene Binden über dem blaugrün gefirhten Rücken.

Von ganz grołen Galloti habe ich nur wenige Individuen zu untersuchen Gelegenheit gehabt; es sind diejenigen Kolosse aus Teneriffa, welche im Pariser Museum sub No. 5277 aufrestellt sind. Ihre Körperoberseite ist auf dunkelbraunem Fond mit hellbraunen, und gegen die Flanken zu mit blauen Augenflecken besetzt, welche, wie es gewöhnlich bei der Galloti der Fall zu sein scheint, von einem schwarzen Ring eingefabit sind. Pileus, Wangen und Kehle sind dunkelbraun; Kehle ohne jegliche helle Streifung. Bei alten Männchen, wie z. B. bei denjenigen, welche sich im British Museum befinden, zeigen nur die Rumpfseiten grofie blaue Ocelli, während der dunkelbrane Rückengrund durch grünliche, sich in die Breite anstehnende Flecken, oder auch durch förmlich geschlängelte, aber vielfach unterbrochene transversale Binden zum Teil verdrängt wird. Die Kehle crscheint nahezu schwarz glänzend oder stahl«rau; das Dunkelblau am Bauche tritt namentlich an der After- und Schwanzwurzelregion gresïtigt auf; öfters komm auch noch Gelb hinzu. Die Kopfoberseite verdunkelt sich mit dem Alter in bedeutendem Grade, so Z. B. bei einem $30 \mathrm{~cm}$ langen Individuum ist dic Oberseite des Kopfes cinfarbig schwarzbraun. 
Vorkommen.

L. Galloti findet sich auf der Insel Tenerifia, so z. B. im Thal von Orotava, auf dem Wege mach dem l'ic de Teide und in Santa Cruz (Böttger, Doria), auf Madeira (Duméril, Bibron, Gray), auf Gomera (Pariser Mus. No. 5276, ded. Verneau) und auf Ferro (Böt g e r). Auf der zuletzt genanuten Insel sollen, nebenbei sei es bemerkt, Eidechsen leben, welche ebenso grob wie die Katzen sein sollen. Ich vermute, dalj diese Riesen-Echsen nichts Anderes als unsere Galloti sein können, anlere sind wiederum der Meiung, dabis sie Smaragdeidechsen sein könnten ${ }^{1}$ ).

Nach de Rochebrunes sFaune de la Sénégambie (Paris, 1883-85) kommt sie in Portendick, Nleb, Elimanié, Gasser-El-Barka, an Kap Blanc und am Kạ Mirik vor. Die im British Museum sich befindende und als \$Zootoca Derbiama bezeichnete $L$. Galloti stammt aus Nogullor. Die betreffende Büchse ist ubrigens wohl seit Gray nicht umetikettiert worden, denn sie enthält aufier der Galloti noch eine $L$. atluntica Peters, Doria. Zugleich möchte ich bemerken, dalis die als " $L$. muratis« im Museum zn Halle determinierten Eidechsen und

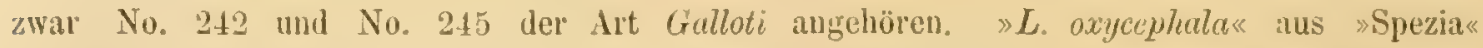
(No. 433) in dem nümlichen Museum ist glcichfalls eine Galloti, aber selbstverständlich keinesfalls aus Spezia stammend.

\section{Lacerta Dugesi Milne Edwards 1829.}

Char. - Sc. occipitale paulo latius, interdum longius scuto interparietali. Sc. frontale Satis latum, mediocriter longum. Scuta nasofrenalia duo, superposita. Discus palpebralis in margine externo serie granorum limbatus. Supralabialia anteriora 5. 'Tempora granosa, disco masseterico nullo, scutis maioribus ad marginem parietalium nullis. Tympanicum adest. Sulcus gularis distinctus, collare integrum. Sc. abdominalia in 6 series longitudinales disposita. Squamae dorsales parvae granosae, laeves. Dentes palatini. Pori femorales utrinque 21-2S. - Lacertu Dugesi L. muralis similis, sed corpore satis compacto latoque. Caput pyramidale, anticum

1) Obgleich die oben angegebenen Mafe von einem geschlechtsreifen Individunm genommen worden sind, erreicht $L$. Galloti eine viel größere Gesamtlänge, dabei hat sie aber einen relativ kurzen Schwanz. Melırere von mir fluchtig verglichene Stücke im Pariser Museum, wie 2. B. dasjenige, das sub No. 5277 aufgestellt ist, erreichen die Rumpflänge der viridis und sind ebenso kräftig gebaut wie die Perleidechse. Böttger führt ebenfalls recht großse, über $32 \mathrm{~cm}$ lange Exemplare auf. Nach den Stücken, welche ich überhaupt zu schen Gelegenheit gehabt habe, zu urteilen, stellen die Galloti zwei Rassen vor, eine größere und eine kleinere. Ob beide an gleichen Orten angetrofien werden, oder ob sie verschiedene Inseln bewohnen, babe ich nicht mit Sicherheit ermitteln können. Da wir hereits von anderen Arten wissen, in welchem Verbältnis die Bewolner der kleinen Inseln zu denen der größeren Eilande stchn, so bin ich geneigt anzunehmen, da $f_{3}$ diese zwei Rassen jetzt noch, oder vormals verschiedene Inseln hewolnen, oder bewohnt haben. 
attenuatum, posticum a collo vix distinctum vel non distinctum. Cauda brevis. Pedes postici axillas contingentes. - Longitudo: $162 \mathrm{~mm}$.

Synonymic.

Lacerte Dugesii Milne Ldwards in: Ann. des sc. nat. t. XVI, pag. St, tab. VI. fig. 2. Duméril et Bibron, Erpétologic généralc, t. V. pag. 236. - P. Gervais in: Hist. mat. des Iles Camaries (Reptiles). Hig. 6, 7. - v. Bedriaga in: Arch. f. Naturg. IXXXV, Bd. 1. S. 330. 'Taf. 18, Fig. $3 \mathrm{a}$, b.

L. mulerensis Fitzinger, Neue Klassifikation d. Reptilien etc. S.51. Wien 1826. - Steindatchner, Reptilien, in: Reise d. österreicl. Fregatte Novara etc. Bd. I. Wien 1867. Alsodromes maderensis Fitzinger, Systema leptilimn I, pag. 20. Wien 1843.

Teira punctate Gray, Cat. Liz. Brit. Mus. pag. 33. London 1545; Ann. nat. hist. I. p. 286. Lacerta punctutu (Gray) Boulenger in: Proc. Zool. Soc. of London 1851, pag. 743.

Körpergestalt und Größze.

Aufer der $L$. Galloti kommt auf derselben Inselgruppe eine ebenfalls dem Kontinente fremdartige Eidechse $\gg L$. Dugesi« vor. Diese Art wurde bereits von Milne Edwals, von Duméril und Bibron, nachtriglich auch von mir kurz beschrieben. Gerva is fügte noch einige Abbildungen, welche Kopf und Analgegend darstellen, hinzu. Ein anch nur obertlïchlicher Vergleich der beiden erwähnten Lacerten genügt, um sie sofort zu unterscheiden. Vor allem ist es die Körperlänge, wclche auffällt. Während die Galloti $30 \mathrm{~cm}$ und noch viel mehr erreichen kitnn, hat die Dugesi kaum die Länge von $22 \mathrm{~cm}$. Der Kopf bei der letzteren ist beleutend kürzer, spitzer und zeigt einen stark winklig erhobenen Discus palpebralis. Entweder ist der Halsumfang mit demjenigen des Kopfes gleich, oder der Hals erscheint breiter als der Kopf. Der Rumpf ist namentlich beim Männchen breit, kräftig gebaut, oben abgeplattet. Der kurze Schwanz ist dick und an seinem vorderen Drittel eher tetragonal als rund; oben an der Schwanzwurzel und sogar bereits am Schwanzanfang ist eine ziemlich stark atsgeprïgte furchenartige Vertiefung erkennbar. Die Vorderbeine reichen bis zur Hälfte des Augipfels; die hinteren Extremitäten erreichen die Achseln. Die Beine sind liräftigg gebaut.

Approximative Mabe einer männlichen Dugesi (Züricher Museum. C. đ. No. 392): T'otallïngre: 161-162 mm. Länge des Kopfes: 16, 0 , des Rumpfes 53, des Schwanzes: 92, der Vorderextremität: 23,5 , der Hinterextremität $37 \mathrm{~mm}$. Kopfhöhe: 8,5 , loppfbreite (in der Schlifengerend): nahezu $11 \mathrm{~mm}$; Kopfumfung: 32,5, Breite d. Pileus: ungefahr 8 mm; Umfang des Halses: $34 \mathrm{~mm}$. 
Schilder und Schuppen:

Milne Edwards' Originaldiagnose zufolge wird das Occipitale bei der Dugesi vermibit; da nun aber sämtliche von mir untersuchten Dugesi stets ein deutlich ausgeprägtes, trapezförmiges Occipitale aufuweisen hatten, so habe ich mich während meiner Anwesenheit in Paris nach Milne Edwards' Originalexemplaren ungesehen und gefunden, dass allerdings, zufäligerweise das von diesem Forscher untersuchte und noch heute im Muséc d'hist. nat. sul) No. 2742 aufgestellte Delalandesche Stück der Dugesi kein Occipitale besitzt. Alle übrigen Exemplare in demselben Nuseum haben hingegen ein Hinterhaptsschild, das häufig die Länge des benachbarten, fünfeckigen, mehr oder weniger länglichen und sclımalen Interparietale übertrifft. Die länglichen, hinten abgerundeten, vorn z. T. leicht ausgerandeten, z. T. geraderandigen Parietalia sind seitlich von einer Reihe von 4 kleinen Schildchen umsäumt. An die verhäitnismäligrg kleinen, vorn und hinten abgerundeten mittleren Supraocularia stolien dic ziemlich ansehnlichen Supraocularia 1 und 4. Discus palpebralis und Supraciliaria sind voncinander durch eine Reihe zierlicher, kleiner Schüppchen getrennt. Mit Bezugr anf die Frontoparietalia und auf das Frontale muf bemerkt werden, dafs bei ersteren alle Ränder, mit Aus. nalme der vorderen, leicht gebogenen, einen geraden Verlauf nehmen, dalz hingegen die zuletzt genannte Tafel, d. h. das breite Stirnschild, leicht eingebogrene Kanten aufweist. Über die Frontonasalia, das grobe, vorn meistens abgerundete Internasale, die klemen Supranasalia und das nach oben ubergebogene und vom Nasenloch getrennte Rostrale ist sonst nichts erwähnenswert, als daf3 sie eine schwache Wölbung zeigen und daf die Suturen der Fronto- und Snpranasalia zicmlich lang sind. Sämtliche Schilderuähte des Kopfes sind namentlich in der Hinterhauptsgegrend schwach ausgesprochen. Das grofise sich seitlich befindende Nasenloch ist von 4 Schildchen umgeben und zwar vom Supranasale, vom Supralabiale I und von 2 kleinen, übercininder stehenden Nasofrenalia. Auf letztere folgen nun nach rückwärts das trapezförmige, teilweise nach oben übergebogene Frenale und das beimahe ebcnso lange wie hohe Frenooculare und endlich das längliche, meistens vicreckige Praeoculare, das die letzte Tafel vom Unteraugenschilde trennt. Supralabialia sind im ganzen 7 vorhanden, vorausgesetzt, dafs man die auf das siebente Supralabiale folgenden, nach hinten zu allmählich kleiner werdenden und schliefalich mit den Temporalia ubereinstimmenden 2 bis 4 Sehildchen nicht zu den Oberlippentafeln rechnet. Von den 5 vorderen Supralabialia zeichnet sich das erste dadurch aus, dafis es länger als hoch ist, wälrend die 3, ihm zunächst liegenden, im Gegenteil im Verhältnis zu der geriugen Breite seh hoch erschehen; das Supralabiale $\mathrm{V}$ ist hingegen wiederum niedriger und hat eine trapezförmige Gestalt. Dem Suboculare, das oben etwas breiter ist als unten, 
schliefien sich hinten das halb so hohe hintere Oherlippenschild und die ziemlich ansehnlichen Postocularia an. Streng genommen sind bei der Dugesi 3-4 grölicre Postocularia, welche die Orbita begrenzen und dieselbe von den Temporalia trennen. Letztere sind hexagonal, vorn schmal und klein, nach rückwärts gröfer werdend. Das Massetericum wird vermifat; hingegen finden wir ein gröfieres Schläfenschildchen, das sich an die schmale, länglich gestaltete und auch nicht im mindesten gebogene Tympanaltafel anschliefit. Der vordere, untere Rand der groken Ohröffnung scheint mir schwach gezähnt z.u sein; der hintere Rand wird von einer Hautfalte verdeckt, welche nichts Anderes ist, als die Fortsetzung derjenigen Plica, die dem ziemlich dentlich ansgeprïgten Sulcus gularis aufliegt. Die Dugesi besitzt an unteren Lippenschildern die konstante Zah! 6. Die Submaxillaria sind in 5 Paaren angeordnet. An die hinterste Submaxillartafel legen sich 3 Tafeln an, dic etwas gröfer sind, als die übrigen Kehlschupıen. Letztere beginnen vorn als langgestreckte, etwa fünfeckige. Schuppen und gehen allmählich nach hinten zu in regelmidijge sechskantige Schuppen uber. Das Halshand ist demjenigen bei $L$. muralis ähnlich; es ist nämlich äußserst schwach gebogen, ganzrandig und in der Regel aus 9 Tafeln bestehend, von denen die mittlere doppelt so grolis ist wie die übrigen. Die in 6 longitudinalen und in 25 transversalen Reihen angeordneten Ventralia zeichnen sich sowohl durch ilıre regelmäbige Anordnung, als auch durch ihre gleichmälßjig rechteckige Gestalt aus. Das Triangulum pectorale besteht aus 10 bis 14 s'childchen. Ein, mitunter zwei kleine Randschildchen grenzen an das äuliere Bauchschild. Im allgemeinen entsprechen abwechselnd 4 und 5 Rückenschuppen der Länge des einzelnen Bauchschildes. Das sind Zahlen, welche bei den Eidechsen seiten konstatiert worden sind und die darauf hindeuten, dalis diese Schuppen sehr klein sein müssen. Dies ist auch der Fall; sowohl die Rücken-, als auch die Flankenschuppen sind auffallend klein und tragen keine Kiele. Die meisten sind rund und leicht gewölbt; bei näherer Betrachtung nimmt man wahr, dal. jerles Schüpuchen oben abgeflacht ist und, so zu sagen, ein kleines Plateau aufweist. In selteneren Fällen geben die Schuppen ihre abgerundete Form auf und zeigen die Neigung, sechs- oder fünfkantig zu werden; übrigens nach rückwärts zu, und zwar vorzugsweise an den Körperseiten sind die Schupџen vorwiegend trapezförmig oder hexagonal. Zwischen den Ansatzstellen der Hinterbeine erscheinen die Schuppen am kleinsten, sonst sind sie überall ziemlich gleich grof. Die Anzahl der Querreihen beträgt meistens 176 bis 179 , obwohl sic übrigens auch bis auf 170 herabsinken kann. Dic Zahl der Längsreihen schwankt zwischen 68 und 74. Die trapezförmigen oder sechsseitigen kleinen Schuppen am Unterschenkel besitzen schwach ausgeprägte Kicle. I)ie in 116 Ringel angeordncten Schwanzschupen sind vorn und oben an iluen freien Riandern entweder abge- 
rundet, oder in stumpfe Winkel ausgezogen; von der Mitte des Schwanzes an erscheinen sic in cine kurze, aber schärfere Spitze ausgezogen. Das nämliche gilt von der Schwanzunterseite; schwach ausgeprïgte Kícle sind sowohl unten, als oben vorhanden. Die Aftergegend ist dureh das breite, aber wenig hohe, 5-oder 4seitige Anale und von 6, selbstverständlich nur voru und seitlich von der Centraltafel sich befindlichen kleineren Grenzschildehen bedeckt.

Schenkeldrüsen und Zähne.

Die Zahl der Drüsen wechselt zwischen 15 (nach Duméril!) und 23; die Zahlen 21 bis 23 scheinen mir am häufigsten vorzukommen. Die Flügelbeine sind bezahnt oder entbehren der Bezahuung. Jede Oberkieferhälfte weist 15, vorn zweispitzige, hinten einfache Zähne auf. Im Zwischenkiefer sitzen 7 bis 9 einfache Zähne. Der Unterkiefer trägt im ganzen 32 Zähne.

Färbung und Zeichnung.

In Hinsicht auf die Färbung und Zeichnung schlielien sich die Dugesi im allgemeinen der muratis fusca an. Die vordere Partie der Oberseite ist grünlichgrau oder olivenfarben, die übrigen Teile des Riückens, die Kopf-, Schwanz- und Extremitäten-Oberseite sind braun oder olivenbraun. Bei den meist bräunlich gefärbten Stücken findet sich jederseits eine, vom Hinteraugenrande über die Hals- und Rumpfseiten bis gegen die Caudalwurzel sich hinziehende breite, nahezu die sämtlichen erwähnten Seitenteile einnehmende, dunkelbraune mit hellbraunen, hellgrünen oder bläulichgrünen Pünktehen besetzte Binde. Diese Binden können übrigens zu Streifen oder schmalen Zackenbinden reduziert oder - und namentlich gegen das Rumpfende hin - schr undeutlich ausgeprägt auftreten. In diesem Falle erscheint die ganze Oberseite des Rumpfes und sogar die der Schwanzbasis besäet mit zahlreichen, weiflichen Pünlitchen, welche stellenweise zusammenfliefien und augenartige Flecken bilden. Sonst aber weist die von den erwähnten Binden eingefałte Rückenmittelzone duukelbraune, in zwei Reihen angeorlnete Flecken auf, welche am hinteren Occipitalrande ihren Anfang haben und sich in der Scliwanzwurzelgegend verlieren. Diese Flecken können aber auch fehlen oder sehr spärlich vertreten sein, orler endlich in Kontakt treten und supplementurische Streifen bilden, was namentlich öfters bei den Weibchen der Fall ist. Bei einigen Individuen, vorzugsweise bei den männlichen, lichtet sich die Grundfärbung der medianen Dorsalzone gegen die dunkelbraunen Seitenbinden dermafien, daß̧ letztere von graubraunen oder graugrünen Feldern begrenzt erscheinen. Die seitlichen, unteren Teile des Halses sind graugrün oder entsprechen in betreff der Färbung dem helleren Kolorit der Rückenzone. Während die Schwanzoberseite in der Regel fleckenlos ist, zeigen Pileus, Kopfseiten und in den meisten Fällen auch die Extremitäten dunkelbraune Makeln. Die äuferen Bauchtafelreihen sind blau oder blaugrün; Kehle und 
Schwanzunterseite ebenfalls bläulich. Die mittlere Bauchpartie, namentlich hinten, die Aftergegend - mit Ausnahme des bläulich getteckten Anale, - sümtliche kleineren Schildchen an der Unterseite der Hinterbeine, die Sohlen und endlich meistens die Mittelzone der Schwanzunterseite erscheinen gelblich oder giünlich. Die grolien Tafeln an der Unterseite der Hinterbeine sind blau, gelb umsäumt. - Die Bauchseite erscheint übrigens bei näherer Betrachtung und insbesondere bei den ausgewachsenen . Iänuchen fein aber dicht gepunktet.

In seltenen Fällen nimmt die Körperoberseite mit Ausnahme jedoch der dunkelbraunen, gelb punktierten Kopfdecke eine schwarzbraune Färbung an, wobei alle Zeichnungen gänzlich verschwinden; dabei erscheinen Bauch- und Schwanzunterseite schwarzbraun; die Brust ist bläulich punktiert; das dunkelgrau auf hellgrauem Grunde gefleckte Anale zeigt an seinem freien Rande einen gelben Flecken; die Kopfseiten sind mit Ausnahme der gelbpunktierten Oberkiefer dunkelbraun, oder schwarzbraun (Brit. Mus.). Die Verlunkelung des Grundkolorits und zugleich das spurlose Verschwinden jeglicher Zeichnung scheint, wie gesagt, selten stattzufinden, denn meistens sind auf der Rückenseite winzig kleine, bläuliche Ocelli auf schwarzbraunem Grunde konstatierbar. Diese Form, welche meist mit einfarbiger, schön blauer, seltener gräulicher Unterseite und gewöhnlich schwarz gefleckten äulieren longitudinalen Bauchschilderreihen vorkommt, findet sich in einigen Sammlungen als $L$. punctata Gray bezeichnet.

Die Jungen sind von den Alten nur wenig verschieden, da sie in der Regel schon als Neugeborene die den Weibchen zukommenden dorsalen Längsstreifen und Bänder aufweisen. Die Längsstreitung tritt in der Jugend stets merklich und auffallender hervor, als in dem späteren Lebensalter.

Vorkommen.

Der sicher kanstatierte Fundort der Dugesi ist Madeira (Berl. Mus. No. 4314, dedit: v. Martens). Duméril und Bibron fügen Teneviffa hinzu, das bedarf aber, wie ich glaube, einer Bestätigung. Morelet (nach v. Fritsch ${ }^{1}$ ) fand sie auf den Azoren (Sta. Maria). Metschnikow ${ }^{2}$ ) giebt sie fül Graciosa, eine ebenfalls der Azorengruppe angehörige Insel an. Als Glied der senegrambischen Fauna (»Cap Mirik, Cap Blanc, Portendik, Argain, iles de la Nadeleine«) wird sie bei de Rochebl"une (1. c.) aufgeführt. - Über die Lebensweise dieser Species ist mir nichts bekannt.

L. Dugesi stellt zweifelsohne, wie es bereits Leydigs Scharfblick erkannt hat ${ }^{3}$ ), einen Abkömmling von einer Form der Mauereidechse vor.

1) Bericht d. Senckenberg. Ges. 1869-70. S. 102.

2) Die Natur III, S. 20. Moskau 1874. Russische Zeitschrift.

${ }^{3}$ ) Die in Deutschland lebend. Arten d. Saurier. Tübingen 1872. 


\section{Lacerta atlantica Peters, Doria 1882.}

Char. - Sc. occipitale scuto interparietali interdum paulo maius. Sc. frontale longum. Sc. nasofrenale unicum. Discus palpebralis in margine externo serie granorum limbatus. Supralabialia anteriora 4. Scuta parietalia in margine externo pone scuto maiore oblongo nonnullisque scutellis parvis limbata. Tempora scutellis parvis tecta. Tympanicum adest, sc. massetericum nullum. Sulcus gularis non distinctus vel nullus. Collare denticulatum. Scuta abdominalia per series octo vel decem disposita. Squamae dorsales satis magnae, subimbricatae, quadrangulares, longiores quam latiores, diagonaliter carinatae vel rhomboidales latiores quam longiores, angulis rotundatis. Dentes palatini. Pori femorales utrinque 17-19. Caput pyramidale, valde accuminatum $\left(\sigma^{7}\right)$, satis planum $(q)$. Corpus satis gracile; cauda dupla corporis longitudine minor; pedes postici axillas superantes $\left(\sigma^{7}\right)$, in $q$ paulo breviores. Longitudo: $142-145 \mathrm{~mm}$.

Synonymie.

Lacerta atlantica Peters, Doria, in: Ann. del MIus. Civ. Storia Nat. die Genova, vol. XVIII, pag. 431 (c. fig.).

L. Galloti, (part.!) de Rochebrune, Fauna de la Sénégambie. Vertébrés. Paris 1883-85.

In Rede stehende Eidechse ist die dritte bis jetzt auf den Kanaren entdeckte gute Species. Es ist vor allem $\mathrm{J}$ an, welcher kurz vor seinem Tode das Tier als $\gg$. Braconoti《 unterschieden und dem Pariser Museum geschenkt hat. Darauf erwarben sich Peters und Doria das Verdienst, diese interessante Art sozusagen der Vergessenheit entrissen und in den Genueser Annalen eine genaue Charakteristik derselben gegeben zu haben. Was die Benennung dieser Species anbetrifft, so muls selhstverständlich der recentere Name gelten, denn Jan hat, soviel ich weili, nirgends eine Eidechse als $\gg L$. Braconoti« beschrieben. Manuskriptoder Musealnamen dürfen in gewissen Fällen nicht in Anwendung gebracht werden.

Körpergestalt.

Wir haben es hier mit einer recht isoliert stehenden Art zu thun, die wiederum Charaktere der verschiedensten Formenkreise in sich birgt. In der Gestalt und besonders in Bezug auf die Kopfform erinnert sie an L. Dugesi. Ihre Kopfpholidose ist nahezu identisch mit

derjenigen bei $L$. muratis und ihr Jugendgewand hat Ähnlichkeit mit dem einer jungen Galloti.

Der Körper ist schlank und walzenförmig. Der nach vorn allmählich zugespitzt verschmälerte Kopf ist beim Weibchen etwas flachgedrückt, beim Männchen hingegen ist der Palpebraldiscus 
ziemlich stark gewölbt, wodurch der Kopf etwas höher erscheint. Vorn fallen die Kopfseiten steil ab; hinten, in der Schlafengegend, ist eine leicht ausgepriagte, backenartige Auftreibung bemerkbar. Der vom Kopfe durch eine Halsverengung gesonderte Rumpf erscheint beim Weibchen ron oben gesehen schwach abgeplattet, daher auch relativ breiter als beim Männchen. Der dünn auslaufende, an der Wurzel abgeplattete und in der Mitte mit einer furchenartigen Vertiefung versehene Schwanz scheint stets etwas kürzer zu sein als das Doppelte der Körperlänge. Wie es auch sonst bei den Eidechsen der Fall ist, erscheint auch bei der atlantica die Schwanzlänge variabel. Die Vorderbeine reichen, an den Körper angelegt, bis zum ersten Supralabiale, berühren folglich nicht die Nasenlöcher. Die Hinterbeine überragen die Achseln und erreichen beinahe das Halsband.

Äußere Körperbedeckung.

Unter den Kopfschildern sind zuerst die Sc. supranasalia zu berücksichtigen; sie sind nämlich, wie es bereits Peters und Doria erwähnen, etwas länger als bei $L$. muralis und scheinen zum Teil auf Kosten des weniger langen Frontonasale entwickelt zu sein. Wührend bei der zuletzt genannten Species die Frontonasalia mit ihren meist abgerundeten Kanten einerseits an das Stirnschild, andererseits an die vorderen Supraocularia stoben, erscheinen dieselben bei der atlantica hinten zugespitzt. Die sogenannte Palpebralscheibe besteht jederseits aus 2 größeren mittleren und 2 kleineren äuferen Tafeln. Die vorderen Kanten des länglichen Frontale scheinen niemals eingebogen zu sein, sondern haben entweder einen geraden Verlauf oder sie sind bogenförmig abgerundet. Infolgedessen ist dieses Schild kaum oder gar nicht zwischen die Frontonasalia eingeschoben; seine seitlichen Ränder sind leicht bogenartig ausgeschnitten; die hinteren dagegen verlaufen gerade. Das fünfechige Interparietale ist nahezu ebenso lang als das trapezförmige Occipitale, was übrigens öfters auch bei unseren Mauereidechsen der Fall ist. Die Schläfe sind mit kleinen sechseckigen Täfelchen bedeckt; gegen die Augen zu zeigen diese Schilder eine leichte Wölbung. Massetericum fehlt gänzlich, hingegen ist ein längliches bohnenförmiges Tympanicum vorhanden. Die den meisten Lacerten charakteristische, aus etlichen, meistens aus $3-4$ schmalen Schildern bestehende äufere Umsäumung der Parietalia wird auch bei der atlentica nicht vermifit. Die den vorderen Rand der Ohröffnung begrenzenden Schüppchen springen in der Form einer lileinen Perlschnur vor. Der Palpebraldiscus ist nach außen beinahe seiner ganzen Länge nach durch eine feine Körnerreihe von den oberen Augenschildern getrennt. Diejenigen Schuppen, welche die Augenlider bedecken, treten viel stärker hervor als bei L. Dugesi, Galloti und muralis und verleihen dem Lide fast ein gepanzertes Aussehen. Das Freno-oculare wird von einer recht ansehnlichen Tafel gebildet; 
indem es nahezu senkrecht steht, trägt es nur äuberst wenig zu der Bepanzerung der Schädeldecke bei. Das kleine, einfache Nasofrenale ist fünfeckig; seine Konturen sind sehr wenig durch das Nasenloch beeinträchtigt, während sonst bei dei Eidechsen das Nasofrenale durch das Nasenloch ausgeschnitten und somit oben verschmälert wird. Das Rostrale beteiligt sich nicht an der Umrandung des Nasenloches. Die Nasenlücher liegen eher seitlich als oben; sie sind ziemlich klein und scheinen von der Schnauzenspitze weiter entfernt zu sein als bei den übrigen verwandten Arten. Auf die 4 vorderen senkrecht abfallenden Oberlippenschilder folgt jederseits ein größeres Suboculare, das vorn oben an ein kleines, schmales, manchmal dreieckiges Praeoculare grenzt. Auf das Suboculare folgen nun das erste und zweite, resp. sechste und siebente Supralabiale. Das achte ist äuferst klein und kann mit den Temporalia verwechselt werden. Über die Sublabialia, deren sich auf jeder Seite 7 vorfinden, und die 5 Submaxillaren ist nichts Erwähnenswertes hervorzuheben. Auf die Beschildung des Unterkiefers geben die Herpetologen weniger acht, weil sowohl die Zahl der Schilder als auch ihre Form bei einer und derselben Species Verschiedenheiten bieten soll. Meiner Ansicht nach ist es nicht die Unterkiefergegend allein, relche bei den Eidechsen zu Störungen geneigt ist und ich habe bereits öfters Gelegenheit gehabt zu zeigen, dali sowohl am Pileus als auch in den Nasal-, Temporal- und Ventralregionen betrïchtliche Abweichungen auftreten können, dals aber diese im großen und ganzen zu Ausnahmen gerechnet werden müßten. Wird das eine oder das andere Kennzeichen nicht erörtert, so ist die Aufstellung einer präcisen Diagnose unmöglich. Nicht ein paar liennzeichen, sondern die Gesamtheit der Merkmale bei den Sauriern müssen vom Monographen in Betracht gezogen werden. Bei den kanarischen Lacerten scheint mir die Zahl der Unterkieferschilder stets konstant zu sein. Das gezähnelte, bogenförmig gestaltete Collare besteht aus 6 bis 7 größeren und 2 bis 4 kleineren Täfelchen; die mediane Tafel ist stets breiter als die übrigen. Die Rückenbeschuppung bei atlantica ist so charakteristisch und so sehr auffallend, dafs man diese Art wohl kaum mit einer anderen zu verwechseln im stande sein dürfte. Der Nacken und die Halsseiten sind allerdings mit gewöhnlichen körnerfümigen Schuppen besetzt, die übrigen Rüclienschuppen dagegen sind eher blattartig, viereckig mit abgerundeten Ecken, geschindeit und mit schrägen, leicht gebogenen und deutlich sichtbareu Kielen verschen (vergl. meine Tafel, Fig. 33 und 34). Sowohl in Bezug auf die Gestalt dieser Schuppen als auch in Hinsicht auf ihre gewirtelte Anordnung erinnern sie an diejenigen beim Acanthodactylus Boskianus. Auf den Körperseiten büßen die Schuppen ihre Kiele ein und verflachen sich allmählich, jedoch erhalten sich bei einigen gewisse Ünebenheiten, man möchte sagen buckelartige Erhabenheiten, welche bei günstiger Beleuchtung gut sichtbar sind. Sonst ist noch ein Unterschied zwischen 
den Schuppen des Rückens und der Seiten vorhanden: gegen die Flanken zu werden nämlich die Schuppen etwas länger, auf der Grenze der Ventralia werden sie aber wiederum kürzer, sie erhalten stark abgerundete Ecken und sind entweder spurweise gekielt oder glatt. Es gehen abwechselnd 2 und 3 Querreihen von Sejtenschuppen auf eine Querreihe der Ventralschilder. Der Schwanz ist oben mit länglichen, viereckigen, mit schrägem Kiel versehenen Schuppen bedeckt. (Vergl. meine Tafel, Fig. 27). Gegen das Schwanzende wird die Bekleidung normal. Die mittlere obere Längsschuppenreihe besteht ausnahmsweise aus trapezförmigen Gebilden. Dic Schwanzringel sind sowohl oben als auch unten schwach gezackt; es sind im ganzen 89 bis 96 rorhanden. Hinzugefügt sei noch, daf die Schuppen auf der Schwanzunterseite anfangs, d. h. am ersten Drittel der Schwanzlänge (von der Schwanzbasis gerechnet), glatt, nach rückwärts aber gekielt erscheinen. Die größeren Schilder am Bauche bilden 8 bis 10 Längsreihen; jederseits nach aukien schliefen sich 2 Reihen kleiner Täfelchen an. Da das Brustdreieck nur wenig ausgesprochen ist, so zähle ich im ganzen 28 bis 30 Querreihen von Bauchschildern. Die Zahl der Querreihen der Rückenschuppen ist 96 bis 99 ; diejenige der Längsreihen 33 bis 35. Die auf den Extremititen befindlichen globeren Schuppen sind gekielt. Das ziemlich ansehnliche fünfkantige Anale ist von 2 Bogenreihen Schuppen gesäumt.

Make in $\mathrm{mm}$.

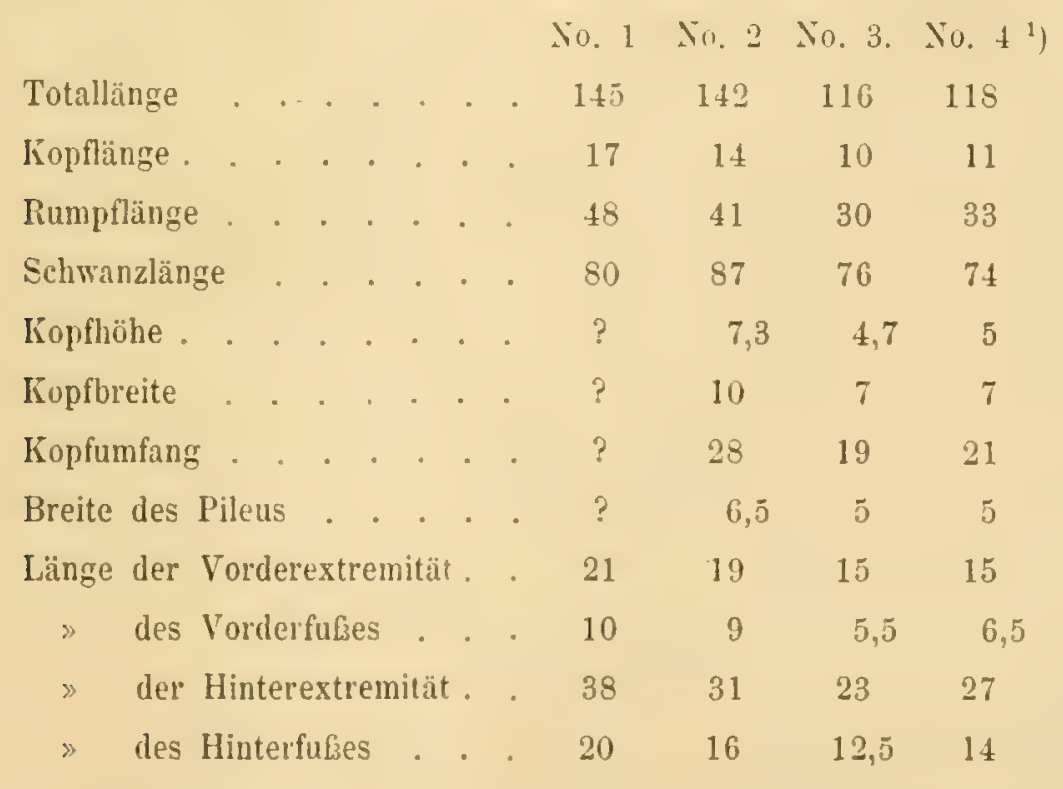

1) Unter No. 1 sind die Körpermaßse der Peters-Doriaschen Individuen angegeben. No. 2 stellt die sub No. 716 als, $L$. Braconoti Jan und Yo. 3 die sub No. 5275 als $=L$ to tarica Pall. im Pariser Museum aufgestelite atlantica vor. No. 4 befindet sich in der Sammlung ron Herrn F. Lat aste in Paris. 
Schenkeldrüsen und Zähne.

Die Drüsenzahl wechselt bei den mir zu Gebote stehenden Stücken wwischen 18-18 und 21-21. Doria und Peters gebeu 17-19 Drüsen an. Die Zahl der Zähne beträgt im Unterkiefer auf jeder Seite 13-15; im Oberkiefer jederseits 11-13; im Zwischenkiefer 6-7. Die Zähne zeigen eine einfache Spitze. Der Gaumen scheint bezahnt zu sein.

Farbenkleid.

Allem Anscheine nach standen Doria lebende Individuen der atlantica zur Verfügung, infolgedessen will ich seine Angaben in Bezug auf die Färbung wörtlich wiedergeben: »Il colore delle parti superiori è bruno ferruginoso; da ciascun lato del dorso corre ina linea giallognola posta fra due serie di punti nerastri e gialli; i lati del corpo mostrano una linea longitudinale pallida meno distinta, al di sopra della quale si osserva una serie di macchiete nere con occhio azzurognolo; le estremità sono superiormente ornate di macchie nere ocellate di bruno rossastro; il di sotto è di un bianco roseo metallico; la gola è in alcuni nerissima, in altri invece questo colore si va sfumando, ma è però sempre distinto.« — Die mir vorliegenden Weingreistexemplare aus dem Pariser Museum weichen von den Doriaschen Stücken in vieler Hinsicht ab. Das größere unter dem Namen »L. Braconoti Jan« erhaltene Stück zeigt oben einen hellnubbraunen Fond, durchzogen von 2 schmalen, an den äußseren Rändern der Parietalia ihren Ursprung nehmenden, grünlichweiliea Länısbinden. Diese hellen Binden sind von aukien und innen von ebenfalls grünlichweißen, dunkelbraun umrandeten Augenflecken umsäumt. Den mehr seitlich gelegenen Ocelli gesellen sich jederseits a Reihen grunlichblauer braun umraudeter Augenflecken bei, von denen die äuliersten (also bereits auf der Bauchgrenze liegenden) nur sehr schwach ausgesprochene braune Ringe aufzuweisen haben. Ähnliche blaue Augen sind spärlich oben auf den hellbraunen, dunkelbraun gefleckten Extremitäten wahrnehmbar. Pileus und Kopfseiten haben leider z. T. ihre Epidermis verloren. Der Schwanz ist nur oben an der Wurzel spärlich dunkelbraun punktiert; sonst erscheint die Schwanzoberfäche einfarbig hellnukbraun. Die Kehle, mit Ausnahme der gelblichen, grau gepunkteten Submaxillaren, ist eisengrau. Das Collare, die mittlere Zone des Bauches und die Schwanzunterseite sind gelblich. Die übrigen Teile, wie z. B. die Unterseite der Beine, die äufsersten Bauchschilderserien und die Seiten des Schwanzes sind entweder perlgrau, grünlich oder grau und grün auf Gelb gepudert.

Das 2weite als staurica $\mathrm{Pall}$.《 bezeichnete Individuum im Pariser Museum ist bedeutend dunkler und erscheint den Originalexemplaren von Peters und Doria im allgemeinen ähnlich zu sehen. Auf dunkelbraunem Rückenfond stehen in 8 Längsreihen angeordnete Augenflecken, 
die von Braunschwarz umrandet erscheinen. Diese Ocelli sind gegen die Körperseiten hin blau, hingegen auf der Rückenzone hellnußsbraun. Diejenige Fleckenreihe, welche in der Achselgegend ihren Anfang hat, zeigt eine gesïttigte blaue Farbe. Blaue Augen zicren gleichfalls die ersten Iongitudizalen Bauchschilderreihen, ferner die Halsseiten und die Oberseite der Extremitäten. Der Nacken und die Parietalia sind braun mit einem Stich ins Metallgrüne; der übrige Teil des Kopfes und die Schwanzunterseite ist dunkelbraun. Die braune Schläfe hat jederseits in der Nähe des Augapfels ein grinliches Pünktchen; die Oberlippenschilder sind braun von Bräunlichgelb umsüumt. Die dunkle Färbung der Kehle scheint charakteristisch für die atluntica zu sein, denn auch bei dem vorliegenden Stück ist die Kehle derjenige Körperteil, welcher am dunkelsten koloriert ist, nämlich pechschwarz. Ob dies lediglich eine Eigentümlichkeit des männlichen Geschlechtes ist, kann ich nicht angeben; die Peters-Doriaschen Stücke scheinen alle eine dunkle Kehle zu haben. In Bezug auf die Färbung des Bauches mufs bemerkt werden, daf dieselbe bei meinem zweiten Individuum gesättigter ist als beim ersteren. Der gelbliche Ton tritt zurück und macht der blaugrünen Nuance Platz. Die eisengrauen Flecken erscheinen intensiver und die gelbe Unterseite des Schwanzes erhält einen Stich ins Rosa. Das Anale ist einfarbig rosagelb; das Halsband grünlichweili, mit etlichen, an den oberen Partien der Tafeln sich befindenden grauen Flecken versehen.

\section{Hab it a t.}

Ich kenne ein gröleres Exemplar dieser Form mit "Braconoti. Madère. Dedit Jan « bezeichnet, das aus dem Mailänder Museum stammt und in der herpetologischen Sammlung des Pariser Jardin des Plantes anfbewahrt wird, ferner ein Stück, das ebenfalls im Pariser Museum aufgestellt ist, und $z$ war als $\gg L$. taurica $\mathrm{Pa} I$. . von der Insel Lancerotte (dedit: Verneau) benannt und endlich ein drittes, aus Arrecife auf Lancerotte stammendes Originalindividuum Dorias in coll. F. Lataste. Aus der oben citierten Abhandlung von Peters und Doria erfahren wil ferner, dabi die attantica auch in Santa Cruz auf Teneriffa gesammelt worden ist. Gedachte Autoren sprechen die Vermutung aus, daß ihre Species mit L. muratis (A. Duméril ${ }^{1}$ ) aus Teneriffi und mit einer Varietät der Mauereidechse von Duméril und Bibron ${ }^{2}$ ) identisch sein könnte. Allein ich hatte neuerdings Gelegenheit die betreffenden Originalexemplare A. Dumérils und Dumérils und Bibrons zu untersuchen und mich zu überzeugen, daks dies nicht der Fall ist. Die von Delalande auf Tenerifa gesammelten und im Katalog von A. Duméril erwähnten Eidechsen sind keine satlantica«, sondern muralis;

1) Catal. méth. de la Collection des Reptiles I, pag. 122. Paris. - (var. B.).

3) Erpétologie générale, vol. V. pag. 232. 
es sind genau dieselben Exemplare, deren Duméril und Bibron in ihrer generellen Herpetologie S. 232 sub »muralis var. b.\& gedenken. Ein Exemplar der L. atlantica, das sich im British Museum befindet und als "Zootoca Derbiana《 bezeichnet worden ist, stammt aus Mogador. Was Senegambien anbetrifft, so wird zwar die aflantica von de Rochebrune in seinem Werk über die Fauna Senegamłjens genannt aber als synonym mit Lacerta Galloti angesehen.

\section{Lacerta taurica Pall. 1831.}

Char. - Sc. occipitale interparietali minus, sc. frontale longum, sc. nasofrenale unicum. Discus palpebralis in margine externo serie granorum limbatus. Scuta supralabialia anteriora 4. Sc. parietalia interdum $2-3$ scutellis oblongis limbata. Tempora parvis scutellis squamisque tecta, sc. massetericum et tympanicum distinctum. Sulcus gularis distinctus, collare subdentatum. Sc. abdominalia per series 6 disposita. Squamae dorsales parvae, rotundatae quadrangulares vel sexangulares, carinatae. Dentes palatini. Pori femurales utrinque 16-23. Corpus sat tenue; caput paulo latius quam altius, pyramidale; cauda dupla corporis longitudine minor; pedes postici axillas fere attingentes. - Longitudo: 130-193 mm.

Synonymie.

Lacerta taurica Pallas, Zoographia rosso-asiatica, Ill, pag. 30. 1831. - Nordmann, Observations sur la Faune Pontique in: A. de Démid off, Voyage dans la Russie méridionale et la Crimée etc. III, pag. 335. Paris 1840 (c. tab.). - Duméril et Bibron, Erp. génér. V, p. 223. - Schinz, Europ. Fauna, S. 15. - Schrejber, Herpetolog. europaea, pag. 423. - Kessler, Zoolog. Reise durch Transkaukisien etc., 1. c. S, 163 (Russisch!) - v. Bedriaga, in: Zoolog. Auzeiger V'I, S. 216. Boulenger, in: Proc. zool. Soc. of London 1881, p. 743. - Rathke, Beiträge z. Fauua d. Krim (l. c.) P. 302. Tab. IL.

Podarcis taurica Bonaparte, Amphibia europaea in: Mem. Acad. Sc. di Torino Ser. 2, T. II; Iconografii delli Fauna italica II. Anfibi. Tah. fig. - ? De Betta, Rettili ed Anfibi del Regno della Grecia in: Atti Ist. Ven. di Scienze, Lettere ed Arti XIII, Ser 3, Venezia.

Zootoca taurica Gray, Cat. Liz. Brit. Mus. pag. 29.

Phenax taurica Fitzinger, Systema reptilium I. p. 20. ${ }^{1}$ )

1) OU die ron Nordmann (1. c.) als synonym hierher gezogene $\gg$ Lacerta catenata Fitzinger (Nuseum Vindobon.) zu dieser Species gehört, kann ich leider nicht entscheiden. 
Lacerta muralis (part.!) Bibron et Bory de St. Vincent in: Expédition scientifique de Мorée III.Paris 1836.

Körpergestalt und Größ e (Vergl. meine Tafel Fig. 28, ð).

Meist minder schlank als $L$. muralis, mit hohem, in der Schlifengegend erweitertem, nach vorn nur sehr allmählich zurespitzt verschmälertem Kopfe. Die Schädeldecke neigt sich von den Augen an gegen die Schnauzenspitze sehr sanft nach abwïts zu; die Palpebralscheibe ist flach oder äufierst schwach gewölbt; die Kopfseiten sind ziemlich senkrecht, die Zügelgegend kaum merkbar der Länge nach vertieft; die Oberkiefer leicht hervortretend. Der Rumpf zeigt einen ziemlich bedeuteuden Umfang und ist von oben meist deutlich abgeplattet. Die Hinterfülse erreichen nicht ganz die Achseln, während die Vorderbeine in der liegel bis zum Vorderrande der Augen reichen. Der beim Männchen kürzere beim Weibchen längere Schwanz ist an der Wurzel, namentlich beim männlichen Geschlecht, breit und etwa vierseitig, dann drehl'und und beim Weibchen allmählich in eine sehr dünne Spitze ausgezogen.

ઇ. - Totallänge: $193 \mathrm{~mm}$. Länge des Kopfes: $17 \mathrm{~mm}$, des Halses: 10, des Rumpfes: 55, des Schwanzes: 121, der Vorderextremität: 20, des Vorderfußes: 9, der Hinterextremität: 36 , des Hinterfufes: 16-17 mm. Kopfhöhe: 9,5, Kopfbreite: 11, Breite des Pileus: $8 \mathrm{~mm}$. Umfang des Kopfes: 37, des Halses: $37-37,5$, des Rumpfes: $39-40 \mathrm{~mm}$. - Q. $_{\text {- Total- }}$ länge: 157,7 mm. Länge des Kopfes: 14,7, des Halses: 9, des liumpfes : 55, des Schwanzes: 88, der Vorderextremität: 20 , der Hand: 9, der Hinterextremität: 33, des Fulies: 17 mm. Kopfhöhe: 8, Kopfbreite: 9-9,5, Breite des Pileus: 7 mm. Umfang des Kopfes: 29, des Halses: 30, des Rumpfes: $29,5 \mathrm{~mm}$.

Schilder und Schuppen (vergl. meine Taf. Fig. 25, 281).

Das kleine, bald längliche, bald kurze dreieckige oder trapezförmige Occipitale ist nach hinten zu leicht abgerundet; das öfters nahezu doppelt so lange, fünfseitige Interparietale grenzt mit seinen erweiterten und mit in stumpfem Winkel zusammenstofenden Seiten versehenen Vorderteile an die gewöhnlich bedeutend längeren als breiten Frontoparietalia; nach hinten zu erscheint es in bedeutendem Malie verschmälert; die 2 hinten abgerundeten, seitlich, nach aufen unter rechtem Winkel zusammentretenden Frontoparietalia, die mitunter bogenförmig geschwungene Kanten zeigen, stoßen mit ihren länglichen Rändern in del Mittellinie des Kopfes zusammen. Die namentlich bei der Krimer taurica alle anderen Kopfschilder an Ausdehnung übertreffenden Parietalen sind länger als breit, hinten und am Aufsenrande abgerundet und auf die Schläfe leicht umgebogen; ihre nach innen zu gekehrten Seiten bestehen jederseits aus drei

1) Vergl. auch die Abbildungen bei Rathke (l. c). 
unter stumpfem Winkel zusammenstobenden und öfters geschwungenen, an das Occipitale, das Interparietale und Frontoparietale sich anfügenden Kanten. Vorn grenzen die Parietalia an das vierte ziemlich grofe, drei- oder vierseitige Supraoculare. Auf dieses folgt das Supraoculare III, das etwas breiter als lang ist und dessen äußere Seite von Schüppchen umsäumt wird, während die vortere längste Seite an das zweite, längere und nach vorn verschmälerte Supraoculare II grenzt, das gleichfalls durch eine Schuppenreihe von den $4-5$ schmalen, über die Augen vorspringenden. Supraciliaria getrennt wird. Vor dem Supraoculare II liegt noch ein kleines schmales Oberaugenschildchen, das zwischev dem ersten Supraciliare und dem langen Frontonasale liegt. Das in seiner Mittellinie oft längsgefurchte Frontale ist die zweitgröfte Kopftafel; es ist ziemlich breit, in seiner Mitte stets, nach hinten zu öfters verengt und nach vorn hin etwas erweitert, seine Vorderseiten in bald stumpfem, bald spitzem Winkel zusammenstoliend; in diesem Falle haben sie einen gradelingen, in jenem einen geschwuugenen Verlauf; seine Hinterseiten treten unter äuferst stumpfem Winkel zusammen und sind mitunter leicht ausgerandet, während seine Außenränder fast immer geschwungen erscheinen. Das leicht auf den Pileus uibergewölbte Rostrale beteiligt sich an der Umrandung des Nasenloches; es ist durch die m der Mittellinie zusammenstolisenden, etwa dreiseitig abgerundeten und seitlich tief eingeschnittenen Supranasalia von dem breiten, etwa rhombenförmigen Internasale getrennt. Supralabialia anteriora sind gewöhnlich 4, Supralabialia posteriora 2 vorhanden; das Auge ist unten von dem breiten Suboculare begrenzt. Zwischen den vorderen Supralabialia und (len Pileistafeln befinden sich: 1) ein dreieckiges oder trapezförmiges, über der Tordernaht des Supralabiale gelegene, das Nasenloch von hinten begrenzende Nasofrenale, 2) das darauf folgende, gröfere und dem Supralabiale II aufliegende Frenale und 3) ein nach vorn zu verschmälertes Freno-oculare, das durch die einen leistenartigen Vorsprung zeigende schmale Praeoculartafel vom Suboculare getrennt erscheint; dieser Vorsprung am Praeoculare und seine Fortsetzung auf dem Suboculare tritt namentlich bei den alten Männchen hervor. Die Schläfe ist mit kleinen schuppenartigen Schildchen bedeckt, welche von fünf- und sechseckiger Form sind und gegen die Parietalränder von 2 bis 3 größseren, länglichen Tafeln begrenzt werden; die Gesamtzahl der Temporalia - das größere Massetericum und das Tympanale mitgerechnet - wechselt zwischen 33 und 40; diese Schildchen sind etwas gröber und flacher als diejenigen bei $L_{\text {. }}$ muralis, bedeutend kleiner und gewölbter als als bei $L$. pelopomesiaca. Die gewöhnlich in der Șechszahl vorhandenen Sublabialia sind um ein geringes höher als es bei der muratis der Fall ist. Von den 5 Submaxillaren sind die 2 ersten bedeutend kleiner als die darauffolgenden; vom vierten Paare an stofen die Submaxillaria in der Mittellinie nicht mehr zusammen; 1-3 kleinere Schildchen folgen dem Sub- 
maxillare V. Die lïnglich-hexagonalen hehlschuppen sind von den dahinterliegenden breiteren, in der Mitte etwa fünf, auf den Seiten sechseckigen Halsschuppen durch eine deutliche Querfurche getrennt, welche gewöhnlich ron einer bis zum Ohr sich hinziehenden Querfalte begleitet wird. Die Anzahl der IKalsbandtafeln beträgt gegen $9(7-10)$; die Tafeln sind wiukelig vorgezogen, wodurch das Halsband an seinem freien Rande ein gezähneltes Aussehen erhült. Wenn Pallas in seiner Originaldiagnose angiebt, dafs die Ventralia in vierfacher Reihe vorkommen, so ist dies, wie bereits Rathke hervorgehoben hat, falsch, denn die Schilder der Bauchseite verhalten sich, der Zahl sowie der Grölse nach, wie bei L. muralis; es sind nämlich circa 29 (す) bis 32 (†) Quer- und 6 Längsreihen; letztere sind allerdings seitlich von kleinen Randschildchen begrenzt. Die Körperschuppen sind verhältnismäbig grölser als bei muralis; die Schuppen des Nackens klein, rundlich, körnig und glatt oder nur undeutlich gekielt, die des Rückens bald eifürmigr-hexagonal oder abgerundet viereckig und deutlich längsoder diagonalgekieit. Gegen die Flanken hin werden die Schuppen etwas breiter und länger und erscheinen an der Bauchgrenze flach, glatt und zuweilen auch äuberst schwach geschindelt. In der Mitte des Rumpfes zählte ich bei zwei taurica aus der Krim 125 Quer- und 48 Längsreihen Dorsalschuppen; drei Schuppengürtel entsprechen der Länge eines Bauchschildes. Die in 97 bis 110 Querreihen gestellten Caudalschuppen sind unterwärts an der Schwanzwurzel ziemlich kurz, hinten beinahe gerade abgestutzt oder abgerundet usd glatt; nach hinten zu erscheinen die Schuppen länglich, schmal, aufliegend gekielt und durch die Kiele in zwei ungleiche Hälften geteilt. Die oberen Schuppen sind stumpfwinkelig ausgezogen und mit Ausnahme der medianen Längsreihe ungleichseitig gekielt. Vor dem grolien Anale liegen in einem Halbkreise 5-6 Schildchen, deren mittelstes häufig halb so grol; ist als das Afterschild. Auf diese größseren Tafeln folgen nun bedeutend kleinere, wiederum im Halbkreise angeordnete Schildchen, welche die Aftergegend vom Bauche trennen.

Ungeachtet dessen, dafis die taurica schon mehrmals beschrieben worden ist, scheint sie dennoch lange Zeit übersehen oder mit anderen Arten verwechselt worden zu sein. Unter den sieben im Iusée d'hist. nat. zu Paris als $L$. taurica aufgestellten Eidechsen gehören nicht weniger als fünf anderen Arten an; so z. B. enthält Büchse 5275 eine atlantica, Büchse 5501 eine muralis vom Faraglioni (ded. v. Bedriaga), Büchse 2708 zwei L. peleponnesiaca. Im Berliner IIuseum habe ich gleichfalls, wenn ich nicht irre, zwei muratis aus Griechenland als taurira bezeichnet vorgefunden (Nr. 6973 und 6982). Die verschiedenerseits geschehenen Äußerungen über die Ähnlichkeit der taurica, einerseits mit $L$. muratis, andererseits mit L. agilis, ferner die Behauptungen uber ihre angebliche Identität mit $L$. peloponnesiaca Bibron, 
Bory, sowie auch der Umstand, dak die Beschreibungen der taurica mitunter in den wesentlichen Punkten nicht übereinstimmen, haben wohl dazu beigetragen, dafi ich in den Irrtum meiner Vorgänger verfiel und in meiner Schrift über die Kriechtiere Griechenlands als taurica eine ganz andere Art, und zwar die pelopomesiaca beschrieb, welche bekanntlich in der »Expédition scientifique de Morée« zum erstenmal charakterisiert und später von Duméril und Bibrou in die Synonymie der taurica versetzt worden sind. Erst als ich durch die Güte der Herren Dr. Strauch und Dr. Schreiber in die Lage versetzt wurde, eine Anzahl Exemplare echter taurica vergleichen zu hönnen, bin ich zur Überzeugung gelangt, daks sowohl Duméril, Bibron, Nordmann, Bonaparte, De Betta, Schreiber als auch meine Wenigkeit irrtümlich in der peloponnesiaca Bibr. Bory die turica zu erkennen glaubten. Wenn mir nun die Frage gestellt werden sollte, worin der Unterschied zwischen diesen beiden Eidechsen besteht, so würde ich in erster Linie auf die Beschaffenheit des Collare und der Schwanzschuppen hinweisen. Bei der taurica ist das Halsband deutlich gezähnelt und die oberen Caudalschuppen erscheinen winkelig ausgezogen. Dagegen bei der von uns irrtümlicherweise als taurica citierten peloponnesiaca erscheint das Halsband ganzrandig und die freien Schwanzschuppenränder sind leicht abgerundet; sie scheinen bei oberflächlicher Betrachtung eher geraderandig zu sein. In der Originaldiagnose, von $L$. taurica, welche ich im Jahre 1880 bei der Durchmusterung meiner griechischen Lacerten zu liate gezogen habe, steht allerdings nur folgendes über das Halsband zu lesen: „Collare insigne e squamis 8 vel 7 a. Erst in den nachträglichen Diagnosen der tarrica wird eines gezühnelten Collare Erwähnung gethan und zwar zu allererst in den Beiträgen zur Fauna der Krim von Rathke, welcher diese Species am treffendsten charahterisiert hat. Da aukerdem $R$ ath ke die Synonymie von L.taurica welche bis jetzt mit Bezug auf diese Art nur Verwirrungen verursacht hat - nicht anführt, so will ich auf die Rathkesche Beschreibung als auf die zuverlälijigste hinweisen. Obgleich Pallas als Auktor von L. taurica gilt, ist diese Eidechse lange Zeit vor der Publikation (1811) oder dem Erscheinen (1831) der Zoographia rosso-asiatica als Varietät von L. agilis, und zwar unter dem Namen "Le petit Lézard bigarré« von einem uns unbekannt gebliebenen Verfasser der interessanten Schrift »Déscription physique de la Contrée de la Tauride«, die in zweiter Auflage, oder richtiger in französischer Übersetzung im Jahre 1787 in Haag erschien, beschrieben worden; folgende Beschreibung, welche ursprünglich in russischer Sprache verfafit und im Jahre 1785 von der Petersburger Akademie reröffentlicht worden ist, dürfte die Aufmerksamkeit des Übersetzers, nämlich Pallas, auf diejenige Eidechse, welche er späterhin als staurica bezeichnet hat, gelenkt haben: „Le petit Lézard bigarré ( $L$. agilis var.). Parmi les 
rochers des plus hautes montagnes maritimes, près de Balaclava. Sa longueur, du hout du nez jusqu' à la racine de la quene, ne surpasse guere un Verchoc et sa quene est beaucoup plus longue que le corps. La peau du dos est unie, verte au milieu, mais jaune aux côtés avec des taches transversales noires. Le dessous du corps est blanc-verdâtre, avec 8 taches bleu de ciel sur chacun des côtés. Le dessus de la queue est verd-foncé, et le dessous plus clair, couvert d'écailles aigues. Il a 5 doigts a chacun de ses pieds. Cette espèce de lézards, ne se rencontre nulle autre part en Russie.« Es ist offenbar, daf darunter unsere taurica gemeint ist.

Folgende nachträgliche Bemerkung R athkes (op. cit. in: Ném. des Savans étrangers de l'Acad. Imp. d. Sc. de St. Petersb. III. pag. 771) dürfte beim event. Vergleich der taurica mit L. muratis von Interesse scin: "Lichtenstein giebt die $L$. taurica Pall. für identisch mit L. muralis (Verzeichn. d. Dubletten d. zoolog. Mus. zu Berlin). Ich habe deshalb 2 Exemplare der $L$. taurica, die ich nach Königsberg mitgebracht hatte, mit der Beschreibung und den Abbildungen verglichen, die Edwards von $L$. muralis gegreben hat (Ann. sc. nat. XXI und Isis vom Jahre 1833). Danach aber zu urteilen sind beiderlei Tiere einander sehr ähnlich, doch bleibt es zweifelhaft, ob sie wirklich nur zu einer Art gehören. Bei L. muralis kommt jederseits zwischen Auge und Ohr nur ein einziges, fast kreisförmiges ziemlich grolies Schild (Sc. massetericum) vor, das ringsum nur von kleinen, körnigen und in großer Zahl vorhandenen Schuppen umgeben ist, bei $L$. taurica dagegen liegen um ein solches mittleres Schild mehrere andere Schilder, die zwar kleiner (die meisten halb so grof) als jenes sind, doch der Mehrzahl nach mälijg grobie Platten darstellen, nicht alle kleine kürnerartige Schuppen, deshalb auch in viel geringerer Anzahl vorhanden sind als bei $L$. muralis. Die Bauchschuppen liegen bei beiden in 6 Reihen beinahe gleich breit und die einzelnen Schuppen beinahe rechtwinklig; bei $L$. taurica dagegen sind die einzelnen Schuppen sehr schief winklig, indem sie gröfitenteils sich Phomben annähern, und es sind jederseits die der mittleren Reihe um sehr vieles größer als die der beiden anderen Reihen, zumal die der inneren, d. h. der Mittellinie des Bauches angrenzenden Reihe, so etwa wie nach Edwards Abbildungen bei $L$. velox. Überdies ist bei taurica das Halsband frei, nicht aber wie Lichtenstein von $L$. muralis angiebt, angewachsen, ${ }^{2}$ ) und die Schuppen des Rückens und der Seiten sind mehr körnig, als sechseckig zu neunen; zwar erscheinen viele dieser Schuppen eckig, doch sind ihre Ecken undeutlich und es lassen sich unter ihnen schr viel mehr unregelmäßige Fünfecke als Sechsecke herausfinden $\ll$.

1) Lichtenstein dürfte die muralis nur oberfächlich untersucht haben! 
Schenkeldrüsen und Bezahnung.

Die Zahl der Drüsen (Poren) giebt Schreiber zu 19-23, Kessler zu 15-22 an. Bei einer Reihe Individuen von der Balkanhalbinsel und von der Insel Tinos traf ich 16-17 und nur bei einem Exemplar 15 Drüsen jederseits. Unter 8 Stücken aus der Krim fanden sich einige mit 16, 18 und 20 und andere mit 21 Drüsen; es scheint beinahe, daf letztere in der Regel eine grölsere Drüsenanzahl aufweisen. Die Ober- und Unterkieferhälfte ist gewöhnlich mit 19 bis 20, der Zwischenkiefer mit 7 Zähnchen bewaffnet. Der Gaumen ist bezahnt.

Farbenkleid.

Obwohl diese Art im ganzen nur wenig abändert, so tritt sie uns doch in ihren verschiedenen Lebensaltern in wechselnder Farbe entgegen, nur die Zeichnung bleibt für alle Fälle ziemlich beständig. Bei jungen Tieren ist sowohl die Oberseite der Kopfes, des Schwanzes und der Gliedmaßen als auch des Rückens nufibraun oder bei etwas älteren Individuen olivenfarben. Die Rumpfseiten werden von 2 weißłlichen oder bräunlichweißen Längsstreifen durchzogen, welche von zahlreichen, öfters weif geaugten und untereinander zusammenhängenden schwärzlichen Flecken von unregelmäßiger Gestalt begrenzt und getrennt erscheinen. Die Seite des Rumpfes zeigt somit: 3 Reihen von schwärzlichen Flecken, deren mittlere, am Hinterrande der Augen entspringende, jederseits von einem hellen Streifeu oder von einer Reihe hintereinanderstehender und öfters verbundener weillicher Flecken umsäumt erscheint; eine vierte, meistens nur spurweise angedeutete Fleckenserie befindet sich auf der ersten bläulichen longitudinalen Ventralschilderreihe. Der bräunliche Schwanz ist an den Seiten braun gestreift und weif gepunktet; die wie der Rücken gefürbten Beine zeigen weißliche Tropfenflecken, die oft mit bald mehr, bald reniger schwarzen Ringflecken untermischt sind. Die ganze Unterseite des Körpers ist weililich oder buttergelb. Diese für die Jungen charakteristische Fürbung und Zeichnung bleibt beim Weibchen sehr selten auch das ganze Leben hindurch bestehen; in der Regel hellt sich die Grundfarbe mit zunehmendem Alter auf, sodals sie bei erwachsenen Männchen durch Mausgrau und Olivenfarben ins Grüne mitunter ins Grasgrüne, bei älteren Weibchen durch Olivenbraun und Bleifarben in Graugrün oder Grün übergeben kann. Bei der gewöhnlichsten auf dem Binneulande lebenden Form zieht sich eine bald schmälere, bald breitere, grüne oder grünliche, fleckenlose mediane Rückenzone bandartig über den Rücken bis auf die Schwanzwurzel hin, welche jederseits von schmäleren, zuweilen aber ebenso breiten, bräunlichen, schwarz gefleckten Binden eingefafit wird. In vielen Fällen, namentlich bei der männlichen taurica aus der Krim, nehmen diese dunkelbraunen oder schwarzen Flecken dermaßen an Größc zu, dą der bräunliche Untergrund uur in den schmalen Zwischenräumen zur Geltung 
komnt und aufierdem noch durch die, die dunklen Flecken öfters begleitende, weiflich oder grünlichweifse Umrahmung verdrängt wird; in anderen Fällen aber, so insbesondere bei den in der Umgebung von Konstantinopel und auf Tinos vorkommenden taurica tritt die dunkle Fleckung weniger uppig hervor, die Flecken sind kleiner und mitunter sind nur Punkte vorhanden, welche nicht so dicht aneinander gereiht sind, so dalis die bräunlichen Binden schärfer ausgeprägt erscheinen, wie es z. B. bei den Konstantinopeler Weibchen der Fall zu sein pHlegt. Diese bräunlichen Binden köunen übrigens bei den Tieren aus Tinos gänzlich fehlen, wobei aber das Grün gegen die hintere Partie des Rückens allmählich abnimmt und einem hellen Braun Platz macht, welche Farbe auch die Oberseite des Schwanzes, der Extremitäten und des Kopfes zeigt; zugleich kanu eine, allerdings kurze und nur auf den Hinterrücken beschränkte Vertebralreihe von schwärzlichen oder schwarzbraunen Fleckchen auftreten. Auf die bräunlichen, schwarz gefleckten Binden oder auf die Längsreihen schwarzer Flecken folgt ein heller, bald weißlicher oder grünlichweißer, mitunter von den dunklen Flecken unterbrochener Streifen, welcher am Aufienrande des Parietale beginnt, oberhalb der Ansatzstellen der Gliedmakien sich hinzieht und sich häufig bis zur hinteren Schwanzhälfte fortsetzt. Darauf fo!gen 2 dunkelbraune, schwarzbraune oder schwarze, schnörkel- oder deltaförmige, breite und oftmals zusammenhängende oder nur aus Punkten bestehende Fleckenserien, welche von einem hellen, am hinteren Ohrande seinen Ursprung nehmenden Streifen z. T. oder vollkommen getrennt erscheinen. Oftmals entsendet dieser Streifen sowohl nach oben als auch nach unten hin Ausläufer, welche die übrig gebliebenen Rüume zwischen den soeben erwähnten dunklen Flecken ausfüllen, sehr häufig aber bleiben diese Verästelungen gänzlich aus; in diesem Fall tritt der Streifen als schmale, zuweilen nur schwach ausgeprïgte Umsäumung der, auf bräunlichem Grunde verteilten dunklen Fleckenserien auf. Die Bauchgrenzen erhalten auf gelblichem, weiblichem oder bläulichem Grunde etliche punktförmige, dunkle Flecken, welche übrigens bei den weiblichen taurica aus Tinos fehlen können. Oberhalb der Wurzeln der Vordergliedmaß3en und auf den Oberschenkeln der Hinterextremitäten treten häufig, namentlich beim Männchen, runde, blaue, dunkel eingefafte Flecken auf. Die bei den grünen Individuen grünlichgraue, bei den grauoder braungrünen Stücken grüngraue oder bräunliche Oberseite der Gliedmafen ist mehr oder weniger stark mit hellen, graubraun oder schwärzlich umrandeten Ocellen und mit braunen und schwarzen Flecken besetzt. Die Kiopfoberfläche ändert durch Braun und Olivenbraun bis zum lebhaften Grasgrün ab und ist nicht selten spärlich dunkelbraun punktiert. Die Kopfseiten erscheinen oberwärts hellbraun oder grünlichbraun, unterwärts grünlich ungefleckt; die hellen Rumpfstreifen und die dunklen Zeichnungen setzen sich meistens auf die Schläfe fort. Das 
obere Lid ist weib oder gelblichweif, das untere bräunlich. Sowohl die Unterkieferränder als auch die Kehle, der Hals und die erste Lüngsbauchschilderreihe sind bei beiden Geschlechtern entweder grünlich oder blaugrün angehaucht ${ }^{1}$ ); das Blau und Blaugrün überzieht sehr häufig auch die übrigen unteren liörperpartien allerdings mit Ausnahme der Hinterextremitäten und des Schwanzes, welche etwa buttergelb erscheinen. Taurica mit weißlicher oder buttergelber Körperunterseite kommen gleichfalls häufig vor; dagegen taurica mit vollkommen einfarbigem Rücken, oder deren Bauch gefleckt wäre, sind mir nicht bekannt. In Bezug auf die Färbung und Zeichnung sieht diese Art der von De Betta als campestris bezeichneten muralis frappant ähnlich; namentlich bei jener, mit einer kurzen, auf den Hinterrucken beschränkten Vertebralreihe von Flecken versehenen taurica aus Tinos geht die Ähnlichkeit so sehr ins einzelne, daf man sie förmlich von der campestris nicht zu unterscheiden vermag. Wenn wir die Thatsache in Betracht ziehen, daßa die taurica hauptsächlich hinsichtlich der Beschaffenheit des Halskragens und der Rückenschuppen von der muralis abweicht, so kommen wir unwillkürlich zur Schlußfolgerung, daf erstere, oder eine der taurica entsprechende Form sich in früheren Zeiten von der muralis abgezweigt haben dürfte. Jedoch darf man, meiner Ansicht nach, die in Rede stehende Art nicht als eine unter $L$. muralis gehörige Form oder gar als eine mit »Podarcis Mferremii Fitz.« identische Eidechse bezeichnen, wie es bekanntlich von seiten Wi e gmanns (Arch. f. Naturg. 1837, S. 222) geschehen ist.

Vorkommen.

Hinsichtlich der Verbreitung der taurica war ich seiner Zeit als ich meine Schrift über die Kriechtiere Griechenlands veröffentlichte, noch mangelhaft unterrichtet; seitdem war es mir vergönnt, mehrere Museen zu besuchen und einige von den früheren. Angaben über das Vorkommen dieser Art zu verifizieren und ich glaube aus meinen Notizen schliefien zu können, daßs die Angaben in betreff des Vorkommens unserer Eidechse auf Sicilien ${ }^{2}$ ), im Kaukasus ${ }^{3}$ ) und der Nordküste Klein-Asiens mit Recht in Zweifel grezogen und bestritten worden sind, denn es ist leicht nachweisbar, daf wenigstens die diesbezüglichen Angaben Dumérils, Bibrons und De Filippis auf einer Verwechselung der taurica mit anderen Species beruhen. Jene jn der Erpétologie générale, t. V, p. 228 citierte sicilianische taurica figuriert nämlich heute noch im Musée d'hist. nat. zu Paris unter dem ihr von Duméril und Bibron verliehenen

1) Vergleiche die kolorierte, von Prêtre unter Nordmanns Leitung ausgeführte Abbildung bei Dẻmi doff.

8) Doderlein, Alcune generalità intorno la Fauna Sicula etc in: Annuario Soc. Natur. in Modena VI. p. 200.

$\left.{ }^{3}\right)$ Nach Pallas Zoographia rosso-asiatica. 
Namen; sie stellt aber, wie ich mich selbst vergewissert habe, nichts Anderes, als die auf der apenninischen Halbinsel, sowie auch auf den italienischen Inseln weit verbreitete $L$. muralis necupolitana vor. ') Hingegen gehört, wie Camerano kürzlich nachgewiesen hat, die vermeintliche, aus Tiflis und Trapezunt stammende taurica De Filippis einer anderen, und zwar neuen Art an ${ }^{2}$ ); man darf wohl vermuten, daßs das nämliche mit jener taurica, welche W a g ner im Norden Klein-Asiens gefunten zu haben behauptet, der Fall sein wird. Das von mir in einer meiner Schriften über das Vorkommen der in Rede stehenden Species in Smyrna Gesagte, scheint mir nun ebenfalls nicht einspruchsfrei zu sein, obschon es möglich wäre, dak die Snyrnaer, im Athener IJuseum aufgestellten Eidechsen echte taurica sind, da letztere von Erhard auf der Insel Mykonos beobachtet und von mir auf Tinos gesammelt worden sind. Daß $L$. taurica in Syrien und Palästina vorhanden sei, ist zu bezweifeln. Ich finde sie nur bei Lortet (Archives du Mus. d'bist. nat. de Lyon III, p. 187), als in »Saida, Sur, Tripolis, Ladikie und an den Ufern des Nalır Kadischa vorkommend, verzeichnet. Und was endlich das von C. und Aug. Duméril behauptete Vorkommen in Persien anbelangt, so wird es sich damit auch nur um ein Versehen in der Fundortsangabe handeln, denn sowohl De Filippi, als auch Blanford sind ihr auf ihren Reisen in Persien nirgends begegnet. Im IIuseum zu Paris befinden sich zwar 2 schlecht erhaltene und der taurica ähnlich sehende Eidechsen von A ucher-Eloy, angeblich aus Persien, allein wenn wir die Pariser Eidechsensammlung durchnehmen und etliche Irrtümer hinsichtlich der Fundortsangabe erblicken, so kommen wir unwillkürlich zur Schlu€folgerung, dafs manches in der Reptilienabteilung von Duméril in höchst nachlässiger Weise etikettiert worden ist.

Die Angabe Krynickis ${ }^{3}$ ), daß $L$. taurica - welche Art Krynicki fälschlicherweise mit L. saxicola identifiziert - auch außerhalb der taurischen Halbinsel, wo sie bekanntlich von $\mathrm{Pallas}$ entdeckt worden ist, vorkommt, ist insofern richtig, als der Verbreitungsbezirk dieser Art sich auch auf dic Balkan-Halbinsel und auf einige Inseln des griechischen Archipels ausdehnt. Sämtliche Autoren, wie z. B. Pallas, Nordmann und Kessler, geben übereinstimmend an, daf in der Krim der Verbreitungsbezirk dieser Art sich auf den südlichen,

1) Seitdem ich diese Erfahrung gemacht habe, zweifle ich, ob L. taurica in Gello rorkommt. Die betreffende Eidechse aus Gello, von der Giglioli im Archiv f. Naturgeschichte 1879, I. S. 93 spricht ist allerdings ron mir selbst als wtaurica bestimmt worden, und zwar, da ich damals noch nie eine taurica gesehen hatte, lediglich auf Grund der mir vorgelegenen Beschreibungen dieser Art.

2) De Filippi in: Arch. per la Zoologia, l'Anatomia e la Fisiologia II. p. 386. Modena. - Came rano, Descrizione di una nuova Specie del Genere Podarcis in: Atti Accad. Sc. di Torino, XIII.

s) Bull. de Yoscou 1837, No. 3, pag. 50. 
gebirgigen Teil der Halbinsel zu beschränken scheint. Kessler (Bulletin de Moscou 1879, No. 3, pag. 209) hat sie wohl noch in der Umgegend von Sympheropol angetroffen, aber nicht melur in den weiter nach Norden sich erstreckenden flachen Vorbergen oder in der eigentlichen Steppe. Auch nach $\mathrm{Rathke}{ }^{1}$ ) soll sie nur auf der Südküste der Krim, und zwar von Sudak an bis Merdwen vorkommen. Kessler hat sie, wie Köppen mitteilt, im oberen Salgir-Thale gefunden ${ }^{2}$ ). Im British Museum sind Stuicke aus Sebastopol, im Senckenbergischen Museum Exemplare aus Sudak und Feodosia und im Berliner Museum Individuen aus Nikita (5992) aufbewahrt. Taurica aus Aluschta (No. 1983) und aus der Umgebung Jaltas stammend, sind mir von Prof. Paulson aus dem Museum zu Kiew freundlichst zugesandt worden. Auch auf den hohen Ufergebirgen bei Balaklawa dürfte sie nicht fehlen. Im südlichen Rußland scheint die taurica sonst nicht vorzukommen. Nordmanu hebt ausdrücklich hervor, dats sie in der Umgebung von Odessa fehlt; es wäre jedoch möglich, daf sie bis jetzt in Bessarabien nur übersehen worden ist, denn Stücke aus Tultscha habe ich neuerdings beim Naturalienhändler Herrn Rey in Leipzig acquiriert. Etliche Stücke dieser Art aus dem Balkangebirge stammend, habe ich im Museum zu Athen aufbewahrt gesehen; aus Konstantinopel hat sie Dr. E. Schreiber erhalten. - Das Vorhandensein der taurica in der Krim und im Balkangebirge und zugleich das Fehlen dieser Art in den südlichen Provinzen Rublands und im Kaukasus erinnert an jene von Kessler ausgesprochene Vermutung, daß einst die Krimschen Gebirge mit dem Balkan durch einen Gebirgszug verbunden waren. Das Vorkommen des Gymnodactylus Kotschyi in der Krim und in Griechenland scheint ebenfalls auf einen ehemaligen Landzusammenhang zwischen der taurischeu und der Balkan-Halbinsel zu deuten. „Da Gymodactylus Kotschyi im Kaukasus nicht vorzukommen scheint (wenigstens ist er daselbst bisher nicht gefunden worden), so bleibt es fraglich«, sagt $\mathrm{K}$ ö p p n (l. c.), „von wo er in die Krim eingewandert ist. Man wäre fast versucht für diese Art sowohl, als für den Coluber quadrilineatus (und vielleicht auch für $L$. tarrica) eine uralte Einwanderung von Westen her anzunehmen, vielleicht längs jenem von Kessler präsumierten Verbindungsrücken zwischen dem Balkan und dem Krimschen Gebirge.« sAlle drei genannten Arten«, fügt Köppen hinzu, skommen nämlich in Griechenland vor und fehlen im Kaukasus. - Viel einfacher liefie sich freilich ihr Vorkommen durch zufällige Einschleppung erklären, die Dr. Strauch, wie bemerkt, für Gymn. Kotschyi in der That annimmt. «

In Griechenland scheint die taurica nur in Morea häufig zu sein (Mus. d'hist. nat. Paris,

1) Beiträge z. Fauna d. Krim, 1. c.

$\left.{ }^{2}\right)$ Zur Herpetologie d. Krim in: Beitr. z. Kenntn. d. Russ. Reiches, Bd. VI. S. 80. St. Petersburg 1883. 
No. 2365). Nach De Betta soll sic auf den Jonischen Inscln, namentlich auf Korfu angetroffen worden sein. "Auf der iiberhaupt durch ihren Reichtum an Eidechsen ausgezeichneten rulkanischen Insel Mykonos«, sagt Elhard, ist diese Eidechse ziemlich häufig, daber wohl auch auf anderen Inseln mit alleiniger Ausnahme Syras zu finden." $\Lambda$ uf der Insel Tinos habe ich die taurica in Gemeinschaft mit der Manereidechse angetroffen. In seiner Iconografia della Fauna italica gedenkt Bon a pre des Vorkommens der taurica im Orient, bezeichnet jedoch nicht die Fundorte; el sagt nämlich: „La ricevemmo dal Chersoneso, dalla Morea, dalle isole Jonie, e da altre piu orientali del Mediterraneo; ma non avendo potuto rinvenirla giammai fra le tante migliaja di Lucertole, che abbiamo ottenute da ogni angolo di tutta Italia, e delle sue isole, nè potendo concedere che i nomerosi esemplari raccolti dal Bib ro $\mathrm{n}$ in Sicilia, e da lui mostratici sotto il di lei nome in Parigi, le appartengano veramente, essendosi sembrati piutosto della Podarcis muralis«.

\section{Lacerta peloponnesiaca Bibr. Bory 1836.}

Char. - Sc. occipitale interparietali vel latius et paulo longius, vel angustius et brevius. Sc. frontale plertmque mediocriter magnum, scuto frontoparietali aequmn vel eo brevius. Scuta supraocularia supraciliaribus adjacentia. Sc. nasofrenale unicum. Sc. parietalia in margine externo interdum 2-3 maioribus laminis oblongis limbata. Supralabialia anteriora 4. Tempora scutis maximis, sc. massetericum plerumque distinctum; sc. tympanicum. Sulcus gularis uullus ( $\sigma^{7}$ ), collare integrum. Sc. äbdominalia per seris sex disposita. Squamae dorsi rotundato-sexangulares, laeves. Dentes palatini. Pori femorales utrinque 18-20. - Caput pyramidale, maris magnum, paulo latius quam altius. Corpus satis robustum et compactum. Canda copore saltem duplo longior. - Longitudo : 172-289 $\mathrm{mm}$.

\section{Synonymie.}

Lacerta peloponnesiaca Bibron et Bory de St. Vincent in: Expédition scientifique de Morée III, p. 66, pl. X, fig. 4. - v. B edriag a, Die Amphibien und Reptilien Griechenlands. Berichtigungen in: Zool. Anzeiger 1883, S, 216.

L. taurica (part.) Duméril et Bibron, Erpétologie générale V, p. 225, 228. - C. et Aug. Duméril, Cat. méth. collect. Rept. pag. 120. Paris 1851. - De Betta, I Rettili ed Anfibi del Regno della Grecia in: Atti R. Ist. Ven. di Sc. Lett ed Arti XIII, Ser. III. (Podarcis.) - Schreiber, Herpetologia europaea, p. 419. - v. Bedriaga in: Bull. de Moscou 1881, No. 3, p. 88. 
? Lacerta muratis, Bibron, Bory 1. c. (part!).

? Lacerta lineata Schinz, Europ. Fauna II, S. 24. Stuttgart 1840.

Die im Bulletin de Moscou 1881, No. 3, pag. 88 als $L$. taurica beschriebene Eidechse stellt eine andere Art vor und zwar die peloponnesiaca Bibron Bory, welche bekanntlich von keinem meiner Vorgänger als selbständige Species anerkannt, sondern in die Synonymie der taurica Pall. oder gar der muralis Laur. versetzt worden ist. So haben z. B. Duméril und Bibron auf S. 225 ihrer Erpétologie générale, t. V. die Bibron-Bory de St. Vincentsche pelopomesiaca als Synonym von taurica angegeben, um später (auf S. 228 des nämlichen Werkes, vergl. die Anmerkung) erstere in die Synonynie der muralis zu versetzen. Nordmann, Bonaparte, De Betta, Schreiber u. a. haben gleichfalls die peloponnesiuca als gleichbedeutend mit der taurischen Lacerta erklärt. Dieser Umstand sowohl als auch derjenige, dafs mir damals keine echte taurica zum Vergleich zur Verfügung stand, haben dazu beigetragen, daf3 ich mich aprioristischen Schlubfolgerungen hingegeben und meine Ausbeute falsch klassifiziert habe. Die pelopomesiaca unterscheidet sich von der taurica erstens dadurch, daf. ihr Halsband ganzrandig erscheint, zweitens dadurch, daf ihre Temporalia bedeutend gröŁer sind und drittens dadurch, daf die Supraocularia und Supraciliaria sich berühren.

Körpergestalt und Grö f̉e (vergl. meine Tafel Fig. 13 q).

Diese Art steht der muratis am nächsten, unterscheidet sich von derselben aber nicht blof durch ihre Körperbedeckung und durch die besonders beim Weibchen völlig verschiedene Färbung und Zeichnung, sondern auch durch ihren Körperbau. Der Körper ist beim Männchen ziemlich gedrungen und größer als bei der Mauereidechse, wie denu überhaupt diese Species unter allen binnenIändischen muralisähnlichen Eidechsen das größste Ausmaf erreicht, da einzelne Stücke derselben sogar die Faraglioni-Abart an Länge übertreffen. Der Kopf ist beim Männchen verlängert pyramidal, seine Höhe in der Hinterhauptregion ist wenig kürzer als der gröfste Breitendurchmesser; die Seiten fallen ziemlich senkrecht ab; die Schläfe erscheint leicht backenartig aufgetrieben und die Kopfdecke gegen die Schnauzenspitze hin sanft nach abwärts geneigt. Der viel niedrigere Kopf des Weibchens ist wie bei $L$. muralis gebaut; der Rumpf aber ist bedeutend breiter und stärker. Während beim Männchen der Discus palpebralis stark hervortritt und sämtliche, durch tiefe Furchen getrennte Kopfschilder starke Wölbungen, namentlich in der Intermasalgegend, aufweisen, ist der Augendiscus des Weibchens nur sehr schwach hervortretend und die Pileusschilder erscheinen bei ihm ziemlich glatt und flach. Eine halsartige Verengung ist nicht vorhanden, im Gegenteil der Hals erscheint seitlich aufgetrieben und etwas breiter als der Kopf. Die beim Nännchen kräftigen, beim Weibchen aber 
schmächtiger gebauten Hinterbeine reichen etwas über die Achseln hinaus, während die Vorlerbeine in der Regel nur den vorderen oder hinteren Rand des Freno-ocularschildes erreichen. Der besonders beim Weibchen sehr dünn ausgezogene Schwanz ist bei diesem wenig länger, beim Mänuchen hingegen, wenn vollstiudig, viel länger als die doppelte Lünge des übrigen Körpers. - Ich lasse hier die Körpermake von beiden Geschlechtern folgen:

๑.- Totallänge: 239, Länge des Kopfes: 20, d. Halses: 14, d. Rumpfes: 59, des Schwanzes: 160, der Vorderextremität: 26, d. Vorderfufes: 11,5, d. Hinterextremität: 45, d. Hinterfußes: $23 \mathrm{~mm}$. Kopfhöhe: 11, Kopfbreite: 12,7, Breite des Pileus: 9,5, Umfang des Kopfes: 41-42, d. Halses: 42, des Rumpfes: 43 mm. - + . - Totallänge: 172, Länge d. Kopfes: 15, d. Halses: 11, d. Rumpfes: 50, d. Schwanzez: 107, d. Vorderextremität: 20, des Vorderfubes: 9, d. Hinterextremität: 34 , l. Hinterfußes: $18 \mathrm{~mm}$; Kiopfhöhe: 7,5, Kopfbreite: 9,3, Breite des Pileus: 7, Umfang d. Kopfes: 28, d. Halses: 27,5, d. Rumpfes: $35-36 \mathrm{~mm}$.

Schilder und Schuppen (vergl, meine Tafel Fig. 7).

L. pelopomesiaca unterscheidet sich von $L$. taurica und $L$. muralis in sehr vielen Stücken wesentlich, so daf3 es überflissig wäre weitläufig darüber zu sprechen, wenn nicht in vielen herpetologischen Nachschlagbüchern und in manchen., Yuseen die pelopomesiacu als taurica oder muralis figurieren würde. Hier lasse ich einige Parallelen folgen, indem ich vorher die interessante Thatsache besonders hervorheben müchte, dals die weibliche pcloponnesiaca in betreff ihrer Kopfbeschildung und, wie ich bereits erwähnt habe, auch in Bezug auf ihre Kïperform vom Männchen abweicht und in dieser Beziehung eher der mualis ähnlich sieht. Diese Erscheinung stimmt ja vollkommen mit der bekannten Thatsache überein, daf̉ die Männchen überhaupt eher eine Variationsneigung, die Weibchen hingegren eine konservative Vererbungsfähigkeit zeigen (in gewissen Formenkreisen sind die Weibchen auch bei anderen Reptilien und Amphibien so sehr älnlich, dafs man erst die Männchen zur Vergleichung herbeiziehen muf, um die Arten voneinander trennen zu können) und ist für uns speciell insofern von Interesse, als sie darauf hinzudeuten scheint, dafs die weibliche peloponnesiaca die Kennzeichen ihrer Mutter. form, und zwar der muratis, im grofen und ganzen beibehalten haben dürfte, während beim Männchen divergierende Merkmale, wohl zum Teil, was namentlich sein Farbenkleid anbelangt, durch die rythmisch und alljährlich wiederkehrenden Hochzeitsattribute beeinflufist, aufgetreten sind. - Was zunächst die hopfschilder bei peloponnesiaca anbelangt, so fält vor allem die geringe Entwickelung des Frontale auf. Während nämlich letzteres sowohl bei muralis, als bei taurica die gröfte unpare Tafel repräsentiert und zugleich größer als das Frontoparietale ist, erscheint bei jelopomesiuca die Stirnplatte beim männlichen Geschlechte mitunter ebenso lang wie das 
davorliegende Internasale und überhumpt kleiner, als das Frontoparietale; beim weiblichen Geschlechte hingegen sind die zuletzt genannten Tafeln gewöhnlich kleiner als das Frontale. bei beiden fieschlechtern, und namentlich beim männlichen, entsendet das Frontale nach vorn zwischen die beiden Frontonasalia einen, im Verhältnis zu seinem kurzen Körper sehr langen Fortsatz, der sich in manchen Fällen vollständig abschnürt und ein supplementarisches unpaares Schildchen bildet. Da die vorderen Frontalränder stark eingebuchtet erscheinen, so treten auch lateralwärts spitz endende Fortsätze auf, welche zwischen die Supraorbitalia II und die Frontonasalii eingeschuben sind; nach rückwärts ist die Frontalplatte merklich verschmälert und in eine kurze Spitze ausgezogen. Bei den Weibchen ist sie in der Regel hinten mit zwei unter äulierst stumpfem oder fast undeutlichen Winkel zusammenstoßenden Seiten versehen. Die ziemlich unregelmäßig gestaiteten und in Bezug auf ihre Konfiguration variierenden, beim Weibchen kürzeren, beim Männchen aber sehr, ja sogar auffallend langen Frontonasalen sind bei letzterem stark gewölbt und mit ihren vorderen, an das sehr kleine Frenale anstofienden Partien nach abwärts überbogen. Ganz eigentümlich nimnt sich das dicht am Frontonasale liegeude erste Supraorbitale aus, denn es ist nicht etwa klein, dreieckig wie bei muralis oder taurica, sondern länglich schmal und einem Supraciliare ähnlich sehend. Von den ziemlich gleich großen, mittleren, stark gewölbten und hervorspringenden Supraorbitalen ist das vordere nach vorn zu verschmälert, das rückwärts liegende mit abgestutztem Hinterrande versehen; das obere Augenschild IV stellt eine ziemlich ansehnliche vier- oder fünfseitige Tafel dar. Sämtliche Supraorbitalia legen sich direkt an die, meistens in Sechszahl vorhandenen Supraciliaren an, die vorn etwas breiter sind als hinten; bei muralis und taurica hingegen erscheinen bekanntlich diese Schilderreihen durch aneinandergefügte kleine Schuppen voneinander getrennt. Die, wie gesagt, auffallend langen Frontoparietalia sind sonst von gewöhnlicher Bildung, es wäre nur zu erwähnen, daßs ibre hinteren Seiten sehr kurz sind und daßs sie den unter stumpfem oder rechtem Winkel zusammenstofenden Vorderseiten des unansehnlichen, nach hinten in eine scharfe und oft ziemlich lange Spitze ausgezogenen Interparietale entsprechen. Das Occjpitale ist bei den Männchen bedeutend breiter und öfters auch länger als das Interparietale, beim Weibchen aber ist es nur in seltenen Fällen breiter und gewöhnlích kürzer als das davorstehende Schild, auch ist es bei ihm entweder trapezförmig oder dreieckig mit abgerundetem Hinterrande, währenddem es beim mäunlichen Geschlecht stets dreieckig und mit einer geradlinigen Hinterkante versehen zu sein scheint. Die groken, leicht auf die Schläfe überbogenen Parietalia sind nach vorn zu etwas ausgerandet, nach hinten abgerundet und seitlich nach außen zu gewöhnlich schwach gezähnt; zwei schmale, aber lange und ein kleines Schildchen 
dienen den Parietalaußenrändern als Umsäumung. Die Schläfe ist mit 10 bis 19 gröferen Schildern bedeckt, die zwischen sich ein deutlich hervortretendes, mitunter grobes Massetericum einschliebien und auch am oberen Teile des Vorderrandes der Ohröffnung ein etwa bohnen. förmiges Tympanicum zeigen. Sowohl das vier- bis fünfseitige Postoculare, als auch das langliche, schmale und in das Freno-oculare ziemlich tief einschneidende Pracoculare grenzen an die Fortsätze des Suboculare. Dieses Schild repräsentiert in der Regel das fünfte, in selteneren Fällen das sechste oder dritte Supralabiale; hinter dem Suboculare steht noch ein grobes supralabiale, welch letzteres ron einem bedeutend kleineren Schilde gefolgt wird. Am Suboculare und am Praeoculare tritt eine auffällig hervorspringende, etwas schief von oben nach unten sich hinziehende Längskinte auf. Endlich muf noch hinzugefugt werden, dals das Internasale sehr groß und mitunter länger als breit ist; in selteneren Fällen, vorzugsweise beim Weibchen erscheint es von gewöhnlicher Billung, von etwas abgerundet rhombischer Form, in den meisten Fällen dagegen zeigt es hinten einen zackigen Rand und ist als mälige Spitze zwischen die Frontonasalia eingeschoben; nach vorn $z u$ ist es mit zwei buchtigen, in ziemlich spitzem Winkel zusammenstobenden Außienrändern und mit einem Fortsatze versehen, der zwischen die etwa dreieckigen, seitlich unten stark ausgerandeten Supranasalia eingekeilt erscheint und oftmals mit dem hohen, gewülbten Rostrale in Berührung hommt. Das einfache, unten erweiterte, oben verschmälerte Nasofrenale ist nur etwas kleiner als das unansehnliche Frenalschildchen; die großen Nasenlöcher werden z. T. vom Rostrale umgeben. Sowohl die Sublabialia, als auch die 6 ansehnlichen Submaxillaria erscheinen an ihren freien Rändern abgerundet; die Wölbungen, welche an den Labialen zu Tage treten, verleihen dem Kopf ein etwas plumpes Ausseheu. Die 3 ersten Submaxillaren stofien zusammen, das dritte und das vierte sind die größten. Die länglich sechseckigen Kehlschuppen sind von den dahinterliegenden, quer erweiterten und gegen das Halsband hin hexagonalen Halsschuppen durch eine Querfalte und durch eine Querreihe kleiner Schüppchen getrennt. Ein Sulcus gularis im eigentlichen Sinne des Wortes kommt höchst selten beim männlichen, dagegen ziemlich häufig beim weiblichen Geschlechte vor; bei jungen Mäunchen scheint die Querfurche allerdings stets vorhanden zu sein. Der Halskragen sieht demjenigen der muralis ähnlich; er ist nämlich ganzrandig und besteht aus 9 bis 11 Tafeln, es ist nur insofern ein Unterschied rorhanden, dal die Tafeln, namentlich beim Weibchen, kleiner sind, als es bei $L$. muratis der Fall ist; beim Männchen sind letztere etwas schief nach aufen gerichtet, beim Weibchen aber sind sie normal. Die dem Halsband zunächst liegenden Brustschilder sind sehr lang; der Bauch bat in jeder Querreihe nur 6 breite Schilder, die beiden mittleren Längsreihen bestehen aus etwas kleineren 
Tafeln als die übrigen. Die Zahl der transversalen Ventralschilderreihen schwankt zwischen 25 und 28, diejenige der Brustdreieckschilder zwischen 6 und 9. Die Randschildchen sind sehr klein.

Drei Querreihen von Rumpfschuppen entsprechen der Länge cines Bauchschildes. Die ungefähr in 150 Quer- und in 50 longitudinale Reihen angeordneten gewölbten, ungekielten Rumpfschuppen sind rundlich-sechseckig, gegen die Bauchgrenze hin etwas länger, als am eigentlichen Rücken und von etwa rundlich-viereckiger oder eifürmiger Gestalt. Auf der Oberseite und an den Seiten des Schwanzes sind ganzrandige, an der Schwanzwurzel ganz glatte oder nur schwach gekielte, gegen die Mitte zu leicht und gegen das Schwanzende hin ziemlich scharf gekielte, zuweilen in eine äuferst stumpfe Spitze ausgezogene und ungleichseitige Schuppen vorhanden. Auf der Unterseite des Schwanzes sind die hinteren Schuppen am Hinterrande leicht abgerundet, die vorderen jedoch in eine sehr schwach angedeutete stumpfe Spitze ausgezogen; es sind etwa 86 bis 115 Schwanzringe vorhanden. Das grofe Anale, das stets breiter als lang ist, wird nach vorn zu von zwei Bogenreihen von Schildern umgeben, von denen die dem Afterschilde zunächst liegende Reihe aus 6 bis 8 gröferen Schildern gebildet wird.

Schenkeldrüsen und Zähne.

Die Zahl der Schenkeldrüsen schwankt zwischen 18 und 22. Die Zahl der Zähne beträgt: im Zwischenkiefer 7 bis 8; im Oberkiefer auf jeder Seite bis 20, im Unterkiefer auf jeder Seite 22 ; der Gaumen ist bezahnt.

Farbenkleid.

Das Weibchen ist von dem Männchen schon durch die Färbung und Zeichnung leicht zu unterscheiden. Bei esterem ist die Grundfarbe der Rumpfoberseite schwarz, schwarzbraun oder dunkelbraun; über den Rücken und auf den Seiten laufen in der Regel 6, ausnahmsweise nur 5 , vorn gelblich- oder grünlichweifse, uach hinten zu bräunlichweifs werdende Längsbinden hin; die 2 mittleren, dicht am Hinterrande des Occipitale beginnenden Rückenbinden vereinen sich stets auf der Schwanzwurzel oder etwas dahinter, am Nacken hingegen nur in seltenen Fällen in eine einzige breite, bräunlich oder graubraun gefärbte Binde, die bisweilen bald auf dem Schwanze verschwindet; oft kann man zwischen diesen beiden Binden noch einen kurzen höchstens bis gegen das Halsende sich fortsetzenden, hellen Vertebralstreifen wahrnehmen. Die 2 dem mittleren Paar zunächst liegenden Binden stehen in der Breite der Kopfschilder ab und gehen einerseits längs des Aufenrandes des Pileus bis zum oberen Augenlid, andererseits 
auf den Schwanz über; endlich nehmen die auf den Seiten befudlichen Binden ihren Urspurung von dem unter dem Auge gelegenen Supralabiale, um in der Caudalwurzel zu verschwinden. Bei braungefärbten Individuen sind die Zwischenrïune sämtlicher hellen Binden mit schwarzen, dicht

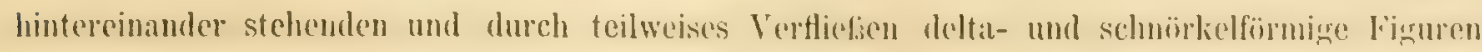
bildenden Flecken besetzt; letztere treten namentlich an den Kürperseiten deutlich hervor. Gegen den Batuch zu hellt sich die Grundfirbung auf; sie erscheint hellbraun, graubraun oder gelblich. Die bräunliche, grauc oder graugrüne Farbe der Oberfläche der Extremitäten ist von runden hellbraunen, grïnbraunen oder grünen, dunkel cingefatisten Flecken unterbrochen. Da die dunklen und hellen Rumpfstreifen, mit Ausnahme der Vertebralbinde und der ihr zunächst liegenden hellen Streifen, nuch auf den Kopf übergehen, so erscheinen die Parietalaubenränder sowie die Schläfe gestreift; die übrigen Partieen am Hinterkopfe und die Schnauze sind hellmulibraun spärlich dunkel gezeichnet. Die Unterseite des Kopfes und IIalses ist grunlich-oder bläulich-gelb; bei einigen hat auch der Bauch, die untere Seite der Beine und des Schwanzes eine solche Farbe, bei anderen eine gelblichweilse. Die äukeren longitudinalen Ventralia sind entweder ganz blin oder blau gefleckt, sonst sind gar keine Flecken an den unteren Kürperteilen sichtbar. Die Jungen sind in Bezug auf Zeichnung und Färbung den ausgewachsenen Weibchen sehr ähnlich, doch verhalten sich in. letzterer Beziehung die jungen Männchen insofern verschieden, als sich ihre Grundfärbung bis zu einem unscheinbaren Lederfarben oder Graugrün aufhellt. Bei ausgewachsenen Männchen kommt die Längsstreifung weniger zur Geltung; es sind meistens 4, und nur am Vorderrücken etwas schärfer ausgeprägte, bald grünlichbraune, bald grünlichblaue oder weifliche Streifen vorhanden, welche eine, am Vorderrücken einfurbige, hell- oder grünlichbraune, am Hinterrücken spärlich dunkelbraun gefleckte Vertebralzone und seitlich 2 andere, nach hinten zu üpig schwarz gezeichneten Zonen einfassen. Oftmals sind sowoh die hellen Streifen, als auch die zwischen ihnen befindlichen Räume nur am Vorderrücken vorhanden und auch hier sehr undeutlich ausgeprägt; in diesem Falle erscheint am Hinterrücken eine ziemlich breite, hellnulibriune oder grünlichbraune, seitlich durch unegelmälïig geformte und meistens wenig hervortretende schwarzbraune Fleckenreihen abgegrenzte Dorsalzone. Die dunkeln Flecken in der Vertebralgegend sind entweder ganz verschwunden, oder teils sehr klein und verwischt, teils kaum bemerkbar. Die Rumpfseiten sind quergestreift; diese schwarzen oder schwarzbraunen Streifen stehen meist überall durch Ausläufer miteinander in Verbindung und bilden somit ein mehr oder weniger zustmmenhängendes Netzwerk, dessen grolie Maschen durch die brïunlich-bläuliche oder graugrune Grundfube ausgefült werden. Die: Achselgegend spielt in der Regel aus dem Braun oder Grau ins Grüne; über den Vorder- 
nliedmafien sind beim Männchen wie beim Weibchen schön ausgebildete blaue Ocelli sichtbar.

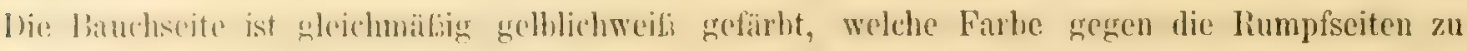
in cin zartes Blau, Grüngelb oder Rosa übergeht. Die Kehle, der Unterkiefer und die Halsseiten zeigen ein lichtes Blangrün oder sind prachtvoll orangegelb gefürbt; zur Zeit der Fortptlanzung überzichen sich öfters auch Bauch, Extremitäten und Schwanz mit Orangegelb. Die Oberseite der Extremitäten und des Schwanzes sind braun oder grau mit einem Stich ins Grüne; die Gliedmafien sind bald einfarbig, bald undeutlich oder deutlich hell geangt; dunkle Punktflecken befinden sich nur am vorderen Schwandrittel reihenweise angeordnet. Die hellnuf.braune, selten spärlich braun gefleckte oder geaderte obere Kopfflïche zeigt oftmals einen rötlichen Anflug; die Kopfseiten sind bräunlich, bei einigen, besonders bei älteren Exemplaren, mit einer starken Beimischung von Orangegelb.

Vorkom men.

Das Originalexemplar, von den Mitgliedern der Expédition scientifique de Morée erbeutet, befindet sich als $L$. taurica aus Morea stammend im Nusée d'histoire naturelle zu Paris (No. 2706) aufbewahrt; dieses Museum enthält auch noch zwei peloponnesiaca, welche Soubeiran auf Korfu erbeutet haben soll (»L. taurica« No. 2708). Exemplare aus Cephalonia habe ich in der zoologischen Sammlung d. K. St. Petersburger Akademie der Wissenschaften zu sehen Gelegenheit gehabt. Meine eigenen peloponvesiaca sind von Dr. Krüper im Taygetos unweit Kalamatas und von mir bei Nanplia gesammelt worlen. Die von mir in meiner Schrift als $L$. taurica erwähnten uber die Kricchtiere Griechenlands Stücke aus Kreta und Neu-Korinth gehören wohl zu dieser Species.

\section{Lacerta vivipara Jacq. 1787.}

Char. - Sc. occipitale interparietali minus, sc. nasofrenale unicum. Sc. supralabialia anteriora 4. Sc. supraocularia supraciliaribus adjacentia ${ }^{1}$ ) Tempora scutellata, sc. massetericum interdum, sc. tympanicum semper praesens. Sc. parietalia interdum in margine externo duabus majoribus laminis limbata. Sulcus gularis nullus, collire denticulatum. Sc. abdominalia per series 6 disposita, in speciminibus Europam orientalem inhabitantibus saepius octo scutorum abdominalium series. Squamae dorsales carinatae, sexangulares. Dentes palatini plerumque nulli. Pori femorales utrinque 9-12. - Caput mediocriter porrectum, latius quam altius, corpus plus minusve gracile. Cauda usque ad medium fere aeque crassa et aequa corporis

$\left.{ }^{3}\right)$ In meiner Bestimmungstabelle (Einleitung, S. 26) ist der Buchstabe $k$ gerade an der Stelle ausgefallen, welche den Hauptpunkt hetrifft. Es muß selhstverstïndlich Z. 17 ๆ. 0 . heifen, daßs der Discus palpehralis von den Supraciliaren durch keine Körnerreihe getrennt erscheint. 
longrtudine vel eo longior. Peles postici axillas nunquan contingentes. - Longitudo: $109-160 \mathrm{~mm}$.

Sy nonymic.

Lacerta vivipura, Jos. Fr. Jacquin, Lacerta vivipara, Observatio in: Nov. Acta Helvetica I. Basileac 1787. - W it gler, Natürl. Syst. d. Amphibien, S. 155. München, Stuttgart u. T'übingen 1830. (Zootoce!). - Duméril et Bibron, Erp. gén. V, p. 204. Fatio, Faune des Vertébrés de la Suisse III, 1) 81. Geuève et Bâle 1872. Schreiber, Herpetolog. curopaea, p. 429. - Schlegel, De Dieren van Nederland. Kriupende Dicren, p. 6, tab. I, fig. 2. Hatarlem 1862. - Lataste, in: Act. Soc. Linn. de Bordeaux XXX. Bordeaux 1871. - Tappe, Dic einheimischen Eidechsen, s. 33. Oberhasen 1868. - Kirschba um, Reptilien u. Fische d. Herzogt. Nassau. Wiesbaden 1865. - Leydig, Die in Deutschland lebend. Arten d. Sturier, S. 212. Tübingen 1872. - Leuckart, in: Isis XXX, S. 511. - Nils son, Skandinawisk Fauna III. Amphibierna, p. 34. Lund 1860. - Brehms Tierleben VII, S. 169. Leipzig 1878. - Boulenger, in: Proc. Zool. Soc. of London 1881. pag. 743. M ejak off, in Bull. de Moscou 1857, No.4, p. 581.

Zootoca vivipara, De Betta, Erpetolog. delle Prov. Venete etc. 1. c. pag. 139. Verona 1857

- Bell, A history of Brit. Rept. London 1839. S. 33 (vergl. auch die Auflage 1849). - Gray, Cat. Liz. Brit. Mus. p. 27. London 1845. - Lessona, in: Atti Accad. Sc. di Torino XIV. - Cooke, Our Reptiles, p. 22. London 1865. - Bonaparte, Iconografia della Fauna italica II. Roma 1832-1841; Amphibia curopaea, in: Mem. Accal. Se. di Torino, Ser. II. T. II. pag. 385. Torino. - De Betta, Rettili ed Anfibi. Fauna d'Italia. IV, in: L'Italia sotto l'aspetto fisico, storico etc. Milano 1874. - Nilde, in: Zool. Garten 1870, S. 103.

Zootoce crocea, Wolf, in Sturms Deutschl. Fauna III. 1805. - Wiegmann, Herpetolog. mexicana I. S. 9. - Gistl, Bemerkungen üb. einige Lurche, in: Isis 1829. Jeitteles, in: Verhandl. zool. botan. Ges. in Wien XIII. S. 278, - Eichwald, Fauna caspio-caucasia, 1) 91. Petropoli 1840.

Lacerta croceu, Fitzinger, Neue Klassifikation d. Rept. S. 52. Wien 1826. - Eversmana, in: Nouv. mém. soc. imper. de Moscou III. p. 347, tab. III, fig. 1-2. - Krynicki, in: Bull. de Moscou 1837, No. 3, p. 51. - Glückselig, Synopsis reptilium et amphibiorum Bohemiae, p. 18. Prag 1832. - Lorek, Fauna prussica. Königsberg 1834. - Rathke, in: Neue Preuf. Provinzialbläter 1846, S. 16. - B uja ck, Natur- 
geschichte d. höheren Tiere. Königsberg 1837. - (Vergl, auch Wolf, Gist! unter sZootoca crocece) - v. Reider u. Hahn, Fauma boica. Nürnberg 1832.

Lecerte montance Mikan in: Sturms Deutschlands Fauna III. Heft 4. c. fig. - Schinz, Naturgr. u. Abbild. Rept. S. 100. Taf. 38. Leipzig 1833; Fauna helvetica in: Neue Denkschrift. d. allg. schweiz. Ges. f. d. gesamt. Naturwiss. Bd. I, S. 138. Neuchâtel 1837. - v. Reider u. Hahn, Fauna boica. Nürnberg. - Glückselig, l. c. Schinz, Europ. Fauna II, S. 19, Stuttgart 1840.

Zootoca montana Tschudi, Monogr. đ. schweiz. Echsen in: Nouv. Mém. Soc. Helv. Sc. nat. 1537, pag. 37. - Prach, Plazové a obojzivelnici zeme Ceske in: Ziva 1561. Bon a p r te, Amphibia europaea, 1. c.

Lacerta muralis (Daud.) Gray, Synopsis of Rept. in: Griffiths Animal Kingdom, 1831.

Z. mualis Gray, Cat. slend, tong. saur. in: Jardines Ann. nat. hist. I (1838), pag. 279.

Lacertus terrestris vulgaris ventre nigromaculato, II errett, Pinax rerum natur. Brittan., p. 169. Lond. 1667. - Lacertus terrestris vulgaris, (part.) Ray, Synops, methodica animalium quadrupedum et serpentium generis, pag. 261. 1693.

Laccrtu ugilis Linné, Systema naturae. Ed. XII. T. I, pag. 284; Lacertus dorso punctis albis duplici serie, in: Fauna suecica, No. 284, p. 103. 1761. - Grasso, Dissert, inaug. medica de Lacerta agiti Linn. Helmstadti 1788. - Schultze, in: Lichtensteins Verzeichnis d. Dubletten d. zoolog. Mus. Berl. 1823. S. 96, 97; vergl, auch die Bemerkung auf S. 93 (var. L. crocea Wolf, var. L. nigra Wolf). - Fleming, Brit. anim. pag. 150. 1825. - Jennyns, Manual of Brit. vertebr. anim. pag. 393. 1835. Cambridge. - Berkenhout, Synopsis of the Nat. Hist. of Great Britain aud Treland. London 1789. - Linné-Retzius, Fauna suecica I, p. 289. Lipsiae 1800. - Gray, in: Proc. Zool. Soc. of London III (1833) p. 112. - Pennant, Brit. Zoology III, fig. 7. Warington 1776.

Lacerta Schreibersiana Gachet in: Act. Soc. Linn. t. V, pag. 233 (Bordenux 1832). - Milne Edwards, in: Ann. sc. Dat. XVI (1829), p. 83, pl. V, fig. 5. - De La Fontaine, Faune du pays de Luxembourg. Rentiles, p. 9. Luxembourg 1870.

L. accura Sheppard, Descript. of the Brit. Liz., in: Transact. Linn. Soc, vol. VII (IS04), p. 50 (auch $L$. agitis, p. 49, 50).

L. unicotor Ku hl, Beitr. z. Zoologie u. vergl. Anatomie, S. 191. Frankf. a. I. 1820.

L. pymhogaster II r rem, Versuch eines Systems d. Amphibien. Marburg 1820 (anch $L$. montana, S. 69). - Tschudi, 1. c. - Schinz, Europ. Fauna II. S. 19. 
? L. porphyrea Dehne, in: Allg. deutsche naturhist. Zeit. II (1856), S. 213.

? L. virilis Latreille, Ilist. nat. des Salamandres de France XVI, g. Paris 1800.

L. nigra Wolf in: Sturms Deutschlands l'auna. Amphibien. Nurnberg 1805. - Fitzinger, I.c.

- Schinz, Naturg. u. Abbild. Rept. S. 100, 'Taf. 38. Leipzig 1833. - v. Reider

u. Hahn, 1. c.

Podurcis nigra Prach, l. c.

Atropis nigra Glatiselig, 1. c.

Lacerta de Jacquin, Cocteau, Sur un genre peu comn de Lézards vivipares in: Mag. de Zool. 1835 (Paris).

Lacertu Guérin, Co ctea u, ebendas. 'Taf. IX, Fig. 1- 3.

Lacerte, Limné, Fauna suecica (Stockholmiae 1746). Appendix, pag. 387 (nach Leydig!).

Körpergestalt und Grölie.

Das Månnchen ist erheblich größel und schlanker als das Weibchen; lauptsächlich Schwanz und Beine sind bei ihm von bedeutender Länge, namentlich die hinteren; bei beiden Geschlechtern erreichen sie die Achseln nicht, während die vorderen bis zu dem vorderen Augenrand oder gar bis zu den Nasenöffnungen reichen, wie es z. B. bei zwei, mir aus dem Kiewer Museum vorliegenden, aus dem Gouvernement Minsk und Kiew stammenden Stücken der Fall ist. Der beim Männchen etwas längere Kopf erscheint am Vorderrande der Augen etwas zusammengedrückt und in der Schliffengegend leicht oder ziemlich stark backenartig aufgetricben; von den Augen nach vorn zu verengt sich der ziemlich hohe Kopf allmählich; seine Obertläche ist oberhalb der Augen äuferst leicht gewölbt und gegen die schmale oder, wie es bei einigen russischen Stücken der Fall ist, breit abgerundete Schnauzenspitze sanft uach abwärts geneigt; die sich vom äuferen Rande der Parietalia durch die Supraciliaria und an der Grenze der Pileus- und Liopfseitensehilder bis zum Nasenloche hinziehende Linie erseheint somach bogenförmig. Der Umfang des Halses an der Stelle seines Ansatzes an den Kopf ist ziemlich bedeutend. Der etwa abgerundet vierseitige Rumpf ist beim Männchen oben weniger gewölbt als beim Weibchen; bei letzterem scheint der Rumpf durchweg von bedeutenderem Unfange zu sein; bei beiden Geschlechtern ist die Bauchseite weniger abgetlacht, als es sonst in der Regel bei den Eidechsen der Fall zu sein pflegt. Der sehr krïftige Schwanz ist in seiner vorderen Hälfte, mit Ausuahme der eigentlichen, stärker aufgetriebenen Caudalwurzel, fast gleich dick, an der Stelle seines Ansatzes an den Rump̧f beim Männchen - aber nicht bcim Weibchen - deutlich eingeschnürt und nach hinten allmählich in eine kurze Spitze ausgezogen. Die Limge des fichwanzes ibertrift diejenige des vibrigen Kürpers beim Weibchen 
gewöhnlich um einige Millimeter, beim Männchen um ein Drittel oder um die Hälfte. In seltenen lällen, und zwar nur bei den Mänchen, ist der Schwanz nabezu doppelt so lang als der übrige Körper. Mit Ausuahme der von oben ziemlich plattgedrückten Schwanzwurzel ist der Schwanz rund. - Approximative Make in mm ausgedrückt:

$f$ aus Orel. $q$ aus Lithauen. ơ ans Berlin.

\begin{tabular}{|c|c|c|c|c|c|c|}
\hline Totall: & . . & . . & . & $109-110$ & $124-125$ & 140 \\
\hline Länge & d. Kopfes & . . & . & 10 & 10,5 & 11 \\
\hline$»$ & 》Halses & . & . & 8,5 & 8 & 8 \\
\hline$》$ & „Rumpfes . & . . & . & 45 & 50 & 39 \\
\hline 》 & »Scliwanzes & . & . & $54-55$ & 64 & 90 \\
\hline » & \#Vorderextre & emitït & . & 14 & 15 & 16 \\
\hline$»$ & »Vorderfufes & s. . & . & 6,5 & 7 & 7 \\
\hline$>$ & „Hinterextrin & mität & . & 22 & 23,5 & 23 \\
\hline$»$ & » Hinterfußes & . . & . & 10,5 & 11 & 12 \\
\hline Hölue & d. Kopfes . & . . & . & 5,7 & 6,3 & 6,3 \\
\hline Breite & d. Kopfes. . & . & . & 6,7 & 8 & 7,7 \\
\hline 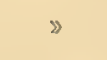 & »Píleus . . & . . & . & 6 & 6,5 & 6 \\
\hline Grölit. & Umfang d. I & Kopfes & . & 23 & 25,3 & 25 \\
\hline$»$ & $\gg \mathrm{r}$ & Zumpfes & . & 32 & 40 & 29 \\
\hline$»$ & $》 \mathrm{H}$ & Halses & . & 24 & 26,5 & 26 \\
\hline$\searrow$ & $\geqslant \mathrm{S}$ & Schwanzl & basis & 18 & 19 & 19,5 \\
\hline
\end{tabular}

Äußere Körperbedeckung.

Das in seiner Form äulierst veränderliche Occipitale erscheint bald stark nach hinten, bald aber nach vorn gerückt; es hat die Form entweder eines Dreiecks, das nach hinten zu einen abgerundeten Rand zeigt, oder eines ungleichseitigen Vierecks; in anderen Fällen wiederum stellt es ein längliches, änberst schmales Schildchen dat. Das meist fünfscitige, vorn erweiterte und spitz- oder stumpfwinklig ausgezogene, hinten verschmälerte und abgestutzte Interparictale berührt mit seinen lïngsten seitlichen Kanten die Parietalia und zeigt in seiner Mitte ein Grübchen. In selteneren Fällen nimmt das Interparictale eine ciförmig-sechsseitige Gestalt an. Dic liurzen aber breiten Parietalia haben nach vorn und innen zu vier geradlinige oder leicht eingebogene Ränder, mit denen sie an das Occipitale, das Interparietale, ferner an die zuweilen ebenso langen als breiten, fünseitigen Frontoparietalia und endlich sowohl an das kleine, öfters abgerundete, dreiseitige Supraoculare IV, als auch an das hinterste Supraciliare grenzen; seit- 
lich nach aufen und hinten zu zeigen die Parietalen zwei gerade oder leicht abgerundete

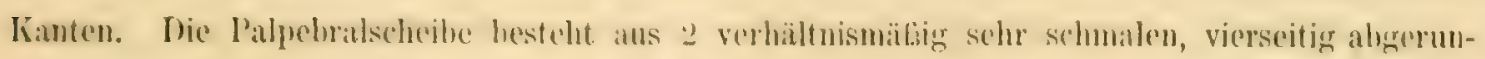
deten Schildern, von denen das vordere linger ist als das hintere; ihro vorderen und hinteren Kanten stofen öfters unter spitzem Winkel zusammen. An diese Schilder grenzt vorn das länglich schmale, mit 4 hogenförmigr verlaufenden Rändron versehene Supraoculare. Das lirontale ist breit und kurz mit parallelen, greradlinigen oder leicht ausgebuchteton liangsten Seiten. I ie zwei vorderen Frontallianten stofen unter stunuffem Winkel zusammen, oder sie sind bogenförmig gekrummt; die hinteren stolien chenfalls unter stumpfem Winkel aneinander und sind entweder geradlinig oder ausgerandet. In der Regel ist das Frontale vorn ebenso breit als linten, in der Mitte aber leicht verengt. Das Internasale ist stets breiter als lang, rhombenförmig oder vorn mit 2, unter rechtem, hinten unter stumpfem Winkel zusammenstofenden Seiten versehen; dasselbe ist meistens durch die in der Mittellinie des Kopfes zusammentreffenden, längeren als breiten, nach hinten stark verschmälerten Nasofrontalen von dem Stirnschilde getrennt. Das das Nasenloch nicht berihrende Rostrale ist ziemlich klein, breiter als lang, von oben gut sichtbar, mit scharfer Spitze versehen; zwischen ihm und dem dahinterliegenden Internasale befinden sich die dreiecligen, mit ctwas bogrigen Seiten versehenen, nach abwärts durch das Nasenloch stark halbkreisförmig ausgerandeten Supranasalen. Das zum Teil dem Lippenschilde I anfliegende und das grobe Nasenloch von hinten begrenzende Frenonasale ist höher als breit, nach oben stark verengt und vorn bogenförmig ausgeschnitten. Das darauffolgende schmale Frenale ist fast doppelt so hoch als breit und mit seinem oberen Teile auf den Pileus übergewolbt; das nämliche ist bei dem verhältnismäligig groben, hinten meist zackig oder bogig geschwungen aussehenden und rom Suboculare grewöhnlich durch 2 kleine, schmale aufeinanderfolgende Praeocularia getrennten Freno-oculare der Fall. Das Suboculare stellt in der Regel das fünfte, ausnahmsweise das vierte Oberlippenschild vor, das namentlich in seinem oberen Teile bedeutend breiter ist als die benachbarten Tafeln; in ganzen zähle ich 6 bis 7 Supralabialia. Die 4 bis 5 länglich schmalen Supraciliaria nehmen nach hinten zu an Gröfse ab; sie legen sich direkt in die Supraocularia an. Die Schläfe ist mit sechs- und fünfeckigen und unregelmäłigg gestalteten Schildern bekleidet, die oben und hinten Hach, vorn und unten leicht gewölbt erscheinen. Ein durch besondere Größse auffallendes Massetericum ist nicht immer vorhanden; es liegt oftmals dicht an ziemlich grolien, länglichen, unregelmäfig gestalteten und mehrere kurze Kanten aufweisenden Tympanicum, das die schmale verhälnismäligg weit nach vorn gerückte (Ohroffunung zum Teil begrenzt. Die Parietalia sind am Aulisenrande, also in der Temporalregion, bald von gräberen, länglich schmalen Tafeln, balk von einfuchen Schlifenschildern umsïumt. Subblabialia 
sind gewöhnlich 5, zuweilen aber 6 oder 4, Submaxillaria 5--6 Paar vorhanden; die drei volderen Submaxillarpare stofien in der Mittellinie zusammen; das sechste I'aar besteht gewöhnlich aus ganz kleinen, eher zu den Kehlschildern gehörenden Täfelchen. Das Mentale zeichnet sich mitunter durch seine Gröfe aus. Die schmalen Kehischuppen sind von den viel breiteren, in der Nihe des mehr oder weniger stark gezähnelten Collare äufierst schwach geschimelten Halsschuppen durch eine Querreihe kleiner Schüppchen abgesondert. Eine eigentliche Querfurche fehlt, hingegen ist öfters eine Andeutung davon und namentlich bei den Weibchen vorhanden. Das nur seitlich gebogene Halsband besteht aus 8, 9 oder 10 Schildern, von denen das mittlere die vibrigen gewöhnlich an Größe übertrifft. Die Bauchseite ist mit 26 oder 27 Qner- und 6 Isingsreihen von Schildern bedeckt, deren äuliere vorn bedeutend gröber, hinten nahezu doppelt so grofs sind als diejenigen Tafeln, welche die 2 Mittelreihen bilden. Die Randschildchen vergröbern sich zuweilen, namentlich bei den nordrussischen, sibirischen und aus Sachalin stammenden Individuen in dem Maße, daßs sie zu einer Reihe von schmalen Bauchschildern werden, wodurch die Zahl der longitudinalen Ventralserien auf acht gesteigert erscheint. Das Brustdreieck ist aus 5-8 Platten zusammengesetzt; las große Anale ist vorn, und meistens auch seitlich von schwach geschindelten und in 2 aufeinanderfolgenden Habkreisen gestelltrn 'Tafeln umgeben, deren mittlere, dem Anale zunïchst liegende, sich durch ihre Grölic auszeichnet. Die Schuppen am Nacken sind rundlich und glatt; bei den westeuropäischen sind sie klein und körnig, bei der nordrussischen erscheinen sie etwas gröler und flacher. In der Beschuppung des Rückens ist die vivipara manchen Veränderungen unterworfen, welche auf bestimmte Gegenden beschränkt zu sein scheinen: so sind die Rückenschuppen bei der central- und westeuropäischen Eidechse länglich sechseckig, länger als breit, mit hinten abgerundeten Ecken und Kanten, während bei der russischen, z. B. aus Lithauen (Mus. Kiew, No. 1978), aus Lappland und aus Sachalin stammenden Exemplaren die Schuppen oftmals nahezu ebenso breit als lang oder sogar breiter als lang und ziemlich unregelmäbig gestaltet auftreten; mitunter aber nehmen sie eine lanzettliche Gestalt an; gegen den Bauch zu werden sie bei der west-, sowie auch hïufig bei der osteuropäischen vivipara breiter und erhalten eine rundlich-vierseitige Form. Die Schuppen in der Mitte des Rückens sind sehr deutlich längsgekielt, erscheinen aber gegen dlie Rumpfseiten zu bei der westeuropäischen, feinbeschuppten Form schwächer, hingegen bei der osteuropäischen, grobbeschuppten viripura noch immerhin ziemlich stark gekielt; gegen die Bauchgrenze hin flachen sich die Schuppen ab, oder lassen nur noch die Spur cines Kieles am Ratude der Schuppen erkennen, wie es z. B. bei einigen russischen Individuen der Fall ist. Da zugleich mit der Ausdehnung der Rückenschuppen auch die Ventralia bedeutend an 
Grölie zunehmen, so bleiht die Zahl der longitudinalen und transversalen Scluppenreihen sowohl bei der fein-, als auch bei der grobbeschupten Form ungefäbr auf demselben Niveau. So zähle ich bei einer mir aus Berlin vorliegenden vivipara 73 Quer- und 34 Längsreihen am Rücken; bei einer anderen, aus Lithauen stammend, mit auffallend grofen Rückenschuppen, fand ich 69 Quer- und 30 Längsreihen vor, endlich bei einer dritten mit etwas kleineren Schuppen (aus Orel stammend) 76 transversale und 33 longitudinale Reihen. Im ganzen lommen 2 Schuppengürtel auf die Lünge einer Ventraltafel. Die beinahe gleichseitigen, in 51 bis 75 Gürtel angeordneten Schwanzschuppen sind oben durchweg scharf gekielt und am vorderen Schwanzteile stumpfwinklig, nach hinten zu spitzwinklig ausgezogen; unterwärts vorn sind die Schuppen glatt, mit abgerundetem Hinterrande, nach hinten zu erhalten sie spitz ausgezogene Hinterenden und erscheinen aufserdem gekielt.

In Bezug auf die Beschildung und Beschuppung sind demnach mancherlei Abweichungen wahrnehmbar, die jedoch, mit Ausnahme der bei den westeuropäischen Stücken erwähnten feinen und bei den im Nordosten einheimischen vivipara groben Beschuppung des Rückens, auf individuelle schwankungen zurückführbar sind; jedenfalls aber scheint es sonderbar, dali jene zahlreichen, angeblich selbständigen Arten, welche nichts Andres als die eben beschriebene. rivipurc vorstellen, blok auf Farbenabänderung und nicht auf der Veränderung in Besclildung und Beschuppung beruhen. Ob die Unbeständigkfit in der Beschildung der Oberseite des Isopfes, so z. B. die Spaltung der Frontoparietalia einerseits und der Parietalia andererseits in 4 Tafeln bei einem mir aus Sachalin vorliegenden Stück blok als individuelle Bildung aufzufassen ist, vermag ich nicht zu entscheiden, da es mir nicht möglich war, in den Besitz von genügendem Material zu gelangen. Diese Eigentumlichleiten in der Beschildung des Kopfes ist schon deshalb erwähnenswert, weil bei dieser; aus Sachalin stammenden vivipara 5 SupraIabialia (3 vordere, 1 hinteres und 1 Suboculare), 10 longitudinale Ventralreihen, 26 bis 28 Längs- und 67 Querreihen von dorsalen Schuppen und nur 7 Schenkeldrüsen vorhanden sind.

Schenkeldrüsen und Zähne.

Die Zahl der Drüsen oder »Poren« schwankt zwischen 9 und 12 jederseits; die beiden Drüsen vor dem After sind durch einen ziemlich großen Zwischenraum getrennt. - Im Zwischenkiefer sitzen 7, im Oberkiefer jederseits 16 bis 17, im Unterkiefer auf beiden Seiten 32 bis 42 Zähnchen. Leydig ${ }^{2}$ ) bemerkt in Bezug auf die Bezahmung folgendes: »Alle Zähne, auch diejenigen des Zwischenkiefers, welche nach W agler nur einspitzig sein sollen, sind zwei-

1) Vergl. sein großes Werk über die in Deutschland lebenden Arten der Saurier. 
spitzig, was allerdings etwas schwieriger zu sehen ist. Am Giamen mangeln meist die Zähne. Ich habe eigentlich unter vielen Exemplaren nur einmal ein Tier getroffen, an dessen skelettiertem Schädel jederseits am Gaumen ein paar Zähne safen und Lücken andeuteten, daf noch einige früher zugegen waren. In manchen Landstrichen scheint die Art immer mit Gaumenzähnen versehen zu sein. Denn Menge (Über L. agilis und crocea. Neueste Schriften der naturf. Gesellschaft in Danzig. 4. Band. 1850), welcher die Species gegenüber von L. agilis gut kennt, teilt ihr ganz einfach vier Gaumenzähne jederseits zu; seine Angabe darf um so weniger in Zweifel gezogen werden, als er sich über die Form der Zähne näher ausspricht.« Farbenkleid.

Lac. vivipara bietet mehrere Beispiele von Variabilität dar, von denen einige als Varietäten, andere als distinkte Arten angesehen worden sind. Die Modifikationen betreffen hauptsächlich Zeichnung und Färbung. So wurde die oberwärts mit nukbrauner Mittelzone und dunklem Vertebralstreifen und zu beiden Seiten mit 2 gelben Punktreihen auf braunem Fond versehene, unterwärts safrangelb, weißlich oder rötlich kolorierte, bald schwarz gefleckte, bald Heckenlose an weitesten verbreitete Gebäreidechse von Merrem und Tschudi als $L$. myrrhogaster, von Wolf und Wiegmann als $L$. crocea und von Andrzejowsky als chrysogastra beschrieben und wurde für eine von der vivipara J acq. distinkte Art gehalten, bis Tschudi alle drei vermeintliche Arten und auferdem noch die aedura.Scheppard, Jacquini Cocteau, Guerini Cocteau und Isidori Geoffroy St. Hilaire in die Synonymie versetzte. Die zweite Form bildet, wie es einige Fachgenossen behaupten, die montana Mi$\mathrm{kan}$, eine vivipara, deren Oberseite auf Grünlichbraun sdurch streifige Farbenabänderungen gleichsam in 3 Felder der Länge ? nach abgeteilt", und überall mit schwarzen weißgeaugten Flecken besetzt ist und deren Unterseite eine meergrüne oder aus dem Perlfarbenen ins Bläuliche oder Blabirelbe spielende Farbe zeigt. Leichte und fast unmerkbare Modifikationen solleu ferner die unter den Namen Guerini, Schreibersiana bekannten Gebäreidechsen zeigen. Auch auffallende Fälle von Verdunkelung oder im Gegenteil von Aufhellung der Färbung haben Anlak zur Aufstellung von Arten oder Varietäten gegeben; namentlich in Bezug auf die sogenanute $L$. nigra Sturm stimmen die Autoren überein, daf sie einer bestimmt geschiedenen Varietät angehöre. Glückselig, l. c. ist sogar weitergegangen und hat die snigra« als der Untergattung Podarcis und die scroceu« und smontana als der Lntergattung Zootocu angehörend angeführt! Wenn mir auch z. Z. genügende Beweise fehlen, um zu zeigen, dak bei den oben erwähnten, angeblichen Zeichnungsvarietäten eine Fixierung der Kennzeichen meistens nicht nachweisbar ist und daf letztere, obschon sie öfters unverändert aufzutreten pflegen, dennoch eher 
individueller Natur sind, oder mitunter atuch auf Polymorphismus zurückfuhrbar sein düften, muli ich aufs entschiedenste die Ansicht meiner Fachgenossen in betreff der sogenannten Varietät nigra bekämpfen, denn wir setzen in der Regel voraus, daf die Hauptcharaktere einer Varietät, und namentlich sobald es sich um die Verdunkelung des Farbenkleides bei Reptilien handelt, wenn auch nur einigermaßen vererbungsiähig sich erweisen, wie es z. B. bei den Negerrassen von Mauereidechsen oder bei der schwarzen Vipera berus bekanntlich der Fall ist, während die dunkle Färbung bei $L$, vivipara lediglich, wje es allgemein zugegeben worden ist, auf der individuellen Beibehaltung des dunklen Jugendgewandes beruht oder durch zufalligen Melanismus verursacht wird. Dals die dunlile Gebäreidechse lieineswegs zu den lokalen, isoliert stehenden Formen gehört, welche, wie es Venance Payot zu glauben scheint, erst bei $1500 \mathrm{~m}$ Meereshöhe zum Vorschein kommt, brauche ich nicht erst hervorheben zu müssen, denn es ist längst bekannt, daf man sie in jeder Höhenschicht wahrgenommen hat; so habe ich letzthin ein schönes, oben dunkelbraun, unten eisengrau nahezu schwarz gefärbtes, aus Pommern stammendes Individuum in Berliner Museum zu sehen Gelegenheit gehabt; dieses wohl im Laufe der Zeit etwas verblichene und an den Leibesseiten Spuren von Längsbänderung zeigemle Exemplar ist insofern interessant, als es unterhalb dunkler als oben koloriert erscheint, während in der Regel der Obelleib »schwarz wie Ebenholz", schwarz mit bläulichem Schiller oder schwarzbraun, der Unterleib aber lichter, sei es schwarzgrau, eisen- und grünlichgrau oder rötlichbraun gefärbt ist. In anderen Fällen wiederum kommen ober- und unterhalb gleichmäbig tief kohlschwarz holorierte Stücke vor, oder solche, deren braunschwarze Rumpfoberseite mit spurweise angedeuteten hellen Punktflecken bedeckt erscheint.

Aus Fatios Angaben geht hervor, dab die schwarze Farbe vorzugsweise bei den Weibchen aufzutreten pflegt, was mit der bekannten Thatsache, daßs in der Regel das Weibchen das Jugendgewand beibehält, übereinstimmen wurde. Über das Jugendkleid giebt Ley dig (l. c.) folgendes an: „Auch bei der letzteren (d. h. L. vivipara) sind bekanntlich die eben aus dem Ei gekrochenen Jungen immer schwarz; Jacquin schop, der erste Beobachter, teilt ja mit, dab sie »atro colore seien. Gistl nennt die Jungen kohlschwarz; die bei Reichenbach über Nacht ausgeschlüpften Lacertchen waren schwarz mit ockergelben Punktreihen für die beiden späteren Rückenstreifen. Die Tierchen, welche in meinem Terrarium zur Welt kanen, waren am Kopf und Vorderrücken dunkel erzfarben mit schönem Bronzeschiller bei günstigem Licht; der Schwanz, die hinteren Extremitäten. der Hinterrücken schwarz; Bauch nur schwärzlich, nach vorue lichter. Bei greller Beleuchtung war schon die Spur eines Rückenstreifens zu sehen, und ebenso zwei Reihen kleiner lichterer Pünktchen nit etwas Dunkel eingefakt; 
man wurde so trotz aller Verschiedenheit doch durch die Zeichnung einigermalien an das ausgekrochene Junge der $L$. agilis erinnert. - Bei zahlreichen Individuen, doppelt so grob als das neugeborene Tierchen, welche ich hier und anderwärts sammelte, war meist schon die spätere Färbung fast am ganzen Körper, wenn auch nur schwach angelegt, selbst der Bauch schon etwas safrangelb oder blok hell, je nach dem Geschlecht; nur der Schwanz war zur Hälfte noch schwarz«. - Bei den wenigen jungen Exemplaren, die mir von $L$. vivipara bis jetzt zu Gebote standen, habe ich ziemlich bedeutende Abweichungen gefunden: so waren die etwa $40 \mathrm{~mm}$ langen Tierchen unmittelbar nach dem Ausschlüpfen oberwärts einfarbig schwarz, braunschwarz odel stahlgrau und im letzteren Fall mit einer dunkleren, allerdings nur spurweise angedeuteten Vertebrallinie, ferner mit einigen ebenfalls äulierst schwach ausgeprägten, hellen, dunkel umsäumten Schuppen versehen; der Unterleib erschien schwarz oder schwarz mit grünem oder bläulichem Anflug. Diese für die im August oder September ausschlüpfenden Jungen eigentümliche Färbung ändert sich nach der ersten Häutung und zwar kurz nach dem Verlassen der Winterverstecke insofern $a b$, als die Grundfärbung heller erscheint, währenddem die Zeichnung im Gegenteil an Intensität gewimnt. So treten namentlich die hellen Punkte schïrfer hervol'; die unteren Körperteile bleiben eine Zeitlang schwarzgrau, die Extremitäten und der Schwanz beinahe schwarz gefärbt; erst gegen deu Herbst zu, also bei einem etwa einjährigen Individuum, hellt sich der Unterleib auf und es treten bald dunklere Seitenzonen auf, welche eine lichtere, von dunklen hellgeaugten Flecken besäete Rückenzone begleiten, bald streifige Farbenänderungen, welche die Oberseite der Länge nach in mehrere Zonen abteilen.

Während die Grundfarbe des Rückens bei den ausgewachsenen Gebäreidechsen verschiedenartig, wenn auch nicht auffallend, von Grau oder Graubraun durch Grünlich- oder Rötlichgrau ins Licht- oder Dunkelbraune abzuändern jtlegt, bleiben doch gewisse Zeichnungen in der Regel bestehen; so scheinen jene hellen, am Aufenrande der Parietalia ihren Ursprung nehmeuden, oberhalb der Gliedmatien nach den Seiten des Rückens zu sich hinziehenden und auch mitunter auf den Schwanz übergehenden Streifen, die schmalen Binden oder Längsreihen von hellen Flecken, ferner jene breiten Seitenbänder, welche stets dunkler als der Grund erscheinen, für die viviparu charakteristisch zu sein, denn einfarbige grane oder braune Gebäreidechsen, oder solche, bei denen die dunkleren Bänder nur spurweise auf hellgrauem oder ganz lichtbraunem Fond auftreten (var. pallida Fatio), oder endlich solche, deren ins Veilchenblau spielende Rücken blof mit kleinen rotgelben Flecken besetzt ist (Aluseum in Brüssel, nach Collin de Plancy), kommen selten vor. Teit häufiger hingegen erscheinen Rücken- und Rumpfseiten gleichmäßig grau, graubraun oder nußsbraun gefärbt und dunkel und hell gefleckt. 
Diese Flecken sind sowohl bei den am Rücken und an den Seiten gleichgefïrbten, als auch bei den seitlich gebänderten Individuen bald mregelmäßigg zerstreut, bald in Längsreihen angeordnet; in letzterem Fall erscheint die Rüchenzone der Länge nach durch eine vom Occipitale sich über die Mittellinie des Rutckens hinziehende Serie von dunkelbraunen oder schwärzlichen, mitunter brïunlich- oder grinlichweils geaunten Flecken viler hlolis von spurweise ausgeprägten Puukten in zwei Felder abgeteilt und von meistens deutlich hervortretenden hellen, länglichen, vou dunkelbraunen Strichen begrenzten Flecken umsäunt; zwischen diesen Säumen und der medianen Fleckenteihe befinden sich mitunter gröfere oder kleinere, in mehr oder weniger grolier Anzahl auftretende, zerstreute dunkelbraune Flecken, welche in seltenen Fällen die Grundfarbe verdrängen. Diese Flecken, ebenso wie diejenigen öfters mit weiflichem Mittelfelde versehenen, dunkelbramen Makeln zeigen eine Neigung sich in Längsserien anzuordnen, während die höher gelegenen, die Rücken- und Seitenzonen trennenden hellen, teilweise dunkelbraun eingefaften Flecken nicht nur deutlich gereiht sind, sondern auch zu förmlichen, streifenartigen, von dunkelbraunen Flecken oder Linien begrenzten Bändern zusammentlief̧en künuen, Was namentlich bei den Weibchen öfters zu beobachten ist, wobei die dunkelbraunen Flecken oder Punkte in der Mittellinie ebenfalls sich auslehnen, miteinander in Berührung treten und auf diese Weise einen vollständigen ununterbrochenen oder unterbrochenen medianen Rückenstreifen bilden. In letzterem Falle findet die Unterbrechung durch helle Flecken statt, welche nichts Andres als die Überreste del ursprünglichen, weißgeaugten Nakeln sind; in ersterem Falle aber verschwindet diese helle Fleckung entweder gänzlich, oder sie erscheint auf einige Punlite, welche am Saume des mediauen Rückenstreifen verteilt sind, reduziert. Der Kopf ist gewöhnlich hellbraun fleckenlos, in seltenen Fällen dunkelbraun oder mit dunklen Punkten gesprenkelt. Die Färbung der unteren Körperteile ist teils mach Alter und Geschlecht, teils auch, wie die meisten Autoren angeben, nach dem Standorte, manchen Verschiedenheiten unterworfen. Die Jungen sind, wie gesagt, unterwärts schwärzlich, bräunlich oder graugrün koloriert. Bei den ausgewachsenen Männchen wandeln sich diese Tinten in hellere Farben um; das Kinn, der Unterkiefer und der Hals erscheinen blau, blaugrün oder rötlich angeflogen, währenddem der Bauch und die Unterseite der Extremitäten und des Schwanzes bedeutend intensiver gefürbt und zwar blaugrün, dottergelb, ledergelb, orangegelb oder, wie es zur Brunstzeit öfters der Fall zu sein pHlegt, prachtvoll orangerot erscheinen; besouders gesättigt tritt die Farbe am hinteren Bauchteile hervor, wïhrendlem die Unterseite der Gliedmalien stets etwas blasser und meistens grünlichgrau oder blaugrün ist. Mitunter sind sämtliche unteren Körperteile, üfters aber nur die rïckwïrts liegenden, schwarz, braunschwarz oder dunkelgrün gefleckit 
oder gepunktet. Zur Zeit der Fortpflanzung heben sich auch die hellen Rückenflecken- oder Streifen besonders stark vom Grundtone $a b$, indem sie gelblich oder grünlich werden. Bei den weiblichen Individuen ist die Körperunterseite entweder einfach weiblich, mit einem perlgrauen, grünlichen oder bräunlichen Anfluge geziert und nur hie und da mit verwachsenen dunklen Punkten versehen, oder mit einem zuweilen starken Stiche ins Rote. Beim Weibchen scheint cbenfalls ein Hochzeitskleirl nicht zu mangreln, denn im Juli trifft man Stücke an, deren Bauch einen karmesinroten Anflug zeigt. Die Unterseite des Kopfes und der Beine ist in der Regel bläulich oder gelblich. Schwarze Flecken sind selten und nur auf den äufieren longitudinalen Bauchschildern, in der Aftergegend, am Schwanze und an den hinteren Gliedmaken vorhanden.

Die Merkmale, auf Grund deren die Unterscheidung von vivipara und montana erfolgt, sind zunächst in der Färbung und Zeichnung zu suchen. Die Farbe der Oberseite bei montanc aut. kann vom grünlichen Grau durch Dunkelgrau oder Grünlichbraun ins Schwärzliche mannigfaltigr abändern; 22 bräunlich- oder grünlichweiße, schwarz oder dunkelbraun eingefaß̧te Streifen trennen die in der Regel heller kolorierte und einen grünlichen Schimmer zeigende Rückenzone von den etwas dunkleren, meistens ins Braune spielenden Rumpfseiten; diese Streifen lösen sich aber auch mitunter in Reihen von. Flecken auf, welche schwarz oder braun sind und in ihrer Mitte einen grünlich-gelblich- oder bräunlichweißen Fleck »wie eine Pupille haben«. Ähnlich geaugte Flecken sind meistens in grołer Auzahl auf dem Rücken, an den Seiten und auf dem Schwanze entweder reihenweise angeordnet oder unregelmäßig zerstreut. »Auch haben manche Exemplare die Augenflecken des Rückens an den Seiten dichter stehen, und in der Mitte nach der Länge des Rückens beinahe fleckenleere Zwischenräume." Der Kopf ist an der Oberseite dunkel-, leder- oder graubraun, schwarz oder braun gepunktet; an der Unterseite ist er bläulich, gelblich oder sblaßs meergrün mit einem Silberglanze«. Der Unterleib ist gelblich, bläulichweif oder smit einem selı sanften Rosenrot überzogen«. Bei manchen Individuen, vorzugsweise bei den oberhalb dunkler gefärbten und unterhalb grüulich angeflogenen, erscheint die Unterseite reichlich mit schwärzlichen, bleifarbigen und ganz dunkelgrünen Fleckchen gemarmelt; diese Marmorzeichnung tritt am schärfsten an den unteren Schwanzpartien auf.

Vergleicht man eine gröfere Anzahl aus verschiedenen Gegenden und Höhen, ferner aus verschiedenen Lokalitäten, wie z. B. vom Hügelland, aus den Mooren, aus Wäldern oder aus sandigen Gegenden stammender, sogenannter typischer Individuen von $L$. vivipara Jacq. in Bezug auf ihre Fürbung und Zeichnung, so bann man sich bei einigermalien minutiöser Untersuchung davon überzeugen, daf̧ jedes einzelne Exemplar vom anderen abweicht und dak die 
Unterschiede oftmals ebenso auffallend sind wie diejenigen zwischen der vivipara und der bald als blolse Varietät, bald als eine grenau geschiedene und, wie man anfangs glaubte, nur im Riesengebirge und in cinigen Schweizergebirgen vorkommende Art citierten montena II ik an. Die allmählichen Übergänge zwischen diesen beiden Gebäreidechsen lassen, meiner Ansicht nach, keine Abgreuzung zu. Vergleicht man die jungen Individuen einer »vivipura« und einer "montuna", so funden sich unter ihnen äbereinstimmend gefärbte Exemplare vor, wihrend II ikan behauptet, dab bei den Jungen seiner »Art« die Flecken am Rücken nur schwach zu erkennen seien und die Körperunterseite meergrün erscheine. Fatio bemerkt. mit Recht, dał mehrere Forscher bei der Aufstellung von Species und Varietïten die sekundären Sexualcharaktere bei $L$. vivipera übersehen und die Verfübung, welche gewöhnlich bei Spiritusprïparaten einzutreten pflegt, außer acht gelassen haben. F'atio fügt ergänzend hinzu, daß̧ er genau dieselben Abweichungen in Bezug auf die Beschuppung und die Grölie des ganzen Körpers und einzelner Teile, welche nach der Angabe Tschudis die vivipara und smontana zeigen, bei den männlichen und weiblichen Gebäreidechsen gefunden habe; dem kann ich beiptlichten.

Geographische Verbreitung.

Berücksichtigen wir, ohne Kritik zu üben, sïmtliche Fundortsangaben der uns hier interessierenden Art, so ergiebt sich, daf ihr Wohngebiet sich von der atlantischen Küste Europas bis zum Küstenbezirk in Sibirien erstreckt und im Norden den $70^{\circ} \mathrm{n}$. Br., im Süden den $35^{\circ} \mathrm{n}$. Br. erreicht. Ziehen wir aber die Thatsache in Betracht, daf3 das Vorkommen von vivipara auf Cypern ganz vereinzelt dasteht (vergl. Unger und Kotschy, Die Insel Cypern. Wien 1865) und dafs Belegstücke, welche die Angaben Machados (Erpetologia hispalensis, in: Revista di Ciencias Literatura y Artes IV. Sevilla 1859), Barcelo y Combis (Catalogo de los Reptiles y de los Moluscos terrestres y de agua duice observados en las Islas Baleares Palma de Mollorca 1876) und Seoanes (Reptiles y Anfibios de Galicia, in: Ann. Soc. Esp. de Hist. nat. VI. Madrid 1871) hinsichtlich ihres Vorkommens in Sevilla, auf der Insel Mallorka und in Galicien bestätigen kümnten, fehlen, so fühlen wir uns bewogen, die Grenzen ihrer südlichen Verbreitung um einige Grade höher nach Norden hinauf zu verlegen. Das Museum in Paris. besitzt allerdings ein Stück dieser Art aus Rom und in der Sammlung von Herrm F. Lataste in Paris befindet sich eine vivipara aus einem noch weiter südlich vorgeschobenen Orte, und zwar aus der ehemaligen Kolonie von Cyrene oder dem jetzigen Barkah-Distrikte im Beylik Tripolis stammend. Allein vergegenwärtigen wir uns wie wählerisch $L$. vivipara sogar in ihrer eigentlichen Heimat in Bezug auf Bodenbeschaffenheit und Klima ist und wie sehr ibr Gedeihen und ihre Entwickelung von ganz gewissen Lebensbedingungen abhängig ist, so 
fragen wir uns unwillkührlich, ob die zuletzt aufgefuhrten Fundorte nicht lediglich imaginär sind und ob ihnen nicht irgend ein Mißverständnis zu Grunde liegt ${ }^{2}$ ). Eher dürfte schon unsere Art aus deu Pyrenäen nach Galicien, wo sie nach Seoane auf den Bergen von Orense, bei Pontevedra, in Santiago und Ferrol einheimisch sein soll ${ }^{2}$ ), und, der Apenninenkette entlang, aus dem Norden Italiens in die Abruzzen vorgedrungen sein, wo bekanntlich Deh ne eine der scrocea《 ähnlich sehende »L. porpluyrea《 gefunden zu haben behauptet (Allg. deutsche Zeitung II. Neue Folge. S. 213. Hamburg 1856). Auch beziiglich Dalmatiens, wo sie laut dem Grayschen Cat. Liz. Brit. Mus, vorkommen soll, hege ich meine Zweifel. Schon der Umstand, daf das von Gray erwähnte angeblich dalmatinische Stück aus der Sammlung von Herm Heckle in das British Museum gelangte, muf Zweifel erwecken, denn zu wiederholten Malen habe ich Kriechtiere aus Heckles Sammlung, von verdächtigen Fundortsangaben begleitet, citiert gesehen und bedauert, daß diese im Werke Grays zum Trotz der Zoogeographen reproduziert worden sind. Bei dieser Gelegenheit will ich in Erinnerung bringen, daf3 die Hecklesche Sammlung ocier das British Museum »Discoglossus pictus« aus 》Wien und 》Salanandrina perspicillata aus »Dalmatien besitzt (Vergl. Grays Catalogue)! Auch im Verzeichnis der Dubletten d. zoolog. Mus. d. Universität zu Berlin S. 93-94 (Berlin 1823) ist Dalmatien unter den Fundorten der vivipara genannt. - Hingegen ist die vivipara seit lange her und mit Sicherheit im Norden Italiens konstatiert worden. Für das piemontesische Gebirgsland ist sie bereits von Bonaparte in der Iconografia della Fauna italica aufgeführt worden; den neuesten herpetologischen Schriften zufolge soll sie anch in der Umgebung von Turin in größerer Zahl beobachtet worden sein (Lessona, La Zootoca vivipara in Piemonte in: Atti Accad. delle Scienze di Torino XIV). Auch nach Venezien und der Lombardei hat sie ihre Verbreitung ausgedehnt und kommt hier namentlich im Veroneser-, Trentiner-, Belluneser- und PaduanerGebirge vor ${ }^{3}$ ). De Betta führt Zevio und Legnano als specielle Fundorte an; bei Verona soll sie nicht nur auf den Bergen, sondern auch in den feuchten Ebenen, auf den Dämmen der Reisgräben hausen (Erpetologia delle Provincie Venete etc. Verona 1857). Massalongo ${ }^{4}$ )

1) Nachträgl. Zusatz. Nach eingezogenen Erkundigungen soll sich eber die Bodenbeschaffenheit als das tropische Ḱlima von Barkah, dem Hesperiden-Garten, für die Lebensbedürfnisse der vivipara eignen, denn der gebirgige Teil dieses Distriktes soll bewaldet und reich an Quellwasser sein.

2) Nachträgl. Zusatz. Herr V. L. Seoane teilt mir in einem Brief rom 3. März 1885 mit, daG, $L$. vivipara in Spanien nicht vorkommt. - In Bos càs Catalogues des Reptiles et Amphibiens de la Peninsule ibérique (Bull. Soc. Zool. de France IV) wird das Vorkommen dieser Species in Spanien für zweifelhaft erk]ärt.

9) Nardo, in: Atti dell' Ist. Ven., V. Serie III. pag. 600. Tenezia 1859-60. - Canestrini, Intorno alla Fauna del Trentino in: Atti Soc. Ven. Trent. 1875, pag. 21. Padora.

4) Saggio di una Erpetologia popolare reronese in: Mem. Accad. Agricolt. XXIX. Verona 1854; Catalogo dei Rettili ed Anfibi delle Provincie Tenete in: Atti R. Ist. Ven. IV. 1800. 
lat sie bei Peschiera an Lago die Garda und Searpa (Catalogo dei Rettili ed Anfibi del 'Irevignano. Atti Soc. Veneto-Trentina 11I. 1876) aufserhalb der Barriera Vittorio Cimanuele und liings des lilusses l'iave bei Treviso beobachtet. Exemplare aus Bergamo stammend, sind im Museo Civico zu Mailand aufbewahrt ${ }^{1}$ ). Daf̉ die vorgeschobensten südlichen Punkte ihrer Verbreitung in Piemont, in der Lombardei und in Venezien liegen, glaube ich vorläufig annehmen zu müssen.

In Tirol hat die vivipara nach Gredler ${ }^{2}$ ) eine bedeutende vertikale und auch die gräbite horizontale Verbreitung von allen ihren Anverwandten und slürfte kaum einem Gebirgszuge gänzlich fehlen«, obwohl sie vorzugsweise dic Kalkgebirge zum Aufenthaltsorte wäht. Der genannte Forscher verzeichnet nachstehende von der viripara bewohnte Lokalititen : Reuthe, am Hahnenkamm und auf der Aschaner Alpe; T'elfs, im s. g. Kaare an der Munda- (Mounta-) Kette. 6500' U. M.; Seeféld, an kleinen Wassern; im Thale Ven am Brenner und auf dem Rol3kopf bei Sterzing; Enneberg, z. B. auf den Bergen um St. Cassian; Innichen, auf der Ebene; lïngs des Rosengartengebirges, wie an Kalbleck, über $6000^{\prime}$; bei Bad liatzes lïngs den hölzernen Röhren der Mineralwasser ${ }^{3}$ ), sowie auch in der Ruine Hauenstein (nach Prosslingers $\gg$ Das Bad Ratzes in Südtirol« etc. S. 38. Berlin 1883) und auf der Seiser Alpe (Leydig); über den Ritten (bei Pemmern hat man »var, croceas beobachtet) bis an die Rittener Alpe, Salten und liollererberg, wo sie gegen das stote Moos* häufig bei Steinhalden und unter Sträuchern sich ansiedelt; bei Presburg und über den Labberg und das Joch Grimm; bei Sigmundskron - wo man durch den halben »Griesner Boden« den trockenen oberen Teil noch allenthalben der Mauereidechse, im feuchten anderen Teil aber, der noch vor nicht seit lange her versumpt gewesen sein soll, der vivipara begegnet; bei St. Jakob auf feuchten Wiesen; um den grofen Teich von Lavace auf Joch Grimm (Gredler, Eine Exkursion auf Joch Grimm. Inusbruck 1867), wo sein fast rotbrïunlich und überhaupt sehr bunt gezeichnetes Individuum von enormer Gröl3e« erbeutet worden ist. In seinen im Jahre $1882 \mathrm{im}$ Korrespondenzbl. d. zool. mineralog. Ver. in Regensburg XXXVI, S. 23-30 erschienenen »Herpetolog. Beobachtungen« giebt Gredler nachträglich an, daf $L$. vivipara überaus häufig bei Steinwand im Hintergrunde des Thales Schalders, auf Thonschiefer vorkommt und dalis hier nicht

$\left.{ }^{1}\right)$ Jan, Cenni sul Museo Cirico di Milano, pag. 40. Milano 1857. - Im Mailänder Museum habe ich neuerdings zwei vivipara und eine agilis aus der Lombardei als $* L$. muralis var. disjuncta bezeichnet gesehen, ferner cine ocellata aus »Süditalien und eine andere aus Alessandria (ded. Panceri)!

$\left.{ }^{2}\right)$ Fauna d. Tŕriechtiere und Lurche Tirols. XXII. Programm d. k. k. Gymnasiums zu Bozen. S. 10. Bozen 1572.

${ }^{8}$ ) Vergl. auch Leydig, Die in Deutschland lebend. Arten d. Saurier, S. 219. 
nur normal gefärbte, sondern auch lichte und schwarze Stücke beobachtet worden sind. Biasoli soll sie auch auf dem Mte. Fargorida im Adamellogebiete gesammelt haben. Nilde hat sie aus Meran nachgewiesen (44. Jahresber. d. schles. Gesell. f. vaterländ. Kultur 1866, S. 55). De Betta sammelte sie in mehreren Lokalitäten Sültirols, so beispielsweise im Nonsberge an Mte. Toval, im Pallade-Gebirge bei 5360 Fuf ü. M. und oberhalb Tret und Senale (Erpetologia delle Prov. Venete ete. und Catalogo dei Rettili della Valle di Non nel Tirolo Meridionale in: Verhandl. zool. botan. Ver. in Wien 1852, S. 153). Ts chudi hat sie in noch höher gelegenen Örtlichkeiten konstatiert und bemerkt, daf. sie sogar bis in die Schneeregion hinein gedeiht und in einer Höhe von 7 bis 8000 Fuß ü. M. verhältnismäßig keine seltene Erscheinung sei, „ja sie wurde sogar noch oberhalb Spada longa am Umbrail in einer Höhe von 9134 Fuß ü. M. gefangen, wo sie über zehn Monate lang unter dem Schnee vergraben liegen mufs und sich während der lurzen Sommerwochen nur notdürftigg von Fliegen, Spinnen und Käfern nähren kann« (Das Tierleben der Alpenwelt. 7. Auflage, S. 272. Leipzig 1865). Nach den Wahrnehmungen dieses Forschers scheint dic vivipara, oder eigentlich, wie ich bemerken muf, die vivipara aus dem hohen Gebirge, in jener Höhe sich wohler zu befinden als im Ticflande, denn ein aus den $7900 \mathrm{Ful}$ hohen Alpen herabgebrachtes Exemplar soll im Thale sich beharrlich geweigert haben, Nahrung zu sich zu nehmen. Sonach bemerkt Leydig mit Recht, dafs $L$. vivipara unter allen Arten die höchste vertikale Verbreitung hat und ebenso richtig ist es, wenn Tschudi vermutet, dafs sie das in Europa noch am höchsten vorkommende Reptil sei, denn obschon Vipera berus, diese tückische Gesellin der harmlosen vivipara, nicht nur der Tierwelt der Alpenregion, sondern auch derjenigen der Schnecregion angehört, scheint sie doch höchst selten über 9000 Fuf Höhe hinaufzugehen, dagegen in Höhen von etwas über 6600 Fuf ï. M. noch recht häufig zu sein. - Auf den Alpen des Walserthales in Vorarlberg soll L. vivipara ebenfalls nicht mangeln ( $\mathrm{Br}$ hin, in: Verhandl, zool. botan. Gesellsch. in Wien XVIII, S. 256. 1869). Wohl die weiteste horizontale und vertikale Verbreitung und zugleich die gröbte Häufgkeit des Vorkommens dieser Species wird die Schweiz aufweisen. Daks sie auf dem Wormserjoch, also auf der schweizer-tiroler Grenze, gesammelt worden ist, habe ich bereits erwähnt. Im Ober-Engadin ist sie von F a tio (Les Reptiles et les Batraciens de la Haute-Engadine in: Arch. sc. phys, et nat. XXI. 1864) und nachträglich auch von Giebel bei Pontresina konstatiert worden (Zeitschr. ges. Naturw. Bd. 50. S. 203). 'Ts ch udi spricht von Exemplaren aus den Churer Alpen (Monographie d. schweizer. Echsen. Nouv. Mém. Suc. Helv. sc. nat. 1837), v. Brügger giebt an, daß sie bis in die Gegend von Chur vordringe (Naturgeschichtl. Beiträge z. Kenntnis d. Ungeb.v. Chur. Tierreich, S. 151. Chur 1874) und 
Leydig und I'schudi teilen mit, dalis sie in den Kantonen Unterwalden, wo sie z. B. bei Wolfensebiessen gefungen worden ist, Schwyz und in einem T'eile von Uri ziemlich häufig vorkomme. Im Tessin, namentich auf dem Gipfel des Mte. Fongio, ist sie gleichfalls beobachtet worden (F. M üller, Mitteilungen aus d. herpetolog. Samml, d. Basler Mus, in: Verhandl. d. naturforsch. Ges. in Basel 1877). In der hügeligen Umgebung von St. Gallen und in den appenzeller Bergen ist sie von Tschudi wiederlsolt gefangen worden; dieser Forscher traf sie auch in der Umagebung von Zürich. Ir. II üller berichtet ${ }^{1}$ ), dalis das Basler Muscum Exemplare der vivipara aus der Näle Basels, beispielsweise aus den EttingerBlauen, fermer aus dem Waalt, wo sie bei Gryon, am Rocher du vent und im marais d'Orbes (F atio) nicht selten angetroffen wird, und vom Pilatus erhalten habe. Auf der Wengernalp bei Rosenlaui, auf den Chureralpen und am Gotthard haben Studer, Schinz ${ }^{2}$ ), T'schudi und C. J. E orsyth Major ${ }^{3}$ ) »dies, wie Tschudi sagst, whöchst seltene *schwarze Varietät« entleckst; er fügt hinzu, daß letztere nie im Tieflande erscheine und überhrupt für das seltenste Reptil der Schweiz gelte. Die vertikale Verbreitung der vivipara im Gebirgsstock des Montblanc hat uns Venance Payot geschildert: nach ihm soll sie in typischer Form, d. h. als vivipara sp., die Region des Nulzbaumes bewohnen und als mmontana" (Mikan) in den nördlich gelegenen Thälern auftreten und hier nicht unter $1000 \mathrm{~m}$ und nicht

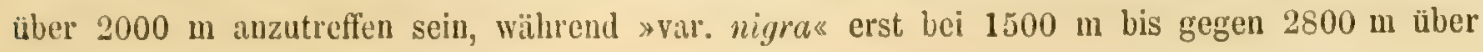
Meer zum Vorschein kommt. Ven ance Payot erwähnt aulserdem cine den beiden zuletzt genannten ähnliche und wohl intermediäre Form, i. e. der »var. alpina«, welche die nördlichen Abhänge der liette Aiguilles-Rouges, ferner das, wegen seiner Vipern berüchtigte Thal de la Diozaz und Pormenaz »auprès des neiges eternelles « bei $2000-2500 \mathrm{~m}$ üb. M. bewohnt ${ }^{4}$ ). Hierselbst will ich hinzufügen, daf Collin de Plancy in seinem Catalogue des Reptiles et Batraciens du département de l'Aube angiebt, $L$. vivipara gehe in der Schweiz über 3000 m hinauf, ohne jedoch die so hoch gelegenen Fundorte zu nennen. Für Kanton Bern werden auferdem einige Lokalitäten von (Fatio (Faune des Vertébrés de la Suisse. Reptiles, p. 88. Genève et Bâle 1872) genannt, so die Ebene bei Bern selbst und das Dorf Belp bei Bern. In den Graubündner-Alpen (F a tio), im Jurn (D u Plessis und Combe in:

1) 1. c. - Vergl. auch II. Nachtrag zum Katalog in: Verhandl. d. naturforsch. Gescllsch. in Basel. Jahrg. 1882.

2) Fauna helvetica in: Neue Denkschrift d. allg. schweizer. Ges. f. d. gesammt. Naturwiss. I. S. 138. Netichâtel 1837.

3) Atti Soc. Toscana sc. nat. residente in Pisa, vol. III, fasc. 1, pag. 83. Pisa 1877.

$\left.{ }^{4}\right)$ Ann. Sc. phys. et nat., d'Agricult. et d'Industrie de Lyon VIII, 1. 456. 'Lyon 1864. 
Bull. Soc. Vaud. sc. nat. IV, p. 640. 1868) und im Berner Oberland (Forsyth Major) soll die schwarke vivipara konstatiert worden sein.

Von der Schweiz erstreckt sich der Verbreitungsbezirk dieser Lidechse nach Frankieich, wo sie in den der Schweiz angrenzenden Départements schon seit lange her bekanut ist. Ogérien führt sie in seiner "Hist. nat. du Jura (Paris 1863, pag. 293) ans Lons-le-Saumier, St. Naur und Montaigu auf. Girod-Chantrans (Essai sur la Géographie physiłue, le Climat et l'Hist. nat. du dép. du Doubs, t. I, p. 114. Paris 1850) und neuerdings auch Olivier (Faune du Doubs in: Mém. Soc. d'Emulation du Doubs. Besançon 1883) verzeichnen sie unter den Reptilien des Département du Doubs (»marais de Saône, près Besançon«), von wo aus sie in nördlicher Richtung, so z. B. bis in die Departements de la Meurthe-et-Moselle und des Ardennes vorgedrungen ist. - Im Südosten Frankreichs dehnt sich ihr Wohngebiet auf Savoyen aus, dagegen die sïdlicher gelegenen Ost-Départements scheint sie eher zu meiden, wenigstens finde ich ih Vorkommen weder im Werke $\mathrm{R}$ is s os, noch in demjenigen Veranys crwähnt. Hier, bei Nizza, fehlt sie ganz bestimnt. Wenn Crespon die vivipara im »Midi de la France $\ll$ beobachtet zu haben behauptet ${ }^{1}$ ), so sind wohl darunter das Département Hérault, wo sie allerdings in den Mooren von Agde und bei Béziers einheimisch sein soll (vergl. Jumeau, Synopsis des Reptiles et Batraciens du Dép. de l'Hérault. Bull. Soc. d'Etudes des sc. nat. de Béziers 1879), ferner das Dép. de la Gironde, wo sie nach Lataste (Essai d'une Faune herpétolog. de la Gironde. Act. Soc. Linn. de Bordeaux XXX) und Gachet (ibidem, t. V, pag. 233) in den Alleen von Boutaut bei Bordeaux haust, und endlich die französischen Pyrenäen gemeint. ${ }^{2}$ ). In den Pyrenïen soll sie beispielsweise an einigen Seen vorkommen. Exemplare aus Lioran im Cantal und aus Nantes habe ich in der Sammlung des Herrn La taste zu sehen bekommen. Alsdann bewohnt die uns hier interessierende Species Lozère (A. Westphal-Castelnau, Cat. coll. Rept. du feu M. Alex. Westphal-Castelnau in: Compte-rendu des travaux du Congrès scientifique de France tenu à Montpellier. 1870), die Umgebung von Montluçon und die Moore von Quinsaines im Dép. de l'Allier ${ }^{3}$ ), Fontainebleau, die Umgegend von Paris, so z. B. St. Denis, Enghien und Bondy (Lataste, Cat. des Batraciens et Rept. des env. de Paris etc. in: Act. Soc. Linn. Bordeaux XXX), die trocken liegenden Strecken der Ilorïste von Argentolle, St. Pouange und Villechétif unweit von Troyes - also ỉm Dép. de l'Aube (Collin de Plancy, Cat. des Rept. et Batraciens du dép. de

\footnotetext{
1) Faune méridionale, pag. 194. Nimes 1844.

$\left.{ }^{2}\right)$ Duméril et Bibron, Ernétologie générale V, pag. 208. - Jumeau, l. c.

${ }^{3}$ ) Olivier, Essai sur la Faune de l'Allier. Bull. Soc. d'Emulation de l'Allier. Moulins-Paris 1880.
} 
l'Aube. Bull. Soc. zool. de France 1877) - und die Umgebung von Coursenain im Dép. de la Marne. In Marais de Lèges und bei St. Quentin im Dép. de l'Aisne (in coll. Lataste: No. 36t, 366), im Dép. des Ardennes (bei Charville, Mezières und Ifarcy ${ }^{2}$ ) und im Dép. du

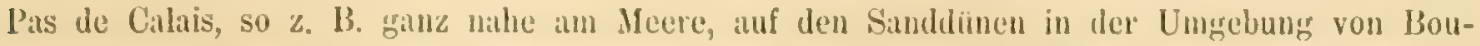
logne (Württemberg. naturwiss. Jahreslefte 1851, S. 128. - Leydiğ, Die in Deutschl. Iebend. Art. d. Saurier, S. 218) fehlt sie ebenfalls nicht. Holandre ${ }^{2}$, Matlie u ${ }^{3}$ ) und Malherbed) lassen sie im Dép. de lia Meurthe et Moselle vorkommen, lingegen ist es Fourne ${ }^{5}$ ) nicht gelungen sie daselust zu entdecken. C. und $\Lambda$ u g. D u méril teilen mit, dala das Musée d'hist. nat. in Parris Exemplate der vivipare aus Vienne, aus der Forêt d'Eu und rom Mont d'Or erhalten habe (Veryl. Cat. méth. coll. des Reptiles. Paris 1851).

In Luxemburg ist sie nach De la Fontaine ${ }^{6}$ ) überall verbreitet, jedoch mit Ausnahme der Torfgrubeu von Ardeme (bei St. Hubert) nirgends hiiufig. De la Font a ine fügt hinzu, dal: in Luxemburgischen eine grünlichbramrückige Vartietit einheimisch sei, deren Leibesseiten liupferrot und deren Batich blafgelb ist. Über ihre Verbreitung in Belgien erfalnen wir aus der Faune belge vou Ldm. de Selys-Longeh amps (Bd. I. Liège 1842) nachstehendes: "1l habite les montagnes boisces et les bruyères de lik rive droite de la Meuse surtout en Ardenue, mais il descend cependant le long des bords de l'Ourthe jusque près de Liège et existe dans les broussailles d'Hippoplaé des dunes d'Ostende et dans les bois de pins des sables de la Campine. Assez commun à Spa et à St. Hubert, à Holloy dans un marais." Aus der Umgebung von Brüssel, wo das Tier fast überall und namentlich im Walde von Soignes vorkommen soll, kennt sie G. A. Boulenger. Collin de Plancy versichert, dafs in Belgien eine ganz eigentümliche Farbenvarictät einheimisch sei, deren liücken ins Veilchenblaue spielt und anstatt mit 3 schwarzen, für das Männchen so charakteristischen Längsbinden, mit kilcineu rotgelben (rousses) Flecken besiiet erscheint und deren Bauch auf Rosit rotgelb gefleckt ist. Hingegen die schwarze Abart ist bis jetzt in Belgien noch nicht konstatiert worden. Aus der Schrift Schlegels »De Dieren van Nederland (Haarlem 1862) ersehen wir, daf diese

1) Nach Collin de Plaucy l. c.

$\left.{ }^{2}\right)$ Cat. des animanx vertébrés observés et recueillis dans le dép. de la Moselle in: Bull. Soc. d'hist. nat. de la Moselle VI. Metz 1851.

3) Zoologie in: H. Lepage, Le Département de la Meurthe: Statistique, Historique et Administration. 1843.

4) Zoologie de la Moselle in: Statistique de la Moselle. Metz 1854.

5) Faune de la Moselle. 1936.

6) Faune du pays de Luxemhourg. Reptiles. Luxembourg 1870. 
Art bei Nimwegen, bei Arnheim und bei Leyden beobachtet worden ist. Exemplare aus Bergen op Zoom stammend sind in der Sammlung von Hern Lataste zu sehen (No, 1609).

Über die Verbreitung der Gebireidechse nach Norden Deutschlands liegen mir mehrere Angaben vor. So giebt F. Brüggeman a an, dals sie in der Bremer Gegend die Moore bevorzugt, wo sie sich in dem Haidegestrüpp aufhïlt. „Nicht selten«, sagt er, »ist sie an derartigen Lokalitäten, $z$. B. bei Lilienthal und Oyten. Bedeutend spärlicher trifft man sie auf der Vorgeest; zu Rockwinkel und Oberneuland habe ich während mehrjähriger Sammelzeit nur drei Exemplare erlangt. In Bremen und der nächsten Umgebung ist sie ebenfalls eine Seltenheit. Übrigens gehörten alle Eidechsen, die ich von den Alluvialterrains der Bremer Gegend gesehen habe, zu dieser Species. Un Vegesack findet sic sich mit L. agilis gemeinschaftlich; aus dem Oldenburgischen kenne ich sie von den Mooren bei Edewecht und bei Varel. Ob $\boldsymbol{L}$. vivipara, wie zu erwarten, in der ganzen norddeutschen Ebene vorkommt, bleibt noch festzustellen ${ }^{1}$ ). Wiepken und Greve fügen ergänzend hinzu, dals sie im Herzogtum Oldenburg auf Sand- und Moorboden häufig ist (Systemat. Verzeichnis d. Wirbelt. im IIerzogtum Oldenburg. S. 73. Oldenburg 1876) und der mir unbelannt gebliebene Verfasser der in X. Jalnesber. d. naturwiss. Ver. f. d. Fürstent. Lüneburg, S. 15. Lüneburg 1861 erschienen »Beitr. z. Naturkunde d. Fürstent. Lüneburg« meint, daßs sie im Lüneburgischen »vereinzclt, doch vicht selten, auch in Stïdten und Dörfern« einheimisch sei. In Mecklenburg kommt sie ebenfills vor. Die Sammlung von Westphal-Castelnau in Montpellier besitzt diese Species aus Holstein und Grasso soll sic bei Helmstädt gesammelt und, wie L eydig glaubt, mit der agilis zusammengeworfen und unter dem Namen »agilis « citiert haben ${ }^{2}$ ). Breh m (Die Kriechtiere und Lurche in: "T'ierleben«, S. 170. Leipzig 1878) nennt sie aus dem Harze; ich besitze Exemplare aus Magdeburg und in dem Museum zu Berlin befinden sich mehrere Stücke aus Spandiu (No. 4528), aus Rügen (No. 946) und aus Pommern, darunter ciu eigentümlich, oben dunkelbraun, unten stahlgrau, nahezu schwarz gefürbtes Exemplar (No. 949 aus Pommern). In Neuvorpommern soll sie ebenfalls nicht mangeln und in der unmittelbaren Nähe Berlins in grober Zahl vorkommen. In Ostpreufen ist sie selten (Rathke, in: Neue Preuf. Provinzial-Blätt., Bd. II. S. 16. Königsb. 1846. Vergl. auch: Bujack, Naturgeschichte der höheren Tiere etc. S. 260. Königsb. 1837 und Lorek, Fauna prussiaca.

1) Über einige Amphibien und Reptilien der Fauna von Bremen in: Abhandl, d, naturv. Ver. zu Bremen 1874, S. 205.

7) Vergl. Grasso, Dissert. inaug. medica de Lacerta agili Linn. Ilelmstati 1788. 
liönigsb. 1834), hingegen in Schlesien begegnet man ihr stellenweise hïufig; so, laut $K$ a 1 u z a ${ }^{1}$ ), auf dem Glatzer und Neilier Gebirge, so, nach Gloger ${ }^{2}$ ), auf dem Schnecberge in der Grafschaft Glatz, laut Mikan ${ }^{3}$ ) im Riesengebirge, wo die sogenannte montana enticclit worden ist. Eingehend mit der Verbrcitung der vivizara in Schlesien lat sich Milde ${ }^{4}$ ) befafist; er sagt: „Auf der Sohle der kleinen Schneegrube in Riesengebirge bei $3440^{\prime}$ gefangen, später verfolgte ich ihre Verbreitung von Charlottenburg an bis Waldenburg, Görbersdorf und von hier bis Adersbach, ferner in der benachbarten Wiese in Böhmen und um Grotkau bei Neilje. liesonders häufig aber ist das Tior um Gürbersdorf bei Waldenhurg und Friedland. In der Nahe von Bächen oder an feuchten Gräben und niemals mit Lacerta agitis zusammen. An solchen Orten erscheint es auch in der gröften Mannigfaltigkeit der Farben, hier fand ich anch kohlschwarze Exemplare. Bei Breslau und Adersbach kommt sie auch vor. Auf den sehr feuchten Torfwiesen bei Adersbach, auf denen-Sphagna, Vaccinium oxycoccos, Erophorum und Carices wuchern, ist die Zootoca auferordentlich gemein und leicht zu fangen. Bei dem Dorfe Karlowitz dicht bei Breslau ziehen sich lange, sonnige, trockene pflanzenreiche Dämme und ein kleiner Zug diluvialer Sandhügel mit Alyssum montanum und Jasimemontana hin. An beiden Lokalitäten, namentlich häufig aber an crsterer, findet sich Lacerta agilis.«. Geinitz versichert ebenfalls, die vivipara sin unendlicher Menge von Charlottenburg und Waldenburgr an nach Görbersdorf bei Adersbach« gesehen zu haben ${ }^{5}$ ); er fügt mit Recht hinzu, daf sie gewils auch in Sachsen verbreitet sei, denn sie ist bei Leipzig, bei Dresden ${ }^{6}$ ) und Annaberg ${ }^{7}$ ) konstatiert worden; auch in der Oberlausitz ${ }^{8}$ ) und in Thüringen, so laut Br ügrgemann, auf dem Gickelhahn, kommt sie ebenfalls vor. Der Güte des Herrn O. Goldfufis verdanke ich etliche Exemplare der vivipara, die in der Abatassine, einem mit kurzem Gestrüpp bewachsenen kleinen Wäldchen in der Nähe von Halle erbeutet worden sind. Über ihre Verbreitung im Rhöngebirge, im Odenwalde und in der Ebene des Untermains hat Leydig ${ }^{9}$ ) einige Beobachtungen gesammelt. $» L$. vivipara«, sagt er, nist in der Rhön nach meiner Erfahrung

1) Systemat. Beschreib. d. schles. Amphibien u. Fische. S. 14. Vergl. auch: Schwenckfcld, Theriotropheun Silesiae etc. Lignici $160: 3$.

2) Schlesiens Wirbeltier-Fauna, S. 66. Breslau 1833.

3) Sturms Deutschlands Fauna.

4) Verhandl. zool. botan. Gesellsch. 1870. S. 1033

5) Sitzungsber. d. naturf. Gesellsch. d. Isis in Dresden 1869, S. 130.

6) Reibisch, Sammlung sächsischer Reptilien, ibidem, Jahrg. 1866 (1867), No. 10-12, S. 113.

$\left.{ }^{7}\right)$ II. Jahresher. d. Annaberg-Buchholzer Ver, f. Naturliunde 1870. S. 98.

8) Tobias, in: Abhandl. d. naturforsch. Gesellsch. zn Görlitz, Bd. XlI. S. 92. Görlitz 1865.

$\left.{ }^{9}\right)$ Uh. d. Verbr. d. Tiere im Rhöngeh. u. Mainthal etc, in: Verhandl. d. nat. Ver, d. preuf. Rheinl. 1. Westf. 38. Jahrg. 4. Folge. VIII. Bd. 
häufiger als $L$. agilis: schon bei Kissingen, nicht selten in westwärts gekelırten, schattigen Abhängen, sammelte ich ferner cine ginze Anzahl am Kreuzberg, an der Milseburg, Stellberg, Walberg; zum 'Teil unter Baumrinde oder Steinen.« »Am Dreistelz hatte ich schon früher die Var. nigra an sehr feuchtem Platze erbeutet. Im Mainthal ist mir die Art nirgends im Bereiche des Weinbaues $z u$ Gesicht gekommen, wohl aber in den waldigen, das Mainthal begrenzenden Bergen, so z. B. im Spessart bei Lohr. Auch hei Amorbach im Odenwalde glaube ich in der Nähe des Wassers die Species gesehen zu haben, ohne des Tieres habhaft geworden zu sein. Nach neueren Beobachtungen anderer kommt unsere Eidechse auch in der Ebene des Untermains, bei Frankfurt und Offenbach auf sumpfigen Strecken vor. Daf3 ich L. vivipara in dem waldigen Höbenzug, welcher die Wasserscheide zwischen der Tauber, Wörnitz und Altmühl bildet - Frankenhöhe - häufig beobachtet habe, wurde anderwärts schon berichtet. Auch hier am Niederrhein fehit die Art nicht: ich fing sie im Kottenforst bei Bonn; Bertkau an sumpfiger Stelle des Venusberg. Ein im Sommer 1878 unmittelbar am nördlichen Saume der Stadt Bonn aufgegriffenes Stück mag wohl nur durch Zufall verschleppt gewesen sein«. Über ihre Verbreitung bei Frankfurt a. M. und im 'Taunus, wo sie bereits Römer-Büchner ${ }^{1}$ ) »in waldigen und steinigen Gegenden «eobachtet haben soll, giebt uns $0 . \mathrm{K} \ddot{\mathrm{r}} \| \mathrm{er}$ in seiner Schrift »Einiges üb. unsere Eidechsen u. Tritonen« (Zoolog. Garten 1880. S. 189) Aufschluk; sie soll nämlich, laut diesem Forscher, in der Ebene nur an einigen Stellen, z. B. im Hengster, einem ausgedehnten Sumpfrebiet südlich von Offenbach und stellenweisc im Frankfurter Walde, ferner im hohen 'Taunus, obwohl seltener, so z. B. auf dem Gipfel des grofen Feldberges $\left(2700^{\circ}\right)$, auf dem Nltkönig an den Ringwällen, am Südabhange des kleinen Fuldberges, besonders aber in dem sich von da gegen Falkensteiu absenkenden Reichbachthale $\left(1400^{\prime}-1800^{\circ}\right)$ vorkommen. Nach Kirschbaum ${ }^{2}$ ) begegnet man ihr im Rheingau, z. B. in einem Buchenwald oberhalb der Ziegelhütte bei Weilburg und vor der Artilleriekaserne zu Wiesbaden. Kirschba um fügt die Bemerkung hinzu, dąs sie an diesen Orten selten zu sein scheine; in Bczug auf die Wiesbadener Gegend kann ich dies bestätigen. Erwähnt muß noch werden, daß M elsheimer ${ }^{3}$ ) unsere Eidechse bei Linz a. Rh. anf feuchten Heiden besonders am Willscheiderberg bei Vettelschlobs entdeckt hat und dals Suffriau sie als einzeln in den südlichen Gebirgskreisen im Regierungsbezirk Arnsberg vorkommend anführt (Jahrbücher d. Ver. f. Naturkunde im Herzogt. Nassau III, S. 163. Wiesbaden 1846). Dafi sie in der Eifel nicht mangelt, er-

1) Verzeichnis d. Steine u. Tiere, welche in d. Gebiete d. freien Stadt Frankfurt u. deren nächsten Umgelung gefunden worden. Frankf. a. M. 1827. S. 71.

3) Die Reptilien und Fische d. Herzogt. Nassau. Wiesbaden 1865.

3) Korrespondenzh). d. naturhist. Ver, d. prenf. Rheinlande u. Westfalen 1876. S. 90. 
sehen wir aus der oben citierten wertvollen Abhandlung Leydigs. (Vergl. auch: M. Schäfer. Moselfauna etc. I. S. 255. 'Trier 1844). Ley dig fand sie bei Gerolstein und teilt mit, daf.s er ein Stück von Montjoie erhalten habe; am Laacher-See dagegen hat Leydig vergeblich danach gesucht. $\Lambda \mathrm{n}$ den alten Mauern der Befestigungen von Metz ist sie von IIolandre beobachtet worden (Cat. des animaux observes dans le dép. de la Moselle in: Bull. Soc. d'hist. nat. de la Moselle VI. Metz 1851. Vergl, auch: Malherbe, Zoologie de la Moselle in: Statistique de la Moselle. Metz 1854). Über ilr Vorkommen, oder genauer üher das Vorkommen einer lebendgebärenden Eidechse in Lothringen, berichtet P. Buchoz in seinem, im Jahre 1771 in Paris publizierten Catalogue des animaux qui habitent la Lorraine et les TroisEvêchés. Nach Nülilin bewohnt sie die Vorberge und höheren Gebirge Badens ${ }^{1}$ ); in der Gegend von Rippoldsau erbeutete Leydig die smontana sin schönen Exemplaren« und zwar "ganz von der Farbe, wie sie Mikan beschrieben und Sturm abgebildet hat. F. Muller, meint (l. c.), daf Lacerta vivipara im Schwarzwalde bis tief herunter vorkommt, denn er hat sie in der Nähe von Batenweiler im Magen einer Cormella lacvis gefunden. Nach Plieninger ${ }^{2}$ ) ist sie in Württemberg häufig, namentlich in den Gegenden von grüferer Meereshöhe, bei Hohenheim, auf der Hardt, bei Tütlingen, bei Heidenheim und Crailsheim; sie scheint hier mehr Laubwäldern als Nadelwäildern anzugehören. Nach Leydig ${ }^{3}$ ) findet sic sich »z. B. im Wald äber Derendingen, im Schünbuch unweit Bebenhausen«; sie »gelangt auch öfters, da sie gerne ihren Aufenthalt unter Baumrinde nimmt, mit frisch gefilltem Holze in lir Strafien hiesiger Stadt« (d. h. Tübingen). Auch die Abänderung »L. nigra Wolf fing L eydig »am Goldersbach, wo sie ihre Wohnung unmittelbar an Wasser, unter einem Wurzelstumpen, aufgeschlagen hatte.« Außerdem soll sie bei Isny (Württemb. zool. Sammlung), bei Bebenhausen ${ }^{4}$, bei Stuttgart und Schussenried ${ }^{5}$ ) einheimisch sein. In Oberschwaben auf der Alb komint sie nach Klunzinger vor. v. Reider und Hahn ${ }^{6}$ ) fanden die Mikansche mmontanas im bayrischen Gebirge und auf dem Riesengebirge, die mnigra Wolf in den Berchtesgadener Alpen, am Tegernsee, auf der Grüneckalpe und in Cham in der Oberpfalz und endlich die scrocca Wolf» in der Umgebung von Nürnberg und in der oberen Pfalz, wo sie sin

1) Tierwelt in: Das Großherzogtum Baden I. Karlsruhe 1883.

2) Jahreshefte d. Ver. f. vaterländ. Naturkunde in Württemberg III. S. 194. 1847.

3) Tierwelt in der Beschreibung $d$. Oberamts Tubingen, herausgegeben $\nabla, d, k$, statistisch-topogr. Bureau. Stuttgart 1867.

4) Krauf, Württemberg. Fauna, S. 497 in: Das Königreich Württemberg. 1882.

5) Das Königreich Württemberg, herausgegeben von dem k. statist.-topograph. Bureau. Stuttgart 1863. S. 291.

6) Fauna boica III. Nürnberg 1832. 
gröfseren Nadelwaldungen gar nicht selten ist. « In den Wäldern der Au zwischen Dinkelscherben und Windshofen, deren Boden feuchter Torfgrund ist, soll sie lant Cles $\sin ^{1}$ ) ziemlich häufigr sein und die ganze Alpenkette der Sülgrenze entlang bewolnen. Leydig sammelte sie auf der Insel Herrenwörth im Chiemsee und bei Reutte, J i ckel²) kennt sie aus Schäftlarn, Landeshut, aus der Münchener Umgrebung, aus der Umgegend von Augsburg (bei Strakberg), von Bobingen, Wellenberg, Dersching, Zusmarshausen, Lechhausen, ferner aus dem bayrisehen Gebirge z. B. aus dem Bade Kreuth, endlich aus Ober- und Mittelfranken z. B. aus Erlangen und Nürnberg und aus der Oberpfalz, wo laut $\mathrm{Koch}$, Herrich-Schäffer und Forster die sogenannte crocea und nigra bei Reichenbach vorkommen soll ${ }^{3}$ ). Dab Leydig die vivipara in Franken konstatiert hat, habe ich bereits erwähnt und es bliebe mir nur noch übrig die bayrischen Fundorte der seltenen schwarzen Gebäreidechse zu rekapitulieren, es sind dies: Frankenhöhe, botanischer Garten zu München (Leydig), Berchtesgader Alpen, Tegernsee, Grüneckalpe, Cham (v. Reider und Hahn), Reichenbach, Roding bei Cham (Jäckel).

Die gebirgigen Gegenden Böhmens sollen, wie Frits $\mathrm{ch}$ behauptet ${ }^{4}$ ), die vivipara fast überall beherbergen. Sie soll namentlich im Böhmerwald, im Mittelgebirge und in der Gegend von Daubic vorkommen. Aus dem Böhmerwald, wo auch »mantana« und migra« zu Hause sind, finde ich die viripura zu wiederholten Malen genannt. Prach ${ }^{5}$ ) erwähnt sie aus Stredohori und »var. montana« und nigra aus Sumave, Glückselig aus den Sudeten (»montana«) und aus Nordböhmen (scroceas) ${ }^{6}$ ). Nach Heinrich ${ }^{7}$ ) kïme sie auch in den Gebirgswaldungen Mährens vor. In betreff ihrer Verbreitung in Niederösterreich giebt uns Kinauer Aufschluf. ${ }^{8}$ ); er fand sie verhältnismäl(3ig zahlieich stellenweise am Hermannskogel, in der Umgebung der Sofienalpe, am Fassel-Berg und im Leopoldslorfer Wald bei Kalchsburg, am Troppberg und dessen Nebenbergen bei Gablitz und am großen Lindkogel bei Baden. Fitzinger ${ }^{9}$ ) erwähnt sie von den Abhängen der Voralpen, von wo sie übrigens schon seit langem durch v. Jacquin, dem Entdecker der vivipara, nachgewiesen worden, ferner vom Gleinkerberge nïchst Spital am Pylın, von Moosbrunn und Margarethen, wo sie jedoch ziemlich selten ist.

1) Korrespondenzbl, A. zool. miner. Ver. in Regensburg, No. 3. XXVII. Jahrg. 1873. S. 50.

$\left.{ }^{2}\right)$ Ebendas. No. 6, 7. XXV. Jahrg. 1871. S, 81.

9) Fauna Ratisbonnensis in: Naturhistor. Topographie von Regensburg III. S. 34. Regensburg 1840.

4) Archiv d, naturw. Landesurelıforschung v. Böhmen II. S. 105.

$\left.{ }^{5}\right)$ Plazové a obojzwelnici zeme Ceske in: Ziva 1861.

$\left.{ }^{6}\right)$ Synopsis Reptilium et Amphibiorum Bohemiae, pag. 19. Pragae 1822.

7) Mührens u. Schlesiens Fischc, Reptilien u. Vögel. Brünn 1856.

8) Die Reptilien und Amphibien Nieder-Österreichs. S. 12. Wien 1875.

$\left.{ }^{9}\right)$ Abhandl. d. k. Böhmisch. Gesellsch. d. Wissensch. I (neue Folge). S. 324. Prag 1829. 
An der Südseite des 'Tatra-Gebirges beobachtete sie $H_{0} r^{\prime}$ w a th') auf dem mit Krummholz bedeckten 'l'eile des sogeninnten wämmchens (4022'). Für die Fauna der Komitate Zólyom und Liptau wird sie von Moscaly ${ }^{2}$ ) angezeigt; in ziemlich grolier Anzahl wurde sic auf den nordwestlich von Kaschan gelegenen äber 3500 Futs hohen Bergen Hola bei Arany-Jaka und Holicza bei Tökes von Jeitteles ${ }^{3}$ ) gesammelt. Über ihre Verbreitung im Suden Ungarns liegen mir leider keine Angaben vor. In Galizien und Bukowina kommt sie snicht so häufig im thichen Latnd als in Gebirger vol, wo sie auf bedeutenden Iöhen noch zu treffen ist ( $\mathrm{C}$ a w a d ski, Fauma d. galizisch-bukowinischen Wirbeltiere. Stuttgart 1840). Leydig spricht die Vermutung aus, dalj die kleine Eidechse, welche der Ornitholog Seidensacher auf seinen Reisen durch die Wälder Kroatiens beobachtet und als agilis bezeichnet hat, wohl eine viviparce gewesen sei. Nach $\mathrm{P}$. Kohlmayer ${ }^{*}$ ) ist sie in Kärnten nicht beobachtet worden; nach Latzel ${ }^{5}$ ) ist ilr Vorkommen daselbst fraglich und in der Abhandlung v. Gallensteins

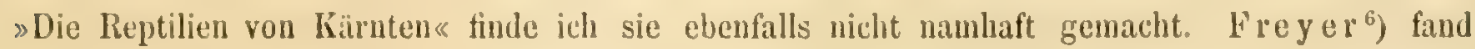
die spyrrhoguster M exr.« an sandigen, steinigen, trockenen Orten, Gartenmauern ete, in Innerkrain am Karst. Darüber, ob unter pyyrhoguster nicht eine andere Art, z. B. die für den Karst von Freyer nicht erwähnte muralis gemeint sei, kann ich kein Urteil fällen. Über das Vorkommen der vivipura in Dalmatien scheinen dem Verfasser der Herpetologia europaea (Vergl. S. 578) keine sicheren Angaben vorgelegen zu haben. - Die Gebäreidechse dürfte auf der Balkan-Halbiusel fehlen, wenigstens scheint sie bis dato von dort nicht angezeigt zu sein. Wenden wir uns daher nach dem Norden Europas und sehen wir wie weit sich hier ihr Verbreitungbezirk erstreckt.

Bezüglich der Häufigkeit des Vorkommens der viviparce auf den Britischen Inseln wiedersprechen sich die Äuberungen der Faunisten. Th. Bell (vergl. seine »A History of British Reptiles. S. 34. London 1839) und der mir unbekanut gebliebene Verfusser der in den Annals of Nat. Hist. or Mag. of Zool. Bot. and Geology, vol. I, p. 223. London 1838 veröffentlichten Biographical Notices geben atı, dits sie allerorts zu den gewöhulichen Erscheinungen gehört und daf ihr Verbreitungsbezirk sich weit nach Norden ausdehnt und Ross-shire und Sutherland in Schottland in sich begreift. Die Verfasser der Notes on the fauna and flora

I) Verhand1. zool. Wotan. Gesellsch. in Wien 1867. S. 560.

") Mathen. u. naturhist. Mitteil. d. ungarischen Akad. d. Wiss. XV. S. 231.

${ }^{3}$ ) Verhandl. zool. botan. Gesellsch. in Wien XIII (1862). S. 278.

4) Jahrb. d. naturw.-histor. Landes-Mus. v. Kärnten, Heft IV. S. 64. Klagenfurt 1859.

5) Ebendas. IIeft XII. S. 91. Kklagenfurt 1876.

-) Fauna d. in Irrain bekanuten Säugetiere, Vögel, Reptilien u. Fische. S. 41. Laibach 1842. 
of the West of Scotland (Glasgow 1876) Alston, Gray, Cameron, Ramsay und Stirton fügen ergänzend hinzu, daßs sie bei Barhead, Gowrock und Krin zu finden sei. Auch Friedel (Zool. Garten XIX. S. 366. 1878) hat sich in letzter Zeit hinsichtlich ihres Vorkommens in Irland dahin geäufert, dalỉ sie sehr verbreitet und vom Volk als giftig sehr gefürchtet sei. $\mathrm{CoOke}^{1}$ ) hingegen behauptet, dats die vivipara in Grofbrittannien und Irland selten vorkäme. Unter den speciellen englischen Fundorten werden Falmouth in Cornwall, Pool-heath in Dorsetshire, East-Bourn in Sussex, einige Lokalitäten in Devonshire, ferner Chiltenham und die Ungebung von Liverpool genanut. In den zuletzt angefülırten Örtlichkeiten sowie auch in Irland soll die schwarze vivipara beobachtet worlen sein (Gray).

Dänische Exemplare dieser Art sind im Pariser Museum zu sehen (vergl, auch: B oje, in: Isis 1841, S. 698); nach Brehm (Tierleben VII. S. 170. 1878) bewohnt sie die Heiden Jütlands. Unter einer Anzahl von Exemplaren, welche Leydig aus Dänemark erhalten hat, befand sich auch eine nigra »von besonderer Grölie«.

Über die Verbreitung der vivipara in Norwegen teilt mir Dr. Collet folgendes mit: "As to your question about $L$. vivipara I can answer, that it is (together with $R$. temporarie) the most widely distributed species in Norway, being found high up in East Fimmark till $70^{\circ}$ N. L. In all the southern parts it is common, and ascends on the mountains to a considerable height ( 3700 feet above the level of the sea). Along the western coast of Norway it is also common, and I can hardly find a single district, where it ist not found, occurring however, nowhere in large numbers (as the Lacerta-species in Southern Europe). In Finmark it is found on the borders of the Varungerfiord, and most likely even up to the North Cape itself. The black variety I have never seen in Norway; in Jutland (Denmark) I found it several times last sommer.« ${ }^{2}$ ) Derselbe Forscher soll, wie ich es aus den Troschelschen Berichten uber die Leistungen in der Herpetologie schlielse, die viripura auf den Walfischinseln enteclit haben ${ }^{3}$ ). Nilsson teilt uns in seiner $\gg$ Skandinawisk Fauna mit, dals das Stockholmer Museum Exemplare aus Smaland ${ }^{4}$ ), Ocland, Stockholm, Wermland, Jentland 5), Finnmarken, Qrickjock und Haparanda besitzt; er berichtet auch, dả L inné diese Art bei Upsala und Lulea in Lappmarken beobachtet habe und fügt ergänzend hinzu, daf sie auch in Norwegen bei

\footnotetext{
1) Our Reptiles etc., pag. 22. Loudon 1865.

${ }^{2}$ ) Vergl. auch R. Collet, Bemaerkinger om Norges Reptilier og Batrachier in: Vid.-Selsk. Forh. 1878.

3) In: Nyt Magazin for Natorvidenskaberne 1867, p. 17.

1) Vergl. auch Oefversigt Vetensk. Akad. Förhandl. 1874, No. 4, pag. 63.

5) Olsson, ebendas. Jahrg. 1876, No. 3, p. 124.
} 
Ilallingdal konstatiert worken sei. Nach Cederström kommt sie in Bohuslïn ${ }^{1}$ ) und nach A. J. Méla in Finnland vor:

Alsdann bewohnt sie Russisch-LappJand, die südlichen Gegenden in den Gouvernements Archangel und Olonetz (Méjak off, in: Bull. de Moscou XXX, No. 2, p. 581), das P'etersburger Gouvernement ${ }^{2}$ ) (bei St. Petersburg und in Peterhof), Livland, z. B. bei Dorpat (v. Dybowsky, in: Sitzungsber. d. Dorpater naturforsch. Gesell. IV, 1. S. 89), die Gouvernements Wologda, Nowgorod und Wjiatka, wo sie nach Méjakoff überitl hiiufig sein soll. In der Ungebung von Moskau in Selo Bogorodskoe, in Petrowskoe-Razumowskoe und im Park Petrowski habe ich sie früher in Menge gesammelt. Das Moskauer Muscun enthält Exemplare dicser Art aus Tula. In Russisch-Polen findet sie sich, wie Taczanowsky im Bull. Soc. zool. de Frauce 1877, p. 167 berichtet, sehr zahlreich vor' auch in Wolhynien ${ }^{3}$ ), so z. B. bei Ostrog (Mus. in Kiew, No. 1975), in Podolien und im Gouvernement Minsk (Ouesd Igumenski. Mus. Kiew, No. 1976) ist sie konstatiert worden. Im Gouvernement Kiew hat sic Kessler beobachtet (Naturgesch. d. z. Kiewschen Lehrbezirk gehörenden Gouvernements. Zoologie. Kriechtiere. Kiew 1853. Russische Abhandlung!) und Andrzejowsky t) giebt an, dats sie im Chersonschen Gouvernement sin vallibus circa Cremenecum allerdings selten gefunden worden sei. An den Ufern des Dnjestr wird sic nach Belke ${ }^{5}$ ) angetroften. Im Charkorschen Gouvernement ist sie, wie Krynicki (Bull. de Moscou X. 1837, No. 3, p. 48) und Czernay (ebendas. XXIV. 1851. No. 1, p. 269) übereinstimmend angeben, gleichfalls einheimisch. In einzelnen sumpigen Gegenden des Tambowschen Gouvernements, so z. B. bei Lipetsk, ist sie gemein. "Im Kasanischen und Orenburgischen Gouvernements«, saut Eversmann, sist $L$. crocea gar nicht selten; sie bält sich nur in Wäldern auf (Nouv. Mém. de la Soc. Imp. des natur. de Moscou III. 1834. S. 347). Aus Uralsk babe ich die vivipara von Herm Dr. Stra uch erhalten. Ihr Vorkommen in der Krim und im Kaukasus ${ }^{6}$ ) steht ganz vereinzelt da und bedarf, meiner Ausicht nach, noch der Bestïtigung. "Dali $L$. viviparce Jac ฯ. (Z. crocea W a gl.) in der Krim vorhanden sei«, sagt K ̈̈ppen in seiuer üfters citierten Schrift über die herpetologische Fauna der Krim, sist sehr zu bezweifeln. Ich finde sic nur von Eichwald als auf der Taurischen Halbinsel vorkommend verzeichnet. Nlle anderen Auturen,

1) Oefversigt of Kongl. Ventenskaps-Akademiens Förhandl. 1876, No. 4, 1. 63. Stockhrolm.

${ }^{2}$ ) v. Fischer, Die Reptilien u. Amphibien d. St. Petersburger Gouvernements in: Zool, Garten XIV. 1873. S. 324.

3) Eichwald, Fauna caspio-caucasia, pag. 91.

") Nouv. Mém. Soc. Imp. des nat. de Moscou 1832, pag. 319.

5) Bull. de Moscou XXXII. 185\%. No. 1, S. 32.

$\left.{ }^{6}\right)$ Eichwald, op. cit., pag. 91. 
als z. B. Rathke, Nordmann, Eversmann, Andrzejowski und Kessler, füren diese Eidechse nicht aus der Krim an. Krynicki (1. c. p. 51) sagt etwas unbestimmt: $L$. crocea Wolf.... a mare baltico usque ad nigrum. Unsere Beobachter, z. B. Eversmann, Czernay und Kessler, sagen einstimmig, dafs $L$. vivipara nur in Wäldern lebt; Kessler fugt hinzu, dafs sie vorzugsweise in Kiefernwäldern angetroften wird und die baumlose steppe meidet. Dieser Umstand würde auch ihre Abwesenheit im waldigen Gubirge der Krim erklären, wohin sie über die nackten Steppen nicht gelangen konnte. In einer Anmerkung fügt Köppen hinzu: «Im Zoologischen Museum der Akademie ist zwar cin Exemplar von Iferru Kuschakewits ch, angeblich aus der Krim; doch kann hier, wie Dl. Stra u ch bemerkt, leicht ein Fehler in der Fundortsangabe vorliegen, da die von Kuschakewitsch mitgeteilten Tiere bisweilen von verschiedenen Fundorten stammten und doch in einem Glise lagen.« - Hingegen im mittleren Ural '), also in der zwischen Slatoust und Bogoslawsk gelegenen Strecke dieses Gebirgszuges, und in Sibirien kommt sie bestimmt vor und es steht auter 'Zweifel, dats bereits Yallas dieselbe aus Sibirien gekannt haben mu(3 ${ }^{2}$ ). Aus Padun am Baikalsee besitze ich ein Exemplar, das jelı der Güte des Herrn Dr. Strauch verdanke. Ein anderes, angeblich in der Kirirgisen-Steppe erbentetes Stück habe ich in der Sammlung von Herrn F. Lataste in Paris zu sehen Gelegrenheit gehabt. Im Thale des Flusses Usura hat sie Maak entdeckt (Reise im Thal d. Flusses Usura. St. Petersburg 1861. S. 189) und auf der Insel Sachalin findet sie sich, wie mir Dr. Strach brieflich mitgeteilt hat, ebenfalls vor.

Aus der vorstehenden Zusammenstellung der mir bekannt gewordenen Angaben über das Vorkommen der L. vivipara ergiebt sich nun, dats iln' Wohngebiet sich etwa vom $10^{\circ}$ westl. L. v. Paris bis zum $140^{\circ}$ o östl. L. v. Paris erstreclit. Der nördlichste Punkt ihres Vorkommens scheint in Europa am Varanger Fjord $\left(70^{\circ} \mathrm{n}\right.$. Br.) zu liegen; bezüglich der Ausdehnung ihres Verbreitungsbezirkes nach Süden ist man zur Zeit noch nicht genügend unterrichtet, denn es bleibt noch festzustellen, dalj dis sehr ausgedehnte Verbreitungsgebiet dieser Art auch Spanien und Mittelasien in sich begreift und dalj der südlichste Punkt ihres Vorkommens in Sibirien, an den Ufern des Baikalsees liegt. Die Angaben uber ihr Vorkommen auf Cypern, in Nordafrika und auf Sardinien ${ }^{3}$ ) erscheinen mir so merkwürdig, dals ich sie nur anzufuhren und nicht näher zu berücksichtigen mich verpflichtet glaube.

1) Bull. de Aloscou 1871, No. 2, pag. 273.

2) Zoographia rosso-asiatica III, pag. 31. Petronoli 1831.

$\left.{ }^{3}\right)$ Fitzinger, Neue Kklassifikation d. Reptilien. S. 52. Wien 1826. - Der Verfasser mufs wohl darunter entweder Algiroides Fitzingeri oder aber eine schwarze muralis, wie solche auf ter kleinen Insel del Toro im Südwesten Sardiniens bei St. Antiocho einheimisch sein sollen, geneint haben. 


\section{Lacerta praticola Eversm. 1834.}

Char. - Sc. occipitale multum brevius interlumqque latius quam scutum interparictale. Sc. nasoftenale unicum. Discus palpebralis in margine externo scrie granorum limbatus. Supralabialia anteriora 4. T'empora maioribus minoribusque scutis. Sc. parietalia in margine cxterno tribus maioribus et minoribus laminis marginalibus limbata, sc. massetericum has laminas marginales contingens. Sc. tympanicum oblongum et angustum. Sulcus gularis nullus, collare subdentatum, sc. abdominalia per series sex disposita. Squamae dorsi carinatae, oblongo-sexangulares. Pori femorales utrinque 10-12. - Lacertae murali et viviparae similis. Corpus tenue, sat breve, caput pro corporis longitudine longum. Pedes postici teneri, axillas circiter contingentes. Canda pone gradatim attenuata et brevis. - Dentes palatini nulli. - Longitudo $113-148 \mathrm{~mm}$.

Synonymie.

Lac. maticolı Eversmann, Lacertae Imperii Rossici, variis in itineribus meis observatae in: Nouv. Mém. Soc. Imp. natur. de Moscou III, pag. 345, tab. XXX, fig. 2. Kessler, Zool. Reise durch Transkaukasien im Jahre 1875 in: Arbeiten d. St. Petersb. Gesell. d. Naturforscher Bd. VIII. Supplement-Heft. St. Petersb. 1878 (russisch l). v. Bedriaga, in: Bull. de Moscou 1879, No. 3. S. 29 ; in: Arch. f. Naturgeschichte XXXXV. Jahrg. Bd. I. S. 299. - Böttger, in: Ber. Senckenberg. naturf. Gesell. 1884. S. 144.

Lacerta muralis Laur. subsp. fusca, v. Bedriaga, in: Bull, de Moscou 1881, No.3. S. 101.

Diese viel verkannte, bald mit $L$. vivipara (Duméril, Bibron, Gray, De Betta, Fatio), bald mit der Manereidechse (v. Bedriaga, Böttger) oder mit der taurica (Schreiber) zusammengeworfene und doch so fut charakteristische, sich an die fiebireidechse anschliefende und den Formenkreis der mulis mit der vivipura gewissermatien verbindente Art läst sich von allen hier in Betracht kommenden Species durch ihre sehr grolie, von einer Bogenreihe von Schuppen umgebene Aftertafel und vou dem Formenkreis der muralis und furica insbesondere durch die sehr stark gekielten und lingen Rïickenschuppen unterscheiden, die sie mit $L$. vivipara gemein hat. Auch die geringe Anzahl der Femoralporen und der IIalsbandschilder, das Vorhandensein cines grolien Massetericum nchen einer Reihe Schuppen, welche zwischen der Palpehrakcheibe und den supraciliaria eingeschohen erscheinen, machen die protirola verhältnisnälig leicht kemntlich. I)als unter den zahlreichen genannten Herpe- 
tologen nur Eversmann, Kessler und Strauch ${ }^{1}$ ) diese Eidechse als selbständige Art gelten lassen, berult einfach darauf, dafis die praticola, so viel ich weif, bis vor kurzem nur in den St. Petershmrer Museen vertreten gewesen ist und erst neuerdings durch Akademiker Dr. Strauch in einige Sammlungen gelangt ist.

Körpergestalt und GröLe.

L. praticola ähnelt der Gebäreidechse hinsichtlich ihrer Gestalt des Kopfes und der relativ kurzen Gliedmalsen; ihre Hinterfüle aber sind schmächtig und ähnlich wie bei der mmalis gebaut. Die Vorlerbeine ragen bei einem mir vorliegenden Männchen über den Vorderrand, bei anderen hingegen erreichen sie nur den Hinterrand der Augen; die Hinterbeine reichen, an den Körper angelegt, nicht ganz bis zu den Achseln. Kessler, dem cine größere Anzahl dieser Eidechsen vorgelegen hat, giebt an, daf3 die Vorderbeine bis zum Vorderrand der Augen reichen, während die IInterbeine bei den Männchen die Achseln, bei den Weibchen aber nur die Ellbogen erreichen. Kessler fügt hinzu, daß der allmählich gegen sein Ende verdünnte Schwanz ein Drittel der ganzen Kürperlïnge betrïgt. Der etwa spindelförmige, kurze Rumpf scheint nie den Umfang von $L$. vivipara zu erreichen; seine Gestalt erinnert vielmehr an diejenige bei der braunen Mauereilechse. In Bezug auf die Kopfgestait muf hinzugefügt werden, dalo der Kopf in der Schlïfengegend am breitesten erscheint und daks er von den Augen nach vorn zu allmählich verschmälert und von der Seite etwas zusammengedrückt ist; die leicht hervorstebenden Oberkieferpartien sind von den Frenaltafeln durch eine ziemlich tiefe rinnenartige Vertiefung getrennt; die in der Frontoparietalregion leicht gewölbte Schädeldecke neigt sich gegen die Schnauzenspitze nach abwïrts; die untere Fläche des Kopfes zeigt eine ziemlich starke Wölbung.

Mafie in mm: Von der Schnauze bis zur Schwanzspitze 113; Länge des Kopfes 12, des Halses 7,7 , d. Rumpfes 37, d. Schwanzes 64, d. Vorderextremität 14, d. Vorderfufes 6,2, d. Hinterextremität 24, d. Hinterfulies 11,2: grölite Kopfhöhe 6 , grüßte Kiopfbreite 7,7 ; Breite d. Pileus 5,7; Umfang d. Kopfes 23,5, d. Halses 23, d. Rumpfes 22.

Schilder und Schuppen.

Wenn Eversmann angiebt, daf seine praticola sich in der Anordnung der Kopfschilder von allen übrigen Eidechsen dadurch unterscheidet, slaf sie 3 mittlere Hinterhauptsschilder hat«, so ist dies offenbar ein Irtum; ein überzühliges drittes unpares Schildchen kommt in der Hinterhauptsregion bei den Eidechsen ziemlich oft vor und mul; als eine Mißbildung angesehen

1) Vergl。v. Bedriaga, Die Amphibien u. Reptilien Griechenlands. Berichtigungen in: Zoolog. Anzeiger VI, S. 219. 
werden. Gerade in Bezug auf die von den Parietalen begrenzten medianen Schildehen weist L. praticola nichts Bemerkenswertes auf. Das Occipitale, das allerdings mitunter viel breiter ist als das davorliegende Interparietale, ist sonst von gewöhnlicher Bildung: dreiseitig, vorn kaum merkbar abgestutat oder trapezformig; das bedeutend liungere, schmale, fünfseitige Interparietale ist nach hinten zu verschniilert und abgestutzt, nach vorn stumpfwinkelig geformt. Sowohl die seitlich an ihrem Aufenrand vorn von einer grofen, hinten von 2 bedeutend kleineren Tafeln umgrebenen Parietalen als auch die Frontoparietalen sind kurz, Die aus 2 Schildern bestehende, vorn von einer winzig kleinen, hinten von einer grö̈seren vierten Supraorbitaltafel begleitete Palpebralscheibe ist flach oder schwach erhoben und von den sechs schmalen Supraciliaria durch eine Reihe Körnchen getrennt. Das lange, nach rückwärts in cine kurze Spitze ausgezogene oder cinen Fortsatz zwischen die Frontonasalia entsendende Stimschild ist an scinem vorderen 'Teile nahezu oder ebenso breit wie hinten. Das ansehnliche beinahe ebenso breite als lange, etwir riutenförmige, seitlich, an der Berührungsstelle mit dem Frenale abgestutzte Internasale erscheint einerseits durch die in der Mittellinie zusammenstofienden Frontonasalia vom Frontale und anderseits durch die kleinen, dreiseitigen, lateralwärts ausgerandeten Supranasalia von dem schwach auf den Pileus übergewölbten Rostrale getrennt. Letzteres grenzt seitlich an das Supralabiale I, das dem einfachen, äufierst kleinen, nach oben verschmälerten Nasofrenale als Stütze dient; auf dieses Schild folgen nun das bedeutend gröbere, dem Supralabiale II aufliegende Frenale und das Freno-oculare, dem sich unten das schmale, kleine Praeoculare, oben die Supraocularia anlegen. Das wie gewöhnlich oben erweiterte und ausgerandete Suboculare stellt das fünfte, orler in selteneren Fällen das vierte (nach Kessler l. c.), nach rückwärts von einem grolsen und einem bedeutend kleineren Schildchen begleitete Oberlippenschild vor. IInsichtlich der Bekleidung der T'mporalregion bin ich nur insofern mit Eversmann einverstanden, als die Schilder dadurch, dafo sic flach sind, an diejenigen bei der agitis erinnern, sonst aber scheint mir sowohl die Anordnung als auch die Form dieser Tafeln sich eher bei der muralis wiederzufinden. Das auffallend grolic Massetericum ist vorn durch 3 Reihen kleiner, fünf- und sechsseitiger Schildehen vom Augenrande und hinten durch nur eine gröfere 'lafel vom länglichen 'Tympanale getrennt; oben legt es sich sonderbarerweise direkt an die die Parietalen umsäumenden gröfieren Schilder an, was weder bei $L$. agilis noch bei vivipara oder mualis vorzukommen scheint; unten erscheint es durch eine Reihe winzigr kleiner schuppenartiger Schildchen von den Oberlippentafeln gretrennt. Die Bekleidung der Schläfe ist somit in systematischer Bezichung von Bedeutung. Der Ohrrand ist gezïhnelt; die verhaltnismaibig schmale Ohröfnung ist weit nach unten geruickt. Die 
ziemlich weite Nasenöfinung befindet sich über der Vordernaht des Suprababiale I: das Lirl ist mdurchsichtig. Sublabialia sind in der Regel 7, zuweilen aber 6 oder 9 (nach Kessler!), Submaxillaria jederseits 6 vorhanden, wovon die 3 ersten Paare zusammenstofien, das vierte Par das größzte ist; eine kleine, von Kessler als sechstes Submaxillare bezeichnete Tafel fügt sich hinten den eigentlichen Unterkieferschildern, an. Der Unterkopf ist mit auffallend grofien Schildern bekleidet; namentlich die unteren Halsschilder zeichnen sich durch ihre Grübe aus; sie sind breiter als die länglich-sechsseitigen Kehlschilder und sind von diesen durch eine transversale Reihe kleiner Schuppen getrennt; eine Querfurche vermisse ich. Das leicht gezähnelte Ifalsband ist schwach bogenförmig; die Tafeln sind meist grof, mit abgerundeten Hinterrändern versehen, in ihrer Zahl vou 7 bis 9 (nach Kessler!) variierend; bei den mir zur Verfügung stehenden Stücken zähle ich nur 6 oder 7 Halsbandtafeln. Als weitere Illustration zu dem hier in aller Kürze geschilderten Verhalten der Kopfschilder mögen die Abbildungen bei Eversmann (l. c.) dienen. Es bliebe mir nunmehr noch übrig die Belileidung des Rumpfes und Schwanzes zu schildern. Im allgemeinen verhalten sich die Schuppen wie bei L. vivipara; nur hinsichtlich der Kiele habe ich den Unterschied gefunden, daf.3 bei der zuletzt genannten Art die Seitenschuppen glatt erscheinen, indem sie ihre Kiele einbüßsen, bei der mraticola hingegen sind alle Rumpfschuppen bis auf die Nacken- und Bauchgrenzenschuppen gekielt; doch hleibt auch dieser Unterschied nicht stichhaltig, sobald wir eine grösscre Anzahl von Stücken durchmustern und wahrnehmen, daß der Kiel sich sehr bald verliert, namentlich an denjenigen Schuppen, welche nahe an den Wurzeln der Beine liegen. Die ersten transversalen Nackenreihen bestehen aus breiten, unregelmäligig gestalteten, glatten oler spurweise gekielten Schuplen; auf diese folgen nun dentlich sechsseitige und längsgekielte, gröl.jere Nackenschuppen, deren Breite ungefähr ihrer Länge entspricht; nach hinten zu werden sie merklich länger jedoch nicht breiter und erscheinen am Rücken etwa doppelt so lang, als sie breit sind; 3 bis I mediane und longitudinale Rückenschuppenserien zeichnen sich öfters dadurch aus, dafs sic schmäler und kürzer erscheinen als die ihnen benachbarten Schuppen. Über die Konfiguration der sehr stark gekielten Rückenschuppen sei bemerkt, dalis sie ungleichseitig, länglich-hexilgonal und mit leicht abgerundeten hinteren Ecken versehen sind. Gegen die Leibesseiten hin werden sie vierseitig und merklich kleiner, gegen den Schwanz zu hingegen größer; mitunter sind sie etwas vor der Caudalwurzelgegend diagonal gekielt und in eine Spitze ausgezogen; diese Spitze tritt öfters an den oberen, stark gekielten Schwanzschụpen schr deutlich hervor. Die länglichen schmalen Schwanzschuppen sind oben durch ihre Längskicle in zwei gleiche, seitwiirts in zwei ungleiche Hülften geteilt; die unteren Schuppen sehen am ersten Drittel des 
Schwanes ghatt, an ihrem freien liande abgerundet aus, nach rïckwärts aber erscheinen sic spitzwinkelig ausgezogen und zugleich gekielt. Die Zahl der Querringe bei Individuen mit normal entwickeltem Schwanze soll nach Kessler bis 94 betragen. Von den Schuppenserien des Rumpfes gehen 2 bis 3 auf eine Reihe der Bauchschilder. Die Schuppenserien lassen sich auch mit unbewaffnetem Auge zählen, ihre Anzihl ist gering; es sind nur etwa 84 Querserien und 39 Längsreihen von Scluppen. Kessler giebt an, dafi die mittlere Querreihe atus. 34 bis 40 Schuppen zusammengesetzt ist. Demselben Forscher zufolge, besitzen die Männchen 25 bis 27 , die Weibchen 25 bis 30 transversale Bauchschilderreihen; bei den mir vorliegenden Stücken zähle ich 26 transversale und o longitudinale Ventralserien; die beiden mittleren und die äuliseren sind, wie Lver s ma n richtig bemerkt, schnäler - namentlich in der Brustgegend als die übrigen beiden leihen; eigentliche Raudschildehen werden bei dieser Art vermift, es sind viehmeh etwas vergrölserte Randschuppen vorhanden, welche die äuß̧eren Ventralen begrenzen. Das Brustdreieck ist aus 3 bis 8 Schildern zusammengesetzt. - Auber diesen, für die maticole charakteristischen Kennzeichen giebt es noch ein anderes wichtiges Erkennungsmittel: nämlich die Grölie, welche das Anale erreicht, ferner ist beachtenswert, dał dieses sehr grolie Schild, mit Ausnalhme des freien Hinterrandes rund herum von nur in einer Bogenreihe stehenden 8 bis 9 kleinen Schildchen umgeben wird; diese Eigrentümlichleit ist bercits Kessler aufgefallen. Es ist ferner erwihnenswert, dal; die spurweise grekielten und gesehindelten Schilder auf der Oberflïche der Hinterfülise verhältnismäßrig grülier sind, als dies bei den Mauer- und Gebäreidechsen der Fall ist.

Obschon L. praticola in mancher Beziehung den zuletzt genannten Species ähnlich sieht und sich ihnen anschliebit, kann sie, meiner Ansicht nach, dennoch nicht etwa als eine Übergrangsform zwischen diesen beiden, so sehr verschiedenen Eidechsen gelten und mülite eher zu den abirrenden, geographisch isoliert dastehenden Formen gehören.

Schenkeldrüsen und Gaumenzähne.

Die Anzahl der Drüsen beträgt 10 bis 12 jederseits (nach Kessler!). Die mir vorliegenden 2 Individuen, die ich der Güte des Herrn Dr. Strauch verdanke, besitzen auf der eimen Seite 10, auf der anderen 11 Drüsen. - Am Gaumen sind keine Zähne vorhanden.

Fiarbung und Zeichnung.

》Die obere Seite des Körpers«, sagt Eversmann, sist bräunlich mit kaum merkbaren schwïrlichen Pünktchen, der Bauch hat ein schönes Gelb, das zur Schwanzspitze hin ins Weifie ubergeht; dic Seiten sind schwarz und haben in der Mitte einen helleren Längsstreifen: in dem Schwarzen zwischen diesen hellen Streifen und dem liücken sind der Länge nach Punkte 
oder kileine Flecken von der braunen Farbe des Rückens wahrunchmen, wodurch eine Art von Angen gebildet werden.« Die mir zu Gebote stehenden praticolce erscheinen etwas anders gezeichnet: auf dem Halse, Rücken, Schwanz und den Beinen herischt die hellnufbraune, auf den Leibesseiten die dunlielbraune Farbe mit eingemischten hellen Schuppen vor; bei dem cinen Stück ist die der Breite der Pileusschilder entsprechende Rückenzone einfarbig hellnuß3braun, bei dem anderen aber erscheint die Rüekenzone durch eine an Hinterrande des Occipitale ihren Ursprung nehmende und sich an der Schwanzwurzel verlierende, seitlich ausgezackte und durch ilne dunklere braune Farbe vom Untergrunde scharf abgehobene Vertebrallinie geteilt und seitlich von einer, ebenfalls dunkleren, braunen, am Hinterrande der Augen entspringenden und zum Teil auch auf die Seiten des Schwanzes übergehenden breiten Binde begrenzt; diese Binde ist sowohl am oberen, zackig aussehenden, als auch am unteren Rande hell, etwa grünlichweif oder bräunlichgelb umsäumt; namentlich am Halse, oberhalb der Vorderbeine und am Schwanz tritt diese Umsäumung etwas deutlicher hervor; dunkelbraune und grïnliche Puuktflecken finden sich, insbesoudere in der Achselgegend, auf dieser dunklen Seitenbinde zerstreut; andere dunkelbraune I'unkte sind entlang der braunen Vertebralbinde und hie und da in der Halsgegend und am Hinterrücken auf hellnulbbraunem Grunde der dorsalen Seitenfelder verteilt. Dic Butuchgrenze ist lebhaft gold- oder liupferglïnzend; auch die hintere Rückenpartie erscheint mit rütlichem Schimmer überflogen. Die spärlich dunkel gepunktete Kopfoberseite ist braun, in der Parietalgegend zeigt sie einen Stich ins Grüne; die Lippenschilder sind hell, etwa bräunlichgelb gefärbt. Die Unterseite, mit Ausnahme der mittleren Ventraltafelı, des Anale und der an die Femoralporen angrenzenden Schilder, welche gelblichrosa erscheinen, ist hell bläulichgrün angetlogen; die ersten, also ïulieren longitudinalen Butuchschilderreihen sind übrigens nur bläulichgrün gerïndert sonst aber goldglänzend. Die Oberseite der Gliedmafsen ist spirlich dunliel gepunktet; auf den Iinterbeinen treten spurweise dunkle ringförmige Figuren auf. - Beim zweiten, im allgemeinen etwas heller kolorierten Individuum der praticola mit cinfarbiger hellnulibrauner Rückenzone ist von einer dunklen Punktierung nahezu gar nichts zu sehen; die zur Umsäumung der etwas dunkleren braunen Rumpfseitenbinden dienenden gelblichbraunen Linien kommen namentlich am Ilalse und am Schwanze zum Vorschein; oberhalb der Wurzeln der Vorderbeine erscheinen letztere bedeutend breiter und zugleich bläulich koloriert; diese Zierde erinnert an die Argusflecken, welche so schön entwickelt bei einigen muralis aufzutreten pflegen. Die Kopfoberseite, die Schlife und die obere Partic der Nasofrenalregion ist braun, fleckenlos; der untere helle Streifen, welcher, wie bereits erwähnt, die dunklen Rumpfseitenbinden umsïumt, setzt sich auch auf die Schläfe fort. Der Gold- 
glanz ist bedeutend schwächer ansgeprägt, sonst ist die Unterseite der Körperteile wie beim oben beschriebenen Individuum koloriert.

Da es Kessler vergönnt gewesen ist, cinc gröfsere snzahl von praticola zu untersuchen, so will ich seine aus dem Russischen ins Deutsche übersetzte Beschreibung hicrselbst folgen lassen. Kessler sagt nämlich: »Die Körperoberseite ist bei den Männchen olivendunkelbraun orler blalsolivenfarben, hei den Weibehen haligelblich. Längs der medianen Itückenpartie zieht sich eine ziemlich breite dunkelbraune, auf beiden Seiten von schwärzlichen kurzen Strichen oder Flecken umsäumte Binde hiı; 2 ähnliche, ziemlich breite dunkelbraune Binden nehmen die Rumpfseiten ein, sie erscheinen aber oberhalb durch schwärzliche kurze Striche, unterhalb durch eine schmale, ununterbrochene weibliche Binde begrenzt, welche am unteren lande der Ohröffnung ihren Aufang hat und sich hinter den Hinterbeinen auf dic Schwanzbasis fortsetzt. Schwarze Pünktchen werden auch anf der Oberseite des Kopfes und zuweilen zwischen der mittleren dorsalen und den dunkelbraunen dorsallateralen Binden wahrgenommen. Es muls aber bemerkt werden, daf3 die Farbe dieser Eidechse, wie es auch sonst bei fast allen anderen Lacerten der Fall zu sein pflegt, ziemlich zahlreichen Veräuderungen unterworfen ist; namentlich künnen die braunen Binden, also die dorsal-mediane und die dorsal-lateralen, bald dunkler, bald heller erseheinen und cinmal deutlich, ein anderes Mal weniger scharf abgegrenzt auftreten; es hommt sogar vor, daßs die mittlere Rückenbinde nahezu gänzlich verschwindet, wie es z. B. bei 2 Exemplaren aus Piatigorsk, welche ich unter meinen Händen gehabt habe, der Fall grewesen ist; in denjenigen Fällen, wo die seitlich liegenden Rückenbinden sehr dunkel gefürbt crscheinen, sind sie mehr oder weniger durch helle Fleckchen unterbrochen. Bei 2 jungen Exemplaren aus der Staniza Dachowskaia ist dic galnze Oberseite des Körpers dunkelolivenfarben und obschon die dunkelbraumen Rückenbinden vorhanden sind, treten sie doch nur sehr wenig zum Vorschein.« Kessler giebt an, dals die Totallïnge der ihm vorgelegenen Exemplare von $L$. praticola $148 \mathrm{~mm}$ betrug, wovon auf den Körper 50 und auf den Schwanz $98 \mathrm{~mm}$ kameu.

\section{Fundorte.}

Der Verbreitungsbezirk dieser interessanten Species ist cin schr beschränkter; die wenigen Stellen, wo sie bis jetzt nachgewiesen ist, befinden sich sämtlich in den westlich liegenden Kaukasuslïndern, und zwar sowohl am Nord- als auch am Südabhang der Ilauptkette des kaukasischen Gebirges. Das Eversmannsche Originalexemplar stammt von einer trocknen Wiese zwischen den Schwefelquellen und Sauerbrunnen zu Nardzana. Nach Kessler soll sie auch in Kubanschen Gebicte, in Piatigorsk, im Thale des Flusses Belaia bis zum Dorfe Dachowskaia, also diesseits der Hauptgebirgskette, und im Aragwa-Thale, namentlich in der Nähe der 
Station Anaum, also in Transkaukasien gesammelt worden sein. Meine eigenen Exemplare stammen aus Suchum-Kale. Nach Böttger (1. c.) lebt sie auch in Uetsch-Deré in Abchasicn. - Unter den von mir besuchten zoologischen Sammlungen (vergl. die Linleitung) befanden sich bis zum Jahre 1885 nur die Museen in St. Petersburg und die Senckenbergsche Sammlung im Besitz von eiuigen L. praticola.

\section{3. (?) Lacerta tessellata Smith 1838.}

Char. - Occipitale ovale, minimum, in partem posteriorem remissum. Interparietale longissimum. Frontale sat breve. Discus palpebralis serie squamarum a scutis supriciliaribus seiunctus. Sc. nasofrenalia duo, superposita. Sc. parietalia in marginibus $2-3$ scutellis oblongis limbata. 'T'empora scutellis parvis; sc. massetericum nullum; sc. tympanicum indistinctum. Supralabialia anteriora 4. Collare vix denticulatum, sulcus gularis nullus. Abdomen lamellarum seriebus longitudinalibus sex vel octo. Squamae dorsales laeves, convexae, rotundulo-sexangulares vel quinquangulares. Sc. anale simplex. Poris fomorales utrinque 13. Dentes palatini. - Corpus elongatum, fere cylindricum, caput breve, in regione temporali amplificatum cauda duplam corporis lougitudinem superans, pedes postici axillas contiugentes. - Longitudo 132 mun.

S y no nymie.

Lacerta tesselluta (Smith), Duméril et Bibron, Érpétologie générale V, p, 244. Paris 1839 - Smith, Contrib. to the nat. hist. of South Africa in: Magaz, of Nat. Hist. New Series, by Charlesworth, t. 2, No.14, pag. 92; Illustrations of the Zoology of South Africr 1841. Appendix. - C. et $\Lambda$ ug. Du méril, Catal. méth. collect. des Rept. 1. Livraison, p. 124. Paris 1851. - Boulengrer, in: Proc. Zool. Soc. of London 1881, pag. 743.

? L. livida Smith, l. c.

Nucras tessellata (S mith) Gray, Cat, Liz. Brit. Mus. p. 33. London 1845.

Körpergestalt und Größze.

In ihrer generellen Herpetologic erwähnen Duméril und Bibron der Ähnlichkeit zwischen L. tesscllata und "Lac. Delalandei M.-Edw.«, worin ich ihnen im großen und ganzen beistimme. Zugleich aber möchte ich hinzufügen, daţ sowohl die tessellata als auch die übrigen, später zu erwähnenden südafrikanischen Echsen auch mit den echten Eidechsen verwandt zu sein scheinen und möglicherweise als intermediäre Formen; welche die Genera "Lacerta« und »Bettaia《 verbinden, betrachtet werden müssen. So ähnelt z. B. im allgemeinen die 
Kürpergestalt der tessellata melu derjenigen bei den Eidechsen; hingegen sind ihre stark backen-

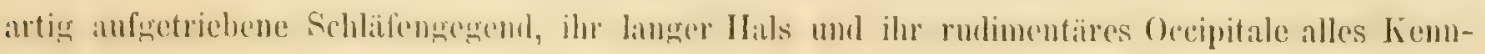
zeichen, welche, wie wir später sehen werden, der »Bettaias eigen sind.

Der ziemlich kurze Kopf ist vorn spitz verschmälert, in der Wangengegend relativ breit mit stark hervortretenden gewölbten Schläfen. Der Ilals ist länger als es sonst bei unseren Ejilechsen der Fall ist; er ist nur um $4 \mathrm{~mm}$ kürzer als der Kopf. Der ziemlich lange Rumpf ist fast cylindrisch; gegen den Schwanz zu plattet er sich von oben allmählich ab und geht in den langen, an seiner Basis sich abflachenden Schwanz über. Die Vorderextremitäten erreichen das Frenale, dic hinteren reichen bis zu den Achseln.

Milise in mm (Muscum in Paris, No. 2747): Totallïnge 232; Länge des Kopfes 15, des IIalses 11, des Rumpfes 59, des Schwanzes 158, der Vorderextremitit 24,5, des Vorderfufes 10,5, der Hinterextremität 39, des Ilinterfußes 18,5. Breite des Kopfes 10,7, d. Pileus (oberhalb der Augen) 6,7; Kopfhöhe 9, Umfang des Kopfes in der Schläfenregion 35,5.

\section{$\ddot{A} u f e r e$ Körperbedeckung; Femoraldrüsen und Zähne (Fig. 3, 14, 15).}

Das ovale Occipitale ist gewöhnlich sehr klein; das Interparietale dagegen auffallend grofa, schmal, fünfseitig und scheint auf Kosten des Ilinterhauptsschildes und der unansehnlichen fünfeckigen, hinten leicht ausgerandeten Frontoparietalen entwickelt zu sein. Der meist leicht gewölbte Augendiscus ist aus zwei gröferen mittleren und zwei kleineren Grenzschildehen gebildet und von den Supraciliaria dureh 5 winzig kleine Schuppen getrennt. Frontonasalia, Supranasalia, Rostrale, Frenalia, Freno-ocularia und die 2 Nasofrenalia zeichnen sich dadurch aus, daf sie stark gewölbt sind. Überhaupt zeigen sowohl die Schilder der Kopfdecke als auch diejenigen der Kopfseiten vielerlei Erhabenheiten und furchenartige Vertiefungen. Auf die 4 vorderen Supralabialia folgen: ein gröferes Suboculare und 3 hintere, immer kleiner werdende Oberlippentafeln. Das Praeoculare ist bedeutend kleiner als das Postoculare. Sämtliche unter dem Auge sich befindenden Plättchen sind rom Orbitalrand durch eine Serie kleiner Schildchen getrennt. Die Temporalregion hat mit Ausnahme des nahezu runden Tympanicum sonst kein gröberes Schild, das als Massetericum gedeutet werden könnte. Die eigentliche Schläfe ist meist mit hexagonalen gewölbten Schildchen bekleidet; runde und ovale Schildchen kommen aber auch vor. Die äußseren Parietalkanten sind von 2 bis 3 länglichen, schmalen Tafeln begrenzt. Die grofe Ohröffnung licgt weiter nach hinten als bei den vorhergehenden echten Eidechsen. Die Zahl der Sublabialia ist 6, diejenige der Submaxillaria nur 4. Die Kehle ist bald mit ovalen oder rundichen, bald mit hexagonalen Schuppen bedeckt. Sulcus gularis fehlt gänzlich. Das sehr schwach gezühnelte, bogig geschwungene Collare wird von 9 
Plïtchen gebildet, von denen das mittlere ziemlich breit ist. Brustdreieck aus 4 Schildern bestehend. Bauchschilder in 6-8 Längsreihen gestellt; die zu äufierst. liegenden Schilder sind ein Drittel so grol:3 wie die ihnen benachbarten; die Zahl der Querbauchschilderreihen variiert zwischen 32 und 35. Die Schuppen auf der Körperoberseite sind ungekielt; in der Nackengegend sind sie stïrker als sonstwo gewölbt, meistens rundlich, seltener hexagonal oder fünfeckig. Nach hinten zu flachen sich die Schuppen etwas ab, sie erscheinen gröbser, oval, fünf-oder sechskantig oder unregelmäßig gestaltet. Die Rumpfschuppen sind in 50 Längs- und etwa 143 Querreihen gestellt, von denen abwechselnd 2 und 3 der Länge eines Bauchschildes entspechen. Gegen die Flanken hin nehmen die Schuppen an Größse zu. Der Schwanz zeigt circa 113 Gürtel. Die dachartig gekielten, an ihren freien Rändern abgerundeten Schuppen treten erst in der Entfernung von $10 \mathrm{~mm}$ von der Schwanzwurzel auf. 1 Analtafel. 12 bis 13 F'emoraldrüsen jederseits. - Die Zahl der Zähne ist: im Zwischenkiefer 7; im Oberkiefer (eine Seite) 17; im Unterkiefer (eine Seite) 21. Der Gaumen ist bezahnt.

Farbenkleid.

Die hellnufabranne Grundfarbe des Rückens wird durch dunkelbraune Binden dermafien verlrängt, daßs sic in Form von sechs Streifen auftritt. Gegen die Caudalwurzel hin verblassen die dunklen Binden allmählich und das hetluulibraume Kolorit wird entschieden vorherrschend. Hals und Schläfe sind auf dunkelbraunem, beinahe braunschwarzem Fond mit helluabbraunen Querbinden besetzt. Auf den gleichfalls braunschwarzen Rumpfseiten treten zahlreiche lileine hellnulibraune, augenartige Flecken sehr scharf hervor. Die oben lederbriunen Vorderextremitäten sind braun gefleckt; die bedeutend dunkleren Hinterextremitäten mit braunen Punkten besetzt. Die hellnufbraune Kopfdecke erscheint hinten - also in der Parietalgegend dunkelbraun gefleckt, vorn hingegen ist sie ungefleckt. Die Nasofrenalgegend hat gleichfalls keine Zeichnungen aufzuweisen. Dic Kehle ist rötlichwcib; die ibrigen Teile der Unterscite des Körpers sind weißlich.

Habitat.

Das Vaterland der tessellata ist Südafrika. Das Muséum d'hist. nat. in Paris verdankt etliche tessellata Dr. A. Smith, dem Entdecker der in Rede stehenden Species; sie sollen an verschiedenen Punkten des Kap der Guten Hoffnung gesammelt worden sein. »L。 tessellata«, sagt Smitl, sinhabits the districts on the Western Coast of Southern Africa, particularly Little Namaqualand. Eine der Abarten von Duméril und Bibron (1. c.), und zwar Var. d, soll ebenfalls aus dem Klein-Namaqualande stammen; jedoch scheint mir diese »Varietät« eine besondere Art oder wenigstens eine Subspecies zu sein. - Das von mir bei der Bear- 
beitung dieses Kiapitels benutzte Individuum ans dem Pariser Jardin des Plantes verdanke ich der Liberalität des Hern Prof. I, Vaillant. Nach de Rochebrune liommt sie in »Mélacorée, Gambie, Casamence, Sedhiou, Albreda« in Senegambien vor. Die im Berliner (No. 6721) und Mailänder Muscum als $\gg$. tessellata« aufgestellten Echsen scheinen mir einer ganz anderen Gattung anzugehören.

? Subsp. pseudotessellata m. (vergl. meine Tafel Fig. 8 u. 21).

Char. - Scuta analia duo. Pori femorales utrinque 17. Pedes postici axillas non contingentes. Longitudo: $205 \mathrm{~mm}$.

Diese vielleicht mit $\gg$. elegans $\mathrm{Sm}$ ith (l.c.) identische südafrikanische Unterart stimmt im allgemeinen mit der tessellata überein, unterscheidet sich von derselben aber vor allem durch die völlig verschiedene Beschildung der Analregion. Auferdem scheint mir ihr Kopf in der Backengegend etwas breiter und der Höhendurchmesser des Kopfes geringer zu sein, als es bei der vorhergehenden der Fall ist. Die Augen sind schmäler und liegen dicht am Unteraugenschilde; 3 Schuppen trennen die Supraciliaren von den Supraocularen. Die Vorderbeine berühren den Vorderrand der Augen, die Hinterbeine sind kaum im stande die Achseln zu erreichen. Gegen den Schwanz hin sind die Schuppen kleiner und erscheinen auf der Schwanzwurzel ungekielt. Es sind $5+5$ Submaxillaria vorhanden (bei der tessellata sind es $4+4$ ). Das Halsband besteht aus 8 größeren und 2 kleineren Schildchen. Das Brustdreieck wird aus 4 'Tafeln gebildet. 35 vorn sehr schmale Querschilderserien bekleiden den Bauch. Die Analregrion zeigt 22 übereinanderstehende, den Ijauchtafeln ähnlich sehende grotie Afterplatten, welche vorn und seitlich von 2 gebogenen Schilderreihen umgeben erscheinen. Die den groben Platten zunächst liegende Serie besteht aus sieben etwas gröfkeren Schildern, die übrigen sind klein.

M a fa in min. - Totallänge 205; Länge des Kopfes 15, des Halses 8-9, des Rumpfes 60, des Schwanzes 130, der Vorderextremitit 23,5, des Vorderfußes 10, der Hinterextremität 41, des Hinterfulies 19. Breite des Kopfes 10, des Pileus 6; Kopfhöhe 8. Umfang des Kopfes 31 , des Halses 29.

17 Femoraldrüsen jederseits. - Im Oberkiefer $22+22$, im Zwischenkiefer 9, im Unterkiefer $24+247$ a h $\mathrm{n}$ e. Der Gaumen ist bezahnt.

Die Grundfarbe der Oberseite ist hellnu(3braun. Vom hinteren Rande des Pileus entspringen 5 weißliche, braun umsäumte Längsbinden, deren mittlere sich aber in der legel schon in der Nackengegeud vereinigen, so dą̇ dann nur 3 Binden die vordere Rückenhälfte zieren. Öfters sind überhaupt nur 3, von dunkelbraunen Punkten begleitete Binden vorhanden. Die hintere Hälfte des läickens und die Caudalwurzel sind nicht gestreift, sondern einfarbig 
hellnu[ibraun. Die Schwanzoberseite ist spärlich dunkelbraun gemakelt. Kurze weißliche, braun umsiiumte Querstreifen zieren die Flankengegend. Ähnliche Streifen sind auferdem auch auf der Schläfe sichtbar. Auf der Kopfdecke sind etliche dunkelbraune Zeichnungen symmetrisch vertcilt. Dic Unterseite des Körpers ist stets ungefleckt gelblichweifi. Nach Smith soll bei seiner selegans« im Leben der Rücken und die Rumpfseiten rotbraun, der Schwanz und die Gliedmafen hellrot und die Körperunterseite rötlichweif gefärbt sein.

Das mir von Prof. v. Martens zur Ansicht zugesandte Stück des Berliner Museums stammt aus Tette. Es ist als »tessellata, No. 1043« bezeichnet. In der nämlichen Glasbüchse befindet sich noch eine zweite, weder der tessellata noch der pscudotessellata angehürige Echse, zu deren Beschreibung ich übergehe.

Über das Vaterland von »L. elegans« sagt $\mathrm{S}$ m ith folgendes: »Inhabits Little Namaqualand and the country towards the Orange riveræ. Wenn ich mich nicht irre, so stammt das im British Museum aufbewahrte Stück der »elegans« vom See Nyassa.

Obschon ich dem Beispiele meiner Vorgänger ${ }^{1}$ ) folgend, die tessellata als »Lacerta «ezeichue, scheint es mir dennoch sehr zweifelhaft, ob diese und die folgenden Arten auch wirklich der Gattung Lacerta angelı̈ren. Belege dafür, daß3 der Verbreitungsbezirk der echten Eidechsen sich nicht jenseits des Äquators erstreckt, dürfte, meiner Meinung nach, die cingehende Untersuchung des Gerippes dieser afrikanischen Echsen liefern.

\section{4. (?) Lacerta Cameranoi $\mathrm{m}$.}

Char. - Sc. occipitale minimum, in posteriorem partem remissum. Interparietale magnum, longissimum, frontali fere aequum. Discus palpebralis in margine externo serie granorum limbatus. Scuta nasofrenalia duo, superposita. Supralabialia anteriora 4. Sc. parictalia in marginibus nonnullis scutis maioribus limbata. Tempora squamata. Sc. massetericum nullum, sc. tympanicum parvum. Sulcus gularis nullus. Collare vix denticulatum. Sc. abdominalia per series octo disposita. Squamae dorsales minores quam in $\gg L$. tessellata《. Pori femorales utrinque 15. Dentes palatini. - Caput altius, collum longius quam in »L. tessellate«. Corpus satis porrectum. Cauda corpore $1 \frac{1}{1} 2$ longior. Pedes postici axillas attingentes, digitis multum brevioribus crassioribusque quam in »Lacerta tessellataณ. - Longitudo: $202 \mathrm{~mm}$.

1) Die Einführung der Gattung $»$ Nucras $*$, welche die Arten stessellata, Delalandei, exigua und chalybdea in sich fassen soll, verdanken wir Gray; sie ist sowohl in qualitativer als auch in quantitativer Hinsicht als gänzlich mißlungen zu betrachten, umsomehr da die taeniolata nicht mit erwähnt, sondern als $\$$ Zootoca bezeichnet worden ist. "Nucrase ist blos eine Kollektivbezeichnung für 3 Gattungen und darf nur als solche citiert werden. 
Körpergestalt und Gröbc. Schilder und Schuppen (Vergl. meine Taf. Fig. 9,11 und 31).

Von dieser, durch ihren hohen Kiopf und insbesondere durch ihre auffallend dicken Zchen gekennzeichneten Species habe ich nur ein als "Lacerta tessellata《 bezeichnetes Individuum im Berliner Museum zu untersuchen Gelegenheit gehabt. Der Kopf ist um $1 \frac{1}{1}$ z resp. um $1 / 2$ mm höher, als bei den vorhergehenden und dic Zchen sind nahezu doppelt so breit und liürzer, als es bei tessellata und pseudotessellata der Fall ist. Ein Blick auf meine Figuren 31 und 8 wird genügen, un sofort die Differenzen in Bezugr auf die Gestalt des Fulies zu erblicken. So milist z. B. die längste Zehe am Vorderbein bei pseudotessellata $7^{1 / 2} \mathrm{~mm}$ und sogar darüber, hingegen bei der Cameranoi nur $6 \mathrm{~mm}$. Die Vorderbeine erreichen die hiuteren Ränder der Freno-ocularia, die Hinterbeine berühren die Achseln. Der Hals ist lang. Die Ohröffuung, die am Halse und nicht an der Ansatzstelle des Rumpfes an den Kopf liegt, ist recht grof, vorn oben von einem kleinen, lïnglich-schmalen Tympanicum begrenzt. Die übrigen, vorn an den Ohrrand anstoßenden und die Schläfengegend bekleidenden Schuppen sind ziemlich grof, hexagonal. Unter den Eigentümlichkeiten in der Beschildung des Kopfes, welche sowohl der Camerunoi als auch den übrigen, ihr naheverwandten südafrikanischen Arten eigen sind, fällt die Länge der die seitlichen Aulienkanten der Parietalia begrenzenden Plïttchen auf; letztere stehen nämlich nicht etwa in nahczu senkrechter Lage, wie es sonst bei unseren einheimischen Lidechsen zu sein pflegt, sondern sie liegen in ein und derselben Ebene mit den übrigen Pileustafeln, folglich nehmen sie hier Anteil bei der Bepanzerung der Schädeldecke und können als Iutplättchen betrachtet werdeu. Auf dieses ganz besondere Kennzeichen aller mir bis jetzt bekannten sülafrikanischen „Lacerten « möchte ich die Aufmerksamkeit der Herpetologen und namentlich derjenigen lenken, welchen es vergönnt sein wird, auch das skelett dieser Tiere zu untersuchen und vielleicht im Schädelbau gewichtige abweichende Merkmale zu finden, welche genügen würden, sämtliche südafrikanischen, eidechsenähnlichen Saurier aus dem Genus »Lacertu« auszuschliefien. An das Gelingen eines derartigen Versuches hege ich keine Zweifel; und wenn ich es vorläufig nicht wage, den Kap-Echsen den ihnen gebührenden Platz im System cinzuräumen, so ist es dadurch zu entschuldigen, dalis es mir fïr die eingehende Charakteristik, geschweige denn für eine anatomische Untersuchung, an Material mangelt. Gegen die Einführung von osteologischen oder überhaupt anatomischen Merkmalen sträuben sich allerdings die Systematiker und zwar nicht mit Unrecht, denn sollte man eine seltene Species - ein Unicum, wie es so oft vorkommt - erst einer anatomischen Untersuchung opfern müssen, um sie sunfehlbar \& klassifizieren zu küunen, so würden in diesem 
Fall mehrere Genera und Species aus unseren Sammlungen gänzlich verschwinden. Wenn ich in meinen früheren Arbeiten die Initiative Leydigs ergriffen und osteologische Merkmale mit in die Diagnosen der schwierig zu bestimmenden formen heranzuzieben versucht, und diese Neuerung - immer mit Bezug auf die Saurier - meinen Fachgenossen empfohlen habe, so geschah letzteres in der Voraussetzung, dafi man mit genügendem Material versehen ist; steht das Material in Hülle und Fülle zur Verfügung und versagt einem der Scharfblick hinsichtlich der äuferen Charakteristik des Tieres, so leistet, meiner Ansicht nach, die vergleichend-anatomische Untersuchung stets zute Dienste. In Bezug auf die südafrikanischen und überhaupt afrikanischen Echsen muf ich hierselbst bemerken, daf es nicht nur unmöglich grewesen ist, mir irgend welches Material für osteologische Untersuchung zu verschaffen, sondern dalis ich sogar behufs des Studiums der äufieren Merkmale dieser höchst seltenen 'licre mich nach London und Berlin begeben mufite. An die Zergliederung solcher Raritäten, wie es die sogenannten »Lac. tessellata, Cameranoi, taeniolata, cchinatu und Delalandei sind, war weder im British-, noch im Berliner Museum zu denken.

Da einerseits der hervorragendsten Kennzeichen unserer ${ }_{\text {Cameranoi }}$ in der lateinischen Diagnose Eiwähnung geschehen ist und anderseits die übrigen Kennzeichen bei der in Rede stehenden Art im allgemeinen identisch mit denjenigen bei der tesscllata sind, so bliebe mir nur noch folgendes himzuzufügen: das Interparietale zeichuet sich sowohl durch seine Länge, als auch durch seine Breite aus; es ist hier, sozusagen, auf Kosten der Parietalia und des kleinen Occipitale entwickelt. Die Frontoparietalia stellen - wie es auch sonst bei den Südafrikanern durchweg konstatiert worden ist - ein unansehuliches Schilderpaar vor; hingegen sind die Supraocularia recht grolie Platten, namentlich fallen die dreiseitigen vordersten und hintersten Scuta supraocularia (also No. 1 und 4), die hier echte, flache Schilder vorstellen, durch ihre Lntwickelung auf. Diese säntlichen, zuletzt grenannten Schilder bilden bei der cumerunoi einen, wenn auch schwach gewölbten, von den Supraciliaria durch eine Reihe von 4 Schuppen getrennten Discus palpebralis. Eine ansehnliche Entwickelung sowohl in die Länge, als auch in dic Breite zeigen die Supranasalia, währendem das Rostrale nur schwach nach oben ubergewölbt erscheint. Die Nasenlöcher sind vorn an den Seiten des ziemlich stumpf abgerundeten Schnatuzenrandes gelegen; sie befinden sich nahezu ausschlieblich in den oberen Nisenschildern, welche sich gegen die Kopfseiten zu hinunterbiegen; folglich erscheinen die Nasofrenalia, deren sich auf jeder Seite zwei befinden, schwach ausgerandet und stellen recht ansehnliche. Schilder vor. Submaxillaria sind beiderseits 5 vorhanden; das fünfte ruckwärts liegende Patar besteht allerdings aus kleinen Plättchen, welche leicht übersehen werden könuten, Das äußerst schwach gezäl- 
nelte, bogig geschwungene Halsband besteht aus 12 'T'äfelchen. Sulcus gularis fehlt. Die Batuchschilder sind in S longitudinale und ungefähr 31 transversale Reihen geotdnet; die cinzelnen Tafeln sind grölier, als wir es bei tesselluta kennen gelernt haben. Die Randschildehen sind vorhanden. Die Aftergegend ist von einem gröliseren, centralen Anale und von 4 kleineren, bogenatrtig um das letztere angeordneten Schildchen bekleidet, also ähnlich wie bei tesscllata. Was die Beschujpung anbetrift, so will ich hinzufügen, dafs dieselbe insofern von derjenigen bei tessellata oder psendotessellata abweicht, als mir die Schuppen des Rückens bei unserer neuen Art eine Idee kleiner zu sein scheinen. Die Zalıl der longitudinalen dorsalen Schuppenreihen beträgt 41 bis 43 , diejenige der transversalen 125. Schwanzringel sind 76 vorhanden.

MaLce in mm eines männlichen Individuuns aus dem Berliner Museum (No. 1043): 'Totallänge 202. Länge d. Kopfes ungefäh 17, d. Halses 15, d. Rumpfes 65, d. Schwanzes 120 (die Spitze ist abgerissen!), d. Vorderextremität 25,5, d. Vorderfulies 10,5, d. Hinterextremitiit 41, d. Hinterfufes 19. Kopfhühe 9,5, Breite d. Kopfes 12, d. Pilcus 7,5; Umfang d. Kopfes 37,5 , d. Halses 36 .

Farbenkleid, Drüsen und Z ähne.

Die Cameranoi zeigt auf der Oberseite ein helles Braun oder cin Braungelb, das an den Seiten und an den Vorderbeinen viel dunkler ist und hier soga in Dunkelbraun übergeht. Die lichteren Körperpartieen sind dunkelbraun gepunktet, lingegen die dunkleren mit zahlreichen gelblichweifien Fleckchen versehen. Auf der Schläfe nimmt man Andeutungen von 2 oder 3 schmalen gelblichen Binden wahr. Den Raum zwischen den letzteren nehmen dunkelbraume Streifen ein. Sämtliche Unterteile sind gelb, nur die äufieren longitudinalen Bauchschilderreihen erscheinen spärlich dunkelbraun gefleckt.

15-15 Schenkeldrïsen. - Die approximative Zahl der Zähne ist: im Zwischenkiefer 9; in Oberkiefer auf einer Seite 24; im Unterkiefer auf einer Seite 23. Der Gaumen ist bezahnt. Fleischige breite Zunge.

Fundort: Tette.

\section{5. (?) Lacerta taeniolata Smith 1838.}

Char. - Sc. occipitale minimum, valde in posteriorem partem remissum. Sc. interparietale et frontale longissima. Sc. nasofrenale unicum. Discus palpebralis in margine externo serie granorum limbatus. Scuta parietalia in marginibus 3-4 scutellis limbata. Tempora squamis convexis; sc. massetericum et tympanicum nulla. Supralabialia anteriora 4. Collare vix dentatum. Abdomen lamellarum seriebus sex. Aiquanate dorsales laeves, irregulares, quinquangulares 
of quadramgulares angulis rotmulatis, granosae, ovali-sexangulares. Pori femorales utrinque 14. Dentes palatini nulli. - Corpus elongatum, caput abbreviatum, posticum incrassatum. Pedes postici axillas non contingentes. Canda longissima, longitudine dupla corporis, ante squamis carinato-muricatistecta. - Longitudo $184 \mathrm{~mm}$.

Synonymie.

Lacerta taniolata Smith in: Magaz. of Nat. Hist. New series, vol. II, No, 14, p. 92. London 1838; Illustration of the Zoology of South Afrika. Appendix, pag. 8. London 1849. - Duméril et Bibron, Erpétologie générale, t. V. p. 247. Paris 1839. - Boulenger, in Proc. Zool. Soc. of London 1881, pag. 743.

Zootoca tacniolate Gray, Cat. Liz. Brit. Mus. pag. 29. London 1845.

Körpergestalt und Gröbe. Schilder und Schuppen.

Der Körper der taeniolata ist gestreckt, in seiner Form der tesscllata gleichend, jedoch etwas schlanker und weniger lang als bei der letzteren. Der ziemlich hohe und verhältnismäligg kurze Kopf ist in der Schläfengegend stark aufgetrieben. Der Discus palpebralis ist gewölbt. Die Schwanzlänge übertrifft um einige $\mathrm{mm}$ die doppelte Länge des Körpers. Die Vorderbeine ragen nicht uber die Niasenlücher hinaus, die hinteren erreichen nicht die Achseln.

Das sehr lange, vorn breite, stumpfwinkelig endende und leicht abgerundete Kanten aufweisende, nach hinten aber verschmälerte, mit geraden, einen stumpfen Winkel bildenden Kinten versehene und seitlich leicht eingebuchtete Frontale stölat rückwärts an das bedeutend schmälere, längliche, vorn stumpfivinkelige, hinten abgestutzte Interparietale, welches seinerseits an das äufierst kleine vorn dreikantige, hinten abgestutzte und weit nach hinten zurückgedrängte und, so zu sagen, aulierhalb des Bereiches der übrigen Pileusplatten sich befindliche Occipitale grenzt. Die verhältnismäbig schmalen Parietalia sind parallelseitig; ihre Hinterränder sind bald gerundet, bald stellen sie stumpfwinkelige, mehrfach gebrochene Linien dar, während die Vorderseiten einfach in stumpfem Winkel zusammenstofen. Die gerade verlaufenden, äufieren Parietalkanten sind von 3 bis 4 .Schildchen gesäumt, deren hinterstes zum Teil auch am Hinterrande der Parietalen zu liegen kommt und somit die hintere Grenzlinie des Pileus übertritt; diese Eigentümlichkeit scheint ien meisten Kạ)-Echsen eigen zu sein. Die sehr kleinen Frontoparietalia weisen fün Kanten auf. Der gewölbte Discus palpebralis ist etwa eiförmig, aus 2 kurzen Schildern gebildet, nach aufen durch eine aus 4-5 kleinen sechseckigen Schuppen hestehende Reihe von deu Supraciliaria getrennt; diese Schuppenreihe reicht jedoch nicht weit nach vorn hin, so daß das vordere große Supraoculare sich zum Teil direkt an die Supraciliaria anlegt; das hinterste, also vierte Supraoculare, ist breiter als lang; ersteres hat 3 Kanten 
und abgerundete Eclien. Das Internasale ist bedeutend breiter als lang, im ganzen von etwa rhombischer Gestalt; es ist einerseits durch die Scuta frontonasalia voin Frontale getrennt und anderseits durch die kleinen, in der Mitte der Schnauzenspitze zusammenstofienden und seitlich durch das Nasenloch beträchtlich ausgerandeten Suprinasalia vom niedrigen, funfliantigen Rostrale geschieden. Das Nasenloch ist hinten nur yon einer Nasofrenalplatte begrenzt; das darauffolgende Frenale ist fünfkintigr : das etwas uröfere, hinten 3 kurze lianten aufwejsende Freno-oculare ist durch ein Praeoculare von dem fünften und grölsten Oberlippenschilde oder Suboculare getrennt. Voln zähle ich 4, hinten 2-3 Supralabialia; aufserdem kommt noch ein Postoculare hinzu. Die Schläfengegend erseheint mit likinen, vier-, fünf- und sechseckigen, ungekielten und eher flachen als crhabenen Schuppen bedeckt. Ein eigentliches Tympanicum ist. nicht vorhanden; an dessen Stelle, $d$. h. nahe an dem Vorderrande der grof̧en, fast kreisförmigen Ohröffnung gelegen, ist eine unregelmäfig gestaltete, nahezu ebenso breite als lange Platte zu sehen, welche nur insofern von den jhr benachbarten Schlïfenschuppen verschieden ist, als sie etwas gröber erscheint. Als Tympanicum jedoch kann ich sie schon aus dem Grunde nicht gelten lassen, weil sie vom Ohrrand durch ein dazwischen liegendes Täfelchen getrennt. ist. Das Mentale ist von 5 Paar schmalen Sublabialen und 4 Paar Submaxillaren gefolgt. Sulcus gularis fehlt. Die Kehlschupjen sind vorn länglich, sechseckig; nach hinten zu erscheinen sie breiter. Die in circa 163 Querreihen angeordneten glatten Rückenschuppen sind am Nacken rundlich lï̈rnig, am Vorderrücken fünf- und vierseitig und am IInterrücken unregelmälisg gestaltet; bald sind sie ovalohexagonal, hald zeigen sie mehrere leutlich ausgeprigte Kanten. Die etwas größeren Seitenschuppen sind schwach geschindelt; etwa zwei Schuppenserien entsprechen der Länge einer Ventraltafel. Das Halsband wird aus 9 größseren und 2 ganz kleinen Schildchen zusammengesetzt. Die Bauchschilder stehen in 32 ()uer- und fi Lüngsreihen, an welche sich jederseits eine Serie sogenannter $x$ Randschildchen anreihet. Das Anale ist vorn von relativ grofen Schildern gesäumt. Der Schwamz besteht aus 126 Schuppenringeln; die Caudalschuppen sind oberseits stumpfwinkelig, unterwïrts hingegen in eine schärfere, aber abgerundete Spitze ausgezogen.

Während Duméril und Bibron angeben, daßs die Species, abgesehen vom Kolorit und dem schlankeren Körperbau, sich einzig und allein durch das Vorhandensein einer Nasofrenaltafel von der zuletzt beschriebenen tessellata unterscheiden läbst, glaubt Gray in der Zahl der Bauchschilderreihen einen genügenden Grund gefunden zu haben, um treniolutu und tessellafa voneinander generisch zu scheiden und erstere der Gattung „Zootoca«, letztere aber der Gattung $\approx$ Nucras\& einzuverleiben! Dafi taeniolata und Canneranoi ebensowenig wie tessellata 
und pseudotessellata echte Lacerten sind gebe ich gern $\mathrm{zu}$; gegen die generische Trennung aber dieser zwei Arten erhebe ich entschieden Einspruch.

Mafie in mm. - Gesamtlänge 183 bis 184. Länge des Kopfes 11,7, des Rumpfes 46, des Schwanzes 126, der Vorderextremität 18, des Vorderfufes 7, der Hinterextremität 30, des Hinterfufies 14; Höhe des Kopfes 5,7, Breite des Kopfes 7, Umfang des Kopfes 26.

Drüsenzahl nach Smith: 14-14, - Gaumen-Zähne fehlen (nach Duméril und Bibron).

Farbenkleid.

Da die Original-Exemplare der taeniolata, namentlich in betreff der Färbung, stark gèlitten haben, so will ich in beifolgendem den Beschreibungen des Farbenkleides von Duméril, Bibron und Smith vor meinen eigenen Notizen den Vorzug geben. - »Eines der beiden Individuen«, sagen Duméril und Bibron, »welche wir in der Lage waren zu untersuchen, war rotfalb. Jede Supralabialtafel weist einen kastanienbraunen Flecken auf; die 2 hinteren Palpebralen sind braunfleckig; das Interparietale und die Parietalen sind kastanienbraun. Fin helles Kastanienbraun überzieht die Oberseite der Beine und die Schläfe; weiße Makeln, oder genauer weilie Streifen heben sich vom kastanienbraunen Grunde ab; Hinterkopf, Halsseiten, Rücken, Flanken und Oberseite der Schwanzwurzel sind von dunkelkastanienbrauner Farbe. In der Hinterhauptsgegend nehmen 2 weife Linien ihren Ursprung, setzen sich auf dem Hals und Rücken fort und verlieren sich am Schwanze. 7/wischen diesen 2 dorsalen Streifen ist noch ein dritter, bis zul Achselgegend sich hinziehender Streifen wahrnelımbar. Die Körperseiten sind gleichfalls mit weifen Streifen versehen; es befinden sich jederseits 3 Streifen, von denen der eine in der Ciliargegend beginnt und sich geradlinig bis zu den Schwanzseiten hinzieht; der zweite entspringt unter dem Auge, zieht sich durch die Schläfengegend und oberhalb des Ohrrandes fort an den lateralen Schwanzpartien; der dritte Streifen endlich nimmt seinen Ursprung am unteren Ohrrande und hört oberhalb der Oberschenkel auf. Hinten erscheint der Schwauz zum grölisten Teil fleischfarben oder rosa angehaucht. Alle Unterteile des Körpers sind weif. Beim zweiten Individuum ist die Grundfarbe auf der Oberseite und den Seiten des Halses, auf der Rückenregion und auf den Flanken braunschwarz, 6 laterale Streifen sind vorhanden, erscheinen aber nach hinten zu sehr schmal. Zugleich nimmt man auch die Rückenstreifen wahr; sie sind bei dem in Rede stehenden Individuum graufalb und werden nach rückwärts so breit, daf sie die hintere Partic des Rückens zum Teil einnehmen.« - Die kurze ursprüngliche Beschreibung, welche Smith uns hinterlassen hat, lautet folgendermatien: „Back brown, with two fine black lines, in places composed of dots; sides black, with 3 longitudinal 
white lines vanishing at or near the base of the tail. Tail brown above, inclined to red near the extremity, and marked on each side, towards the base, with a blackish line; under parts dull white. Abdominal plates in 6 longitudinal rows; collar of 9 scales; femoral pores 14. Length about 9 inches. - Joung. Black above, with 9 longitudinal white lines, the central one extending only a little distance above the neck. Inhabits the grassy districts of the Cape Colony .

\section{Hab it at.}

Nach Smith soll $\gg$ L. tacniolata« ilur Wolngebiet mit der tessellata teilen, nämlich an der Westliüste Südafrikas, namentlich in Klein-Namaqua vorkommen. Smith fügt hinzu, dals sie die mit Gras bewachsenen Distrikte zum Aufenthaltsorte vorzieht und nie in Gemeinschaft mit der ihr so ähnlich :sehenden tessellata angetroffen worden ist. - Von "L. taeniolata « sind, so viel ich weiß, überhaupt nur die zwei Originalexemplare im British Museum vorhanden.

\section{6. (?) Lacerta echinata Cope 1862.}

Char. - Sc. occipitale scuto interparietali vel brevius et latius vel ei aequum. Sc. nasofrenale unicum. Squamae temporum parvae; sc. massetericum, sc. tympanicum, sulcus gularis nulla. Supralabialia anteriora 4. Discus palpebralis a supraciliaribus squamarum serie non separatus. Collare denticulatum. Sc. abdominalia per series sex disposita. Squamae dorsales quadrangulares, angulis posticis rotundatis, diagonaliter carinatae, longiores quam latiores. Pori femorales utrinque 12-13. Dentes palatini nuili. - Caput longum, latius quam altius, corpus porrectum, fere aeque crassum, dorsale convexum, ventrale planum. Cauda longissima, totius corporis longitudinem fere ter superans; squamae in citudac basi maximae, spinosissime aculeatae, apicem versus regulariter carinatae. - Longitudo: $370 \mathrm{~mm}$.

Synony mie.

Lacerta echinata Cope, in: Proc. Acad. Nat. Sc. of Philadelphia 1862, pag. 189.

L. hirticauda Vaillant, in: Bull. Soc. zool. de France 1884, pag. 344. Pl. XII, fig. 1.

Körpergestalt und Gröbe.

Der Rumpf ist gestreckt, ziemlich gleich dick, am Rücken gewölbt, mit platter Unterseite. Der Kopf ist lang, breiter als hoch, nach vorn allmählich zugespitzt verschmälert, mit zugespitzt gerundeter, seitlich nahezu steil abfallender Schmauze. Gegen die Schnauzenspitze erscheint die Schädeldecke sinft mach abwärts geneigr; der Palpebraldiscus zeigt vorn eine schwach ausgeprïigte Wöbung; die Schlifengegend ist schwach aufgetrieben. Die Nasen- und 
Ohröfinumgen sind grob, die Augen klein. Unmittelbar hinter llem Kopf ist der Hals in der Regel breiter als der Kopf und zeigt dicht am Occipitale eine wulstartige Erhabenheit, welche wahrscheinlich entweder auf die stark entwickelten, ersten, oberen Dornfortsätze, oder vielleicht auf den ganz abnorm ausgebildeten, stäbehenartigen Fortsatz am Ilinterhauptsbein, der bekanntlich zur Stütze der Schädeldecke dient, zurückführbar ist. Die Vorderbeine reichen, an den Hals angelegt, bis zu den Frenalen, die Hinterbeine erreichen nicht die Schultern. Der in seinem vorderen Drittel breite, mit dornig ausgezogenen Schuppen bekleidete, gegen sein Ende verdünnte Schwanz ist äufierst lang, den Körper fast dreimal übertreffend. Die echinata sieht in Bezug auf ihren Körperbau im allgemeinen der südafrikanisehen Echse »Dclatundei M.-Edw. ähnlich, nur besitzt letztere einen kürzeren IKopf und namentlich kürzere Gliedmafien.

Malise in mm (3 Exemplare).

British Museum. Berliner Museum.

No. 1. No. 2. No. 3 .

$\begin{array}{lccc}\text { Totallänge . . . } & 177 & 282 & 370 \\ \text { Länge des Kopfes . . } & 22 & 18 & 24 \\ \text { Breite des Kopfes . . } & 13,5-14 & 10,5-11 & 14 \\ \text { Höhe des Kopfes . . } & 10 & 8,5 & 11-11,5 \\ \text { Umfang des Kopfes . . } & 41 & 32,5 & 48 \\ \text { Breite des Pileus . . } & 10 & 8,3 & 11 \\ \text { Länge des Halses . . } & 11 & 11,5 & 14 \\ \text { Umfang des Halses . . } & 40-42 & 33 & 44 \\ \text { Länge des Rumpfes . } & 70 & 53-54 & 83 \\ \text { Umfang des Rumpfes . } & ? & ? & 46 \\ \text { Länge des Schwanzes . } & 85 & 210 & 263 \\ \text { » d. Vorderextremität } & 33 & 27 & 33 \\ \text { » des Vorderfufies : } & 11 & 9 & 12,5 \\ \text { » d. Hinterextremität } & 42 & 39 & 46 \\ \text { » des Hinterfuries . } & 19 & 20 & 22\end{array}$

Átiere Körperbedeckung (Fig. 24).

Das vier- bis fünfkantige Rostrale ist breit, etwas übergewölbt, durch die in der Mittellinie zusammenstolienden, schmalen, hinten durch die Nasenlöcher ausgeschnittenen Supranasalia von dem nahezu ebenso breiten als langen Internasale getrennt. Das zuletzt genannte Schild erscheint nach vorn zu verengt mit abgerundeter Spitze, nach hinten stumpf-oder spitzwinkelig 
ausgezogen; mitunter ragt sein Ilinterteil als ziemlich lange Spitze zwischen die bald schmiileren und lämgeren, bald breiteren und liürzeren Froutonasalen hinein. Von den 3 fast geraden, nach der Kopfmitte gerichteten Frontonasalkanten stolien gewöhnlich dic kürzesten in der Mittellinie des lopfes aneinander; von den 3 bis 4 nach aufien gelegenen Seiten fügt sich die längste Seite an das grolie fünfeckige Freno-oculare, während die übrigen etwas liürzeren ¿auferen Fontonasalkanten einerseits die Frenalen und anderseits die Augenschilder berühren. Das liontale ist lang und breit, nach vorn stumpf- oder rechtwinkelig ausgezogen und gebuchtet, oder mit abgerundeten Ründern versehen. Dic längsten lateralwärts liegenden und an die Suprnocularen sich anfügenden Ränder sind schwach ausgerandet; die kürzesten, mit den Frontoparietalen zusimmenstolienden liänder sind ebenfalls schwach ansgeschnitten. Die Frontoparrictalen zeigen in betreff ilurer äuscren Konturen mancherlei Verschicdenheiten: bald haben sie bogig geschwungene Seiten, bald aber geradlinig verlaufende und unter rechtem oder stump̨em Winkel zusammenstobende Kanten; sonst sind sie von gewöhnlicher Bildung. Das Interparietale ist vom Occipitale an Größe verschieden; ersteres bedeutend länger als breit, nach hinten verschmälert, letzteres ebenso breit oder breiter, aber zugleich hürzer wie das Interparietale, dreieckig, an der vorderen Spitze stets abgestutzt, die Form also mehr oder weniger trapezförmig. Die grobien Parietalen, die stets länger als breit sind, haben nach innen 3 mehr oder weniger stark ausgerandete Seiten, welche durch das Occipitale, das Interparietale und die Frontoparietalen begrenzt werden; ihre Aufsenränder sind abgerundet; mit der sechsten bach vorn zu gekehrten kurzen Kante kommen die Parietalen mit dem kleinen, gerundet dreieckigen oder viereckigen Supraoculare in Berülırung. Zwischen diesem und dem zunächst sich befindenden grölieren Supraoculare III fügt sich mitunter von außen her noch ein Schüppchen hinein. Im ganzen sind vier obere Augenschilder vorhanden und zwar: das vierte hintere, das soeben erwähnt worden ist, das dritte linten abgestutzte, mit einem abgerundeten Aukenrande und mit meistens 3, unter mehr oder weniger spitzem, ofters aber undeutlichem Winkel zusammenstoßenden Innenseiten versehen, ferner das zweite - von vorn gerechnet - und zugleich gewöhnlich das gröfte Supraoculare, das ungefähr cinem Kreisausschnitt ähnlich sieht, dessen bogig geschwungener liand liateralwïrts zu liegen kommt, bald aber eiförmig, hinten abgestutzt erscheint; endlich das vierte vorderste kleine, drei- oder viereckige Schildchen, das gegen den Orbitalrand gerückt ist und nit cinem Supraciliare leicht verwechselt werden könnte. Diese Supraoculitrschilder sind am Aulienrande durch 4 länglich schmale Supraciliaria gesäumt. Ias grofe Nasenloch wird hinten lurch das hohe, vorn ziemlich tief auscreschnittene Frenonasale, unten durch dis erste Sugmalabiale begrenzt. Auf 
crsteres folgt dann das grolic fünfkantige Frenale, welchem nach hinten zu ein noch grölieres, öfters hinten ausgerandetes, ebenfalls fünfkantiges Freno-oculare folgt, das durch ein grölieres oder 2 kleinere Praeocularia vom Augenrande getrennt ist. Von den 4 vorderen Supralabialia sind die 3 ersten ziemlich gleich grolj und parallelseitig, währenddem das vierte Schild etwas breiter erscheint; an dieses schliefen sich das füfseitige, nach unten zu etwas verschmälerte, oben, d. h. am Orbitalrande schwach ausgeschnittene Suboculare und 1 -2 Supralabialia posteriora an. Nach Cope kann die Zahl der Oberlippenschilder sich auch bis auf 8 steigern, wobei daun das sechste Supralabiale unter das Auge zu liegen kommt. Die kürzesten Seiten des Suboculare legen sich vorn an die Praeocularia, hinten an die kleinen Postocularia mitunter ist nur ein Postocularplättchen vorhanden. Der hintere Augenrand ist aufserdem noch mit drei gröfseren Schildchen ungeben. Die Schlïfe ist mit zahlreichen kleinen, bald unregelmälßjig gestalteten, bald sechs- und fünfeckigen, deutlich gekielten Schuppen bedeckt; sowohl Massetericum und Tympanicum, als auch gröliere, den Aufienrand der Parietalia gewöhnlich umgebende Schilder fehlen gänzlich. Die Ohrüffnung ist schmal. Am Unterkiefer zähle ich 6, ziemlich schmale fünfseitige Sublabialia und 5 Submaxillaria; die 22 ersten Submaxillarpalire stofien zusammen. Das kleine Mentale ist nach hinten zu mit 4 Kanten versehen. Sulcus gularis ist nicht vorhanden, hingegen existiert eine Kehlfalte; aulierdem ist eine Falte am Halse sichtbar, welche am Unterrande der Ohröffnung beginnt und sich bis zu den Ansatzstellen der Vorderbeine hinzieht. Die Kehle ist mit gekielten Schupen bedeckt, welche vorn kileiner, r'und, rhombisch oder länglich schmal sind, nach hinten zu aber allmählich gröfer und gerundeter werden. In der Nähe des Collare bülen die Kehlschuppen ihre Kiele ein und nehmen mehr die Gestalt von Schildern an. Das aus 8 bis 9 Schildern bestehende Halsband ist gezähnelt und mit freiem Rande versehen. Die in 102, in der Rückenmitte öfters unterbrochenen Querund in 33 bis 36 Längsreihen stehenden Körperschuppen sind am Nacken klein, rundlich, körnig, gewölbt, stark hervortretend und gekielt; am Rücken erscheinen sie gröfer, flacher, lïnger als breit und meistenteils durch kleine eingestreute Schüppchen gäuzlich voneinander getrennt: stellenweise gegen die Rückenmitte und gegen die Flanken zu sind die Schupnen kleiner, d. h. schmäler, hingegen sind sie sowohl auf den seitlich liegenden Rückenzonen, als auch auf den Bauchgrenzen größer. Dic Konturen der Rumpfschuppen weisen mancherlei Verschiedenheiten auf: die schmälern Schuppen in der Rückenmitte sind nämlich lïnglich abgerundet und mit einem nahezu median liegenden, longitudinalen Kicle versehen; die grö̈̇eren diagonal gekielten Rücken- und Rumpfseitenschuppen weisen nach vorn und innen zwei, etwa in stumpfem Winkel zusammenstolsende, geradlinige Sciten auf, lateralwirts und nach linten 
zeigen sie aber einen bogig verlaufenden Rand. Gegen dic Batuchschilder hin erscheinen die Grenzsehuppen, wic gesiant, grölier und stellen, sozusagen, gekielte »handschuppen « vor. Von den in 26 bis 32 Quer- und in 6 Längsreihen stehenden Bauchschildern sind die zwei äulieren lieihen ziemlich greich grols, etwas breiter als lang, nach hinten lateralwärts abgerundet; die mittleren sind, insbesondere nach vorn zu, schmäler und mit abgerundetem Ilinterrande versehen. Das Brustdreieck enthält etwa 8 T'afeln. Das bald grölsere (beim Exemplar im Brit. Mus.), bald kleinere (Berl. Mus.), fünfseitige Anale ist mit Ausnahme des freien Hinterrandes rund herum von 6 ziemlich ansehnlichen S'childern umsäumt. Der Schwanz ist mit ungleichartigen, gekielten, in 157 (Berl. Mus.) Quergürtel angeordneten Schuppen bedeckt. Oberwärts, am Vorderteile des Schwanzes erscheinen die Schuppen sehr grol, scharf grekielt und am Hinterrande in eine ziemlich lange Spitze ausgezogen (vergl. meine Taf. Fig. 24). Die in der Mittellinie des Schwanzes gelegenen schuppen sind gleichseitig, an ihrer Basis schmal, nach hinten zu erweitert, mit bogig geschwungenem Rande und einem in eine scharfe Spitze ausgehenden und die Schuppe in zwei völlig gleiche Hälften teilenden Kiele versehen. Die dieser medianen Längsschuppenreihe benachbarten Schuppen sind lingegen mehr rhombisch; sie büfen ihre symmetrische Gestalt ein, erscheinen diagonal gekielt und sind nur an dem gegen die Schwanzmittellinie gerichteten Ende in eine scharfe Spitze ausgezogen. Die Schuppen der Schwanzseiten sehen wiederum normal gekielt und gestaltet aus, da sie ziemlich gleichseitig und längs ihrer Mitte gekielt erscheinen; außserdem verlieren sie allmäblich ihre scharfen Spitzen und, indem sie zugleich immer schmäler werden, wandeln sie sich in länglich schmale, nicht allzu stark gekielte, vorn am Schwanze mit abgerundeter, hinten mit stumpfwinkeliger Spitze versehene, untere Caudalschuppen um. Die oberen Schwanzschuppen zeigen ebenfalls manchcrlei Verschiedenheiten; so erhalten sie ungefähr vom zwölften Quergürtel an (von vorn gerechnet) auffallend stark nach hinten zu vorspringende Kiele, welche durch zunehmendes Schärferwerden die Schuppe endlich vollkommen dornartig erscheinen lassen; gegen den 21. und 24. Quergürtel zu ragen die Dornen am meisten nach aufwärts und gehen von da an allmählich in normal gestaltete Schuppen über; am 35. Quergürtel ist meistens keine Spur mehr von Dornen oder Stacheln an den Schuppen zu schen, dagegen sind die scharfen Spitzen noch vorhanden. Dab mit der Ausbildung des Dornes der Körper der Schuppe gegen den freien IRand hin bedeutend dicker wird, braucht wohl kaum hinzugefügt zu verden. Die echinata ist somit mit cinem teilweise vollkommen dorntragenden Schwanze versehen. Dic Schuppen auf den Hintergliedmaßen sind ziemlich stark gekielt. 
Femoraldrüsen und Zälne.

Das aus Kamerun stammende, im British Museum aufbewalıte Exemplar der echinata weist jederseits 12 Drüsen auf, dasjenige aus Liberia (Berl. Mus.) hat auf der einen Seite 12 und auf der anderen 13 Femoraldrisen. Im Ober- und Zwischenkiefer scheinen im ganzen 32 bis 34, im Unterkiefer 34 bis 39 Zühne zu sitzen. Gaumenzäbne habe ich nicht entdecken können; die dem Zwischenkiefer entsprechende Partie des Unterkiefer's scheint gleichfalls zahnlos zu sein, jedoch muf ich ausdrücklich bemerken, daf3 ich die Exemplare, die mir zur Verfügung gestanden, hinsichtlich ihrer Bezahnung aus leicht erklärlichen Gründen nicht nach Belieben untersuchen konnte.

\section{Farbenkleid.}

Beim grofen, im Berliner Museum aufbewahrten Exemplar der echinata ist die Rumpfoberseite graugrü॥, mit ziemlich breiten schwarzen Querbinden, welche am Vorderrücken gelblichweifße, gut ausgeprägte Ocelli einschliefen. Der Kopf ist auf graugrünem Grunde dunkel gepunktet; Kehle und Bauch sind orangegelb; die Afterschilder erscheinen orange gefïrbt. IDic: Gliedmaßen sind oben graugrün, schwarz gefleckt, unten mit Ausmahme der gelblichen, schwarz gestreiften, an die Poren angrenzenden Schilder, graugrün, schwarz gefleckt. Der Schwanz urscheint oberwärts bräunlich, unterwärts grünlichgrau gefärbt und mit etlichen schwarzen Punktflecken besetzt. In Bezug auf die Zeichnung sieht dieses Individuum der Betlaia etwas ähnlich. Die kleinere, etwa $282 \mathrm{~mm}$ lange, im British Museum sich befindende echinata aus "West Afrika ist auf dem Rücken und den Seiten, auf bläulichgrünem Fond der Quere nach braunschwarz gestreift ; diese öfters geschlïngelten, etwa 23 Streifen stossen stellenweise zu unregelmäliggen Querbinden zusammen und bilden auljerdem in der Rückenmitte durch gegenseitiges Zusammentliefen der Länge nach ein Netzwerk, dessen ziemlich große Masclien durch die helle Grundfarbe auscrefültt werden. Die bei dem zuerst beschriebenen Exemplar der cchinuta zu Targe tretenden, gelblichweißen Augenflecken fehlen hier gänzlich. Die auf dem Vorderteile des Schwanzes vom bräunlichgrünen Fond sich abhebenden dunlielbraunen Flecken lassen ebenfalls die Tendenz, sich in die Breite zu ordnen und Querbinden zu bilden, erkennen; gegen das Schwanzende zu sind die Flecken nur noch auf den Seiten sichtbar. Die Kopfdecke ist braunschwarz gezeichnet; die gröfłeren Schilder auf den Gliednaßzen sind dunkelbraun gerïndert. Die Kehle ist gelblich, der Bauch und die Unterseite des Schwanzes bläulich gefürbt.

Das größsere Stück dieser Species aus Kamerun stammend, das ich im British Museum zu untersuchen Gelegenheit hatte, zeigt eine blaugrüne Grundfürbung und ist auf der Rumpfoberseite mit ziemlich gleichmäfig verteilten dunkeln Fleckchen besetzt, die gewöhnlich am 


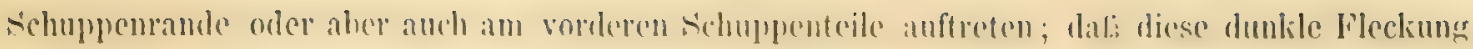
dazu beitrïgt, den Grundton dunliler erscheinen z.u lassen, versteht sich von selbst. Die RückenHäche des Kopfes ist fast cinfarbig bläulich; die Schlife, die Halsseiten und die Achselgegend sind hingegen bald mit Punkten, bald mit Strichen oler schnörkclartigen Figuren versehen. l)er Batuch ist gelblichweil:; rinige Bauchschilder haben einen hlaulichen Anflug oder sind bliulich umsïumt; die Brust ist blau. Die Extremitäten sind oberwärts brïunlich, mit hellgrünen, schwarz oder dunkelbraun eingefaliten Ausenflecken besetzt, unterwitrts bau. Auf dem Schwanze, namentlich seitlich, nimmt man etliche gelbliche Hlecken wahr. Vorn auf der Schwanzunterseite sind die Schuppen bläulich gelb umsäumt, nach hinten zu treten auf bläulichem Grund unregelmäßig verteilte gelbliche F'lecken hervor.

Vorkommen.

Der Verbreitungsbezirk dieser Art scheint ein ziemlich beschränkter zu sein, da cchinata bis jetzt nur von wenigen Gebieten im nordwestlichen Afrika nachgewiesen ist. Ihre IJeimat dürfte Ober-Guinea sein und zwar vorzugsweise die gebirgigen Küstenstriche. Das gröfsere, im British Museum sich befindende Stück ist von Rusherford in Kamerun erbeutet worden, währenddem das kleinere einfach als aus $》 W$. Africa stammend etikettiert worden ist; die echinata im Berliner Museum stammt aus Liberia. Nach Mitteilung des Herrn Prof. Vaillant

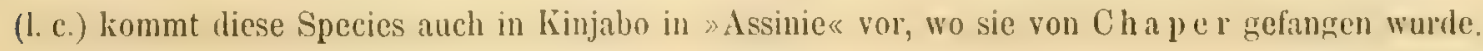
Dr. F. Müller in Basel hat sie neuerdings aus Gabun erhalten.

\section{Unteryattung Algiroides.}

Algyroides, Bibron et Bory de St. Vincent, Expédition scientifique de Moréc III. Paris 1832. Lacerta, Fitzinger, Neue Klassifikation d. Reptilien etc. Wien 1826. - Duméril et Bibron, Erpétologie générale, t. V. Paris (part.).

Tropidopholis, Fitzinger, Systema reptilium. Wien 1843.

Notophotis, Wiegmann, Herpetologia mexicana. Berlin 1834. - Bonaparte, Amphibia europaea in: Mem. Accad. Scienze di Torino Serie II. T'. II. - Gray, Catalogue of the Specimens of Lizards in the collection of the British Museum. London 1845. - Schreiber, Herpetologia europaea. Braunschweig 1875. - C a m e ran o, Considerazioni sul Genere Lacerta Linné. etc. in: Atti Accad. Scienze di Torino 1877.

Zur Bestimmung der drei süideuropäischen Arten mag nachfolgende Tabelle dienen:

A. nigropunctatus, D. B. - Frontale lang. Collare aus 8-9 Tafeln bestehend. Die Räckenschuppen sind hinten leicht abgerundet und bedeutend gröber, etwa doppelt so grobis als 
die Scitenschuppen. Die unteren Schuppen an der Caudalwurzel stumpfwinkelig endend. Das Anale ist von einer Bogenreihe kleiner Schildchen umgeben. 14 bis 18 Schenkeldrüsen jederseits. Körper ziemlich schlank und gestreckt. Lange Extremitäten. Hinterbeine die Achseln oft etwas überragend, Vorderbeine über die Augen hinausragend. Schwanz lang, mitunter von doppelter Körperlänge. 'Totallänge : $164 \mathrm{~mm}$. Habitat. Korfu, Istrien, Illyrien.

A. moreoticus Bibr. Bory. - Frontale kurz und verhältnismäfig breit. Collare aus 7 bis 9 Tafeln bestehend. Die Rückenschuppen sind fast ebenso lang, aber etwas breiter als die Seitenschuppen. Die unteren Schuppen an der Caudalwurzel spitz endend. Das Anale ist von 2 Bogenreihen kleiner Schildchen umgeben. 12 bis 15 Schenkeldrüsen jederseits. Körper ziemlich kräftig, kurz. Lange, krïftige Extremitäten; Hinterbeine die Achseln erreichend oder oft etwas überragend, Vorderbeine über die Augen hinausragend, etwa bis zum Frenale reichend. Schwanz ziemlich kurz, wenig länger als der Körper. Totallänge: $110 \mathrm{~mm}$. Habitat. Morea und Zaute.

A. Fitzingeri Wiegm. - Frontale kürzer als bei nigropunctatus, länger als bei moreoticus. Collare aus 5 bis 7 Tafeln bestehend. Die Rückenschuppen etwas kürzer und schmäler als die Seitenschuppen, oder im Gegenteil gröfier als letztere. Die unteren Schuppen an der Caudalwurzel stumpfwinkelig endend. Das Anale ist von einer Bogenreihe kleiner Schildchen umgeben. 10 bis 12 Schenkeldrüsen jederseits. Körper zart gebaut, gestreckt, schlank. Kopf sehr klein, vorn verschmälert, flach. Sehr kurze Extremitïten. Hinterbeine die Achseln nicht erreichend, Vorderbeine den vorderen Augenrand erreichend. Sehr langer Schwanz, mitunter die doppelte Körperlänge übertreffend. Totallänge: 100 bis $124 \mathrm{~mm}$. Habitat. Sardinien und Korsika.

Die Linien eines Schemas der Affinität dieser drei Algiroides-Arten lassen sich in folgender Weise ziehen:

Illyrien, Istrien,

Dalmatien (?), Korfu

A. nigropunctatus.

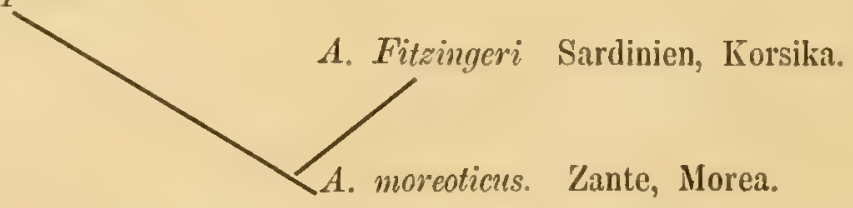

Dem Namen Algiroides Bibron, Bory gebe ich aus dem Grunde den Vorzug, weil die Gattungsnamen »Notopholis« und »Aspitis« von Wagler für Psammodromus hispanicus und nicht für die lejodaktylen Formen 》Fitzingeri, moreoticus und snigropunctalus vorgeschlagen worden sind, worauf die Verfasser der generellen Herpetologie bereits hingewiesen haben. 
Wagler kannte nicht, wie er es selbst zugiebt, den »1'sammodromus hispanicus Fitzing er*, sondern nux die "Lacertu Educurdsianu Dugès《 und anstatt beide zı vereinigen, schlïgt er für letztere den Gattungsnamen "Aspitis« oder "Notopholis« vor und spricht die Vermutung aus, „Psammodromus hispanicus litz. «ehöre zu seiner Sippe » Psammerus oder zu unserer "Tropidosaura Fitz.*

\section{Algiroides nigropunctatus D. B. 1839.}

Char. - Sc. frontale longum. Collare 8-9 scutellis comprositum. Squamae dorsales pone subrotundatae et squamis lateralibus multum (circiter duplo) maiores. Squanate in caudae basi inferiores obtuso-angulatae. Scutum anale squamarum serie arcuata circumdatum. Pori femorales utrinque 14-18. Corpus sat gracile porrectumque; pedes longi, postici saepe axillas paulo superantes, antici oculos superantes. Cauda longa, interdum corpore duplo longior. Longitudo: $164 \mathrm{~mm}$.

\section{Synonymie.}

Lacerta nigropenctata Duméril et Bibron, Erpétologie générale V, p. 190. - C. et $\mathbf{A u g .}$ Duméri l, Cat. méth. collect. Rept., 1. Livraison, p. 119. Paris 1851. - Schinz, Europ. Fauna, Bd. II. S. 16. Stuttgart 1840. - Leunis, Synopsis d. drei Naturreiche I. S. 311. 1860.

Tropridophotis Schreibersi Fitzinger, Versuch einer Geschichte d. Menagerie d. ̈̈sterr. k. Hofes in: Sitzungsber. d, k. Akad. d. Wiss, math.-naturw. Klasse, Bd. I. S. 654 ").

Notophotis nigropunctata Bon aparte, Amphibia curopaea in: Mem. Accal. Scienze di Torino, Seric II. T. II. - Gray, Cat. Liz. Brit. Mus. London 1845, p. 35. - De Betta, I Rettili ed Anfibi del Regno della Grecia in: Atti del'Ist. Ven. sc. lett. ed arti, Ser. III, vol. XIII. 1868, - Schreiber, Herpetologia europaea, S. 452. Braunschweig 1875. - v. Bedriaga, Die Amphibien und Reptilien Griechenlands in: Bull. de Moscou 1881, No. 3, S, 72.

Körpergestalt und Gröbe.

Der gewöhnlich ziemlich schlanke und gestreckte, mitunter etwas gedrungene Köörper ist von oben leicht zusammengedrückt. Der Kopf lang, flach und wenig oder gar nicht vom

1) Darüber, ob Lacerta (Tropidophotis) Schreibersii bei Schinz (Furop. Fauna, II. S, 28) mit A. nigropunctatus identisch ist, kann ich kein Urteil fallen; namentlich ist es das Farhenkleid und die Fundortsatgahe sKorfue, welche den Leser stutzig machen; es ist leicht möglich, daf larunter das Junge von Lac. viridis oder vielleicht die spanische Acanthodactylus-Art »vulgaris \& gemeint worlen ist. 
Hitlse alhgesetzt; die latnge, ziemlich stark zugespitzte Schnauze ist mit nahezu senkrecht abfallenden Seiten und seitlich liegenden kleinen Nasenöffnungen versehen; die Wangengegend ist schwach backenartig aufgetrieben. Die Vorderbeine reichen bei den, mir zu Gebote stehenden Männchen bis zum Hinterrand der Frenalen, die hinteren überragen die Achseln oder zum mindesten reichen sie bis an dieselben (nach Schreiber). Der Schwanz ist an seiner Wurzel zusammengedrückt. etwa vierseitig, allmählich sich zuspitzend, fast so Jang als die doppelte Länge von Kopf und Rumpf.

Mąie in mm. - Männchen aus Görz: Totallänge 164; Länge des Kopfes 15, des Halses 9, des Rumpfes 40, des Schwanzes 109, der Vorderextremität 19,5, des Vorderfufies 9,5-10, der Hinterextremität 32, des Hinterfulies 16,5; Höhe des Kopf's 6,7, Breite des Kopfes 9,5, des Pileus 6,3; Umfang des Kopfes 28, des Halses 27, des Rumpfes 29.

Männchen aus Korfu (Mus. d'hist. nat. in Paris: No. 1837): Totallänge 150; Länge des Kopfes 13,5, des Halses 7 , des Rumpfes 47,5, des Schwanzes 89, der Vorderextremität 19, des Vorderfufies 9,5, der Hinterextremität 30,5 , des Hinterfufes 16; Höhe des Kopfes 7 , Breite des Kopfes 9, des Pileus 7; Umfang des Halses 23,5, des Rumpfes 26,5.

Körperbedeckung.

Der Beschreibung der Körperbedeckung bei dieser Species habe ich kaum etwas hinzuzufügen, nur muls ich in 'Zusammenhange nochmals auf die Unterschiede aufmerksam machen, welche mir zwischen dieser und den A. Fitzingeri und moreoticus als bedeutend aufgefallen sind. Vor allem ist da die verschiedene Grölie des Occipitale zu erwähnen; A. nigropnnctatus zeigt ein grolies Ilinterhauptsschild, das ein Dreieck mit nach vorn gekehrter abgestutzter Spitze und in der Regel schwach gebogenem Linterrande bildet; das in der Regel kürzere und schmälere Interparietale ist nach vorn in eine kurze, stumpfwinkelige, uach hinten aber in eine lange, an der Berührungsstelle mit dem Occipitale abgestutzte Spitze ausgezogen. Bei den hier zum Vergleich gezogenen A. moreoticus und Fitzingeri erreicht die Occipitaltafel die Länge des Interparietale nicht, im Gegenteil das letztere ist gewöhnlich ziemlich bedeutend länger und bei Fitzingeri ebenso breit oder nur etwas schmbäler als das Hinterhauptsschild. Die beiden Parietalschilder sind grölier als die fünfseitigen, in der Mittellinie zusammenstobenden Frontoparietalia und dabei um ein Drittel länger als breit; ihr Hinter- und Auljenrand vereinigt sich im Bogen, ihr Vorder- und Innenrand besteht aus vier, unter stumpfem Winkel zusammentretenden Kanten, wolurch die Schilder eine unregelmäfige, schwer zu beschreibendo Form erhalten; die längsten inneren Kanten grenzen an das Occipitale und an die Frontoparietalia, während die vordere und innere Kante an das Interparietale und das ziemlich grofie 


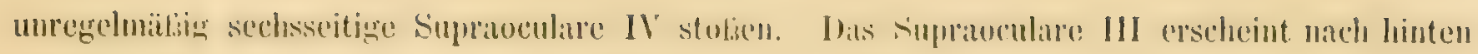
zu schmäler als vorn und besitzt vier Kónten, währendem das davordiegende Supraoculare im ganzen eher dreiseitig, nach vorn stark verschmälert erscheint und mit seiner abgestutzten Spitze an das frontonasale stölit; sowohl dieses, als auch das vorher erwähnte Schild erscheint von den 5 bis 6 kleinen schmalen Supraciliaren durch eine Reihe körnerartiger, durch ihre starke Wölbung viemlich aufillender Schuppen getrennt; dis vorderste, unansehnliche, meist fünfliantige obere Augenschild endlich befindet sich in einem engen liaume zwischen dem Supratoculare II, dem lïngeren als breiten, fünf- bis sechsseitigen, in der Mittellinie mit dem gleichmamigen Schilde der entgegrengesetzten Seite zusanmenstolienden firontonasale und dem grolsen vier- bis fünfseitigen Freno-oculare. A. nigropunctatus unterscheidet sich von den übrigen anverwandten Species durch die Grölise der Frontaltafel; bei nigropunctatus nämlich ist das Frontale verhältnismälisig sehr lang, nach vorn deutlich erweitert und weiter als nach rückwärts vorgezogen; ich werde später (ielegenheit haben zu zeigen, dalis sowohl bei morcoficus als auch bei Fitzingeri das bedeutend kürzere Frontale vorn und hinten ziemlich gleich breit ist und dati dessen Vorderende äulierst wenig nach vorn ausrezogen erscheint; bei nigropunctutus treten sowohl die vorleren, als auch meistens die hinteren Frontalseiten unter stumpfem Winkel zusammen; in seltenen Fällen ist das Frontale hinten als ziemlich grolie Spitze zwischen die Frontoparietalia eingefügt; die lingsten, an die Palpebralscheibe grenzenden Seiten sind nicht ganz gerade, sonderu schwach bogenförmig. Das grolie Internasale mit seinem öfters abgerundeten, zwischen die Supranasilen eingeschobenen Vordereck und seinen, unter stumpfem Winkel zusammenstof enden Hinterseiten ist breiter als lang, im ganzen rhombenfürmig. Das deutlich nach oben über⿳rewölbte Rostrale ist ziemlich grols, vom Internasale in der Regel durch die in der Mittellinie zusammentreffenden Supranasalia gretrennt. Die deutlich sichtbaren seitlich liegenden Nasenöffnungen sind über der Oberkante des Supralabiale I gelegen und erscheinen vorn von den Supramasalen, hinten von 2 kleinen, übereinander gestellten Nasofrenalen begrenzt. Zwischen diesen Tafeln und dem bereits erwähnten Freno-oculare befindet sich ein großes Frenale eingeschoben, das zum Teil dem zweiten und zum Teil dem dritten Supralabiale aufgesetzt ist. Supralabialschilder finden sich meistens jederseits 7 , obwohl ihre Zahl sich nach Schreiber manchmal auch bis 9 steigern kann, von denen im ersteren Fall die vorderen 5, im letzteren abel die vorderen 6 als Supralibjalia anteriora bezeichnet werden kïmnen. Selten kommt das vierte oder siebente Lippensehild unterhalb des Auges zu liegen, gewöhnlich bildet das sechste Sichild den unteren Augenrand und zcichnet sich sowohl durch seine bedeutende Länge, als auch dadurch aus, dalis seine obere Kante bogenförmig ausge- 
schnitlen und vorn mit einem, übrigens auch am länglichen schmalen Praeoculare dentlich sichtbaren leistenartigen Vorsprung versehen ist. Die schlafe ist mit ziemlich lileinen, unregelmäfỉg fünf- oder sechsseitigen Schildchen bedeckt, dic in der Regel ein, durch seine Grölíe hervortretendes Massetericum einschliclien; bei gunstiger Beleuchtung nimmt man walu, dal: die Temporalia, namentlich die hinteren, nicht nur eine Wölbung, sondern auch eine Spur von Kiclen tragen. Ein grobes, meist bogenförmig gekrummtes Ohrschild, das an seinem hinteren Rande eine ziemlich deutlich vorspringende Kante aufiweist und vom Ohrand durch eine Reihe körnerartiger Schüppchen getrennt erscheint, ist stets vorhanden. Am Unterkiefer sitzen jederseits 6-7 lange, aber sehr schmale Sublabialia, im Kinnwinkel ein ziemlich grolies Mentale und 5 bis 6 Paar Submaxillaria, von denen die 3 vorderen Pare zusammenstolisen und die nach hinten liegenden successiv an Grötse zunchmen. Die durch winzig kleine Schüppchen bedeckte und deshalb deutlich sichtbare Kehlfurche trennt die länglichen Kinnschuppen von den bedeutend breiteren Halsschuppen, welche von einen, aus 8 bis 9 grolien, an ihren freien Rändern abgerundeten und aufeinander geschindelten Schidern bestehenden, schwach gezähnelten Collare begrenzt sind. Hinsichtlich der Gestalt und Grölıe der Rumpfschuppen zeigt diese Art cinige Ëigentümlichkeiten, welche nicht übersehen werden dürfen, sobald es sich um die Determination der Algivoides handelt. Nigropunctatus ist nämlich mit einer heterogenen Beschup pung versehen; ihre am Rücken rhombisch geformten, diagonal gekielten und mit abgerundeter, nach hinten geliehrter spitze versehenen schuppen gehen am Nacken in nahezu gerundet sechseckige, durch ihre Kiele in zwei ziemlich gleiche Hälften geteilte Schuppen über, die breiter als lang sind; gegen die Caudalwuzel hin werden die Dorsalschupen allnählich länger als breit, nehmen entschieden eine rautenfürmige Form an und erhalten ein allerdings liurzes, aber dennoch ziemlich gut erkenubares winkelig zugespitztes Hinterende, das am s'chwanze deutlicher hervortritt. Nach den Rumpfseiten zu erscheinen die schuppen bedeutend schmäler und verkürzen sich nach unten dermalien, daf etwa 2 bis 3 Querreihen von Schuppen auf die Länge eines Ventralschildes kommen, wïhrend die Rückenschuppen mindestens ebenso lang sind wie die Banchtafeln (vergl. meine Taf. Fig. 17); aulierdem muli noch hinzugefügt werden, dadj die Flankenseluppen die rautenförmige Gestalt verlieren, dals sie lïnglich, schmal, nach hinten bald zugrespitzt, bald gerundet und somit unregelmäliag geformt sind und endlich, dalj sie mit ihren nach rückwärts gerichteten 'Teilen nicht übereinandergreifen, wie es dort der Fall ist. Auffallend klein erscheinen die gekielten Schuppen an den Halsseiten und die schilderïhnlichen Schuppen etwas vor der Insertionsstelle der hinteren Gliedmaßen und hinter der Wurzel der Vorderbeine. Der Rumpfgürtel besteht in der Mitte des Rückens gewöbnlich atus 11 gröferen Dorsalschuppen, 
6 bis 7 schmäleren Schuppen auf jeder Rumpiseite und aus 6 Ventraltafeln, vou denen die 2 mittleren schmäler als die ihmen benachbarten sind. Am Rücken zühle ich 40 und am Schwanze etwit 85 Querschuppenreihen, währonddem die Zihlı der aus kleinen Schuppen bestehenden transversalen Reihen an den Seiten und zwar zwischen den Ansatzstellen der Gliedmalien sich anf 52 und etwas darüber belaufen kann. Die oben in eine Spitze ausgezogenen Schwanzschuppen sind deutlich gekielt und durch dic Kiele in zwoi gleiche Hälften greteilt. Oberhalb erscheinen die Beine nit scharf gekielten Schuppen, uach vorn hin mit sehr stark in die Quere erweiterten Tafeln und endlich nach hinten zu mit winzigen körnerartigen Schuppen bekleidet. Das sehr breite, oftmals halbkreisförmige Anale ist mit Ausnahme des freien Hinterrandes ganz von 8 bis 10 unregelmäß̊g gestalteten Schildchen gesäumt. Es sind 26 Querreilien von Bauchtafeln vorhanden.

Schenkeldrüsen und Bezahnung.

Die, wie Schreiber (1. c.) angiebt, »in der Praeanalgegend einander oft stark genäherten Schenkelporen betragen in der Regel etwa 15 (14 bis 18) in jeder Reihe « Die mir zur Verfügung stehenden Stïcke aus Görz und aus Korfu besitzen jederseits 16 und 17 Drusen oder Poren. - Es sind keine Gaumenzähne vorhanden.

F a r benkleid.

Dis Kolorit des Oberkörjers ist ziemlich monoton. (irundfarbe bräunlich oder bald dunkler oder heller olivengrün, an Kopf und Rumpf teilweise mit Kupferglanz oder mit grünlichem oder rötlichem Metallschimmer überflogren, der besonders lebhaft zur schönen 'Jahreszeit bei den mänulichen Individuen zu Tage tritt. Oberhalb uniform kolorierte Stücke scheinen selten vorzukommen, wenigstens babe ich nur wenige solche, und zwar nur aus Korfu stammende Exemplare zu sehen (ielegenheit gehabt; meistens erscheinen Kopf, Rumpf, Extremititen und Caudalwurzel mit zerstreuten dunkelbraunen oder schwarzen Flecken versehen, welche nebenbei bemerlit, kleiner als die Schuppe selbst sind; diese dunklen, äfters an den Schwanzseiten vou blïulich- oder grünlichweilsen P’unktchen begleiteten Flecken verlieren sich allmählich am Schwanze, indem die dunkle Tinte der Flecken in diejenige des Untergrundes überzugehen pHtegt; zum Teil weililich gefärbte Schuppen gesellen sich aber anch mittuter den dunkleren Rumpfschuppen bei. Die Leibesseiten erscheinen hin und wieler weil oder bläulichweib gepunktet; bei anderen Individuen wiederum ist die Farbe der Fleckchen etwas heller, ins (irau spielend, mit eingemengten rostbrimn oder rötlich gefleckten śchuppen, wodurch dic Leibesseiten schön gesprenkelt erscheinen; gegen die Bauchgrenzen nimm die Zihl der grell kivlurierten schupgen dermalien zu, dals dieselben total ziegelrot werden. Diese Zierde kommt 
namentlich denjenigen Mämnchen zu, deren Unterseite der Oberschenkel und des Batuches ziegelrot, resp. rotgelb gefärbt oder überflogen und deren Unterkopf intensiv blau koloriert ist; mitunter aberzichen sich nicht nur Kehle, Hals und schwanzunterseite mit Blan, sondern auch alle ibrigen unteren Körperteile und zwar bei beiden Geschlechtern. Es mufo hinzugefügt werden, dati bei den rotbauchigen Exemplaren die vorderen Lrusttafeln blau oder blau und rötlich gefleckt erscheinen, dals die medianen ventralen Schilder seitlich blau grerändert und dals die T'afeln am Unterschenkel umgekchrt bläulich gefürbt und rötlich umsäumt sind, ferner diıt das Anale entweder auf blïulichem Grunle äuferst zart rötlich gefleckt oder in toto rötlich erscheint und cndlich, dafà die Schwanzseiten in der praeanalen Gegend mit rötlichem Anflug versehen sind. Die größeren Extremitäten-Schilder, die Kopfseiten, die Submaxillaren sind dunkelbraun gefleckt, die Kopfoberseite zierlich dunkelbraun gepunktet.

Vorkommen.

Diese Species hat ein ziemlich beschränktes Wohngebiet. Nach Schreiber (1. c. S. 454) soll sic bei Görz nicht selten sein und auch in Istrien und Fiume vorkommen. „Da das T'ier«, sagt der Verfasser der »Herpetologia europaea , "aluf den crsten Anblick mit muralis und vivipara sehr ähnlich ist, so mag es häufig übersehen worden sein, und glaube ich keinen so grolsen Fehlschlut zu machen, wenn ich dasselbe vom südlichen Illyrien angefangen durch ganz Istrien, Dalmatien und Griechenland vorkommend vermute, obwohl es sich wahrscheinlich mehr an die Küstengegend halten dürfte. »Diese Art«, fügt Schreiber hinzu, »bewohnt vorzüglich steinige, mit Buschwerk bewachsene Standorte und findet sich besonders gern in alten Ölbäumen. Daf Dr. E. Schreiber der erste gewesen ist, der diese Algiroides-Art bei Görz entdeckt hat, brauche ich wohl kaum hinzuzufügen; bis zum Erscheinen der Herpetologie Europas war das Tier nur aus Fiume, Dalmatien ${ }^{1}$ ) und von den Jonischen Inseln (Fitzing er), namentlich aus Korfu (Bonaparte, Duméril, Bibron, De Betta) bekannt. Nach den Exemplaren zu urteilen, die ich im Athener Museum zu sehen Gelegenheit hatte, kommt sie auch in Akarnanien vor.

\section{Algiroides moreoticus Bibr., Bory de St. Vincent 1832.}

Char. - Sc. frontale breve et proportionaliter Jatum. Collare 7 -9 scutellis compositum. Squamae dorsales squamis lateralibus fere aequales, sed is paulo latiores. Squamae in ciudae basi inferiores acuminatae. Sc, anale duabus squamarum seriebus arcuatis circundatum. Pori

1) Jan, Cenni sul Museo Cirico di Milano, pag. 40. Milano 1857. 
femorales utrinque 12-15. - Corpus robustius breviusque quam in Alg. Fitzingeri. l'edes longi, robusti, postici axillas attingentes vel saepius paulo superantes, antici oculos superantes, scutum frenale circiter attingentes. Cauda sat brevis, corpore paulo longior. - Longitudo $110 \mathrm{~mm}$.

\section{S ynony in e.}

Algyroides moresticus Bibron et Bory de St. V incent, Expédition scientifique de Morée III, pag. $67, \mathrm{pl} . \mathrm{IX}$, fig. $50 a, \mathrm{~b}, \mathrm{c}$.

Notopholis moreotica Bou ap arte, Iconogratia della Fauna italica II. Tab. Fig. 4. Roma 1832 -1841; Amphibia europaea in: Mem. Accad. Sc. di Torino, Serie II, Tom. II. pag. 385. - Gray, Cat. Liz. Brit. Mus. p. 35. London 1845. - De Betta, I rettili. ed anfibi del Regno della Grecia in: Atti del $R$. Istituto Ven. di sc. lett. ed arti, Vol. XVII, Ser. III. - Schreiber, Herpetologia europaea, pag. 452. - v. B edriaga, in: Bull. de Moscou 1881, No. 3, S. 73.

Lacerta moreotica D uméril et B ibron, Erpétologie générale, t. V, 1. 194. - Schinz, Europ. Fauna, II. S. 29 (Eidechse von Morea, L. moreotica; Moreotische Kielechse). ${ }^{1}$ ) - C et Aug. Duméril, Cat. méth. collect. des Rept. p. 57. Paris 1851. - Leunis, Synopsis d. Naturgesch. d. Tierreichs I. S. 311.

Im alltäglichen Leben pflegt man gewöhnlich die Tiere als »seltene« oder shäufig vorkommende Arten zu bezeichnen und ich habe mir öfters die Frage aufwerfen müssen, ob wir uns denn auch immer darüber Rechenschaft ablegen, was wir eigentlich unter der Bezeichnung »seltene« Form meinen. Für mich persünlich giebt es nur selten gewordene, individuenarme Species, welche einstmals in grölierer Anzahl existiert haben mügen und durch nachträglich sich ausgebildete oder eingewanderte neue Formen verdrängt und dem Artentode ausgesetzt worden sind, oder aber solche Arten, welche lediglich in unseren Museen selten vertreten sind. Namentlich gelten, wie es scheint, letztere in den Augen der meisten als »seltene Arten « und das mit Unrecht, denn viele von diesen mügen sehr zahlreich in ihrem, in manchen Fällen allerdings sehr beschränkten und von uns weniger besuchten Verbreitungsbezirk vorkommen. Die Art "Fitzingcri« gilt beispielsweise als »selten « und würde allerdings einem Forscher, welcher sich die Aufrabe stellen sollte, die Fauna Korsikas oder Süd-Sardiniens zu erforschen, als solche

$\left.{ }^{1}\right)$ Es ist mir unerklärlich, weshalb Schinz $\boldsymbol{L}_{\text {. }}$ moreotica zweimal im obigen Werke anführt; auf S. 16 lesen wir, daf die "Eidechse von Morea* mit Alg. moresticus B ibr., Bory identisch ist, auf S. 29 aber wird $\gg I$. moreotica ehenfalls mit einem anderen deutschen Namen belegt und mit Notopholis morcotica B on a p. thin Alyiroides morcoticus Bonap. identifiziert! 
erscheinen, obschon das Tier in seiner eigentlichen Heimat, d. h. im Norden Sardiniens eine höchst gemeine Erscheinung ist. Es ist Jeicht möglich, daf auch Alg. moreoticus ebenfalls nur deshalb als höchst selten betrachtet wird, weil nur wenige unserer Museen sie aufuweisen haben und sogar das Pariser Musée d'hist. nat. sich bis vor kurzem im Besitz nur eines einzigen Individuums und zwar des Bibron, Bory de St. Vincentschen Originalexemplares befand. Neuerdings sind die Sammlungen Berlins, Genuas und meine eigene von Marquis G. Doria durch einige Stücke aus Zante bereichert worden; diese Exemplare aber unterscheiden sich in manchen Stücken von der griechischen, binnen]ändischen, typischen Form und scheinen den Übergang derselben zu Alg. Fitzingeri zu vermitteln; ich möchte mir erlauben diese insulanische Form zu Ehren ihres Entdeckers als Var, oder Subsp. Doriae zu benennen.

Algiroides moreoticus sp. ist wohl eine gute, wenn auch mit der Art »Fitzingeris und nicht mit smigropnetatus sehr nahe verwandte und ähnliche Species; denn abgesehen von den Körpermalien und der Körpergestalt, welche allerdings eher denjenigen bei nigropunctatus gleichen, zeigt sie mehrere Kennzeichen, so namentlich in betreff der äußeren Körperbedeckung, welche sich bei Fitzingeri wiederfinden lassen.

\section{Allgemeine Körpergestalt und Gröbe.}

Alg. morcoticus ist gröber als Alg. Fitzingeri, kleiner aber als nigropunctatus und unterscheidet sich von beiden dadurch, dał der Schwanz kürzer ist, namentlich kürzer als es bei Fitzingeri der Fall ist. In Bezug auf ihre Kopfgestalt steht diese Art A. nigropunctatus näher, indem moreoticus einen bedeutenderen Breitendurchmesser zeigt als die zuletzt genannte Art, jedoch scheint mir bei der Art »moreoticus * der Kopf kürzer und ihre Schnaze viel weniger stark verengt und zugespitzt zu sein, als bei allen übrigen Algiroides-Species; der gröLite Breitendurchmesser geht durch die Backengegend. Da der Schnauzenteil verhältnismäligig kurz ist, so verengt er sich von den Augen an nach vorn ziemlich schnell, olne dadurch von der Seite zusammengedrückt zu erscheinen; die Schnauzenkante ist abgerundet; die Kolfflecke neigt sich einerseits gegen die Schnauzenspitz', anderseits gegen den Nacken hin sanft nach abwärts, so daf der grülite Höhendurchmesser des Kopfes durch das Hinterende des Frontalschildes rurchgeht und zwischen den Palpebralscheiben zu suchen ist. Die Kopfseiten fallen ziemlich steil ab, dic Zügelgegend ist der Lünge nach schwach vertieft; der Discus palpebralis ist flach. Die kleinen Nasenlöcher sind seitlich gelegen und die grofien ovalen Ohröffnungen weit nach unten gerückt. A. moreoticus ist im ganzen weniger schlank als $A$. Fitzingeri; der Rumpf ist relativ breiter, jedoch kürzer als bei der zuletzt genannten Art. Der allmählich in eine ziemlich kurze Spitze ausgezogene Schwanz erreicht bei weitem nicht das Längenmabs des Schwanzes bei der kleineren Species "Fitzingerik 
oder bei $A l$. vigropmetutus und ist wenig linger als der Körper. Die Vorderbeine ragen über die Augen hinaus, rreichen jedoch die Nasofrenalen nicht, die Hinterbeine reichen etwas über die Achselu hinaus. Im die gegenseitigen Mal:verhältnisse der einzelnen hörperregrionen bessel' übersehen zu können, lasse ich hier cine Zusammenstellung derselben folgen:

No. 2675 (Pergament-Litikette), No. 2308 (Büchsen-Etikette) aus dem Musée d'hist. nat. in Paris. Originalexemplar. - Totallïnge $110^{1 / 2} \mathrm{~mm}^{\mathrm{1}}$ ). Länge des Kopfes 12, d. Rumpfes $32^{1} / 2$, d. Schwanzes 66 , d. Vorderextremität $15^{1} / 2$, d. Vorderfulies 6 , d. Hinterextremität 27, d. Hinterfufes $13 \mathrm{~mm}$. Grölte Breite d. Kopfes 7, Umfang (l. Kopfes $221 / 2 \mathrm{~mm}$.

Äußzere Körperbedeckung (vergl. meine Taf. Fig. 30 und 32).

Hier kann ich mich kurz fassen, indem ich nur einige gewichtige Unterschiede zwischen dieser Art und Alg. Fitzingeri gefunden habe; die meisten Charaktere der zuletzt genannten Species sind auch hier vorhanden. Das kurze, aber ziemlich breite Occipitale erscheint als gleichschenkeliges Dreieck mit leicht abgerundeten Seiten, dessen Spitze nach vorn gerichtet ist, und das mit seincr Basis an die Nackenschuppen grenzt. An dieses Schild stofen seitlich die lïngeren als breiten, sechskantigen, hinten leicht abgerundeten und nach innen zu sich berührenden Parictalia. Occipitale und Interparietale erscheinen folglich voneinander, wenn auch nicht yollständig, getrennt; letzteres ist auffallend schmal, vierseitig und nach hinten in eine scharfe und lange Spitze ausgezogen; in Bezug auf seine Grölie muf hinzugefügt werden, dab seine Länge die Breite um das Doppelte überschreitet, und dafis es gut anderthalbmal so lang ist als das Occipitale. Während die übrigen paarigen Pileustafeln von gewöhnlicher Bildung sind, zeichnet sich das Frontale, dadurch aus, dak es breit und kurz ist; nach hinten erscheint us mälijg erweitert, mit medianwärts vortretenden, abgerunleten, seitwärts aber ausgebuchteten Vorderkanten und bogenförmig ausgerandeten lateralen Ründeru versehen, sein hinterer Teil ist als mäßsige Spitze zwischen die Frontoparietalia eingeschoben. Die 2 mittleren Suprarbitalen sind nach aulien von in einer Reihe stehenden Kürnerschuppen umgeben und erscheinen somit von den länglich-schmalen Supraciliaren getrennt. Die Schläfe ist mit 16 bis 20 grölıeren und kleineren, zum Teil schwach geschindelten, fünf- und sechseckigen Schuppen bedeckt; die kleineren Schuppen sind gekielt, oder lassen doch wenigstens unter der Lupe und bei grünstiger Beleuchtung die Spur eines Kieles erkennen. Bei dem von mir untersuchten Stück dieser Art

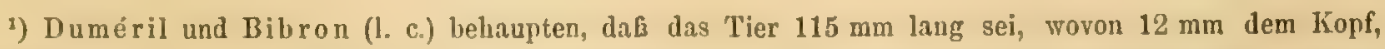
$30 \mathrm{~mm}$ dem Rumpf und $65 \mathrm{~mm}$ dem Schwanz zukommen, jedoch wenn wir die drei Zahlen adlieren, erhalten wir 107 nicht $115 \mathrm{~mm}$. Nach Schreiber (IIerpetologia europaea, pag. 451) mift die Totallïnge der Art "morenticuse 13 lis $16 \mathrm{~cm}$. 
grenzt sich das Massetericum nur auf der einen Seite ab; das bohnenförmige Tympanicum dagegen kommt an beiden Seiten zum Vorschein; auferdem muß erwähnt werden, daßs die seitlichen, nach aulien liegenden Parietalränder von grölieren Schildern begrenzt werden und daf diese in der Schläfenregion liegren. Hinter dem seitlich liegenden Nasenloche finden sich 2 übereinander gestellte kleine Nasofrenalia; auf diese folgen nun die Frenalia und Irenoocularia, welche von gewöhnlicher Bildung sind und durch das von 2 kleinen Tafeln hegleitete Praeoculare von dem Suboculare und dem Augenrande getrennt erscheinen. Auf der einen Seite zähle ich :3 auf der anderen 4 rordere Oberlippenschilder, ferner ein grölseres Suboculare, 2 ziemlich ansehmliche Supralabialia posteriora, 5 bis 6 nach unten immer kleiner werdende Postocularia, welche die Orbitalhöhe von hinten umsäumen und endlich 6 bis 7 Sublabialia und 6 Par Submaxillaria. Die Kehlfurche tritt deutlich hervor; das gezähnelte Collare besteht aus 7 Tafeln, deren mittelste grölier ist, als die daranstolienden. Die eigentlichen Halsschuppen sind gut doppelt so breit als lang und scheinen mir seitlich Spuren von Kielen zu zeigen, welche allerdings nur bei günstiger Beleuchtung sichtbar sind. Der Vorderrand der grofsen, eher runden als ovalen Ohrüffuung ist mit winzigen Schüppchen besetzt. Was die Schuppen der Rumpfoberseite anbelangt, so mufs vor allem bemerkt werden, daf die des Rückens denen der Seite an Gröbe nahezu gleich liommen; letztere sind allerdings etwas schmäler als erstere, hinsichtlich ihrer Länge aber von denen des Rückens nicht verschieden und sind ebenso lang als die Ventraltafeln. Es ist erwähnenswert, daf nur diejenigen Schuppen der Rumpfoberseite, welche an die Hinterränder der Pileusschilder grenzen, klein erscheinen, während alle übrigen Nackenschuppen beinahe ebenso grof sind wie diejenigen am Rücken. Sämtliche Rumpfschuppen, mit Ausnahme der Flankenschuppen und derjenigen fast körnerartigen Schuppen welche die Halsseiten bedecken, sind rhombisch, groß, diagonal gekielt, geschindelt und ziemlich spitz endend (vergl. meine Taf. Fig. 30); insbesondere scharf treten die Kiele an denjenigen Partien auf, welche sich oben zwischen den Vorder- und Hinterextremitäten befinden. Gegen die Bauchgrenzen hin sind die Schuppen stellenweise weniger deutlich oder auch gar nicht grekielt, auch büssen diese Schuppen ihre regelmätßige rautenförmige Gestalt ein, indem sie nach hinten zu mäbig erweitert und leicht zugerundet erscheinen. Die Rumpfschuppen sind in 33-34 Quer- und 20-23 Längsreihen angeordnet. Da die Rumpfseitenschuppen an den Bauchgrenzen grofs und mitunter flach sind, so ist keine scharfe Abgrenzung zwischen diesen und den äuferen Bauchschilderreihen vorhanden, darin liegt eben der Hauptunterschied zwischen der Art "morroticus « und Alg. nigropunctatus. Die Bauchschilder sind in 22-24 Querreihen und in 6 Lüngsreihen angeordnet; das Brustdreieck ist nicht scharf abgegrenzt, es wird aus 
etwa 7 'Tafehn lionstituiert; sïmlliche Ventralplatten sind meht oder weniger dentlich geschindelt und mit abgerundeten Ecken verschen; die mittleren und äubersten Schilder stehen an Breite den dawwischenliexemlen nich, nanentlich sind die zuletzt genannten unansehnlich, sie sind nahezu dreimal so klein als die daranstolienden. Das Anale ist kleiner als bei nigromuctutus, vorn ist es von 2 länglichen 'Tafeln begrenzt, seitlich aber von 2, aus je 4 Schildern bestehenden Reihen gesiumt. Es ist ferner bemerkenswert, dal: die Schuppen an der Unterscite der Schwanzwurzel rhombenfürmig und sehr stark gekielt und atserdem noch mit ciner scharf ausgeprïgten Spitze versehen siud. Die Schuppen auf der Schwanzoberseite sind im gamzen, sozusagen, leicht modifizierte Rückenschuppen, nur sind sie ctwas länger und an den Enden mehr zugespitzt; in der Mittellinie des schwanzes sind die Schuppen am Hinterrande in eine ziemlich lange Spitze ausgezogen und, da die liele sich durch dic Mitte der Schuppen zichen, in zwei gleiche Hälften geteilt; die übrignen Schwanzschuppen aber sind ungleichseitig. Gegen das Schwanzende hin erscheinen übrigens nahezu alle Schuppen grleich- oder beinahe gleichseitig; sie werden auch schmäler oder länger und erhalten aulierdem eine kürzere oder stumpfere Spitze. Es sind 69 Schwanzringel vorhanden. Auf der oberen Seite der Extremitïten sind die Schuppen deutlich gekielt; an den Sohlen gleichfalls.

Schenkeldrüsen und Bezahnung.

An der Unterseite des einen Schenkels sind 13, an der Unterseite des anderen aber nur 12 Drüsen; die Reihen sind in der Praeanalgegend durch einen engen Zwischenraum voncinander getrennt. - Da das mir von Prof. L. Vaillant zur Untersuchung gütigst anvertraute Originalstuck, obschon sehr defekt, dennoch zu wertvoll ist, un noch mehr beschädigt zu werden, habe ich nicht gewagt, die Rachenhöhle zu untersuchen und mufs mich mit der Bemerkung Bibrons und Borys begnügen, wonach die Pterygoülal-Zähne bei Algiroides morcoticus fehlen würden.

Farbenkleid.

Da das mir vorliegende, vor beinahe 60 Jahren von der Morea-Expedition mitgebrachte Originalexemplar stark ausgeblichen ist und namentlich in Bezug auf die Zeichnung viel zu wïnschen übrig lälït, so bin ich leider gezwungen, die Beschreibung des Farbenkleides aus der Expétologie générale und aus dem zoologrischen Berichte der Expédition scientifique de Morée« (vol. III, p. 67) zu entuehmen.

Duméril, Bibron und Bory de St. Vincent geben an, dali sowohl die Kopfoberscite sowie der Nacken, die Rückenregion und die Oberseite der Gliedmalien und des Schwanzes cine einförmige olivenfarbene oder olivengrune Tinte aufweisen und dals jederseits eine grelbe 
oder falbe Linie sich hinzieht, die oberhalb der Ohröflnung ihren Ursprung nimmt, um sich an der Schwanzwurzel zu verlieren. Nach Biblon und Bory sollen dic Rumpfseiten auf schmutzig weiliem Fond mit likeinen schwarzen Punkten besäet sein, hingegen nach Du méril und Bibron sollen bei dem Tierchen Halsseiten und Flanken schwarz gefärbt und weib gefleckt sein; auch sollen einige schwarze Flecken auf den Lippenschildern zerstreut sein. Laut diesen Forschern sollen Kehle und Brtist sowie anch alle anderen unteren Körperteile weiblich erscheinen; jene aber geben an, dalj Hals und Abdominalregion grünlich-grau seien. Der fünfte Band der generellen Herpetologie ist bekanntlich etwa sieben Jahre später als der Bericht der Morea-Expedition erschienen und es ist daher leicht möglich, dala das, von den Mitgliedern der Expedition erbeutete Stück bereits verfürbt in die Hände der Verfasser der » Erpétologie générale« gelangt ist.

\section{Fundort.}

Über den Fundort teilen Bibion und Bory de St. Vincent folgendes mit: „Cet élegant saurien a été pris dans un lieu herbeux découvert, mais un peu humide, sur le plateau de Koubeh«. Auf der Insel Mykonos, wo das Tier nach Erhar ${ }^{1}$ ) häutig vorkommen soll, habe ich es nicht konstaticren können, glaube aber Algiroides moreoticus, aus dem TaygetosGebirge stammend, im Museum zu Athen gesehen zu haben.

Subsp. vel Var. Dorice m.

Dasjenige Exemplar von Alg. moreoticus, welches mir Marquis G. Dolia von der Insel Zante zu senden die Freundlichkeit hatte, weicht in einigen Stücken von dem Originalindividuum, das von dem Festlande Griechenland- stammt, ab. Ein eingehender Vergleich dieser Exemplare hat gezeigt, daf3 die insulanischen und binnenländischen mmoreoticus nicht blof in den morphologischen Merkmalen, sondern auch in der Beschuppung voneinander abweichen: bei Alg. morcoticus aus Zante sind die Vorderbeine etwas kürzer, die hinteren aber länger als bei den binnenländischen; die Stücke aus Zante sind von etwas schlankerem Körperbau und im allgemeinen eher der sardinisch-korsikanischen Art »Fitzingeri« ähnlich. Das Interparie. tale ist ziemlich breit und hinten abgestutzt; das Massetericum tritt auf beiden Schliafen deutlich hervor. Die auch an den Bauchgrenzen deutlich grekielten Rumpfschupen scheinen mir etwas kürzer zu sein als bei der typischen Form; da die Schuppen auf der Schwanzoberseite in eine ziemlich kurze Spitze ausgezogen sind, so erscheinen sie gleichfalls kürzer als bei der letzteren; das schwach gezähnelte Collare besteht aus 9 Tafeln; auch die Schenkeldrüsenzahl ist etwas größer, denn es sind jederseits 15 Drüsen vorhanden. -- Was die Fürbung anbetrifft, so sieht

1) Fauna d. Cykladen, I. Leipzig 1858. 
die neue Form "Doriae eher der Species s Fitzingeri« abulich; die der typischen Form zukommenden hellen Streifen sind nimmlich bei ihr nur schwach ausgeprïgt und sind grüulichgrau, nicht gelb; diese Streifen fangen an den Hinterenden der Palpebralscheiben an, ziehen sich am Ausenrande der Parietalia hin und gehen auf IIs und Vorderrücken über; gegen die Schwanzwurzel hin sind sie litum sichtbar; vom Unterrando der Augenhöhle entspringt jederscits eine Reihe blïulichgrauer, kleiner Flecken, welehe längs der Körperseiten bis auf den Schwanz verlatufen; vor und oberhalb der Wurzel der Vorderextremititen gesellen sich diesen Flecken mehrere andere Ocelli hinzu. Diese Streifen und Fleckenreihen grenzen, wenn auch nicht scharf, die liumpfoberseite in 3 longitulinale Hauptzonen ab; jenes Mittelfeld, welches zwischen den liellen, wie gesagt nur vorn ziemlich deutlich ausgepriggten Streifen zu liegen kommt, ist oliveufurben, wätrend die 'Gwischenräume, welche durch diese Streifen und die hellen Fleckenreihen begrenzt sind, dunkler erscheinen, einen Stich ins Braune zeigen und stellenweise kupferglänzend sind. Die Kopf- und Schwanzoberseite ist dunkelbraun; der Unterkiefer zeigt dunkle Flecken; die Unterseite des Körpers ist blan und mit Ausmahme der dunkidgetleckten gröliseren Tafeln an der Unterseite der Schenkel und der äuberen longitudinalen Bauchschilderreihen ungetleckt; die graublinen schuppen an der schwanzunterseite erscheinen hell, etwa blaugrün gerändert. Sollte es sich heratusstellen, dals die angefühten Unterscheidungsmerkmale von Alg. moreoticus aus Zante konstant sind, so finde ich es gerechtfertigt, diese Form von der Bibron, Bory de St. Viucentschen zu trennen; in diesem Fall möchte ich proponieren, das Tier zu Ehren ihres Entdeckers, dem wir schon so manche herpetologische Acquisition verdanken, als subsp. oder var. Doriue zu benennen und sie als eine Form zu betrachten, welche den Übergang von der typischen Form moreoticus zur Art »Fitzingeri« vermitteln dürfte. Es ist anderseits für diejenige, welche sich mit den Verwandtschaftsverhälnissen der Silurierformen befassen und dabei die geographische Verbreitung berücksichtigen, interessant wahrzunehmen, dals die zoogeographisch getrennten, und auf den ersten Anblick so sehr verschiedenen Algiroides, - ich meine die mehr in Norden vorkommende Art migropunctatus « und die sardinischkorsikanische Fitzingeri - eine Zwischenform in Alg. moreoticus besitzen und dafs diese Zwischenform, namentlich diejenige aus Zante, die beiden extremen Formen atuch in phylogenetischer Bezichung einander näher treten lälit.

\section{Algiroides Fitzingeri Wiegm. 1834.}

Char. - Sc. frontale brevius quam in Alg. nigromunctato, longius quam in Alg. moreotico. Collare $5-7$ scutis compositum. Squamac dorsales squamis lateralibus aut paulo 
breviores et angustiores aut maiores. Squamae in caudae basi inferiores obtuso-angulatae. Sc. anale squamarum serie arcuata circumdatum. Pori femorales utrinque 10-12. - Corpus parvum gracile sat longum; pedes brevissimi, postici axillas non attingentes, antici oculorum partem anteriorem attingentes. Cauda longissima, interdum corpore duplo longior $\left(\sigma^{7}\right)$. Longitudo: $100-124 \mathrm{~mm}$.

S y n ony i ie.

Notopholis Fitzingeri Wiegmann, Herpetologia mexicana I, p. 10. Berlin 1834. - Bonaparte, Iconografia della Fauna italica II. Tab. Fig. 3; Amphibia europaea in: Hem* Accad. Se. di Torino, Ser. II., Tom. II, pag. 385. - Gené, ebendas. Tom. I, pag. 257; Tab. I, fig. 2, 2a. - Gray, Cat. Liz. Brit. Mus., pag. 34. - De Betta, Rettili ed Anfibi in: Fauna d'Italia IV (1. c.). Milano 1874. - Schreiber, Herpetologia europaea, S. 449. - v. Bedriaga, in: Archiv f. Naturgeschichte 1883, Bd. I, S. 259.

Lacerta nigra (Wolf) Fitzing er, Neue Klassifikation d. Reptilien. Wien 1826. S. 52. Lac. Fitzingeri D unéril et Bibron, Erpétologie générale V, pag. 194" ).

Tropidophorus nigra Wretschko, in: Fitzingers Bild. Atl. d. Wirbelt. S. 81 (nach Schreiber!).

Allgemeine Körpergestalt und Gröbe.

Die ziemlich gedrängte Form des Kopfes sowie auch des Körpers bei $A$. moreoticus geht bei $A$. Fitzingeri in zartere und feinere Formen über, und ich möchte die zuletzt genamnte Art als eine Zwergform unter unseren Echsen betrachten; sic erreicht allerdings die Länge der Species mmorcoticus« und überschreitet oftmals das Längenmala der letzteren um cinige Centimeter, erreicht aber die Breite der letzteren nicht und erscheint deshalb viel kleiner als sie in der That ist. Der Kopf ist klein, niedrig, in der Backengegend bedeutend aufgetrieben, nach vorn aber ziemlich oder mitunter auch stark zugespitzt verschmälert. Die Augenbulbi treten seitlich ziemlich stark hervor. Die Zügelgegend ist der Länge nach, an jener Stelle, wo die Lippen- und Zügelschilder in Kontakt treten, etwas vertieft. Die Schnauzenliante ist abgerundet; die Kopfdecke senkt sich von der Occipitalgegend an nach vorn zu sebr sanft und da die Palpebralscheibe flach, oder kaum merkbar gewölbt ist, verläuft sie meistens ohne Unterbrechung in der Supraorbitalgegend. Dicht am Hinterrande der Pileusschilder und der Ohröffnung ist eine von einer Falte begleitete Halseinschnürung sichtbar; der Hals aber

1) Nachträgl. Zusatz: L. Fitzingeri Schinz, Europ. Fauna, S. 27, Stuttgart 1840. 
ist meistenteils bedeutend breiter als der Kopf. Beim Weibchen ist der Rumpf meist dicker und weniger schlank als beim Männchen, namentlich erscheint dex Rumpf bei den träichtigen Individuen schr stark aufgetrichen. Die dor Schrift frós beigefügte Figur stellt zweifolsohne ein trächtiges Weibchen dar. Auch in betreff der Schwanzlänge unterscheiden sich die beiden (ieschlechter voneinander; beim Minnchen nïmlich übertrifte der Schwanz die ganze Lünge des Kö̈rpers um mehr als das Doppelte und ist derselbe erst gegen sein Ende zu verdünnt; beim Weibchen aber ist der Schwanz bedeutend kürzer und verdickt, er ist in eine kurze Spitze ausgrezogen. Die Schwanzwurzel ist bei beiden (ieschlechtern von oben flach gedrückt und beim Mämehen auch hinter der Aftergegend abgeplattet; im ührigen ist der Schwanz, mit Ausuahme des beim Männchen fast vierseitigen Basalteiles, drehrund. Die Beine sind kurz und zart, die vorderen reichen, an den Körner angelegt, bis zum vorderen Augenrand, die Hinterbeine reichen beim Jiunchen nicht ganz bis zu den Schultern, beim Weibchen nicht viel über die Rumpfmitte hinaus. Die Größenverhältnisse bei A. Fitzingeri verglichen mit denjenigen bei den vorhergehenden Species sind sehr verschieden.

Mafe in mm. - $\sigma$ aus Sardinien: Totallänge 117; Länge des Kopfes 8,5, des Halses 5-6, des Rumpfes 27,5, des Schwanzes 81, der Vorderextremität 9,5, des Vorderfufes 4, der Hinterextremität 15, des Hinterfulies 6 ; Höhe des Kopfes 3,7, Breite des Kopfes 5, des Pileus 4,5; Umfang des Kopfes 16, des Halses 16,5, des Rumpfes 18,5. - $Q$ aus Sardinien: Totallïnge 95; Länge des liopfes 8,5, des Halses 6, des Rumpfes 28, des Schwanzes 59, der Vorderextremität 10, des Vorderfulies 4, der Hinterextremität 16, des Hinterfulies 7,5; Höhe des Kopfes 3,3, Breite des Kopfes 5,5, des Pileus 4; Umfang des Kopfes 16, des Halses 17,5-18, des Rumpfes 22-23.

$\ddot{A} u \mathfrak{s}$ re Körperbedeckung.

Alg. Fitzingeri unterscheidet sich von Alg. nigropunctutus, mit welcher Species Alg. Fitzingeri hinsichtlich der Konfiguration der Kopfschilder im allgemeinen übereinstimmt, hauptsächlich durch die Form der Iiumpfschuppen und durch die Grölie der Flankenschuppen. Die Unterscheidung dieser Art aber von Alg. moreoticus bietet gröliere Schwierigkeiten, da beide einander in betreff ihrer äulieren Körperbedeckung sehr ähnlich sind und Alg. morcoticus in ler Form der Pileusschilder, wamentlich derjenigen, welche den Hinterkopf bekleiden, sehr variiert; so haben wir gresehen, daf bei der Species smorenticus« vom Festlande Griechenland das Interparietale schmäler, lingegen bei Subsp. "Doriue aus Zante nahezu ebenso breit ist, wie das dahinter liegende Occipitale und gleichzeitig hinzugefïgt, dafis diese in ihrer Breitenentwickelung variabelen Schilder dennoch ein Kennzeichen bicten, das bei der Unterscheidung der Arten mmorcoticus * 
und mnigropnetatus« nicht zu unterschätzen ist. Gehen win aber auf die Beschildung des Kopfes von A7g. Fitzingeri näher ein, so werden wir alsbald zu der Überzeugung gelangen, dafs die umparen Schilder auf dem Hinterkopfe genau ebenso beschaffen sind wie bei der Form aus Zante, d. h. bei Subsp. Doriae, nur scheint mir das Occipitale bei Fitzingeri meist trapezförmig und weiter nach hinten gerückt zu sein, als dies bei den zwei mir vorliegenden griechischen Algiroides der Fall ist. Die Untersuchung einer größseren Anzahl von Alg. moreoticus dürfte ergeben, ob die dreieckige Gestalt des Occipitale bei dieser Art von diagnostischem Wert ist. - Die Parietalia sind bei den mir zahlrcich vorliegenden Stücken der sardinischen Art schmal, nahezu doppelt so lang als breit und zeigen nach innen und vorn zu vier unter stumpfem Winkel zusammenstobende Kanten, während die äubere und hintere Seite eines jelln meistens bogenfürmig ineinander übergehen; an ihrem Aulseurande sind sie von einem ziemlich langen, schmalen vorderen und 22 kleineren, rïckwärts liegenden Schililchen gesäumt und rorn durch ein unregelmäßjig polygonales oder dreikantiges Schildchen von der aus 2 größereu Suprarbitalia bestehenden und mach aulien durch eine Reihe feiner Körnerschuppen begrenzten, flachen Palpebralscheibe getrennt. Supraorbitale III zeigt vier längere und eine äuferst kurze, mit dem Frontale in Berührung tretende Seite; das mit seinem schmal auslaufenden Teile nach vorn gerichtete Supraorbitale II stellt ein Dreieck dar, dessen 2 längere, nach aufen und innen gekehrten Seiten schwach bogenförmig sind und dessen vorderer Winkel mitunter eine Abstutzung zeigt. Das darauffolgende erste obere Angenschild repräsentiert wiederum ein winziges, etwa dreieckiges Täfelchen. Die mit ihrem Innenrande aneinander grenzenden Frontoparietalen sind quer fünfeckig; sie grenzen vorn an die in stumpfem Winkel zusammenstoßenden hinteren Seiten des Frontale. Letzteres scheint mir etwas länger und schmäler zu sein, als dies bei der Art »moreoticus der Fall ist, namentlich dürfte der vordere Teil stärker vorgezogen sein und spitzer enden. In betreft der Breite des Frontale muls hinzugefügt werden, dafis es bei einigen Individuen vorn und hinten nahezu gleich breit, bei anderen aber vorn entschieden breiter als hinten ist und endlich, das es im mittleren Teile stets, bald mehr, bald weniger bogig verengt erscheint. Die beiden Frontonasalen scheinen mir etwas länger zu scin als bei Alg. moreuticus. Das rhombenförmige, öfters längere als breite Internasale ist cntweder durch die in der Mittellinie zusammenstofenden Supranasalen von dem ziemlich schmalen, mit seinem spitzen Hinterende stark auf den Pileus übergebogenen Rostrale getrennt, oder es erscheint mit seinem Vorderteil zwischen die Supranasalia eingekeilt; in letzterem Fall berührt es das Rostrale. Wichtiger für die Speciesunterscheidung scheint die Kopfseiten-Beschildung zu sein. Die Hauptunterscheidungsmerkmale von "Fitzingeri" bestehen aulerdem darin, daf ihre 


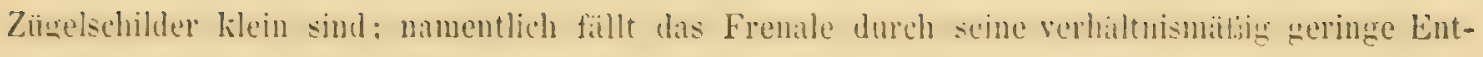
wickelung auf; ctwas gröber erscheint das Freno-oculare. Die beiden äbereinanderstehenden und das Nasenloch rou hinten begrenzenden Nasofrenalia sind wiederum äuferst klein. Die Schläfe wird in ihrem oberen Teile von 3 gröferen, die Parietalia umsïumenden Platten bedeckt, während auf dem ubrigen Teile sich zahlreiche ungleichartig mestaltete, vorn meistens kümerartige, gewölhte und glatte, hinten und unten polygonale oller sechsseitige, Hache, wribliere und zum Teil spurweise gekielte Schuppen finden, in. deren Mitte cin gröberes ovales oder rundlich-polygonales Massetericun auftritt. Die rundliche, oder eifürmige, senkrecht gestellte Ohrötinung zeigt am Vorderrande nach oben zu ein verhältnismälizig grofies, nach hinten zu ausgebuchtetes und mit einel vorspringenden Längskante versehenes Tympanicum. Die Augenhöhle erscheint an ihrem oberen Raude von 4 bis 5 schmalen Supraciliaren umsäumt, welche durch eine Körnerreihe von der Palpebralscheibe getrennt sind. Das vierte, bedeutend erweiterte, aber niedrige, vorn ausgerandete Supralabiale dient zur Begrenzung des unteren Orbitalrandes. Supralabiala posteriora sind gewöhnlich 2, Sublabialia 6-7, Submaxillaria 6 vorhanden, von letzteren die 3 vorderen Pare in der Mittellinie zusammenstofiend, das vierte und fünfte die größten; dazwischen liegen ziemlich große, längere als breite und durch eine transversale Kehlfurche von den dahinterliegenden, etwa sechsseitigen und breiteren Halsschuppen getrennte Kinnschuppen. Das Halsband ist deutlich gezähnelt und besteht in der Regel aus nur 5, ausnahmsweise aus 7 breiten Schuppen, von denen, wie gewöhnlich, die mittlere die grölate ist. Die geringe Anzahl der Halsbandtafeln dürfte ein ganz brauchbares Unterscheidungsmerkmal darbieten, denn sowobl bei Alg. moreoticus, als auch bei Aly. nigropunctatus habe ich nie 5 , sondern stets 7 bis 9 dieser Schilder angetroffen. Die Rückenschuppen sind rhombenförmig, am Nacken kürzer, am Rücken länger und zwar länger als breit; sie sind schief nach auswärts gerichtet, diagonal gekielt, hinten mitunter spitz ausgezogen und mit einer, nach hinten und lateralwärts gerichteten, schwach ausgerandeten Seite versehen; nach den Seiten hinten, namentlich gegen die Bauchgrenze zu, erscheinen die Schuppen kürzer und schmäler als die Rückenschuppen, jedoch ist in der Regel hinsichtlich ihrer Größse kein auffallender Unterschied vorhanden. Die Länge der mittleren Schuppen an den Rumpfseiten entspricht derjenigen der Batuchschilder : diejenigen aber, welche an der Wurzelgegend der Gliedmalien liegen, sind kleiner als die Ventraltafeln. Die Größe der Rumpfschuppen ist variabel, so zählte ich bei einigen Individuen 39 Quer- und 19 Längsschuppenreihen, während bei anderen die Zahl der Querreihen nur 33 und die Zahl der Längsreihen 15 beträgt; auferdem kommen noch 3 bis 5 trausversale Körnerreihen hinzu, welche sich am Nacken, hinter den Pileustafeln, befinden; an 
den Halsseiten und oberhalb der Wurzeln der Gliedmatien sind gleichfalls körnerartige, bald deutlich gekielte, bald ziemlich glatte, gewölbte Schuppen vorhanden. Die beim Mãnnchen in 86 bis 91 , beim Weibchen in 70 bis 72 Reihen angeordneten Schuppengürtel bestehen aus mehr oder weniger spitz endenden, gekielten, oben und unten gleichseitigen, unten ungleichseitigen S'chuppen. Die Bauchschilder bilden beim Münnchen 22, beim Weibchen 25 Querreihen und bei beiden Geschlechtern 6 Längsreihen, deren äußerste Tafeln klein, fast etwas länger als breit und um ein Drittel schmäler als die daranstoßenden sind; letztere wiederum gut doppelt so breit, wie die mittleren Bauchschilder. Das Brustdreieck besteht aus groben Tafeln; sie sind bedeutend größer und namentlich länger als bei der. Art smoreoticus« und verhältnismäßig gröber als bei Alg. nigropunctatus. Die grofe, die Praeanalgegend bekleidende Platte ist vorn und seitlich von einer Bogenreihe kleiner Schildchen umgeben; von diesen 7 bis 8 . Schildchen ist das mittlere, vorn liegende sowie auch diejenigen, welche die Bogenreihe an freien, hinteren Rande des Anale schließzen, die grö́ten.

Schenkeldrüsen und Zähne.

Die Zahl dex Drüsen beträgt jederseits 10 bis 12; in den meisten Fällen sind 11-11, in der Praeanalgegend durch '2 Schildchen getrennte Drüsen vorhanden, während bei Alg. moreoticus die aus 12-13 bis 15-15 Drüsen bestehenden Reihen nur durch ein Schildchen separiert werden. Die Analgegend scheint überhaupt brauchbare Unterscheidungsmerkmale zu liefern, denı wir haben schon gesehen, dak bei der groken Art »nigropunctatus sowie bei der kleineren »Fitzingeri« die Aftertafel nur von einer Reihe, bei Alg. moreoticus aber von 2 Reihen kleiner Schildchen begrenzt ist. - Keine Gaumenzähne.

\section{F år b ung.}

Die Färbung der oberen Körperteile ist monoton; sie wechselt vom Graugrün durch dunkel Olivenfarben einerseits bis zum Schwarz, anderseits bis zum Dunkelbraun. Bei den heller gefärbten Individuen nimmt man in der Regel eine lichtere Rückenzone und dunklere Seitenzonen wahr, sowie auch etliche, diese Zonen am Vorderrücken begrenzende schwärzliche Punkte; mitunter treten auch am Rücken unregelmäbig zerstreute schwarze Punkte auf. Gleichfalls spärlich dunkel gepunlitet erscheint die Kopfdeche, welche stets heller gefärbt ist als der übrige Körper. Bei den vollkommen einfarbigen Stücken sind die braunen Kopfseiten fleckenlos, sonst aber ist das Tier ziemlich stark dunkel gefärbt. Die Körperunterseite, mit alleiniger Ausnahme der meist dunkel, etwa graubraun oder blaugrau kolorierten Schwanzunterseite, ist bläulich, bläulichgrün, gelb oder orange gefärbt. Die Kehle und die Brust sind oftmals tief- 
blau überlaufen; sämtliche unteren limmpteile haben einen perluntterartigen schimmer, während der Oberkürper zur schönen Jahreszeit schwach mit Metallghanz iberflogen erscheint.

Vorkommen.

Aus Sardinien wird diese Zwergform zuerst von Wiegmann angegeben. Gené führt sie für Nord- und Mittel-Sardinien an und ich selbst hatte Gelegenheit, einige Exemplare ans Siliqun, Orosei und aus der Umgebung von Sassari, wo das Tier häufig vorkommt, zu untersuchen. Giglioli ') fand es auch bei Ajaccio auf Korsika; korsikanische Exemplare sind übrigens schon seit längerel Zeit bekannt (vergl. Lichtenstein, Nomenclator reptilium et amphibiorum musei zoologici berolinensis, pag. 14. Berlin 18.56). Während meines Aufenthaltes auf Korsika ist mir diese Echse in Orezza, bei Bocognano und Cauro begegnet; vielleicht aber mag es größerer Aufmerksamkeit gelingen, sie noch an anderen Orten, namentlich in Italien, wo sie nicht fehlen dürfte, nachzuweisen.

\section{Untergattung Zeraumia. $\left.{ }^{2}\right)$}

Zerzoumia Lataste, Diagnoses de reptiles nouveaux d'Algérie in: Le Naturaliste 1880. Paris. Algira (Zerzumia Lat.) Böttger, Die Reptilien und Amphibien von Marokko II. Frankfurt a. M. 1883.

\section{Zerzumia Blanci Lataste. 1880.}

Synonymie.

Zerzoumia Blanci Lataste, 1. c. Algira (Zerzumia) Blanci Böttger, 1. c.

Char. - Tropidosaurae et Alg. Fitzingeri similis. Collare vix distinctum, denticulatum. Sc. nasofrenale unicum. Squamae dorsi acutae, magnae, planae, rhomboidales, carinatae, imbricatae. Scuta abdominalia in ti series longitudinales disposita. Pori femorales utrinque 10-12. Dentes palatini nulli. Corpus parvum, gracile, sat breve (む), caput in anteriore parte angustatum. Cauda sat brevis. Pedes antici oculos superantes, scutum nasofrenale interdum attingentes, pedes postici axillas attingentes (ठ) vel paulo breviores (q). Longitudo: $112 \mathrm{~mm}^{3}$ ).

1) Beiträge z. Kenntnis d. Wirbeltiere Italiens in Arch. f. Naturg. Jahrg. 45, Bd. I, S. 93.

2) Vergl. die Diagnose der Gattung "Zerzumias in meiner Einleitung.

s) Z. Blanci sieht im allgemeinen der sogenannten Algira (Zerzumia) microdactyla Böttger ähnlich (vergl. Böttgers »Die Rentilien u. Amphibien v. Marokkos II. Frankfurt a. M. 1883). Die Böttgersche Form scheint aber eher pristidaktyl zu sein und dürfte, meiner Meinung nach, einer anderen Gattung angehören. 
Körpergestalt und Grölse.

Der kurze, in der Schläfen- und Augengegend ziemlich gleichbreite, nach vorn allmählich verschmälerte, mit einer spitzen, aber abgerundeten Schnauze versehene Kopf sieht im allgemeinen dem der Tropidosaura algira ähnlich. Der Discus palpebralis ist wenig stark erhoben, so daß diejenige Profillinie, welche am Rande der Parietalen und über den Augen sich zu den Nasenlöchern hinzicht, einen sanften Bogen vorstellt. Vorn fallen die Kopfseiten seukrecht ab. Die Nasenlöcher liegen seitlich; die Augenlider sind längsgespalten. Die Ohröffnung ist rorn abgerundet, hinteu ziemlich geraderandig. Der Hals erscheint etwas breiter als der Kopf. Plica axillaris ist vorhanden. Der oben abgeplattete Rumpf ist beim Weibchen breiter und länger als beim Männchen; beim letzteren erreichen die Hinterbeine die Achseln, beim Weibchen jedoch nicht. Die Länge der Vorderbeine ist verschieden, bei einigen Individuen, namentlich bei den weiblichen reichen sie nur bis zu den Frenalplatten, bei anderen wiederum können dieselben mit Leichtigkeit die Nasenlöcher erreichen. Der Schwanz ist verhältnismäßig kurz.

Maße in mm. - Totallänge 112; Länge des Kopfes 9,5, des Halses 5, des Rumpfes 31,5, des Schwanzes 71, der Vorderextremität 12,5, des Vorderfußes 5, der Hinterextremität 19,5, des Hinterfußes 9; Höhe des Kopfes 5,5; Breite des Kopfes 6,3, des Pileus 4,7; Umfang des Kopfes 19, des Halses 20, des Rumpfes 21,5̄.

Schilder und Schuppen.

Das Occipitale ist eine ziemlich ansehnliche Platte, mitunter ebenso breit, aber kürzer wie das Interparietale; es ist in der Regel trapezförmig, in selteneren Fällen dreieckig, spitz nach vorn endend. Die breiten Parietalia zeigen hinten gerade Ränder; mit ihren nach aulien gekehrten, leicht abgerundeten und sich etwas auf die Schläfengegend überbiegenden Kanten grenzen sie an 3 bis 4 Schildchen an, welche größer sind, als die eigentlichen Temporalia. Die Zahl der nach innen gelegenen Kanten an jedem Parietale ist 4. Die Parietalia schliefen zwischen sich das meistens fünfseitige, kleine Interparietale ein, das stets länger als breit ist, und grenzen vorn an die ziemlich kleinen, etwa fünfeckigen, hinten abgerundeten, oder auch geraderandigen Frontoparietalia und an die trapezfürmigen oder dreiseitigen, mit abgerundeten Ecken versehenen, hinteren Supraocularia. Auf letztere folgt nun jederseits ein Paar bedeutend größerer, schwach gewölhter Oberaugenschilder, welche die sogenannte Palpebralscheibe bilden. Vorn gesellt sich ihnen jederseits ein kleines vierseitiges, schmales, längliches Supraocularschildchen hinzu, das wohl nur ausnahmsweise fehlen kann, denn unter den mir vorliegenden 9 Exemplaren wird dieses Schildchen nur bei einem Stücke vermifst. Folglich ist die Zahl der oberen Augenschilder bei der uns hier interessierenden Zerzumia genau dieselbe 
wie bei Tropidosaura algira, auch scheint mir die Aufeinanderfolge dieser Schilder in Bezug auf ihre Größe bei beiden Sauriern übereinzustimmen; die mittleren Schilder sind nämlich die grölisten, die hinteren sind kleiner als letztere und die vorderen endlich die kleinsten. Sobald wir mit einigen Autoren annehmen, dafi del Augendiscus bei Tropidosaura algira aus 3 Platten zusammengesetzt wird, so müssen wir das nämliche von Zerzumia Blanci sagen; jedoch, meiner Ansicht nach, müssen bei beiden Untergattungen jederseits nur die 2 größreren, mittleren, über dem Auge sich befindenden Schilder ais Palpebralscheibe angesehen werden. Sämtliche Supraocularia legen sich direkt an die Supraciliaria an. Sowohl die Zahl als Gestalt der letzteren ist genau wie bei Trop. algira; es sind nämlich 2 nach rückwärts liegende, wie grobe Körner aussehende Schüppchen, dann ein mittleres, langes, schmales und gewölbtes Schildchen, das beinahe den ganzen oberen Augenrand einnimmt und endlich noch ein vorderes, kleines, unregelmälsig geformtes, nach hinten spitz auslaufendes, nach vorn zu ahgerundetes Schildchen, das jederseits an das vorderste Supraoculare und an das Freno-oculare grenzt. Das vorn sehr breite und zwei leicht abgerundete Kanten aufweisende Frontale ist in seiner Mitte verengt und wird nach hinten wieder allmählich, aber nur wenig breiter. Sowohl seine längsten seitlichen, als auch seine zwei kürzesten hinteren, an die Frontoparietalia stofenden lianten sind schwach ausgerandet. Die sechsseitigen, hinten stumpf, vorn ziemlich spitzwinkelig endenden Frontonasalen treten untereinander mit ihren langen, nach imnen zu gekehrten Kanten in Kontakt und trenuen somit das vorn und hinten abgerundete Zwischennasenschild, das bedeutend breiter als lang ist, vom Frontale ab. Seitlich berühren die Frontonasalen die kleinen unregelmälisig gestalteten Freno-ocularia sowie auch die trapezförmigen Frenalia. Die mäßig großsen, von den seitlich gelergenen Nasenlüchem ausgerandeten supranasalia werden jederseits durch ein einziges, ziemlich hohes, aber schmales, trapezförmiges Frenonasale getrennt. Das schwach nach oben übergewölbte Rostrale erscheint oben leicht ausgerandet. Es sind 4 vordere Supralabialia vorhanden, von denen das vierte und zugleich das hinterste am breitesten erscheint, iudem es hinten in eine längere Spitze ausgrezogen ist, so dals das Unteraugenschild an seiner Basis sich ziemlich verengt ausuimmt. Das erste Supralabiale grenzt an das Nasenloch und an das Nasofrenale, das zweite schliefist sich an die untere Kante des Frenale an, während das dritte an das Freno-oculare anstölit; das vierte Supralabiale endlich grenzt an das, zwischen dem Freno-oculare und dem Suboculare sich befindende Praeoculare. Dieses vorn breitere Scbild palit mit seiner abgerundeten vorderen Liante genau in den hinteren Ausschnitt am Freno-oculare. Es ist bemerkenswert, dafs sowohl das Prae- als auch das Suboculare eine wulstartige Emporragung zeigen, welche höchst wahrscheinlich auf eine derartige Bildung am 
Schädelknochen zurückzuführen ist. Auf das Suboculare folgt nun ein grölèeres und ein kleineres Schildchen; die Schläfe ist mit größeren, unregelmäßig gestalteten, bald vier-, bald fünf- oder sechsseitigen Plättchen bekleidet, welche mit ihren freien Rändern sich zum Teil überdecken. Sublabialen finden sich jederseits 1; Submaxillaren aber nur 4. Eine eigentliche Kehlfalte, wie wir sie bei manchen Eidechsen-Arten stark ausgeprägt vorfinden, existiert bei $Z$. Blanci nicht. Die Beschuppung des Unterkopfes erscheint vor allem durch eine, der Quere nach sich hinziehende lineare Impression, wclche seitlich am schärfsten ausgesprochen ist, unterbrochen. Nicht nur durch ihre Länge, sondern auch dadurch, dabi sie, namentlich seitlich, von Schuppen begleitet wird, die kleiner sind als sonst, entspricht diese lineare Impression der Kehlfurche der Lacerten, ohne jedoch dermaken aufzufallen, wie es bei den letzteren gewöhnlich der Fall zu sein pflegt. Dadurch, daß diese Impression besonders, wie gesagt, auf der Kehle ziemlich tief ist, erhebt sich daneben die Haut wulstartig und es kommt auf diese Weise zur Bildung einer spurweise angedeuteten queren Kehlfalte; mitunter aber ist diese Kehlfalte nicht vorhanden. Die Beschaffenheit des Collare habe ich in der Genusdiagnose erörtert und verweise infolgedessen auf meine Einleitung, ich will hier nur bemerken, dati das Halsbanı, obschon selır undeutlich ausgeprägt, bei $Z$. Blanci vorhanden ist, währenddem bei der mit ihr verwandten Trop. alyir a das Collare gänzlich fehlt. Es muli hinzugefügt werden, dabs bei $Z$. Blanci das Halsband gezähnelt erscheint und dalj die es zusammensetzenden Plättchen von den Brusttafeln wesentlich verschieden sind. Bei Trop. algira ist die Grenze der Kehl- und Brustschilder ebenfalls an der Form erkennbar, jedoch fältt die Differenz nicht dermafenen auf, wie es bei $Z$. Blanci der Fall ist, weil bei letzteren die Ventraltafeln gröfer sind und in deutliche, weniger zahlreiche Quer- und Längsreihen angeordnet erscheinen als bei Trop. algira. Es sind nämlich nur 6 longitudinale und 30 transversale Serien vorhanden. Diese Verteilung der Ventralschilder genügt schon, um das in Rede stehende Tier von Tropidosaurc zu unterscheiden. Gehen wir auf die Umrisse der einzelnen Tafeln ein, so nehmen wir wahr, daf dieselben eine hexagonale Figur bilden, welche mit ihrer längsten Linie nach der Quere des Bauches gestellt ist. Die Halsseiten, d. h. die zwischen Ohr und Achsel liegenden Partien, sind entweder mit ungekielten, aber stark nach hinten zu gewölbten, oder schwach gekielten, hinten abgerundeten oder stumpfwinkelig endenden und ziemlich gerundeten Schuppen bekleidet. Die Schuppen in der Achselhöhle sind relativ grörer als bei Tropidosuura algira, dabei aber bedeutend kleiner als die übrigen großen, doppelt so langen als breiten, deutlich aufliegend gekielten und in eine Spitze ausgrezogenen Rückenschuppen. Mit Ausnahme derjenigen Schuppen, welche direkt an die Schilder des Bauches grenzen und ungekielt erscheinen, sind die Rumpfseitenschuppen den- 
jenigen der Rückenzone ähnlich und erscheinen wie jene vollkommen geschindelt. Außjerdem muf hinzugefügt werden, dałs sämtliche Schuppen der Oberseite, mit Ausuahme der kleinen Nackenschuppen und der schon erwähnten, sehr kleinen Schuppen in der Achselhöhle, gleich grolis sind. Transversaler Schuppenreihen zähle ich ungefähr 45, longitudinaler 26. Jede von den übereinandergreifenden Schuppen ist etwas länger als eine Bauchtafel. Dic Schuppen auf der Oherseite der Extremititen, mit Ausnahme sowoh derjenigen kleinen, welche die Wurzeln der Fülıe, als auch der größeren Schuppen, welche die Füße selbst bekleiden, sind gekielt. Übrigens bemerkte ich Spuren von Kielen an der vierten Zehe, oder richtiger, an der Wurzel derselben. Die Unterseite der Zehen ist auf eine eigentümliche Weise beschuppt. Es sitzen nämlich an den 3 mittleren Hinterzehen und an sämtlichen Vorderzehen nach hinten zu stark verdickte und sich emporhebende, in 2 Längsreilien geordnete Schuppen, welche denjenigen auf Böttgers Fig. 2, e, welche die Zehe der sog. Zerzumia microdactyla veranschaulicht, etwas ähnlich sehen, nur scheinen auf dieser Figur die Schuppen der Länge nach nicht geteilt, d. h. nicht doppelreihig, sondern blofs einreihigr und in der Medianlinie gefurcht zu sein, was möglicherweise in der nicht ganz korrekten Ausführung des Strichs seine Erklärung findet; jedenfalls aber sind bei der Böttgerschen Form die Zehen eher pristidaktyl, bei der Blanci Lat aste aber leïodalityl. Die länglichen schmalen, oben scharf, unten dachförmig gekielten, spitz auslaufenden Caudalschuppen sind in 80 Ringel angeordnet. Das fünfeckige, mit seiner rückwärts liegenden Kante an die Afterspalte grenzende Analschild ist vorn und seitlich mit 7 oder 8 kleineren Schuppen umgeben. Endlich muf noch hinzugefügt werden, dab ein längliches, schwach gebogenes Tympanicum den vorderen, oberen Raud der grolien, etra ovalen Ohröffnung bekleidet, dafs der untere Teil des nämlichen Randes in der Regel mehr oder weniger stark gezähnelt erscheint, ferner, dats die vorderen Kehlschuppen weniger vollkommen geschindelt sind als bei Trop. algira und endlich, dati die längsgespaltenen Augenlider undurchsichtig, braun gemakelt erscheinen.

Schenkeldrüsen und Zähne

An der Unterseite jedes Schenkels sind 10 bis 12 Drüsen, vorhanden. - An jeder Oberkieferhälfte zähle ich 14 bis 16, am Zwischenkiefer 6 und am Unterkiefer im ganzen zwei Dutzend auffallend kleiner Zähnchen. Der Gaumen ist nicht bezahnt.

Färbung und Zeichnung.

Z. Blanci sieht insofern der Trop. algira ähnlich, als beiderseits des Körpers 2 gelbe oder grunlichgelbe Streifen sich hinziehen, von denen die oberen, die an den äuferen Parietalkanten ihren Ursprung nehmen. auf die Schwanzwurzel, mitunter auch auf die vordere Hälfte 
des Schwanzes übergehen, die unteren am hinteren Olurand anfangend, sich bis zur Ansatzstelle der Hinterbeine erstrecken. Diese Streifen sind nahezu stets von dunkelbraunen oder braunschwarzen, in der Regel den Raum einer ganzen Schuppe einnehmenden Flecken begrenzt. Öfters, namentlich bei weiblichen Individuen, werden diese Streifen nach aufien und nach innen zu von breiten dunkelbraunen Binden begleitet, welche somit diejenigen Teile, welche sich zwischen den Bauchplatten und dem unteren Streifen, ferner diejenigen Partien, die sich zwischen den seitlichen Streifen befinden, einnehmen. Auferdem kommt in den meisten Fällen noch ein drittes dunkelbraunes Bindenpaar zum Vorschein, das an die oberen Streifen grenzt, gegen die Rückenmitte zu liegt und den hellbraunen Fond des Rückens dermaken verdrängt, dals derselbe in Gestalt eines ziemlich schmalen, median-longitudinalen Bandes auftritt. Mitunter aber nimmt der hellere Grundton insofern überhand, als die zuletzt erwähnten, dunkelbraunen, die oberen gelblichen Streifen von innen begrenzenden Binden vermifst werden. Die Grundfarbe der weiblichen Blanci aus Lambèze ist kastanienbraun: bei den Männchen aus derselben Lokalität grünlichbraun. Bei den ersteren erscheinen die erwähnten hellen Streifen gelblich, bei den letzteren grünlich. Die aus Algier stammenden Individuen zeigen entweder einen helleren (q) oder dunkleren $\left(\sigma^{7}\right)$ Grundton. In jenem Fall erscheint der Nacken grünlich und die übrigen Teile des Oberkörpers hellnußbraun; die duaklen Flecken treten besonders scharf hervor und die hellen Streifen sind vorn grünlich, hinten gelb, stellenweise mit einem Stich ius Bräunliche; in diesem Falle, d. h. bei den Männchen, sind die blafgelben Streifen schrnäler und weniger deutlich auf eher dunkel- als hellbraunem Grunde markiert; die dunklen Binden sind nahezu verwischt und die dunklen Flecken treten spärlich auf der Hinterhälfte des Rückens auf. Der braune oder grünlichbraune Hut erscheint fleckenlos oder fein gefleckt. Auf der Schläfe zieht sich jederseits ein, am Hinterrande des Auges anfangender, hellgelber Streifen hin, der parallel den zwei übrigen erwähnten Streifen verläuft und sich etwa $2 \mathrm{~mm}$ weiter auf den Hals erstreckt. Die zwei Rückenstreifen setzen sich übrigens auch auf den Kopfseiten fort, obwohl sie hier immer undeutlicher werden und zur Bildung der Kopfzeichnungen Veranlassung geben; so mul z. B. jene helle Linie, welche meistens über dem Auge, also in der Supraciliargegend auftritt, und zum Frenale sich hinzieht, als Fortsetzung des oberen hellen Rumpfstreifens betrachtet werden. Eine andere hellgelbe Linie, welche ich für die Fortsetzung des an Rumpfe zu unterst sich befindenden Streifens halte, bildet sozusagen einen Saum für das Suboculare und erstreckt sich ebenfalls auf das Frenalschild, jedoch ohne die zuerst erwähnte Linie zu berühreu. denu zwischen beiden befindet sich ein dunkler, kurzer Streifen, welcher einen zarten, das untere Lid umsäumenden Ausläufer absendet. Bei den Weibchen erscheint die Unterseite 


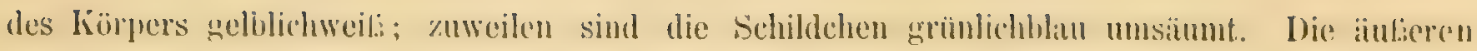
longitudinalen Bauchschilderreihen zeigen mitunter eine Neigung ins Bräunliche und weisen auferdem dunkle F'lecken auf. Bei den Mäunchen aus Lambèze ist die Unterseite, namentlich Batuch und Kehle, bläulich; das Anale hingegen weiflich und an den Submaxillaren nimmt man nur einen bläulichen Anflug wahr. Bei den Stücken aus Algier sind Kehle und die iufseren Batuchschilderreihen grünlich metallisch glinzend. Überhapt mufi im Leben an sämtlichon Körperteilen des Tierchens cin ausgeprägter Metallglanz zu Tage treten. Endlich sind die Extremitäten bei beiden Geschlechtern spärlich dunkelbraun oder schwarz auf hellerem Grunde getleckt.

Vorkommen.

Lataste hat folgende Fundorte der $Z$. Blanci angeführt: Umgebung von Algier und die Stadt Algier, Lambèze in der Provinz Konstantine. Aus Marokko und Tunis kennen wir diese Art bis jetzt noch nicht.

Man kann aber, ohne Fehlgriff zu thun, voraussetzen, dalis das Wohngebiet der Blanci sich nicht auf die oben genannten Lokalitäten beschränkt und dils wir, sobald man die Unterscheidungsmerkmale der $Z$. Blanci und der Trop. algira kennen gelernt hat, noch mehreres über den Verbreitungsbezirk der ersteren erfahren werden, denn ich glaube Grund zur Annahme zu haben, dali $Z$. Blanci in einigen Sammlungen als junge Tropidosaura algira, mit der sie allerdings viel Ähnlichkeit hat, figuriert.

\section{Untergattung Tropidosama.}

Tropidosaura Fitzinger, Neue Klassifikation d. Reptilien. Wien 1826. - Duméril et Bibron, Erpétologie générale, V. - Gray, Cat. Liz. Brit. Mus. London 1845. Schreiber, Herpetologia europaea. 1875. - Wiegmann, Herpetologia mexicana. 1834. Algira Cuvier, Règne animal II. Paris 1829. - Gray l. c. (part.).

Lacerta Merrem, Versuch eines Systems d. Amphibien. Marburg 1820 (part.) - Linné, Systema naturae I. 1758 (part.).

Psammuros Wagler, Natürl. Syst. d. Amphibien. München, Stuttg. u. Tübingen 1830. Wiegmann, Herpetologia mexicana. Berlin 1834.

Scincus Latreille et Sonnini, Hist. nat. des Reptiles III. 1802 (part.). - Daudin, Hist. nat. des Reptiles, vol. III. 1802 (part.).

Amciva M eyer, Synopsis reptilium. Güttingen. 1795 (part.). 
Die zwei uns bekannten Tropidosaura-Arten können vorläufig in folgender Weise leicht unterschieden werlen:

Tropidosaura algira L. - Ein Nasofrenale. Ziemlich breite Rückenschuppen. 13-18 Schenkeldrüsen jederseits. - Die Beine sind lang und ziemlich kräftig; Vorderbeine mindestens bis zum Frenale oder Frenonasale reichend, die Hinterbeine die Achseln oft überragend. Sehr langer Schwanz, den Körper an Länge mitunter fast dreimal übertreffend. Totallänge: $235-247 \mathrm{~mm}$.

Tropidosaura montana D. B. - 2 Nasofrenalia. Occipitale und Frontoparietalia kleiner, Rückenschuppen etwas schmäler und länger als bei der vorhergehenden Art. 6 bis 7 Schenkeldrüsen jederseits. - Kurze, schwache Gliedmafen; Vorderbeine bis zum Vorderrand der Augen reichend, Hinterbeine die Achseln nicht erreichend. Schwanz meist doppelt so lang als der Rumpf. Totallänge: $138 \mathrm{~mm}$.

\section{Tropidosaura algira L. 1758.}

Char. - Sc. nasofrenale unicum. Squamae dorsales sat latae, acutae, carinatae, imbricatae. Collare nullum. Pori femorales utrinque 13-18. Pedes longi satisque robusti; antici saltem scutum frenale vel scutum frenonasale attingentes; postici axillas saepe superantes. Cauda longissima, interdum corpore ter longior. - Longitudo: $247 \mathrm{~mm}$.

Synonymie.

Lacerfa algira Linné, Syst. nat. pag. 203 (10. Auflage), p. 363 (12. Auflage). - Da udin, Hist. nat. des Reptiles, IV, p. 269. - Schlegel, in: M. Wagners Reisen in d. Regentschaft Algier in d. Jahren 1836, 1837 u. 1838. Bd. 3. S. 113. 1841. Merrem, Versuch eines Systems d. Amphibien. S. 67. Marburg 1820. - Poiret. Voyage en Barbarie, I, p. 287. Paris 1789. - Schinz, Europ. Fauna, II. S. 26. Ameiva algira Meyer, Synops. reptil. p. 29. No. 8. 1785.

Psammuros algira Wagler, Natürl. Syst. d. Amphibien, S. 156. - W ieg mann, Herpetologia mexicana. 1834.

Tropisodaura algira Duméril et Bibron, Erpétologie générale V, p. 168. - Bonaparte, in: Mem. Accad. scienze di Torino, Ser. 2, Tom. II, p. 416; Iconografia della Fauna italica II. Tab. Fig. 5. - Gray, Cat. Liz. Brit. Mus. pag. 35. - Strauch, in: Mem. Acad. Imp. sciences de St. Petersb. VIII. Série, t. IV, No. 7, p. 31. v. Bedriaga, in: Arch. f. Naturg. 45. Jahrg. I. Bd. S. 322. - Böttger, Reptilen v. Marokko etc. in: Abhandl. d. Senckenberg, naturf. Gesellsch. Bd. IX. Frank- 
furt a. M. 1874; Reptilien und Amphibien aus Südportugal in: Zeitschr. f. d. ges. Naturwiss. 1879, S. 507. - Schreiber, IIerpetologia europaca, pag. 455.

Algire barborica Guérin Meneville, Iconographie du Règne animal, tab. V, fig. 2. Paris 1829. - Gray, Cat. Liz. Brit. Mus. pag. 35. - Cuvier (nach Wiegmann!).

Scincus algira Latreille et Sonnini, Hist. nat. des Rept. II. p. 73. Paris 1802. - Daudin I. c. (Le scinque algire, Lac, algira L.).

Algerine Lizarl Shaw, Gener. Zool. Vol. III. 1 part, pag. 251. London 1802.

Algira (Lac. algira L.) Cuvier, Règne animal. 2 édit. t. II. pag. 31. Paris 1829. Daubenton, Dictionnaire erpétologique in : Encyclop. méthod. II. (L'Algrire). Paris $1784-92$.

Zermoumeah, Shaw, Voyage dans plusieurs provinces de la Barbaric ete. t. I, p. 324. Lal Haye $17+3$.

Die gelbgestreifle Eidechse Bechstein, De la Cepédes Naturgesch. d. Amphibien, II. S. 94. Weimar 1800 .

Algira (Tropidosaura) algira Böttger, Die Rept. u. Amphibien v. Marokko II in: Abhandl. d. Senckenb. naturf. Ges. in Frankfurt a. M. 1883.

Es ist allgemein angenommen worden, daf Shaw in der Beschreibung seiner Reise nach der Barbarey diese schöne Echse zum ersten Male unter dem vulgären, arabischen Namen "Zermoumeal« erwähnt und daß sie nachträglich von Linné mit dem Speciesuamen »algiraa bedacht worden ist. $\mathrm{Ob}$ dies auch wirklich der Fall ist, lasse ich dahingestellt, weil die kurzen Diagnosen Shaws und Linnés uns keine Anhaltspunlite geben; dieselben passen vielmehr ebenso gut auf diese Echsenart als auch auf diejenige, welche vor liurzem Lataste als "Zerzumia Blanci« bezeichnete. Wenn ich dessenungeachtet dem Linuéschen Namen sulgiru vor der ebensowenig auf die uns hier interessierende Tropidosauru passenden ${ }^{1}$ ), aber hinreichend sichergestellten Benennung sbarbarica Cuvier, Guérin Mencville, Gervais« den Vorzug gebe, oder richtiger gesagt, den Linnéschen Artnamen beibehalte, so geschieht es lediglich aus dem Grunde, weil der Name sulgire son meinen Vorgängern als die allgemein verbreitete Bezeichnung acceptiert worden ist und eine Änderung leicht zu Miliverständnissen führen könnte.

1) Obschon die Art salgira von Linné nach einer ihm vom Naturforscher 13 ander aus Algerien zugesandten Echse gegründet worden ist, rechtfertigt letztere iusofern ihren Namen nicht, als sie auch außerhalb Afrikas und zwar in Europa vorkommt, wo sie zum ersten Male, wenn ich nicht irre, durch Marcel Serres bei Montpellier entleckt worden ist. 
Körpergestalt und Gröbe.

Trop. algira ist eine an dem überaus langen, das Körpermab un mehr als das Doppelte uberragenden Schwanz leicht kenntliche Echse; sie besitzt einen etwa vierseitigen, pyramidenfürmigen, bald hohen $\left(\sigma^{\prime}\right)$, bald etwas niedrigeren ( nach vorn zu neigt und dessen Seiten vorn senkrecht abfallen, in der Temporalgegend aber leicht gewölbt erscheinen. Der Unfang des Kopfes beim Weibchen steht hinter demjenigen lles Männchens zurück; beim letzteren endigt er weniger stark verschnälert und zugespitzt, als es bei ersterem der Fall ist. Kopf und Hals sind von gleichem Umfang, öfters sogar hat der Hals einen bedeutenderen Umfang. Der beim Männchen leicht von oben niedergedrückte Rumpf ist kräftiger und weniger schlank als beim Weibchen. Die Vordergliedmafen ragen selten über die Schnazenspitze hinaus, mitunter erreichen sic nur die Nasenlöcher; die Iinterbeine ragen über die Achseln etwas hinaus oder erreichen sie zum mindesten. Der an seiner Wurzel, insbesondere beim Kämnchen, sehr breite und plattgedrückte, etwa cylindrische, dann allmählich in eine sehr dünne Spitze ausgezogene und gerundete Schwanz ist in der Regel beim Mïnnchen etwas kürzer als beim Weibchen.

Approximative Malse in mm. - 7 . - Totallänge 234-235. Länge d. Kopfes 17; d. Rumpfes 57-58, d. Schwanzes 160. Höhe d. Kopfes 9, Breite d. Kopfes 11, Breite d. Pileus 8,5. Umfang d. Kopfes 37 , d. Halses 38,5 , d. Rumpfes 49-50. Länge d. Vorderextremität 21 , d. Vorderfufes 19 , d. Hinterextremität 40 , d. Hinterfufes 19 . - ๆ. - Totallänge 247. Länge d. Kopfes 16, d. Rumpfes 56-57, d. Schwanzes 175. Höhe d. Kopfes 8, Breite d. Kopfes 9,5, Breite d. Pileus 8. Umfang d. Kopfes 31, d. Halses 31, d. Rumpfes 34. Lïnge d. Vorderextremität 19,5 , d. Vorderfufes 7,5 , d. Hinterextremitait 35 , d. Hinterfußes $17-17,5$. - Nach Schreiber (Herpetologia europaea, S. 455) soll diese Art die Länge von $320 \mathrm{~mm}$ erreichen (vergl, auch die Maßstabellen bei Böttger in: 'Zeitsch. f. d. ges. Naturwiss. 1879. Bd. LII. S. 508).

\section{Schilder und Schuppen.}

Das in der Jugend breitere, im Alter aber sehmale Occipitale ist dreieckig oder es stellt ein Dreieck vor, dessen nach vorn gerichtete Spitze abgestutzt erscheint, dessen an die Parietalen grenzende, lange Seiten leicht abgerundet sind, wïhrend die Hinterkante schwach ausgerandet ist. Das Interparietale, nicht viel breiter als lang, ist von wechselnder Gestalt: bald vor'n stumpfwinkelig, hinten abgestutzt, bald vierseitig vorn stumpf-, hinten aber spitzwinkelig ansgezogen. Die fünfseitigen Frontoparietalia sind bei den jungen Individuen ebenso, oder annihernd gleich breit als lang; mit zunehmendem Alter werden sie bei den Weibchen etwas, bei 
den Mänuchen aber bedeutend länger wie breit. Sowohl die kürzesten Vorder-, als auch die Ilinterseiten dieser Schilder treten unter stumpfem Winkel zusinmen; mit ihren in der Mittellinie des Kopfes liegrenden längsten Sciten stofien die Frontoparietalia aneinander, wälnend sie mit ihren hinteren Aufsenrïnderu an die Parietalen und mit ihren nach vorn gekehrten, leicht ansgerandeten Aubenkanten an die Supraocularia sich anlegen. Die Parietalia, welche bei deu crwachsenen Tieren länger als breit sind, haben nach innen zu entweder 2, unter stumpfem Winkel zusammenstobende und das Occipitale, Interparietale und lirontoparietale begrenzende Kinten, oder aber 3 Kanten, welche fur die Begrenzung der benachbarten 3 Platten bestimmt sind. Vorn an jener Stelle, wo das Supraoculare IV sich an das Parietale anfügt, erscheint letzteres abgestutzt, hinten und seitlich aber leicht abgerundet. Von den 4 Supraocularen ist das vorderste dreieckige sehr klein, während die 2 darauffolgenden mittleren bedeutend gröfser sind und endlich das ganz hinten liegende wiederum kleiner als diese, gröfser aber als jenes erscheint. Sämtliche oberen Augenschilder legen sich direkt an 4 schmale Supraciliaria an, von denen das zweite (von vorn gerechnet), genau über dem Auge liegende Schildchen sehr lang und etwas gekrümmt ist und auferdem, wenn auch nur schwach, über die Augen vorspringt. Der Supraorbitalbogen ist beim Männchen stärker, beim Weibchen schwächer entwickelt. Das vorn und hinten ziemlich gleich breite, in der Mitte aber verschmälerte Frontale besitzt hinten 2, unter stumpfem Winkel zusammentretende seiten, mit denen es an die Frontoparietalia stülit, vorn 2 einen rechten Winkel bildende Kanten und seitwärts je einen bogeufürmigen ausgeschnittenen Rand, der sich an die Palpebralscheibe anlegt. Die aneinanderstolienden Frontonasalia lï̈nnen als Dreiecke aufgefalist werden, deren nach hinten gerichtete Ecken gerundet und deren nach vorn gekehrte Ecken abgestutzt erscheinen; dadurch crhält jede Frontonasalplatte 5 Seiten, von denen die vordere die lüngere, leicht ausgerandete Seite mit dem Internasale in Kontakt kommt, während die seitliche innere an das Frontale und die seitliche äulsere an das Freno-oculare sich anlegen; die vierte, kürzere äußere Kante grenzt an das Fronale und die fünfte, gleichfalls kurze innere Kante berührt den Rand der gleichnamigen Platte der entgegengesetzten Seite. Das Internasale, das meist etwas breiter als lang ist, zeigt vorn 2 leicht cingebogene, im stumpfen Winkel zusammenstolsende sciten und rückwärts einen, im stumpfen Winkel gebogenen Rand. Das fünfseitige, deutlich übergewülbte, breite Rostrale ist vom Internasale dureh die nach innen abgerundeten und verschmälerten, lateralwärts aber längeren und stark eingebuchteten Supranasalen getrenut. Sowohl die zuletzt genannten Platten, als auch das Rostrale bilden vorn die Umrandung der kleinen, rundlichen, seitlich über der Vondernaht des supralabiale I gelegenen Nasenlücher; nach hinten zu erscheint die Nasenüff- 
nung jederseits voln ersten vierseitigen Supralabiale und anderdem vom einfachen, fünfseitigen Nasofrenale begrenzt; diese beiden Schilder sind nach rückwärts in eine ziemlich lange Spitze ausgezogen. Das ebenfalls fünfseitige Frenale ist nach hinten zu zicmlich lang ausgezogen; es liegt über dem zweiten Supralabiale, währendem das unregelmälig gestaltete, vorn abgerundete, hinten ausgezackte Freno-oculare über das viereckige Supralabiale IV gestellt ist. Auf diese beiden Schilder folgen nun ganz oben das erste, länglich schmale Supraciliare, ferner nach abwärts zu das füufseitige, nach hinten etwas verschmälerte, der Länge nach stumpf gekielte Praeoculare und endlich unten das vierte, etwa dreicckige oder trapezförmige, nach rückwärts in eine ziemlich lange Spitze ausgezogene Supralabiale, dem sich das oben in bedeutendem Malie in die Breite entwickelte und unten verschmälerte Suboculare anlegt. Die längste, dic Orbitalhöhle umgebende Seite dieses Schildes ist stak eingebogen und zugleich vorspringend, während die ihr entgegengesetzte, nahezu halb so linge freie Kiante leicht grerundet ist, was übrigens auch bei den übrigen Oberkiefertafeln der Fall ist; vorn und hinten weist das Suboculare je 2 winkelig zusammenstofsende Ränder auf, von denen die kürzeren oberen vorn das Praeoculare, hinten das Postoculare berühren. Supralabialia posteriora sind 2 vorhanden. Die Schläfe wird oben und unten durch gröfsere, flache Platten und zwar durch die Jateralwärts nach unten sich umbiegenden Parietalia, ferner durch die, an Aulienrande der Parietalia sich befindenden :3, der Lünge nach aufgetricbenen oder sogar stumpf gekielten Schilder und endlich durch die auf das Postoculare folgenden fünf- und sechsseitigen Schilder bedeckt; die Schlafennitte hingegen ist von 2 bis 3 , am Hinterrande des Auges beginnenden und sich bis zum Tympanicum hinziehenden Reihen kleiner, meist länglich hexagonalen, aber auch fünfseitigen, gekielten Schildern besetzt, bei der Tropidosuner aus Algerien sind allerdings diese Kiele entweder nur äuferst schwach ausgeprägt, oder sie werden gänzlich vermilit. Das schmale, bogenfürmig gekrümmte Tympanicum zeichnet sich durch seine bedeutende Länge aus; es begrenzt nihezu vollständig den Vorderrand des Ohres und springt dabei etwas hervor. Das Massetericum scheint stets zu fehlen. Die jederseits aus 6 bis 7 länglich schmalen, bald stark, bald nur schwach anfgetriebenen Supralabialen bestehende Reihe grenzt vorn an das grobe, hinten meist 4 Kanten aufweisende Mentale und seitlich, $d$, h. nach innen zu, an 4 Paar Submaxillaria, von denen die 2 vorderen und auch teilweise das dritte Paar in der Mittellinie zusammenstolien. Die Schuppen auf dem Rücken und an den Sciten sind vollkommen geschindelt, flach, scharf gekielt und hinten in eine ziemlich lange und scharfe Spitze ausgezogen; sic zeigen sich im allgemeinen wenig und hauptsächlich nur in Bezug auf ihre Gröbe voneinander verschieden; so sind die Schuppen auf den Halsseiten und in der Achselgegend kleiner, die- 


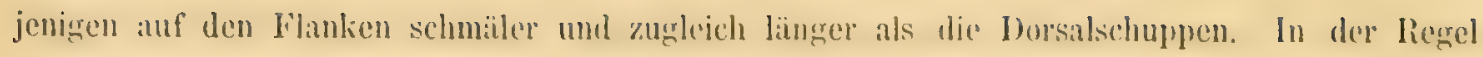
erscheinen die Schuppen mach der Bauchgrenze hin nur spurweise oder auch gatr nicht gelicht, gegen die schwanzwurzel hin und auf dem vorderen Teile des tichwanzes selhst erreichen die Schuppen ihre grölte Breitemausilehnung; ihre freien Rïnler stotien unter stumplem IVinkel zusammen, dabei aber erscheint die Schuppe dornartig verlingert, dadurch, dafis die längs der Mittellinie der Sehuppe sich hinzichenden Kiele lïnger als der flache Schuppenkörper sind, am Ende stachelirtig ausgezogen erscheinen und hervorragen. Aulierdem mul hinzugefügt werden, daf die Hinterränder sämtlicher, in 34 bis 39 Querreihen und in 23 bis 27 Längsreihen angeordneter Rumpfschuppen, sowic auch die oberen Hinterränder der 106 bis 110 Ringel bildenden Caudalschuppen bogenfürmig geschweift sind. Auf den Schwanzseiten erscheinen die Schuppen schmäler und mit diagonalen Kielen verschen, auf der Schwanzunterseite aber sind die an ihrer Basis breiteren, gegen ihr freies Ende allmählich verschmälerten Schuppen der Länge nach und in ihrer Mitte gekielt. Obschon die Flankenschuppen allmählich in die vollkommen flachen Bauchtafeln übergehen, so sind letztere dennoch schon auf der Bauchgrenze, ihrer bedeutenderen Breite und ihrer dreikantigen, öfters Ieicht abgerundeten Ränder halber, deutlich unterscheidbar; sie sind alle aufeinander geschindelt, mit Ausnahme derjenigen, welche unterhalb der Ansatzstellen der Beine und auf der Brust sich befinden; sie sind ziemlich gleich grols und in sechs Längs- und in etwa 31 Querreihen geordnet. Das den Lacerten eigentümliche "Brustdreicck wird bei Tropidosuma vermilit; die Grenze der Brust-, Hals- nul Kehlplatten ist gleichfalls nicht angedeutet, die Bauchschilder gehen viclmehr, indem sie dichter angeordnet erscheinen und sich in ziemlich bedeutenden Mafse verschmälern, direkt in die IIals- und Kehltafeln über. Die Schulterfalte hingegen ist vorhanden. Die $\Lambda$ ftergegend ist von einer gröbleren dreikantigen Zentraltafel, deren freier Hinterrand ofters ausgezackt erscheint, bedeclit; das Anale wird seitlich von 2 bis 3 kleinen Tüfelchen und vorn von 6 bis 8 Schuppen, welche dem Anale zum Teil aufliegen, besetzt. Während die Beine oberwärts mit gekielten und spitz endenden Schuppen bedeckt erscheinen, sind sie unten mit vollstïndig flachen und an ihren freien Kanten gerundeten Schildern bekleidet.

Schenkeldrüsen und Zähne.

Dic Zahl der Schenkeldruisen giebt Schreiber auf 17 oder 18 an; bei den portugiesischen algir fand Büttger 14-15 bis 19-1s Drüsen; bei den mir vorliegenden Individuen aus Spanien, Algier und T'unis betright die Zahl der Drisen 13-1.3 bis 16-16. - Im Zwischenkiefer züllte ich 9, im Oberkiefer auf der einen Seite 16 und im Unterkiefer auf der einen Seite 24 zweispitzige Zühnchen. Der Gaumen ist bezahnt. 
Farbenkleid.

Was zunächst die Grundfärbung der Rumpfoberseite betrift't, so erscheint dieselbe beim Mïnnchen viel gesättigter und schöner als beim Weibchen. Die von mir untersuchten, männlichen Individuen sind kupferbraun, metallisch glïnzend, die Weibchen dagegen eher matt und etwas heller koloriert. Die auf beiden Seiten des Körpers hinlaufenden 2 hellen Streifen oder Binden erscheinen beim Männchen intensiv gelb oder bräunlichgelb, beim Weibchen hellgelb, nahezu weif; ; in nur seltenen Fällen, und wie es scheint nur bei ersterem, bleibt diese Streifung vorn und auch auf den Flanken gänzlich aus; weit häufiger kommt es hingegen vor, daß diejenigen Streifen, welche der Rückenmitte näher gelegen sind, bereits an den Aufuenrändern der Parietalia ihren Ursprung nehmen, wïhrend die zu unterst sich befindlichen Streifen jederseits am Hinterrande des Ohres oder vom Mundwinkel beginnen und sich bis zur Insertion der Hintergliedmalien fortsetzen. Diese Streifen können aulierdem noch dadurch besonders scharf hervortreten, dali sie meistens schwärzlich braun umsäumt, oder von dunkelbraunen Flecken begleitet erscheinen. Die oberen dunkeln Säume der zu unterst sich befindenden hellen Streifen verbreitern sich mitunter in bedeutendem Malie und werden zu ziemlich ansehnlichen, jederseits die hellen Streifen voneinander trennenden Binden; hingegen nach aufien, $d$. $h$. gegen die Bauchgrenze hin, wird die dunkle Umsäumung meistens vermilit. Bei den scharf hell und dunkel gestreiften Exemplaren tritt aulierdem noch ein mittlerer, dunkelbrauner, am Hinterrande des Occipitale entspringender Streifen hinzu, welcher oftmals, namentlich bei den Weibchen, jederseits von hellen grünlichblau gefleckten, von perlmutterartigem Schimmer überflogenen Binden begrenzt erscheint. Tritt aber die helle streifung weniger deutlich ausgeprägt hervor, was besonders bei alten Männchen häufig der Fall zu sein scheint, so wird nicht nur dieser dunkle Mittelstreifen vermilit, sondern es fehlen auch die dunkeln Säume an den hellen Seitenstreifen und öfters auch die unteren hellen Seitenstreifen selbst. Bei den Männchen befinden sich an der Wurzel der Vorderextremität 2 prachtvoll ausgeprägte, meist dunkel cingefafite hellblaue oder bläulichgrüe, lebhaft glänzende Ocelli, welche je 3 bis 7 Schuppen einnehmen; öfters gesellen sich ihnen noch 4 oder 5 derartige, hintereinander folgende, in eine Reihe angeordnete, bei den weniger scharf gestreiften Exemplaren von gelblichgrünen Makeln begleitete Augenfecken hinzu. Die Hinterseite der Hinterschenkel und die Seiten der Caudalwurzel sind bald ziegelrot, mit verloschenen grauen Marmorzeichnungen, oder einfach rötlich braun, bald mit stahlgrauem Schimmer uberflogen. Die obere braune Mittelzone des Schwanzes ist selten von helten, dunkelbraunen, oder schwarz umsäumten Streifen eingefalit: weit häufiger kommt es hingegen vor, daf die Mittelzone jederseits von einer Reihe kleiner, dunkler Fleckchen 
begrenzt erscheint; sonst ist, mit Ausnalme dunkler Punkte, welche sich an den freien Schuppenrändern eingestreut finden, keine Spur von Zeichnung auf dem Schwanze vorhanden. Dic Schwanzsciten sind graubraun oder brïunlichgelb. Die Körperunterseite ist weibłich, mit rötlich-

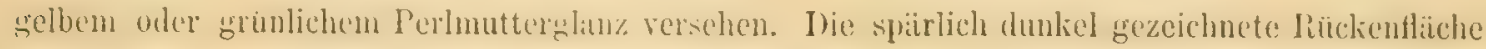
des Kopfes erscheint nuf3- oder kastanienbraun; oberhalb der Augen und gegen die Schnauze hiv, tritt seitlich und am Unterkopf mitunter eine ziegelrote Tinte auf. Die Schläfe weist in der Regel einen gelblichen Längsstreifen auf. - Bein Weibchen sind oberhalb und hinter den Ansatzstellen der Vordergliedmalien nur 2 kleine blaugrüne Ocelli vorhanden; die Schuppen stehen in ihrem Metallglanze weit hinter denjenigen bcim Männchen zurück. Die Grundfarbe des Oberkörpers ist eher olivenfarben als kupferbraun und ohne jegliche Spur von Ziegelrot; die weißliche Unterseite, und namentlich die Kehle zeigt einen grünlichen oder bläulichen Perlmutterglanz. - Da die beschriebenen Exemplare von mir im September, also nicht etwa zur Brunstperiode gefangen worden sind, so würde es sich bei Tropidosaura algira um eine konstante geschlechtliche Färbung handeln.

Die jungen, circa 9 bis $11 \mathrm{~cm}$ langen Individuen sind viel dunkler und einförmiger koloriert, als die alten. Die Mittelzone des Rückens ist dunkelbraun, selten schwarz. Die Seiten erhalten jederseits 4 alternierende, hellilia, metallisch glänzende und braunschwarze Streifen. Wiihrend die ersteren der gelben Streifung des. ausgewachsenen Tieres entsprechen, stellen letztere die bei den Alten schwarz oder braunschwarz gefärbten Streifen vor. Von den augenartigen Flecken, die wir bei den ausgewachsenen Individuen kennen gelernt haben, ist auch keine Spur vorhanden. Die Bauchseite erhailt eine Nuance ins Lila. Die Kehle ist weif. Die Oberseite des Schwanzes ist dunkelbraun, die Unterseite hellbraun. Die Hinterextremitäten und Sohlen sind braungelb. Bei den Jungen vermifat man meistens den Metallglanz und erscheinen dieselben matt gefärbt.

Eine in Hinsicht auf die Färbung auffallende und auch sonst von den binnenländischen algin abweichende Form hat neuerdings Marquis G. Doria auf der kleinen Insel Galitone - unweit der zwischen Sardinien und der afrikanischen Küste liegenden Insel Galita - entdeckt. Sie ist nämlich oben dunkelbraun, beinahe schwarz, unten bläulich. Jede Rückenschuppe hat ein bläuliches Fleckchen, das mehr an das Ende der Schuppe gerückt erscheint. A uf den Rumpfseiten nehmen diese blauen Flecken dermaßen an Größse und Zahl zu, daß der Grundton verdrängt wird und in Gestalt von schwach ausgeprägten Makeln auftritt; gegen den Bauch zu erhalten die nilhezu ganz blau ausschenden Schuppen nur stellenweise einen dunkeln Anflug. Die für algira sp. charakteristischen hellgelben Seitenstreifen werden bei unserer neuen Var. Doriae aus Galitone gänzlich vermifat. Die bläulichen, in der Brustgegend grün- 
lichen Bauchplatten sind hell, sogar weißlich gerändert und fuin dunkelgrün gezeichnet. Die oberen Kopfschilder sind dunkelbraun, fleckenlos, diejenigen an den Kopfseiten ebenfalls braun mit einem namentlich nach unten zu ausgeprägten gelblichgrünen Anfluge. Die Oberseite rler Extremitäten und des vorderen Schwanzdrittels ist dunkelbraun, nahezu schwarz, also ähnlich gefärbt wie der Rücken; sie erscheint spärlich bläulichgrün gesprenkelt; die übrige obere Schwanzpartie und die Zehen sind olivenbraun.

Die Beschildung unserer Var. Doriae ist insofern von derjenigen bei der Mutterform verschieden, als sich bei ihr eine Anzahl kleiner Schüppchen unter die großen Temporalschuppen mengt, auch ist bei ihr das Tympanicum länger, als es sonst der Fall ist. Unter den Schuppen auf der Körperoberseite fallen namentlich diejenigen auf, welche den Nacken bekleiden; sie sind nämlich bei der Doriae entweder gar nicht spitz endend, oder hinten nur mäfig zugespitzt, während bei der algira sp. die Nacken- und Rückenschuppen hinten in eine ziemlich lange Spitze ausgezogen sind. Letztere erscheinen bei der Galitone-Form breiter und wiederum mit einer viel kürzeren hinteren Spitze versehen, als es bei der algira sp. der Fall ist. Diese Unterschiede sind so stark ausgesprochen, daf sie sofort auffallen müssen. Var. Dorice reihet sich somit jenen Negerrassen an, welche wir in den letzten Jahren so zahlreich unter den echten Eidechsen kennen gelernt haben. Ob es sich auch hier um eine angebliche Anpassung an den Boden handeln soll?! Marquis G. Doria verdanke ich ebenfalls eine Trop. algira sp. aus Gebel Resas in Tunis; ihr Vorderrücken ist metallischgrün, ihre hellgelben Seitenstreifen erscheinen grün gefleckt. Dieses Exemplar ist auferdem noch dadurch interessant, daji es leine Frenalplatte aufzuweisen hat.

Vorkommen.

Die Verbreitung der algira in Spanien und Portugal ist nach E. B oscà (Bull. Soc. zool. de France 1880, p. 279) folgende: Ciudad-Real, Madrid, Eskorial, Robledo de Chavela, Fuencaliente, Despoblado de la Caracollera und Almadenejos in Neu-Kastilien; Pozo-Hondo (Murcia); Las Hurdas in Leon; Badajoz in Estremadura; Gerona in Katalonien; Belmez, Belalcazar; Castellon, Navajas, Puebla de Regat, Jativa und Dosaguas in Valencia; Beira in Portugal. Rosenhauer (vergl. seine »Die Tiere Andalusiens«, S. 14. Erlangen 1856) traf sie in Malaga, Machado ${ }^{1}$ ) in Sevilla. Steindachner. ${ }^{2}$ ) führt sie für Alicante, Jerez de la Frontera, Granada und Lissabon an. Böttger kennt sie aus Algeciras und von Monchique in Algarve (Abhandl. Senckenberg. naturforsch. Gesellsch. XII, S. 378; Zeitschr. f. d. ges. Naturwiss. LII,

1) Erpetologia Hispalensis etc. in: Revista di Ciencias, Literatura y Artes IV. Sevilla 1859.

$\left.{ }^{2}\right)$ Reise der Novara. Zoolog. Teil. Bd. I. Reptilien. Wien 1869. 
S. 507). Ich selbst fing das Tier bei Valencia auf der Dehesa de la Albufera und in Albacete; aulierdem habe ich cin Stück in der Umgebung Barcelonas gesehen. Seoanc (l. e.) ist geneigt zu glauben, dafs sie auch in den gebirgigen Gegenden in der Provinz Orense einheimisch sei. Ihr Vorkommen auf den Balearischen Inseln bezweifle ich, auch finde ich sie im Catalogo de los Reptiles y de los Moluscos terrestris y de agua dulce observados en las Islas Baleares von F. Barcelo y Combis (Palma de Mallorca 1876) nicht genannt. - Von Spanien dringt die algirc in das sudliche Frankreich ein; so soll sie $z$. B., wie ich es aus der brieflichen Mitteilung des Herrn G. Jumeau in Beziérs erfahre, am Kap Cerbère in den OstPyrenäen konstatiert worden sein. Ilerr La tas te besitzt ein Individuum aus der Umgebung von Seffiez (Dép. de l'Hérault). Im Museum zu Berlin sollen Exemplare aus Montpellier und im Museum an der landwirtschaftlichen Schule zu Montpellier Individuen dieser Art, aus Cette stammend, aufbewalnt werden; auch auf den Hyeren soll sie angetrofien worden seiu (stra uch, Essai d'une Erpétologie de l'Algérie in: Mém. de l'Acad. Imp. des Sc. de St. Petersb. VII. Série, t. IV, No. 7). „Aus Marokko«, sagt Böttger ${ }^{1}$ ), skennt man die Art bis jetzt nur von Tanger (Steindachner), von Casablanea und aus der Umgebungs der Stadt Marolico (Bttg.) selbstæ. Sonst findet sie sich in Afrika noch in Algerien und Tunis, und zwar an den Küsten Algeriens, in der Stadt Algier (Strauch, l. c.), in Oran (F. Müller, in: Verhandl. naturf. Ges. Basel VI, Heft 4, S. 625. Basel 1878), in Tlemcen (B öt ger), in Oued-Sideur (L a taste) und in Gebel Resas in Tunis (G. Doria); endlich findet sich auf der kleinen Insel Galitone eine Form, welche hinsichtlich der Färbung und Beschildung sich von der binnenländischen algira wesentlich unterscheidet ${ }^{2}$ ).

Daß der Verbreitungsbezirk der algira sich weiter nach Osten erstreckt, bezweifle ich. Erhard behauptet zwar, dafs sie auf allen Inseln des griechischen Archipels, selbst Syra nicht ausgenommen, einheimisch sei und dafs sie hier die kolossale Länge von 2 Fulj erreicht, jedoch berult diese Behauptung, wie ich es schon in meiner Arbeit über die Kriechtiere Griechenlands bemerkt habe, wohl auf einer Verwechselung mit irgend einer anderen Surier-species, weil Erhard ausdrücklich angiebt, dats seine angehliche ulgira gekörnte Rückenschuppen aufweist,

1) Die Reptilien und Amphibien von Marokko in: Alhandl. Senckenberg. nat. Gesellsch. XIII. 1883.

$\left.{ }^{2}\right)$ Nach Vaillant kommt die algira im Somali-Lande vor (Faune et Flore des Pays Çomalis. Mission G. Révoil. Paris 1882). Auch am Kap Mirik, in Argain, Elimané, Gasser-El-Barka, Aleb, Portendik, Bandoube und Kita würde sie, wenn man sich auf den Verfasser der »Faune de la sénégambie ohne weiteres verlassen wollte, einheimisch sein. Unter den ron mir Ende Jnli 1886 im Berner Museum flüchtig untersuchten Reptilien babe ich eine Algira barbarica aus "Teneriffa und zwei als $»$ Lacerta Forbesiana $0 t \mathrm{th}$ « bezeichnete $L$. pater aus Algier vorgefunden. 
was ja bekanntlich bei der echten Tropidosaura nicht der Fall sein kann. Auf meinen Streifzügen in Griechenland und auf den Cykladen habe ich die Trop. algira nirgends angetroffen und glaube infolgedessen nicht, dafs der von II a si us in seiner »Tierwelt« S. 202, Berlin 1862 , als im südlichen Griechenland vorkommend angefübrte »Psammosauves« zu »Psammuros Wag $1 . \ll$. d. h. zu Tropidosaura Fitz. (Boie) gehört, was bekanntlich seitens einiger Forscher vermutet worden ist. - Dafi Trop. algira noch in keinem bis dato publicierten Verzeichnisse der Kriechtiere Syriens, Ägyptens und Klein-Asiens genannt worden ist, brauche ich wohl kaum hinzuzufügev. Bei dieser Gelegenheit möchte ich aber nicht unerwähnt lassen, daf L acepède und Bechstein die Vermutung aussprechen, Trop. algira sei mit Lacerta cruenta Pall. identisch und daß sie, d. h. L. cruenta, sin den mittägigen Gegenden des russischen Reiches« vorkommit. Darauf muf bemerkt werden, daf die srotschwänzige Eidechse Suckow, Borowsky und Meyer (Ameiva) sich auf eine Eremias- oder auf eine Acanthodactylus-Art bezieht.

\section{Tropidosaura montana (Boie) D. B. 1839.}

Char. - Scuta nasofrenalia duo. Sc. occipitale et scuta frontoparietalia minora, squamae dorsales paulo angustiores et longiores quam in Trop. algira. Collare nullum. Pori femorales utrinque 6-7. Pedes brevissimi, graciles; antici oculorum marginem anteriorem; postici nunquam axillas attingentes. Cauda plerumque trunco duplo longior. - Longitudo: $138 \mathrm{~mm}$.

Synonymie.

Tropidosaura montana (Boie) Schlegel, Notice sur l'Erpétologie de l'Lle de Java par Boie, in: Bull. Sc, nat, et de Géologie. 2. section publiée par De Férussac. Paris 1826. - Duméril et Bibron, Erpétologie générale, t. V, p. 172. - Fitzinger, Syst. rept., pag. 21. Wien 1843. - Gray, Cat. Liz. Brit. Mus. p. 35. London 1845. C. et A. Duméril, Cat. méthod. coll. des Rept., pag. 199. Paris 1851.

Trop. capensis (non Smith) Steindachner, Reptilien in: Reise d. österr. Fregatte Novara um die Erde. Zool. Teil. I. Bd. Wien 1867.

Themophitus capensis Fitzinger in: Sitzungsber. Akad. Wien. Bd. 42, S. 402. 1861.

Tropidosaura Burchellii Smith, Illustration of the Zoology of South Africa. Appendix, pag. 7. London 1849.

Die Ergebnisse zeitraubender und schwierigel Untersuchungen werden öfters nur deswegen angezweifelt, weil dieselben dem Leser nitunter olne jegliche Auseinandersetzung vorgelegt 
werden, und das mit Recht, den der Federstrich allein genügt in den meisten Fiillen nicht, um eingebürgerte, wenn auch viclfach irrige Ansichten zu widerlegen. Namentlich da, wo es sich um eine tabellarische Zusammenfassung der Synonyme handelt, dürften die Vorarbeiten des Verfassers dem Leser nicht vorenthalten, sondern müisten vielmehr mitgeteilt werden. Im vorliegenden Kapitel handelt es sich, wie es bereits aus der voranstehenden synonymischen Zusammenstellung ersichtlich ist, um die Zusammenziehung von nicht weniger als drei Arten, nämlich der montana (Boie) D. B., Burchellii Smith und caponsis Fitz. Steind. (non Smith!) in eine einzige Species und, wie ich noch hinzufügen möchte, um die gåuzliche Entfernung der Smithschen sogenanuteu Algive capensis, welche dem Genus Ichnotropis ${ }^{1}$ ) angehört. Ls handelt sich also um einen Fall, der sicherlich einiger erlïuternder Bemerkungen bedarf.

Sowohl das typische Individuum der Trop. montana »aus Java , das seinen Namen Boic verdankt, als auch die ursprüngliche, bis dato unveröffentlicht geblicbene und in Vergessenheit geratene Diagnose dieser Art, befinden sich im Museum zu Leyden und sind beide - sowoll Tier als auch Diagnose - weil das dortige Material schwer zugänglich ist, den Herpetologen wenig bekannt. Nur Duméril, Bibron und Peters scheinen mit der Charakteristik dieser Echsenart genau vertraut gerresen zu sein, denn sowohl im Museum zu P'aris, als auch in demjenigen zu Berlin finden sich Tropidosaura vor, an deren Bezeichnung als »montana« nichts auszusetzen ist; dafs aber die betreffenden Stücke nicht aus Java, dem angeblichen Vaterlande der typischen montana, sondern vom Kap der Guten Hoffnung stammen, ist weder Duméril und Bibron noch Peters aufgefallen. Da wir aber, wenigstens so viel ich weib, in betreff der Kriechtiere keine Beispiele von einer Ähnlichkeit oder Übereinstimmung zwischen der Fauna Javas und der des Kap haben, so kamen mir anfangs die Bestimmungen von Duméril, Bibron und Peterș etwas verdächtiğ vor; zugleich erschien mir die Ansichtuahme des OriginalIndividuuns von mmontana« höchst wünschenswert, ja sogar notrendig, in Anbetracht dessen, daß die in British Museum als » Burchellii Smith« und in dem Wiener k. k. zoologischen Kabinett als scapensis $\mathrm{Smith \ll} \mathrm{bezeichneten} \mathrm{Tropiclosaura} \mathrm{rom} \mathrm{Kap} \mathrm{sich} \mathrm{als} \mathrm{identisch} \mathrm{mit} \mathrm{den}$ smontana im Pariser und Berliner Museum erwiesen, welche, wie bereits gesagt, ebenfalls vom Kap stammen. Erst nachdem ich die typische montana in Leyden zu Gesicht bekam und das Boiesche Manuskript »Erpetologia javanica« ${ }^{2}$ ) zu Rate gezogen hatte, erlangte ich

1) Monatsb. Berl. Akad. 1859, S. 616.

2) In Bezug auf das Boiesche Manuscriptum glaube ich meinen Fachgenossen einen Dienst zu erweisen, wenn ich hierselbst die Bemerkung einschalte, dab dieses ohnehin unter den zahlreichen Handschriften schwer zu findende Werk in der M.-S.-Abteilung des zoolog. Mus, zu Leyulen unter dem holländischen Titel $\triangleright$ Beschryringen van Reptilien door II. Boi e aufberahrt wirl. 
die Gewifheit über die vollkommene Identität der »montana" in Leyden, Paris und Berlin mit den »Burchellii in London und den scapensis« in Wien. Es bliebe folglich nur noch ein unaufgeklärter Punkt in Bezug auf die Herkunft der Leydener mmontana«, doch darüber später; vorerst will ich zeigen, inwiefern es gerechtfertigt ist, Boie als Autor der Trop. montana gelten zu lassen. Das Manuskript Boies „Erpetologia javanica" ist, wie bereits erwähnt, nicht im Druck erschienen und da es keine Jahreszahl trägt, so köunen wir nur vermuten, dafs es vor 1826 niedergeschrieben worden ist, weil im Jahre 1826 im Bull. des sc. nat. et de Géologie eine Notiz Schlegels über Boies Herpetologie von Java erschien, worin der Referent unter anderem die Genera Boies vorführt, Trop. montana Boie als neue Species namhaft macht, sie als »animal très singulier de l'île de Java« bezeichnet und die Absicht Temmincks mitteilt, das Werk Boies in der "Galerie zoologique du Musée des Pays-Bas « erscheinen zu lassen. So ward nun »Trop. montana« bis zum Jahre 1839, d. h. bis die Erpétologie générale erschien, lediglich ein Museal-Name; erst Duméril und Bíbron war es vergönnt, eine kurze Diagnose dieser Echse zum erstenmal zu veröffentlichen. Daraufhin lieb Gray in seinem Verzeichnisse der Eidechsen im British Museum einen Auszug aus dieser Diagnose erscheinen. Beides fiel aber so unbefriedigend aus, dafs man in einigen Museen sich bewogen fühlte, die montana als scapensis« zu bezeichnen. Endlich im Jahre 1849 beschrieb Smith die smontana« in ziemlich befriedigender Art und Weise, leider aber als Tropidosaura Burchellii. Damals glaubte man an die Existenz von nahezu einem halben Dutzend Tropidosaura-Arten, während eigentlich nur zwei Species bekannt sind und eine dritte mit der Burchellii resp. montana zusammengeworfene Species noch der Beschreibung harrt.

Körpergestalt und Größe.

Trop. montana ist mit der vorigen Art nahe verwandt, jedoch von ihr gut unterschieden. Der Körper ist bedeutend kleiner und schmächtiger, mit schwach niedergedrücktem, in der Mitte mehr oder weniger bauchigr erweitertem Rumpf und leicht gewölbter Unterseite. Der Kopf ist klein und schmal, nach vorn zu ziemlich stark verschmälert, mit schwach abgerundeter Schnauze; die Quer-Axe, unterhalb der Orbitalregion gezogen, repräsentiert die größte Breitenausdehnung des Kopfes; die Schädeldecke erscheint sanft von hinten nach vorn und abwärts gewölbt; die Seiten fallen, namentlich vorn, senkrecht ab; die Palpebralscheibe zeigt lateralwärts eine Senkung. Die mäligrg grobien Ohröffnungen sind nahe der Mundspalte und ziemlich weit nach unten gerückt; die oberen Lider sind bedeutend kürzer als bei der Tropidosaura algira. Eine halsartige Verengung ist nicht vorhanden. Die Beine sind äuferst kurz und zart gebaut; die vorderen reichen bis zum Vorderrand der Augen, die hinteren erreichen nicht 
die Rumpfinitte; sie sind nur 18 bis $19 \mathrm{~mm}$ lang, wälrend der Rumpf etwa 42 bis $43 \mathrm{~mm}$ milit. Der an der vorderen Partie uberill ziemlich gleich dicke mu scitlich leicht komprimicrte Schwanz ist nach hinten allmählich dünn ausgezogen und drehrund, seine Länge, dic des Rumpfes melur als un das Doppelte überwiegend. - Make in mm (No. $2673 \mathrm{im} \mathrm{Museum}$ in Paris): Totallänge 137,5-138. Lünge d. Kopfes 10,5, d. Halses 6,7, d. Rumpfes 42, d Schwanzes 85; Kopfhöhe 5,5; Breite d. Kopfes 6,5, d. Pileus 5; Umfang d. Kopfes 20, d. Halses 20, d. Rumpfes 30; Länge d. Hinterextremität 19, d. Fußes 10, d. Vorderextremitil 14, d. Hand 5.

\section{Schilder und Schuppen.}

Das leicht gewölbte, kleine, ovale Occipitale erscheint ziemlich weit nach hinten gerüclit und seitlich nur partiell von den länglich schmalen, lateralwärts und hinten abgerundeten Parietalen begrenzt. Die zuletzt erwähnten Tafeln haben einen 0 -förmigen, schwach ausrgeluägten Wulst; mit ihren lateralen, etwas bogig geschweiften Innenrändern fügen sie sich an das fünfscitige, vorn breite, winkelig angrezogene, hinten stark verschmälerte und abgestutzte Interparictale an; mit ibren vorderen, unter stumpfem Winkel zusammenstofendeu Kanten grenzen die Parietalia einerseits an das Supraoculare IV, das drei- oder funfseitig ist, und anderscits an die mäfig grofen fünfseitigen, mit ihren kürzesten Kanten in der Mittellinie des Kopfes aneinanderstoßsenden Frontoparietalen. Im Vergleich zu den kleinen hintersten und den winzig kleinen, körnerförmigen vordersten Supraocularen sind die mittleren gleichnamigen Schilder groli; namentlich zeichnen sich die zweiten (von vorn gerechnet), etwa dreieckigen, hinten leicht ausgerandeten oberen Augenschilder durch ihre Länge aus, während das darauffolgende dritte Paar aus kürzeren, aber gleich breiten und seitlich und vorn abgerundeten Schildern besteht. Das lange, vorn und hinten gleich breite, in der Mitte etwas verengte Stirnschild ist bedeutend breiter als die sich ihm anschliefende flache PaJpebralscheibe; hinten ist das Frontale etwas gewülbt und endet stumpfwinkelig, vorn aber ist es abgeplattet und leicht abgerundet; seine seitlichen Kanten erscheinen äutierst schwach ausgerandet. Die Frontonasalen erreichen kaum die halbe Länge des Frontale; vorn und seitlich erscheinen sie abgerundet, hinten von 2 Kanten begrenzt, von denen die eine längere, schwach ausgerandete an den Vorderrand des Frontale stöft, während die andere, und zwar die bedeutend liurzere, das zweite Supraoculare berührt (das Supraoculare I liegt mehr seitlich mach aufen zwischen Frontonasale, Supriaculare II und den Supraciliaria); der innere, gerade verlanfende Rand des einen Frontonasale grenzt an die gleichmamigen Schilder auf der entgegengesetzten Seite. Das Iuternasalc, welches breiter als lang ist, zeigt einen stumpfwinkeligen Hintel- und Vorterrand, wobei der Hinterrand ziemlich 
stark ausgeschnitten erscheint; seitlich stölit dieses Schild mit seinen kurzen, abgestutzten Ecken an das hohe, etwa trapezförmige Frenale, dessen Vorderseite leicht abgerundet, dessen Hinterseite abor leicht ausgerandet erscheint. Vor diesem Schilde stchen 2 kleinere Nasofrenalen, von denen das obere, fünfeckige jederseits mit dem Supranasale in Kontakt tritt. Die Supranasalen stellen dreieckige Platten vor, deren abgestutzte Spitzen nach innen gerichtet sind, sich gegenseitig berühren und deren stark eingebuchtete Basalteile die kleinen rundlichen Nasenlöcher umgeben. Diese schmalen Platten trennen einerseits das Internasale von dem wenig breiten, fünfseitigen, hinten stark auf die Schädeldecke übergebogenen und mit seiner Spitze zwischen die Supranasalia eingeschobenen Rostrale; anderseits trennen sie mit Hülie des unteren, vierseitigen Nasofrenale das viereckige, vorn leicht verschmälerte Supralabiale I vom Nasenloch. Das zweite und dritte Supralabiale ist viereckig und etwas höher als breit, währenddem das vierte, gleichnamige Schild nach hinten und unten in eine ziemlich lange Spitze ausgezogen, und somit länger erscheint als es hoch ist. Über dem zweiten und dritten Oberlippenschilde befindet sich das relativ ansehnliche, vorn breite und abgerundete, nach hinten zu hingeren verengte und abgestutzte Praeoculare. Das nach aufwärts schwach übergewölbte viereckige Freno-oculare kommt nur mit seiner vorderen, nach unten hin lang ausgezogenen und abgestutzten Ecke mit dem Supralabiale III in Berührung. Der obere Orbitalrand wird von 5 länglich schmalen Supraciliaria begrenzt; zu unterst erscheint die Orbita vom sechsseitigen, oben ausgerandeten und von einer Körnchen-Serie umsäumten Suboculare umgeben. Diese Platte ist oben nahezu dreimal so lang als hoch, unten erscheint es allerdings in bedeutendem Maße verschmälert, aber immerhin so lang als es hoch ist; an seinem oberen Rande ist es mit einer Längsleiste versehen, welche ubrigens auch am Pracoculare deutlich hervorzutreten pflegt. Auf die Suboculartafel folgen zwei fünfseitige Supralabialia posteriora. Die Schlïe ist zum grö̈len Teil mit ziemlich umregelnäliig gestalteten, bald vier-, bald fünfseitigen, glatten oder kleinen, länglich schmalen, stumpfgekielten Schildchen bekleidet; letztere, $d . h$. die kleineren, sind nach hinten gerückt. Die äußere Parietalkante ist von 2 langen hexagonalen, vorn etwas verschmälerten Platten begrenzt; der Vorderrand des Ohres, und zwar oben, erscheint vom länglich schmalen und gebogenen Tympanicum umgeben. Sublabialia sind 6, Submaxillaria 5 vorhanden; die dritten Submaxillaren (von vorn gerechnet) stofen nahezu ihrer ganzen Länge nach aneinander. Die kleinen, etwa fächerförmigen Kehlschuppen gehen ohne jedwede Unterbrechung in die gröferen, hinten dreikantigen und in 25 oder 26 Quer- und in 6 Längsreihen angeordneten Bauchschilder 'über, von denen die 2 median und lateralwärts liegenden Längsserien aus kleinen, die dazwischen liegenden aus gröferen, resp. breiteren 
Platten bestehen. Smith giebt die Zahl der Längsserien auf 8 oder 9 an, was mich vermuten liaft, daf er die den Bauchplatten allerdings sehr ähnlichen, aber dennoch schwach gekielten äußsersten Flankenschuppen zu den Ventralschildern gerechnet hat; unpaare Zahlen longitudinaler Bauchschilderserien, wie 9 z, B., liommen bei den Lacertiden überhaupt nicht vor. Der Übergang der Ventralschilder in die Flankenschuppen ist doutlich wahruehmbar; letztere erscheinen nämlich länglich, lanzettlich und deutlich gekielt. Die Schuppen sind am Rïcken rhombisch, diagonal gekielt, nach hinten mehr (I'ariser Exemplar) oder weniger stark (Wien. Exempl.) zugespitzt, im Nacken sind sie lanzettförmig und kürzer; unmittelbar am Hinterrande der Pileustafeln, an der Ohröffnung und in der Achselgegend sind die Schuppen körnig und bei näherer Betrachtung zum Teil schwach gekielt. Die scharf gekielten Caudalschuppen sind oben. in der Mittellinie nach rückwärts zu stumpfwinkelig ausgezogen und mit scharfen Spitzen versehen, welche nichts Anderes als die am Ende dornartig ausgezogenen Kiele sind; gegen die Seiten des Schwanzes erscheinen die Schuppen eher rhombisch, dabei kommen die Kiele näher an die der Schwanzmitte zugekehrten Kanten zu liegen. Auf der Schwanzunterseite sind die Schuppen an ihren freien, stets verschmälerten Rändern vorn leicht abgerundet, hinten spitzwinkelig endend. Das lange, schmale, öfters dreieckige Anale ist vorn und seitlich von. 6 bis 8 kleineren Täfelchen umgeben. Die mittlere Querreihe von Rumpfschuppen besteht aus circa 19 (Wiener Exempl.) oder etwa 23 (Pariser Exempl.) Schuppen; die mittlere Lüngsreihe von Rumpfschuppen enthült ungefüh :37 bis :38 Stück. Die Zihl der Schwinzringel beträgt 69-70. Die Extremitäten erscheinen oberhalb mit gekielten Schuppen bekleidet. Endlich ist noch erwähnenswert, daf3 die Schulterfalte bei dem mir vorliegenden Individuum äuferst schwach ausgeprägt zu sein scheint:

Schenkeldrïsen.

Die jederseits aus 7 Femoraldrüsen bestehenden Reihen erreichen die Kniekehle nicht; sie erscheinen von ihr durch 2 Schildchen getrennt.

Farbenkleid des im k. Hofnaturalien-Kabinett zu Wien aufbewahrten Exemplares:

Der Kopf ist oben olivenbraun, hinten mit groken dunkelbraunen, fast die Schilder: ganz einnehmenden, vorn aber mit kleinen Flecken bedeckt; die Kopfseiten erscheinen in der Temporal- und Frenalgegend olivenfarben dunkelbraun gefleckt. Das Suboculare und die hinteren Oberlippenschilder sind oben grüulichweil, unten dunkelbraun. Zwischen der schwarzen, am Hinterrande des Occipitale ihren Ursprung nehmenden und sich bis zur Schwanzwurzel hinziehenden Fleckenbinde und den braunen Seitenfeldern des Rückens befinden sich graue, im Leben wohl olivenfarbene Bünder; anf den Rumpf- und Schwanzseiten stehen kleine, weifliche 
oder grünlichweife Flecken in zwei longitudinale Reihen angeordnet; von denen die obere am hinteren Rande der Parietalen. und zwar oberhalb der Ohröffnung, beginnt, während die untere, weniger scharf prononcierte Reihe bereits unterhalb des Auges entspringt, sich durch die Ohröffnung und die Achselgegend auf den Rumpf, unweit der Bauchgrenze, fortsetzt und sich an der hinteren Hälfte des Schwanzes verliert. Bei wäherer Betrachtung ergiebt es sich, daßs diese hellen, seitlich von dunkelbraunen Streifen eingefafiten Fleckenreihen aus dreieckigen, gegen das Schuppenende zu sich verlierenden Makeln bestehen. Oberwärts erscheinen die Extremitäten braun, spärlich dunkelbraun gefleckt; die nach vorn und unten gerichteten größseren Schuppen sind grünlichweiß, grau gepudert und dunkelbraun gepunktet. Die Schilder aller unteren Körperteile sind bläulich, an ihren freien Rändern weißlich umsäumt und vorn, namentlich am Batuche, schwarz gefleckt. Die Kehle ist spärlich dunkel gefleckt. Auf der Schwanzunterseite hingegen fliefen dunkelbraune Flecken zu Querbinden zusammen; das Anale ist vorn blau, hinten schmutzig weik. Die Schwanzoberseite ist gegen das Ende hin einfarbig braun, sonst spärlich weiblich und grünlich punktiert; diese Punkte stellen nichts Anderes, als die Fortsetzung der Rumpffleckenreihen vor. Die im Museum in Paris aufgestellten Individuen sind im allgemeinen ähnlich gefärbt und gezeichnet, nur sollen sie nach Duméril und Bibron oben und unten mit einem Goldglanz übergossen gewesen sein; jetzt ist davon nichts mehr zu sehen. Die Tropidosaura montana im British Museum haben im Laufe der Zeit gleichfalls in Bezug auf ihre Färbung gelitten, denn von den schöneณ Tinten, wie sie uns die Illustration of the Zoology of South Africa zeigt, ist wenig zu sehen. Smith habeu sicherlich frische Stücke der montana vorgelegen.

Vorkom men.

Die in den Museen zu Wien (Thermoptitus capensis Fitz. Kap, ded. Zelebor), Berlin (No. 1147, Kap d. Guten Hoffnung), Paris (No. 2673, Kap, ded. J. Verneau. - No. 296, ded. Castelnau. - No. 1252, Kap) und London (Trop. Burchellii Smith, Cape) aufbewahrten Trop. montana sind im Kaplande und im Kaffern-Gebiete gesammelt worden, während das im Leydener Museum sich befindende Originalexemplar nach Boie auffallenderweise aus Java stammen soll. Die Bemerkung Boies (Vergl. seine oben citierte Erpetologia javanica), dab diese Art im Manuscriptum von Kuhl und van Hasselt nicht beschrieben (»non descripta«), also wohl auch nicht erwähnt ist, scheint mir darauf hinzudeuten, daf das betreffende Stück der montana nicht von den soeben genannten Erforschern Javas erbeutet und mitgebracht worden ist; vielleicht ist es nachträglich dem Leydener Museum aus Süd-Afrika zugesandt und infolge eines Mibverständnisses den Jara-Tieren beigefügt worden; jedenfalls ist die 
Angabe über das Vorkommen dieser Art auf Java höchst verdächtig ${ }^{1}$ ). Nach Fitzingers Neue Klassifikation d. Rept., S. 22. würde sie aus Cochinchina stammen! Es ist leicht möglich, dafi näheres darüber im Bulletin universel des Sciences angegeben worden ist. Ich erfahre, leider zu spät, un das betreftende Bulletin nachzuschlagen, daß Bd. II, S. 79, 370-371, Bd. X, S. 160 und Bd. XVI. S. 127 Briefe von $K u h l$ und van Hasselt über Java, ferner ein Schreiben an Wag ler und endlich die Charakteristik von Reptilien aus Java von Bo i e enthalten.

\section{Untergattung Bettaia. $\left.{ }^{2}\right)$}

Lacerta (part.) Milne Edwards, Recherches zool. pour servir à l'hist. nat. des Lézards in: Ann. sc. nat. 1829. Paris. - Duméril et Bibron, Erpétologie générale, t. V. Boulenger, in: Proc. Zool. Soc. of London 1881, pag. 743.

Helioplilus Fitzinger, Systema reptilium. Wien 1843.

Nucras (part.) Gray, Cat. Liz. Coll. Brit. Mus. London 1845.

Bettaia Delalandei, die Repräsentantin unserer neuen Untergattung »Bettaia« stellt eine isoliert stehende, abirrende Form dar, welche sich vielleicht an die südifrikanischen sogenamnten ¿acerten anreihen lief3e. Sowohl die erstere als auch die letzteren müssen erst genauer untersucht werden, bevor sie einen bestimmten Platz im System erhalten.

\section{Bettaia Delalandei M. Edw. 1829.}

Char. - Sc. occipitale minimum, latius quam longius, in posteriorem partem valde remissum. Interparietale longum et angustum. Nasofrenalia duo. Freno-oculare maximum. Discus palpebralis supraciliaribus appositus. Supralabialia anteriora 4. Regio temporalis valde extensa scutis quinquangularibus et sexangularibus tecta. Parietalium margines externi $2-3$ scutis oblongis circumdati. Nassetericum uullum, sc. tympanicum interdum pratens. Submaxillaria 4. Sulcus gularis nullus. Collare subdenticulatum. Scuta abdominalia in 8 series longitudinales disposita. Pars corporis ventralis scutis tecta et parte dorsali squamata latior. Squamae dorsales ovales vel rotundulae, non carinatae; squamae laterales dorsalibus longiores et planiores, imbricatae, gradatim in scuta mutatae. Squamae caudae basales squamis dorsalibus similes. Regio analis 14 scutis imbricatis vel appositis tecta. Pori femorales utrinque 13. Palatum

1) Nachträgl. Zusatz: In Schlegels Essai sur la Physionomie des Serpens S. XXI finde ich Folgendes über die Ausbente von Kuhl und van Hasselt: M. M. Kuhl, van Hasselt, Boie et Macklot, abordant la ville du Cap lors de leur voyage aux Indes y ont formé des collections. * Diese Mitteilung scheint mir die Herkunft der montana in Lejden zu erklären.

$\left.{ }^{2}\right)$ Vergl. dit Diagnose der Untergattung ${ }^{2}$ Bettaia in meiner Einleitung. 
dentatum. - Truncus elongatus, cylindricus vel ubique fere aequale rotundatus. Caput brevissimum, a trunco distincte seiunctus, satis obtuse terminans. Aurium orificium in posterioren partem valde remissum. Collum longissimum. Pedes brevissimi. Digitorum posticorum falculae longiores quam anticorum. Cauda longa. - Longitudo: 240-272 $\mathrm{mm}$.

Synonymie.

Lacerta Delatandei Milne Edwards, in: Ann. sc. nat. t. XVI, 1. 70, 84. - Duméril et Bibron, Erpétologie générale, t. V. pag. 241. - S mith, Illustration of the Zoology of South Africa. Reptiles. Appendix, pag. 7. - Boulenger, in: Proc. Zool. Soc. of London 1881, pag. 743.

L. intertexta Smith, in: The Nagaz. of Nat. Hist., vol. II. p. 92 (1838).

Nucras Lalandei Gray, Cat. Liz. Coll. Brit. Mus., pag. 33.

Der von Milne Edwards als Lac. Delalandei und von Smith als L. intertexta benannte und beschriebene Saurier ist, meiner Ansicht nach, mit Unrecht von Herpetologen, wie Duméril und Bibron und anderen, einfach im Genus Lacerta beibehalten worden, denn abgesehen von allen untergeordneten Merlmalen unterscheidet sich die Delalundei in Bezug auf die Körpergestalt in so bedeutendem Grade von den echten Lacerta, dafs die subgenerische oder generische Auseinanderhaltung dieser beiden nicht erst durch weitliufige Untersuchungen nachgewiesen zu werden braucht. Die Nichtzusammengehörigkeit dieser beiden Saurier ist bereits Gray aufgefallen, aber der Versuch, für die uns hier interessierende Kap-Echse eine acceptierbare Gattung zu kreieren, miflang diesem Forscher und zwar aus dem einfachen Grunde, reil Gray diejenigen »Arten«, welche sein neues Genus »Nucras« enthalten sollte, mit alleiniger Ausnahme vou der sog. Lac. Delatandei M. Edw. und von Lac. tessellata Smith, nur vom Hörensagen kannte. So war es z. B. mit "Nucras exigua« - oder L. exigua Eichw. - und "Nucras chatibdea Eichw.« (Lac. chalibdea Eichw.) der Fall; denn erstere ist blow der Jugendzustand von $L$. agilis, während letztere mit Var. saxicola ( $L$. muratis) identisch sein dürfte. Infolge der Zusammenwürfelung von ganz verschiedenen Elementen fiel auch die für Nucras proponierte Diagnose mangelhaft aus, denn mit Ausnahme einiger Kennzeichen von zweifelhaftem Werte, wie $z$. B. »Abdominal plates rhombic, with the outer sides oblique and contracted behind oder :Temples covered with keeled scales«, welche, nebenbei sei es bemerlit, auch nicht im mindesten auf die »Delalandei passen, gehört alles Übrige ebensogut in die Charakteristik des Genus Lacerta wie in diejenige der Gattung Nucras. Somit wäre die Aufrechterhaltungr der Grayschen Gattung, dem Namen Nucras zuliebe, nur nach einer vollständigen Umarheitung der ursprüuglichen Diagnose und der Ausschlieliung von drei »Arten« mög- 
lich, was leicht zu weiteren Lonfusionen führen könnte, umsomehr, da es von jetzt an unserem Gutdiuken überlassen ist, den sich auf gar keine Kategorie beziehenden Grayschen Genusnamen "Nucras entweder der Delatandei M. Edw. oder der von dieser verschiedenen Echsenform stessellata Smith« beizulegen. Aus diesen Gruiden habe ich es vorgezogen, von der Verwertung des Namens »Nucras« gänzlich abzusehen und fü die Delalandei den Gattungsnamen s Bettaiu« - Herrn Ed. de Betta in Verona zu Ehren - zu proponieren. Ehe ich zur Diagnose schreite, möchte ich hier die Bemerkung eiuschalten, dafs Fitzinger unsere Echse mit dem Nomen nudum »Heliophilus« bedacht hat (vergl. Systema reptilium I. Wien 1843).

Körpergestalt und Größe.

Abgesehen davon, dafi der Kopf vom Rumpfe bei der Bettaia stets deutlich gesondert erscheint, erinnert ihre Körpergestalt, wie Duméril und Bibron richtig bemerken, im allgemeinen an gewisse Chalcides. Der Kumpf ist nämlich langgestreckt, beinahe schleichenförmig, cylindrisch und fast überall von gleichem Umfange, namentlich tritt kein grofer Unterschied zwischen dem Umfang des Rumpfendes und dem der Schwanzwurzel auf. Diese Eigentümlichkeit ist umsomehr auffallend, als der Schwanz an seiner Basis, von oben gesehen, auch nicht im mindesten aufgetrieben erscheint; der kräftigere und dickere Vorderteil des Schwanzes geht vielmehr ganz allmählich in das dünnere Schwanzende über, nur an der Unterseite der Schwanzbasis erscheint bei den männlichen Individuen eine Wölbung, welche durch die sich dort befindenden Begattungsorgane verursacht wird. Der Kopf ist verhältnismäßig sehr kurz; sein Verhältnis zum Rumpf ist wie 1:6. Der Hals aber ist lang, länger als bei irgend einer echten Lacerta-Art; er verhält sich zum Kopf wie 5:4. Wenn man einerseits das Verhältnis der liopf- zur Rumpflänge, und anderseits das Verhältnis der Kopflänge zur Halslänge bei den Lacerten sich ins Gedächtnis zurückruft, so wird man wohl zugeben müssen, daß die angeführten Längsverhältnisse für die Bettaia sehr charakteristisch sind. Nimmt man aber ausserdem Rücksicht auf die bei den Lacerten eher normalen Proportionen in betreff des Umfanges der verschiedenen Körperteile und achtet man darauf, daß bei ihnen die Schultergürtelregion und der Schwanz vom übrigen, gegen die Caudalgegend hin stets dicker werdenden Rumpfe deutlich abgesetzt sind und endlich, dafs bei ihnen die Hinterextremitäten bis zu den Achseln oder sogar darüber hinausreichen, währenddem bei der Bettaia letztere halb so lang sind wie die Entfernung zwischen den Ansatzstellen des vorderen rom hinteren Beinpare, so düufte man wohl bald einsehen, daßs genügender Grund für die subgenerische Auseinanderhaltung von Lacerta und Bettaia vorhanden ist. Die Vorderextremititen erreichen nicht ganz den Vorderrand der Augen. Die Zehen, namentlich an den hinteren Gliedmaßen, sind auffallend 
liurz und dick; ich hatte Gelegeuheit die längsten Zehen bei einer $272 \mathrm{~mm}$ langen Bettaia Delalantei, bei einer $242 \mathrm{~mm}$ messenden Lacerta viridis und bei einer $200 \mathrm{~mm}$ langen Lac. agilis (letztere zeichnet sich bekanntlich durch ihre liurzen Zehen aus) zu vergleichen und zu finden, dafis bei der zuerst genannten Echse die längste Zehe $9 \mathrm{~mm}$, bei L. viridis aber $23 \mathrm{~mm}$ und bei agilis $13 \mathrm{~mm}$ lang ist. Währenddem bei den echten Eidechsen die Krallen an den Hinterextremitäten stets lïnger sind als diejenigen an ten Vordergliedmalsen, erscheinen bei der Bettaia im Gegenteil die ersteren bedeutend kürzer als die letzteren, was wohl damit zusammenhängen dürfte, daf die Bettaia ihre Vorderbeine zum Graben benutzt. Die Afterspalte ist bei Bettaia weit von der Schwanzbasis, oder genauer von den vordersten Femoraldrüsen entfernt.

Approximative Nafe in mm. - Totallänge $240 \mathrm{~mm}$. Länge d. Kopfes 16, des Halses 13 , von d. Schnauzenspitze bis zur Schwanzwurzel 88, d. Schwanzes 152, d. Vorderextremität 22,5, d. Vorderfufes 10,5, d. Hinterextremität 33, d. Hinterfufes 13 ; Entfernung zwischen d. Ansatzstellen d. Vorder- und Hintergliedmafen j1; Entfernung d. vordersten Drisenpaares von d. Afterspalte 7,5. Höhe d. Kopfes 16, Breite d. Kopfes 11, d. Pileus 7,7, Umfang d, Kopfes 36,5 .

Schilder und Schuppen. ${ }^{1}$ )

Besonders für die Bettaia charakteristisch scheint mir folgende Eigentümlichkeit zu sein: die beschuppte Partie des Rumpfes, insbesondere in der Rumpfmitte, ist bedeutend schmäler als die beschildete Körperunterseite; bei Lacerta ist gerade das Umgekehrte der Fall; so mifst z. B. bei einer aufs Geratewohl zum Vergleich gezogenen Zauneidechse die beschuppte Rumpfoberseite in der Breite $31 \mathrm{~mm}$, hingegen ist die beschildete Unterseite nur $22 \mathrm{~mm}$ breit; bei Bettcia ist die beschuppte Rückenpartie 16,5 bis $17 \mathrm{~mm}$ und die beschildete Körperunterseite $23 \mathrm{~mm}$ breit. - Da man zuweilen die Körpergestalt und die Maße weniger in Betracht zieht, und namentlich in denjenigen Fällen, wo es sich um eine Neuerung handelt, leicht darüber hinweggeht, so glaube ich etliche Eigentümlichkeiten in Bezug auf die äulere Kürrperbedeckung hierselbst hervorheben zu müssen.

Das äuferst kleine, abgerundete Occipitale, das breiter als lang ist, erscheint sehr weit nach hinten vom langen und schmalen fünfseitigen Interparietale zurücligedrängt. An die ziemlich ansehnlichen, fünfseitigen Parietalia grenzen vorn die kleinen fünfeckigen Frontoparietalia und die dreieckigen hinteren Supraocularia an, deren äufere seitliche und vordere Kanten fast genau so lang sind wie die sich ihnen auschließenden Ränder der dritten Oberaugenschilder.

${ }^{1}$ ) Vergl. die Abbildungen bei Milne Edwards (Ann. Sc. nat. vol. XVI. pl. V, fig. 6, pl. VII, fig. 5 pl. VIII, fig. 5) und bei Duméril und Bibron (Ernétologie générale. Atlas). 
Die vorderen Seiten des Frontale erscheinen bei der Bettuiu schwach ausgerandet. Die vierbis fünfeckigen Frontonasalen sind nahezu ebenso grols wie die Frontoparietalen; das Internasale stellt hingegen eine relativ unansehnliche Platte vor; es ist rhombisch, mit abgeruudeten Ecken; rorn stölst es an die hinteren, gebogenen Kanten der oberen Nasenschilder, seitlich an die oberen kleineren Nasofrenalen und an die schmalen, aber hohen Frenalia. Das zweite, zu unterst liegende Nasofrenale ist unten an seiner Basis breiter als oben. Das fünfeckige Rostrale ist wenig nach oben übergewölbt. Das ansehnlichste Schild an der Kopfseite, das Freno-oculare nämlich, wird vom Suboculare durch 2 aufeinanderfolgende Praeocularen getrennt. Der Palpebraldiscus und die Scuta supraciliaria legen sich direkt aneinander; soweit die Orbitalgrube ron den zuletzt genannten Plättchen nicht begrenzt wird, also zu unterst, wird sie ron einer ununterbrochenen, aus 10 verhältnismäßig grölseren Schuppen bestehenden Reihe begrenzt. Von den 8 Supralabialia begrenzt das fünfte das Auge. Die auffallend, namentlich nach hinten ausgedehnte Schläfenregion ist vor allem von einer Anzahl — in der Regel ron 6 - grüferer, funf- und sechsseitiger Schildchen bedecht, welche durch ein grölieres Postoculare vom Unteraugenschilde getrennt sind, dann mit 2 bis 3 länglicben, jederseits an die äußeren Parietalkanten stoßenden Täfelchen bekleidet; ein durch besondere Größe hervortretendes Tympanicum ist nicht vorhanden. Das Massetericum ist nicht vorhanden. Die Ohröffnungen sind sehr weit nach hinten gerückt und liegen auf den Halsseiten; der Ohrrand ist vorn durch längliche, hinten durch rundlich körnige Schuppen begrenzt. Es sind 7 Unterlippenschilder und nur 4 Supramaxillaren vorhanden. Kehlschuppen oval, rund und unregelmälijg geformt. Sulcus gyularis nicht vorhanden; Halsband schwach gezähnelt, aus 10 grö́cren und 2 kleinen Plättchen bestehend. - Die Nackenschuppen sind rundlich körnerartig; die übrigen Rumpfschuppen auf der Rüchenmitte oval oder rund, bei oberflächlicher Betrachtung körnerartig, gewölbt. unter der Lupe aber leicht abgeflacht; auf den Seiteu erscheinen sie gröbier, flachen sich ab und zeigen sich schwach geschindelt, gegen den Bauch hin gestalten sic sich allmïhlich zu Schildem; hingegen erstrecken sich die ejgentlichen Rumpfschuppen viel weiter uber die Schwanzregion als dies bei Lacerta der Fall ist. Erst in der Entfernung von ungefähr 8 bis $10 \mathrm{~mm}$ von der Caudalbasis hören bei Bettain die ungekielten, bald rundlichen, bald eiförmigen oder eckigen, kleinen Schulpen auf, um den ziemlich breiten, stark dachartig gekielten, stumpfwinkelig ausgezogenen Schwanzschuppen Platz zu machen. Ich zähle 104 bis 107 Schwanzringel, 62 Quer- und 41 Lüngsschuppeureihen an Rücken; 3 Querschuppenreihen entsprechen der Länge des Bauchschildes. Die Bauchplatten sind in 8 Längsreihen georduet, deren mittlere 6 Reihen aus sehr breitell, deren auberste aber aus bedeutend schmäleren Schil- 
dern zusammengesetzt erscheinen. Die Randschildchen grenzen an die äußersten Bauchschilderreihen. Das Brustdreieck hat nur 3 Schilder. Die Aftergegend ist mit 14 geschindelten Tafeln bedeckt. - Von der Milne Edwardschen Diagnose weicht das mir zur Verfügung stehende Exemplar dadurch ab, dafs es, wie Boulenger (I. c.) richtig bemerkt, 8 und nicht 6 longitudinale Ventralschilderserien hat.

Farbenkleid, Drüsen und Zähne.

Das aus dem Iusée d'histoire naturelle in Paris entliehene Exemplar (No. 29S, ded. Castelnau) ist auf der Oberseite braun; der Rücken erscheint mit zahlreichen weilsen, von dunkelbraunen Ringen umgebenen runden Flecken bedeckt. Der Kopf ist dunkelbraun getleckt; die nach rückwirts liegenden Supramaxillaren und Halsseiten zeigen auf hellem Braun schwarz-

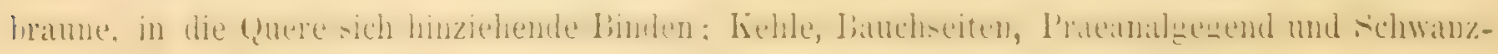
unterseite sind auf gelbem Girunde dunkelbraun oder grau gemarmelt; die iibrigen unteren Körperteile sind gelb, Heckenlos. Diese Form entspricht allem Anschein nach der Abart a. von Duméril und Bibron. Diese Autoren führen uns noch zwei andere „rarietiten auf, und zwar eine Var. b. oder die sintertextu Smith« aus Latakoo, deren Rücken mit 2 Reihen meiblicher, schwarz umrandeter Fleckchen, und deren Körperseiteu mit kurzen, schwärzlichen Querbinden besetzt sind - und eine braun quergebänderte Var. c. Bei diesen beiden Abarten soll die Grundfarbe der Körperoberseite gräulich, graubraun oder rostbraun (roussître) sein; bei Var. b. ist die Schläfe weilj. mit 2 vertikalen schwärzlichen Binden versehen, währendden bei Var. c. die Schläfe von bramen, sich schlängelnden, vou reilen, schwarz umrandeten Flecken begleiteten Querbinden durchzogen erscheinen. Die Kö̈perunterseite bei Var. b. soll meifs sein. - Dic angebliche Zusammengehüriglicit von Bettaia Dclalandei M. Edw. und "Lac. intertexta Smith habe ich leider nicht verifizieren kiümen.

Die Anzahl der Schenkeldrisen betrïgt 13-13. Der Oberkiefer ist jederseits uit 18 oder 19, der Zwischenkiefer mit 8-9 und de! Oberkiefer nit 44 Zïhnchen bewafinet. Sowohl die Zwischenkieferzähne, als auch die vordersten, längsten und schwach nach binten gebogenen

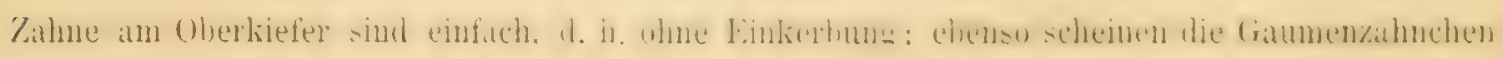

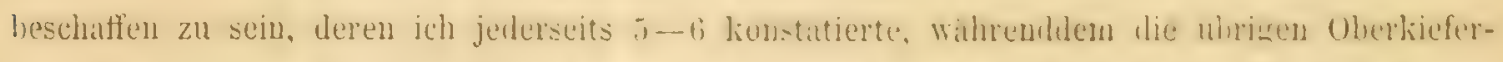

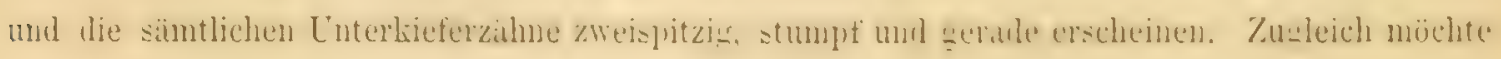
ich hinzufügen, dab die Zunge schwarz ist.

Vorkommen.

Das von mir untersuchte Individuum stammt aus dem Grof-Namaqualande in Südafrika.

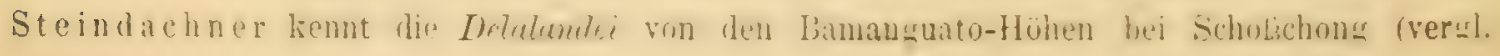


seine Schrift: Über eine neue Eidechse - Eremias Holubi - aus dem Thale des Krokodilflusses in Transvaal in: Sitzungsber. d. k. Akad. d. Wiss. I. Abt. Juni-Heft 1882), Das Berliner Museum hat sie von Port Natal in der Kaffrerei erhalten (No. 7032). Nach Peters kommt sie auch in Tette und Boror vor (Monatsber. Berl. Akad. 1859, S. 616). - In der Sammlung von Herm F. Lataste in Paris habe ich eine als »Lac. Delalandei? non type etikettierte Bettaia gefunden, welche in einigen Stücken von der typischen Delalandei abweicht und vielleicht eine besondere Subspecies oder Species reprïsentiert. Sie unterscheidet sich von Bettuiu Delalamlei vor allem durch ihren sehr kurzen Kopf, ihre abgestutzte Schuauze und durch ihren längeren Schwanz. Das deutlich ausgeprägte Tympanicum ist ziemlich groß; die unteren Schwanzschuppen sind spitz ausgezogen und haben äuferst schwach ausgeprägte Kiele. Die 13 Praeinalschilder sind nicht geschindelt. Jederseits simd 14 Schenkeldrüsen vorhanden ${ }^{2}$ ). Die Grundfarbe der Oberseite ist braum. Breite, wellig verlaufende, dunkelbraune Querbinden durchziehen den Rumpt und erscheinen mit weilsen Punlitfecken besetzt. Gleichfalls weif geaugt sind diejenigen dunkelbraunen Flecken, welche in gewissen Abständen die Schwanzschuppenringel zieren; diese Flecken sind genau ebenso lang wie die Schuppen selbst. Kopfdecke, Wangen und Oberseite der Gliedmaken sind auf hellbraunem Grunde dunkelbraun gefleckt. Alle Bauchteile sind gelb; gegren die Bauchseiten hiu und auf den beschildeten Partien der Extremitäten treten dunkelbraune Makeln und Punkte zum Vorschein.

Approximative Mafse in $\mathrm{mm}$ : Totallänge 272; Länge d. Kopfes 15, d. Halses 12, von d. Schnauzenspitze bis zur Schwanzwurzel 10, d. Vorderextremitït 24, d. Vorderfufes 9, d. Hinterextremität 31, d. Hinterfußes 12, d. Trialle am Vorderfuf 2, am Hinterfuf 1,5. Entfernung zwischen der Ausatzstelle der Vorder- und Hinterextremität 52 ; Kopfhöhe 9,5, Kopfbreite (in der Backengegend) 11, Breite d. Pileus 8, Umfang d. Kopfes 35,5. - Fundort: Lessouto.

Nach de Rochebrune (l. c.) kommt » Nucras Delalandeik in Senegambien vor.

\section{E r $\mathbf{1}^{\circ} \mathrm{t}$ a.}

Aur S. 4, Z. I6 V. 0. ist nach, Cameranow die Anmerkung ${ }^{1}$ ) ausgelassen worden.

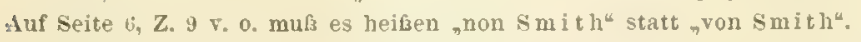

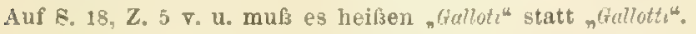

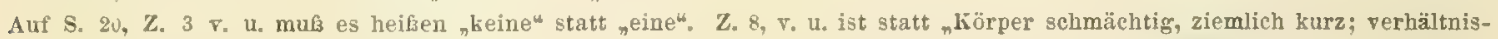
mäfig lang, breiter als hoch" zu lesen: wï̌rper schmächtig, ziemlich kurz; Kopf verhältnismäGig lang, breiter als hoch."

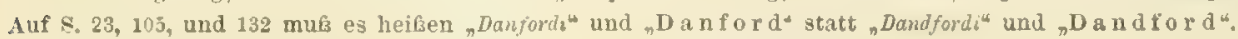

Auf $\mathrm{S} .46, \mathrm{Z} .10 \mathrm{~V}$. 0 . ist statt ,interparietale $\mathrm{zu}^{4}$ lesen, interparietali".

Auf S. $107, Z, 3$ v, 0. ist statt ,prafrontali* zu lesen "luaefrontali."

Auf S. 256, Z. 8 マ. 0. ist statt "minor" zu lèsen ${ }_{7}$ minus".

Auf S. 395, 7. 4 จ. u. ist statt "Gattung' zu lesen ,Untergattung".

${ }^{1}$ ) Vergl. meine Tafel, Fig. 1,5 und 35. 


\section{Inhalts - Verzeichnis.}

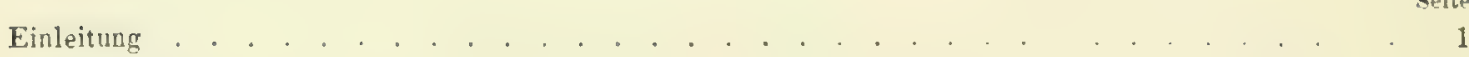

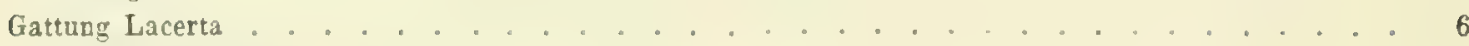

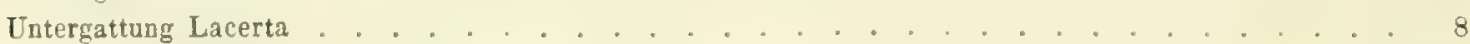

L. ocellata Daud. . . . . . . . . . . . . . . . . . . . . . . 23

L. pater Lataste. . . . . . . . . . . . . . . . . . . . . . . . . 38

L. viridis Laur. . . . . . . . . . . . . . . . . . . . . . . . . . . . 46 46

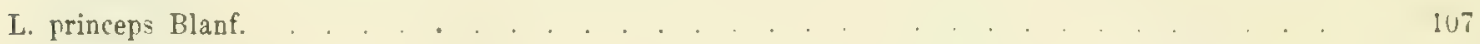

L. agilis Wolf . . . . . . . . . . . . . . . . . . . . . . . 111

L. paradoxa de Bedr. . . . . . . . . . . . . . . . . . . . . . . . . . . 154

L. muralis Laur. . . . . . . . . . . . . . . . . . . . . . . . 160

, s subsp. fusca de Bedr. . . . . . . . . . . . . . . . . . . . . . . 171

$>$ $>$ neapolitana de Bedr. . . . . . . . . . . . . . 204

$\therefore$ > $>$ Brugemanni de Bedr. . . . . . . . . . . . . . . . . . . 231

$\gg$, balearica de Bedr. . . . . . . . . . . . . . . . . . . 232

> $>$, Steindachneri de Bedr. . . . . . . . . . . . . . . . . . . . 240

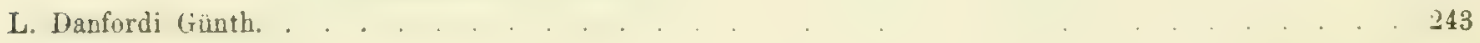

L. laevis Gray . . . . . . . . . . . . . . . . . . . . . . . . . . . . . . . . . . .

L. Brandti De Fil. . . . . . . . . . . . . . . . . . . . . . . 252

L. depressa Cam. . . . . . . . . . . . . . . . . . . . . . . . . . 256

L. oxycephala D. B. . . . . . . . . . . . . . . . . . . 260

L. Bedriagae Cam. . . . . . . . . . . . . . . . . . . . . . . . . . 268

L. graeca de Bedr. . . . . . . . . . . . . . . . . . . . . . . . . . . 274

L. perspicillata D. B. . . . . . . . . . . . . . . . . . . . . . . . . 279

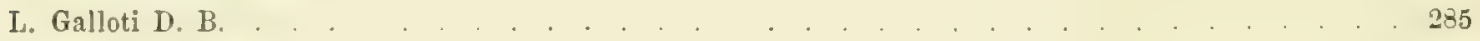

L. Dugesỉ M. Edw. . . . . . . . . . . . . . . . . . . . 292

L. atlantica Peters, Doria. . . . . . . . . . . . . . . . . . . . . . 298

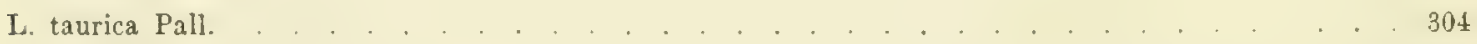

L. peloponnesiaca Bibr. Bory . . . . . . . . . . . . . . . . . . . . . . . 315

L. viripara Jacq. . . . . . . . . . . . . . . . . . . . . . . . . . . 322

L. praticola Erersm. . . . . . . . . . . . . . . . . . . . . . . . . . 351

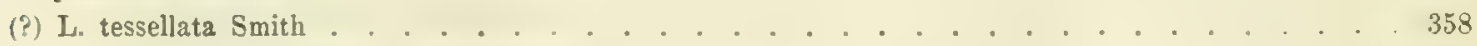

> , > subsp. pseudotessellata de Bedr. . . . . . . . . . . . . . . . . . 361

(?) L. Cameranoi de Bedr.. . . . . . . . . . . . . . . . . . . . . . . . . . 362

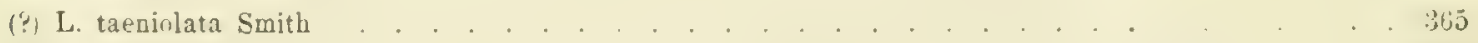

(?) L. echinata Cope . . . . . . . . . . . . . . . . . . . . . . . . . . . . . . 369

Tntergattung Algiroides . . . . . . . . . . . . . . . . . . . . . . . .

A. nigropunctatus D. B. . . . . . . . . . . . . . . . . . . . . . . . . . 377 
A. moreoticus Bibr. Bory . . . . . . . . . . . . . . . . . . . . . 382

A. Fitzingeri Wiegm. (?) subsp. Doriae de Bedr. . . . . . . . . 388

A . . . . . . . . . . . . . 389

Untergattung Zerzumia . . . . . . . . . . . . . . . . . . . . . . . . . $\quad 395$

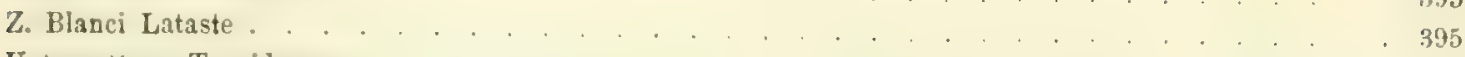

Untergattung Tropidosaura . . . . . . . . . . . . . . . . . . . . . . . . . . . . . 401

T. algira L. . . . . . . . . . . . . . . . . . . . . . . . . . . . . . . . . . . . . . 401

T. montana (Boie) D. B. . . . . . . . . . . . . . . . . . . . . . . . . . . . 412

Untergattung Bettaia. . . . . . . . . . . . . . . . . . . . . . . . . . . . . . . . 419

B. Delalandei . . . . . . . . . . . . . . . . . . . . . . . . . . . . . . 419

Errata . . . . . . . . . . . . . . . . . . . . . . . . . . . . . 425 


\section{Erklärung der Tafel.}

Mit Ausnahme der Figuren 6, 10, 12, 13, 15, 18, 20, 22, 23, 28, 29 und 35, welche in natürlicher Gröfe wiedergegeben sind, sind alle Figuren unter Zuhülfenahme eines E. Böckerschen Zeichenapparates ( Embryograph $\ll$ ) gezeichnet.

Fig. 1. Bettaia Delalandei M. Edw. (Samml. v. Herrn Lataste). Kopf ron der Seite.

Fig. 2. Afterschilder von Lacerta Cameranoi m. (No. 1043, Berl. Mus.).

Fig. B. Lacerta tessellata Smith. Kopf von der Seite.

Fig. 4. L. graeca m. Kopf von der Seite.

Fig. 5. Bettaia Delalandei M. Edw. Kopf von oben.

Fig. 6. Lacerta Bedriagae Camerano. Kopf von oben.

Fig. 7. L. peloponnesiaca Bibron, Bory de St. Vincent. Kupf von der Seite (J').

Fig. 8. L. tessellata subsp. pseudotessellata m. Vorderfufi (No. 1043, Berl. Mus.).

Fig. 9. L. Cameranoi m. Kopf ron der Seite.

Fig. 10. L. paradoxa m. Kopf von oben $\left(\sigma^{7}\right)$.

Fig. 11. L. Cameranai m. Konf ron oben.

Fig. 1:. L. graeca m. Kopf von oben.

Fig. 13. L. peloponnesiaca Bibr, Bory (q).

Fig. 14. Afterschilder von $L$. tessellata (Mus, in Paris).

Fig. 15. L. tessellata Smith. Kopf ron oben (Mus, in Paris).

Fig. 16. L. oxycephala D. B. aus Dalmatien. Kopf von oben.

Fir. 17. Seitenschuppen von Algiroides nigropunctatus D. B.

Fig. 18. L. laevis Gray. Kopf von der Seite $\left(\sigma^{7}\right)$.

Fig. 19. Afterschilder von Bettaia Delalandei II. Edw.

Fig. 20. Lac. Bedriagae Cam. Kopf von der Seite.

Fig. 21. L. tessellata subsp. pseudotessellata. Afterschilder.

Fig. 2.2. L. laevis Gray. Lopf ron oben.

Fig. 23. L. paradoxam hopf ron der Seite $\left(\sigma^{7}\right)$.

Fig. 21. Schwanzschuppen ron $L$. echinata Cope.

Fig. 25. L. taurica $\mathrm{Pall}$. Kopf von der Seite.

Fig. 26. $L$. agitis Wolf. Hinterfub.

Fig. 27. Schwanzschuppen von $L$. atlantica Peters, Doria.

Fig. 23. L. taurica o (Mus. in Kiew).

Fig. 23. L. oxycephala D. B. Kopf ron der Seite.

Fig. :0. Rückenschuppen von Algiroides moreoticus Bibr., Bory (Mus. in Paris).

Fig. 31. L. Cameranoim. Vorderfufs (Berl. Mus. No. 1043).

Fig. 3.3. Algiroides moreaticus. Kopf ron der Seite (Originalexemplar).

Fig. 33. Rückenschuppen von $L$. atlantica juv.

Fig. 3i. Rückenschuppen von $L$. atlantica ad.

Fig. 35. Bettaia Delalandei subsp.? (Samml. v. Herrn Lataste). Analgegend.

Fig. 36. Schwanzschuppen ron $L$. Galloti. D. B. 

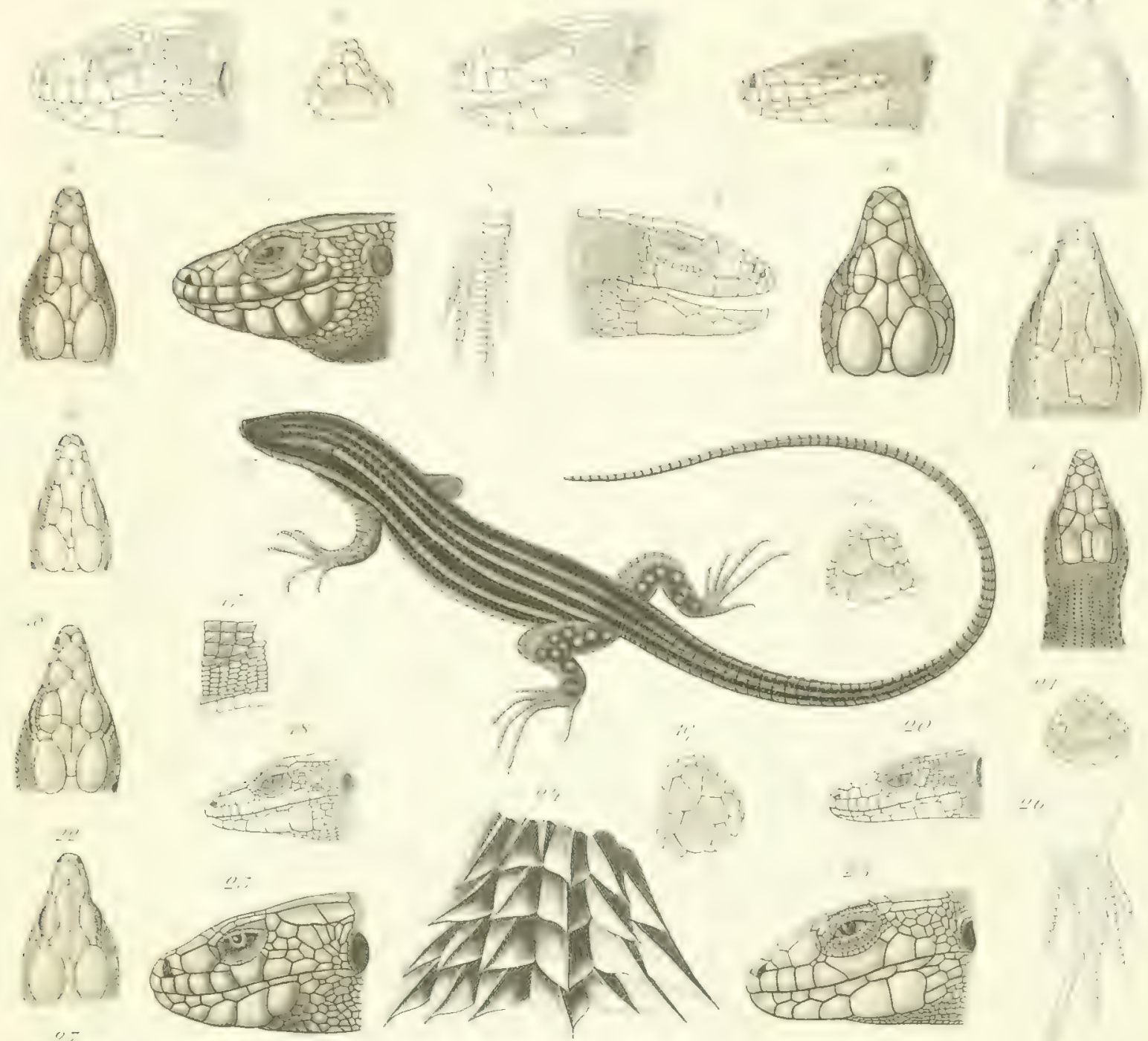

$2 e^{-75-1}=1$
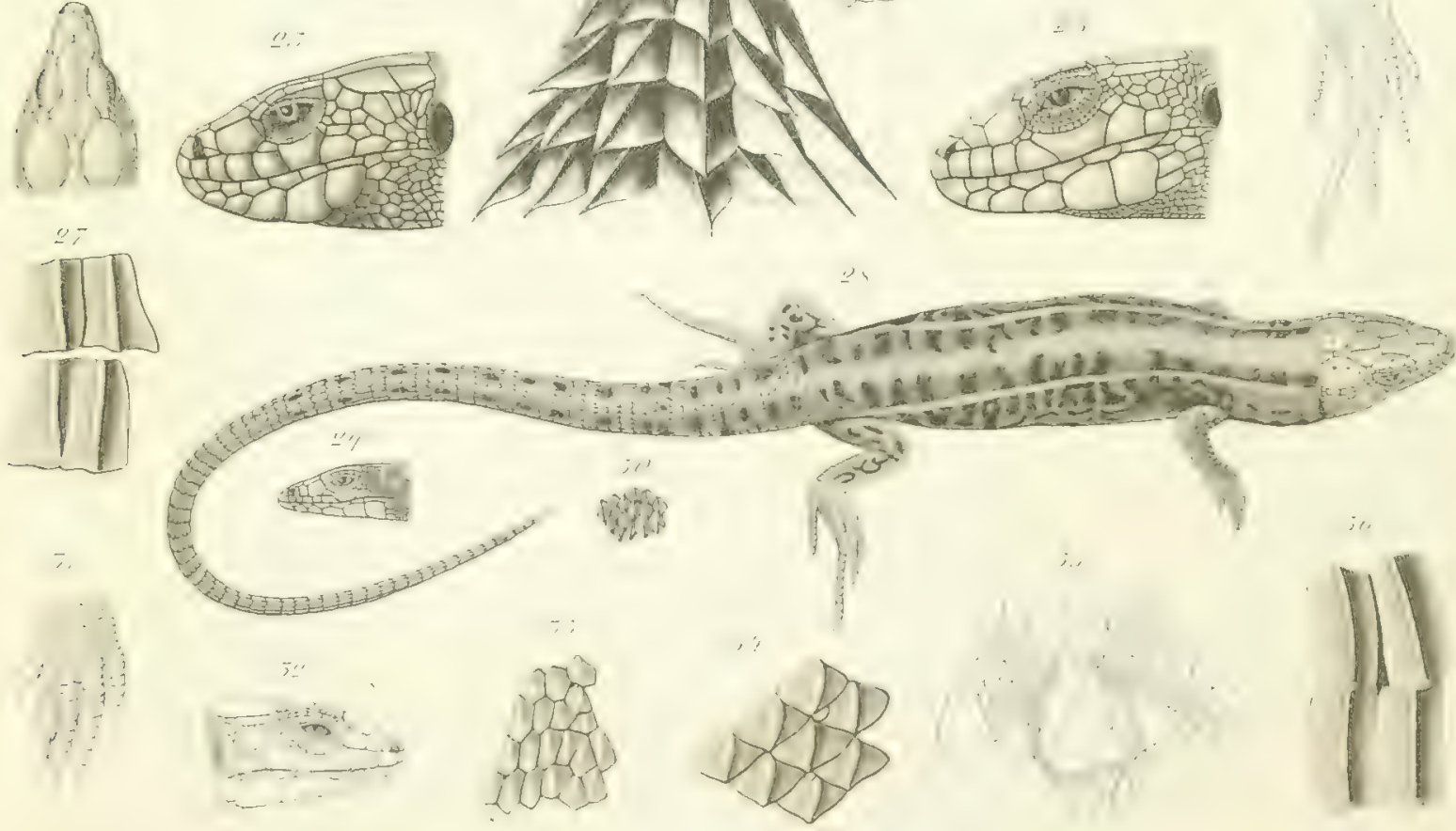

. 
